Nevada

Environmental

Restoration

Project

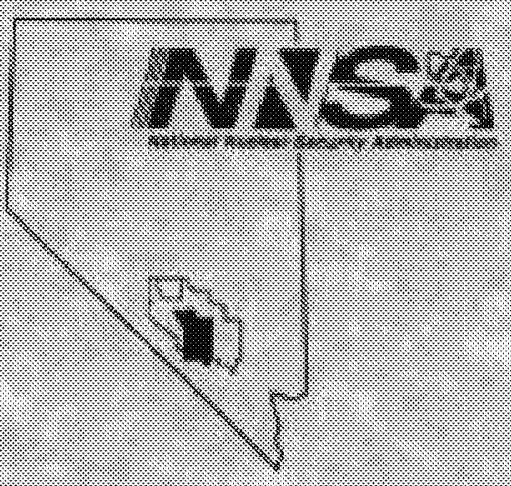

\title{
Closure Report for Corrective Action Unit 398: Area 25 Spill Sites, Nevada Test Site, Nevada
}

Controlled Copy No:

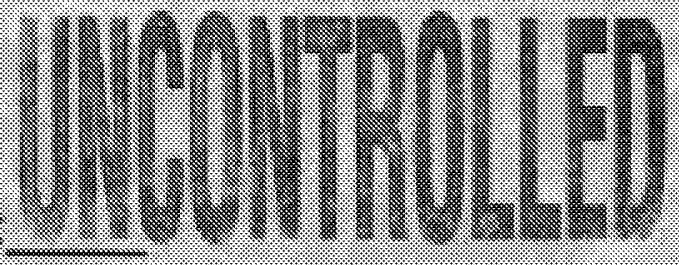

Revision: 1

April 2003

Environmental Restoration

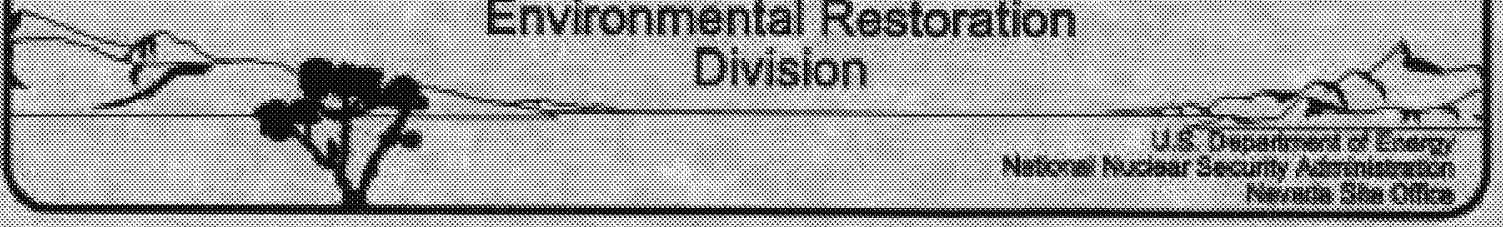




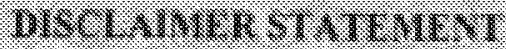

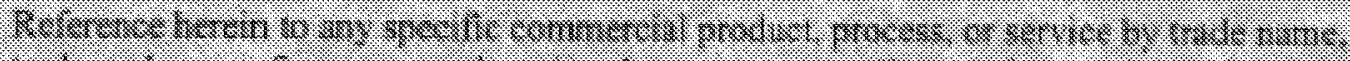

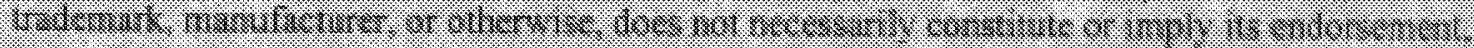
.

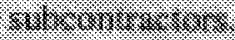

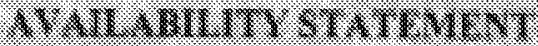

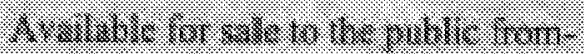

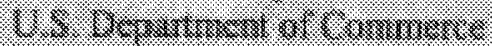

T.:

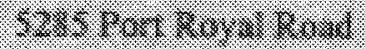

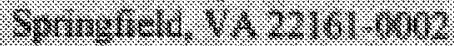

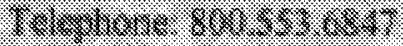

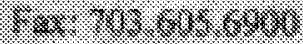

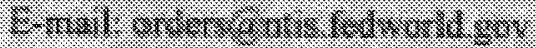

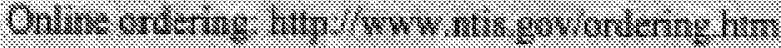

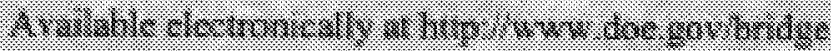

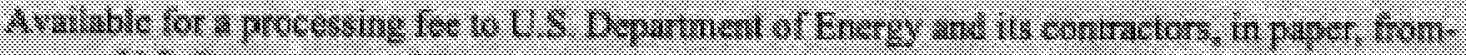

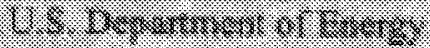

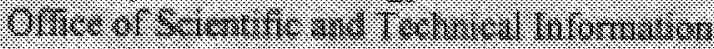

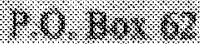

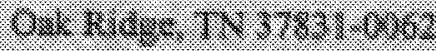

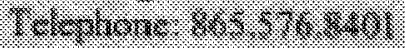

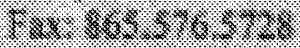

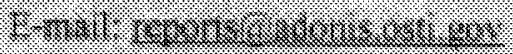




\section{CLOSURE REPORT \\ FOR CORRECTIVE ACTION UNIT 398: \\ AREAS 25 SPILL SITES, NEVADA TEST SITE, NEVADA}

Prepared for:

U.S. Department of Energy

National Nuclear Security Administration

Nevada Site Office

Work Performed Under Contract No. DE-AC08-96NV11718

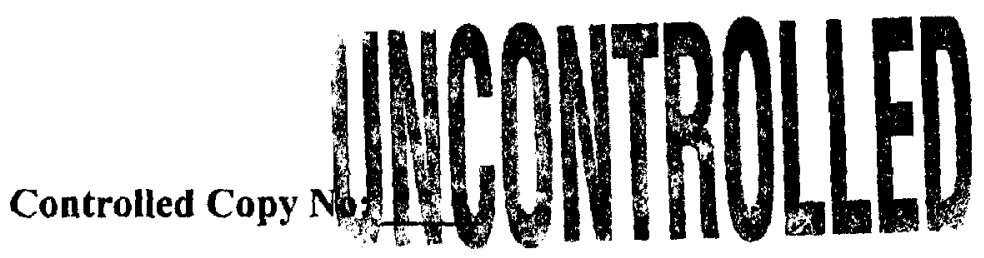

Revision: 1

April 2003 
THIS PAGE INTENTIONALLY LEFT BLANK 


\section{CLOSURE REPORT FOR CORRECTIVE ACTION UNIT 398: AREA 25 SPILL SITES, NEVADA TEST SITE, NEVADA}

\footnotetext{
Approved by: $\frac{\operatorname{Sabin} \operatorname{Cortis}}{\text { Janet Appenzeller-Wing Project Manager }}$ Date: 1/23/03

for Janet Appenzeller-Wing, Project Manager Industrial Sites Project

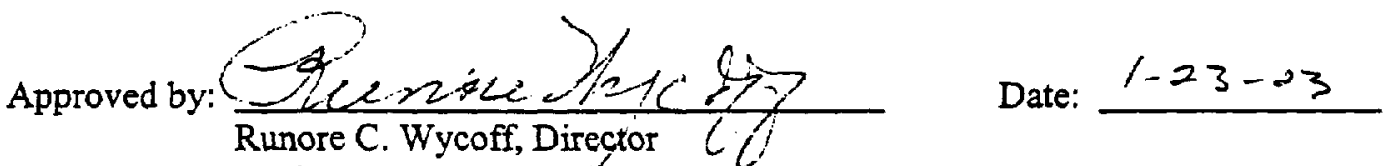

Environmental Restoration Division
} 
THIS PAGE INTENTIONALLY LEFT BLANK 


\section{TABLE OF CONTENTS}

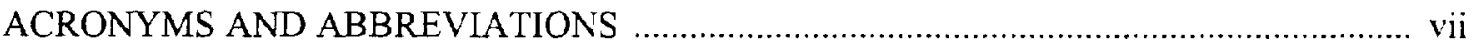

EXECUTIVE SUMMARY

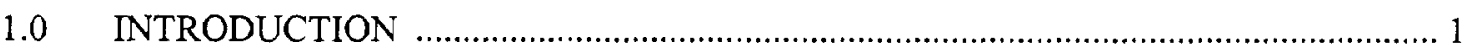

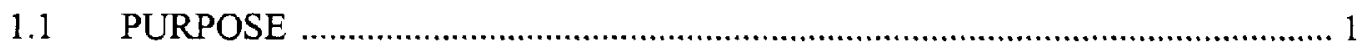

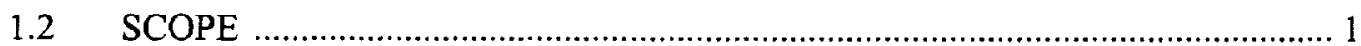

1.3 CLOSURE REPORT CONTENTS ……................................................. 3

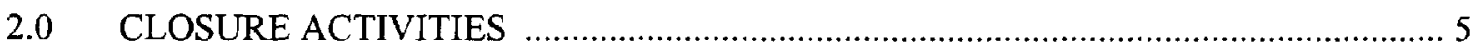

2.1 DESCRIPTION OF CORRECTIVE ACTION ACTIVITIES ……..................... 5

2.1.1 Preplanning and Site Preparation ........................................................ 5

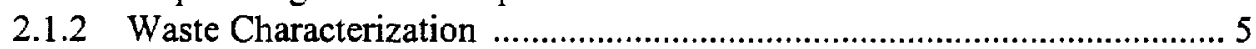

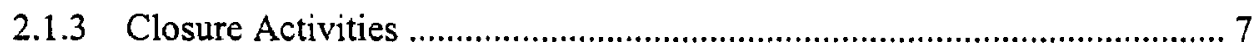

2.2 DEVIATIONS FROM SAFER PLAN AS APPROVED ….............................. 27

2.3 CORRECTIVE ACTION SCHEDULE AS COMPLETED …............................2 27

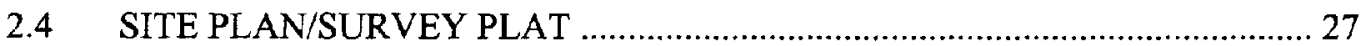

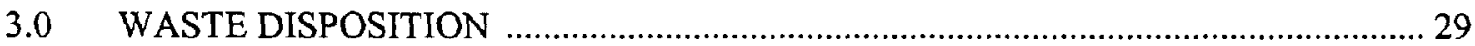

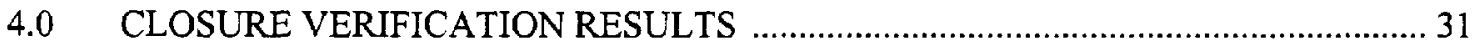

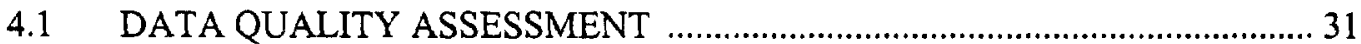

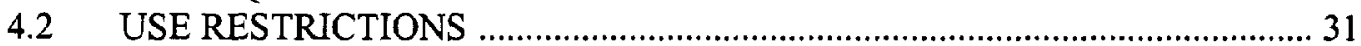

4.2.1 “A THROUGH K”EVALUATION ……...................................................... 32

4.2.1.1 CAS 25-25-07, Hydraulic Oil Spill(s) "A Through K" Evaluation ....... 32

4.2.1.2 CAS 25-25-08, Hydraulic Oil Spill(s) A Through K Evaluation ........... 34

4.2.1.3 CAS 25-25-17, Subsurface Hydraulic Oil Spill "A Through K"

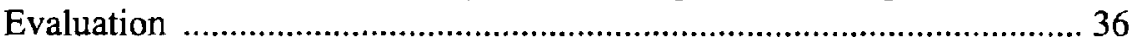

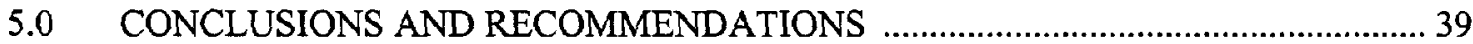

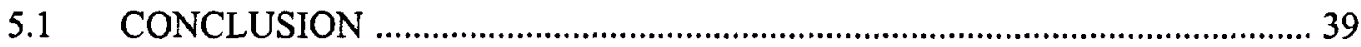

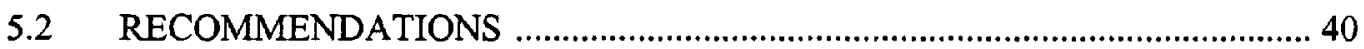

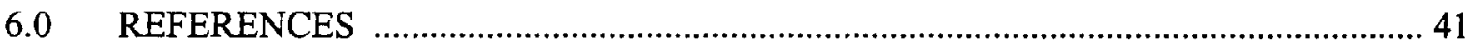

\section{FIGURES}

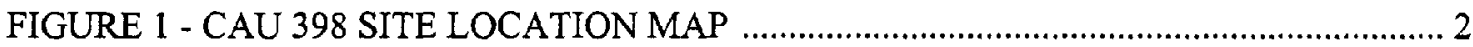

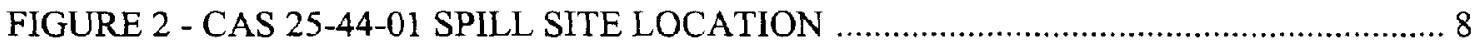

FIGURE 3 - CAS 25-44-02 VERIFICATION SAMPLE LOCATIONS .................................. 9

FIGURE 4 - CAS 25-44-03 VERIFICATION SAMPLE LOCATIONS ….............................. 10 


\section{TABLE OF CONTENTS (continued)}

FIGURE 5 - CAS 25-25-02 VERIFICATION SAMPLE LOCATIONS (FIRST SET) ............. 16

FIGURE 6 - CAS 25-25-02 VERIFICATION SAMPLE LOCATIONS (SECOND SET) ........ 17

FIGURE 7 - CAS 25-25-03 VERIFICATION SAMPLE LOCATIONS .................................. 18

FIGURE 8 - CAS 25-25-04 VERIFICATION SAMPLE LOCATIONS (FIRST SET) ............. 19

FIGURE 9 - CAS 25-25-04 VERIFICATION SAMPLE LOCATIONS (SECOND SET) ........ 20

FIGURE 10 - CAS 25-25-04 TPH VERIFICATION SAMPLE LOCATIONS ......................... 21

FIGURE 11 - CAS 25-25-05 VERIFICATION SAMPLE LOCATIONS (FIRST SET) ........... 23

FIGURE 12 - CAS 25-25-05 VERIFICATION SAMPLE LOCATIONS (SECOND SET) ...... 24

FIGURE 13 - CAS 25-25-16 (from CAS 25-01-02) VERIFICATION SAMPLE LOCATIONS

FIGURE 14 - CAU 398 CLOSURE SCHEDULE AS COMPLETED 28

\section{TABLES}

TABLE 1 - SUMMARY OF CAU 398 WASTE CHARACTERIZATION SAMPLES 6

TABLE 2 - SUMMARY OF ANALYTICAL RESULTS FOR TOTAL PETROLEUM HYDROCARBONS, POLYCHLORINATED BIPHENYLS, AND RCRA METALS IN VERIFICATION SAMPLES

\section{APPENDICES}

APPENDIX A - DATA QUALITY OBJECTIVES FOR CAU 398

APPENDIX B - VERIFICATION SAMPLE ANALYTICAL RESULTS

APPENDIX C - USE RESTRICTION INFORMATION

APPENDIX D - WASTE DISPOSITION DOCUMENTATION

APPENDIX E - FIELD PHOTOGRAPHS

APPENDIX F - NEVADA ENVIRONMENTAL RESTORATION PROJECT DOCUMENT REVIEW SHEET

DISTRIBUTION LIST 


\section{ACRONYMS AND ABBREVIATIONS}

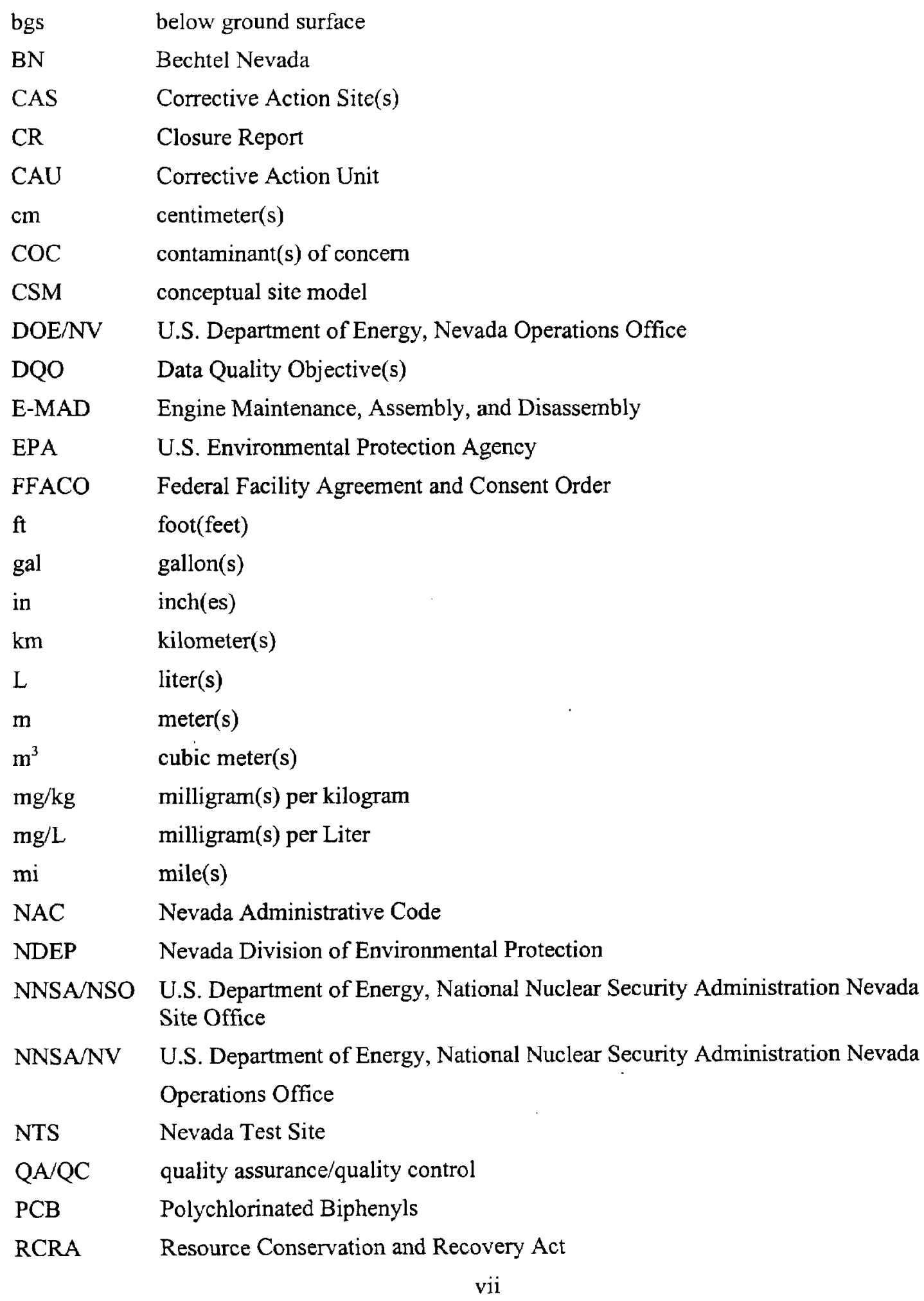


Date: April 2003

\section{ACRONYMS AND ABBREVIATIONS (continued)}

SAFER Streamlined Approach for Environmental Restoration

SVOC Semivolatile Organic Compound(s)

TPH Total Petroleum Hydrocarbons

VOC Volatile Organic Compound(s)

$\mathrm{yd}^{3} \quad$ cubic yard(s) 


\section{EXECUTIVE SUMMARY}

Corrective Action Unit (CAU) 398 consists of 13 Corrective Action Sites (CASs) all located in Area 25 of the Nevada Test Site. The unit is listed in the Federal Facility Agreement and Consent Order (FFACO, 1996) as CAU 398: Area 25 Spill Sites and consists of the following CASs:

$\begin{array}{ll}\text { - } & \text { CAS 25-25-02, Oil Spills } \\ \text { - } & \text { CAS 25-25-03, Oil Spills } \\ \text { - } & \text { CAS 25-25-04, Oil Spills } \\ \text { - } & \text { CAS-25-05, Oil Spills } \\ \text { - } & \text { CAS 25-25-06, Oil Spills } \\ \text { - } & \text { CAS 25-25-07, Hydraulic Oil Spill(s) } \\ \text { - } & \text { CAS 25-25-16, Diesel Spill (from CAS 25-01-02) } \\ \text { - } & \text { CAS 25-25-17, Subsurface Hydraulic Oil Spill } \\ \text { - } & \text { CAS 25-44-02, Suel Spill } \\ \text { - } & \text { CAS 25-44-03, Spill } \\ & \text { CAS 25-44-04, Acid Spill (from CAS 25-01-01) }\end{array}$

CAU 398 was closed in accordance with the FFACO and the Nevada Division of Environmental Protection-approved Streamlined Approach for Environmental Restoration Plan for CAU 398: Area 25 Spill Sites, Nevada Test Site, Nevada (U.S. Department of Energy, Nevada Operations Office, 2001). The implemented closure strategy consisted of the activities listed below.

Three CASs were closed by taking no further action. At these CASs, analytical sample results showed no contaminants of concern (COCs) present above action levels. The following CASs were closed with no further action:

- CAS 25-25-06, Oil Spills

- CAS 25-44-01, Fuel Spill

- CAS 25-44-04, Acid Spill (from CAS 25-01-01)

Seven CASs were clean closed by removal of all impacted soil. At four CASs total petroleum hydrocarbons (TPH) was identified as the only COC present above action levels. At one CAS TPH and Polychlorinated Biphenyls (PCBs) were identified as COCs present above action levels. At one CAS TPH, PCBs, lead and cadmium were identified as COCs, and at a final CAS, TPH and cadmium were identified as COCs present above action levels. These seven CASs were clean closed by removal of all impacted soil, collecting soil verification samples from the bottom and sidewalls of the excavations, submitting soil samples for laboratory analysis to verify that all impacted soil was removed, backfilling the excavations with clean fill, and grading the backfilled areas to the approximate original site contours. Copies of the analytical results for the collected soil verification samples are included in Appendix B of this report. The following CASs were clean closed:

- CAS 25-25-02, Oil Spills 
- CAS 25-25-03, Oil Spills

- CAS 25-25-04, Oil Spills

- CAS 25-25-05, Oil Spills

- $\quad$ CAS 25-25-16, Diesel Spill (from CAS 25-01-02)

- CAS 25-44-02, Spill

- CAS 25-44-03, Spill

Three CASs were closed in place with administrative controls, i.e., implementing use restrictions. TPH as diesel/oil were the only COCs present at two of these sites. At the remaining CAS, TPH and PCBs were the COCs present. Given specific site conditions (e.g., presence of utilities, limited working space, shallow depth to bedrock, and limited lighting), a risk assessment of each of these sites, based on the "A through $\mathrm{K}$ " evaluation as presented in Nevada Administrative Code (NAC) Section 445A.277, was performed (NAC, 2002a) for each CAS and land use restrictions implemented. The following CASs were closed in place with administrative controls, i.e., implementing use restrictions:

- CAS 25-25-07, Hydraulic Oil Spill(s)

- $\quad$ CAS 25-25-08, Hydraulic Oil Spill(s)

- CAS 25-25-17, Subsurface Hydraulic Oil Spill

Copies of the CAU Use Restriction Information forms for these three sites are included in Appendix $\mathrm{C}$ of this report. 


\subsection{INTRODUCTION}

This Closure Report (CR) documents the activities performed to close Corrective Action Unit (CAU) 398: Area 25 Spill Sites, in accordance with the Federal Facility Agreement and Consent Order (FFACO) of 1996, and the Nevada Division of Environmental Protection (NDEP)approved Streamlined Approach for Environmental Restoration (SAFER) Plan for CAU 398: Area 25 Spill Sites, Nevada Test Site, Nevada (U.S. Department of Energy, Nevada Operations Office [DOE/NV], 2001). CAU 398 consists of the following thirteen Corrective Action Sites (CASs) all located in Area 25 of the Nevada Test Site (NTS) (Figure 1):

- CAS 25-25-02, Oil Spills

- CAS 25-25-03, Oil Spills

- CAS 25-25-04, Oil Spills

- CAS 25-25-05, Oil Spills

- CAS 25-25-06, Oil Spills

- CAS 25-25-07, Hydraulic Oil Spill(s)

- CAS 25-25-08, Hydraulic Oil Spill(s)

- CAS 25-25-16, Diesel Spill (from CAS 25-01-02)

- CAS 25-25-17, Subsurface Hydraulic Oil Spill

- CAS 25-44-01, Fuel Spill

- CAS 25-44-02, Spill

- $\quad$ CAS 25-44-03, Spill

- CAS 25-44-04, Acid Spill (from CAS 25-01-01)

Copies of the analytical results for the site verification samples are included in Appendix B. Copies of the CAU Use Restriction Information forms are included in Appendix C.

\subsection{PURPOSE}

The purpose of this CR is to document that the closure of CAU 398 complied with all of the closure requirements as stated in the NDEP-approved CAU 398 SAFER Plan, (DOE/NV, 2001) CAU 398 consists of 13 CASs which are spill sites located in Area 25 of the NTS.

CAU 398 was closed as detailed in the NDEP-approved SAFER plan (DOE/NV, 2001). Seven CASs were clean closed by removal of all impacted soil, three CASs were closed with no further action being taken and three CASs were closed in place with administrative controls.

\subsection{SCOPE}

The approved closure strategy for CAU 398 was specified in the SAFER Plan for CAU 398 (DOE/NV, 2001). The implemented closure strategy consisted of the following activities. 


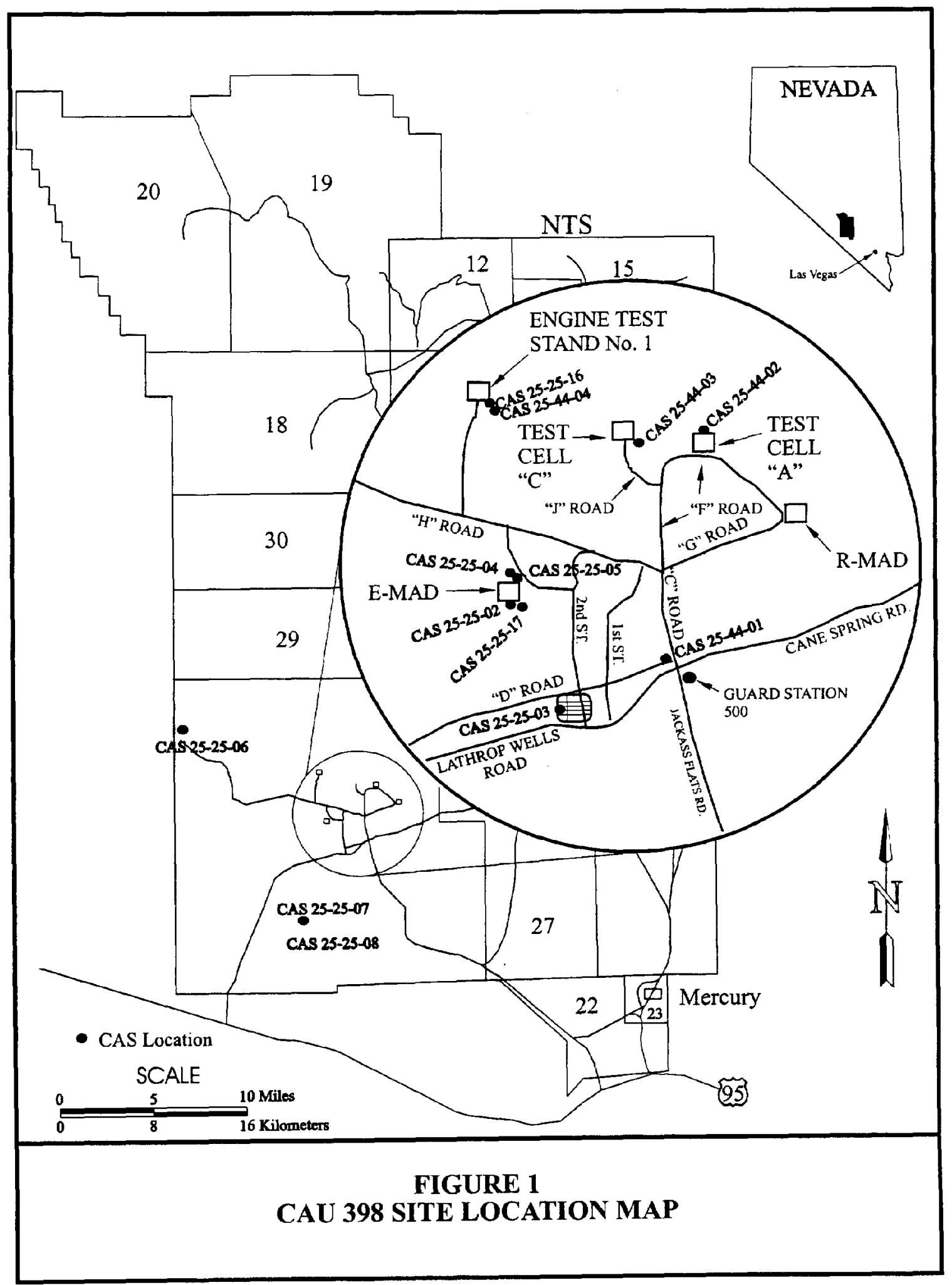


Three CASs were closed by taking no further action. At these CASs, characterization sample results showed no contaminants of concern (COC) present at levels above action levels. Therefore, the following three sites were closed by taking no further action:

- CAS 25-25-06, Oil Spills

- $\quad$ CAS 25-44-01, Fuel Spill

- CAS 25-44-04, Acid Spill (from CAS 25-01-01)

Seven CASs were clean closed by removal of all impacted soil. At four CASs total petroleum hydrocarbons (TPH) was identified as the only COC present above action levels. At one CAS TPH and Polychlorinated Biphenyls (PCBs) were identified as COCs present above action levels. At one CAS TPH, PCBs, lead and cadmium were identified as COCs, and at a final CAS, TPH and cadmium were identified as COCs present above action levels. These seven CASs were clean closed by excavation and removal of impacted soil, collecting soil verification samples from the bottom and sidewalls of the excavations, submitting samples for laboratory analysis to verify that all impacted soil was removed, backfilling the excavation with clean fill, and grading the backfilled sites to the surrounding contours. The following CASs were clean closed:

- $\quad$ CAS 25-25-02, Oil Spills

- CAS 25-25-03, Oil Spills

- CAS 25-25-04, Oil Spills

- $\quad$ CAS 25-25-05, Oil Spills

- CAS 25-25-16, Diesel Spill (from CAS 25-01-02)

- $\quad$ CAS 25-44-02, Spill

- $\quad$ CAS 25-44-03, Spill

Three CASs were closed in place with administrative controls by implementing use restrictions. $\mathrm{TPH}$ as diesel/oil was the only COC present at two of these CASs and at the remaining site, TPH and PCBs were the COCs present. Given specific site conditions (e.g., presence of utilities, limited working space, safety considerations, shallow depth to bedrock, restricted access and limited lighting), these three CASs were closed in place. As part of the site closure, a risk assessment for each of the three sites, based on the "A through $\mathrm{K}$ " evaluation as presented in Nevada Administrative Code (NAC) Section 445A.227 (NAC, 2002a), was performed. Based on the results of the "A through $\mathrm{K}$ " risk assessment, the following three CASs were closed in place with administrative controls by implementing use restrictions:

- CAS 25-25-07, Hydraulic Oil Spill(s)

- $\quad$ CAS 25-25-08, Hydraulic Oil Spill(s)

- CAS 25-25-17, Subsurface Hydraulic Oil Spill

\subsection{CLOSURE REPORT CONTENTS}

This CR is divided into the following sections:

Section 1.0-Introduction

Section 2.0-Closure Activities 
Section 3.0-Waste Disposition

Section 4.0-Closure Verification Results

Section 5.0-Conclusions and Recommendations

Section 6.0-References

Appendix A-Data Quality Objectives (DQOs) for CAU 398

Appendix B-Verification Sample Analytical Results

Appendix C-Use Restriction Information

Appendix D-Waste Disposition Documentation

Appendix E-Field Photographs

Distribution List

This report was developed using information and guidance from the following documents:

- Streamlined Approach for Environmental Restoration Plan for Corrective Action Unit 398: Area 25 Spill Sites, Nevada Test Site, Nevada, (DOE/NV, 2001).

- $\quad$ Field Management Plan for Corrective Action Unit 398: Area 25 Spill Sites, Nevada Test Site, Nevada (Bechtel Nevada [BN], 2002a).

- Site Specific Health and Safety Plan for Corrective Action Unit 398: Area 25 Spill Sites, Nevada Test Site, (BN, 2002b). 


\subsection{CLOSURE ACTIVITIES}

This section details the specific corrective action activities completed during the closure of CAU 398: Area 25 Spill Sites. Copies of the analytical data for all collected soil verification samples are included in Appendix B, and copies of the CAU Use Restriction Information forms are included in Appendix C.

\subsection{DESCRIPTION OF CORRECTIVE ACTION ACTIVITIES}

\subsubsection{Preplanning and Site Preparation}

Closure of CAU 398 was completed using the NDEP-approved Streamlined Approach for Environmental Restoration Plan for Corrective Action Unit 398: Area 25 Spill Sites, Nevada Test Site, Nevada, Revision 0, (DOE/NV, 2001). Prior to beginning closure activities, the following prefield activities were completed:

- Preparation of a National Environmental Policy Act documentation (checklist).

- Preparation of the Field Management Plan for Corrective Action Unit 398: Area 25 Spill Sites, Nevada Test Site, Nevada, (BN, 2002a).

- Preparation of the Site-Specific Health and Safety Plan for Corrective Action Unit 398: Area 25 Spill Sites, Nevada Test Site, (BN, 2002b).

- Preparation of the U.S. Department of Energy, National Nuclear Security Administration Nevada Operations Office (NNSA/NV) Real Estate/Operations Permit.

The following is the scope of the closure actions implemented for CAU 398.

\subsubsection{Waste Characterization}

Site preliminary assessments were performed by the International Technology Corporation. Waste classification samples were collected and analyzed by BN personnel and the results are presented in the CAU 398 SAFER Plan (DOE/NV, 2001). Table 1 shows the analyses that were conducted for waste classification samples, the results of these analyses, and the resulting waste classification.

Additional waste classification samples for PCBs and Resource Conservation and Recovery Act (RCRA) metals were collected at CAS 25-25-04 and CAS 25-25-05 on April 03, 2002, to determine lateral extent of contamination and to better define and reduce the area of excavation and, hence, to reduce the volume of waste generated.

Approximately 245 cubic meters $\left(\mathrm{m}^{3}\right)$ ( 320 cubic yards [yd $\left.\left.{ }^{3}\right]\right)$ of impacted soil was excavated from the seven clean closed CASs from April 23 to June 28, 2002. 
TABLE 1 - SUMMARY OF CAU 398 WASTE CHARACTERIZATION SAMPLES

\begin{tabular}{|c|c|c|c|c|}
\hline CAS & $\begin{array}{l}\text { SAMPLE } \\
\text { TYPE }\end{array}$ & ANALYSIS & $\begin{array}{l}\text { ANALYTICAL } \\
\text { RESULTS }\end{array}$ & $\begin{array}{l}\text { WASTE } \\
\text { TYPE }\end{array}$ \\
\hline $25-44-01$ & Soil & $\begin{array}{l}\text { TPH }^{a}, \text { TCLP }^{b} \text { RCRA }^{c} \text { Metals, and } \\
\text { gamma spectroscopy }\end{array}$ & $\begin{array}{l}\text { All analyses lower than } \\
\text { action levels }\end{array}$ & Sanitary \\
\hline $25-44-02$ & Soil & $\begin{array}{l}\text { TPH, TCLP RCRA Metals, and } \\
\text { gamma spectroscopy }\end{array}$ & $\begin{array}{l}\text { TPH higher than action } \\
\text { level }\end{array}$ & Hydrocarbon \\
\hline $25-44-03$ & Soil & $\begin{array}{l}\text { TPH, TCLP RCRA Metals, } \\
\text { PCBs }^{\mathrm{d}} \text {, and gamma spectroscopy }\end{array}$ & $\begin{array}{l}\text { TPH higher than action } \\
\text { level }\end{array}$ & Hydrocarbon \\
\hline $\begin{array}{c}25-44-04 \\
\text { (from CAS } \\
25-01-01 \text { ) }\end{array}$ & Soil & $\mathrm{pH}$, and gamma spectroscopy & $\begin{array}{l}\text { All analyses lower than } \\
\text { action levels }\end{array}$ & No further action \\
\hline $25-25-02$ & Soil & $\begin{array}{l}\text { TPH, TCLP RCRA Metals, } \\
\text { TCLP SVOCs }{ }^{c} \text { PCBs, and } \\
\text { gamma spectroscopy }\end{array}$ & $\begin{array}{l}\text { TPH and PCBs higher } \\
\text { than action level }\end{array}$ & $\begin{array}{l}\text { Hydrocarbon and } \\
\text { Polychlorinated } \\
\text { Biphenyls }\end{array}$ \\
\hline $25-25-03$ & Soil & TPH, and gamma spectroscopy & $\begin{array}{l}\text { TPH higher than action } \\
\text { level }\end{array}$ & Hydrocarbon \\
\hline $25-25-04$ & Soil & $\begin{array}{l}\text { TPH, TCLP RCRA Metals, } \\
\text { TCLP VOCs } \mathrm{f} \text {, TCLP SVOCs, } \\
\text { PCBs, and gamma spectroscopy }\end{array}$ & $\begin{array}{l}\text { TPH, RCRA Metals, and } \\
\text { PCBs higher than action } \\
\text { level }\end{array}$ & $\begin{array}{l}\text { Hydrocarbon, } \\
\text { Polychlorinated } \\
\text { Biphenyls, Lead, } \\
\text { and Cadmium }\end{array}$ \\
\hline $25-25-05$ & Soil & $\begin{array}{l}\text { TPH, TCLP RCRA Metals, } \\
\text { TCLP VOCs, TCLP SVOCs, } \\
\text { PCBs, and gamma spectroscopy }\end{array}$ & $\begin{array}{l}\text { TPH, and RCRA Metals } \\
\text { higher than action level }\end{array}$ & $\begin{array}{l}\text { Hydrocarbon and } \\
\text { Cadmium }\end{array}$ \\
\hline $25-25-06$ & Soil & TPH, and gamma spectroscopy & $\begin{array}{l}\text { All analyses lower than } \\
\text { action levels }\end{array}$ & No further action \\
\hline $25-25-07$ & Soil & $\begin{array}{l}\text { TPH, PCBs, and gamma } \\
\text { spectroscopy }\end{array}$ & $\begin{array}{l}\text { TPH higher than action } \\
\text { level }\end{array}$ & Hydrocarbon \\
\hline $25-25-08$ & Soil & $\begin{array}{l}\text { TPH, PCBs, and ganma } \\
\text { spectroscopy }\end{array}$ & $\begin{array}{l}\text { TPH higher than action } \\
\text { level }\end{array}$ & Hydrocarbon \\
\hline $\begin{array}{l}25-25-16 \\
\text { (from CAS } \\
25-01-02)\end{array}$ & Soil & $\mathrm{TPH}$, and gamma spectroscopy & $\begin{array}{l}\text { TPH higher than action } \\
\text { level }\end{array}$ & Hydrocarbon \\
\hline $25-25-17$ & Soil & $\begin{array}{l}\text { TPH, TCLP RCRA Metals, } \\
\text { TCLP SVOCs, PCBs, and gamma } \\
\text { spectroscopy }\end{array}$ & $\begin{array}{l}\text { TPH higher than action } \\
\text { level }\end{array}$ & Hydrocarbon \\
\hline $\begin{array}{l}\text { TPH - Total } \\
\text { 1996). } \\
\text { TCLP - Tox } \\
\text { RCRA - Res } \\
\text { PCBs - Poly } \\
\text { SVOCs - Se }\end{array}$ & $\begin{array}{l}\text { Petroleum Hyd } \\
\text { icity Character } \\
\text { ource Conserv } \\
\text { chlorinated Bir } \\
\text { mivolatile Org }\end{array}$ & $\begin{array}{l}\text { ocarbons, by SW-846 } 8015 \text { modifie } \\
\text { tic Leaching Procedure, sample pre } \\
\text { tion and Recovery Act metals by SV } \\
\text { henyls, by SW- } 8468082 \text { (EPA, } 199 \\
\text { nic Compounds, by SW-846 } 8270 \text { ( } \\
\text { mpounds, by SW-846 } 8260 \text { (EPA, }\end{array}$ & $\begin{array}{l}\text { (U.S. Environmental Prot } \\
\text { aration method SW-846 } \\
-8466010 \mathrm{~B} \text { and } 7471 \mathrm{~A} \text { (E) } \\
\text { PA, 1996). }\end{array}$ & $\begin{array}{l}\text { ction Agency [EPA] } \\
1 \text { (EPA, 1996). } \\
\text { A, 1996). }\end{array}$ \\
\hline
\end{tabular}




\subsubsection{Closure Activities}

CAS 25-44-01, Fuel Spill (Figure 2). This site is described as a fuel spill on soil that covers a concrete pad. The origins and use of the spilled material are unknown, although the material is suspected of being railroad bedding material. Analytical results for characterization samples showed no COCs present above action levels (DOE/NV, 2001).

As a best management practice the railroad bedding material and construction debris were removed from the site on April 4, 2002. The debris was placed into an end dump and transported to the NTS Area 9 U10c Landfill for disposal. Waste disposition documentation is included in Appendix D and photographs documenting the site closure activities in Appendix E. No further action was required at this site.

CAS 25-44-02, Spill (Figure 3). This site consisted of a historic spill to soil from leaking drums. The source of the drums is unknown. The drums were removed from the site and disposed of prior to this corrective action. Analytical results for characterization samples showed TPH as the only COC present above action levels (DOE/NV, 2001). This site was clean closed by excavation and disposal of TPH-impacted soil.

TPH-impacted soil was excavated and transported to the NTS Area 6 Hydrocarbon Landfill for disposal on May 15-20, 2002. Soil verification samples (254402-1, 254402-2, 254402-3, $254402-4,254402-5,254402-6$ ) were collected from the excavation on May 20, 2002, and analyzed for TPH. Results showed TPH levels less than the action level of 100 milligrams per kilogram ( $\mathrm{mg} / \mathrm{kg}$ ) (NAC, 2002b), verifying that the site was clean closed. The excavation was then backfilled with clean fill and wheel rolled with heavy equipment on June 18, 2002. Analytical results for the verification samples are summarized in Table 2 and are included in Appendix B. Waste disposition documentation is included in Appendix D and photographs documenting the site closure activities in Appendix E.

CAS 25-44-03, Spill (Figure 4). This site consisted of a spill from leaking drums onto a concrete pad and surrounding soil. The drums were removed prior to this corrective action. Analytical results for characterization samples showed TPH as the only COC present above action levels (DOE/NV, 2001). This site was clean closed by excavation and disposal of TPH-impacted soil.

TPH-impacted soil was excavated and transported to the NTS Area 6 Hydrocarbon Landfill for disposal on April 24-30, 2002. Soil verification samples (254403-1, 254403-2, 254403-3, 254403-4, 254403-5, 254403-6, 254403-7) were collected on May 7, 2002, and analyzed for TPH. Results showed TPH concentrations less than the action level $(100 \mathrm{mg} / \mathrm{kg})(\mathrm{NAC}, 2002 \mathrm{~b})$, verifying that the site was clean closed. The excavation was then backfilled with clean fill and wheel rolled with heavy equipment on May 28, 2002. Analytical results for the verification samples are summarized in Table 2 and are included in Appendix B. Waste disposition documentation is included in Appendix D and photographs documenting the site closure activities in Appendix E.

CAS 25-44-04, Acid Spill (from CAS 25-01-01). This site consisted of spills from two tanks used for a water demineralization process. Tank T-2002 contained sodium hydroxide and Tank T-2003 contained sulfuric acid. The tanks were removed from the site prior to this corrective action (DOE/NV, 1998). Analytical results for characterization samples showed no evidence of 


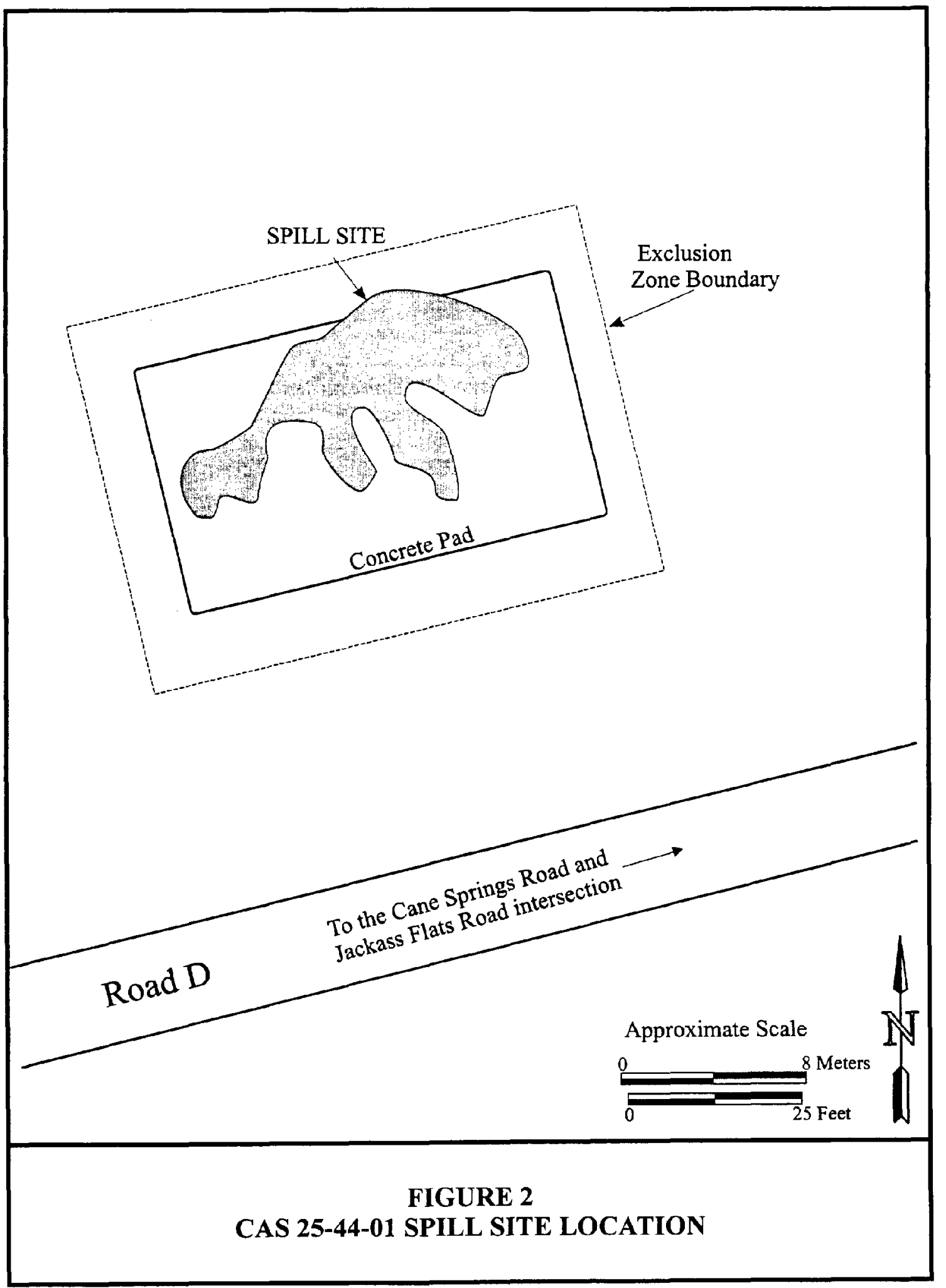




\section{TEST CELL A}

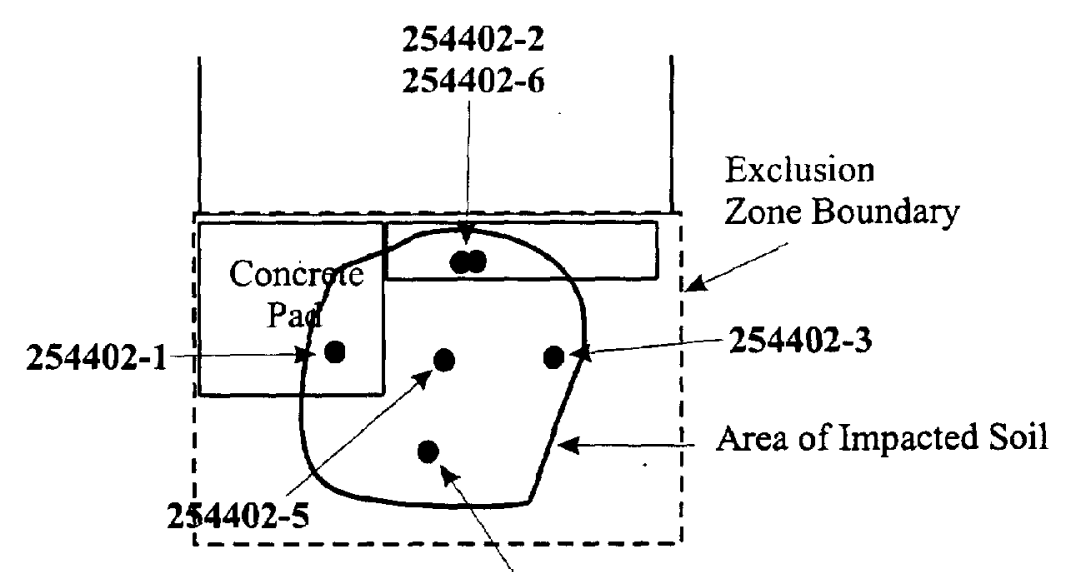

254402-4

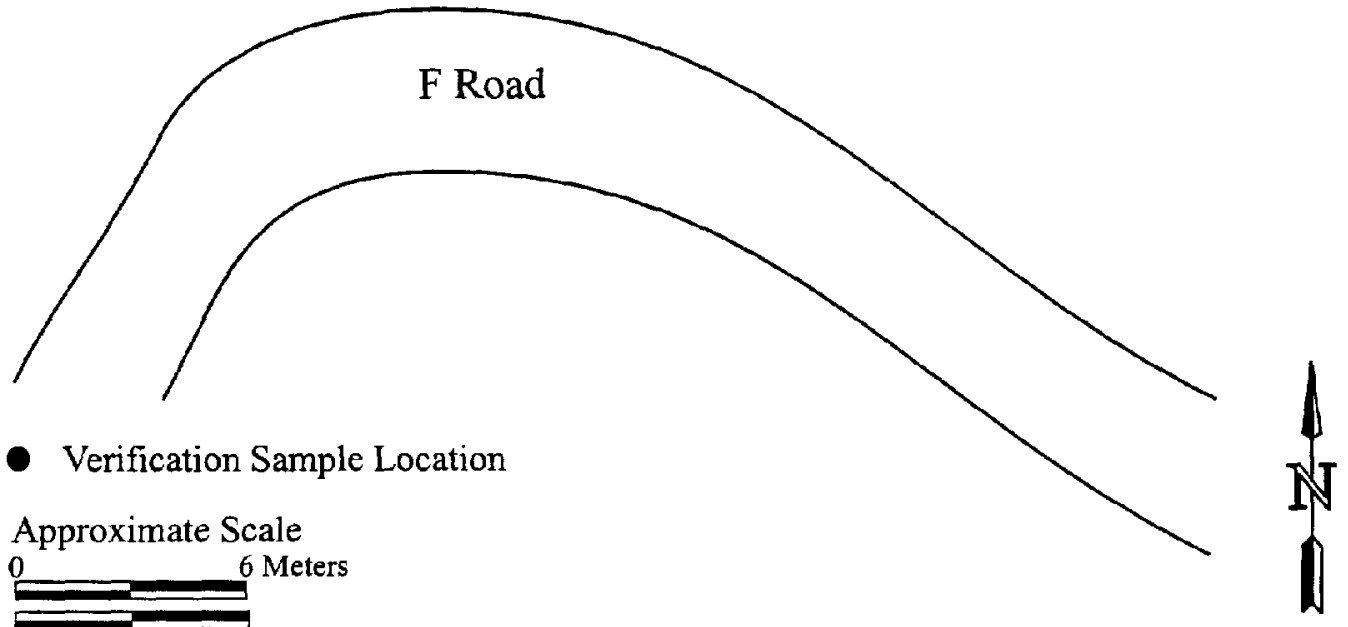

20 Feet

FIGURE 3

CAS 25-44-02 VERIFICATION SAMPLE LOCATIONS 


\section{TEST CELL C}

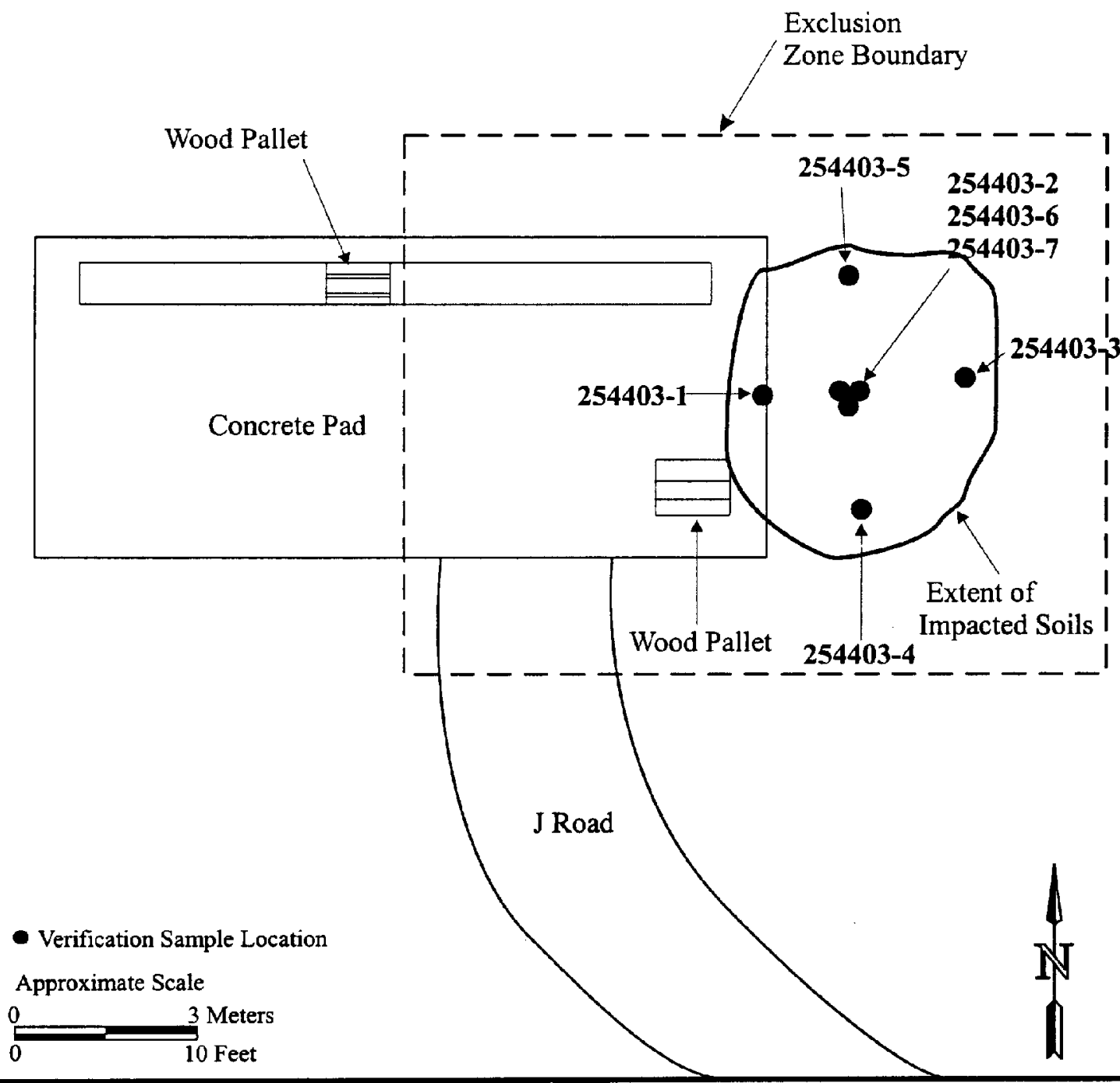

FIGURE 4

CAS 25-44-03 VERIFICATION SAMPLE LOCATIONS 
TABLE 2 - SUMMARY OF ANALYTICAL RESULTS FOR TOTAL PETROLEUM HYDROCARBONS, POLYCHLORINATED BIPHENYLS, AND RCRA METALS IN VERIFICATION SAMPLES

\begin{tabular}{|c|c|c|c|c|c|c|c|}
\hline $\begin{array}{c}\text { SAMPLE } \\
\text { IDENTIFICATION }\end{array}$ & $\begin{array}{l}\text { GASOLINE } \\
\text { RANGE } \\
\text { (mg/kg) }\end{array}$ & $\begin{array}{l}\text { DIESEL } \\
\text { RANGE' }^{\mathrm{b}} \\
\text { (mg/kg) }\end{array}$ & $\begin{array}{c}\text { OIL } \\
\text { RANGE }^{b} \\
(\mathbf{m g} / \mathbf{k g})\end{array}$ & $\begin{array}{c}\text { TOTAL } \\
\text { PETROLEUM } \\
\text { HYDROCARBONS } \\
\text { HY } \\
\text { (mg/kg) } \\
\end{array}$ & $\begin{array}{l}\text { POLYCHLORINATED } \\
\text { BIPHENYLS } \\
(\mathbf{m g} / \mathbf{k g})\end{array}$ & $\begin{array}{l}\text { LEADe } \\
(\mathbf{m g} / \mathbf{k g})\end{array}$ & $\begin{array}{l}\text { CADMIUM } \\
\text { (mg/kg) }\end{array}$ \\
\hline Action Levels & $100^{T}$ & $100^{\prime}$ & $100^{f}$ & $100^{f}$ & $1^{8}$ & $750^{\mathrm{h}} \mathrm{mg} / \mathrm{kg}$ & $450^{\mathrm{h}} \mathrm{mg} / \mathrm{kg}$ \\
\hline \multicolumn{8}{|c|}{ CAS 25-44-02 (Sample Delivery Group 1596) } \\
\hline $254402-1$ & $N^{i}$ & ND & ND & ND & $\mathrm{NS}^{\mathrm{j}}$ & NS & NS \\
\hline $254402-2$ & ND & ND & ND & ND & NS & NS & NS \\
\hline $254402-3$ & ND & ND & ND & ND & NS & NS & $\mathrm{NS}$ \\
\hline $254402-4$ & ND & ND & ND & ND & NS & NS & NS \\
\hline $254402-5$ & ND & ND & ND & ND & NS & NS & NS \\
\hline $254402-6$ & ND & ND & ND & ND & NS & NS & NS \\
\hline \multicolumn{8}{|c|}{ CAS 25-44-03 (Sample Delivery Group 1580) } \\
\hline $254403-1$ & ND & ND & ND & ND & NS & NS & NS \\
\hline $254403-2$ & ND & ND & ND & ND & NS & NS & NS \\
\hline $254403-3$ & ND & ND & ND & ND & NS & NS & NS \\
\hline $254403-4$ & ND & ND & $\mathrm{ND}$ & ND & NS & NS & NS \\
\hline 254403-5 & ND & $\mathrm{ND}$ & ND & ND & NS & NS & NS \\
\hline $254403-6$ & ND & ND & ND & ND & NS & NS & NS \\
\hline $254403-7$ & $\mathrm{ND}$ & $\mathrm{ND}$ & ND & ND & NS & NS & NS \\
\hline \multicolumn{8}{|c|}{ CAS 25-25-02 (Sample Delivery Group V1596 and V1627) } \\
\hline $252502-1$ & ND & ND & ND & ND & 0.870 and 0.630 & NS & NS \\
\hline $252502-2$ & ND & ND & $\mathrm{ND}$ & ND & 2.6 & NS & NS \\
\hline $252502-3$ & ND & $\mathrm{ND}$ & ND & $\mathrm{ND}$ & 54.0 & NS & $\mathrm{NS}$ \\
\hline $252502-4$ & ND & $\mathrm{ND}$ & ND & $\mathrm{ND}$ & 0.190 and 0.140 & $\mathrm{NS}$ & NS \\
\hline $252502-5$ & ND & ND & ND & ND & 0.120 and 0.240 & NS & $\mathrm{NS}$ \\
\hline $252502-1^{*}$ & NS & NS & NS & NS & 0.960 & NS & NS \\
\hline $252502-2^{*}$ & NS & NS & NS & NS & 0.430 & NS & $\mathrm{NS}$ \\
\hline $252502-3^{*}$ & NS & NS & NS & NS & 0.064 & NS & NS \\
\hline $252502-4^{*}$ & NS & NS & NS & NS & 0.590 & NS & $\mathrm{NS}$ \\
\hline $252502-5^{*}$ & NS & NS & NS & NS & 0.480 & NS & NS \\
\hline
\end{tabular}


TABLE 2 - SUMMARY OF ANALYTICAL RESULTS FOR TOTAL PETROLEUM HYDROCARBONS, POLYCHLORINATED BIPHENYLS, AND RCRA ${ }^{2}$ METALS IN VERIFICATION SAMPLES (continued)

\begin{tabular}{|c|c|c|c|c|c|c|c|}
\hline $\begin{array}{c}\text { SAMPLE } \\
\text { IDENTIFICATION }\end{array}$ & $\begin{array}{c}\text { GASOLINE } \\
\text { RANGE }^{\mathbf{b}} \\
(\mathbf{m g} / \mathbf{k g})^{\mathbf{c}}\end{array}$ & $\begin{array}{c}\text { DIESEL } \\
\text { RANGE }^{\mathbf{b}} \\
(\mathbf{m g} / \mathbf{k g})\end{array}$ & $\begin{array}{c}\text { OIL } \\
\text { RANGE' } \\
\text { (mg/kg) }\end{array}$ & $\begin{array}{c}\text { TOTAL } \\
\text { PETROLEUM } \\
\text { HYDROCARBONS } \\
\text { (mg/kg) }\end{array}$ & $\begin{array}{l}\text { POLYCHLORINATED } \\
\text { BIPHENYLS } \\
\text { (mg/kg) }\end{array}$ & $\begin{array}{l}\mathbf{L E A D} \mathbf{D}^{\mathbf{2}} \\
(\mathrm{mg} / \mathbf{k g})\end{array}$ & $\begin{array}{c}\text { CADMIUM } \\
\text { (mg/kg) }\end{array}$ \\
\hline Action Levels & 100 & 100 & 100 & 100 & 1 & $750 \mathrm{mg} / \mathrm{kg}$ & $450 \mathrm{mg} / \mathrm{kg}$ \\
\hline \multicolumn{8}{|c|}{ CAS 25-25-03 (Sample Delivery Group 1565) } \\
\hline $252503-1$ & ND & ND & ND & ND & NS & NS & NS \\
\hline $252503-2$ & ND & ND & ND & ND & NS & NS & NS \\
\hline $252503-3$ & ND & ND & ND & ND & NS & NS & NS \\
\hline $252503-4$ & ND & NS & ND & ND & NS & NS & NS \\
\hline $252503-5$ & ND & 57 & 530 & 590 & NS & NS & NS \\
\hline $252503-1^{*}$ & ND & ND & ND & ND & NS & NS & NS \\
\hline \multicolumn{8}{|c|}{ CAS 25-25-04 (Sample Delivery Group V1581, V1609 and V1815) } \\
\hline $252504-1 \mathrm{~W}$ & ND & ND & ND & ND & ND & ND & ND \\
\hline $252504-2 \mathrm{~W}$ & ND & ND & ND & ND & ND & ND & ND \\
\hline $252504-3 \mathrm{~W}$ & ND & $\mathrm{ND}$ & ND & ND & 0.045 & ND & ND \\
\hline $252504-4 \mathrm{~W}$ & ND & ND & ND & ND & ND & ND & ND \\
\hline $252504-5 \mathrm{~W}$ & ND & ND & $\mathrm{ND}$ & ND & ND & ND & ND \\
\hline $252504-1 \mathrm{E}$ & ND & ND & ND & ND & ND & ND & $0.012 \mathrm{mg} / \mathrm{L}^{\mathrm{k}}$ \\
\hline 252504-2E & ND & ND & ND & ND & 0.029 & ND & ND \\
\hline 252504-3E & ND & ND & ND & ND & ND & ND & $0.012 \mathrm{mg} / \mathrm{L}$ \\
\hline $252504-4 \mathrm{E}$ & ND & ND & ND & ND & ND & ND & ND \\
\hline $252504-5 \mathrm{E}$ & ND & ND & ND & ND & ND & ND & ND \\
\hline $252504-1^{*}$ & ND & ND & ND & ND & NS & NS & NS \\
\hline $252504-2^{*}$ & ND & ND & ND & ND & NS & NS & NS \\
\hline $252504-3^{*}$ & ND & ND & ND & ND & NS & NS & NS \\
\hline $252504-4^{*}$ & ND & ND & ND & ND & NS & NS & NS \\
\hline $252504-5^{*}$ & ND & ND & ND & $\mathrm{ND}$ & NS & NS & NS \\
\hline $252504-6^{*}$ & ND & NI) & ND & ND & NS & NS & NS \\
\hline $252504-7^{*}$ & NI) & NI) & NI) & ND & NS & NS & NS \\
\hline $252504-8^{*}$ & NII & $\mathrm{NII}$ & NI) & ND & NS & NS & NS \\
\hline $252504-9 *$ & $\sqrt{11}$ & $\mathrm{NT}$ & Nin & ND) & NS & NS & NS \\
\hline $252504-10^{*}$ & Si) & (11) & NII & NI) & NS & NS & NS \\
\hline
\end{tabular}


TABLE 2 - SUMMARY OF ANALYTICAL RESULTS FOR TOTAL PETROLEUM HYDROCARBONS,

POLYCHLORINATED BIPHENYLS, AND RCRA² METALS IN VERIFICATION SAMPLES (continued)

\begin{tabular}{|c|c|c|c|c|c|c|c|}
\hline $\begin{array}{c}\text { SAMPLE } \\
\text { IDENTIFICATION }\end{array}$ & $\begin{array}{l}\text { GASOLINE } \\
\text { RANGE }^{\mathbf{b}} \\
(\mathrm{mg} / \mathrm{kg})^{\mathrm{c}}\end{array}$ & $\begin{array}{c}\text { DIESEL } \\
\text { RANGE }^{b} \\
(\mathbf{m g} / \mathbf{k g})\end{array}$ & $\begin{array}{c}\text { OIL } \\
\text { RANGE }^{b} \\
(\mathrm{mg} / \mathrm{kg})\end{array}$ & $\begin{array}{c}\text { TOTAL } \\
\text { PETROLEUM } \\
\text { HYDROCARBONS } \\
(\mathbf{m g} / \mathbf{k g})\end{array}$ & $\begin{array}{c}\text { POLYCHLORINATED } \\
\text { BIPHENYLS }{ }^{\mathbf{d}} \\
(\mathrm{mg} / \mathrm{kg})\end{array}$ & $\begin{array}{l}\text { LEADe } \\
(\mathrm{mg} / \mathrm{kg})\end{array}$ & $\begin{array}{c}\text { CADMIUM' } \\
(\mathrm{mg} / \mathrm{kg})\end{array}$ \\
\hline Action Levels & 100 & 100 & 100 & 100 & 1 & $750 \mathrm{mg} / \mathrm{kg}$ & $450 \mathrm{mg} / \mathrm{kg}$ \\
\hline $252504-11^{*}$ & $\mathrm{ND}$ & ND & ND & ND & NS & NS & NS \\
\hline $252504-12^{*}$ & ND & ND & $\mathrm{ND}$ & ND & NS & NS & NS \\
\hline $252504-\mathrm{V} 1$ & NS & NS & NS & NS & NS & 5.1 & ND \\
\hline $252504-\mathrm{V} 2$ & NS & NS & NS & NS & NS & 3.6 & ND \\
\hline $252504-V 3$ & NS & NS & NS & NS & NS & 4.0 & ND \\
\hline $252504-V 4$ & NS & NS & $\mathrm{NS}$ & NS & $\mathrm{NS}$ & 4.7 & ND \\
\hline $252504-\mathrm{V} 5$ & NS & NS & $\mathrm{NS}$ & NS & NS & 4.1 & ND \\
\hline 252504-V6 & NS & NS & NS & NS & NS & 4.8 & ND \\
\hline 252504-V7 & $\mathrm{NS}$ & NS & NS & NS & NS & 3.5 & ND \\
\hline 252504-V8 & NS & NS & NS & NS & NS & 4.5 & ND \\
\hline 252504-V9 & NS & NS & NS & NS & NS & 4.1 & ND \\
\hline $252504-\mathrm{V} 10$ & NS & NS & NS & NS & NS & 4.6 & NI) \\
\hline $252504-\mathrm{V} 11$ & NS & NS & NS & NS & NS & 5.8 & 0.05 \\
\hline \multicolumn{8}{|c|}{ CAS 25-25-05 (Sample Delivery Group V1581 and V1815) } \\
\hline $252505-1$ & ND & ND & ND & ND & NS & NS & NS \\
\hline $252505-2$ & ND & ND & 68 & 68 & NS & NS & $\mathrm{NS}$ \\
\hline $252505-3$ & ND & ND & ND & ND & NS & NS & $\mathrm{NS}$ \\
\hline $252505-4$ & ND & ND & $\mathrm{ND}$ & ND & NS & NS & NS \\
\hline $252505-5$ & ND & 46 & ND & 46 & NS & NS & ND \\
\hline $252505-6$ & ND & $\mathrm{ND}$ & ND & ND & NS & NS & ND \\
\hline $252505-7$ & ND & ND & ND & ND & NS & $\mathrm{NS}$ & ND \\
\hline $252505-8$ & ND & ND & ND & ND & NS & $\mathrm{NS}$ & ND \\
\hline $252505-9$ & ND & ND & ND & ND & NS & $\mathrm{NS}$ & ND \\
\hline $252505-10$ & ND & ND & ND & ND & $\mathrm{NS}$ & $\mathrm{NS}$ & ND \\
\hline $252505-\mathrm{V} 1$ & NS & NS & NS & NS & NS & 4.6 & ND \\
\hline $252505-\mathrm{V} 2$ & $\mathrm{NS}$ & NS & NS & NS & $\mathrm{NS}$ & 5.3 & 0.05 \\
\hline 252505-V3 & NS & NS & NS & NS & NS & 4.6 & 0.04 \\
\hline $252505-\mathrm{V} 4$ & NS & NS & NS & NS & $\mathrm{NS}$ & 4.3 & $\mathrm{ND}$ \\
\hline
\end{tabular}


TABLE 2 - SUMMARY OF ANALYTICAL RESULTS FOR TOTAL PETROLEUM HYDROCARBONS, POLYCHLORINATED BIPHENYLS, AND RCRA ${ }^{2}$ METALS IN VERIFICATION SAMPLES (continued)

\begin{tabular}{|c|c|c|c|c|c|c|c|}
\hline $\begin{array}{c}\text { SAMPLE } \\
\text { IDENTIFICATION }\end{array}$ & $\begin{array}{c}\text { GASOLINE } \\
\text { RANGE }^{\mathbf{b}} \\
\text { (mg/kg) }^{\mathbf{c}}\end{array}$ & $\begin{array}{c}\text { DIESEL } \\
\text { RANGE }^{\mathbf{b}} \\
(\mathbf{m g} / \mathbf{k g})\end{array}$ & $\begin{array}{c}\text { OIL } \\
\text { RANGE }^{b} \\
(\mathbf{m g} / \mathbf{k g})\end{array}$ & $\begin{array}{c}\text { TOTAL } \\
\text { PETROLEUM } \\
\text { HYDROCARBONS } \\
(\mathbf{m g} / \mathbf{k g})\end{array}$ & $\begin{array}{c}\text { POLYCHLORINATED } \\
\text { BIPHENYLS } \\
\text { (mg/kg) }\end{array}$ & $\begin{array}{l}\text { LEADe } \\
(\mathrm{mg} / \mathbf{k g})\end{array}$ & $\begin{array}{c}\text { CADMIUM } \\
(\mathrm{mg} / \mathrm{kg})\end{array}$ \\
\hline Action Levels & 100 & 100 & 100 & 100 & 1 & $750 \mathrm{mg} / \mathrm{kg}$ & $450 \mathrm{mg} / \mathrm{kg}$ \\
\hline $252505-V 5$ & NS & NS & NS & NS & NS & 5.1 & 0.04 \\
\hline $252505-\mathrm{V} 6$ & NS & NS & NS & NS & NS & 4.8 & 0.09 \\
\hline \multicolumn{8}{|c|}{ CAS 25-25-16 (from CAS 25-01-02) (Sample Delivery Group V1580) } \\
\hline $252516-1$ & ND & ND & ND & ND & NS & NS & NS \\
\hline $252516-2$ & ND & ND & ND & ND & $\mathrm{NS}$ & NS & NS \\
\hline $252516-3$ & ND & 17 & ND & 17 & NS & NS & NS \\
\hline $252516-4$ & ND & 16 & ND & 16 & NS & NS & NS \\
\hline $252516-5$ & ND & ND & 14 & 14 & NS & NS & NS \\
\hline
\end{tabular}

${ }^{2}$ RCRA - Resource Conservation and Recovery Act

b TPH - Total Petroleum Hydrocarbon full scan, gasoline, diesel, and waste oil by SW-846 8015 modified (EPA, 1996).

${ }^{\mathrm{C}} \mathrm{mg} / \mathrm{kg}$ - milligrams per kilogram.

dPCBs - Polychlorinated Biphenyls by SW-846 8082 (EPA, 1996).

'Total lead and cadmium by method SW-846 6010B (EPA, 1996).

${ }^{\mathrm{f}}$ Hydrocarbon action level of $100 \mathrm{mg} / \mathrm{kg}$ established by the State of Nevada (NAC, 2002b)

B PCB action level established by 40 Code of Federal Regulation Section 761.61 (EPA, 2001).

h Preliminary Remediation Goals used as action levels were established by U.S. EPA Region 9 (EPA, 2002)

${ }^{i}$ ND - Not Detected at the laboratory reporting limits.

${ }^{j}$ NS - Not Sampled.

${ }^{k} \mathrm{mg} / \mathrm{L}$ - milligrams per liter.

* Sample was collected from the excavation following the removal of additional soil. 
any COCs present above action levels (DOE/NV, 2001). This site was closed by taking no further action.

CAS 25-25-02, Oil Spill (Figures 5 and 6). This site consisted of an oil/fuel spill associated with leaking drums that had previously been removed. Analytical results for characterization samples showed TPH and PCBs as the COCs present at concentration greater than action levels (DOE/NV, 2001). This site was clean closed by excavation and removal of TPH- and PCBimpacted soil.

TPH- and PCB-impacted soil was excavated and transported to the NTS Area 6 Hydrocarbon Landfill for disposal on April 25 and 29, 2002. The NTS Area 6 Hydrocarbon Landfill permit allows disposal of soil contaminated with up to $10 \mathrm{mg} / \mathrm{kg}$ of PCB. Soil verification samples (252502-1, 252502-2, 252502-3, 252502-4, 252502-5) were collected on May 21, 2002, and submitted for TPH and PCB analysis. Results showed TPH levels less than action levels, but PCB levels above the action level of $1 \mathrm{mg} / \mathrm{kg}$ (U.S. Environmental Protection Agency [EPA], 2001 ) at two locations (252502-2 and 252502-3) at the bottom of the excavation. On June 5, 2002 , additional PCB-impacted soil was excavated from the bottom of the excavation and disposed of at the NTS Area 6 Hydrocarbon Landfill. A second set of soil verification samples (252502-1, 252502-2, 252502-3, 252502-4, 252502-5) were collected on June 17, 2002, from the bottom of the excavation. Results showed PCB levels less than the regulatory limit of $1 \mathrm{mg} / \mathrm{kg}$ (EPA, 2001), verifying that the site was clean closed. The excavation was then backfilled with clean fill and wheel rolled with heavy equipment on May 27, 2002. Analytical results for both sets of verification samples are summarized in Table 2 and are included in Appendix B. Waste disposition documentation is included in Appendix $\mathrm{D}$ and photographs documenting the site closure activities in Appendix E.

CAS 25-25-03, Oil Spills (Figure 7). This site consisted of a spill adjacent to an over-turned drum. The source of the drum is unknown and the drum was removed prior to this corrective action. Analytical results for characterization samples showed TPH as the only COC present (DOE/NV, 2001). This site was clean closed by excavation of TPH-impacted soil.

TPH-impacted soil was excavated and transported to the Area 6 Hydrocarbon Landfill for disposal on April 24, 2002. Verification soil samples (252503-1, 252503-2, 252503-3, 252503-4, 252503-5) were collected on April 24, 2002, and analyzed for TPH. Analytical results showed TPH levels greater than the action level at one location in the center of the bottom of the excavation. On May 14, 2002, excavation activities resumed at the site removing additional TPH-impacted soil. On May 21, 2002, and additional verification soil sample (252503-1) was collected from the center of the bottom of the expanded excavation. Analytical results showed TPH concentrations less than the action level of $100 \mathrm{mg} / \mathrm{kg}$ (NAC, 2002b), verifying that the site was clean closed. The excavation was then backfilled with clean fill and wheel rolled with heavy equipment on June 6,2002. Analytical results for the verification samples are summarized in Table 2 and are included in Appendix B. Waste disposition documentation is included in Appendix $\mathrm{D}$ and photographs documenting the site closure activities in Appendix E.

CAS 25-25-04, Oil Spills (Figures 8, 9 and 10). This site consisted of an area on the north side of the Engine Maintenance, Assembly, and Disassembly (E-MAD) facility, where used oils and cooling fluids from metal machining operations had been poured directly onto the ground. 


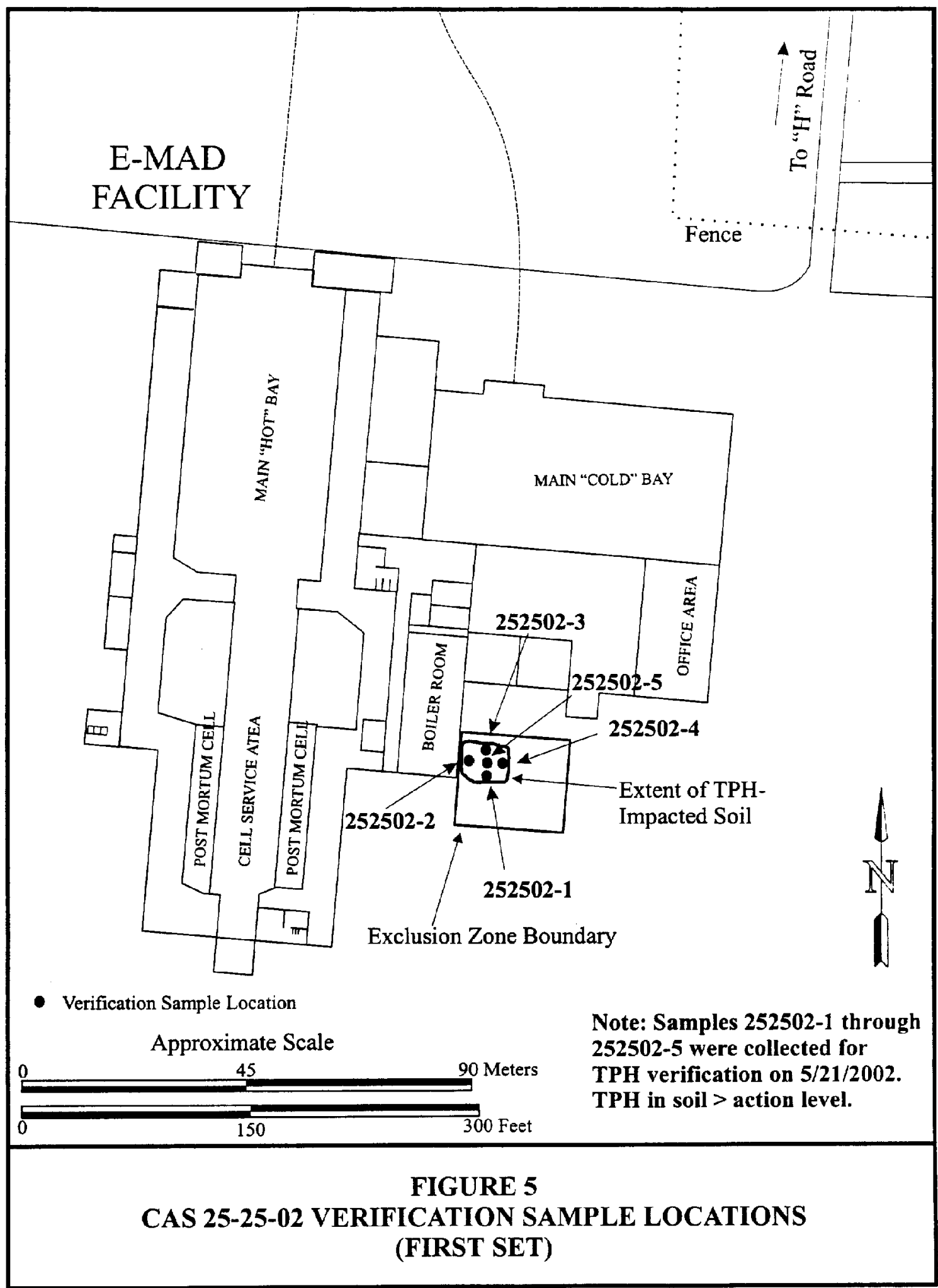




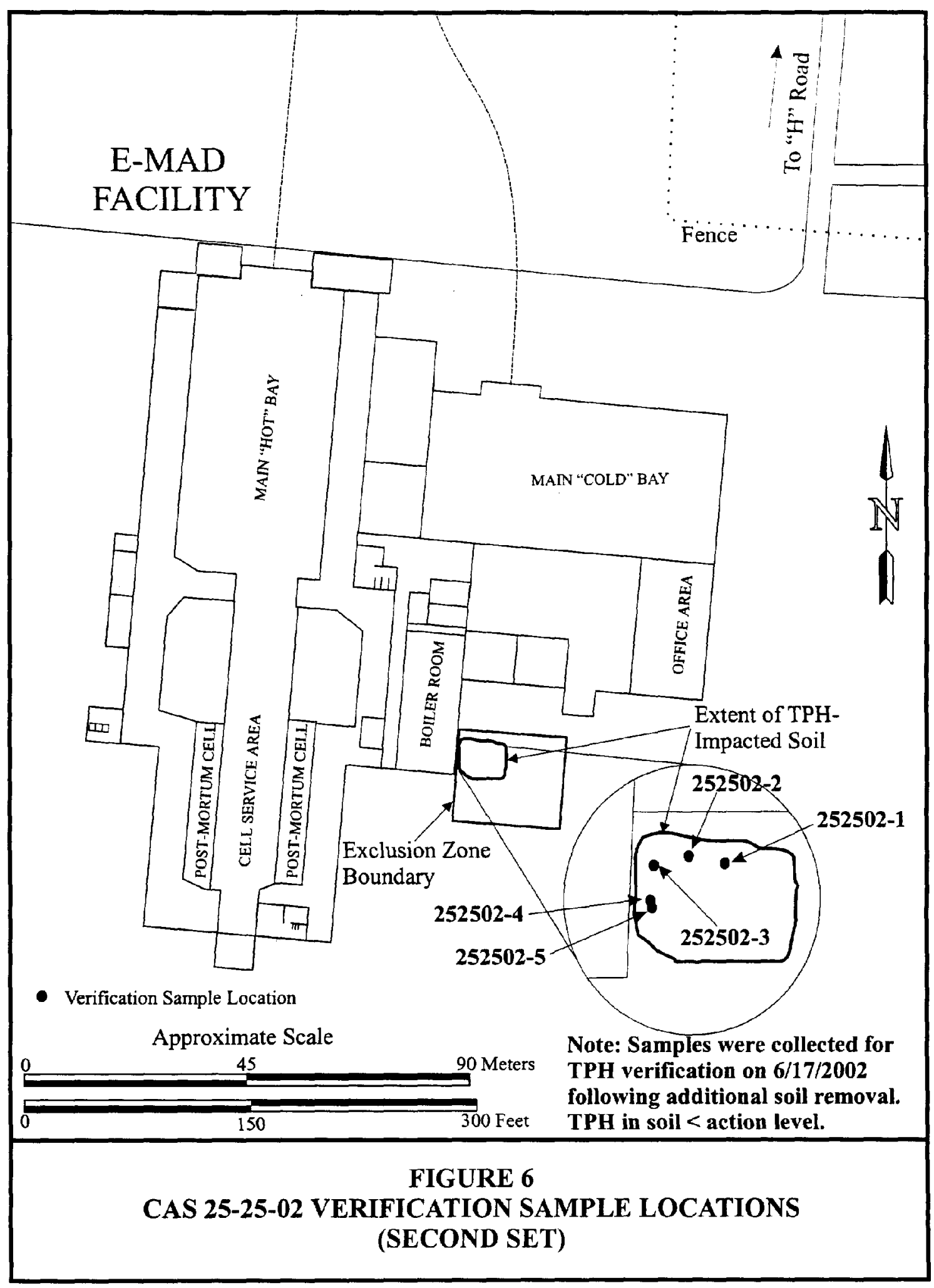




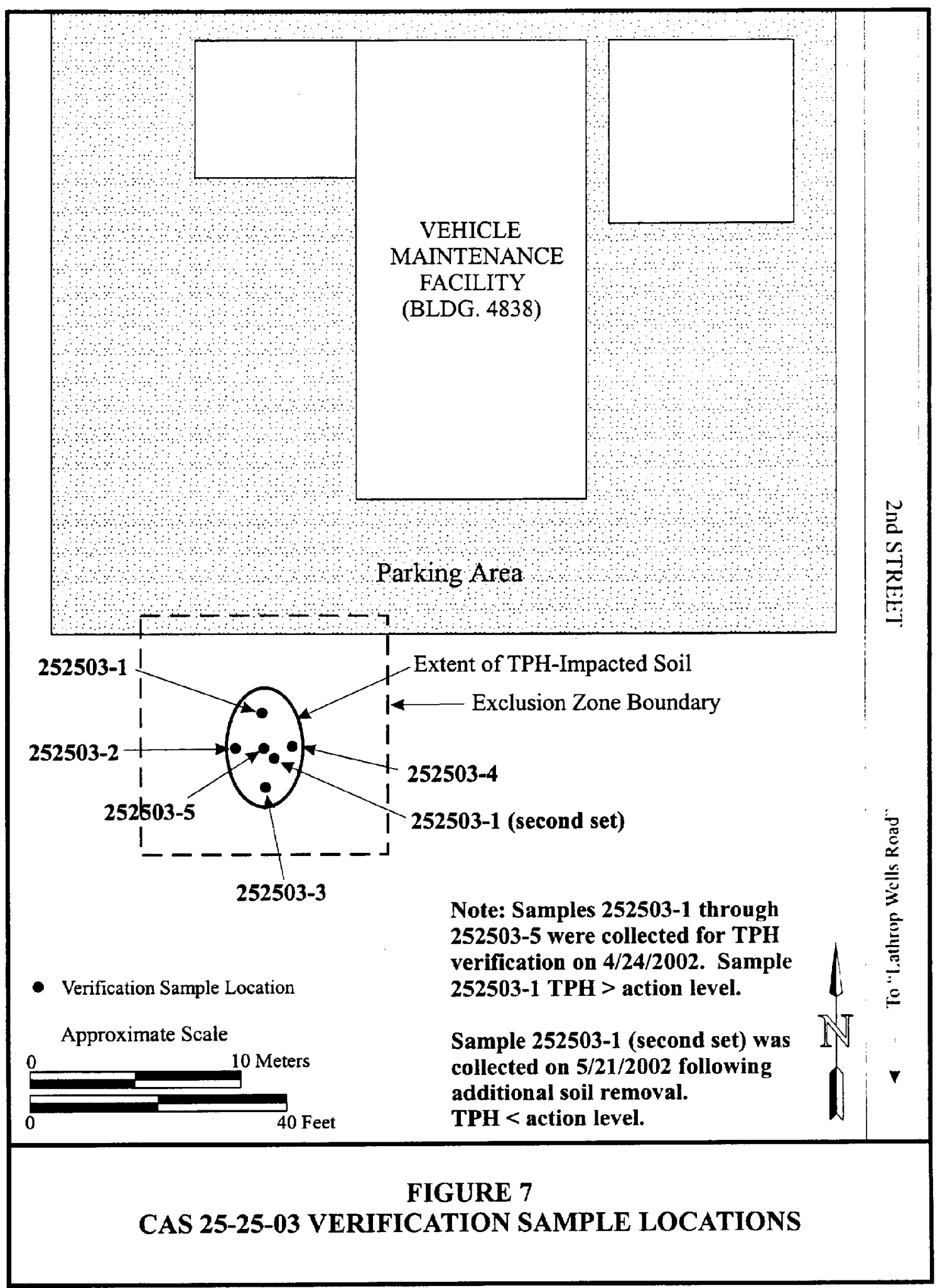




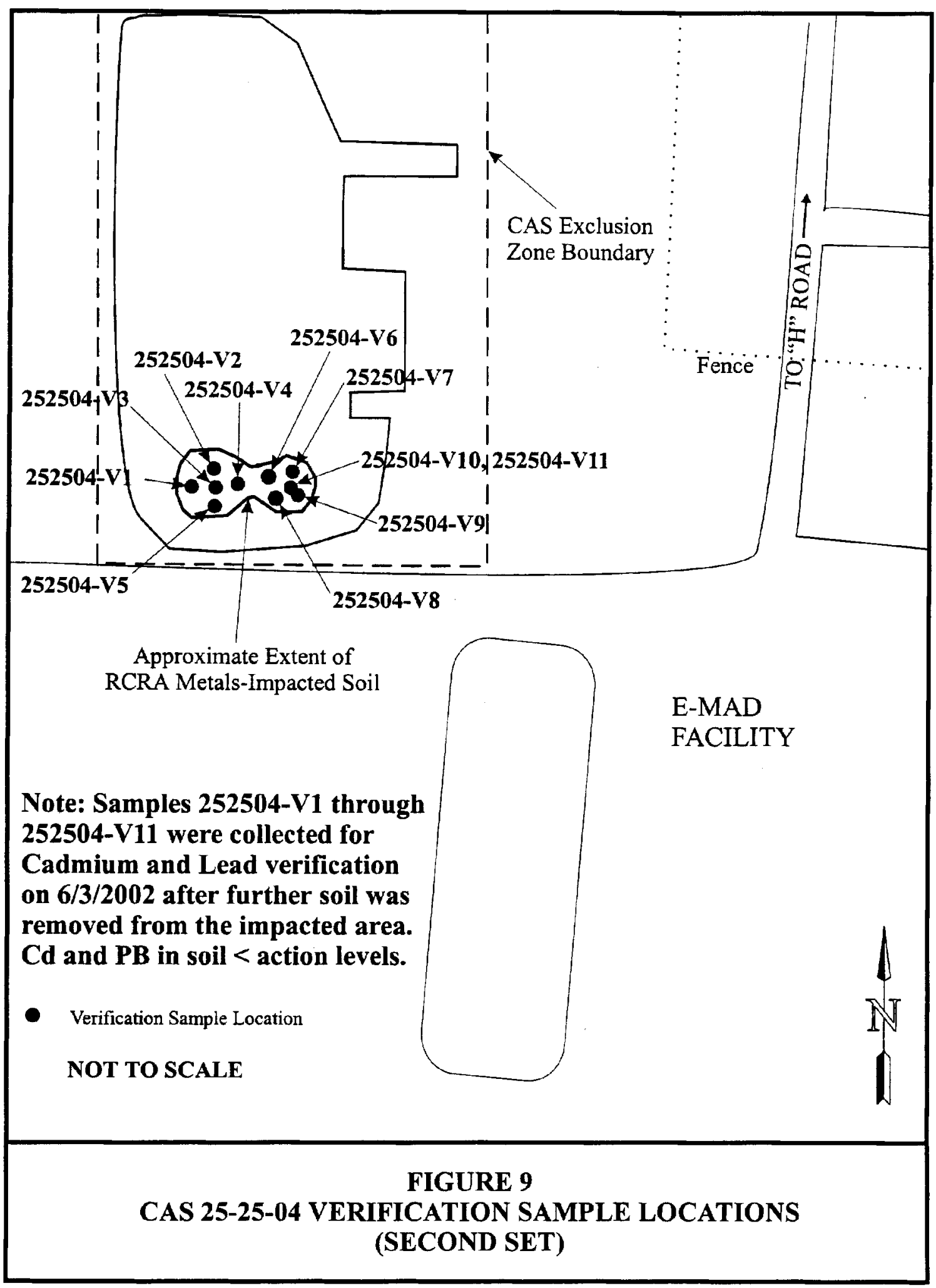



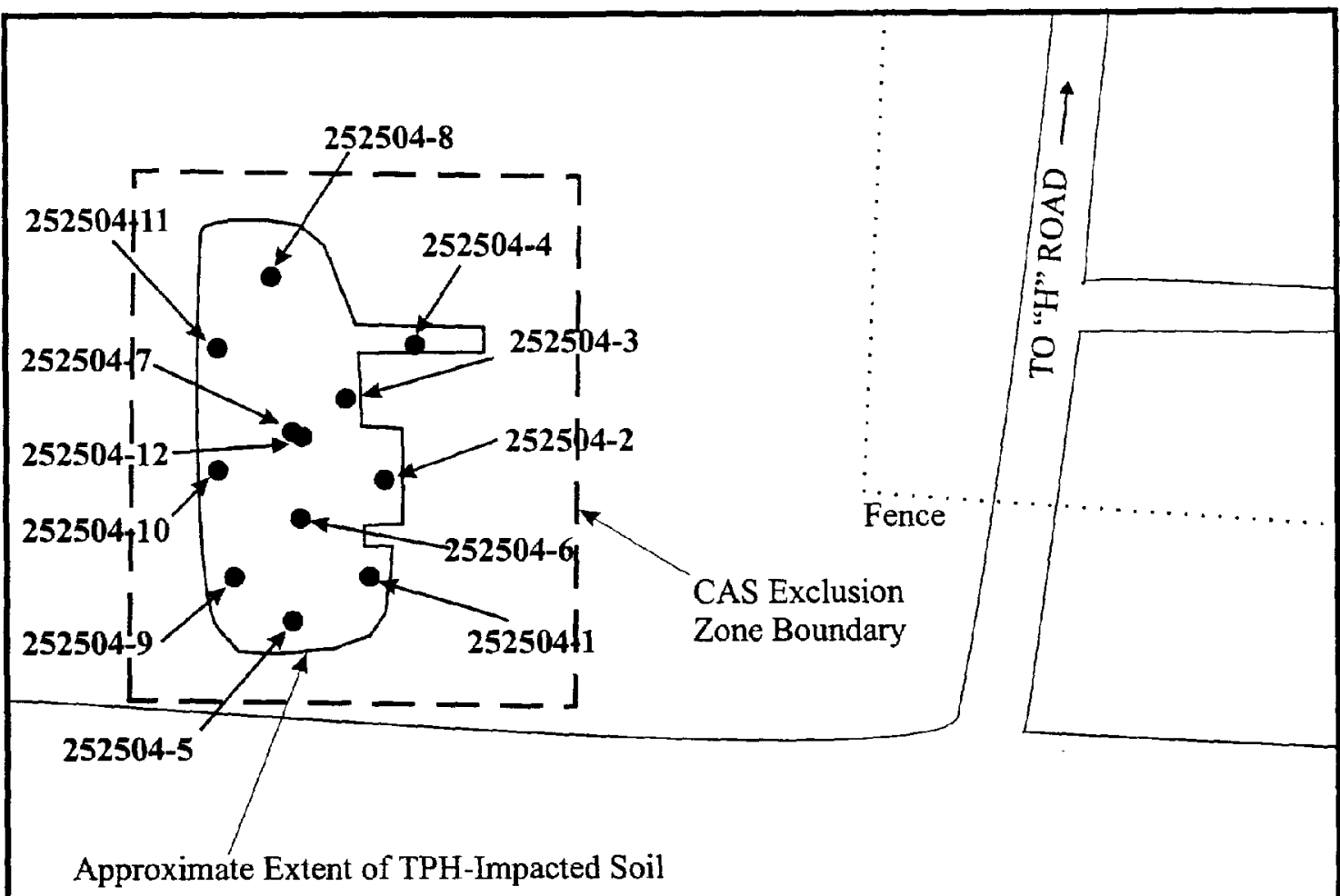

Note: Samples 252504-1 through 252504-12 were collected for TPH verification on $6 / 3 / 2002$. TPH in soil < action level.

- Verification Sample Location

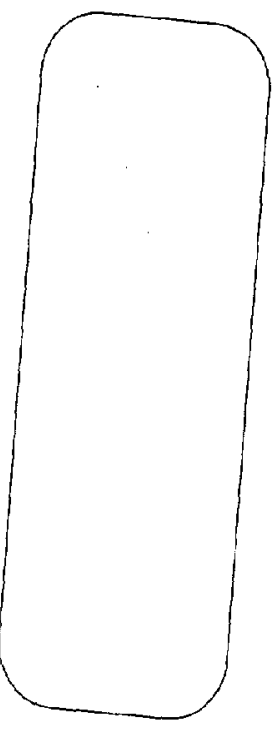

E-MAD FACILITY

NOT TO SCALE 
Analytical results for characterization samples showed TPH, PCBs, and RCRA metals (cadmium and lead) as COCs. PCBs and metal COCs were present in soil confined to a small area located at the south end of the CAS (Figure 9) (DOE/NV, 2001). This site was clean closed by excavation of TPH, PCB, and RCRA metals-impacted soil.

Soil contaminated with TPH, PCBs, lead, and cadmium was excavated from an area measuring approximately 1.2 by 1.8 meters $(\mathrm{m})(4$ by 6 feet [ft]) located at the south end of the CAS. The excavated soil was placed into fourteen 208-liter (L) (55-gallon [gal]) drums that were moved into a 90-Day Accumulation Area for storage pending off site disposal. On May 1 and 2, 2002, the 14 drums of hazardous waste were shipped off site to an approved permitted hazardous waste disposal facility. Verification soil samples (252504-1 W, 252504-2W, 252504-3W, 252504-4W, 252504-5W, 252504-1E, 252504-2E, 252504-3E, 252504-4E, 252504-5E) were collected on May 2, 2002, from the excavation and analyzed for TPH, PCBs, TCLP lead and TCLP cadmium. Additional soil verification samples (252504-V1 through 252504-V11) were collected on December 13, 2002, and analyzed for total lead and total cadmium. Results showed no COCs above action limits (NAC, 2002b; EPA, 2001; EPA, 2002), verifying that the site was clean closed. Analytical results for the verification samples are summarized in Table 2 and are included in Appendix B. Waste disposition documentation is included in Appendix D and photographs documenting the site closure activities in Appendix E.

Between May 21-30, 2002, TPH-impacted soil was excavated from the remainder of the CAS and transported to the Area 6 Hydrocarbon Landfill for disposal. Verification soil samples (252504-1, 252504-2, 252504-3, 252504-4, 252504-5, 252504-6, 252504-7, 252504-8, 252504-9, 252504-10, 252504-11, 252504-12) were collected on June 3, 2002, from the excavation and analyzed for TPH. TPH results for all samples were less than the action level $(100 \mathrm{mg} / \mathrm{kg})(\mathrm{NAC}, 2002 \mathrm{~b})$, verifying that the site was clean closed. The entire excavation was then backfilled with clean fill and wheel rolled with heavy equipment on June 18, 2002. Analytical results for the verification samples are summarized in Table 2 and are included in Appendix B. Waste disposition documentation is included in Appendix D and photographs documenting the site closure activities in Appendix E.

CAS 25-25-05, Oil Spills (Figures 11 and 12). This site consisted of oil and hydraulic fluid spills located where heavy equipment was once staged. Analytical results for characterization samples showed TPH and cadmium as COCs. Cadmium contamination was confined to the east end of the CAS (DOE/NV, 2001). This site was clean closed by excavation of TPH- and cadmium-impacted soil.

TPH-impacted soil was excavated and transported to the Area 6 Hydrocarbon Landfill for disposal on April 23 and 29, 2002. Verification soil samples (252505-1, 252505-2, 252505-3, 252505-4, 252505-5) were collected from the excavation on May 7, 2002, and analyzed for TPH. Results showed TPH levels less than the action level, verifying that the site was clean closed.

On April 29, 2002, cadmium-impacted soil was excavated from the east end of the CAS and placed in four 208-L (55-gal) drums. The drums were moved into the 90-Day Accumulation Area for storage pending off site disposal. The extent of the excavation was guided by field screening results for cadmium using a portable hand-held $X$-Ray Fluorescence instrument with a detection limit of $50 \mathrm{mg} / \mathrm{kg}$. Verification soil samples $(252505-6,252505-7,252505-8$, 


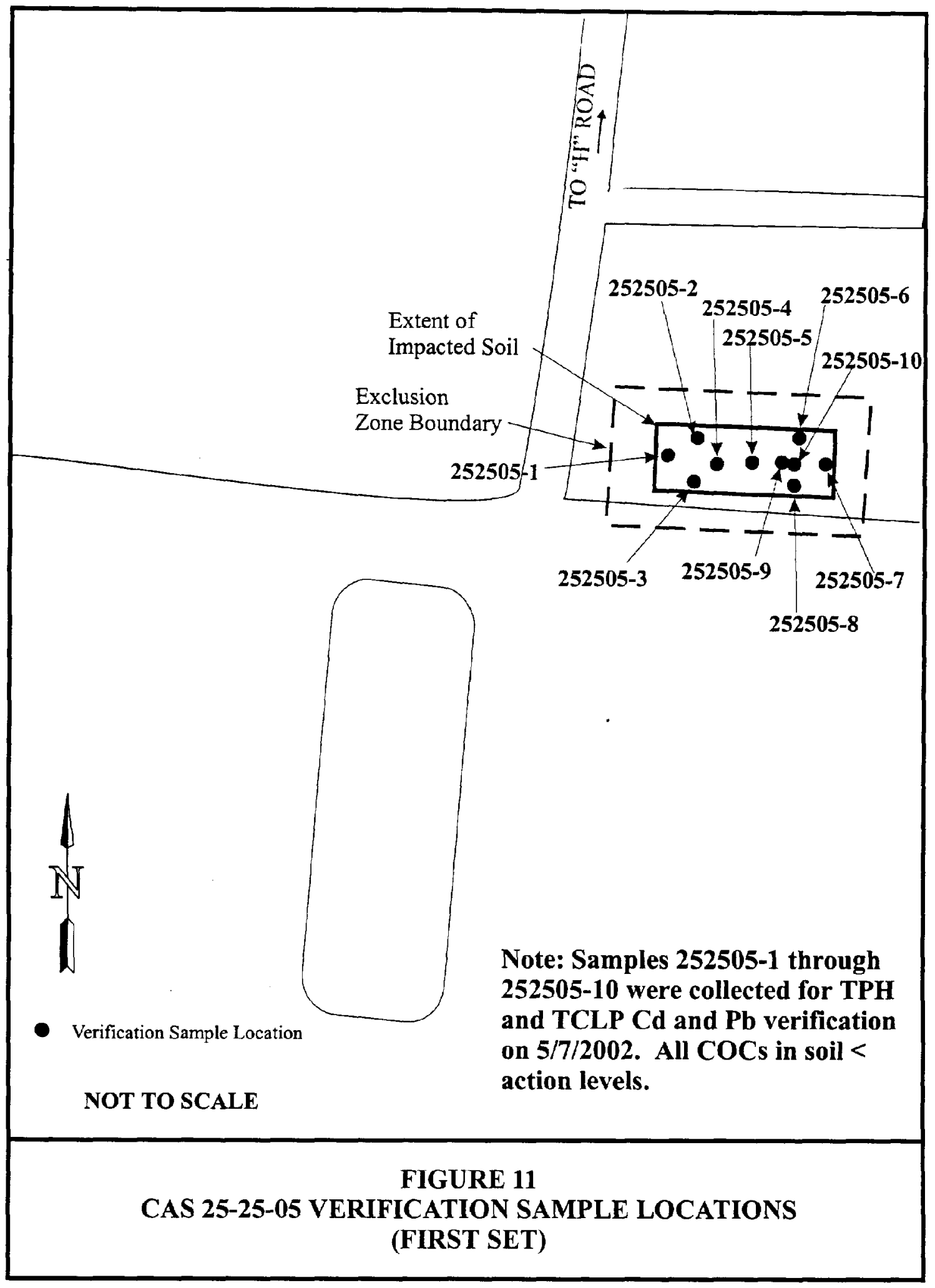




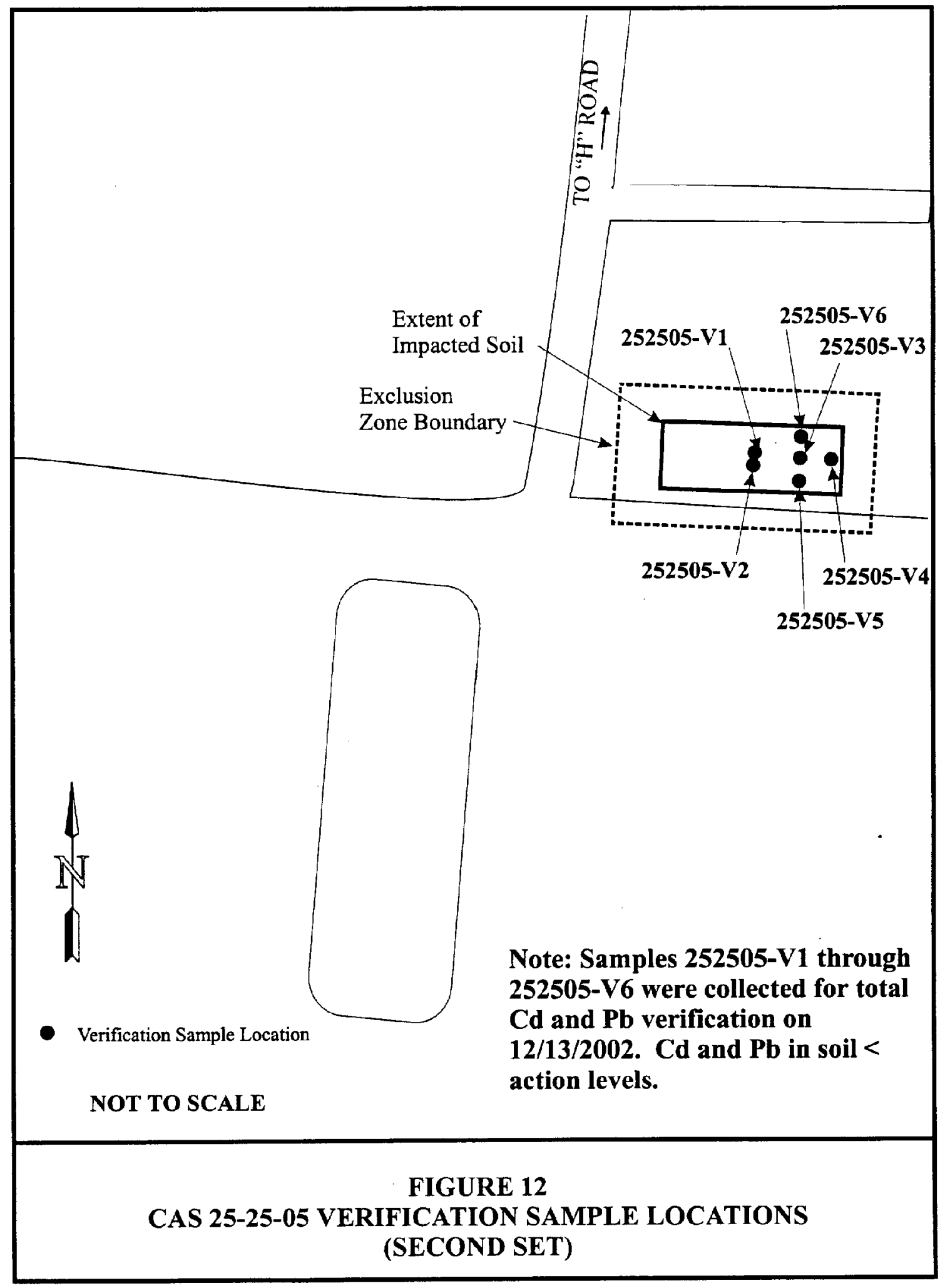


252505-9, 252505-10) were collected from the excavation on May 7, 2002, and analyzed for TPH and TCLP cadmium. Additional verification samples (252505-V1 through 252505-V6) were collected on December 13,2002, and analyzed for total lead and total cadmium. Results from the two sets of samples showed TPH, lead and cadmium less than action levels (NAC, 2002b; EPA, 2002), verifying that the site was clean closed. The excavation was then backfilled with clean fill and wheel rolled with heavy equipment on May 28, 2002. Analytical results for the verification samples are summarized in Table 2 and are included in Appendix B. Waste disposition documentation is included in Appendix $\mathrm{D}$ and photographs documenting the site closure activities in Appendix E.

CAS 25-25-06, Oil Spills. This site is listed as diesel fuel stains beneath the location of two generators that had been removed. Analytical results for characterization samples show no evidence of any COCs (DOE/NV, 2001). This site was closed by taking no further action.

CAS 25-25-07, Hydraulic Oil Spill(s). This site consisted of a hydraulic oil spill that was released from a tunnel-boring machine left onsite when X-Tunnel was placed on inactive status. Due to the fact that TPH is the only COC present and that site conditions limit access and successful removal of contaminants, this CAS has been closed in place with administrative controls; i.e., use restrictions implemented. An "A through K" risk assessment (NAC, 2002a) of the site has been provided (Section 4.2), and use restrictions have been implemented. Use restriction information is provided in Appendix C.

CAS 25-25-08, Hydraulic Oil Spill(s). This site consisted of a hydraulic oil spill that was released from a hydraulic oil pump left onsite when $Y$-Tunnel was placed on inactive status. Due to the fact that TPH is the only COC present and that site conditions limit access and successful removal of contaminants, this CAS has been closed in place with administrative controls; i.e., use restrictions implemented. An "A through K" risk assessment (NAC, 2002a) of the site has been made (Section 4.2) and use restrictions have been implemented. Use restriction information is provided in Appendix C.

CAS 25-25-16, Diesel Spill (from 25-01-02) (Figure 13). This site consisted of diesel fuel spill from an aboveground storage tank located near Building 3320 at Engine Test Stand-1. The tank was removed prior to these corrective actions. Analytical results showed TPH as the only COC (DOE/NV, 2001) present. This site was clean closed by excavation of TPH-impacted soil.

On May 6, 2002, hydrocarbon-impacted soil was excavated and transported to the Area 6 Hydrocarbon Landfill for disposal. Verification soil samples (252516-1, 252516-2, 252516-3, 252516-4, 252516-5) were collected on May 7, 2002, and analyzed for TPH. Results showed TPH levels less than the action level ( $100 \mathrm{mg} / \mathrm{kg})(\mathrm{NAC}, 2002 \mathrm{~b})$, verifying that the site was clean closed. The excavation was then backfilled with clean fill and wheel rolled with heavy equipment on May 28, 2002. Analytical results for the verification samples are summarized in Table 2 and are included in Appendix B. Waste disposition documentation is included in Appendix $\mathrm{D}$ and photographs documenting the site closure activities in Appendix E.

CAS 25-25-17, Subsurface Hydraulic Oil Spill. This site is associated with the historical operations of a vacuum pump oil recovery system at the E-MAD facility. Due to the fact that TPH is the only COC present and that site conditions limit access and successful removal of contaminants, this CAS has been closed in place with administrative controls; i.e., use 


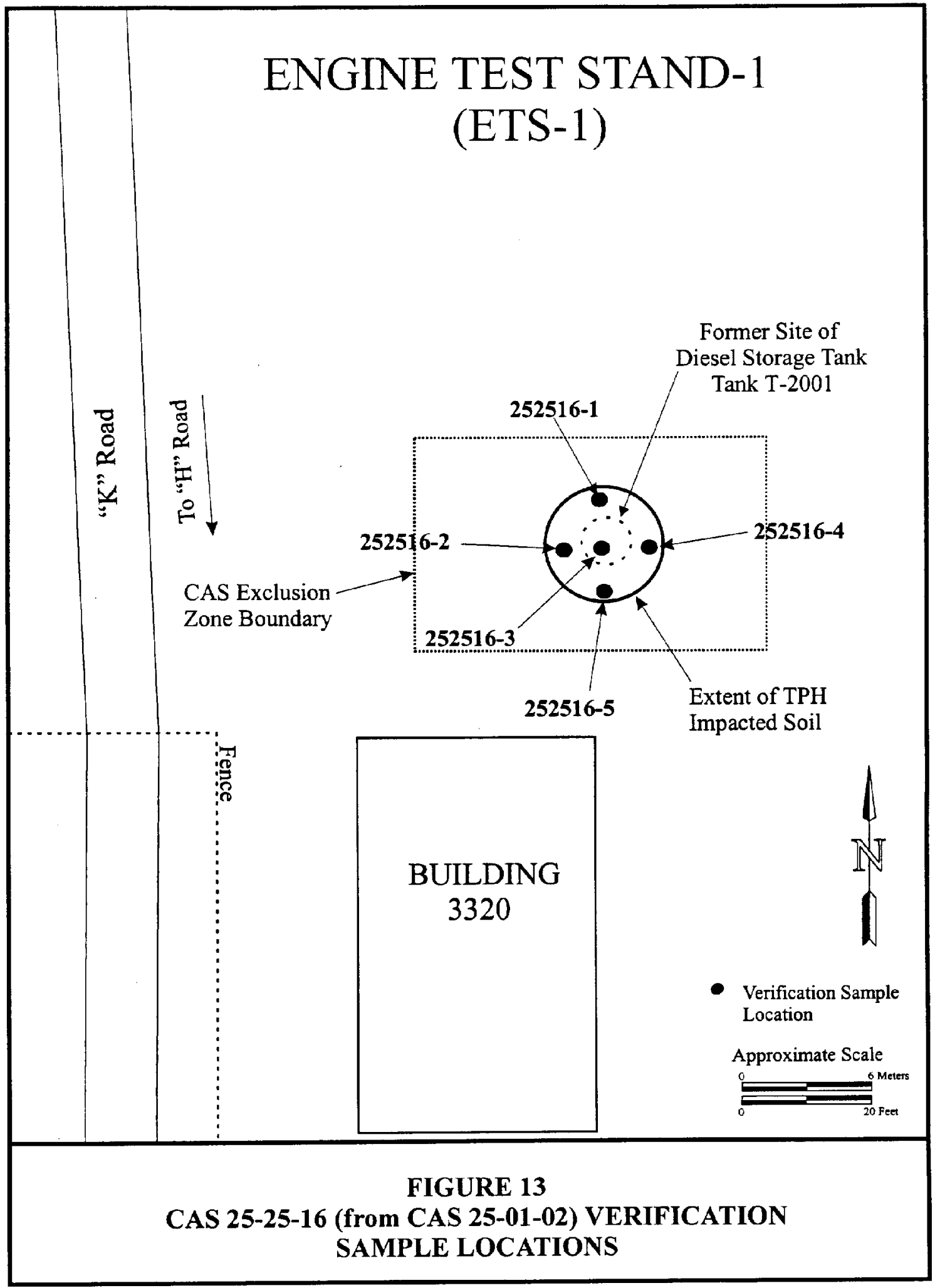


restrictions implemented. An "A through K" risk assessment (NAC, 2002a) of the site has been made (Section 4.2) and use restrictions have been implemented. Use restriction information is provided in Appendix $\mathrm{C}$.

\subsection{DEVIATIONS FROM SAFER PLAN AS APPROVED}

There were no deviations from the NDEP-approved SAFER plan (DOE/NV, 2001).

\subsection{CORRECTIVE ACTION SCHEDULE AS COMPLETED}

The corrective action field activities began on April 23, 2002, and were completed on June 28,2002 . A corrective action schedule as completed is provided in Figure 14.

\subsection{SITE PLAN/SURVEY PLAT}

Because engineered construction was not required as part of this closure, as-built drawings are not included in this $\mathrm{CR}$. Use restriction information forms and Figures showing the location and corner coordinates for sites closed administratively with use restrictions implemented are provided in Appendix $\mathrm{C}$ of this CR. 


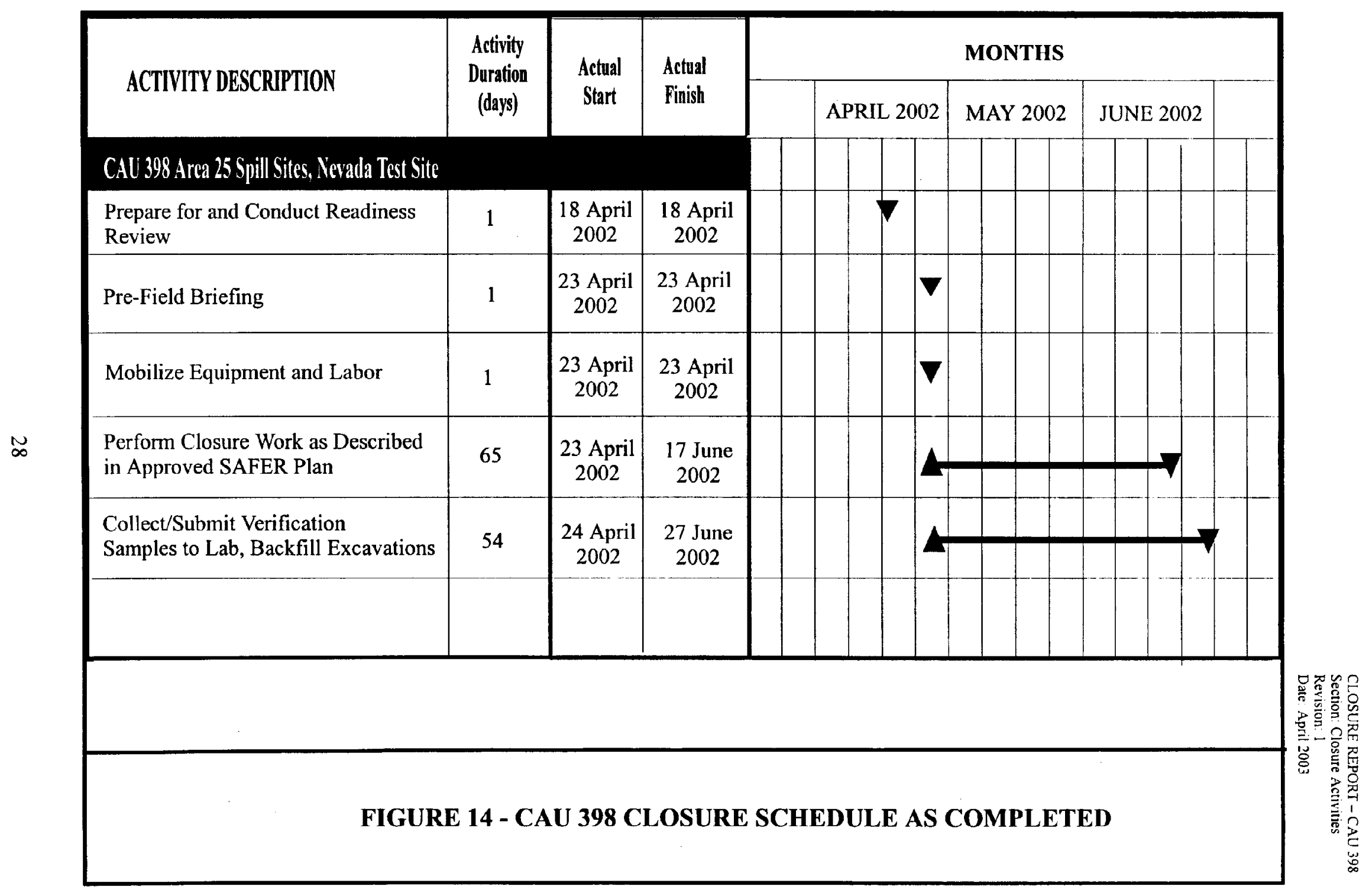




\subsection{WASTE DISPOSITION}

Wastes generated during the closure of CAU 398: Area 25 Spill Sites were disposed of as follows:

- CAS 25-44-01. Approximately $8.2 \mathrm{~m}^{3}\left(9 \mathrm{yd}^{3}\right)$ of railroad beading and construction debris was removed from the site and transported to the Area 9, U10C Landfill.

- CAS 25-44-02. Approximately $25.6 \mathrm{~m}^{3}\left(28 \mathrm{yd}^{3}\right)$ of TPH-impacted soil was excavated and transported to the NTS Area 6 Hydrocarbon Landfill for disposal.

- CAS 25-44-03. Approximately $23.8 \mathrm{~m}^{3}\left(26 \mathrm{yd}^{3}\right)$ of TPH-impacted soil was excavated and transported to the NTS Area 6 Hydrocarbon Landfill for disposal.

- CAS 25-25-02. Approximately $12.8 \mathrm{~m}^{3}\left(14 \mathrm{yd}^{3}\right)$ of TPH- and PCB-impacted soil was excavated and transported to the NTS Area 6 Hydrocarbon Landfill for disposal. Four drums of PCB-impacted soil were generated and transported to a 90-Day Area for temporary storage. The drums were shipped offsite to Safety-Kleen on June 27, 2002, for disposal.

- CAS 25-25-03. Approximately $1.8 \mathrm{~m}^{3}\left(2 \mathrm{yd}^{3}\right)$ of TPH-impacted soil was excavated and transported to the NTS Area 6 Hydrocarbon Landfill for disposal.

- CAS 25-25-04. Approximately $182.9 \mathrm{~m}^{3}\left(200 \mathrm{yd}^{3}\right)$ of TPH-impacted soil was excavated and transported to the NTS Area 6 Hydrocarbon Landfill for disposal. Fourteen drums of TPH-, PCB-, lead-, and cadmium-impacted soil were generated and transported to a 90-Day Area for temporary storage. The drums were shipped offsite to Safety-Kleen on June 27, 2002, for disposal.

- CAS 25-25-05. Approximately $21.0 \mathrm{~m}^{3}\left(23 \mathrm{yd}^{3}\right)$ of TPH-impacted soil was excavated and transported to the NTS Area 6 Hydrocarbon Landfill for disposal. Four drums of TPH- and cadmium-impacted soil were generated and transported to a 90-Day Area for temporary storage. The drums were shipped offsite to Safety-Kleen on June 27, 2002. for disposal.

- CAS 25-25-16 (from CAS 25-01-02). Approximately $16.5 \mathrm{~m}^{3}\left(18 \mathrm{yd}^{3}\right)$ of TPH-impacted soil was excavated and transported to the NTS Area 6 Hydrocarbon Landfill for disposal.

A total of approximately $245 \mathrm{~m}^{3}\left(320 \mathrm{yd}^{3}\right)$ of impacted soil was excavated and removed from CAU 398 during closure activities from April 23 to June 28, 2002. Waste disposition records are provided in Appendix D. 
CLOSURE REPORT - CAL 398

Section: Waste Disposition

Revision 0

Date: April 2003

THIS PAGE INTENTIONALLY LEFT BLANK 


\subsection{CLOSURE VERIFICATION RESULTS}

Site closure was verified by collecting verification soil samples from each CAS that was clean closed. A total of 83 verification samples were collected from the seven clean closed CASs. All verification samples were collected with clean disposable plastic scoops, placed in labeled sample containers, and secured with custody seals. The sample containers were then placed on ice in a cooler, transported under chain of custody to the BN Sample Management group in Mercury, Nevada, and shipped to an off site laboratory for analysis. Analytical results for all collected verification samples are summarized in Table 2 and included in Appendix B.

The analytical results verify that no COCs at levels above action levels remain in the ground at the seven CASs that were clean closed by excavation. The action level for TPH in soil is $100 \mathrm{mg} / \mathrm{kg}$ as established by the state of Nevada (NAC, 2002b). Action levels for lead and cadmium in industrial soils are $750 \mathrm{mg} / \mathrm{kg}$ and $450 \mathrm{mg} / \mathrm{kg}$, respectively, as established by EPA Region 9 (EPA, 2002). The action level for PCBs in soil is $1 \mathrm{mg} / \mathrm{kg}$ as established by the Toxic Substance Control Act (EPA, 2001). The analytical results are summarized in Table 2, and the analytical reports are included in Appendix B.

\subsection{DATA QUALITY ASSESSMENT}

CAU 398 closure activities were performed to the criteria specified in the DQOs provided in the NDEP-approved CAU 398 SAFER Plan (DOE/NV, 2001) and in Appendix A of this CR. The DQOs primary model was the actual scenario for the conditions at the spill sites in Area 25. The proposed activities are based on the assumption that diesel and oil range petroleum hydrocarbons are the prevalent COCs at the sites. The petroleum hydrocarbons are also assumed to act as a carrier for the other COCs which will not extend beyond the limits of the petroleum hydrocarbons. All the sites are expected to fit the primary Conceptual Site Model (CSM) presented in the DQOs (DOE/NV, 2001; Appendix A), with minor variations caused by sitespecific preferential pathways.

During collection of all verification soil sample, standard quality assurance/quality control (QA/QC) samples were also collected; e.g., one field duplicate per 20 samples submitted blind to the analytical laboratory for analysis. Also, the analytical laboratory followed standard QA/QC procedures during sample analysis. This included matrix spike/matrix spike duplicate and spiked surrogate percent recovery analysis (Appendix B).

\subsection{USE RESTRICTIONS}

The three CASs listed below have been closed in place administratively. The only COC at these sites is TPH as diesel/oil. Given specific site condition (e.g., location of utilities, limited space, depth to bedrock, and poor lighting) and the associated problems with removing the TPHimpacted soil and the safety risk to personnel, a risk assessment of each of these sites, based on the "A through K" evaluation as presented in NAC Section 445A.227 was made (NAC, 2002a). 
Use restrictions were implemented for the following CASs:

- CAS 25-25-07, Hydraulic Oil Spill(s)

- $\quad$ CAS 25-25-08, Hydraulic Oil Spill(s)

- $\quad$ CAS 25-25-17, Subsurface Hydraulic Oil Spill

CAU Use Restriction Information forms were completed for each of the three CASs and are included in Appendix C. This form includes the CAU number and site description, post-closure monitoring requirements, and survey coordinates of the unit boundaries. Future use is restricted from any activity that may alter or modify the containment controls as approved by the NDEP, unless appropriate concurrence is obtained in advance. The information on the completed form will be added to the U.S. Department of Energy, National Nuclear Security Administration Nevada Site Office (NNSA/NSO) Facility Information Management System and the NNSA/NSO online Common Data Repository. The Original CAU Use Restriction Information forms are filed in the CAU 398 project file. A copy of each form is located in Appendix C of this report.

\subsection{1 “A THROUGH K” EVALUATION}

Analytical results showed TPH concentration in soil exceeded the state action level of $100 \mathrm{mg} / \mathrm{kg}$ at three CASs. To close these sites in place with administrative controls, a risk evaluation based on the eleven factors that are listed as "A through $K$ " in the Section 445A.227 of the NAC (NAC, 2002a) was performed. This section provides the "A through K" evaluation required under NAC 445A.227 (NAC, 2002a) for the three CASs listed above.

\subsubsection{CAS 25-25-07, Hydraulic Oil Spill(s) “A Through K” Evaluation}

\section{Depth of Groundwater (A)}

Groundwater is approximately $352 \mathrm{~m}(1,155 \mathrm{ft})$ below ground surface (bgs). The estimated depth is taken from the regional general potentiometric surface map provided in the U.S. Geological Survey Water Resources Investigations Report "Summary of Hydrogeologic Controls on Ground-Water Flow at the Nevada Test Site, Nye County, Nevada (Laczniak et. al., 1996) and a letter from the Defense Nuclear Agency (Harris-West, 1992) on the elevations of the X-Tunnel.

\section{Distance to Irrigation or Drinking Water Wells (B)}

The nearest drinking water supply is Water Well J-12, which is approximately 9.6 kilometers $(\mathrm{km})(6 \mathrm{miles}[\mathrm{mi}])$ east-southeast of the site. The static water level in the well is approximately $225 \mathrm{~m}(739 \mathrm{ft})$ bgs (DOE/NV, 1996).

\section{Type of Soil that is Contaminated (C)}

The site is located inside X-Tunnel on the south side of Little Skull Mountain. The tunnel was drilled out of bedrock and a thin layer of drilling residue currently covers the tunnel floor. The drilling residue consists of sand with varying amounts of gravel and silt and is approximately 15 centimeters $(\mathrm{cm})(6$ inches [in]) thick. Bedrock underlies this layer at depths of $15 \mathrm{~cm}(6 \mathrm{in}) \mathrm{bgs}$ and consists of a hard, competent tuff. 


\section{Annual Precipitation (D)}

Average annual precipitation for valleys in the South-Central Great Basin ranges from 7.6 to $15 \mathrm{~cm}$ ( 3 to $6 \mathrm{in}$ ) and the annual evaporation is roughly 5 to 25 times the annual precipitation, (Winograd and Thordarson, 1975). The high evaporation and low precipitation rates create an negative water balance for the area. However, the CAS is located inside X-Tunnel and receives no direct precipitation; therefore, no driving force associated with precipitation is available to mobilize COCs vertically.

Type of Waste or Substance Released (E)

The spill is non-PCB hydraulic fluid.

\section{Extent of Contamination (F)}

The vertical extent of the impacted area does not extend deeper than the bedrock, which is approximately $15 \mathrm{~cm}(6 \mathrm{in})$ bgs. Hydrocarbons were detected at concentrations up to $100,000 \mathrm{mg} / \mathrm{kg}$. Due to limited site access the lateral extent of the hydrocarbon contamination was not determined, but is estimated to be approximately 4 by $1.5 \mathrm{~m}(13$ by $5 \mathrm{ft})$ and $15 \mathrm{~cm}(6$ in) deep.

\section{Present and Potential Land Use (G)}

CAS 25-25-07 is located inside X-Tunnel on the south side of Little Skull Mountain, located on NTS which is a restricted area that is guarded on a 24-hour, 365-day per year basis.

Unauthorized personnel are not admitted to the NTS. X-Tunnel is currently an inactive facility and is locked with access controlled by the BN Operations Center group. There are no plans to change the future land use of the facility; future use is expected to remain the same. A land use restriction has been implemented for this CAS.

\section{Preferred Routes of Migration (H)}

Migration of the hydraulic fluid from the site is not expected to occur. Surface migration is unlikely because the fluid remaining in the soil is located at a depth of approximately $15 \mathrm{~cm}$ (6 in) bgs. Additional vertical migration of hydrocarbons downward due to gravity is not likely because of the bedrock barrier beneath the site. The site does not have an exposure pathway because all impacted soil is below the ground surface inside X-Tunnel.

\section{Location of Structures of Impediments (I)}

CAS 25-25-07 is located inside X-Tunnel on the South side of Little Skull Mountain.

$\mathrm{X}$-Tunnel is currently inactive. CAS 25-25-07 is located adjacent to an escape drift of X-Tunnel. Lateral and vertical impediments consist of bedrock that is located at $15 \mathrm{~cm}$ (6 in) bgs.

\section{Potential for a Hazard Related to Fire, Vapor, or Explosion ( $J$ )}

The potential for fire, vapor ignition, or explosion as a result of the hydraulic fluid release is low due to low volatility of hydraulic fluid and the absence of ignition sources within the tunnel.

\section{Other Information Specific to the Site (k)}

The following are additional factors specific to the site which should be considered in the evaluation for closure:

- Material contaminated with hydraulic fluid present at the site would be difficult to remove by excavation due to the thickness of contaminated material and limited site 
access. The contaminated material is $15 \mathrm{~cm}$ ( 6 in) or less thick and overlies hard bedrock making it difficult to excavate cleanly using a backhoe. Also, the contaminated material is located in a narrow area of the tunnel which limits site access and working area.

- The CAS is located inside X-Tunnel with no direct exposure to precipitation, which eliminates hydrocarbon migration caused by infiltration of precipitation.

- The CAS is located within the secured boundaries of the NTS, which is a restricted area that is guarded on a 24-hour, 365-day per year basis. Unauthorized personnel are not admitted to the NTS, eliminating the potential of personnel contacting site contaminants. The likelihood that the site will be used for future private use is very low.

\subsubsection{CAS 25-25-08, Hydraulic Oil Spill(s) A Through K Evaluation}

\section{Depth of Groundwater (A)}

Groundwater is approximately $351 \mathrm{~m}(1,154 \mathrm{ft}) \mathrm{bgs}$. The estimated depth is taken from the regional general potentiometric surface map provided in the U.S. Geological Survey Water Resources Investigations Report (Laczniak et. al., 1996) and a letter from the Defense Nuclear Agency (Harris-West, 1992) on the elevations of Y-Tunnel.

\section{Distance to Irrigation or Drinking Water Wells (B)}

The nearest drinking water supply is Water Well J-12, which is approximately $9.6 \mathrm{~km}(6 \mathrm{mi})$ east-southeast of the site. The static water level in this well is approximately $225 \mathrm{~m} \mathrm{(739} \mathrm{ft)} \mathrm{bgs}$ (DOE/NV, 1996).

\section{Type of Soil that is Contaminated (C)}

The site is located inside Y-Tunnel on the south side of Little Skull Mountain. The tunnel was drilled into bedrock and a thin layer of drilling residue currently covers the floor of the tunnel and consists of sand with varying amounts of gravel and silt overlying bedrock. Bedrock underlies this layer at depths of $15 \mathrm{~cm}$ (6 in) bgs and consists of a hard, competent tuff.

\section{Annual Precipitation (D)}

Average annual precipitation for valleys in the South-Central Great Basin ranges from 7.5 to $15 \mathrm{~cm}$ ( 3 to $6 \mathrm{in}$ ) and the annual evaporation is roughly 5 to 25 times the annual precipitation, the high evaporation and low precipitation rates create an negative water balance for the area (Winograd and Thordarson, 1975). In addition, the CAS is located inside Y-Tunnel and receives no precipitation directly; therefore, no driving force associated with precipitation is available to mobilize COCs vertically.

Type of Waste or Substance Released (E)

The spill is non-PCB hydraulic fluid.

\section{Extent of Contamination (F)}

The vertical extent of impacted area does not extend deeper than the bedrock which is approximately $15 \mathrm{~cm}$ (6 in) bgs. Hydrocarbons were detected at concentrations of $130,000 \mathrm{mg} / \mathrm{kg}$. Limited accessibility to the site prevented determining the lateral extent of the hydrocarbon contamination. The extent of contamination is estimated to be 9.4 by $2.7 \mathrm{~m}$ ( 31 by $9 \mathrm{ft})$ and $15 \mathrm{~cm}(6 \mathrm{in})$ or less in depth. 


\section{Present and Potential Land Use (G)}

CAS 25-25-08 is located inside Y-Tunnel on the south side of Little Skull Mountain, which is located on a government-controlled facility. The NTS is a restricted area that is guarded on a 24-hour, 365-day per year basis; unauthorized personnel are not admitted to the facility. The tunnel is currently inactive and there are no plans to change the future land use of the facility. Future use at the site is expected to remain the same. A land use restriction has been implemented for this site.

\section{Preferred Routes of Migration (H)}

Migration of the hydraulic fluid from the site is not expected to occur. Surface migration would not occur because the fluid remaining in the soil is located at a depth of approximately $15 \mathrm{~cm}$ ( 6 in) bgs. Additional vertical migration of hydrocarbons downward due to gravity is not likely because of the bedrock barrier beneath the site. The most likely route of migration then becomes subsurface migration laterally; however, further migration of hydrocarbons in the soil is not expected because of the lack of driving forces.

The site does not have an exposure pathway because all impacted soil is below ground surface inside Y-Tunnel. Volatile components of the hydraulic fluid are expected to be minimal because observations indicate that the hydraulic fluid has been present in the soil for many years.

\section{Location of Structures of Impediments (I)}

CAS 25-25-08 is located inside Y-Tunnel on the South side of Little Skull Mountain. Y-Tunnel is currently inactive. CAS 25-25-08 is located adjacent to a tunnel boring machine at the end of Y-Tunnel. Lateral and vertical impediments consist of bedrock that is located at $15 \mathrm{~cm}(6$ in) bgs.

\section{Potential for a Hazard Related to Fire, Vapor, or Explosion (J)}

The potential for fire, vapor ignition, or explosion because of the hydraulic fluid that has been released is low; there are no ignition sources within the tunnel.

\section{Other Information Specific to the Site (K)}

The following are additional factors specific to the site which should be considered in the evaluation for closure:

- Contaminated material at the site would be very difficult to excavate. The material is only $15 \mathrm{~cm}$ ( $6 \mathrm{in}$ ) thick and overlies bedrock. A backhoe would not likely be able to excavate this layer cleanly because of the thin layer of material and the hardness of the underlying bedrock.

- The CAS is inside Y-Tunnel, which eliminates hydrocarbon migration caused by precipitation influx.

- The site is located within the secured boundaries of the NTS. The NTS is a restricted area that is guarded on a 24-hour, 365-day per year basis; unauthorized personnel are not admitted to the facility. The likelihood that the site will be used for future private use is very low. 


\subsubsection{CAS 25-25-17, Subsurface Hydraulic Oil Spill "A Through K" Evaluation}

\section{Depth of Groundwater (A)}

Ground water is approximately $347 \mathrm{~m}(1,139 \mathrm{ft})$ bgs (Laczniak et. al., 1996).

\section{Distance to Irrigation or Drinking Water Wells (B)}

The nearest drinking water supply is Water Well J-12, which is approximately $4.8 \mathrm{~km} \mathrm{(3} \mathrm{mi)}$ east-southeast of the site. The static water level is measured at depths of $225 \mathrm{~m}$ (739 ft) bgs (DOE/NV, 1996).

\section{Type of Soil that is Contaminated (C)}

The site is located inside a significant power/utility corridor feeding into the E-MAD Building 3900. Soil at the site is thin and consists of sand with varying amounts of gravel and silt.

\section{Annual Precipitation (D)}

Average annual precipitation for valleys in the South-Central Great Basin ranges from 7.5 to $15 \mathrm{~cm}$ ( 3 to 6 in) and the annual evaporation is roughly 5 to 25 times the annual precipitation. The high evaporation and low precipitation rates create an negative water balance for the area (Winograd and Thordarson, 1975).

\section{Type of Waste or Substance Released (E)}

The hydraulic fluid spill occurred as a result of the continual overfilling of two 38-L (10-gal) aboveground metal containers that were used for recirculating oil in a vacuum pump oil recovery system.

\section{Extent of Contamination (F)}

Hydrocarbons were detected at a concentration of $600 \mathrm{mg} / \mathrm{kg}$ in the sample collected in the corridor. The spill is located within a power/utility corridor feeding into the E-MAD Building 3900. The corridor is approximately 2.7 by $5 \mathrm{~m}$ ( 9 by $16 \mathrm{ft})$.

\section{Present and Potential Land Use (G)}

CAS 25-25-17 spill is located in a significant power/utility corridor feeding into the south side of E-MAD (Building 3900) facility which is located on a government-controlled facility. The E-MAD facility is currently being used; however, the area that is being used will not affect the power/utility corridor. The NTS is a restricted area that is guarded on a 24-hour, 365-day per year basis; unauthorized personnel are not admitted to the facility. A land use restriction has been completed for this site.

\section{Preferred Routes of Migration (H)}

The most likely route of subsurface migration is vertically through the porous alluvial soil. However, further migration of hydrocarbons in the soil is not expected because the potential source (spill/overfill) of hydrocarbons was removed when the vacuum oil recovery system was removed and the surrounding impacted soil was removed to a depth of $0.5 \mathrm{~m}(1.5 \mathrm{ft})$, then backfilled with clean fill in December 1998 as CAS 25-25-01, part of CAU 297. Hydrocarbons remaining subsurface are in low concentration $(600 \mathrm{mg} / \mathrm{kg})$.

Physical contact or disturbance of impacted surface soil is not possible. The impacted soil that was associated with the vacuum oil recovery system was removed to a depth of approximately 
$0.5 \mathrm{~m}(1.5 \mathrm{ft})$ then backfilled with clean fill. Protection of personnel from exposure and of the environment from improper handling of impacted soil, should it occur, can be controlled through land use restrictions.

\section{Location of Structures of Impediments (I)}

CAS 25-25-17 is located in a power/utility corridor feeding into the south side of E-MAD (Building 3900). The power/utility corridor is approximately $2.7 \mathrm{~m}(9 \mathrm{ft})$ by $4.9 \mathrm{~m}(16 \mathrm{ft})$, the west, north, and east sides of the corridor are surrounded by the E-MAD building with utilities approximately $0.6 \mathrm{~m}(2 \mathrm{ft})$ bgs.

Potential for a Hazard Related to Fire, Vapor, or Explosion (j)

The potential for fire, vapor ignition, or explosion because of the hydraulic fluid that has been released is low. The concentration of hydraulic fluid in the soil is low $(600 \mathrm{mg} / \mathrm{kg})$. Staining of remaining soil indicates that hydrocarbons have been present in the soil long enough for some degradation to have already occurred.

\section{Other Information Specific to the Site (K)}

The following are additional factors specific to the site which should be considered in the evaluation for closure:

- In 1998 during the housekeeping closure of CAU 297 two 38-L (10-gal) metal containers used in the closed vacuum pump oil recovery system were removed. This removes the source that would drive any further migration.

- Soil at the site would be very difficult to excavate because of the location of the utilities in the power/utility corridor and the narrowness of the corridor.

- The site is located within the secured boundaries of the NTS. The NTS is a restricted area that is guarded on a 24-hour, 365-day per year basis; unauthorized personnel are not admitted to the facility.

- This site is also located within the security fencing of the E-MAD compound. 
CLOSURE REPORT - CAU 398

Section: Closure Verification

Revision 0

Date: Apri] 2003

THIS PAGE INTENTIONALLY LEFT BLANK 


\subsection{CONCLUSIONS AND RECOMMENDATIONS}

\subsection{CONCLUSION}

The following site closure activities were performed at each CAS comprising CAU 398 and are documented in the report:

- CAS 25-25-02. All soil containing TPH and PCB levels at or above the action levels of $100 \mathrm{mg} / \mathrm{kg}$ and $1.0 \mathrm{mg} / \mathrm{kg}$, respectively (NAC, 2002b; EPA, 2001), was removed and disposed in the NTS Area 6 Hydrocarbon Landfill and/or at an approved permitted off site disposal facility. The excavation was backfilled with clean fill.

- CAS 25-25-03. All soil containing TPH levels at or above the Nevada State action level of $100 \mathrm{mg} / \mathrm{kg}$ (NAC, 2002b) was removed and disposed in the NTS Area 6 Hydrocarbon Landfill. The excavation was backfilled with clean fill.

- CAS 25-25-04. All soil containing TPH, PCBs, lead, and cadmium levels at or above the action levels of $100 \mathrm{mg} / \mathrm{kg}, 1.0 \mathrm{mg} / \mathrm{kg}, 750 \mathrm{mg} / \mathrm{kg}$, and $810 \mathrm{mg} / \mathrm{kg}$, respectively (NAC, 2002b; EPA, 2001; EPA, 2002), was removed and disposed in the NTS Area 6 Hydrocarbon Landfill and/or at an approved permitted off site disposal facility. The excavation was backfilled with clean fill.

- CAS 25-25-05. All soil containing TPH and cadmium levels at or above the action levels of $100 \mathrm{mg} / \mathrm{kg}$ and $810 \mathrm{mg} / \mathrm{kg}$ ) (NAC, 2002b; EPA, 1996) was removed and disposed in the NTS Area 6 Hydrocarbon Landfill and/or at an approved permitted off site disposal facility. The excavation was backfilled with clean fill.

- CAS 25-25-06. No COC present, site was closed by taking no further action.

- CAS 25-25-07. TPH was the only COC present and due to site location, limited access and safety risks, the site was closed in place with administrative controls instituted.

- CAS 25-25-08. TPH was the only COC present and due to site location, access and safety risks, the site was closed in place with administrative controls instituted.

- CAS 25-25-16 (from CAS 25-01-02). All soil containing TPH levels at or above the Nevada State action level of $100 \mathrm{mg} / \mathrm{kg}$ (NAC, 2002b) was removed and disposed in the NTS Area 6 Hydrocarbon Landfill. The excavation was backfilled with clean fill.

- CAS 25-25-17. TPH was the only COC present and due to site conditions and limited access, the site was closed in place with administrative controls instituted.

- CAS 25-44-01. As a best management practice, all railroad bedding and construction debris was removed and disposed of in the NTS Area 9 U10C Landfill. This site was closed by taking no further action. 
- CAS 25-44-02. All soil containing TPH levels at or above the Nevada State action level of $100 \mathrm{mg} / \mathrm{kg}$ (NAC, 2002b) was removed and disposed in the NTS Area 6 Hydrocarbon Landfill. The excavation was backfilled with clean fill.

- CAS 25-44-03. All soil containing TPH levels at or above the Nevada State action level of $100 \mathrm{mg} / \mathrm{kg}$ (NAC, 2002b) was removed and disposed in the NTS Area 6 Hydrocarbon Landfill. The excavation was backfilled with clean fill.

- CAS 25-44-04. No COC present, site was closed by taking no further action.

\subsection{RECOMMENDATIONS}

Based upon completion of site activities, it is requested that a notice of completion be provided by the NDEP to the NNSA/NSO for the closure of CAU 398. Upon closure approval, CAU 398 will be promoted from Appendix III to Appendix IV of the FFACO, "Closed Corrective Action Units." 


\subsection{REFERENCES}

Bechtel Nevada. 2002a. Field Management Plan for Corrective Action Unit 398: Area 25 Spill Sites, Nevada Test Site, Nevada, Las Vegas, NV.

Bechtel Nevada. 2002b. Site-Specific Health and Safety Plan for Corrective Action Unit 398: Area 25 Spill Sites, Nevada Test Site, Nevada, Las Vegas, NV.

BN, see Bechtel Nevada.

DOE/NV, see U.S. Department of Energy, Nevada Operations Office.

EPA, see U.S. Environmental Protection Agency.

FFACO, see Federal Facility Agreement and Consent Order.

Federal Facility Agreement and Consent Order. 1996 (as amended). Agreed to by the State of Nevada, U.S. Department of Energy, and U.S. Department of Defense.

Harris-West, B. 1992. Letter to Morris Grives and Parsons Brinkerhoff, 9 July.

Laczniak, R. J., Cole J. C., Sawyer D. A., and Trudeau, D. T. 1996. Summary of Hydrogeological Controls on Ground-Water flow at the Nevada Test Site, Nye County, Nevada, U.S. Geological Survey Water-Resources Investigations Report 96-4109. Denver, $\mathrm{CO}$.

NAC, see Nevada Administrative Code.

Nevada Administrative Code. 2002a. Section 445A.227, "Contamination of Soil: Order by Director for Corrective Action; Factors to be Considered in Determining Whether Corrective Action is Required." Carson City, NV.

Nevada Administrative Code. 2002b. Section 445A.2272, "Contamination of Soil: Establishment of Action Levels." Carson City, NV.

U.S. Department of Energy, Nevada Operations Office. 1996. Final Environmental Impact Statement for the NTS and Off-Site Locations in the State of Nevada, DOE/EIS 0243. Las Vegas, NV.

U.S. Department of Energy, Nevada Operations Office. 1998. Streamlined Approach for Environmental Restoration Closure Report for Corrective Action Unit 126: Area 25 Aboveground Storage Tanks, Nevada Test Site, Nevada, DOE/NV/11718--260, Las Vegas, NV. 
U.S. Department of Energy, Nevada Operations Office. 2001. Streamlined Approach for Environmental Restoration Plan for Corrective Action Unit 398: Area 25 Spill Sites. Nevada Test Site, Nevada; Rev 0, DOE/NV--785, Las Vegas, NV.

U.S. Environmental Protection Agency. 1996. Test Methods for Evaluating Solid Waste, Physical/Chemical Methods, EPA Publication SW-846, Third Edition. Washington, D.C.

U.S. Environmental Protection Agency. 2001. Title 40 Code of Federal Regulations 761.61, PCB Remediation Waste, Washington, D.C.

U.S. Environmental Protection Agency. 2002. Region IX Preliminary Remediation Goals (PRGs), San Francisco, CA.

Winograd, I. J., and W. Thordarson. 1975. Hydrologic and Hydrochemical Framework, SouthCentral Great Basin. Nevada-California, with Special Reference to the NTS, U.S. Geological Survey Professional Paper 712C. Washington, DC: U.S. Government Printing Office. 
CLOSURE REPORT - CAU 398 Section: Appendix A

Revision: 1

Date: April 2003

\section{APPENDIX A}

\section{DATA QUALITY OBJECTIVES FOR CAU 398*}

* As presented in the approved and published Streamlined Approach for Environmental Restoration Plan for Corrective Action Unit 398: Area 25 Spill Sites, Nevada Test Site, Nevada, November 2001, DOE/NV--785, Rev. 0. Las Vegas, NV. 
CLOSURE REPORT - CAU 398

Section: Appendix A

Revision: 1

Date: April 2003

THIS PAGE INTENTIONALLY LEFT BLANK 


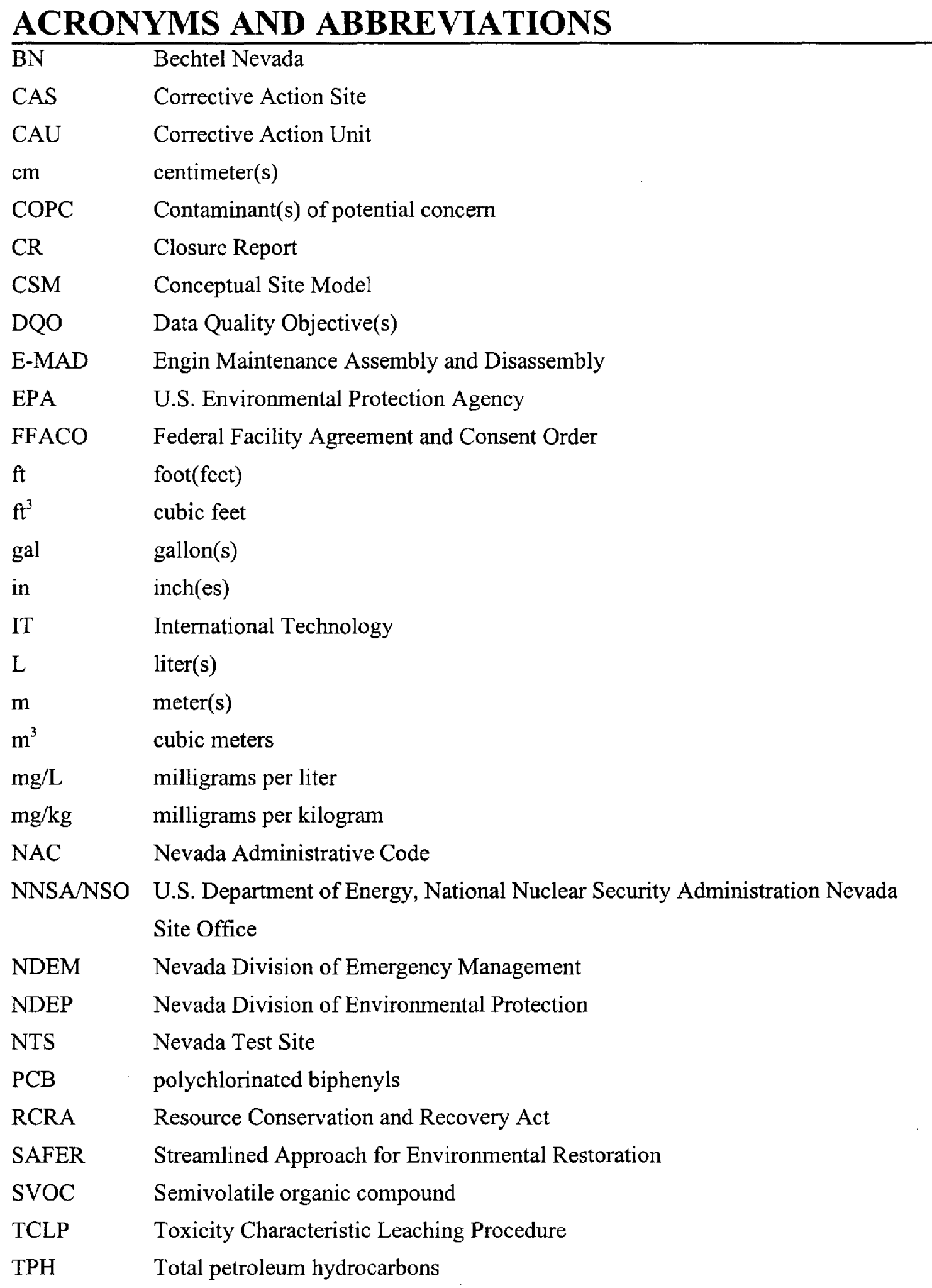


CLOSURE REPORT - CAU 398

Section: Appendix A

Revision: ]

Date: April 2003

\section{ACRONYMS AND ABBREVIATIONS (continued)}

VOC Volatile organic compound

$\mathrm{yd}^{3} \quad$ cubic yards

RPD Relative Percent Difference

$\%$ Percent Recovery 


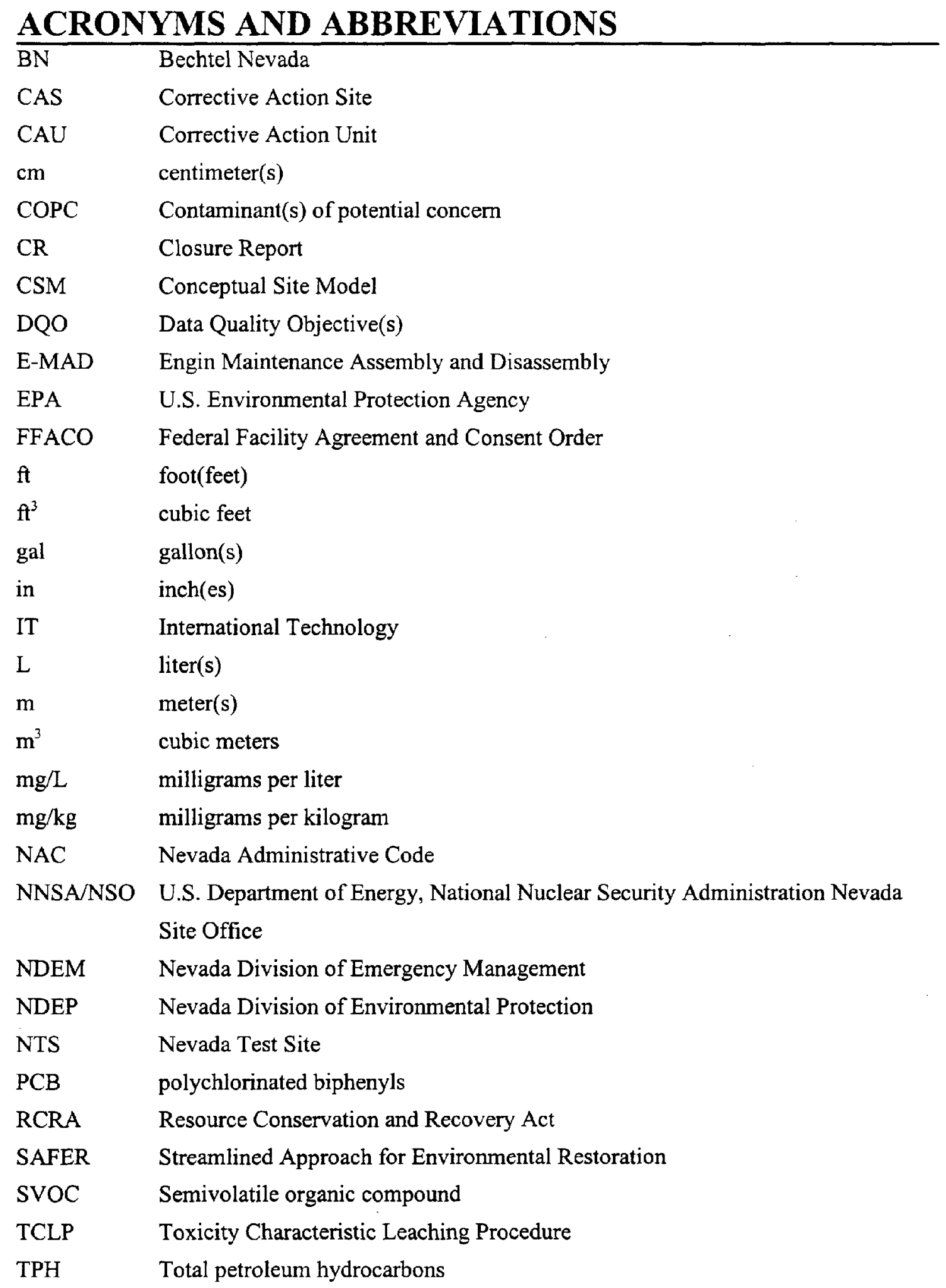


CLOSURE REPORT - CAU 398

Section: Appendix A

Revision: 0

Date: April 2003

\section{ACRONYMS AND ABBREVIATIONS (continued)}

$\begin{array}{ll}\text { VOC } & \text { Volatile organic compound } \\ \mathrm{yd}^{3} & \text { cubic yards } \\ \text { RPD } & \text { Relative Percent Difference } \\ \% \mathrm{R} & \text { Percent Recovery }\end{array}$




\section{APPENDIX A \\ DATA QUALITY OBJECTIVES WORKSHEET FOR CORRECTIVE ACTION UNIT 398: AREA 25 SPILL SITES (Presentation of Known Data Related to Corrective Action Unit 398)}

The information presented in this worksheet is based on historical data generated from preliminary assessment activities for Corrective Action Unit (CAU) 398 at the Nevada Test Site (NTS). Data quality objective (DQO) worksheets follow the U.S. Environmental Protection Agency (EPA) DQO guidance outline (EPA, 2000). The steps systematically build on the data acquired during preliminary assessment work and background research. Copies of the preliminary assessment work are retained in the project files.

Members of the Scoping Team:

1. U.S. Department of Energy, National Nuclear Security Administration, Nevada Site Office (NNSA/NSO)

Janet Appenzeller-Wing

Sabine Curtis

2. Nevada Division of Environmental Protection (NDEP)

Ted Zaferatos

3. Bechtel Nevada (BN)

Thomas Fitzmaurice

Jeff Smith

Dan Tobiason

Kraig Knapp

Core Decision Team

Janet Appenzeller-Wing

Sabine Curtis

Thomas Fitzmaurice

Primary Decision Makers

Janet Appenzeller- Wing

Sabine Curtis

\subsection{PROBLEM STATEMENT}

\subsection{State the problem}

Thirteen sites have been identified for closure. In order to properly close these sites, currently available data must be evaluated to determine if the data adequately identify. constituents of potential concern (COPC). These data will also be use to ascertain cleanup levels and verification sampling requirements. CAU 398 is comprised of the following 13 Corrective Action Sites (CASs): 
- CAS 25-44-01, Fuel Spill

- CAS 25-44-02, Spill

- CAS 25-44-03, Spill

- CAS 25-44-04, Acid Spill

- CAS 25-25-02, Oil Spills

- CAS 25-25-03, Oil Spills

- CAS 25-25-04, Oil Spills

- CAS 25-25-05, Oil Spills

- CAS 25-25-06, Oil Spills

- CAS 25-25-07, Hydraulic Oil Spill(s)

- CAS 25-25-08, Hydraulic Oil Spill(s)

- CAS 25-25-16, Diesel Fuel

- CAS 25-25-17, Subsurface Hydraulic Oil Spill

1.2 Summarize the problem - combine the relevant background information into a concise description of the problem to be resolved and known or suspected sources of disposed waste.

\subsubsection{CAS 25-44-01, Fuel Spill}

This site is located near the northwest corner of Road C and Road D in Area 25 of the NTS on a concrete pad at what was known as the Fuel Storage Facility. During site visits in 1996 and 1998, the spill was determined to be fuel spilled on soil that covers the concrete pad. The dimensions of the spill were measured to be 18 by 12 meters $(\mathrm{m})(60$ by 40 feet [ $\mathrm{ft}])$ with the depth ranging from 0 to 13 centimeters $(\mathrm{cm})(0$ to 5 inches [in]).

Two samples of the suspected spill material were collected on August 15, 1997, by International Technology Corporation (IT) and analyzed for volatile organic compounds (VOCs), semivolatile organic compounds (SVOCs), total petroleum hydrocarbons (TPH), polychlorinated biphenyls (PCBs), total Resource Conservation and Recovery Act (RCRA) metals, gross alpha and beta, and gamma spectroscopy. The results indicated that the only COPCs were the RCRA metals lead (186 milligrams per kilogram [mg/kg]) and chromium $(3,120 \mathrm{mg} / \mathrm{kg})$.

Sampling was conducted by BN on May 24, 2001. The spill material sampled was a dense, metallic material and was analyzed for Toxicity Characteristic Leaching Procedure (TCLP) metals and gamma spectroscopy. Samples were also collected of the soil surrounding the down gradient side of the pad and analyzed for full scan TPH. The results indicate that the dense metallic material did not contain TCLP metals or radiological constituents above regulatory levels. The soil surrounding the pad did not contain TPH above regulatory levels.

Historical information about this site is limited. It is unknown where the spill material came from or what it was used for. It is suspected to be railroad bedding material or shielding. There is no process knowledge of the area being used for fuel storage. The surrounding area (not part of the CAS) is littered with various construction debris and concrete. This indicates that the area may have been used as a dumping area for unused concrete and excess construction material. 
Available information is adequate to show that this site contains no COPCs and can be properly closed with no further action.

\subsubsection{CAS 25-44-02, Spill}

This CAS is located on and near a concrete pad on the north side of Building 3117 at Test Cell A, Area 25, NTS. The CAS consists of a spill to the soil caused by leaking drums. A literature search and site visit by IT in 1993 determined that the barrels had been removed and shipped out of state for disposal as hazardous liquid waste. The shipping manifest indicated that the waste contained various oils, lead, and chromium. A previous contractor collected samples from one of the drums and of the soil in the spill area. The samples were analyzed for PCBs, TPH, and total chlorinated hydrocarbons. The only COPC detected was TPH in the soil.

BN conducted a site investigation on May 23, 2001, and collected soil samples from around the pad and the suspected spill area. It appeared that the area had been disturbed as if the impacted soil had been removed. The samples were analyzed for full-scan TPH, TCLP chromium and lead, and gamma spectroscopy. The sample results indicate that THP as diesel/oil above regulatory levels exists on the edge of the spill area pad.

The source of the drums is unknown. Building 3117 was used to support activities at Test Cell A, but it is unclear if activities at Building 3117 created the waste in the drums.

Sufficient information exists to properly clean-close this site by excavation and disposal.

\subsubsection{CAS 25-44-03, Spill}

This CAS is located on a concrete pad on the southeast side of Test Cell C. This was a temporary drum storage area where two drums labeled as containing PCBs leaked onto the pad and surrounding soil. On December 14, 1990, the drums were removed and shipped to the Area 6 PCB storage facility. The drums were later shipped off site for disposal after being characterized as non-PCB.

IT conducted a site assessment on December 2, 1999, and identified the staining on the pad and soil staining extending approximately $2 \mathrm{~m}(7 \mathrm{ft})$ east of the pad. Sampling was conducted by BN on May 24, 2001. The spilled material and surrounding soil were sampled and analyzed for full scan TPH, PCBs, TCLP metals, and gamma spectroscopy. The results indicate that TPH at levels of up to $5,320 \mathrm{mg} / \mathrm{kg}$ (diesel/oil range) are in the spill material.

The source of the drums and contents is unknown but likely resulted from the draining of transformers or other electrical equipment. Available documentation indicates that the oil was non-PCB. Adequate information exists to sufficiently clean-close this site by excavation and disposal.

\subsubsection{CAS 25-44-04, Acid Spill}

This CAS is located on a concrete pad on the east side of Building 3320 at the Engine 
Test Stand-1 facility. The site consists of spills from two tanks which were used for a water demineralization process. Tank T-2002 contained sodium hydroxide and Tank T-2003 contained sulfuric acid. Each tank had a 18,927-liter (L) (5,000-gallon [gal]) capacity.

A site visit on December 2,1999, determined the size of the spill to be approximately 10 by $5 \mathrm{~m}$ ( 33 by $15 \mathrm{ft})$. The spill extended another $3 \mathrm{~m}(10 \mathrm{ft})$ east off the pad into a small gully. The spill was identified by the red-brown and yellow staining. The spill from the sulfuric acid tank was believed to have occurred over a period of time due to corrosion of the tank bottom. The spill was reported to the Nevada Division of Emergency Management (NDEM) as NDEM 980819-3014. The spill was estimated to be approximately $380 \mathrm{~L}$ (100 gal). The sodium hydroxide spill (NDEM 980811-3001) occurred on August 10, 1998, during tank removal activities. Approximately $380 \mathrm{~L}$ (100 gal) were spilled and mixed with the residue from the sulfuric acid spill. A pH meter measured the $\mathrm{pH}$ of the standing liquid to be 8.5 . Approximately 2.3 cubic meters $\left(\mathrm{m}^{3}\right)$ (3 cubic yards $\left[\mathrm{yd}^{3}\right]$ ) of impacted soil were excavated and disposed in the NTS U10c construction landfill on August 12, 1998.

BN collected samples of the material on the pad and soil on May 24, 2001. The samples were analyzed for soil $\mathrm{pH}$ and gamma spectroscopy. The results indicated that the $\mathrm{pH}$ of the samples ranged from 7.48 to 9.90 , which is not RCRA-corrosive. No radiological constituents were present above regulatory levels.

Sufficient information exists to properly close this site with no further action.

\subsubsection{CAS 25-25-02, Oil Spills}

CAS 25-25-02 is located adjacent to a small concrete loading ramp on the south side of the Engine Maintenance, Assembly, and Disassembly (E-MAD) facility (Building 3900). Available documentation indicates that the spill was associated with leaking drums that were removed in 1992. No documentation exists to indicate that the spill was removed. The source of the drums is not listed in the documentation. The loading ramp leads to the boiler room, so the drums could have been waste oil or fuel from operations conducted there. The spill was described as 3 by $3 \mathrm{~m}$ ( 10 by $10 \mathrm{ft}$ ) and approximately $10 \mathrm{~cm}$ (4 in) below the surface, and appeared to have been covered with soil.

IT collected a sample of the spill on August 27, 1997. The sample was analyzed for total VOCs, total SVOCs, TPH, PCBs, total RCRA metals, gross alpha/beta, and gamma spectrometry. The results indicated that the only COPCs were lead $(137 \mathrm{mg} / \mathrm{kg})$ and PCBs $(34 \mathrm{mg} / \mathrm{kg})$.

BN collected two samples of the spill material and soil on May 31, 2001. One sample was collected from the original IT sample location. The other sample was collected just off the southwest corner of the loading ramp from an obvious spill area of a dark grey to black tar- like material. Both samples were analyzed for TPH full scan, PCBs, TCLP SVOCs, TCLP metals, and gamma spectroscopy. 
The results indicate that the soil contains TPH at levels up to $566 \mathrm{mg} / \mathrm{kg}$ (diesel/oil range) and PCBs up to $5.7 \mathrm{mg} / \mathrm{kg}$. The spill material contained TPH in the diesel/oil range at levels up to $3,440 \mathrm{mg} / \mathrm{kg}$ and PCBs up to $9.2 \mathrm{mg} / \mathrm{kg}$. No other chemical or radiological constituents were present above regulatory levels.

Adequate information exists to sufficiently clean-close this site by excavation and disposal.

\subsubsection{CAS 25-25-03, Oil Spills}

This CAS is located south of Building 4838 (Gas Station) in Area 25 of the NTS. The site was originally described as being a spill adjacent to a tipped-over drum. The drum was documented as being removed in July 1991 and in 1993 the spill was measured at 2 by 1 by $1 \mathrm{~m}$ ( 6 by 3 by $3 \mathrm{ft})$.

IT collected a sample from the site on August 15, 1997, and analyzed the sample for VOCs, SVOCs, TPH, PCBs, RCRA metals, gross alpha/beta, and gamma spectrometry. No COPCs were detected.

BN collected samples from two locations on May 24, 2001. One sample was collected from the original IT sample location approximately $3 \mathrm{~m}(10 \mathrm{ft})$ off the southwest corner of the paved parking area. The second sample was collected approximately $15 \mathrm{~m} \mathrm{(50 \textrm {ft } )}$ southwest of the first location near where the IT CAS identification stake was. Samples were collected from the surface and at a depth of $0.3 \mathrm{~m}(1 \mathrm{ft})$ from both locations. Samples were analyzed for TPH full scan and gamma spectroscopy. The results indicated that TPH levels were below detection limits at the surface and $0.3 \mathrm{~m}(1 \mathrm{ft})$ below the surface at the original IT sample location. At the sample near the IT CAS identification stake, TPH levels at the surface were $800 \mathrm{mg} / \mathrm{kg}$ diesel and $12,000 \mathrm{mg} / \mathrm{kg}$ oil. The TPH

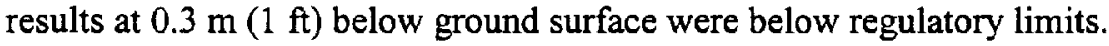

The source of the drum is not listed in the documentation although the drum was removed. The source of the drum was likely from vehicle maintenance operations at the gas station.

Adequate information exists to sufficiently clean-close this site by excavation and disposal.

\subsubsection{CAS 25-25-04, Oil Spills}

This site is located on the north side of the E-MAD facility near a flammable storage building. The site is described by the E-MAD facility engineer as an area where used oils and cooling fluids from metal machining operations were poured directly onto the ground. An estimated $133-151 \mathrm{~L}$ ( 35 - 40 gal) of waste liquids were discharged to the soil. The spill area is approximately 5 by $5 \mathrm{~m}(15$ by $15 \mathrm{ft})$.

IT collected two samples on August 27, 1997, and analyzed the samples for VOCs, SVOCs, TPH, PCBs, total RCRA metals, gross alpha and beta, and gamma spectrometry. COPCs include TPH, PCBs $(2,300 \mathrm{mg} / \mathrm{kg})$, and the RCRA metals cadmium 
$(88.5 \mathrm{mg} / \mathrm{kg})$, chromium $(9,780 \mathrm{mg} / \mathrm{kg})$ and lead $(6,090 \mathrm{mg} / \mathrm{kg})$.

Samples of the area were collected by BN on May 26, 2001. Samples were collected from the original IT locations and from other locations within the CAS. Samples were collected from the surface and from a depth of $1 \mathrm{~m}(3 \mathrm{ft})$. Surface samples were analyzed for TPH full scan, PCBs, TCLP VOCs, TCLP SVOCs, TCLP metals, and gamma spectroscopy. Subsurface samples were analyzed for only TPH full scan. The results indicated the presence of PCBs (up to $77 \mathrm{mg} / \mathrm{kg}$ ), TPH (up to $3,920 \mathrm{mg} / \mathrm{kg}$ in the diesel/oil range), and lead (up to 11 milligrams per liter [mg/L]). One sample was collected from a small area on the surface of what appeared to be machine shop trash. This appeared to be a very oily, greasy, absorbent material that contained metal turnings. The analytical results from this area were PCBs at $920 \mathrm{mg} / \mathrm{kg}$, TPH at $21,600 \mathrm{mg} / \mathrm{kg}$ total diesel and oil range, and cadmium at 1.1 milligram per liter $(\mathrm{mg} / \mathrm{L})$. This area was approximately 0.3 by $0.3 \mathrm{~m}(1$ by $1 \mathrm{ft}$ ) and appeared to be only surficial. All the

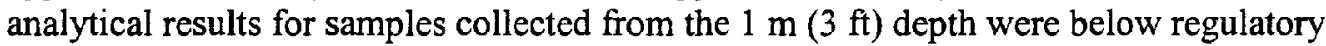
limits.

The source of the waste was from operations at the flammable storage building or the machine shop.

Adequate information exists to sufficiently clean-close this site by excavation and disposal.

\subsubsection{CAS 25-25-05, Oil Spills}

This CAS is located on the northeast side of the E-MAD facility. The spills are oil and/or hydraulic fluid associated with heavy equipment that was stored there. There are four oil spills within the footprint of the heavy equipment. The spills are presumed to be from the same source (equipment oil tank) but leaked from different parts of the equipment.

IT collected two soil samples from the spills on August 27, 1997. The samples were analyzed for VOCs, SVOCs, TPH, PCBs, total RCRA metals, and gross alpha/beta. Possible COPCs include TPH and RCRA metals cadmium at $46.1 \mathrm{mg} / \mathrm{kg}$ and lead $208 \mathrm{mg} / \mathrm{kg}$.

BN collected samples from the spill on May 25, 2001. Samples were collected from the surface and from a depth of $0.6 \mathrm{~m}(2 \mathrm{ft})$. Surface samples were analyzed for TPH full scan, PCBs, TCLP VOCs, TCLP SVOCs, TCLP metals, pesticides, and gamma spectroscopy. Samples collected from the subsurface were analyzed for only TPH full scan. TPH results revealed concentrations as high as $46,500 \mathrm{mg} / \mathrm{kg}$ in the total diesel and

oil range. Cadmium was detected in concentrations as high as $1.1 \mathrm{mg} / \mathrm{L}$. Results of samples collected from $60 \mathrm{~cm}(2 \mathrm{ft})$ depth were below regulatory levels.

Adequate information exists to sufficiently clean-close this site by excavation and disposal. 


\subsubsection{CAS 25-25-06, Oil Spills}

CAS 25-25-06 is located at the Drill Hole Wash Monitoring Station which is past the Yucca Mountain facility in Area 25 of the NTS. The site was described as diesel fuel stains underneath two generators. The generators likely provided power for two trailers and monitoring equipment. A January 1996 site visit by IT determined that the generators were gone and no soil staining was apparent. The two trailers remained. A later IT site visit on March 5, 1998, revealed that the larger of the two trailers was gone. However, dark-brown staining was evident on the soil where the larger trailer had been. The staining was approximately 9 by $2 \mathrm{~m}(28$ by $8 \mathrm{ft})$. No samples were collected.

A BN site visit on May 31, 2001, revealed no indication of the staining identified earlier. Based on descriptions and photographs, the location of the previously stained area was noted and samples were collected. Samples were analyzed for full scan TPH and gamma spectroscopy. The results indicated that TPH and radiological constituents are not present in the soil above regulatory limits. This CAS contains no COPCs and can be properly closed with no further action.

\subsubsection{CAS 25-25-07, Hydraulic Oil Spill(s)}

This site is located adjacent to a tunnel boring machine in an escape drift of X-Tunnel. The boring machine was left in place when X-Tunnel was placed on inactive status in 1982. Over time, the hydraulic lines leaked fluid to the surrounding substrate material. The lines may also have leaked due to damage from removing salvageable parts from the boring machine. It is estimated that approximately $1,514 \mathrm{~L} \mathrm{(400} \mathrm{gal)} \mathrm{of} \mathrm{hydraulic} \mathrm{fluid}$

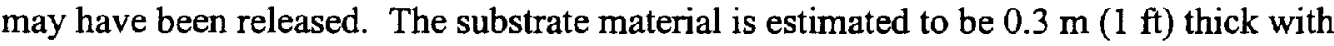
bedrock beneath. Since the site is underground, there is no driving force for migration of the hydraulic fluid except for gravity.

A sample of the hydraulic reservoir was collected on January 31, 1997, and analyzed for PCBs. Results indicated that PCBs were below regulatory levels. The reservoir was later drained.

BN collected samples of the impacted material on June 20,2001. The samples were analyzed for full scan TPH, PCBs, and gamma spectroscopy. Due to the presence of fixed depleted uranium within the drift, a radiological control technician was present during sampling activities. No radiological levels above background were detected in the sampling areas. Sample results indicated TPH concentrations in the diesel/oil range of up to $105,000 \mathrm{mg} / \mathrm{kg}$.

Based on the safety risks to personnel associated with cleaning up the hydrocarbonimpacted soil (confined mine shaft, limited lighting, hanging utility lines) as compared to the risk associated with leaving the soil in place, closure should consist of administrative controls using a use restriction with no further action. 


\subsubsection{CAS 25-25-08, Hydraulic Oil Spill(s)}

This site is located adjacent to a tunnel boring machine at the end of the main drift of $Y$ Tunnel. The boring machine was left in place when Y-Tunnel was placed on inactive status in 1982. Over time, the hydraulic lines leaked fluid to the surrounding substrate material. The lines may also have leaked due to damage from removing salvageable parts from the boring machine. It is estimated that approximately 1,514 L (400 gal) of hydraulic fluid may have been released. The substrate material is estimated to be $0.3 \mathrm{~m}$ $(1 \mathrm{ft})$ thick with bedrock beneath. Since the site is underground, there is no driving force for migration of the hydraulic fluid except for gravity.

BN collected samples of the impacted substrate material on June 20, 2001. The samples were analyzed for full-scan TPH, PCBs, and gamma spectroscopy. A radiological control technician was present during sampling activities as a precautionary measure. No radiological levels above background were detected in the sampling areas. Sample results indicated TPH results in the diesel/oil range of up to $140,000 \mathrm{mg} / \mathrm{kg}$.

Based on the safety risks to personnel associated with cleaning up the hydrocarbonimpacted substrate material (confined mine shaft, limited lighting, hanging utility lines) as compared to the risk associated with leaving the substrate material in place, closure should consist of administrative controls using a use restriction with no further action.

\subsubsection{CAS 25-25-16, Diesel Fuel}

This site is located east of the Engine Test Stand entrance in Area 25 of the NTS. The site consists of soil staining from a diesel release from an aboveground storage tank. Tank T-2001 was a 79,000-L (21,000-gal) capacity steel tank used to store diesel fuel for a boiler located in Building 3320.

The tank was removed during August 1998 closure activities for CAU 126. There was no evidence that the tank had leaked. However, the soil surrounding a valve connected to the drain pipe was moist and had a strong diesel odor.

On August 10,1998, an attempt was made to determine the extent of the spill. Approximately $10.7 \mathrm{~m}^{3}\left(14 \mathrm{yd}^{3}\right)$ were removed and disposed before it was determined that additional excavation was beyond the scope of that project.

$\mathrm{BN}$ collected samples from the surface and from a depth of up to $0.6 \mathrm{~m}(2 \mathrm{ft})$ in the area of the impacted soil on May 25, 2001. The samples were analyzed for full-scan TPH and gamma spectroscopy. The results indicated that diesel and oil range organics were present at a maximum concentration of $1,320 \mathrm{mg} / \mathrm{kg}$ at the surface.

Adequate information exists to sufficiently clean-close this site by excavation and disposal.

\subsubsection{CAS 25-25-17, Subsurface Hydraulic Oil Spill}

This CAS is located on the south side of the E-MAD facility. The spill was identified on 
December 1, 1998, during the housekeeping closure of CAU 297. Closure activities consisted of the removal of two $38 \mathrm{~L}$ (10 gal) metal containers used in a closed vacuum pump oil recovery system.

Completion of the closure activities identified a hydrocarbon release associated with historical operations of the oil recovery system. The spill is located in a significant power/utility corridor feeding into the building. The first of the utilities was located at a

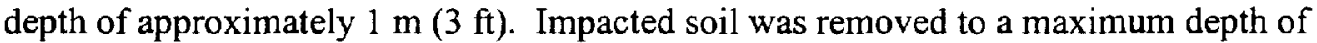
approximately $46 \mathrm{~cm}$ (18 in). Work was discontinued due to the extent of the impacted area, confining work space limitations, and proximity to utilities. Clean soil was used to backfill over the excavated area.

Samples of the soil were collected by BN for verification and waste disposition during CAU 297 closure activities. The samples were analyzed for TPH, TCLP VOCs, TCLP SVOCs, TCLP metals, PCBs, pesticides, and gamma spectroscopy. The results indicated COPCs as TPH and PCBs $(7.2 \mathrm{mg} / \mathrm{kg})$.

BN re-sampled the site on May 31, 2001. Soil samples were collected from a minimum depth of $0.3 \mathrm{~m}(1 \mathrm{ft})$ to get below the level of the backfill. The samples were analyzed for full-scan TPH, PCBs, and gamma spectroscopy. The results indicate the soil is impacted with petroleum hydrocarbons up to $647 \mathrm{mg} / \mathrm{kg}$.

Based on the risks (utility corridor) associated with cleaning up the hydrocarbonimpacted soil as compared to the risk associated with leaving the soil in place, closure should consist of administrative controls using a use restriction with no further action.

\subsection{DEVELOP AND REFINE THE CONCEPTUAL SITE MODEL (CSM)}

Available information, including site process knowledge and historical background information, is sufficient to support the CSMs for CAU 398. The CSMs describe the most probable scenarios for current conditions at each site and define the assumptions that are the basis for identifying appropriate data collection methods.

Ten of the eleven above-ground sites involve releases of petroleum hydrocarbons to surface or near-surface soil. Other COPCs are present at some of these sites and are associated with the petroleum hydrocarbons, which acts as a carrier for the other COPCs. The remaining above-ground site is an acid release to surface soil. In the $\mathrm{X}$ - and $\mathrm{Y}$-tunnel sites, petroleum has been released to the floor of the tunnel. The released substances will typically migrate downward due to gravity and will also flow downslope from the source if the substrate conditions do not allow the fuel to seep in as quickly as the release is occurring. Previously disturbed ground, such as occurs along buried piping and utility corridors, will also serve as a preferential pathway. After the initial release has stopped, the fuel typically continues to migrate downward with gravity until equilibrium is reached. If additional pressure is added to the system after equilibrium is reached, such as what occurs with a new release or as a result of rainfall, downward migration will continue. 


\subsection{Primary Conceptual Site Models}

The primary CSMs are considered the most probable scenarios for current conditions at the CAU 398 sites. Available information from which the CSMs are based were derived from site process knowledge, historical background information, and site sampling and analysis. The proposed activities are based on the assumption that diesel- and oil- range petroleum hydrocarbons are the most prevalent COPCs at the sites. The petroleum hydrocarbons are also assumed to act as a carrier for the other COPCs which will not extend beyond the limits of the petroleum hydrocarbons. All of the sites are expected to fit the basic CSM with minor variations caused by site-specific preferential pathways, as identified below for each CAS:

- CAS 25-44-01, Fuel Spill: A CSM has not been developed for this site because sample analysis indicated that COPCs are not present above regulatory levels. No further action is recommended for this site.

- CAS 25-44-02, Spill: The primary CSM assumes that only petroleum hydrocarbons were released to the soil. Sample analysis supports this CSM and indicates that

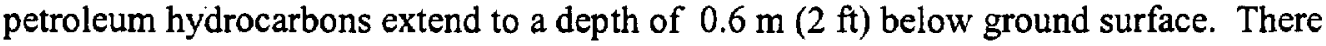
are no preferential pathways identified for this site.

- CAS 25-44-03, Spill: The primary CSM assumes that only petroleum hydrocarbons were released to the soil. Sample analysis supports this CSM. It is assumed that the hydrocarbons extend to a maximum depth of $0.3 \mathrm{~m}(1 \mathrm{ft})$ below the ground surface. There are no preferential pathways identified for this site.

- CAS 25-44-04, Acid Spill: A CSM has not been developed for this site because sample analysis indicated that COPCs are not present above regulatory levels. No further action is recommended for this site.

- CAS 25-25-02, Oil Spills: The primary CSM assumes that only petroleum hydrocarbons and associated PCBs were released to the soil. It is also assumed that the PCBs did not extend beyond the limits of the hydrocarbon release and that the PCBs present are below land ban concentration of $50 \mathrm{mg} / \mathrm{kg}$. It is assumed that the COPCs

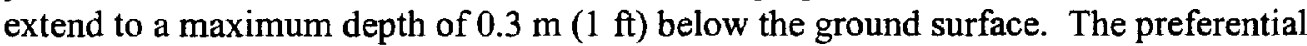
pathway for this site may be down along the foundation of the E-MAD Building.

- CAS 25-25-03, Oil Spills: The primary CSM assumes that only petroleum hydrocarbons were released to the soil. Sample analysis supports this CSM and

indicates that petroleum hydrocarbons extend to a depth of $0.3 \mathrm{~m}(1 \mathrm{ft})$ below ground surface. There are no preferential pathways identified for this site.

- CAS 25-25-04, Oil Spills: The primary CSM assumes that only petroleum hydrocarbons and associated COPCs (PCBs, lead, cadmium) were released to the soil and that the COPCs did not extend beyond the limits of the hydrocarbon release. Sample analysis supports this CSM and indicates that petroleum hydrocarbons extend

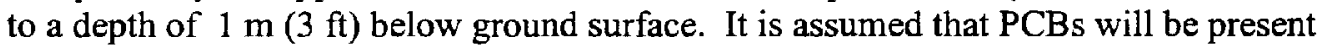


in concentrations above the land ban limit of $50 \mathrm{mg} / \mathrm{kg}$. Lead and cadmium are also assumed to be above the land ban concentrations of $7.5 \mathrm{mg} / \mathrm{kg}$ and $1.1 \mathrm{mg} / \mathrm{kg}$, respectively. The preferential pathway for this site may be the nearby (within $3 \mathrm{~m}$ $[10 \mathrm{ft}])$ storm drain.

- CAS 25-25-05, Oil Spills: The primary CSM assumes that only petroleum hydrocarbons and associated COPCs (cadmium) were released to the soil and that the COPCs did not extend beyond the limits of the hydrocarbon release. Sample analysis supports this model and indicates that petroleum hydrocarbons extend to a depth of $0.6 \mathrm{~m}(2 \mathrm{ft})$ below ground surface. It is assumed that cadmium is present above the land ban concentration of $1.1 \mathrm{mg} / \mathrm{kg}$. There are no preferential pathways identified for this site.

- CAS 25-25-06, Oil Spills: A CSM has not been developed for this site because sample analysis indicated that COPCs are not present above regulatory levels. No further action is recommended for this site.

- CAS 25-25-07, Hydraulic Oil Spill(s): The primary CSM assumes that only petroleum hydrocarbons were released to the substrate in X-Tunnel. Sample analysis supports this CSM. It is assumed that the hydrocarbons extend to a maximum depth of $0.3 \mathrm{~m}(1 \mathrm{ft})$ below the ground surface. There are no preferential pathways identified for this site.

- CAS 25-25-08, Hydraulic Oil Spill(s): The primary CSM assumes that only petroleum hydrocarbons were released to the substrate in Y-Tunnel. Sample analysis supports this CSM. It is assumed that the hydrocarbons extend to a maximum depth of $0.3 \mathrm{~m}(1 \mathrm{ft})$ below the ground surface. There are no preferential pathways identified for this site.

- CAS 25-25-16, Diesel Spill: The primary CSM assumes that only petroleum hydrocarbons were released to the soil. Sample analysis supports this CSM. It is assumed that the hydrocarbons extend to a maximum depth of $0.6 \mathrm{~m}(2 \mathrm{ft})$ below the ground surface. There are no preferential pathways identified for this site.

- CAS 25-25-17, Subsurface Hydraulic Oil Spill: The primary CSM assumes that only petroleum hydrocarbons were released to the soil. Sample analysis supports this CSM. It is assumed that the hydrocarbons extend to a maximum depth of $0.6 \mathrm{~m}(2 \mathrm{ft})$ below the ground surface. Preferential pathways for this site may be the utility corridor and the building foundation.

\subsection{Alternate Conceptual Site Models}

The conditions under the alternate CSM are considered less likely than conditions outlined in the primary CSM.

- CAS 25-44-01, Fuel Spill: An alternate CSM is not necessary for this site because sample analysis indicated that COPCs are not present above regulatory levels.

- CAS 25-44-02, Spill: An alternate CSM has not been developed for this site because 
existing data show the primary CSM to be an adequate representation of current site conditions.

- CAS 25-44-03, Spill: The alternate CSM provides for a more extensive petroleum hydrocarbon release (depth) than assumed in the primary CSM.

- CAS 25-44-04, Acid Spill: An alternate CSM is not necessary for this site because sample analysis indicated that COPCs are not present above regulatory levels.

- CAS 25-25-02, Oil Spills: The alternate CSM provides for a more extensive release of COPCs than assumed in the primary CSM. The preferential pathway remains the same as in the primary CSM.

- CAS 25-25-03, Oil Spills: The alternate CSM provides for a more extensive release of petroleum hydrocarbons than assumed in the primary CSM.

- CAS 25-25-04, Oil Spills: The alternate CSM provides for a more extensive release of COPCs than assumed in the primary CSM. The preferential pathway remains the same as in the primary CSM.

- CAS 25-25-05, Oil Spills: An alternate CSM has not been developed for this site because existing data show the primary CSM to be an adequate representation of current site conditions.

- CAS 25-25-06, Oil Spills: An alternate CSM is not necessary for this site because sample analysis indicated that COPCs are not present above regulatory levels.

- CAS 25-25-07, Hydraulic Oil Spill(s): The alternate CSM for the X-Tunnel spill provides for a more extensive release of petroleum hydrocarbons that has impacted the bedrock.

- CAS 25-25-08, Hydraulic Oil Spill(s): The alternate CSM for the Y-Tunnel spill provides for a more extensive release of petroleum hydrocarbons that has impacted the bedrock.

- CAS 25-25-16, Diesel Spill: The alternate CSM provides for a more extensive release of petroleum hydrocarbons than assumed in the primary CSM.

- CAS 25-25-17, Subsurface Hydraulic Oil Spill: The alternate CSM provides for a more extensive release of petroleum hydrocarbons than assumed in the primary CSM and for PCB concentrations above the cleanup level. The preferential pathways remain the same as in the primary CSM.

\subsection{IDENTIFY THE DECISION}

Development of a Streamlined Approach for Environmental Restoration (SAFER) plan can begin based on the currently available process knowledge, historical data, and sampling data. 
Decisions regarding the closure alternatives for the CASs can be made based on the available site data. The CASs have been grouped into three closure alternatives based on site conditions. The most probable closure decisions are identified below:

\subsection{No Further Action}

The CASs included in the no further action alternative are as follows:

- CAS 25-44-01, Fuel Spill

- CAS 25-44-04, Acid Spill

- CAS 25-25-06, Oil Spills

Are existing data sufficient to support the no further action alternative?

\subsection{Clean Closure}

The CASs and associated COPCs included in the clean closure alternative are as follows:

- CAS 25-44-02, Spill

- CAS 25-44-03, Spill $\mathrm{COPC}=\mathrm{TPH}$ as diesel/oil

- CAS 25-25-02, Oil Spills

- CAS 25-25-03, Oil Spills $\mathrm{COPC}=\mathrm{TPH}$ as diesel/oil $\mathrm{COPCs}=\mathrm{TPH}$ as diesel/oil; PCBs (below land ban) $\mathrm{COPC}=\mathrm{TPH}$ as diesel/oil

- CAS 25-25-04, Oil Spills

- CAS 25-25-05, Oil Spills

- CAS 25-25-16, Diesel Fuel

COPCs=TPH as diesel/oil; lead, cadmium, PCBs (above land ban)

$\mathrm{COPCs}=\mathrm{TPH}$ as diesel/oil; cadmium (above land ban)

$\mathrm{COPC}=\mathrm{TPH}$ as diesel/oil

Are existing data sufficient to support the clean closure by excavation and disposal alternative?

\subsection{Administrative Closure}

The sites included in this group are as follows:

- CAS 25-25-07, Hydraulic Oil Spill(s)

- CAS 25-25-08, Hydraulic Oil Spill(s)

- CAS 25-25-17, Subsurface Hydraulic Oil Spill

Are existing data sufficient to support administrative closure of these sites with no further action other than implementation of a Use Restriction? 


\subsection{IDENTIFY THE INPUTS TO THE DECISION}

4.1 Identify the information inputs needed and resolve the decision.

\subsubsection{No Further Action}

The sites included in this group are as follows:

- CAS 25-44-01, Fuel Spill

- CAS 25-44-04, Acid Spill

- CAS 25-25-06, Oil Spills

At these CASs, sample results revealed no evidence of COPCs above action levels. Therefore, these sites can be properly closed with no further action.

\subsubsection{Clean Closure}

The sites included in this group are as follows:

- CAS 25-44-02, Spill

- CAS 25-44-03, Spill

- CAS 25-25-02, Oil Spills

- CAS 25-25-03, Oil Spills

- CAS 25-25-04, Oil Spills

- CAS 25-25-05, Oil Spills

- CAS 25-25-16, Diesel Fuel

Sufficient information exists for these CASs to be clean closed by excavation and disposal of impacted soil. All of these sites consist of TPH-impacted soil. Three sites contain COPCs in addition to TPH and are associated with the TPH. CAS 25-25-02 also contains PCBs below the land ban restrictions; CAS 25-25-05 also contains cadmium above land ban restrictions; CAS 25-25-04 contains lead, cadmium, and PCBs above land ban restrictions in addition to the TPH. CASs with COPCs above the land ban restrictions must be sent to an off-site treatment and disposal facility.

\subsubsection{Administrative Closure}

The sites included in this group are as follows:

- CAS 25-25-07, Hydraulic Oil Spill(s)

- CAS 25-25-08, Hydraulic Oil Spill(s)

- CAS 25-25-17, Subsurface Hydraulic Oil Spill

TPH as diesel/oil is the only COPC at sites included in this group. Given specific site conditions (utilities, limited space, limited lighting), it is likely that a risk assessment of each of these sites, based on the "A through $\mathrm{K}$ " evaluation as presented in Nevada Administrative Code (NAC) 445A.227 (NAC, 2002), would show that there is no significant risk to human health or the environment from the hydrocarbon-impacted soil. 
This "A through $\mathrm{K}$ " evaluation is recommended for inclusion in the SAFER Plan, so data supporting administrative closure of the site must be gathered. If risk-based closure is supported, the sites would then be recommended for administrative closure with no further action and a use restriction prepared for inclusion in the Closure Report (CR).

\subsection{List types of COPCs and affected media.}

The CASs and their associated COPCs are listed below:

- CAS 25-44-01, Fuel Spill - No COPCs above action levels

- CAS 25-44-04, Acid Spill - No COPCs above action levels

- CAS 25-25-06, Oil Spills - No COPCs above action levels

- CAS 25-44-02, Spill - TPH as diesel/oil

- CAS 25-44-03, Spill - TPH as diesel/oil

- CAS 25-25-02, Oil Spills - TPH as diesel/oil, PCBs

- CAS 25-25-03, Oil Spills - TPH as diesel/oil

- CAS 25-25-04, Oil Spills - TPH as diesel/oil, lead, cadmium, PCBs

- CAS 25-25-05, Oil Spills - TPH as diesel/oil, cadmium

- CAS 25-25-16, Diesel Fuel - TPH as diesel/oil

- CAS 25-25-07, Hydraulic Oil Spill(s) - TPH as diesel/oil

- CAS 25-25-08, Hydraulic Oil Spill(s) - TPH as diesel/oil

- CAS 25-25-17, Subsurface Hydraulic Oil Spill - TPH as oil

For all of the CASs, the affected media is soil.

\subsection{Identify potential sampling approaches and appropriate analytical methods.}

Existing documentation, process knowledge, and sample data are adequate to close the sites under the no further action and administrative closure alternatives without collecting additional data. For these sites, existing data will be referenced in the SAFER Plan and documented in the closure documentation to demonstrate adequate closure of the sites. The sites under the clean closure by excavation and disposal alternative can also be closed using existing data but will also require confirmation samples to verify that all COPCs have been removed to below action levels. The confirmation sampling approach will be discussed in the SAFER Work Plan.

\subsection{DEFINE THE BOUNDARIES OF THE STUDY}

5.1 Define the geographic areas of the field investigation.

\subsubsection{Define the geographic area within which all decisions must apply (in some cases this} may be defined by the CAU).

The geographic areas of the field investigation are those areas of each CAS which are impacted by COPCs as identified by the CSM. Descriptions of each area are found in Section 1.2 of this report. 


\subsubsection{Specify the characteristics that define the population of in terest.}

The population of interest consists of soil containing COPCs at concentrations above action levels.

5.2 Define the time frame of the decision.

\subsubsection{Determine the time frame to which the study data apply.}

- The study data should be relevant with the length of time allowed for by the SAFER process under the Federal Facility Agreement and Consent Order (FFACO) (FFACO, 1996).

- Migration (if occurring) is assumed to be imperceptibly slow. This is based on minimal surface water infiltration and the constraints of the CSM.

\subsubsection{Determine when to collect data.}

Field activities are scheduled to take place in Fiscal Year 2002 after approval of the final SAFER Work Plan. Field activities will be conducted at times that meet the security and safety constraints of the NTS.

\subsubsection{Define relevant time constraints.}

The FFACO deadline for delivery of the final SAFER Work Plan is December 31, 2001.

The FFACO deadline for delivery of the final CR is December 31, 2002.

\subsection{Identify any practical constraints on data collection.}

- Approval of the DQO process and the SAFER Plan by the NDEP.

- Site operations - NTS operational and security constraints.

- Equipment and personnel access.

- Meteorological.

- Availability of heavy equipment.

- Health and safety of workers.

\subsection{DEVELOP A DECISION RULE - DEFINE A LOGICAL BASIS FOR CHOOSING} AMONG ALTERNATIVE ACTIONS

6.1 Specify the action level or preliminary action level for the decision.

Sufficient analytical data and process knowledge exists to support the CSM. The action level is $100 \mathrm{mg} / \mathrm{kg}$ for TPH based on NAC 445A.2272 (NAC, 2002). Based on Preliminary Remediation Goals for EPA Region 9 for Industrial Soils, the action levels are $1.0 \mathrm{mg} / \mathrm{kg}$ for PCBs, $750 \mathrm{mg} / \mathrm{kg}$ for lead, and $810 \mathrm{mg} / \mathrm{kg}$ for cadmium. 
7.0 OPTIMIZE THE DESIGN - OUTLINE A SAMPLING DESIGN, SPECIFYING THE OPERATIONAL DETAILS OF THE SAMPLING PLAN WHICH FALLS WITHIN THE PROJECT'S CONSTRAINTS

7.1 Develop general sampling and analysis design alternatives.

Refer to Section 4.3 for sampling and analysis alternatives.

7.2 Select the most resource-effective design that satisfies all of the DQOs.

- For those sites requiring clean closure by excavation and disposal, excavate impacted to lateral and vertical extent and collect confirmation samples to verify that all soil impacted with COPCs above action levels has been removed.

- Survey and implement Use Restrictions for those sites to be administratively closed.

7.3 Document the operational details and theoretical assumptions of the selected design in the sampling and analysis plan.

Detailed documentation of sampling and analysis will be discussed in the SAFER Work Plan.

TABLE A1 - LABORATORY ANALYTICAL REQUIREMENTS FOR CAU 398 SOIL SAMPLES

\begin{tabular}{|c|c|c|c|c|c|c|}
\hline $\begin{array}{l}\text { Parameter } \\
\text { or Analyte }\end{array}$ & $\begin{array}{c}\text { Medium } \\
\text { or } \\
\text { Matrix }\end{array}$ & $\begin{array}{l}\text { Analytical } \\
\text { Method }\end{array}$ & $\begin{array}{l}\text { Minimum } \\
\text { Reporting } \\
\text { Limit }\end{array}$ & $\begin{array}{c}\text { Regulatory } \\
\text { Limit }\end{array}$ & $\begin{array}{c}\text { Relative } \\
\text { Percent } \\
\text { Difference } \\
(\text { RPD })^{\mathbf{a}} \\
\end{array}$ & $\begin{array}{c}\text { Percent } \\
\text { Recovery } \\
(\% \mathbf{R})^{\mathbf{b}}\end{array}$ \\
\hline Cadmium & Soil & $6010 B^{c}$ & $1 \mathrm{mg} / \mathrm{kg}^{\mathrm{e}}$ & & 35 & Lab - specific \\
\hline Lead & Soil & $6010 \mathrm{~B}^{\mathrm{c}}$ & $0.3 \mathrm{mg} / \mathrm{kg}^{\mathrm{e}}$ & & 35 & Lab - specific ${ }^{d}$ \\
\hline $\begin{array}{l}\text { Polychlorinated } \\
\text { Biphenyls } \\
\text { (PCBs) }\end{array}$ & Soil & $8082^{\mathrm{c}}$ & $\begin{array}{l}\text { Analyte- } \\
\text { specific }^{c} \\
\text { Contract- } \\
\text { required } \\
\text { quantitation } \\
\text { limit }\end{array}$ & $0.001 \mathrm{mg} / \mathrm{kg}$ & $\begin{array}{l}\text { Lab - } \\
\text { specific }^{d}\end{array}$ & $\begin{array}{l}\text { Lab - } \\
\text { specific }^{d}\end{array}$ \\
\hline $\begin{array}{l}\text { Total } \\
\text { Petroleum } \\
\text { Hydrocarbons } \\
\text { (TPH) } \\
\end{array}$ & Soil & $\begin{array}{l}8015 \mathrm{~B} \\
\text { modified }^{c}\end{array}$ & $25 \mathrm{mg} / \mathrm{kg}^{\mathrm{e}}$ & $100 \mathrm{mg} / \mathrm{kg}$ & $\begin{array}{l}\text { Lab- } \\
\text { specific }^{d}\end{array}$ & $\begin{array}{l}\text { Lab - } \\
\text { specific }^{d}\end{array}$ \\
\hline
\end{tabular}

RPD - relative percent difference is used to calculate precision.

b \% R - percent recovery is used to calculate accuracy.

c U.S. Environmental Protection Agency (EPA) Test Methods for Evaluating Solid Waste, $3^{\text {rd }}$ Edition, Parts 1-4, SW-846 (EPA, 1996).

In-House Generated RPD and \%R Performance Criteria.

'Industrial Sites Quality Assurance Project Plan (NNSA/NV, 2002). 
THIS PAGE INTENTIONALLY LEFT BLANK

A-1 8 


\section{REFERENCES}

FFACO, see Federal Facility Agreement and Consent Order.

Federal Facility Agreement and Consent Order. 1996 (as amended). Agreed to by the State of Nevada, U.S. Department of Energy, and U.S. Department of Defense.

NAC, see Nevada Administrative Code.

NNSA/NV, see U.S. Department of Energy, National Nuclear Security Administration Nevada Operations Office

Nevada Administrative Code. 2002. Section 445A.227, "Contamination of Soil: Order by Director for Corrective Action; Factors to be Considered in Determining Whether Corrective Action is Required." Carson City, NV.

U.S. Department of Energy, National Nuclear Security Administration Nevada Operations Office. 2002. Industrial Sites Quality Assurance Project Plan, DOE/NV--372--REV. 3, Las Vegas, NV.

U.S. Environmental Protection Agency. 1996. Test Methods for Evaluating Solid Waste Physical/Chemical Methods, EPA Publication SW-846, Third Edition. Washington, D.C.

U.S. Environmental Protection Agency. 2000. Guidance for the Data Quality Objective Process. EPA QA/G-4, Washington, D.C. 
THIS PAGE INTENTIONALLY LEFT BLANK 
CLOSURE REPORT - CAU 398 Section: Appendix B

Revision: 1

Date: April 2003

\section{APPENDIX B}

\section{VERIFICATION SAMPLE ANALYTICAL RESULTS}


CLOSURE REPORT - CAU 398

Section: Appendix B

Revision: 1

Date: April 2003

THIS PAGE INTENTIONALLY LEFT BLANK 


\section{TABLE OF CONTENTS - SAMPLE ANALYTICAL RESULTS BY SAMPLE DELIVERY GROUP}

Analytical results for the verification samples collected at the Corrective Action Unit 398 Corrective Action Sites (CASs) are presented in this Appendix. The analytical results are grouped into Sample Delivery Groups (SDGs), which are arranged in numerical order in this Appendix. Analytical results for a specific CAS can be found in the indicated SDGs, or by consulting Table 2 in the main document text.

CAS 25-25-02, Oil Spills: SDG V1596 and V1627

CAS 25-25-03, Oil Spills: SDG V1565

CAS 25-25-04, Oil Spills: SDG V1581, V1609 and V1815

CAS 25-25-05, Oil Spills: SDG V1581 and V1815

CAS 25-25-16, Diesel Spill (from CAS 25-01-02): SDG V1580

CAS 25-44-02, Spill: SDG V1596

CAS 25-44-03, Spill: SDG V1580

Six CASs in CAU 398 were closed by implementing closure alternatives other than clean closure; three CASs were closed by taking no further action, and three CASs were closed in place with administrative controls. For these CASs no verification samples were required or collected as part of the CAU 398 closure. Analytical results for characterization samples collected at these CASs were presented in the approved CAU 398 SAFER plan, and are included in this Appendix as required by the agreed upon Closure Report outline. The analytical results are grouped by SDG which are arranged numerically. Results for a specific CAS can be found in the indicated SDGs.

CAS 25-25-07, Hydraulic Oil Spill(s): SDG V1169 and V1170 CAS 25-25-08, Hydraulic Oil Spill(s): SDG V1169 and V1170

CAS 25-25-17, Subsurface Hydraulic Oil spill: SDG V1139 and V1140

CAS 25-25-06, Oil Spills: SDG V1139 and V1140

CAS 25-44-01, Fuel Spill: SDG V1122, V1123 and V1170

CAS 25-44-04, Acid Spill (from CAS 25-01-01): SDG V1122 and V1123 
CLOSURE REPORT - CAU 398

Section: Appendix B

Date: April 2003

\section{THIS PAGE INTENTIONALLY LEFT BLANK}


CLOSURE REPORT - CAU 398

Section: Appendix B

Revision:

Date: April 2003

\section{SAMPLE DELIVERY GROUP}

V1122 
CLOSURE REPORT - CAU 398

Section: Appendix B

Revision: 1

Date: April 2003

THIS PAGE INTENTIONALLY LEFT BLANK 


\section{CLIENT: Bechtel Nevada}

P.O. Box 98521, M'S NTS273

Las Vegas, NV 89193-8521

ATTN:

Ted Redding

PROJECT NAME: V1122

NEL ORDER ID: L0105275

PROJECT NUMBER: 23081

Attached are the analytical results for samples in support of the above referenced project.

Samples submitted for this project were not sampled by NEL Laboratories. Samples were received by NEL in good condition, under chain of custody on 5/29/01.

Should you have any questions or comments, please feel free to contact our Client Services department at (702) $657-1010$.

Some QA results have been flagged as follows:

$\mathrm{Jl}$ - The batch MS and/or MSD were outside acceptance limits. The batch LCS was acceptable.

Some surrogate results have been nagged as follows:

D - Sample required dilution. Sample QC results were diluted outside the calibrated range.
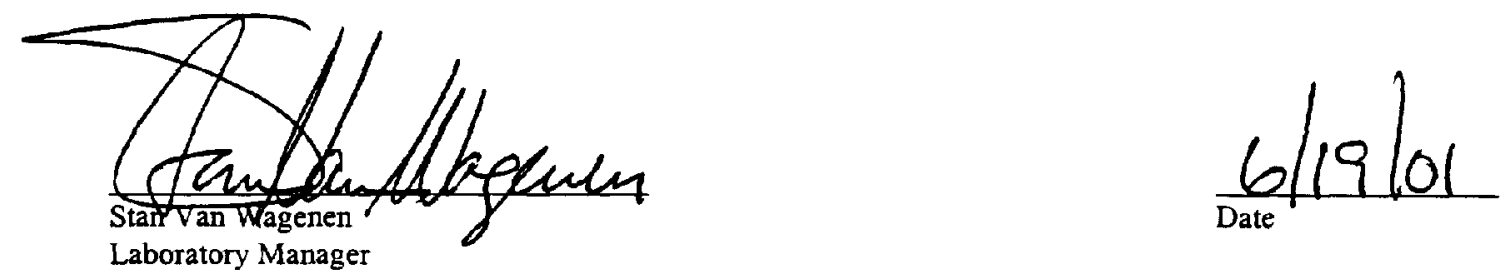

CERTIFICATIONS:

\begin{tabular}{llll}
\hline & Reno & Las Vegas & S. Califomia \\
\cline { 2 - 4 } Arizona & AZ0520 & AZ0518 & AZ0605 \\
California & 1707 & 2002 & 2264 \\
US Army Corps & Certified & Certified & \\
of Engineers & & &
\end{tabular}

Idaho

Montana

Nevada

L.A.C.S.D.

\begin{tabular}{lll} 
Reno & Las Vegas & S. California \\
\hline Certified & Certified & \\
Certified & Certified & \\
NV033 & NV052 & CA084 \\
& & 10228
\end{tabular}


NEL LABORATORIES

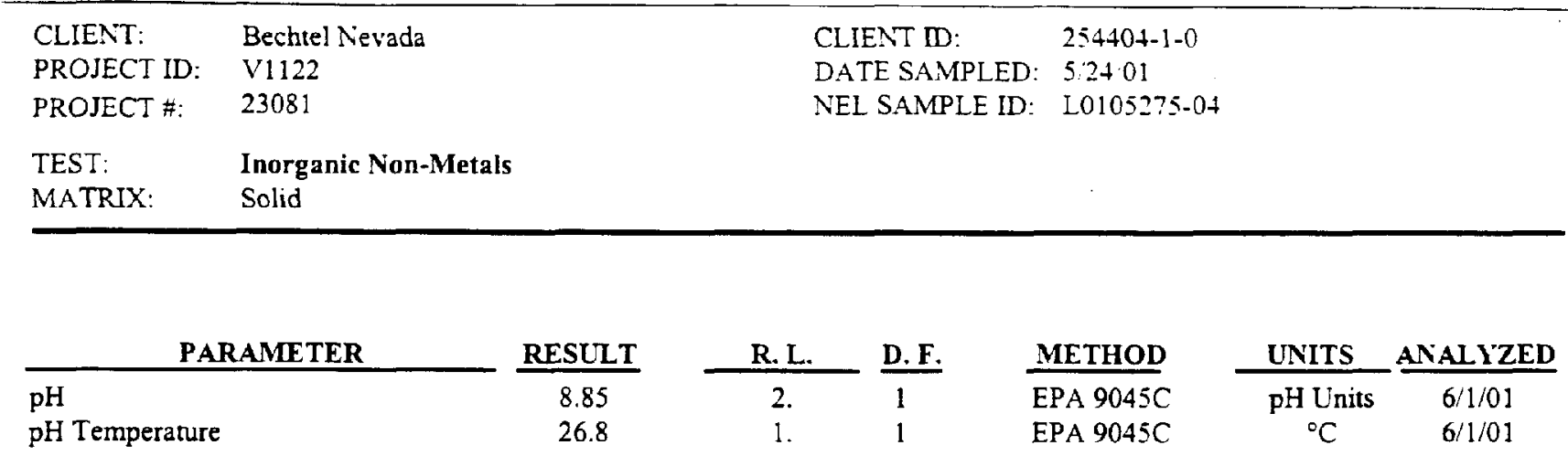

R.L. - Reporting Limit

D.F. - Dilution Factor

ND - Not Detected

This report shall not be reproduced except in full, without the written approval of the laboratory. 
NEL LABORATORIES

\begin{tabular}{llll}
\hline CLIENT: & Bechtel Nevada & CLIENT ID: & $254404-2-0$ \\
PROJECT ID: & V1122 & DATE SAMPLED: 52401 \\
PROJECT \#: & 23081 & NEL SAMPLE ID: $20105275-05$ \\
TEST: & Inorganic Non-Metals & \\
MATRIX: & Solid & \\
\hline
\end{tabular}

\begin{tabular}{|c|c|c|c|c|c|c|}
\hline PARAMETER & RESULT & R. L. & D. F. & METHOD & UNITS & ANALYZED \\
\hline $\mathrm{pH}$ & 7.48 & 2. & 1 & EPA $9045 C$ & $\mathrm{pH}$ Units & $6 / 1 / 01$ \\
\hline pH Temperanure & 26.6 & 1. & 1 & EPA $9045 C$ & ${ }^{\circ} \mathrm{C}$ & $6: 1 / 01$ \\
\hline
\end{tabular}

R.L. - Reporting Limit

D.F. - Dilution Factor

ND - Not Detected

This report shall not be reproduced except in full, without the written approval of the laboratory. 


\section{NEL LABORATORIES}

\begin{tabular}{llll} 
CLIENT: & Bechtel Nevada & CLIENT ID: & 254404-3-0 \\
PROJECT ID: & V1122 & DATE SAMPLED: 5/2401 \\
PROJECT \#: & 23081 & NEL SAMPLE ID: & L0105275-06 \\
TEST: & Inorganic Non-Metals & & \\
MATRIX: & Solid & & \\
\hline
\end{tabular}

\begin{tabular}{|c|c|c|c|c|c|c|}
\hline PARAMETER & RESLLT & R. L. & D. F. & METHOD & UNITS & ANALYZED \\
\hline $\mathrm{pH}$ & 9.77 & 2. & 1 & EPA 9045C & $\mathrm{pH}$ Units & $6 / 1 / 01$ \\
\hline pH Temperature & 26.3 & 1. & 1 & EPA $9045 C$ & ${ }^{\circ} \mathrm{C}$ & $6 / 1 / 01$ \\
\hline
\end{tabular}

R.L. - Reporting Limit

D.F. - Dilution Factor

ND - Not Detected

This report shall not be reproduced except in full, without the written approval of the laboratory. 
NEL LABORATORIES

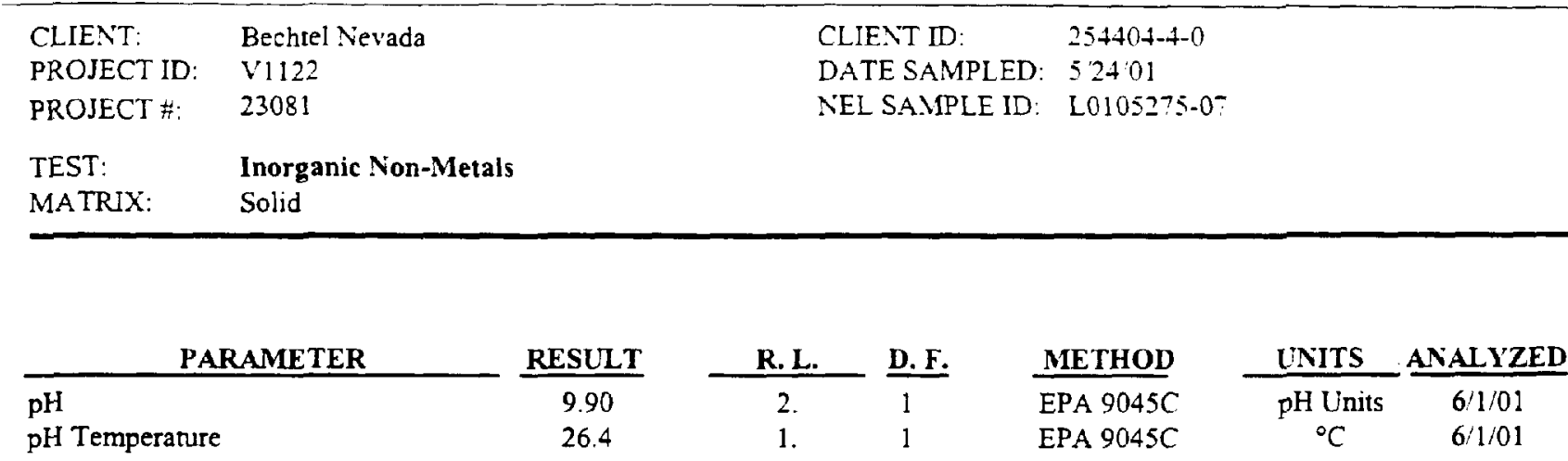

R.L. - Reporting Limit

D.F. - Dilution Factor

ND - Not Detected

This report shall not be reproduced except in full, without the written approval of the laboratory. 
NEL LABORATORIES

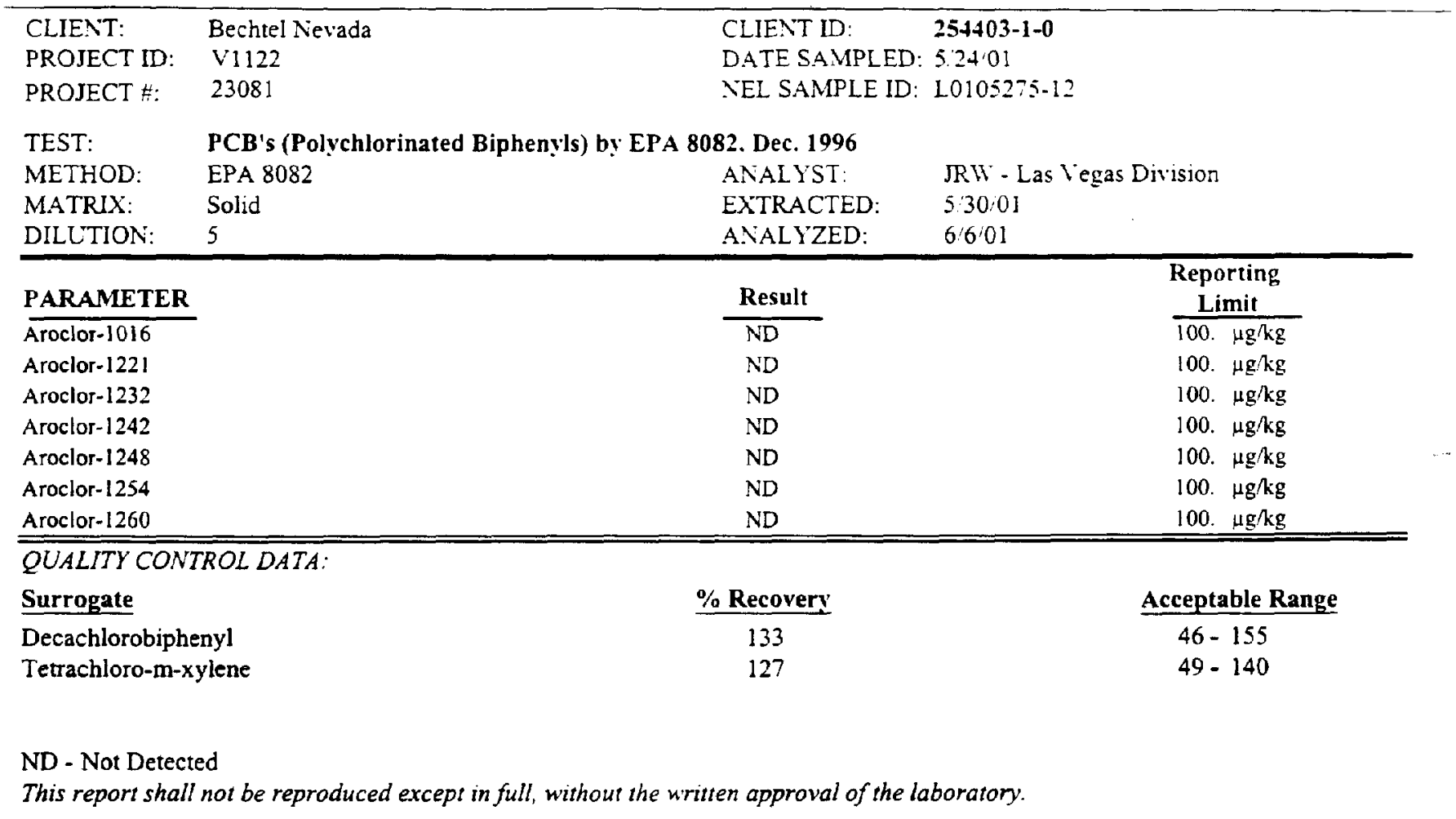


NEL LABORATORIES

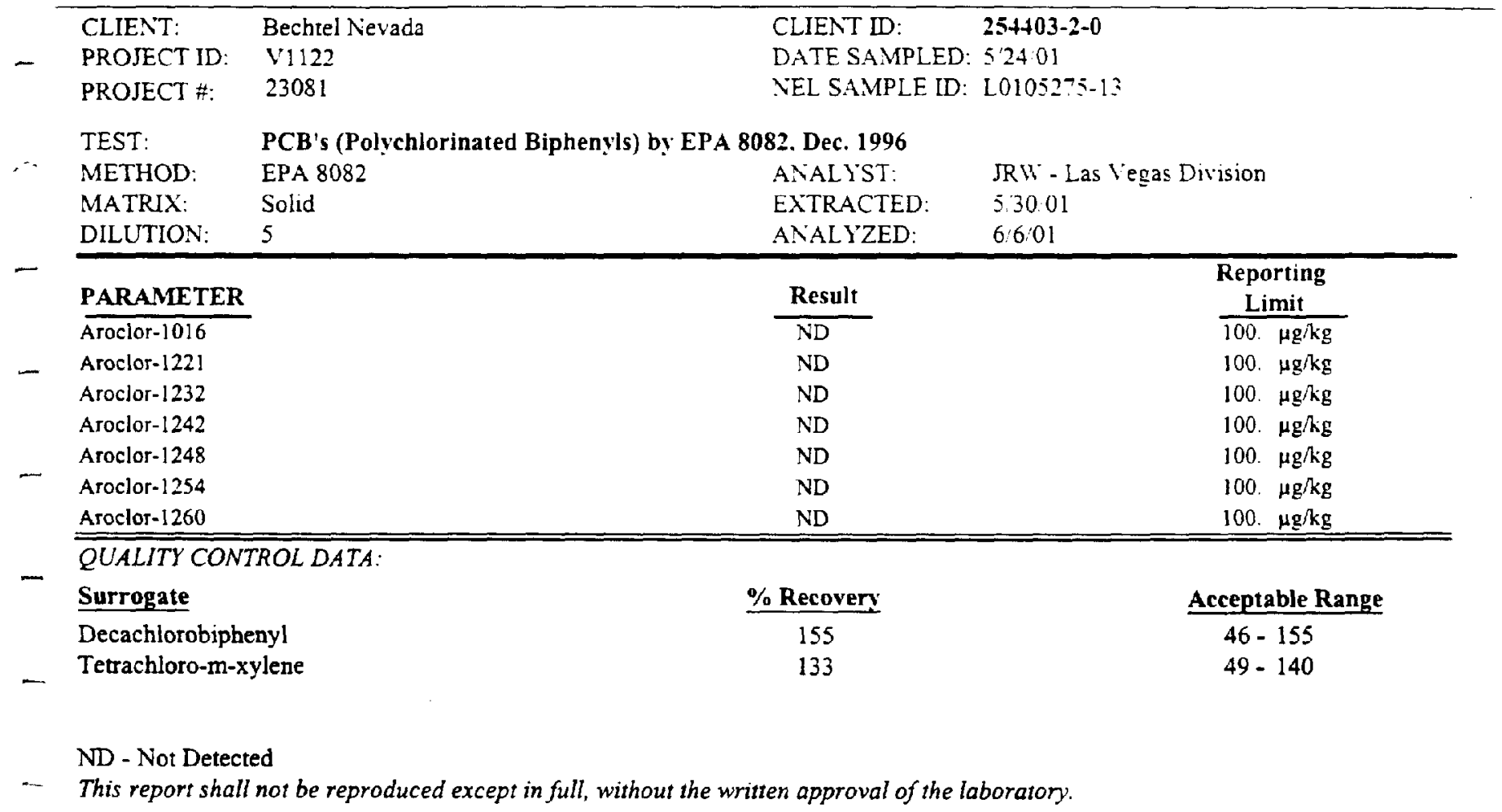




\section{NEL LABORATORIES}

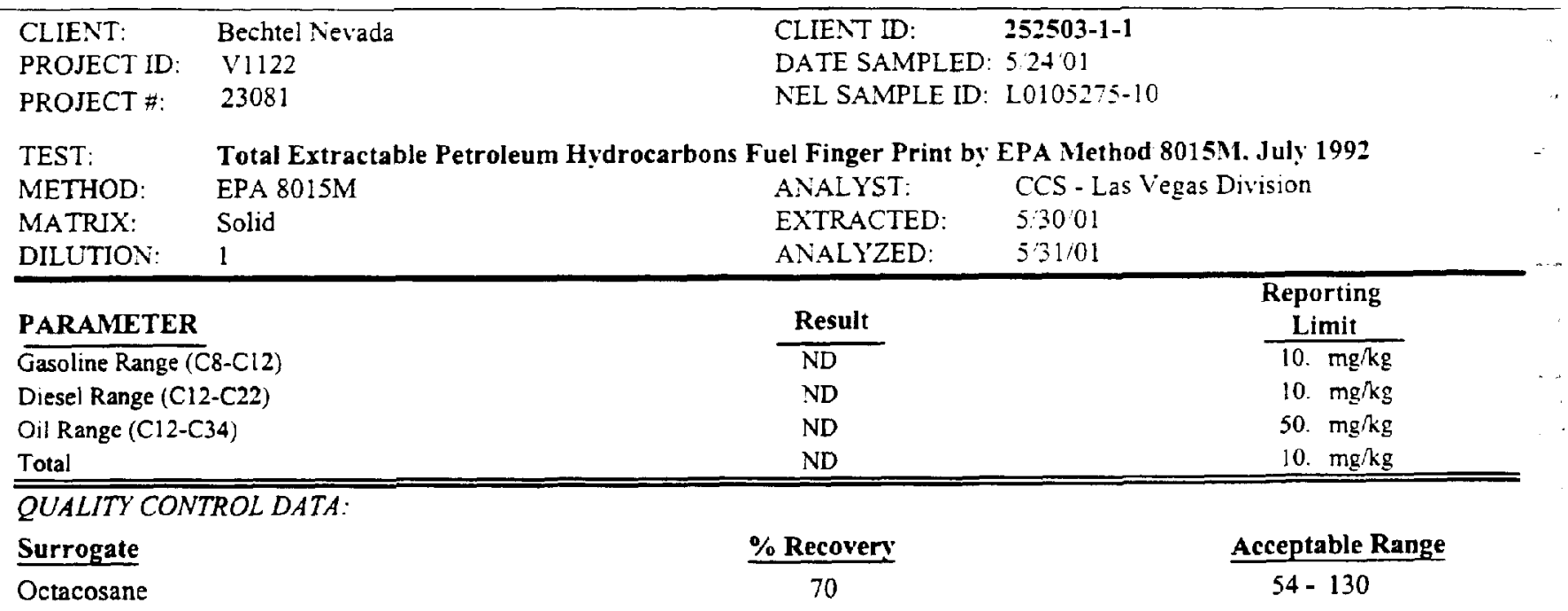

ND - Not Detected

This report shall not be reproduced except in full, without the written approval of the laboratory. 
NEL LABORATORIES

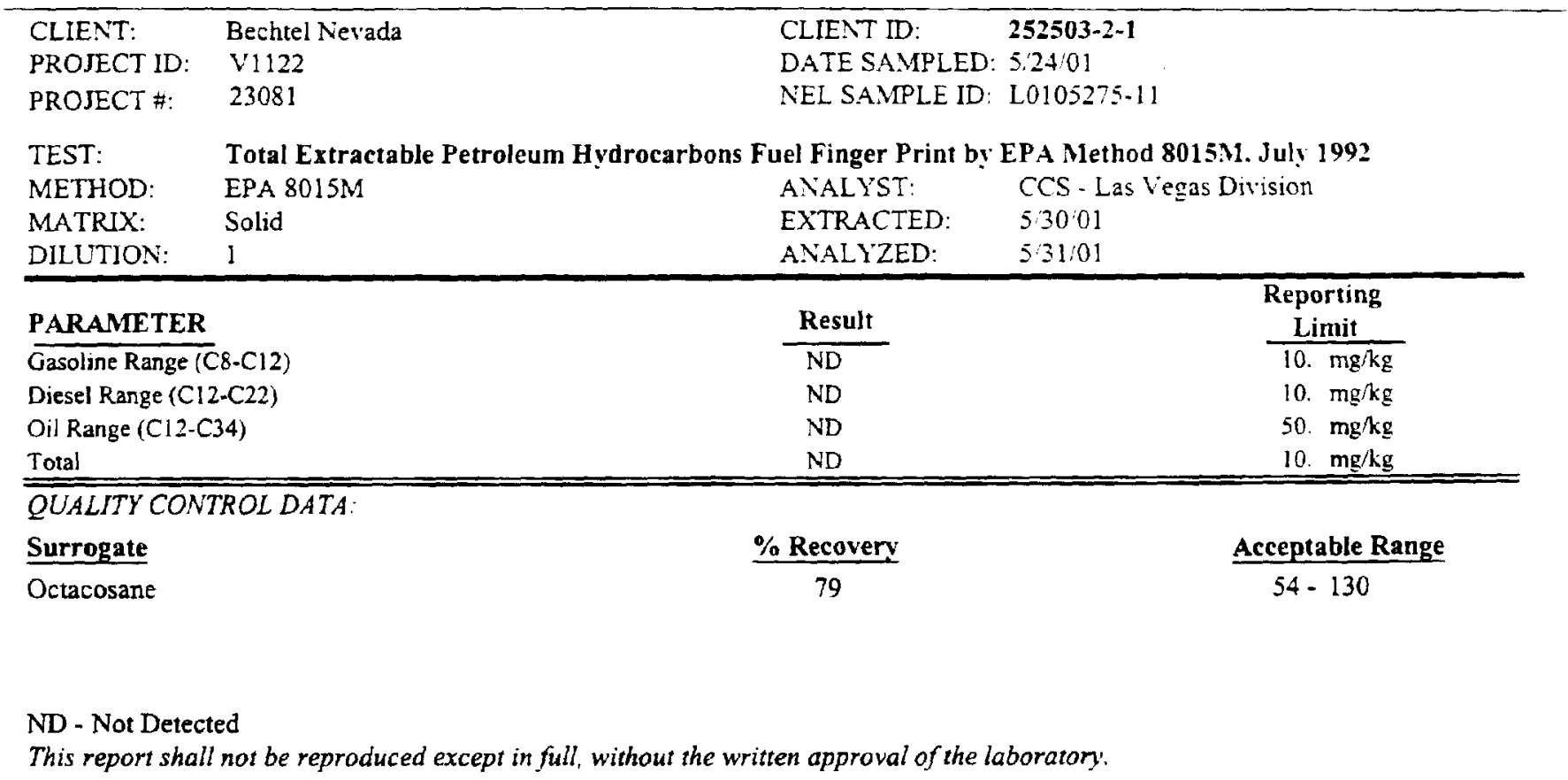


NEL LABORATORIES

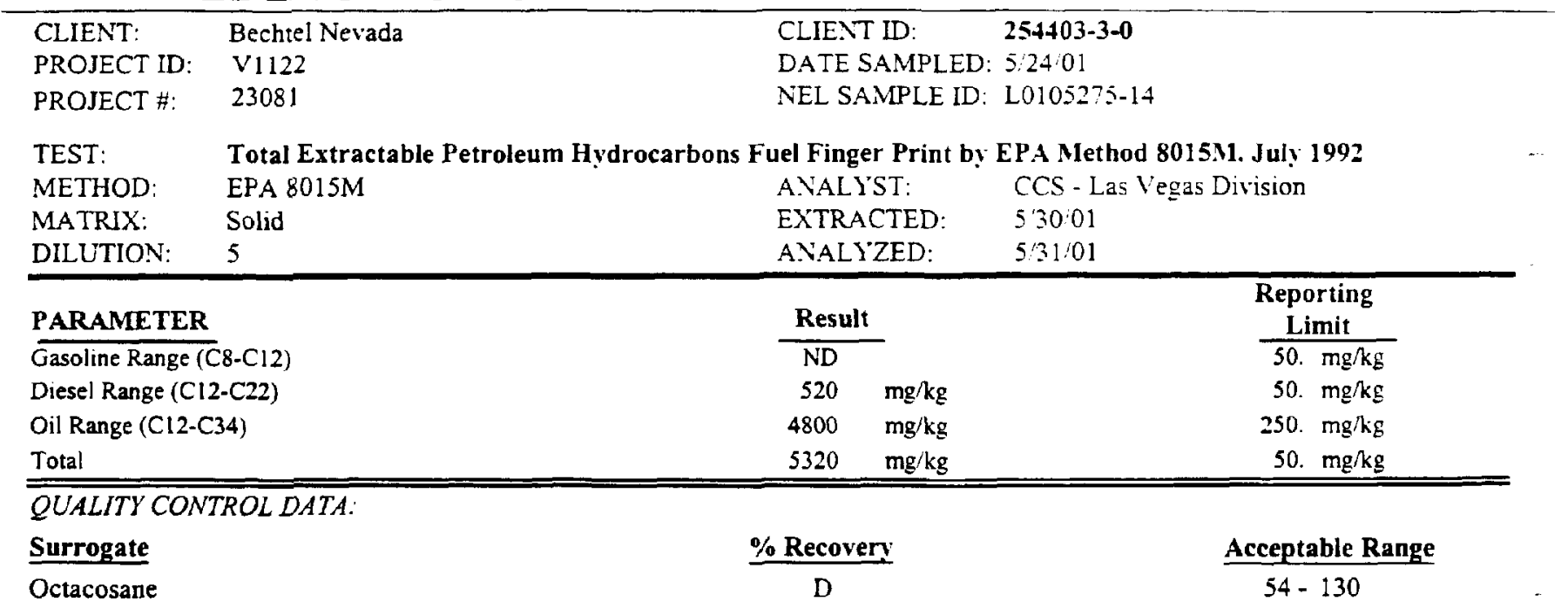

ND - Not Detected

This report shall not be reproduced except in full, without the written approval of the laboratory. 
NEL LABORATORIES

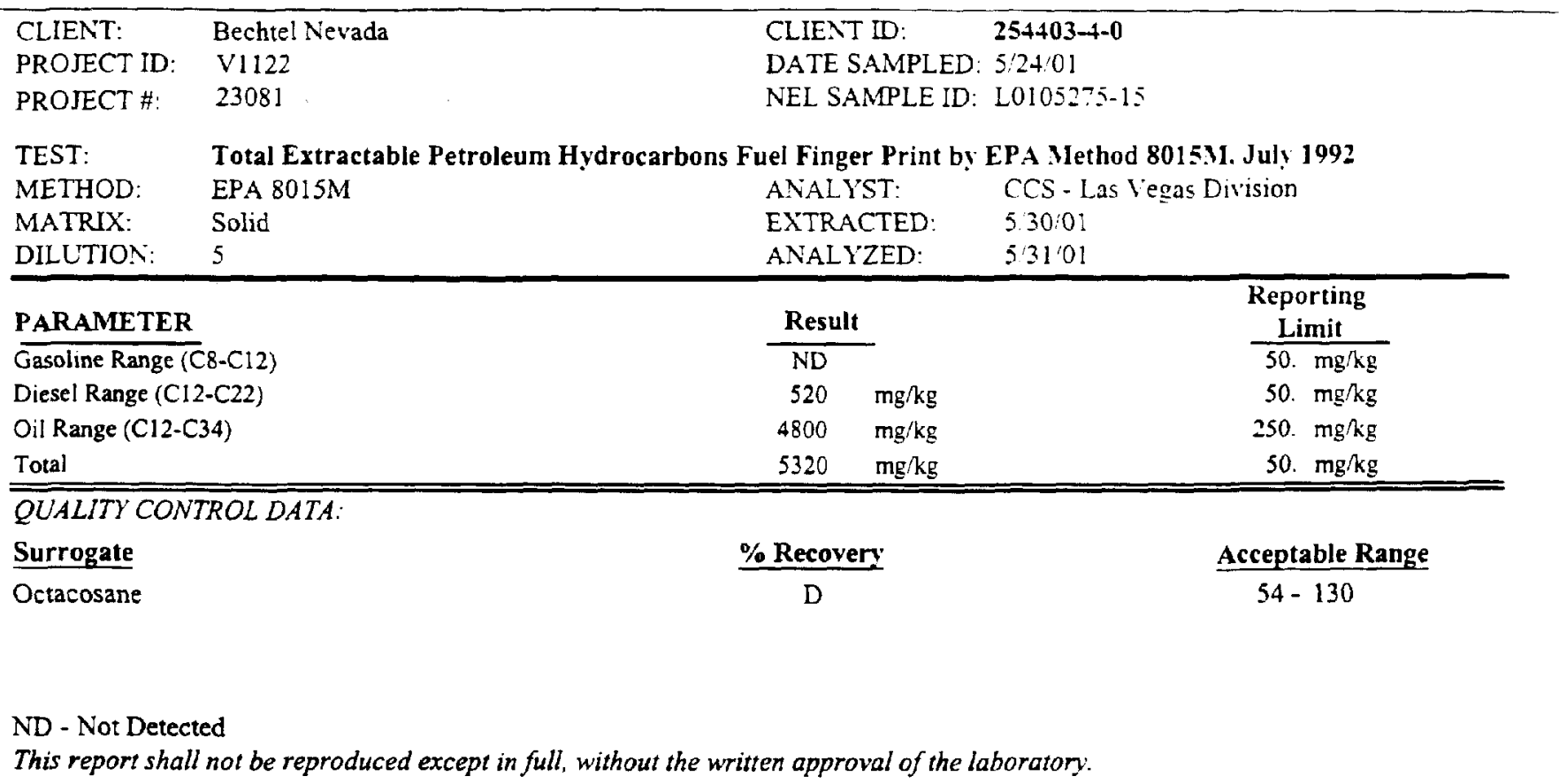


NEL LABORATORIES

$\begin{array}{llll}\text { CLIENT: } & \text { Bechtel Nevada } & \text { CLIENT ID: } & \mathbf{2 5 4 4 0 3 - 6 - 0} \\ \text { PROJECT ID: } & \text { V1122 } & \text { DATE SAMPLED: } 52401 \\ \text { PROJECT \#: } & 23081 & \text { NEL SAMPLE ID: } & \text { L0105275-16 }\end{array}$

TEST: $\quad$ Total Extractable Petroleum Hydrocarbons Fuel Finger Print by EPA Method 8015M. July 1992

METHOD: EPA 8015M ANALYST: CCS - Las Vegas Division

MATRIX: Solid EXTRACTED: $5: 3001$

DILUTION: 1 ANALYZED: $5 / 31 / 01$

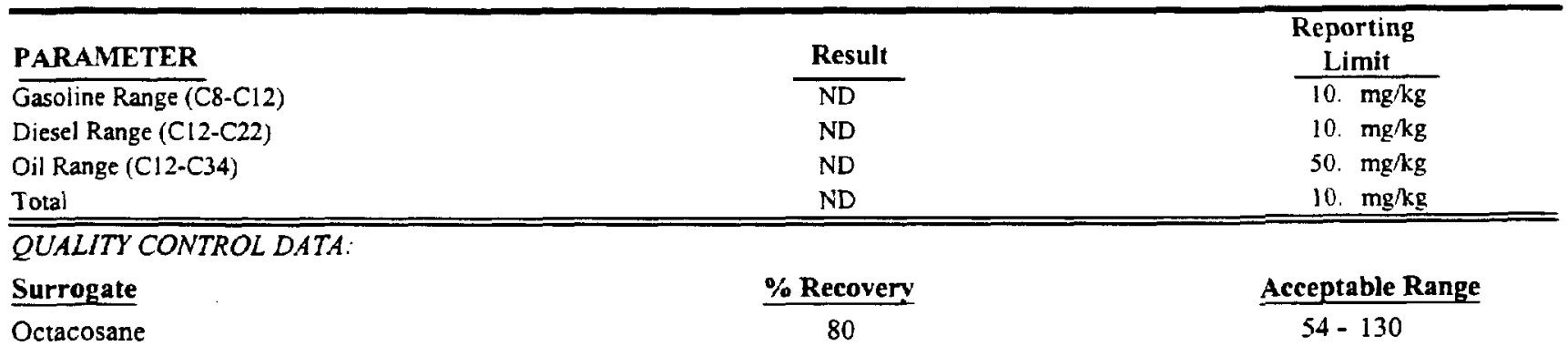

ND - Not Detected

This report shall not be reproduced except in full, without the written approval of the laboratory. 


\section{NEL LABORATORIES}

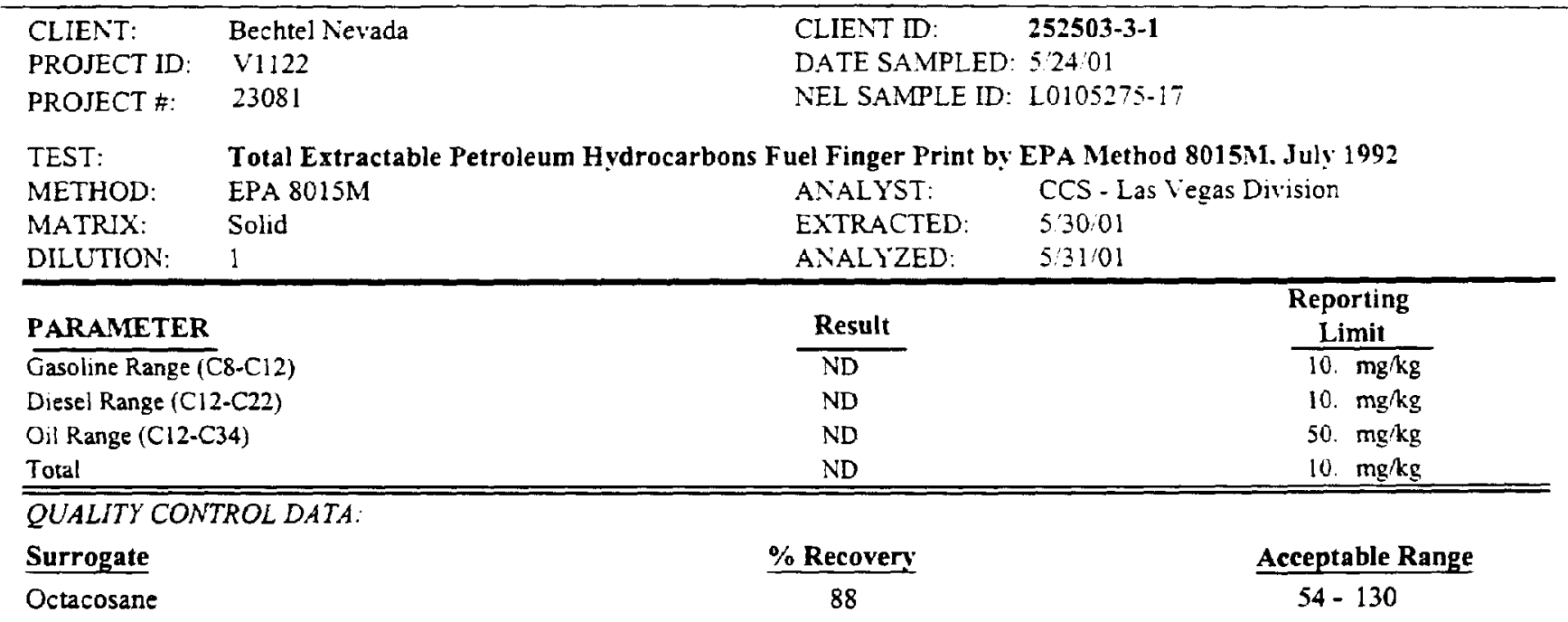

ND - Not Detected

This report shall not be reproduced except in full, without the written approval of the laboratory. 
NEL LABORATORIES

\begin{tabular}{|c|c|c|c|}
\hline $\begin{array}{l}\text { CLIENT: } \\
\text { PROJECT ID: } \\
\text { PROJECT } \$\end{array}$ & $\begin{array}{l}\text { Bechtel Nevada } \\
\text { V } 1122 \\
23081\end{array}$ & $\begin{array}{l}\text { CLIENT ID: } \\
\text { DATE SAMPLED: } \\
\text { NEL SAMPLE ID: }\end{array}$ & $\begin{array}{l}\text { Method Blank } \\
\text { NA } \\
010530 \text { PCBS-BLK }\end{array}$ \\
\hline $\begin{array}{l}\text { TEST: } \\
\text { METHOD: } \\
\text { MATRIX: }\end{array}$ & $\begin{array}{l}\text { PCB's (Polychlo } \\
\text { EPA } 8082 \\
\text { Solid }\end{array}$ & $\begin{array}{l}\text { 8082. Dec. } 1996 \\
\text { ANALYST: } \\
\text { EXTRACTED: } \\
\text { ANALYZED: }\end{array}$ & $\begin{array}{l}\text { JRW - Las Vegas Division } \\
53001 \\
6 / 6 / 01\end{array}$ \\
\hline PARAMETER & & Result & $\begin{array}{c}\text { Reporting } \\
\text { Limit } \\
\end{array}$ \\
\hline Aroclor-1016 & & $\mathrm{ND}$ & $20 . \mu \mathrm{g} / \mathrm{kg}$ \\
\hline Aroclor- 1221 & & ND & 20. $\mu \mathrm{g} / \mathrm{kg}$ \\
\hline Aroclor-1232 & & ND & 20. $\mu \mathrm{g} / \mathrm{kg}$ \\
\hline Aroclor- 1242 & & ND & 20. $\mu g / \mathrm{kg}$ \\
\hline Aroclor- 1248 & & ND & 20. $\mu \mathrm{g} / \mathrm{kg}$ \\
\hline Aroclor -1254 & & ND & 20. $\mu \mathrm{g} / \mathrm{kg}$ \\
\hline Aroclor 1260 & & ND & 20. $\mu \mathrm{g} / \mathrm{kg}$ \\
\hline \multicolumn{4}{|c|}{ QUALITY CONTROL DATA: } \\
\hline $\begin{array}{l}\text { Surrogate } \\
\text { Decachlorobiph } \\
\text { Tetrachloro-m-x }\end{array}$ & $\begin{array}{l}\text { enyl } \\
\text { ylene }\end{array}$ & 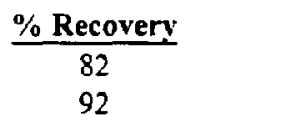 & $\begin{array}{c}\text { Acceptable Range } \\
46-155 \\
49-140\end{array}$ \\
\hline \multicolumn{4}{|c|}{$\begin{array}{l}\text { ND - Not Detected } \\
\text { This report shall not be reproduced except in full, without the written approval of the laboratory. }\end{array}$} \\
\hline $\begin{array}{l}\text { CLIENT: } \\
\text { PROJECT ID: } \\
\text { PROJECT \#: }\end{array}$ & $\begin{array}{l}\text { Bechtel Nevada } \\
\text { V } 1122 \\
23081\end{array}$ & $\begin{array}{l}\text { CLIENT I: } \\
\text { DATE SAMPLED: } \\
\text { NEL SAMPLE ID: }\end{array}$ & $\begin{array}{l}\text { Method Blank } \\
\text { NA } \\
\text { 010530TPHS-FP-BLK }\end{array}$ \\
\hline $\begin{array}{l}\text { TEST: } \\
\text { METHOD: } \\
\text { MATRIX: }\end{array}$ & $\begin{array}{l}\text { Total Extractab } \\
\text { EPA } 8015 \mathrm{M} \\
\text { Solid }\end{array}$ & $\begin{array}{l}\text { Fuel Finger Print by } \\
\text { ANALYST: } \\
\text { EXTRACTED: } \\
\text { ANALYZED: }\end{array}$ & $\begin{array}{l}\text { EPA Method 8015M, July } 1992 \\
\text { CCS - Las Vegas Division } \\
5 / 30 / 01 \\
5 / 31 / 01\end{array}$ \\
\hline PARAMETER & & Result & $\begin{array}{c}\text { Reporting } \\
\text { Limit } \\
\end{array}$ \\
\hline Gasoline Range ( & $8-(12)$ & ND & 10. $\mathrm{mg} / \mathrm{kg}$ \\
\hline Diesel Range ( $\mathrm{Cl}$ & $-C 22)$ & ND & 10. $\mathrm{mg} / \mathrm{kg}$ \\
\hline Oil Range ( $\mathrm{Cl} 2-\mathrm{C}$ & & ND & 50. $\mathrm{mg} / \mathrm{kg}$ \\
\hline Total & & ND & 10. $\mathrm{mg} / \mathrm{kg}$ \\
\hline \multicolumn{4}{|c|}{ QUALITY CONTROL DATA: } \\
\hline Surrogate & & $\%$ Recovery & Acceptable Range \\
\hline$\overline{\text { Octacosane }}$ & . & 81 & $54-130$ \\
\hline
\end{tabular}


NEL LABORATORIES

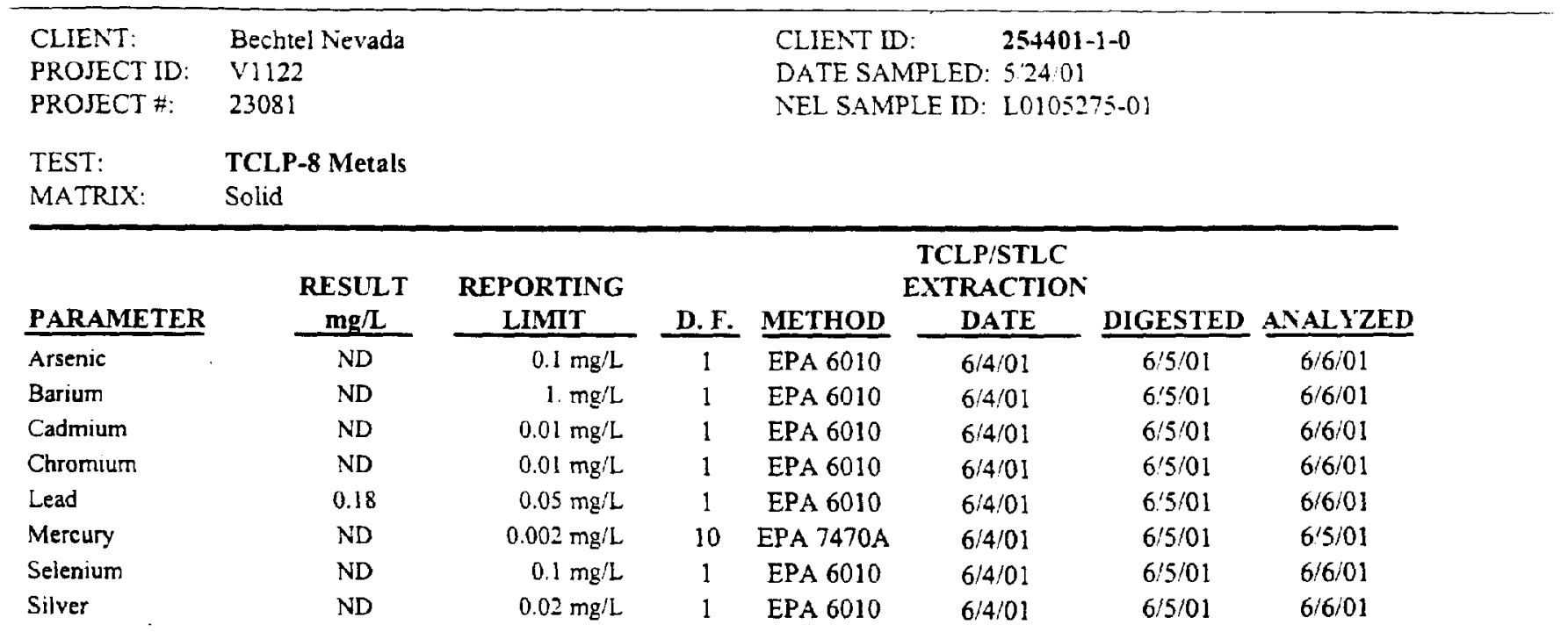

D.F. - Dilution Factor

ND - Not Detected

This report shall not be reproduced except in full, without the written approval of the laboratory. 
NEL LABORATORIES

\begin{tabular}{|c|c|c|c|c|c|c|c|}
\hline $\begin{array}{l}\text { CLIENT: } \\
\text { PROJECT ID: } \\
\text { PROJECT \#: }\end{array}$ & $\begin{array}{l}\text { Bechtel Nevada } \\
\text { V1122 } \\
23081\end{array}$ & & & $\begin{array}{l}\text { CLIENT II } \\
\text { DATE SAI } \\
\text { NEL SAM }\end{array}$ & $\begin{array}{ll} & \mathbf{2 5 + 4 0 1 -} \\
\text { MPLED: } & \mathbf{5} 24.01 \\
\text { PLE ID: } & \text { L01052 }\end{array}$ & $\begin{array}{l}2-0 \\
75-02\end{array}$ & \\
\hline $\begin{array}{l}\text { TEST: } \\
\text { MATRIX: }\end{array}$ & $\begin{array}{l}\text { TCLP-8 Metals } \\
\text { Solid }\end{array}$ & & & & & & \\
\hline PARAMETER & $\begin{array}{c}\text { RESULT } \\
\mathrm{mg} / \mathrm{L}\end{array}$ & $\begin{array}{c}\text { REPORTING } \\
\text { LIMIT } \\
\end{array}$ & D. F. & METHOD & $\begin{array}{c}\text { TCLP/STLC } \\
\text { EXTRACTION } \\
\text { DATE } \\
\end{array}$ & DIGESTED & ANALYZED \\
\hline$\overline{\text { Arsenic }}$ & ND & $0.1 \mathrm{mg} / \mathrm{L}$ & 1 & $\overline{\text { EPA } 6010}$ & $6 / 4 / 01$ & $6 / 5 / 01$ & $6 / 6 / 01$ \\
\hline Barium & ND & 1. $\mathrm{mg} / \mathrm{L}$ & 1 & EPA 6010 & $6 / 4 / 01$ & $6 / 5 / 01$ & $6 / 6 / 01$ \\
\hline Cadmium & $\mathrm{ND}$ & $0.01 \mathrm{mg} / \mathrm{L}$ & 1 & EPA 6010 & $6 / 4 / 01$ & $6 / 5 / 01$ & $6 / 6 / 01$ \\
\hline Chromium & ND & $0.01 \mathrm{mg} / \mathrm{L}$ & 1 & EPA 6010 & $6 / 4 / 01$ & $6 / 5 / 01$ & $6 / 6 / 01$ \\
\hline Lead & 0.12 & $0.05 \mathrm{mg} / \mathrm{L}$ & 1 & EPA 6010 & $6 / 4 / 01$ & $6 / 5 / 01$ & $6 / 6 / 01$ \\
\hline Mercury & $\mathrm{ND}$ & $0.002 \mathrm{mg} / \mathrm{L}$ & 10 & EPA $7470 \mathrm{~A}$ & $6 / 4 / 01$ & $6 / 5 / 01$ & $6 / 5 / 01$ \\
\hline Selenium & ND & $0.1 \mathrm{mg} / \mathrm{L}$ & 1 & EPA 6010 & $6 / 4 / 01$ & $6 / 5 / 01$ & $6 / 6 / 01$ \\
\hline Silver & ND & $0.02 \mathrm{mg} / \mathrm{L}$ & 1 & EPA 6010 & $6 / 4 / 01$ & $6 / 5 / 01$ & $6 / 6 / 01$ \\
\hline
\end{tabular}

D.F. - Dilution Factor

ND - Not Detected

This report shall not be reproduced except in full, without the written approval of the laboratory. 
NEL LABORATORIES

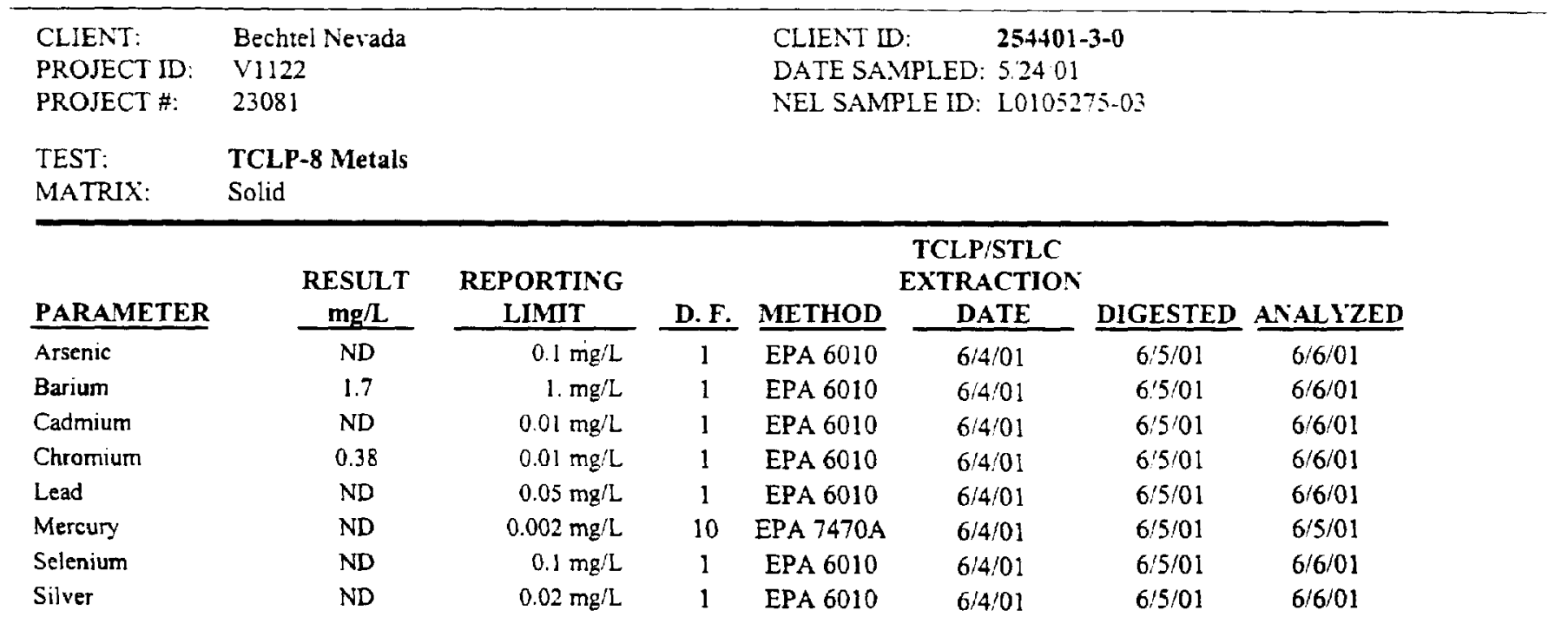

D.F. - Dilution Factor

ND - Not Detected

This report shall not be reproduced except in full, without the written approval of the laboratory. 
NEL LABORATORIES

\begin{tabular}{|c|c|c|c|c|c|c|c|}
\hline $\begin{array}{l}\text { CLIENT: } \\
\text { PROJECT ID: } \\
\text { PROJECT \#: }\end{array}$ & $\begin{array}{l}\text { Bechtel Nevada } \\
\text { V1122 } \\
23081\end{array}$ & & & $\begin{array}{l}\text { CLIENT ID } \\
\text { DATE SAN } \\
\text { NEL SAMF }\end{array}$ & $\begin{array}{ll}\text { D: } & \mathbf{2 5 4 4 0 3 -} \\
\text { MPIED: } & 524 / 01 \\
\text { PLE ID: } & \text { L010527 }\end{array}$ & $\begin{array}{l}1-0 \\
75-12\end{array}$ & \\
\hline $\begin{array}{l}\text { TEST: } \\
\text { MATRIX: }\end{array}$ & $\begin{array}{l}\text { TCLP-8 Metals } \\
\text { Solid }\end{array}$ & & & & & & \\
\hline PARAMETER & $\begin{array}{c}\text { RESULT } \\
\mathrm{mg} / \mathrm{L} \\
\end{array}$ & $\begin{array}{c}\text { REPORTING } \\
\text { LIMIT }\end{array}$ & D. F. & METHOD & $\begin{array}{c}\text { TCLP/STLC } \\
\text { EXTRACTION } \\
\text { DATE } \\
\end{array}$ & DIGESTED & ANALYZED \\
\hline Arsenic & $\mathrm{ND}$ & $0.1 \mathrm{mg} / \mathrm{L}$ & 1 & EPA 6010 & $6 / 4 / 01$ & $6 / 5 / 01$ & $6 / 6 / 01$ \\
\hline Barium & ND & 1. $\mathrm{mg} / \mathrm{L}$ & 1 & EPA 6010 & $6 / 4 / 01$ & $6 / 5 / 01$ & $6 / 6 / 01$ \\
\hline Cadmium & ND & $0.01 \mathrm{mg} / \mathrm{L}$ & 1 & EPA 6010 & $6 / 4 / 01$ & $6 / 5 / 01$ & $6 / 6 / 01$ \\
\hline Chromium & ND & $0.01 \mathrm{mg} / \mathrm{L}$ & 1 & EPA 6010 & $6 / 4 / 01$ & $6 / 5 / 01$ & $6 / 6 / 01$ \\
\hline Lead & 0.10 & $0.05 \mathrm{mg} / \mathrm{L}$ & 1 & EPA 6010 & $6 / 4 / 01$ & $6 / 5 / 01$ & $6 / 6 / 01$ \\
\hline Mercury & ND & $0.002 \mathrm{mg} / \mathrm{L}$ & 10 & EPA $7470 A$ & $6 / 4 / 01$ & $6 / 5 / 01$ & $6 / 5 / 01$ \\
\hline Selenium & ND & $0.1 \mathrm{mg} / \mathrm{L}$ & 1 & EPA 6010 & $6 / 4 / 01$ & $6 / 5 / 01$ & $6 / 6 / 01$ \\
\hline Silver & ND & $0.02 \mathrm{mg} / \mathrm{L}$ & 1 & EPA 6010 & $6 / 4 / 01$ & $6 / 5 / 01$ & $6 / 6 / 01$ \\
\hline
\end{tabular}

D.F. - Dilution Factor

ND - Not Detected

This report shall not be reproduced except in full, without the written approval of the laboratory. 
NEL LABORATORIES

\begin{tabular}{|c|c|c|c|c|c|c|c|}
\hline $\begin{array}{l}\text { CLIENT: } \\
\text { PROJECT ID: } \\
\text { PROJECT \#: }\end{array}$ & $\begin{array}{l}\text { Bechtel Nevada } \\
\text { V1122 } \\
23081\end{array}$ & & & $\begin{array}{l}\text { CLIENT II } \\
\text { DATE SAI } \\
\text { NEL SAMI }\end{array}$ & $\begin{array}{ll} & \mathbf{2 5 4 4 0 3 - 2} \\
\text { MPLED: } & 5.24: 01 \\
\text { PLE ID: } & \text { L01052? }\end{array}$ & $2-0$ & \\
\hline $\begin{array}{l}\text { TEST: } \\
\text { MATRIX: }\end{array}$ & $\begin{array}{l}\text { TCLP-8 Metals } \\
\text { Solid }\end{array}$ & & & & & & \\
\hline PARAMETER & $\begin{array}{c}\text { RESULT } \\
\mathrm{mg} / \mathrm{L} \\
\end{array}$ & $\begin{array}{c}\text { REPORTING } \\
\text { LIMIT } \\
\end{array}$ & D. F. & METHOD & $\begin{array}{c}\text { TCLP/STLC } \\
\text { EXTRACTION } \\
\text { DATE } \\
\end{array}$ & DIGESTED & ANALYZED \\
\hline Arsenic & ND & $0.1 \mathrm{mg} / \mathrm{L}$ & 1 & EPA 6010 & $6 / 4 / 01$ & $6 / 5 / 01$ & $6 / 6 / 01$ \\
\hline Barium & ND & 1. $\mathrm{mg} / \mathrm{L}$ & 1 & EPA 6010 & $6 / 4 / 01$ & $6 / 5 / 01$ & $6 / 6 / 01$ \\
\hline Cadmium & ND & $0.01 \mathrm{mg} / \mathrm{L}$ & 1 & EPA 6010 & $6 / 4 / 01$ & $6 / 5 / 01$ & $6 / 6 / 01$ \\
\hline Chromium & ND & $0.01 \mathrm{mg} / \mathrm{L}$ & 1 & EPA 6010 & $6 / 4 / 01$ & $6 / 5 / 01$ & $6 / 6 / 01$ \\
\hline Lead & 0.18 & $0.05 \mathrm{mg} / \mathrm{L}$ & 1 & EPA 6010 & $6 / 4 / 01$ & $6 / 5 / 01$ & $6 / 6 / 01$ \\
\hline Mercury & ND & $0.002 \mathrm{mg} / \mathrm{L}$ & 10 & EPA $7470 A$ & $6 / 4 / 01$ & $6 / 5 / 01$ & $6 / 5 / 01$ \\
\hline Selenium & ND & $0.1 \mathrm{mg} / \mathrm{L}$ & 1 & EPA 6010 & $6 / 4 / 01$ & $6 / 5 / 01$ & $6 / 6 / 01$ \\
\hline Silver & ND & $0.02 \mathrm{mg} / \mathrm{L}$ & 1 & EPA 6010 & $6 / 4 / 01$ & $6 / 5 / 01$ & $6 / 6 / 01$ \\
\hline
\end{tabular}

D.F. - Dilution Factor

ND - Not Detected

This report shall not be reproduced except in full, without the written approval of the laboratory. -.. 
NEL LABORATORIES

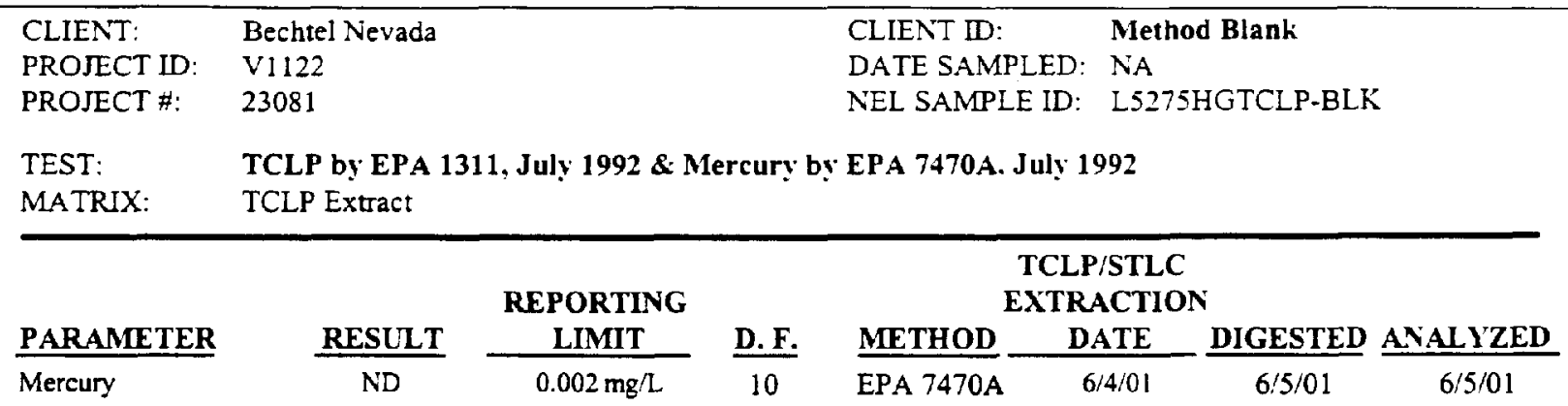

D.F. - Dilution Factor

ND - Not Detected

This report shall not be reproduced except in full, without the wntten approval of the laboratory. 
NEL LABORATORIES

\begin{tabular}{llll}
\hline CLIENT: & Bechtel Nevada & CLIENT ID: & Method Blank \\
PROJECT D: & VI122 & DATE SAMPLED: & NA \\
PROJECT \#: & 23081 & NEL SAMPLE ID: & L5275I-BLK
\end{tabular}

TEST: $\quad$ TCLP by EPA 1311, July 1992 \& 7 Metals by EPA 6010A. July 1992

MATRIX: TCLP Extract

\begin{tabular}{|c|c|c|c|c|c|c|c|}
\hline \multirow[b]{2}{*}{ PARAMETER } & \multirow[b]{2}{*}{ RESULT } & \multirow{2}{*}{$\begin{array}{c}\text { REPORTING } \\
\text { LIMIT } \\
\end{array}$} & \multicolumn{5}{|c|}{$\begin{array}{l}\text { TCLP/STLC } \\
\text { EXTRACTION }\end{array}$} \\
\hline & & & $\underline{\text { D. F. }}$ & METHOD & DATE & DIGESTED & ANALYZED \\
\hline Arsenic & ND & $0.1 \mathrm{mg} / \mathrm{L}$ & 1 & EPA 6010 & $6 / 4 / 01$ & $6 / 5 / 01$ & $6 / 6 / 01$ \\
\hline Barium & ND & 1. $\mathrm{mg} / \mathrm{L}$ & 1 & EPA 6010 & $6 / 4 / 01$ & $6.5 / 01$ & $6 / 6 / 01$ \\
\hline Cadmium & ND & $0.01 \mathrm{mg} / \mathrm{L}$ & 1 & EPA 6010 & $6 / 4 / 01$ & $6 / 5 / 01$ & $6 / 6 / 01$ \\
\hline Chromium & ND & $0.01 \mathrm{mg} / \mathrm{L}$ & 1 & EPA 6010 & 6/4/01 & $6 / 5 / 01$ & $6 / 6 / 01$ \\
\hline Lead & ND & $0.05 \mathrm{mg} / \mathrm{L}$ & 1 & EPA 6010 & $6 / 4 / 01$ & $6 / 5 / 01$ & $6 / 6 / 01$ \\
\hline Selenium & ND & $0.1 \mathrm{mg} / \mathrm{L}$ & 1 & EPA 6010 & $6 / 4 / 01$ & $6 / 5 / 01$ & $6 / 6 / 01$ \\
\hline Silver & ND & $0.02 \mathrm{mg} / \mathrm{L}$ & 1 & EPA 6010 & $6 / 4 / 01$ & $6 / 5 / 01$ & $6 / 6 / 01$ \\
\hline
\end{tabular}

D.F. - Dilution Factor

ND - Not Detected

This report shall not be reproduced except in full, without the written approval of the laboratory. 
NEL LABORATORIES

CLIENT: Bechtel Nevada

PROJECT ID: V1122

PROJECT \#: 23081

TEST: $\quad$ PCB's (Polychlorinated Biphenyls) by EPA 8082, Dec. 1996

MATRIX: Solid

\begin{tabular}{|c|c|c|c|c|c|c|c|}
\hline PARAMETER & NEL Sample ID & $\frac{\text { Spike }}{\text { Amount }}$ & $\frac{\text { Spike }}{\text { Result }}$ & Percent & & $\frac{\text { Acceptable }}{\text { Range }}$ & $\underline{\text { RPD }}$ \\
\hline Aroclor-1016 & 010530PCBS-LCS & 333 & 262 & 79 & & $63 \cdot 127$ & \\
\hline Aroclor -1016 & 010530PCBS-LCSD & 333 & 258 & 77 & & $63-127$ & 1.5 \\
\hline Aroclor-1016 & L0105277-01-MS & 333 & 0 & 0 & $\mathrm{Jl}$ & $55-142$ & \\
\hline Aroclor- 1016 & L0105277-01-MSD & 333 & 0 & 0 & J1 & $55-142$ & 0 \\
\hline Aroclor -1260 & 010530PCBS-LCS & 333 & 274 & 82 & & $57-138$ & \\
\hline Aroclor -1260 & 010530PCBS-LCSD & 333 & 244 & 73 & & $57-138$ & 11.6 \\
\hline Aroclor- 1260 & L0105277-01-MS & 333 & 340 & 102 & & $48-129$ & \\
\hline Aroclor- 1260 & L0105277-01-MSD & 333 & 337 & 101 & & $48-129$ & 0.9 \\
\hline
\end{tabular}

ND - Not Detected

This report shall not be reproduced except in full, without the written approval of the laboratory. 
NEL LABORATORIES

CLIENT: Bechtel Nevada

PROJECT ID: VI122

PROJECT \#: $\quad 23081$

TEST: $\quad$ Total Extractable Petroleum Hydrocarbons Fuel Finger Print by EPA Method 8015N1. July 1992

MATRIX: Solid

\begin{tabular}{|c|c|c|c|c|c|c|}
\hline PARAMETER & NEL Sample ID & $\frac{\text { Spike }}{\text { Amount }}$ & $\frac{\text { Spike }}{\text { Result }}$ & $\frac{\text { Percent }}{\text { Recovery }}$ & $\frac{\text { Acceptable }}{\text { Range }}$ & $\underline{\text { RPD }}$ \\
\hline Diesel Range (C12-C22) & 010530TPHS-FP-ICS & 166.7 & 128 & 77 & $53-91$ & \\
\hline Diesel Range (C12-C22) & 010530TPHS-FP-LCSD & 166.7 & 133 & 80 & $53-91$ & 3.8 \\
\hline Diesel Range (C12-C22) & L0105247-02-MS & 166.7 & 135 & 81 & $34-114$ & \\
\hline Diesel Range (C12-C22) & L0105247-02-MSD & 166.7 & 142 & 85 & $34-114$ & 5.1 \\
\hline Total & 010530TPHS-FP-LCS & 166.7 & 128 & 77 & $53-91$ & \\
\hline Total & 010530TPHS-FP-LCSD & 166.7 & 133 & 80 & $53-91$ & 3.8 \\
\hline Total & L0105247-02-MS & 166.7 & 135 & 81 & $34-114$ & \\
\hline Total & L0105247-02-MSD & 166.7 & 142 & 85 & $34-114$ & 5.1 \\
\hline
\end{tabular}

ND - Not Detected

This report shall not be reproduced except in full, without the written approval of the laboratory. 
NEL LABORATORIES

$\begin{array}{ll}\text { CLIENT: } & \text { Bechtel Nevada } \\ \text { PROJECT ID: } & \text { V } 1122 \\ \text { PROJECT \#: } & 23081 \\ \text { TEST: } & \text { Inorganic Non-Metals } \\ \text { MATRIX: } & \text { Solid }\end{array}$

7.00 Buffer
NEL Sample ID 010601PH2-LCS

\begin{tabular}{|c|c|c|c|c|}
\hline Spike & Spike & Percent & $\frac{\text { Acceptable }}{\text { Ranae }}$ & RPD \\
\hline 7 & 6.98 & 100 & $99-101$ & \\
\hline
\end{tabular}

ND - Not Detected

This report shall not be reproduced except in full, without the written approval of the laboratory. 
NEL Laboratories

\begin{tabular}{|c|c|c|c|c|c|c|c|}
\hline $\begin{array}{l}\text { CLIENT: } \\
\text { PROJECT ID: } \\
\text { PROJECT \#: }\end{array}$ & $\begin{array}{l}\text { Bechrel Nevada } \\
\text { V1122 } \\
23081\end{array}$ & & & & & & \\
\hline $\begin{array}{l}\text { TEST: } \\
\text { MATRIX: }\end{array}$ & $\begin{array}{l}\text { TCLP/STLC Metals } \\
\text { Solid }\end{array}$ & & & & & & \\
\hline PARAMETER & & NEL Sample ID & $\frac{\text { Spike }}{\text { Amount }}$ & $\frac{\text { Spike }}{\text { Result }}$ & $\frac{\text { Percent }}{\text { Recovery }}$ & $\frac{\text { Acceptable }}{\text { Range }}$ & RPD \\
\hline Mercury & & L5275HGTCLP-LCS & 0.05 & 0.0515 & 103 & $85-115$ & \\
\hline Mercury & & L0105275-01-MS & 0.05 & 0.0518 & 104 & $75-125$ & \\
\hline Mercury & & L0105275-01-MSD & 0.05 & 0.056 & 112 & $75-125$ & 7.8 \\
\hline
\end{tabular}

ND - Not Detected

This report shall not be reproduced except in full, without the written approval of the laboratory. 
NEL LABORATORIES

\begin{tabular}{ll}
\hline CLIENT: & Bechrel Nevada \\
PROJECT ID: & V1122 \\
PROJECT \#: & 23081 \\
TEST: & TCLP/STLC Metals \\
MATRIX: & Solid \\
\hline
\end{tabular}

\begin{tabular}{|c|c|c|c|c|c|c|}
\hline PARAMETER & NEL Sample ID & $\begin{array}{c}\text { Spike } \\
\text { Amount }\end{array}$ & $\frac{\text { Spike }}{\text { Result }}$ & $\frac{\text { Percent }}{\text { Recovery }}$ & $\frac{\text { Acceptable }}{\underline{\text { Range }}}$ & $\underline{\mathbf{R P D}}$ \\
\hline Arsenic & L5275I-LCS & 0.5 & 0.529 & 106 & $85-115$ & \\
\hline Arsenic & L0105275-01-MS & 0.5 & 0.553 & 111 & $75-125$ & \\
\hline Arsenic & L0105275-01-MSD & 0.5 & 0.547 & 109 & $75-125$ & 1.1 \\
\hline Silver & L5275I-LCS & 0.5 & 0.434 & 87 & $85-115$ & \\
\hline Silver & L0105275-01-MS & 0.5 & 0.45 & 90 & $75-125$ & \\
\hline Silver & L0105275-01-MSD & 0.5 & 0.455 & 91 & $75-125$ & 1.1 \\
\hline Barium & L5275I-LCS & 1 & 0.99 & 99 & $85-115$ & \\
\hline Barium & L0105275-01-MS & 1 & 1.2 & 120 & $75-125$ & \\
\hline Barium & L0105275-01-MSD & 1 & 1.19 & 119 & $75-125$ & 0.8 \\
\hline Cadmium & L5275I-LCS & 0.5 & 0.472 & 94 & $85-115$ & \\
\hline Cadmium & L0105275-01-MS & 0.5 & 0.484 & 97 & $75-125$ & \\
\hline Cadmium & L0105275-01-MSD & 0.5 & 0.505 & 101 & $75-125$ & 4.2 \\
\hline Chromium & L5275I-LCS & 0.5 & 0.478 & 96 & $85-115$ & \\
\hline Chromium & L0105275-01-MS & 0.5 & 0.504 & 101 & $75-125$ & \\
\hline Chromium & L0105275-01-MSD & 0.5 & 0.513 & 103 & $75-125$ & 1.8 \\
\hline Lead & L5275I-LCS & 1 & 0.928 & 93 & $85-115$ & \\
\hline Lead & L0105275-01-MS & 1 & 1.11 & 93 & $75-125$ & \\
\hline Lead & L0105275-01-MSD & 1 & 1.17 & 99 & $75-125$ & 6.2 \\
\hline Selenium & L5275I-LCS & 0.5 & 0.507 & 101 & $85-115$ & \\
\hline Selenium & L0105275-01-MS & 0.5 & 0.48 & 96 & $75-125$ & \\
\hline Selenium & L0105275-01-MSD & 0.5 & 0.485 & 97 & $75-125$ & 1. \\
\hline
\end{tabular}




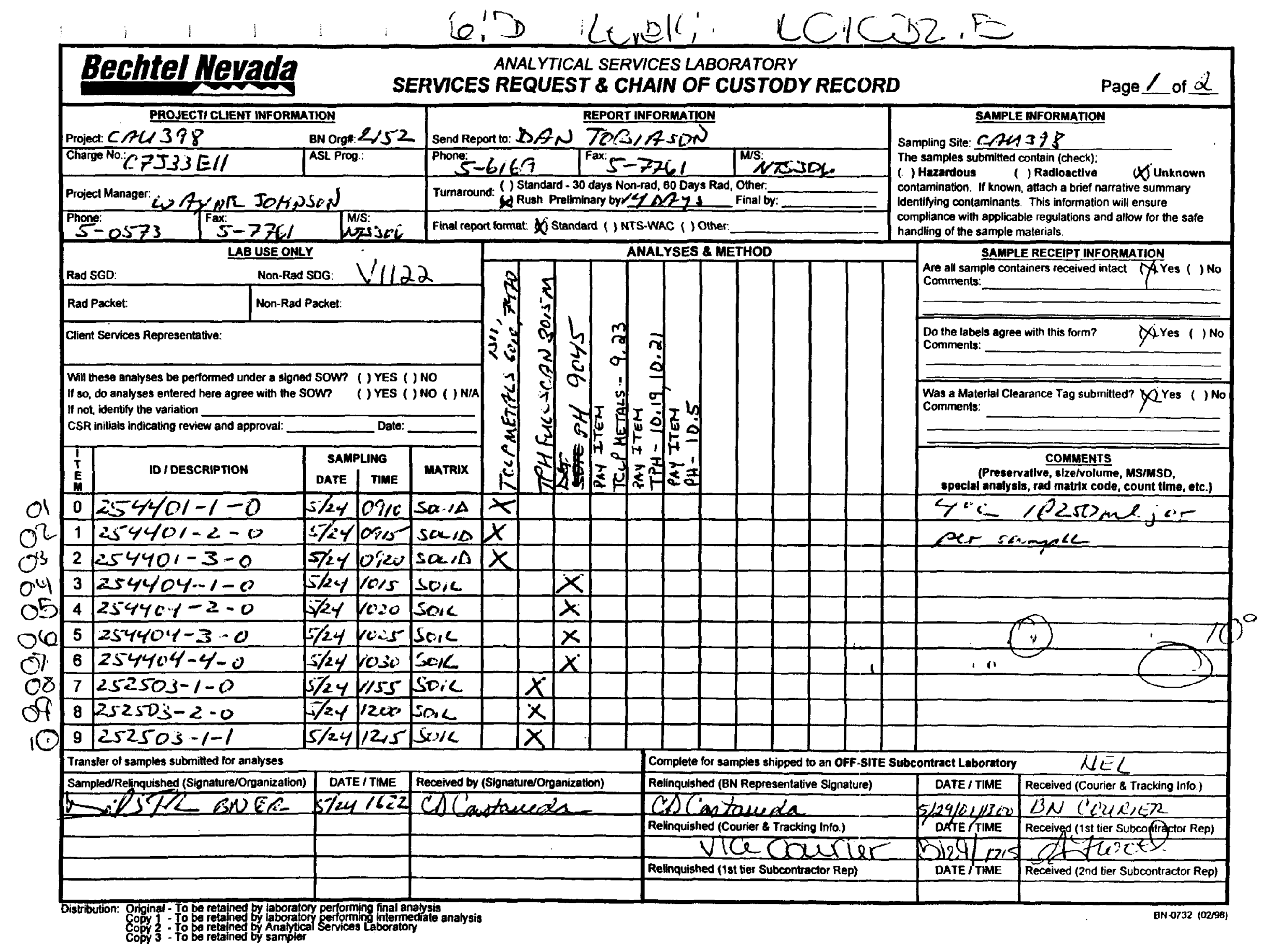




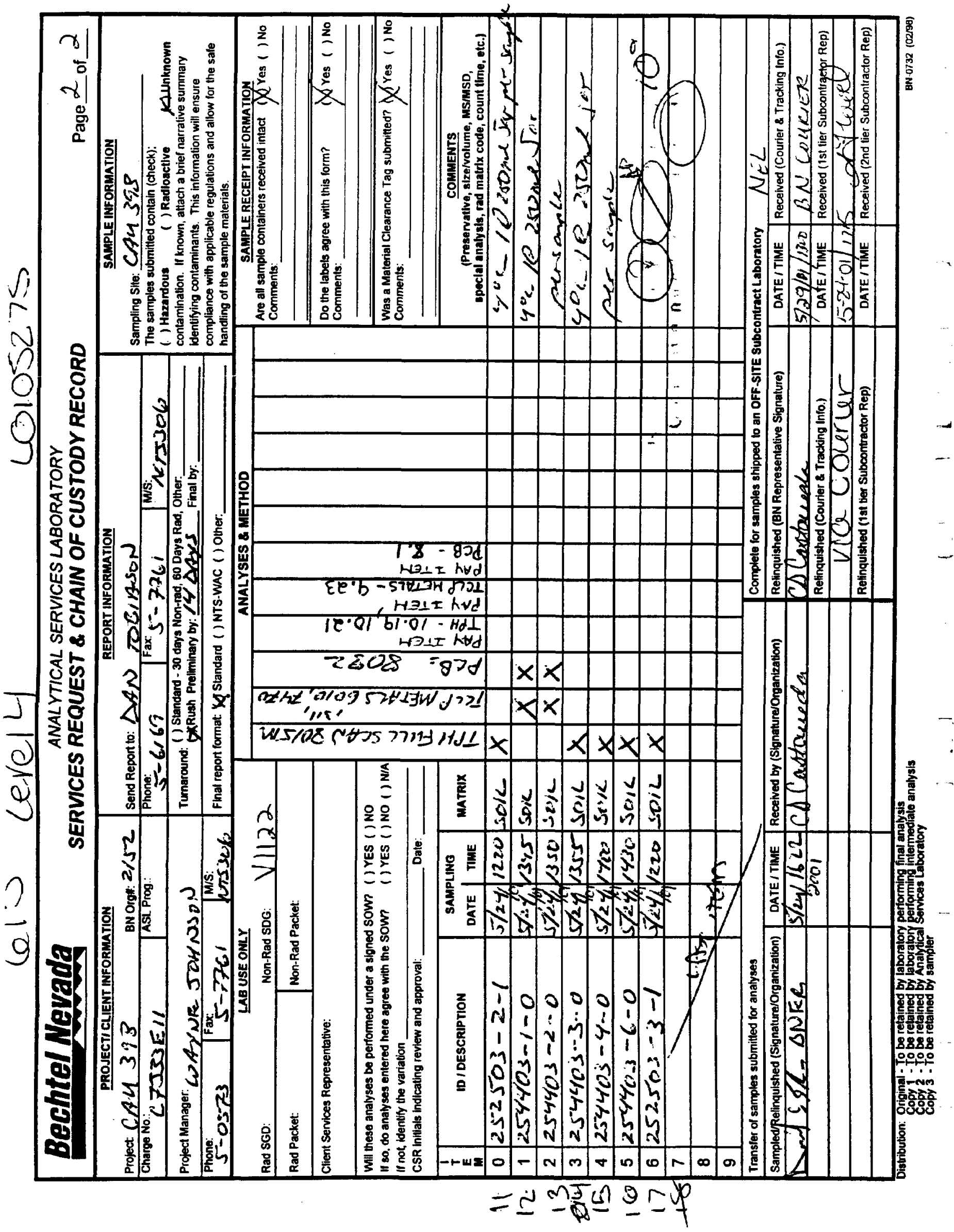


CLOSURE RFPORT - CAU 398

Section: Appendix B

Revision: 1

Date: $A$ pril 2003

\section{SAMPLE DELIVERY GROUP}

\section{V1123}


CLOSURE REPORT - CAU 398 Section: Appendix B

Revision: 1

Date: April 2003

THIS PAGE INTENTIONALLY LEFT BLANK 


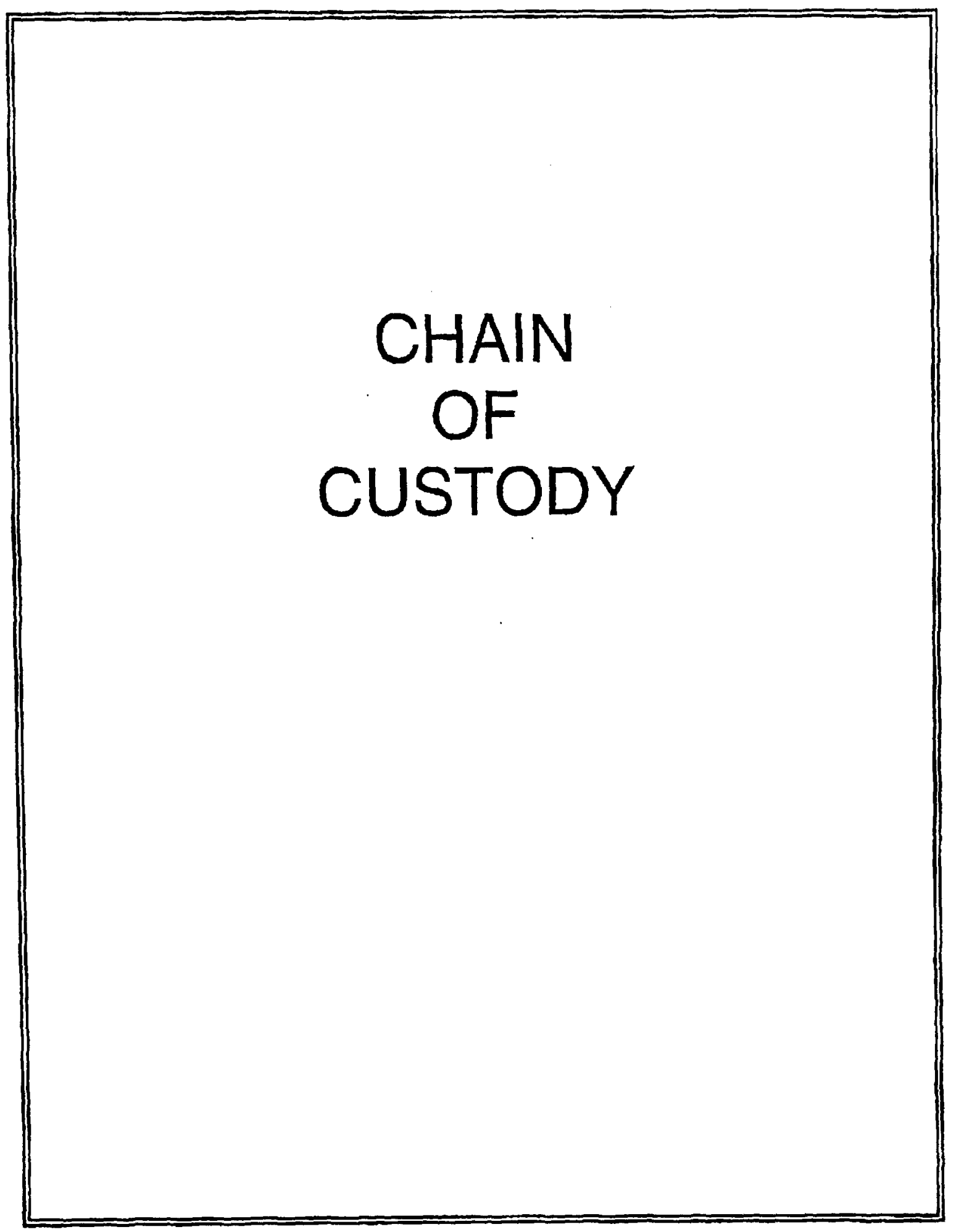




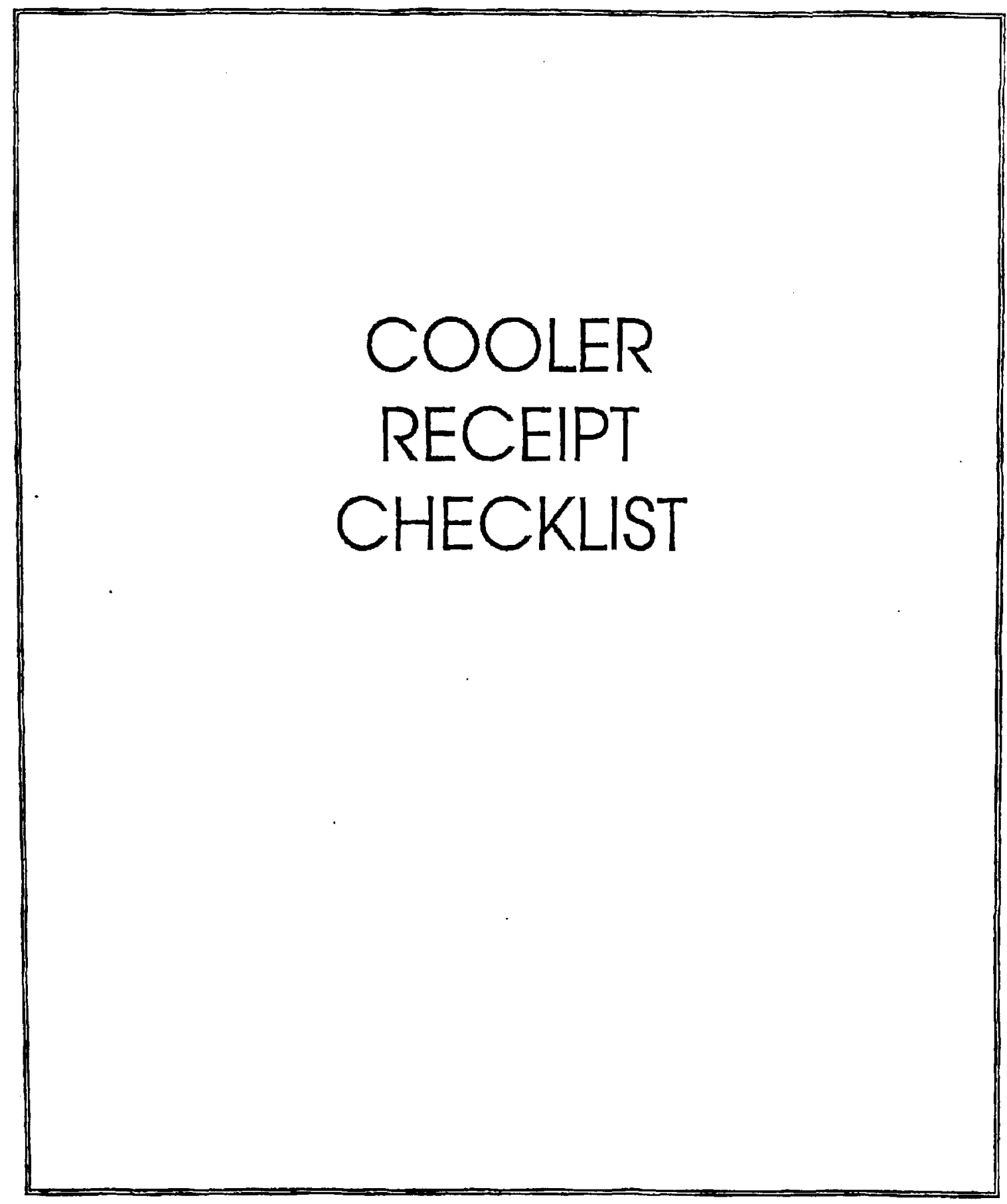




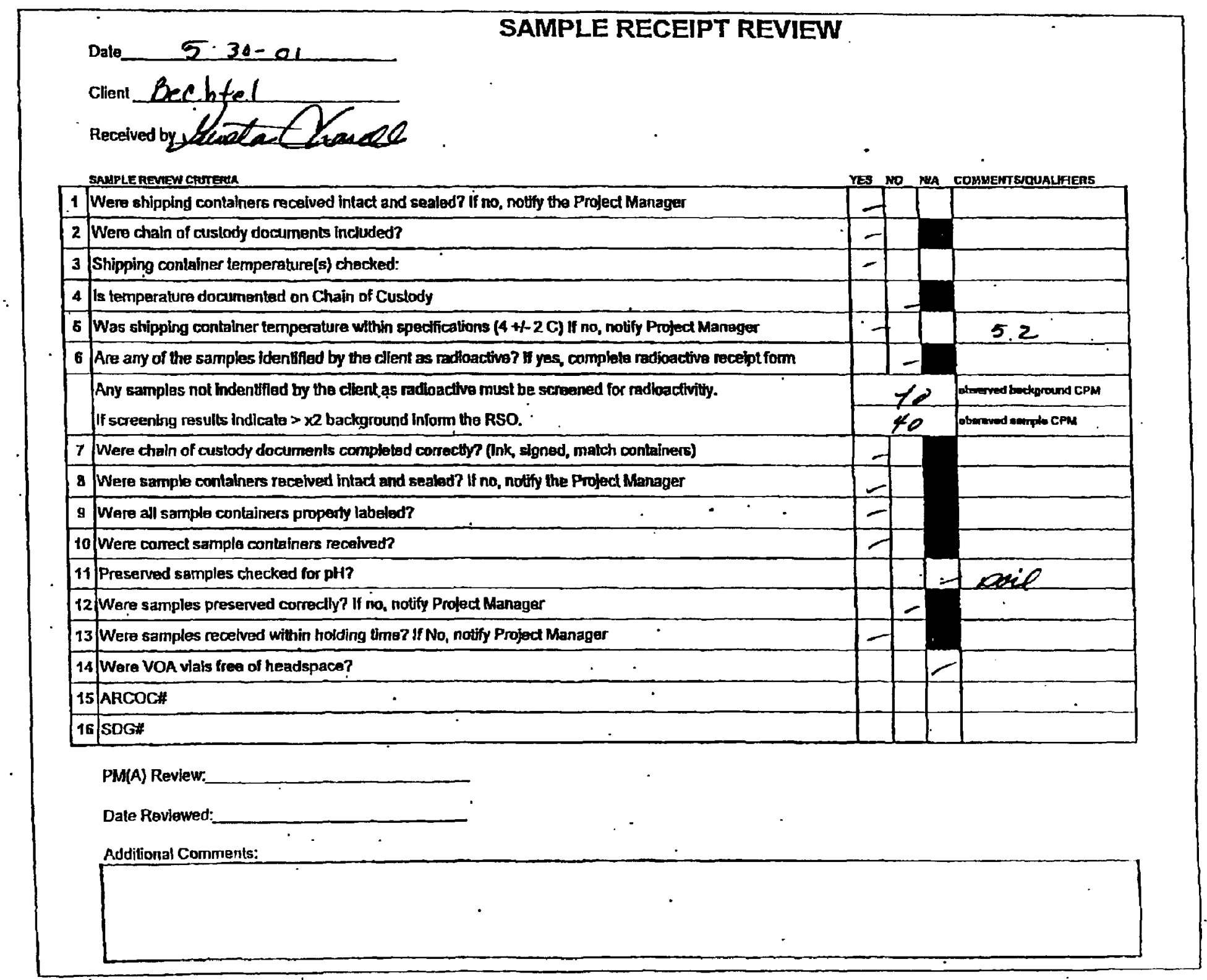




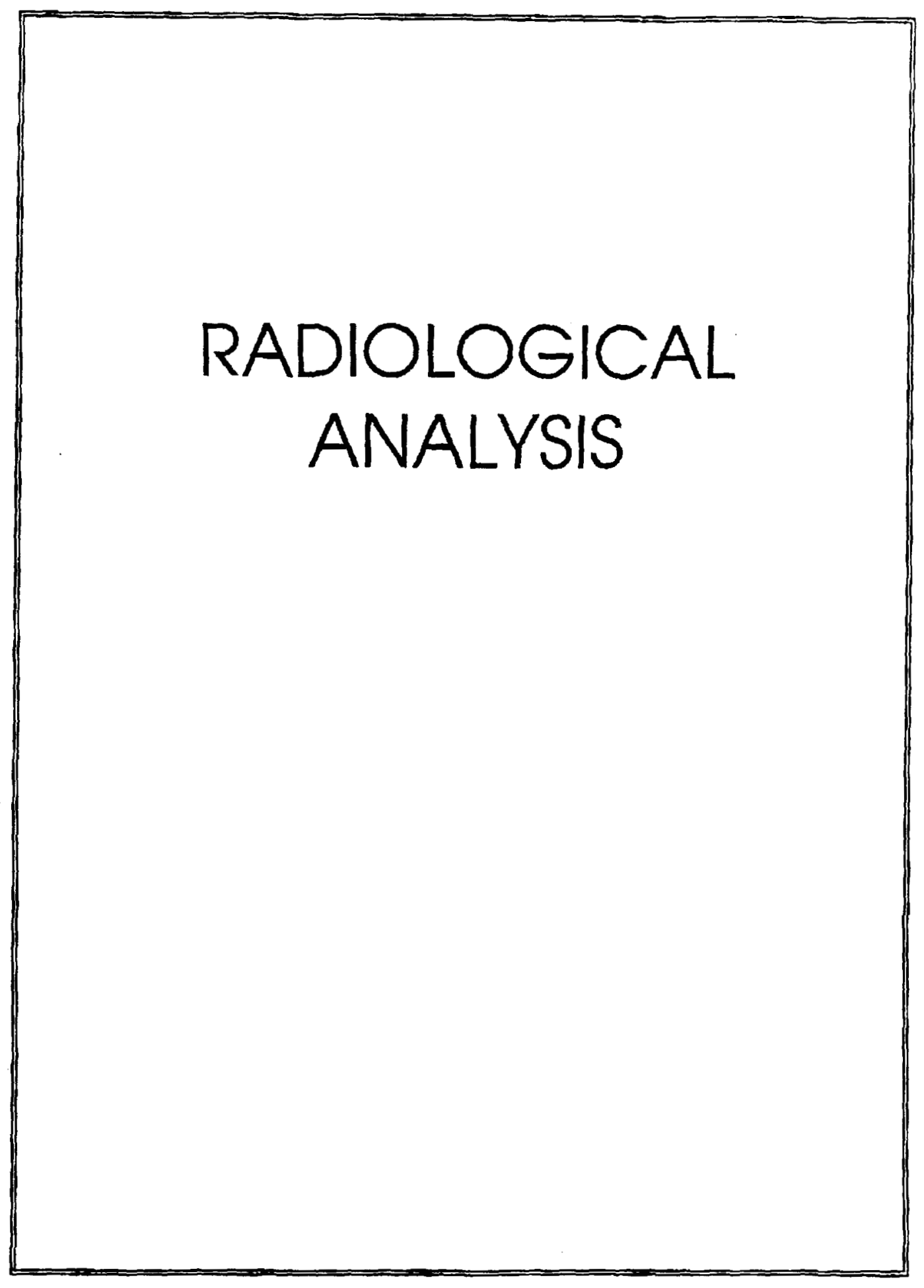




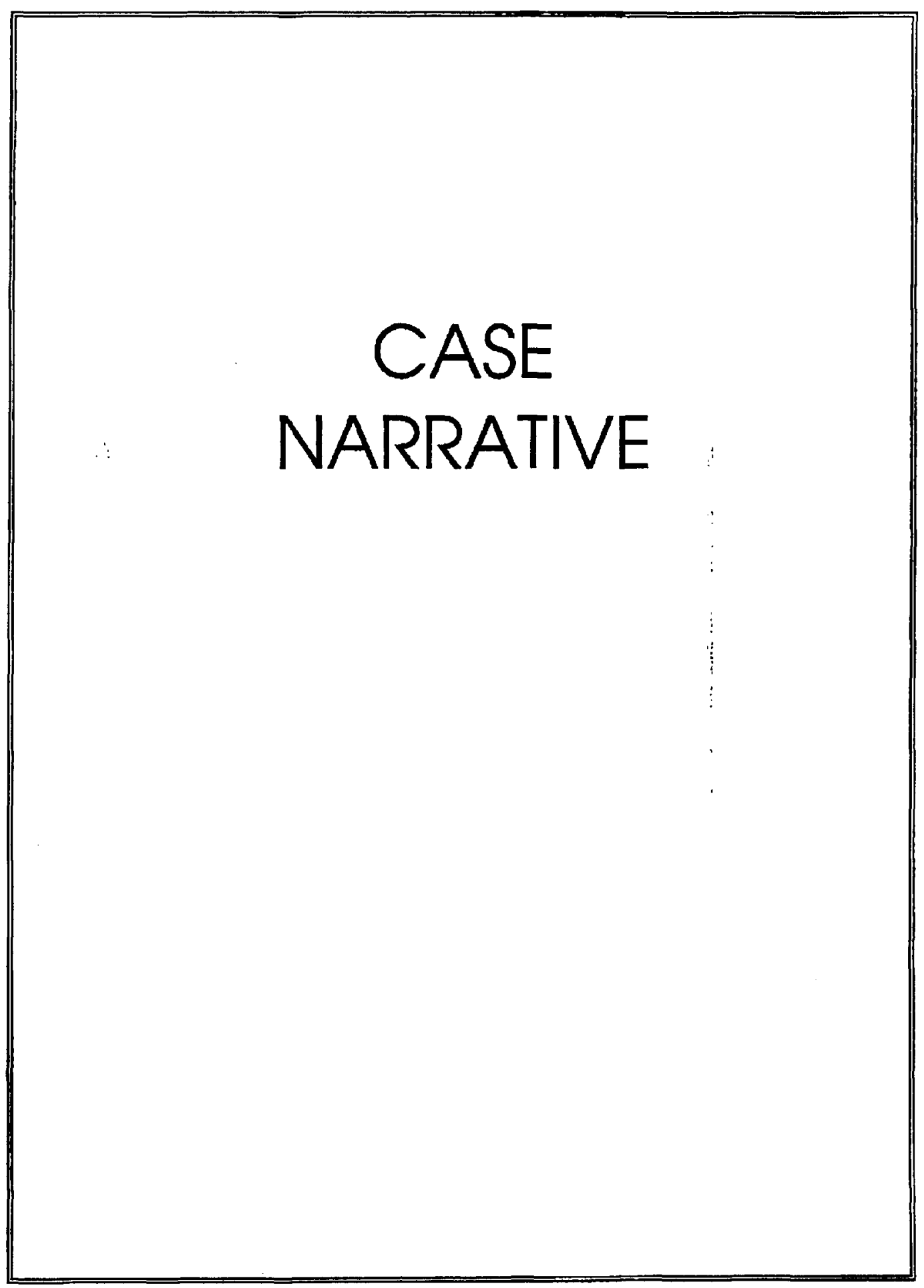




\section{Radiochemistry Case Narrative}

Bechtel Nevada Corp. (NEVA)

SDG V1123

Method/Analysis Information

Batch Number:

80749

Procedure:

Analytical Method:

Determination of Gamma Isotopes in Water and Soil

DOE EML HASL 300

Sample ID
43010001
43010002
43010003
43010004
1200013917
1200013918
1200013919

Client ID

254401-3-0

254404-2-0

252503-2-0

254403-1-0

MB for batch 80749

254402-1-0(42918001DUP)

LCS for batch 80749

\section{SOP Reference}

Procedures for preparation, analysis and reporting of analytical data are controlled by General Engineering Laboratories, Inc. as Standard Operating Procedures (SOP). The data discussed in this narrative has been prepared and analyzed in accordance with GL-RAD-A-013.

\section{Calibration Information:}

Calibration Information

All initial and continuing calibration requirements have been met.

\section{Standards Information}

Standard solution(s) for these analyses are NIST traceable and used before the expiration date(s).

\section{Sample Geometry}

All counting sources were prepared in the same geometry as the calibration standards.

\section{Quality Control (OC) Information:}

Blank Information

The blank volume is representative of the sample volume(s) in this batch.

\section{Designated QC}

The following sample(s) was used for QC: 42918001 .

\section{QC Information}

All of the QC samples met the required acceptance limits.

\section{Technical Information:}

\section{Holding Time}

All sample procedures for this sample set were performed within the required holding time.

\section{Preparation Information}

All preparation criteria have been met for these analyses.

Sample Re-prep/Re-analysis

None of the samples in this sample set required reprep or reanalysis. 


\section{Miscellaneous Information:}

\section{NCR Documentation}

No NCR were generated for the preparation or analysis of this sample set.

Manual Integration

No manual integrations were performed on data in this batch.

Additional Comments

$\mathrm{K}-40$ is being reported in all samples in this batch.

\section{Reviev Validation:}

GEL requires all analytical data to be verified by a qualified data validator. In addition, all data designated for CLP or CLP-like packaging will receive a third level validation upon completion of the data package.

The following data validator verified the information presented in this case narrative:

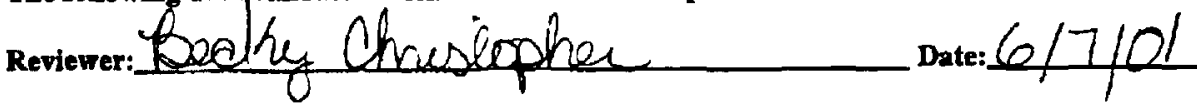




\section{GENERAL ENGINEERING LABORATORIES}

Meeling rodoy's needs with a vision for tomorrow:

\section{Certificate of Analysis}

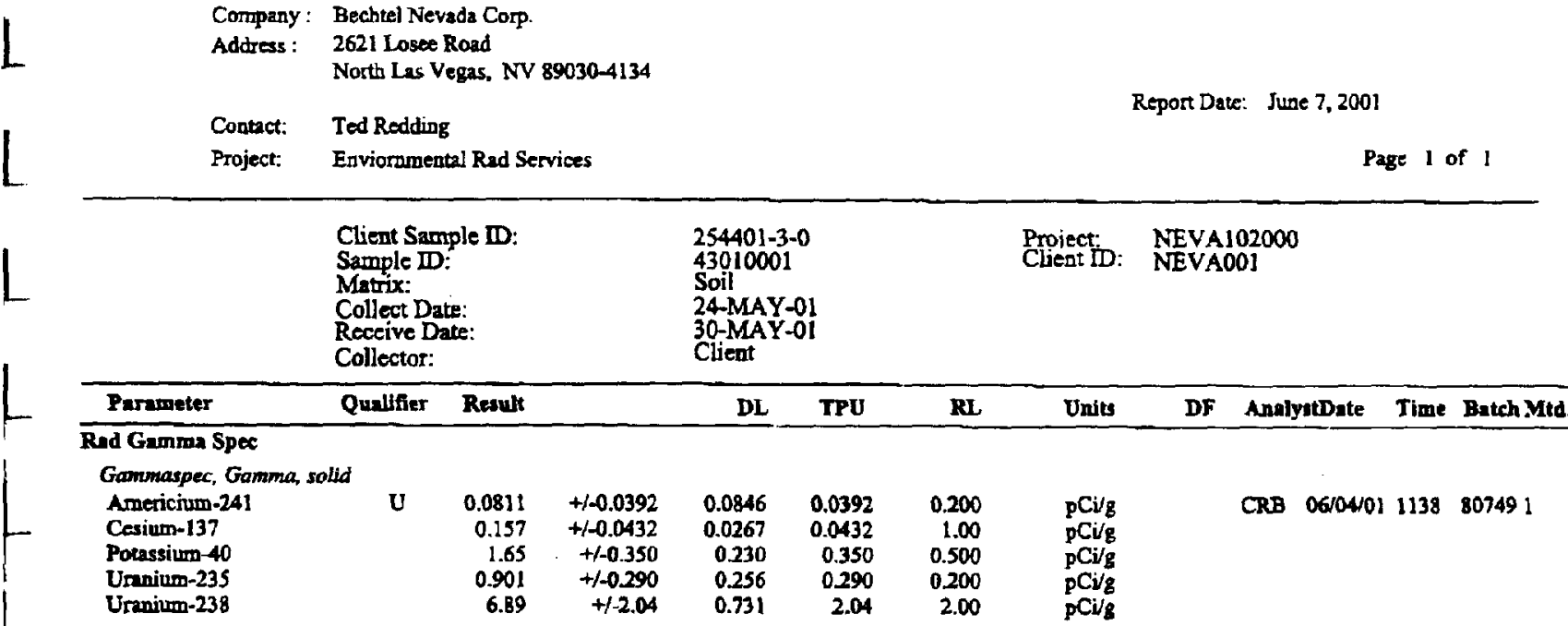

The following Prep Methods were performed

\begin{tabular}{llllll}
\hline Methad & Description & Analyst & Date & Tlize & Prtp Bateh \\
\hline Dry Soil Prep & Dry Soil Prep RAD A-021,A-021B,A-026 & CCMI & $05 / 31 / 01$ & 1534 & 80663
\end{tabular}

The following Analytical Methods were performed

Method Description

1 DOE EMI HASL 300

Notes:

The Qualifiers in this report are defined as follows :

* Indicates the anatyce is a surrogate compound

$<$ Actual result is less than amount reported

$>$ Actual result is greater than amount reported

J Indicates an estimated value. The result was greater than the detection Jimit, but less than the reporting limit.

$U$ Indicates the compound was analyzed for but not detected above the detection limit

The above sample is reported on an "as received" basis.

This data report has been prepared and reviewed in accordance with General Engineering Laboratories, Inc. standard operating procedures. Please direct any questions to your Project Manager, Stacy L. Griffin at 843-556-8171 Ext. 4264.

Roviewed by

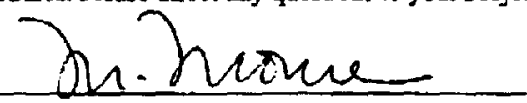

P O Box 30712 - Charleston, SC 29417 - 2040 Savage Road • 29407

(843) $556-8171$ - Fax (843) 766-1178 


\section{GENERAL ENGINEERING LABORATORIES}

Meeling today's needs with a vision for tomarraw:

\section{Certificate of Analysis}

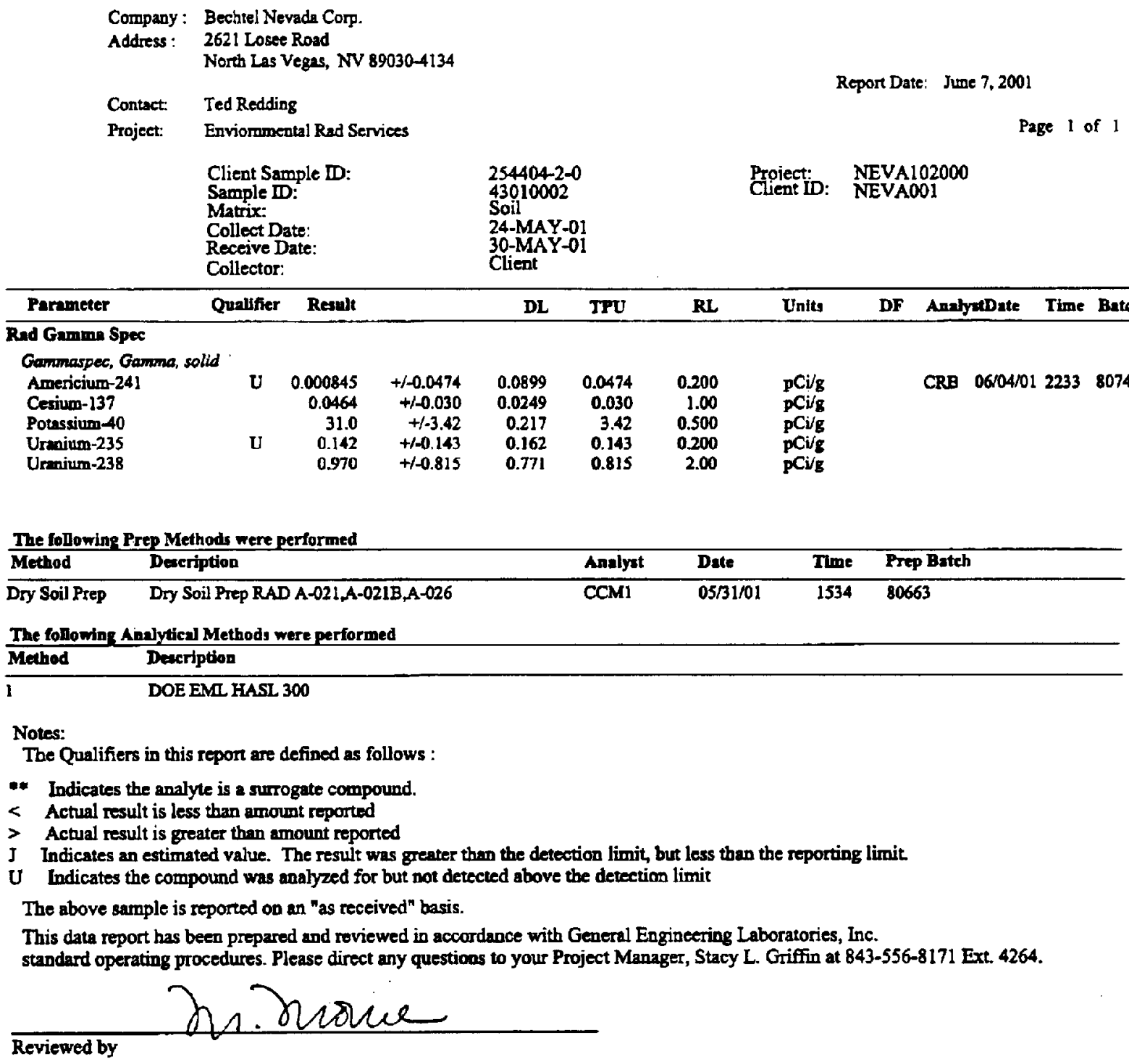




\section{GENERAL ENGINEERING LABORATORIES}

Meeting today's needs with a vision-for tomorrow:

\section{Certificate of Analysis}

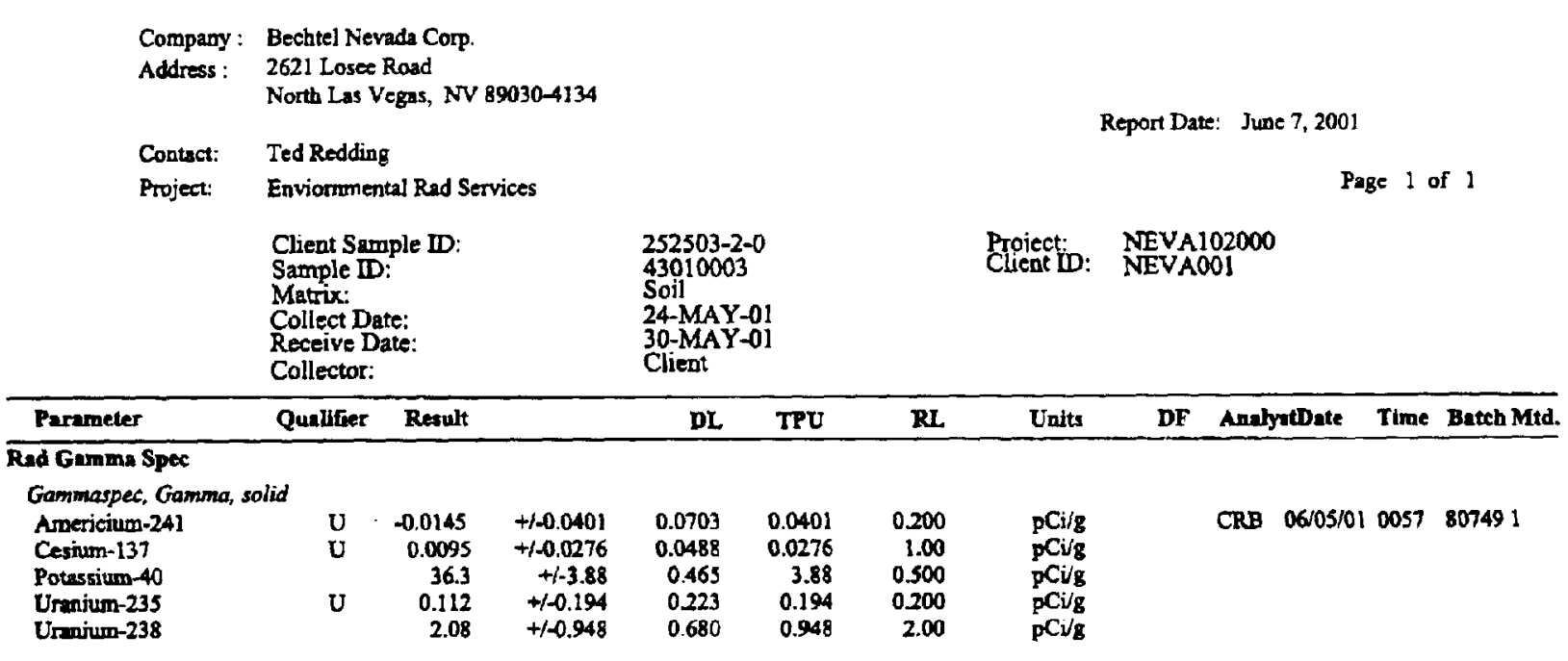

The followine Prep Methods were perforned

\begin{tabular}{llllll}
\hline Method & Deacription & Andyat & Date & Time & Prep Batch \\
\hline Dry Soil Prep & Dry Soil Prep RAD A-021,A-021B,A-026 & CCM3 & $05 / 31 / 01$ & 1534 & 80663
\end{tabular}

The following Analytical Methods were performed

Method Description

DOE EML HASL 300

Notes:

The Qualifiers in this report are defined as follows:

-* Indicates the analyte is a surrogate compound.

$<$ Actual result is less than amount reported

$>$ Actual result is greater than amount reported

J Indicates an estimated value. The result was greater than the deteetion limit, but less than the reporting limit.

- U indicates the compound was analyzed for but not detected above the detection limit

The above sample is reported on an "as received" basis.

This data report has been prepared and reviowed in accordance witb General Engineering Laboratories, Inc.

standand operating procedures. Please direct any questions to your Project Manager, Stacy L. Giffin at 843-556-8171 Ext. 4264.

ha. nadre

Reviewed by 


\section{GENERAL ENGINEERING LABORATORIES}

Meeting today's needs with a vision for tomorrow

\section{Certificate of Analysis}

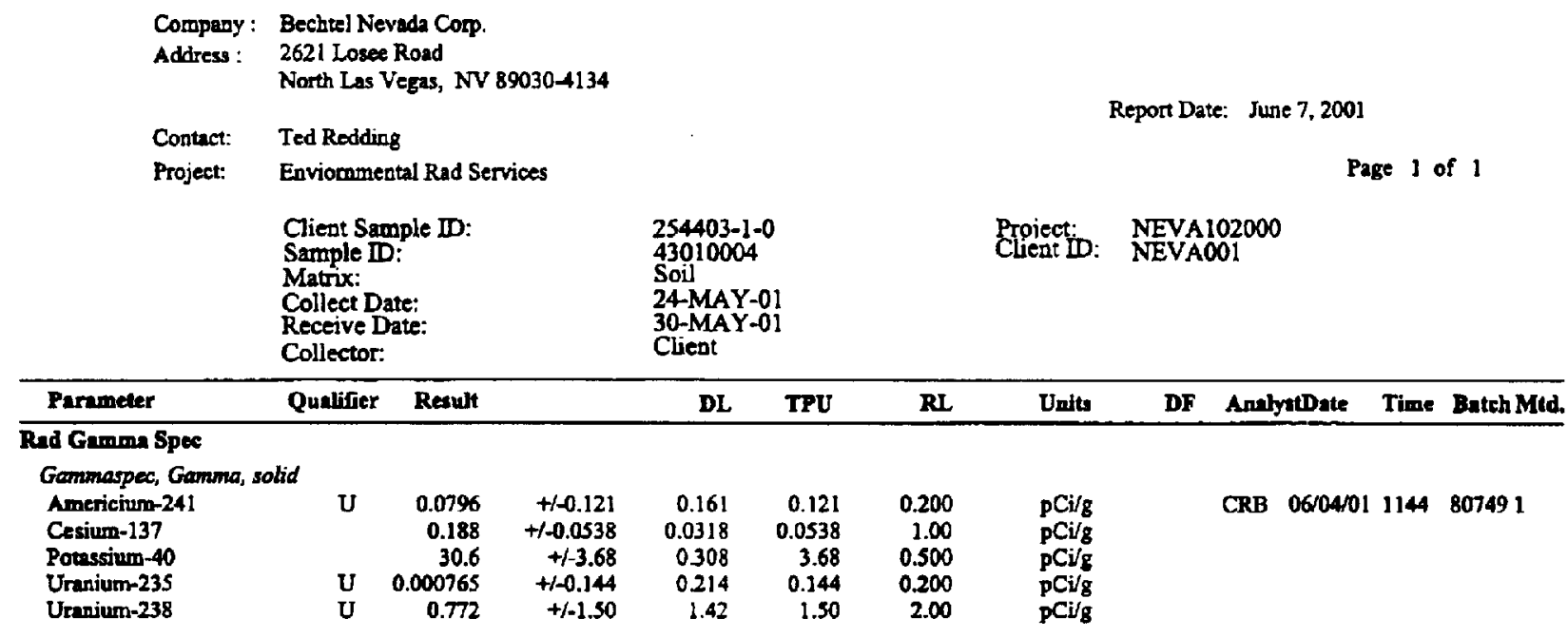

The following Prge Methods were pertormed

\begin{tabular}{llllll}
\hline Methed & Description & Annlyat & Date & Time & Prep Bateh \\
\hline Dry Soil Prep & Dry Soil Prep RAD A-021,A-021B,A-026 & CCM1 & $05 / 31 / 01$ & 1534 & 80663
\end{tabular}

The following Analytical Methods were performed

$\frac{\text { Methed }}{1}$ Deseription

Notes:

The Qualifiers in this report are defined as follows :

* Indicates the analyte is a surrogate compound

$<$ Actual result is less than amount reported

$>$ Actual result is greater than amount reported

J Indicates an estimated value. The result was greater than the detecoon limit, but less than the reporting limit.

$U$ Indicates the compound was analyzed for but not detected above the detection limit

The above sample is reported on an "as received" basis.

This data report has been prepared and reviewed in accordance with Geoeral Engineering Laboratories, Inc. standard operating procedures. Please direct any questions to your Project Manager, Stacy L. Griffin at 843-556-8171 Ext. 4264.

Reviowed by

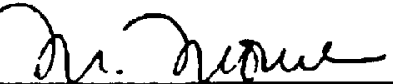




\section{GENERAL ENGINEERING LABORATORIES}

Meeting todoy's need's with a vision for tomorrow.

\section{QC Summary}

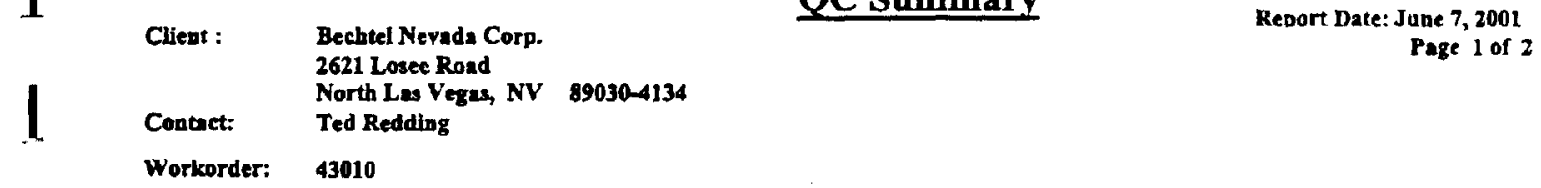

$\begin{array}{llll}U & -0.00041 & U & 0.0291\end{array}$
TPU:

$+1-0.0574$

0.0574

Uncert: $\quad+1-0.023$
TPU: $\quad 0.023$

35.2
Uncert: $\quad+/-3.91$

TPU:

3.91
0.0615

0.0615

$+/-0.159$

0.159

0.752

$+-0.975$

0.975

TPU:

Uncert:

TPU:

441

Uncent:

TPU:

Uncer:

TPU:

Uncent:

TPU:

Uncert:

IPU:

Uncent:

TPU:

Uncent:

IPU:

Uncert

TPU:

Uncert:

$+-0.0292$

0.0292

$+/ 4.21$

$+/-0.172$

0.172

$+/ 1.56$

1.56

1220

$+7-132$

132
486

$+\mid-61.1$

U -0383

$+\$ 2.19$

$+-1.81$

181

$+/ 6.52$

U $\quad 0.030$

$+1-0.0852$
DCi/g N/A

$\mathrm{pCi} / \mathrm{g} \quad$ ^

$35.6 \quad \mathrm{pCi} / \mathrm{g} \quad 1$

$0.056 \mathrm{pCi} / \mathrm{g} \quad 10 \wedge \quad(+1-0.200)$

$1.90 \mathrm{pCi} / \mathrm{g} \quad 87^{\wedge} \quad(+1-2.00)$

$\mathrm{pCi} / \mathrm{g}$

06/05/01 07:09

$\mathbf{p C i g}$

$110 \quad(75 \%-125 \%)$

pCigs

2.19

$0.744 \mathrm{pCi} / \mathrm{s}$

$\mathrm{U}^{\circ} \quad-1.93 \quad \mathrm{pCi} / \mathrm{s}$

$\mathrm{pCi} / \mathrm{g}$

$060550107: 08$

P O Box 30712 • Charleston, SC 29417 - 2040 Savage Road • 29407

(843) 556-8171 * Fax (843) 766-1178 


\section{GENERAL ENGINEERING LABORATORIES}

Meeting today's needs with a vision for tomorrow:

\section{QC Summary}

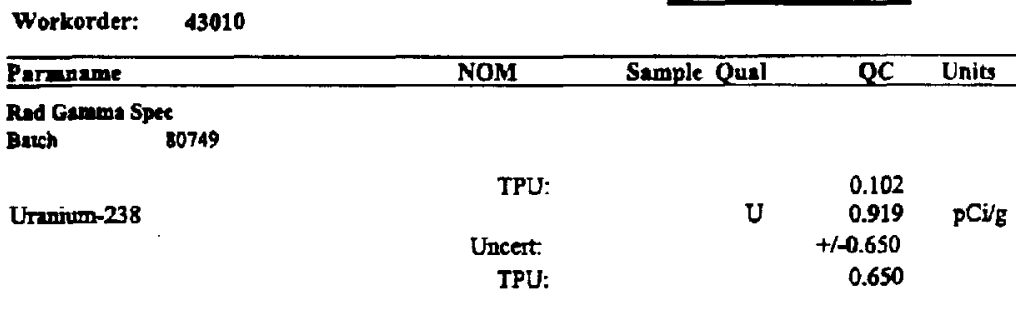

Notes:

The Qualifiers in this report are defined as follows:

- Indicates the enalyte is a surogate compound

$<\quad$ Actual result is less than amount reported

$>$ Actual result is greater thm annount reported

J Indicates an estimated value. The result was greater thm the detection limit, but less than the reporting limit

U Indicates the compound was analyzed for but got detected above the detection limit

N/A indicates that spike recovery limits do not apply when sample concentration exceeds spike cone. by 2 factor of 4 or more.

$\wedge$ The Relative Percent Difference (RPD) obtained from the sample duplicate (DUP) is evaluated against the acceptence criteria when the sampie is greater than five times (5X) the contrict required detection limit (RL). In cases where either the sample or duplicate value is less then $5 X$ the RI, a control limit of $+\%$ the $R$ is used to evaluate the DUP result.

For PS, PSD, and SDILT results, the values listed are the measured monounts, not fimal eoncentrations. 
CLOSURE REPORT - CAU 398

Section: Appendix B

Revision: 1

Date: April 2003

\section{SAMPLE DELIVERY GROUP}

V1139 
CLOSURE REPORT - CAU 398

Section: Appendix B

Revision: 1

Date: April 2003

THIS PAGE INTENTIONALLY LEFT BLANK 


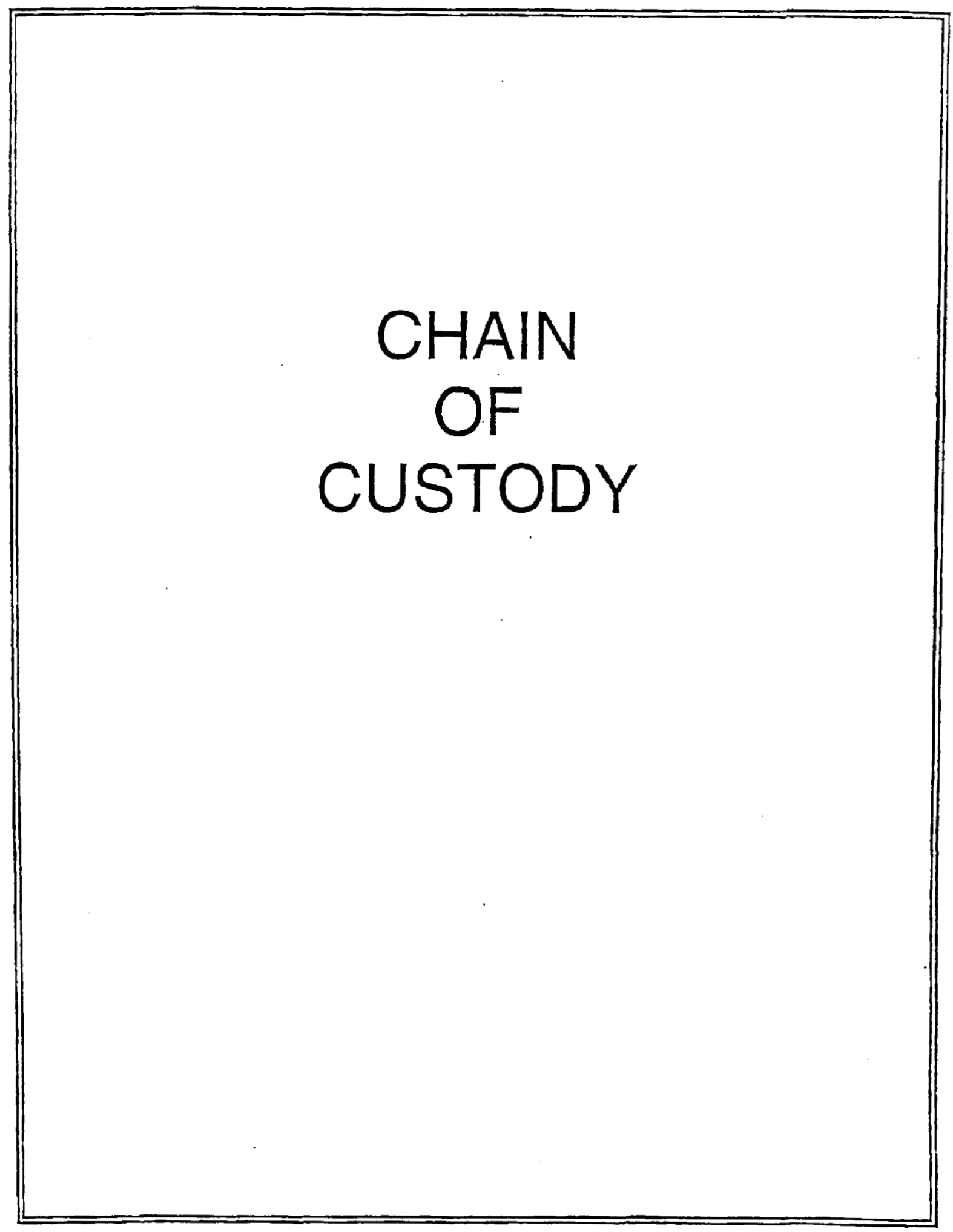




\section{Bechtel Nevada}

ANALYTICAL SERVICES LABORATORY

$4.2345 \%$

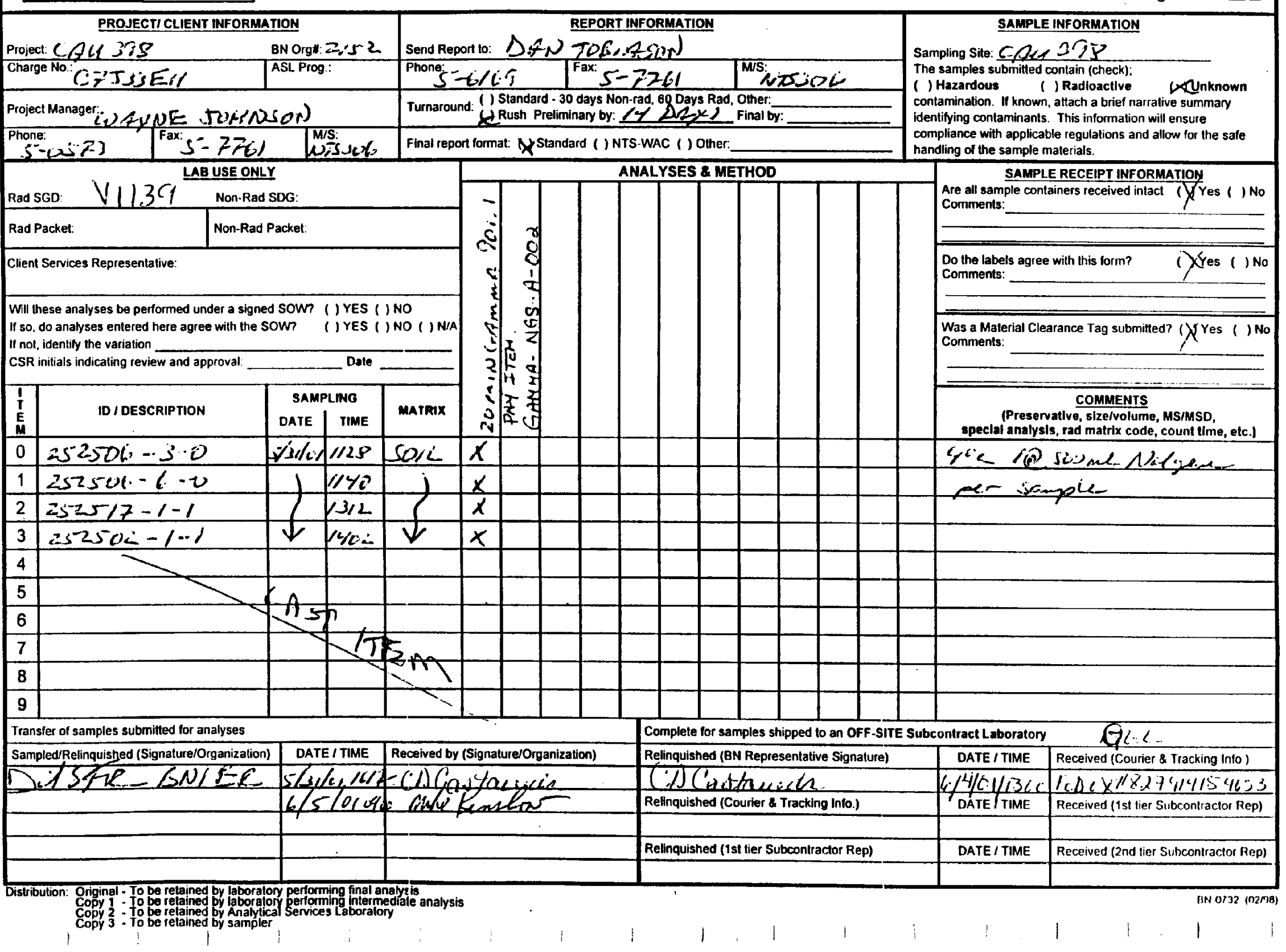




\section{COOLER \\ RECEIPT \\ CHECKLIST}




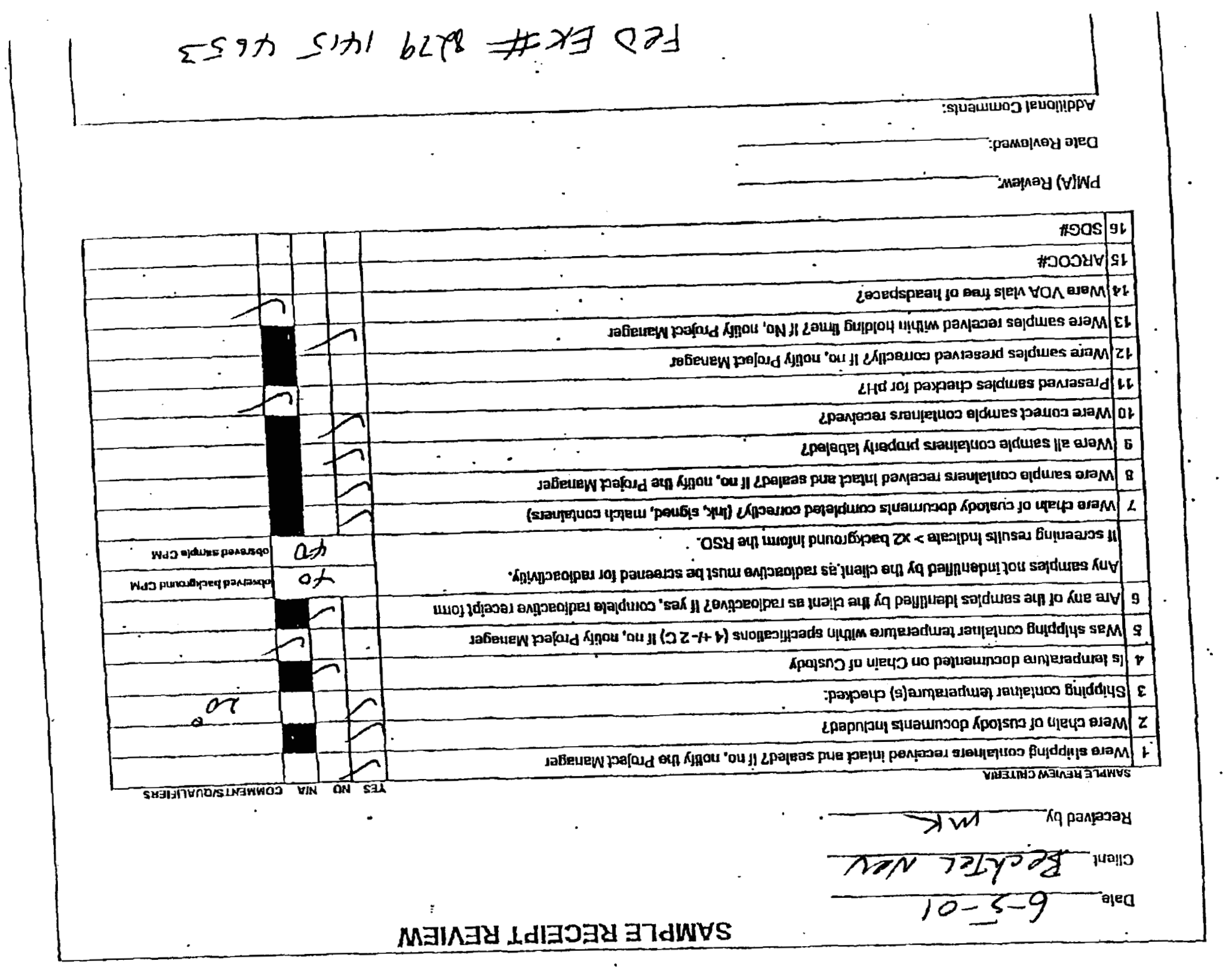




\section{DATA REVIEW \\ QUALIFIER FLAG \\ DEFINITION SHEET}




\section{Greneal Enginesing Lijoratories. Inc. \\ DATA QUALTFERS FOR INORGANTC ANALYSES}

Daca Qualiniess used on Form is or Certiñeares of Analysis $(C$ of $A$ ) follow the specinicacions ser forth in the tectroical specificarions of the mosi eursest CLP Siarement of Work and are deined as follows.

\begin{tabular}{|c|c|c|}
\hline Secion & Erolanation & Locarion \\
\hline $\bar{E}$ & 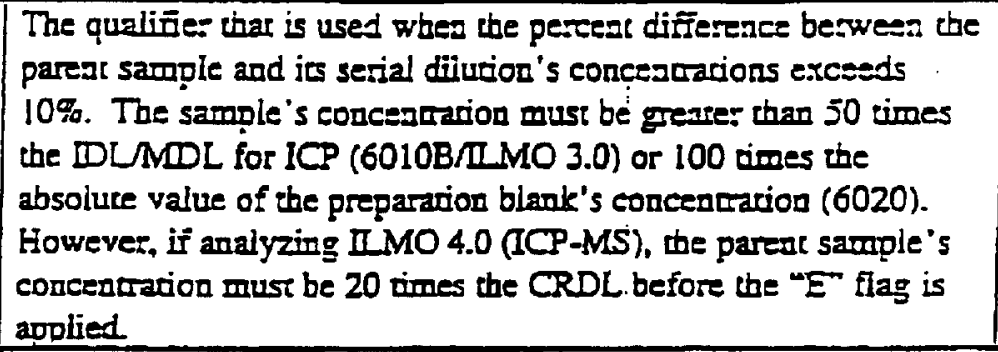 & $\begin{array}{l}\text { Form } 1 \text {, } \\
\text { and EDD }\end{array}$ \\
\hline 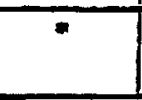 & $\begin{array}{l}\text { The qualifie- thar is used to indicate thar the duplicare sample } \\
\text { analysis for an analve is our of eontrol. }\end{array}$ & $\begin{array}{l}\text { Form } 1 . \\
\text { and EDD }\end{array}$ \\
\hline$\div$ & $\begin{array}{l}\text { Correlarion coefficiear the Mechod of Standard Addicion (MSA) } \\
\text { is less than } 0.095 \text {. }\end{array}$ & $\begin{array}{l}\text { Form } 2 \\
\text { and EDD }\end{array}$ \\
\hline $\bar{B}$ & $\begin{array}{l}\text { The qualifie: is used to indieare thar the reported result fell above } \\
\text { the DLMDL bur below the CRDL. }\end{array}$ & $\begin{array}{l}\text { Form l, } \\
\text { and EDD }\end{array}$ \\
\hline $\bar{M}$ & $\begin{array}{l}\text { The qualifier is used to indicare that the replicate injection } \\
\text { readings of the GFAA sample analysis do pot agree within } 20 \% \\
\text { relarive standari deviarion (RSD) or coefficient of variacion (CV). }\end{array}$ & Form 1 , \\
\hline $\bar{N}$ & $\begin{array}{l}\text { This qualifier is used to indicale that the marrix or pre-digested } \\
\text { spike sample recovery for an analyre is not within the specified } \\
\text { consol limit. }\end{array}$ & $\begin{array}{l}\text { Form l, } \\
\text { and EDD }\end{array}$ \\
\hline $\bar{S}$ & $\begin{array}{l}\text { The reported value was derermined by the Method of Standard } \\
\text { Addition (MSA). }\end{array}$ & $\begin{array}{l}\text { Form 1. } \\
\text { and EDD }\end{array}$ \\
\hline $\bar{U}$ & The analyte's resuit was less than the DLMDL & $\begin{array}{l}\text { C of } A \text {. Form } 1 . \\
\text { and EDD }\end{array}$ \\
\hline $\bar{W}$ & $\begin{array}{l}\text { Post-digestion spike for GFAA analysis is out of control limits } \\
(85 \%-115 \%) \text {, while sampie results are less than } 50 \% \text { of the spike } \\
\text { absoriance. }\end{array}$ & $\begin{array}{l}\text { EDD, and } \\
\text { Form S. parn ? }\end{array}$ \\
\hline $\bar{x}$ & Other reporing flag as defined in report narmative. & $\begin{array}{l}\text { Form } 1 . \\
\text { and EDD }\end{array}$ \\
\hline$=$ & $\begin{array}{l}\text { Thus qualifier is used to indicare that the Laboratory Control } \\
\text { Sample (LCS) resovery for an analyre is outside of the specified } \\
\text { limics. }\end{array}$ & $\begin{array}{l}\text { QC Summary } \\
\text { Repor }\end{array}$ \\
\hline
\end{tabular}

All surtogate recoveries and ressplanes ranges are repored af the bouom of Form 2 or $C$ of $A$. Any recoveries falling outside the ecceptance range will be flagged with a =-

All thags do not apply to QC Summory and Ceriñieare of Analysis pacterges. 


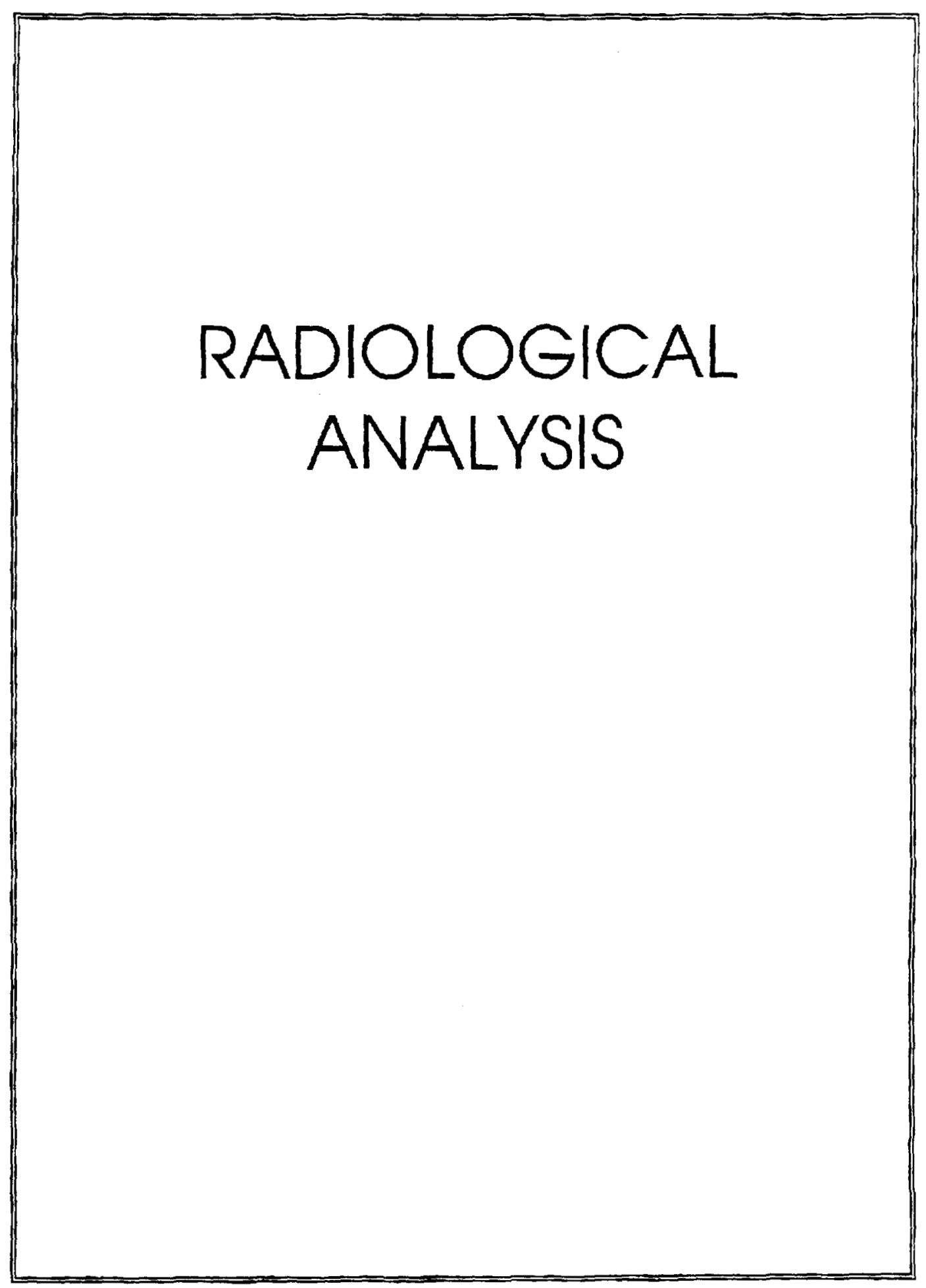




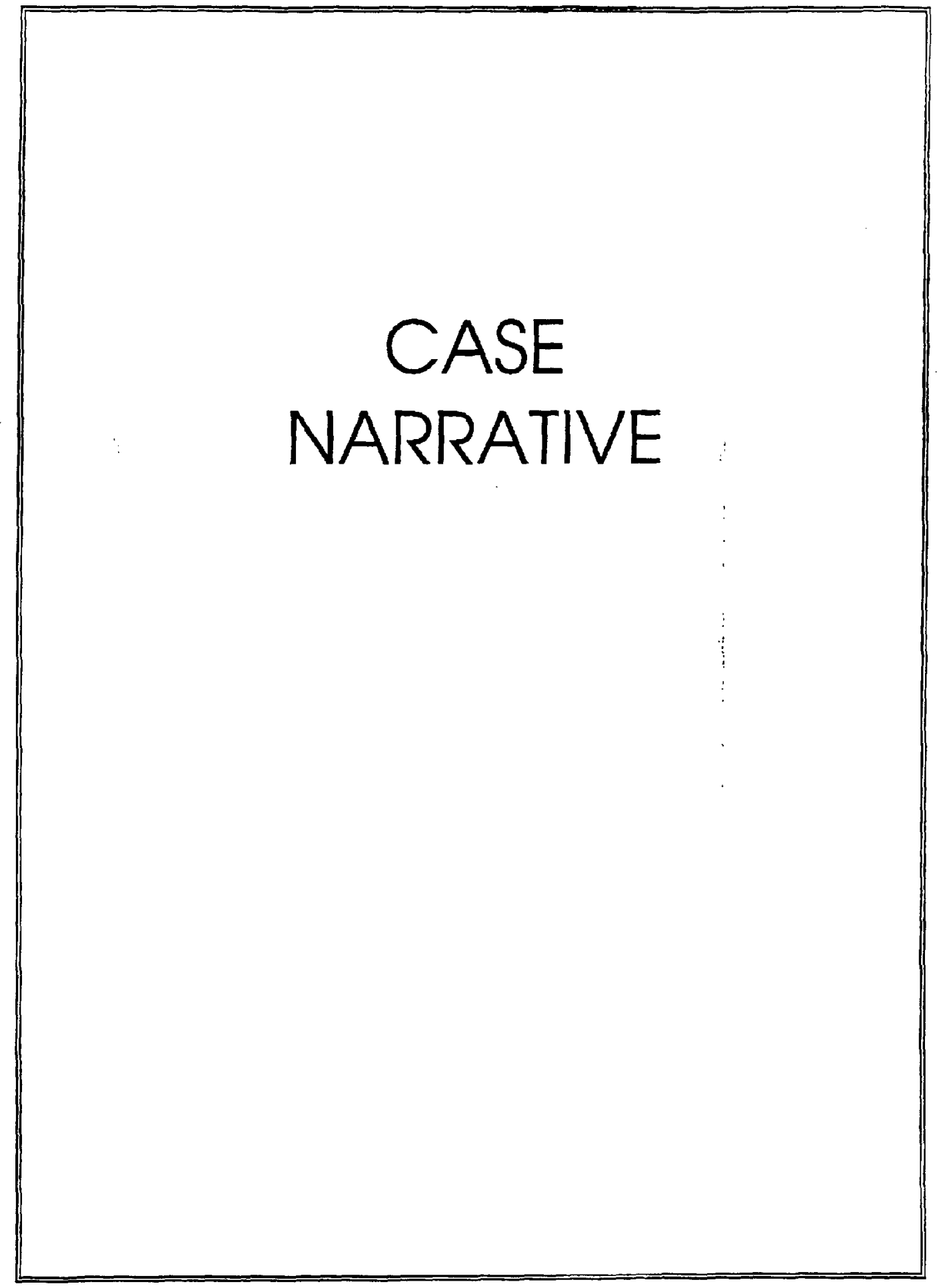




\section{Radiochemistry Case Narrative \\ Bechtel Nevada Corp. (NEVA) \\ SDG V1139}

Method/Analvsis Information

Batch Number:

82420

Procedure:

Determination of Gamma Isotopes in Water and Soil

Analytical Method:

DOE EML HASL 300

Sample ID
43345001
43345002
43345003
43345004
1200018241
1200018242
1200018243

Client ID

252506-3-0

252506-6-0

$252517-1-1$

252502-1-1

MB for batch 82420

252506-3-0(43345001DUP)

LCS for batch 82420

\section{SOP Reference}

Procedures for preparation, analysis and reporting of analytical data are controlled by General Engineering

Laboratories, Inc. as Standard Operating Procedures (SOP). The data discussed in this narrative has been prepared and analyzed in accordance with GL-RAD-A-013.

\section{Calibration Information:}

\section{Calibration Information}

All initial and continuing calibration requirements have been met.

Standards Information

Standard solution(s) for these analyses are NIST traceable and used before the expiration date(s).

Sample Geometry

All counting sources were prepared in the same geometry as the calibration standards.

\section{Qualitv Control (OC) Information:}

Blank Information

The blank volume is representative of the sample volume(s) in this batch.

\section{Designated QC}

The following sample(s) was used for QC: 4.3.345001.

QC Information

All of the QC samples met the required acceptance limits.

\section{Technical Information:}

\section{Holding Time}

All sample procedures for this sample set were performed within the required holding time.

Preparation Information

All preparation criteria have been met for these analyses.

\section{Sample Re-prep/Re-analysis}


None of the samples in this sample set required reprep or reanaiysis.

\section{Miscellaneous information:}

NCR Documentation

No NCR were generated for the preparation or analysis of this sample set.

Manual Integration

No manual integrations were performed on data in this batch.

Review Validation:

GEI requires all aralytical data to be verified by a qualified data validator. In addition, all data designated for CLP or CLP-like packaging will receive a third level validation upon completion of the data package.

The following data validator verffed the information presented in this case narrative:

Reviewer: Dn. nume

Date: 12 lut 2001 


\section{GENERAL ENGINEERING LABORATORIES}

Meeing raday's needs with a vision for tomorrow:

\section{Certificate of Analysis}

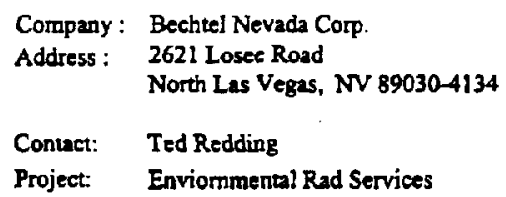

Repor Date: June 20, 200

Page 1 of 1

\begin{tabular}{|c|c|c|c|c|c|c|c|c|c|c|c|}
\hline \multirow[b]{2}{*}{ Parnmeter } & \multicolumn{2}{|c|}{$\begin{array}{l}\text { Client Sample ID: } \\
\text { Sample ID: } \\
\text { Matix: } \\
\text { Collect Date: } \\
\text { Receive Date: } \\
\text { Collector: }\end{array}$} & & \multicolumn{2}{|c|}{$\begin{array}{l}252506-3-0 \\
43345001 \\
\text { Soil } \\
31-\mathrm{MAY}=01 \\
\text { O5-JUN-01 } \\
\text { Client }\end{array}$} & \multirow[b]{2}{*}{$\mathbf{R L}$} & \multirow{2}{*}{$\begin{array}{l}\text { Proiect: } \\
\text { Client ID: }\end{array}$} & \multicolumn{2}{|c|}{$\begin{array}{l}\text { NEVA102000 } \\
\text { NEVA001 }\end{array}$} & \multirow[b]{2}{*}{ Time } & \multirow[b]{2}{*}{ Batch Mid. } \\
\hline & Qualifier & Result & & DI & TPU & & & DF & Analystbate & & \\
\hline \multicolumn{12}{|l|}{ Rad Gamma Spec } \\
\hline \multicolumn{12}{|c|}{ Gammaspec, Gamma, solid } \\
\hline $\begin{array}{l}\text { Americium-241 } \\
\text { Cesium-137 } \\
\text { Potassium-40 } \\
\text { Urnium-235 } \\
\text { Uranium-238 }\end{array}$ & $\begin{array}{l}\mathbf{U} \\
\mathbf{U}\end{array}$ & $\begin{array}{r}0.235 \\
0.0542 \\
38.4 \\
0.129 \\
0.951\end{array}$ & $\begin{array}{r}+-0.283 \\
+/-0.0469 \\
+/-4.66 \\
+/-0.214 \\
+/-2.08\end{array}$ & $\begin{array}{r}0.295 \\
0.0417 \\
0.363 \\
0.256 \\
223\end{array}$ & $\begin{array}{r}0.283 \\
0.0469 \\
4.66 \\
0.214 \\
2.08\end{array}$ & $\begin{array}{r}0.200 \\
1.00 \\
0.200 \\
2.00\end{array}$ & $\begin{array}{l}\mathrm{pCi} / \mathrm{g} \\
\mathrm{pCi} / \mathrm{g} \\
\mathrm{pCi} / \mathrm{g} \\
\mathrm{pCi} / \mathrm{g} \\
\mathrm{pCi} / \mathrm{g}\end{array}$ & & CRB $06 / 14 / 01$ & 0741 & 824201 \\
\hline
\end{tabular}

The following Prep Methods were performed

\begin{tabular}{llllll}
\hline Method & Dezeription & Anslyst & Date & Time & Prep Bateb \\
\hline Dry Soil Prep & Dy Soil Prep RAD A-021,A-021B,A-026 & WEO & 06/06/01 & 1126 & 81601
\end{tabular}

The following Analytical Methods were performed

Method Description

1 DOE EML HASL 300

Notes:

The Qualifiers in this report are defined as follows :

** Indicates the analyte is a surrogate compound.

$<$ Actual result is less than amount reported

$>$ Actual result is greater than amount reported

J Indicates an estimated value. The result was greater than the detection limit, but less than the reporting limit.

$U$ Indicates the compound was analyzed for but not detected above the detection limit

The above sample is reported on an "as received" basis.

This data report has been prepared and reviewed in accordance with General Engineering Laboratories, Inc.

standard operating procedures. Please direct any questions to your Project Manager, Stacy L. Griffin at 843-556-8171 Ext. 4264.

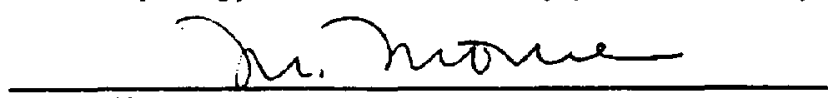

Reviewed by 


\section{GENERAL ENGINEERING LABORATORIES}

Meeting roday's needs with e vision for somorrow:

\section{Certificate of Analysis}

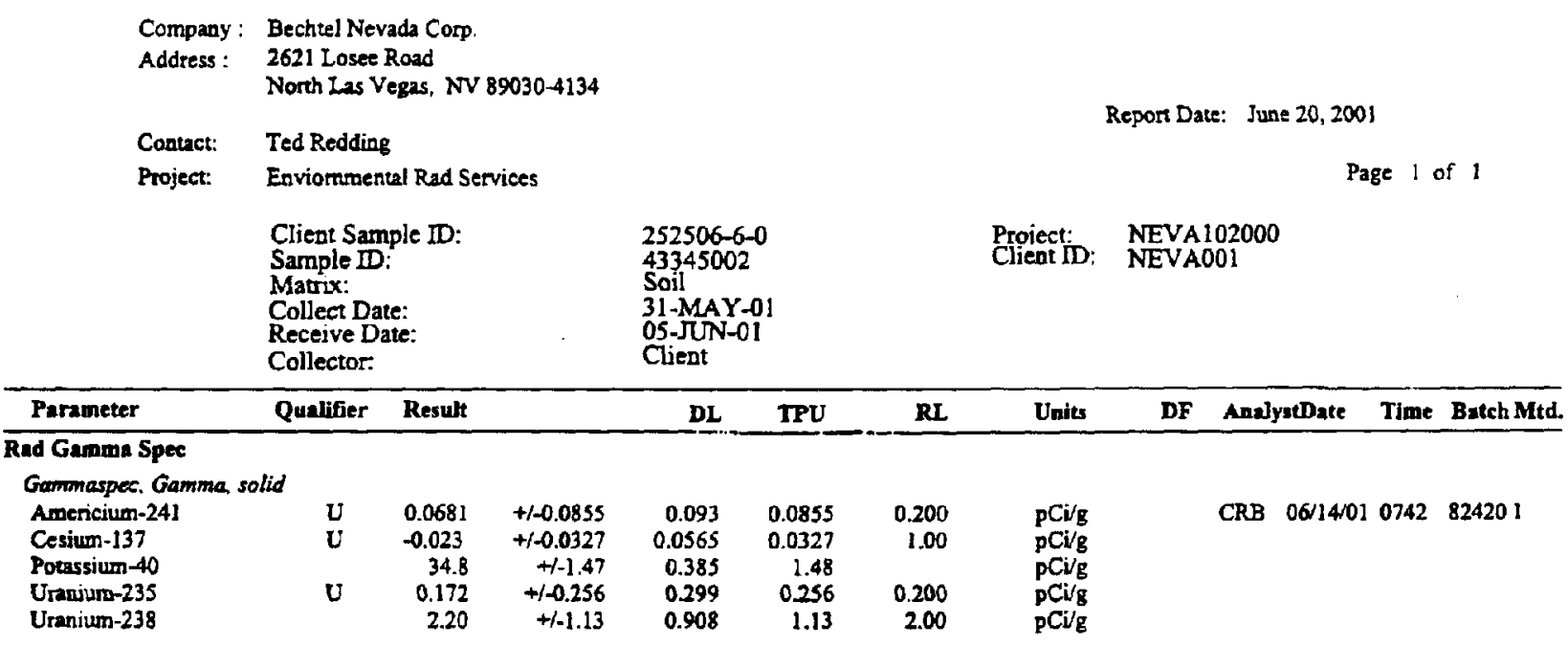

The following Prep Methods werc performed

\begin{tabular}{llllll}
\hline Method & Description & Analyst & Date & Time & Prep Batch \\
\hline Dry Soil Prep & Dry Soil Prep RAD A-021,A-021B,A-026 & WEO & $06 / 06 / 01$ & 1126 & 81601
\end{tabular}

The following Analytical Methods were performed

Method Description

1 DOE EML HASL 300

Notes:

The Qualifiers in this report are defined as follows:

** Indicates the analyte is a surrogate compound.

< Actual result is less than amount reported

$>$ Acrual result is greater than amount reported

I Indicates an estimated value. The result was greater than the detection limit, but less than the reporting limit.

$\mathrm{U}$ Indicates the compound was analyzed for but not detected above the detection limit

The above sample is reported on an "as received" basis.

This data report has been prepared and reviewed in accordance with General Engineering Laboratories, Inc. standard operating procedures. Please direct any questions to your Project Manager, Stacy L. Griffin at 843-556-8171 Ext. 4264.

Tr. Thome

Reviewed by 


\section{GENERAL ENGINEERING LABORATORIES}

Mcering today's needs with a vision for comorrow:

\section{Certificate of Analysis}

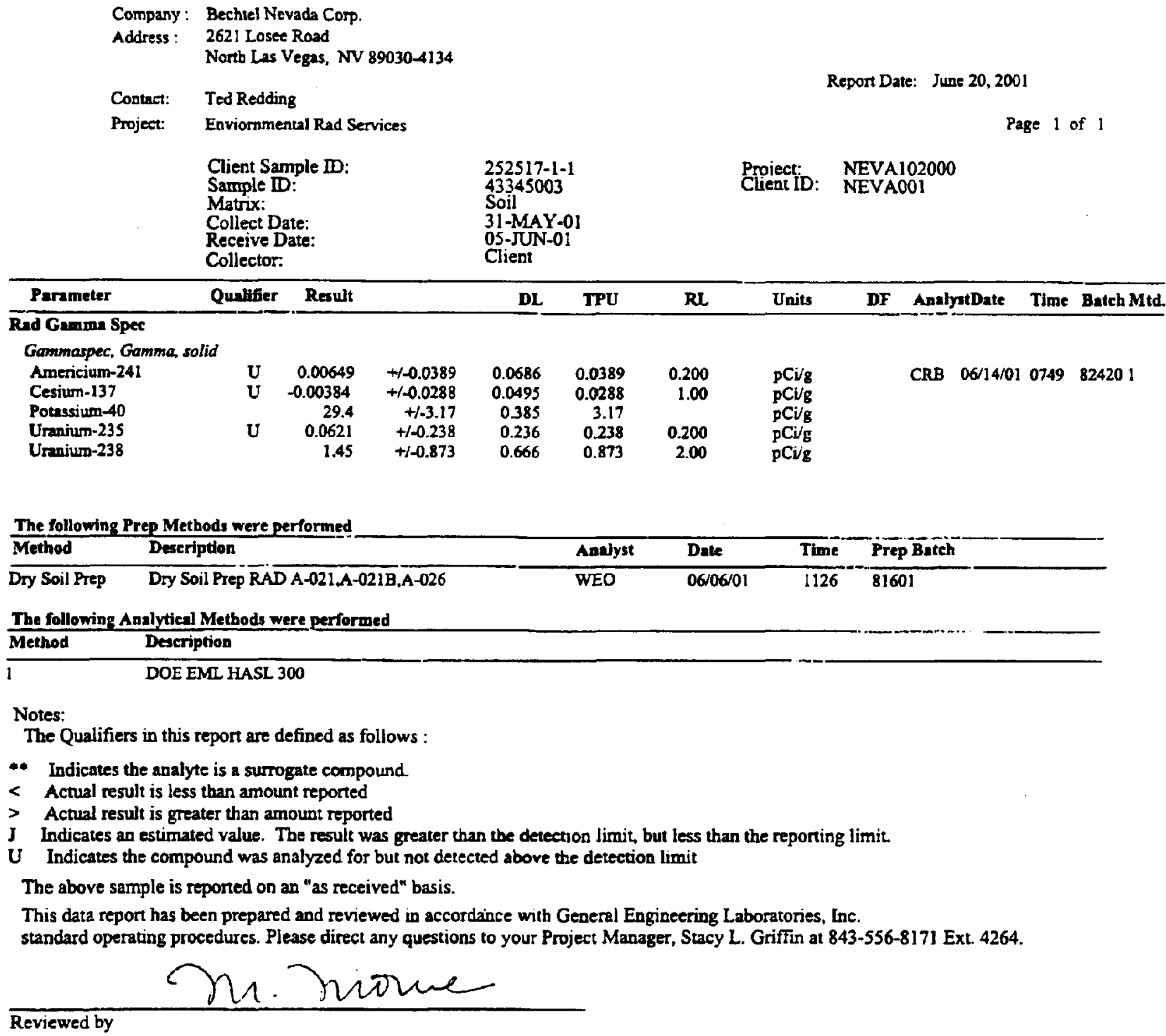

P O Box 30712 - Charleston, SC 29417 • 2040 Savage Road - 29407

(843) $556-8171 \cdot$ Fax (843) 766-1178 


\section{GENERAL ENGINEERING LABORATORIES}

Meeting roday's needs with a vision for tomorrow

\section{Certificate of Analysis}

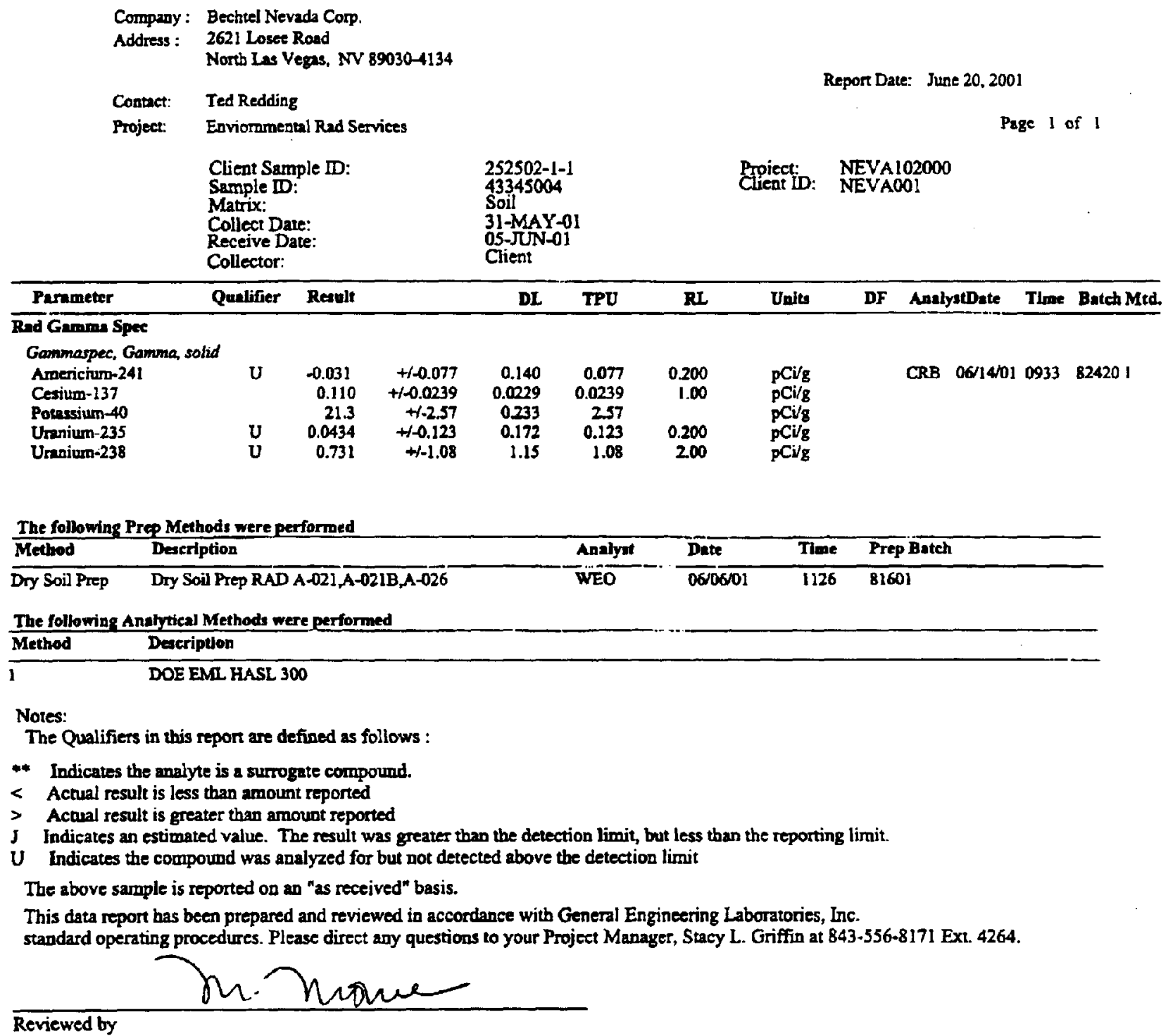

P O Box 30712 - Charleston, SC 29417 - 2040 Savage Road - 29407

(843) $556-8171$ - Fax (843) 766-1.178 


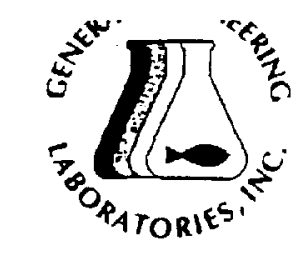

\begin{tabular}{|c|c|}
\hline Client : & $\begin{array}{l}\text { Bechtel Nevady C } \\
2621 \text { Losee Rand } \\
\text { North Las Vegas, }\end{array}$ \\
\hline Conlact: & Ted Redding \\
\hline Workorder: & 43345 \\
\hline \multicolumn{2}{|l|}{ Parmaname } \\
\hline \multicolumn{2}{|c|}{ Rud Gamma Spec } \\
\hline Batch & 2420 \\
\hline
\end{tabular}
Americium-241

Cesium-137

Potassium-40

Uranium-235

Unnium-238

QC1200018243 LCS Americium-241

Cesium-137

Polessium-40

Uranium-235

Uranium-238

OC1200018241 MB Americium-241

Cesium-137

Potassium-40

Uranium-235

\section{GENERAL ENGINEERING LABORATORIES}

Meesing today's needs with a vision for tomorrow:

\section{QC Summary}

Report Date: July 12, 2001

Page 1 of 2

$89030-4134$

NOM

Sample Oual Units RPD \% REC\% Range Anlst Date Time 1

NOM Sample Qua

Range Anlat Date Tine

\begin{tabular}{|c|c|}
\hline $\mathbf{U}$ & 0.235 \\
\hline Uncert & $+\sqrt{-0.283}$ \\
\hline TPU: & $\begin{array}{r}0.283 \\
0.0542\end{array}$ \\
\hline Uncert: & +-0.0469 \\
\hline TPU: & $\begin{array}{r}0.0469 \\
38.4\end{array}$ \\
\hline Uncert: & $+/-4.66$ \\
\hline $\begin{array}{l}\text { IPU: } \\
\mathbf{U}\end{array}$ & $\begin{array}{r}4.66 \\
0.129\end{array}$ \\
\hline Uncert: & $+v-0.214$ \\
\hline${ }^{\text {TPU: }}$ & $\begin{array}{l}0.214 \\
0.951\end{array}$ \\
\hline Uncer: & $+1-208$ \\
\hline TPU: & 2.08 \\
\hline
\end{tabular}

U $\quad 0.0596$

$\mathrm{pCig}$

$(+-0.200) \quad C R B \quad 06 / 14 / 0113: 52$

$\begin{array}{r}0.120 \\ \hline \quad 0.0269\end{array}$

$0.0269 \mathrm{pCi} / \mathrm{g} \quad 67 \wedge$

$(+-1.00)$

0.0251

38.6
+-4.55

4.55

4.55

$\mathrm{pCi} / \mathrm{g} \quad 174 \wedge \quad(+/-0.200)$

$+1-0.133$

0.133

$1.93 \mathrm{pCi} g \quad 68 \wedge \quad(+1-2.00)$

$+1.69$

1.69

1250
Uncert:
$+/-135$

TPU: 135

441

Uncert:

TPU:

487

$+61.1$

Uncert:

U

61.1

$0.923 \quad \mathrm{pCi} / \mathrm{g}$

TPU:

Uncert:

$\mathbf{U}$

1.55

pCi/g

IPU:

$+129$

-1.29
1.29

$-1.17$

$+-4.64$

Uncert:

TPU:

$\mathrm{pCi}_{\mathrm{g}}$

4.64

$\mathrm{pCi} / \mathrm{g}$

06/14/01 13:53

$\mathrm{Ci} / \mathrm{g} \quad 110 \quad(75 \%-125 \%)$

(n)

pCig

06/14/01 09:33 


\section{GENERAL ENGINEERING LABORATORIES}

Meeting today's needs with a vision for tomorrow.

\section{QC Summary}

Workorder: 43345

NOM
Sample Qual

oc Units

Page 2 of 2

Parminame NOM

RPD\%

REC $x$

Range Anist

Rnd Cammon Spec
Batch 82420

Uranium-238

TPU:

Uncert

U $\begin{array}{r}0.140 \\ 0.0446 \quad \mathrm{pCV} / \mathrm{g} \\ +/-0.651\end{array}$

TPU:

0.651

Notes:

The Qualifiers in this report are defined as follows:

* Indicates the amalyte is a surrogate compound.

< Achul result is less than amount reported

$>$ Actual result is greater than amount reported

J Indicates an estimated value. The result was greater than the detection limit, but less than the reporting limit.

U Indicates the compound was analyzed for but not detected above the detection limit

N/A indicates then spike recovery limits do not apply whed sample coocentration exceeds spike conc. by a factor of 4 or more.

A The Relative Percer Differesce (RPD) obtained from the sample duplicate (DUP) is evaluated against the acceptence criteria when the sample is greater than five times ( $5 X)$ the contract required detection limit (RL). In cases where either the sample or duplicate value is less then $5 X$ the $R L$, a control limit of $+\%$ the $R L$ is used to evaluate the DUP resull

For PS. PSD, and SDILT resulus, the values listed are the measured amounts, nor find concenumions. 
CLOSURE REPORT - CAU 398

Section: Appendix B

Revision: 1

Date: April 2003

\section{SAMPLE DELIVERY GROUP}

\section{V1140}


CLOSURE REPORT - CAU 398

Section: Appendix B

Revision: 1

Date: April 2003

THIS PAGE INTENTIONALLY LEFT BLANK 
CLIENT:

Bechtel Nevada

P.O. Box 98521, M/S NTS273

ATTN:

Las Vegas, NV 89193-8521

Ted Redding

PROJECT NAME: $\quad$ V 1140

NEI ORDER ID: L0106022

PROJECT NUMBER: 23081

Attached are the analytical results for samples in support of the above referenced project.

Samples submitted for this project were not sampled by NEL Laboratories. Samples were received by NEL in good condition, under chain of custody on 6/4/01.

Should you have any questions or comments, please feel free to contact our Client Services department at (702) $657-1010$
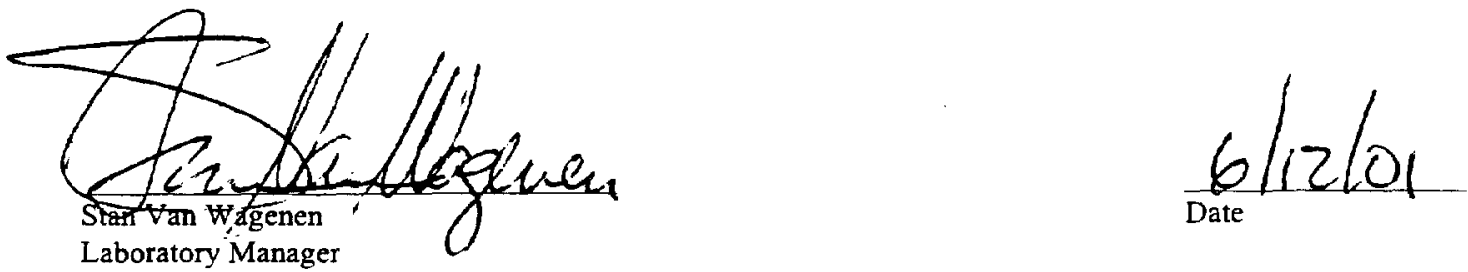

\section{CERTIFICATIONS}

\begin{tabular}{llllllllll}
\hline & Reno & Las Vegas & S. Califormia & & & \multicolumn{2}{c}{ Reno } & Las Vegas & S. California \\
Arizona & AZ0520 & AZ0518 & AZ0605 & & Idaho & & Certified & Certified & \\
California & 1707 & 2002 & 2264 & & Montana & Certified & Certified & \\
$\begin{array}{l}\text { US Army Corps } \\
\text { of Engineers }\end{array}$ & Certified & Certified & & Nevada & NV033 & NV052 & CA084 \\
& & & & L.A.C.S.D. & & & 10228
\end{tabular}




\begin{tabular}{|c|c|c|}
\hline CLIENT: & Bechtel Nevada & CLIENT ID: \\
\hline PROJECT ID: & $V 1140$ & DATE SAMPLED: 5/31/01 \\
\hline PROJECT \#: & 23081 & NEL SAMPLE ID: L0106022-0 \\
\hline
\end{tabular}

TEST: $\quad$ Total Extractable Petroleum Hydrocarbons Fuel Finger Print by EPA Method 8015M. July 1992

METHOD: EPA $8015 \mathrm{M}$

MATRIX: Solid

ANALYST: CCS - Las Vegas Division

DILUTION: $\quad 1$

EXTRACTED: $\quad 6 / 5 / 01$

ANAIYZED: $\quad 6 / 6 / 01$

\begin{tabular}{|c|c|c|}
\hline PARAMETER & Result & $\begin{array}{l}\text { Reporting } \\
\text { Limit } \\
\end{array}$ \\
\hline 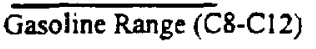 & ND & 10. $\mathrm{mg} / \mathrm{kg}$ \\
\hline Diesel Range (C12-C22) & ND & 10. $\mathrm{mg} / \mathrm{kg}$ \\
\hline Oil Range (C12-C34) & ND & 50. $\mathrm{mg} / \mathrm{kg}$ \\
\hline Total & $\mathrm{ND}$ & 10. $\mathrm{mg} / \mathrm{kg}$ \\
\hline
\end{tabular}

QUALITY CONTROL DATA:

Surrogate

Octacosane
\% Recovery

72
Acceptable Range

54 - 130

ND - Not Detected

This report shall not be reproduced except in full, without the written approval of the laboratory. 


$\begin{array}{llll}\text { CLIENT: } & \text { Bechtel Nievada } & \text { CLIENT ID: } & \mathbf{2 5 2 5 0 6 - 2 - 0} \\ \text { PROJECT ID: } & \text { V1140 } & \text { DATE SAMPLED: } 5 / 31 / 01 \\ \text { PROJECT \#: } & \mathbf{2 3 0 8 1} & \text { NEL SAMPLE ID: } 20106022-02\end{array}$

TEST: $\quad$ Total Extractable Petroleum Hydrocarbons Fuel Finger Print by EPA Method 8015M. July 1992

METHOD: $\quad$ EPA $8015 \mathrm{M}$

MATRIX: Solid

ANALYST: $\quad$ CCS - Las Vegas Division

DILUTION: 1

EXTRACTED: $\quad$ 6:5:01

ANALYZED: $\quad 6 / 6.01$

\begin{tabular}{lcc}
\hline PARAMETER & Result & Reporting \\
\cline { 2 - 3 } & ND & Limit \\
Gasoline Range $(\mathrm{C} 8-\mathrm{Cl} 2)$ & ND & $10 . \mathrm{mg} / \mathrm{kg}$ \\
Diesel Range $(\mathrm{C} 12-\mathrm{C} 22)$ & ND & $10 . \mathrm{mg} / \mathrm{kg}$ \\
Oil Range $(\mathrm{C} 12-\mathrm{C} 34)$ & ND & $50 . \mathrm{mg} / \mathrm{kg}$ \\
Total & & $10 . \mathrm{mg} / \mathrm{kg}$
\end{tabular}

QUALITY CONTROL DATA:

Surrogate

Octacosane
\% Recovery

79
Acceptable Range

$54-130$

ND - Not Detected

This report shall not be reproduced except in full, without the written approval of the laboratory. 


\begin{tabular}{|c|c|c|}
\hline CLIENT: & Bechtel Nevada & CLIENT ID: \\
\hline PROJECT ID: & V1140 & DATE SAMPLED: $5 / 31 / 01$ \\
\hline PROJECT \#: & 23081 & NEL SAMPLE ID: L0106022-03 \\
\hline
\end{tabular}

TEST: $\quad$ Total Extractable Petroleum Hydrocarbons Fuel Finger Print by EPA Method 8015M. July 1992

METHOD: EPA 8015M ANALYST: CCS - Las Vegas Division

MATRIX: Solid $\quad$ EXTRACTED: $\quad 6 / 5 / 01$

DILUTION: $1 \quad$ ANALYZED: 6X 6/61

\begin{tabular}{|c|c|c|}
\hline PARAMETER & Result & $\begin{array}{c}\text { Reporting } \\
\text { Limit }\end{array}$ \\
\hline 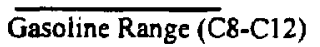 & ND & 10. $\mathrm{mg} / \mathrm{kg}$ \\
\hline Diesel Range (C12-C22) & ND & 10. $\mathrm{mg} / \mathrm{kg}$ \\
\hline Oil Range (C12-C34) & ND & 50. $\mathrm{mg} / \mathrm{kg}$ \\
\hline Total & ND & 10. $\mathrm{mg} / \mathrm{kg}$ \\
\hline \multicolumn{3}{|c|}{ QUALITY CONTROL DATA: } \\
\hline Surrogate & $\%$ Recovery & Acceptable Range \\
\hline Octacosane & 84 & $54-130$ \\
\hline
\end{tabular}

ND - Not Detected

This report shall not be reproduced except in full, without the written approval of the laboratory. 


\begin{tabular}{|c|c|c|}
\hline CLIENT: & Bechtel Nevada & CLIENT ID: \\
\hline PROJECT ID: & $V 1140$ & DATE SAMPLED: $5: 31: 01$ \\
\hline PROJECT \#: & 23081 & NEL SAMPLE ID: L0106022-04 \\
\hline
\end{tabular}

TEST: $\quad$ Total Extractable Petroleum Hydrocarbons Fuel Finger Print by EPA Method 8015M. July 1992

METHOD: EPA 8015M ANALYST: CCS - Las Vegas Division

MATRIX: Solid $\quad$ EXTRACTED: $\quad 6 / 5 / 01$

DILUTION: $1 \quad$ ANALYZED: $\quad 6 / 6 / 01$

\begin{tabular}{|c|c|c|}
\hline PARAMETER & Result & $\begin{array}{c}\text { Reporting } \\
\text { Limit }\end{array}$ \\
\hline$\overline{\text { Gasoline Range (C} 8-C 12)}$ & $\mathrm{ND}$ & 10. $\mathrm{mg} / \mathrm{kg}$ \\
\hline Diesel Range (Cl2-C22) & ND & 10. $\mathrm{mg} / \mathrm{kg}$ \\
\hline Oil Range (C12-C34) & ND & 50. $\mathrm{mg} / \mathrm{kg}$ \\
\hline Total & $\mathrm{ND}$ & 10. $\mathrm{mg} / \mathrm{kg}$ \\
\hline \multicolumn{3}{|c|}{ QUALITY CONTROL DATA: } \\
\hline Surrogate & $\%$ Recovery & Acceptable Range \\
\hline Octacosane & 83 & $54-130$ \\
\hline
\end{tabular}

ND - Not Detected

This report shall not be reproduced except in full, without the written approval of the laboratory. 


\begin{tabular}{|c|c|c|}
\hline CLIENT: & Bechtel Nevada & CLIENT ID: \\
\hline PROJECT ID: & V1140 & DATE SAMPLED: $5 / 31 / 01$ \\
\hline PROJECT \#: & 23081 & NEL SAMPLE ID: L0106022-05 \\
\hline
\end{tabular}

TEST: $\quad$ Total Extractable Petroleum Hydrocarbons Fuel Finger Print by EPA Method 8015M. July 1992

METHOD: EPA 8015M ANALYST: CCS - Las Vegas Division

MATRIX: Solid EXTRACTED: $6 / 5 / 01$

DILUTION: $1 \quad$ ANALYZED: $\quad 6 / 6 / 01$

\begin{tabular}{|c|c|c|}
\hline PARAMIETER & Result & $\begin{array}{l}\text { Reporting } \\
\text { Limit }\end{array}$ \\
\hline 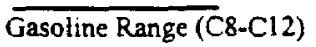 & ND & 10. $\mathrm{mg} / \mathrm{kg}$ \\
\hline Diesel Range (C12-C22) & - ND & 10. $\mathrm{mg} / \mathrm{kg}$ \\
\hline Oil Range (Cl2-C34) & $\mathrm{ND}$ & 50. $\mathrm{mg} / \mathrm{kg}$ \\
\hline Total & ND & 10. $\mathrm{mg} / \mathrm{kg}$ \\
\hline
\end{tabular}

QUALITY CONTROL DATA:

Surrogate

$\%$ Recovery

83

Acceptable Range

Octacosane

$54-130$

ND - Not Detected

This report shall not be reproduced except in full, without the written approval of the laboratory. 


\begin{tabular}{|c|c|c|}
\hline CLIENT: & Bechtel Nevada & CLIENT ID: \\
\hline PROJECT ID: & V1140 & DATE SAMPLED: 5/31/01 \\
\hline PROJECT \#: & 23081 & NEL SAMPLE ID: L0106022-06 \\
\hline
\end{tabular}

TEST: $\quad$ Total Extractable Petroleum Hydrocarbons Fuel Finger Print by EPA Method 8015M, July 1992

METHOD: EPA 8015M ANALYST: CCS - Las Vegas Division

MATRIX: Solid EXTRACTED: $6 / 5 / 01$

DILLTION: $1 \quad$ ANALYZED: $\quad 6 / 6 / 01$

\begin{tabular}{lcc}
\hline PARAMETER & Result & $\begin{array}{c}\text { Reporting } \\
\text { Limit }\end{array}$ \\
\cline { 2 - 2 } Gasoline Range (C8-C12) & $\mathrm{ND}$ & $\frac{10 . \mathrm{mg} / \mathrm{kg}}{10 . \mathrm{mg} / \mathrm{kg}}$ \\
Diesel Range (C12-C22) & $\mathrm{ND}$ & $50 . \mathrm{mg} / \mathrm{kg}$ \\
Oil Range (C12-C34) & $\mathrm{ND}$ & $10 . \mathrm{mg} / \mathrm{kg}$ \\
Total & $\mathrm{ND}$ & Acceptable Range \\
\hline \hline QUALITY CONTROL DATA: & Recovery & $54-130$
\end{tabular}

ND - Not Detected

This report shall not be reproduced except in full, without the written approval of the laboratory. 


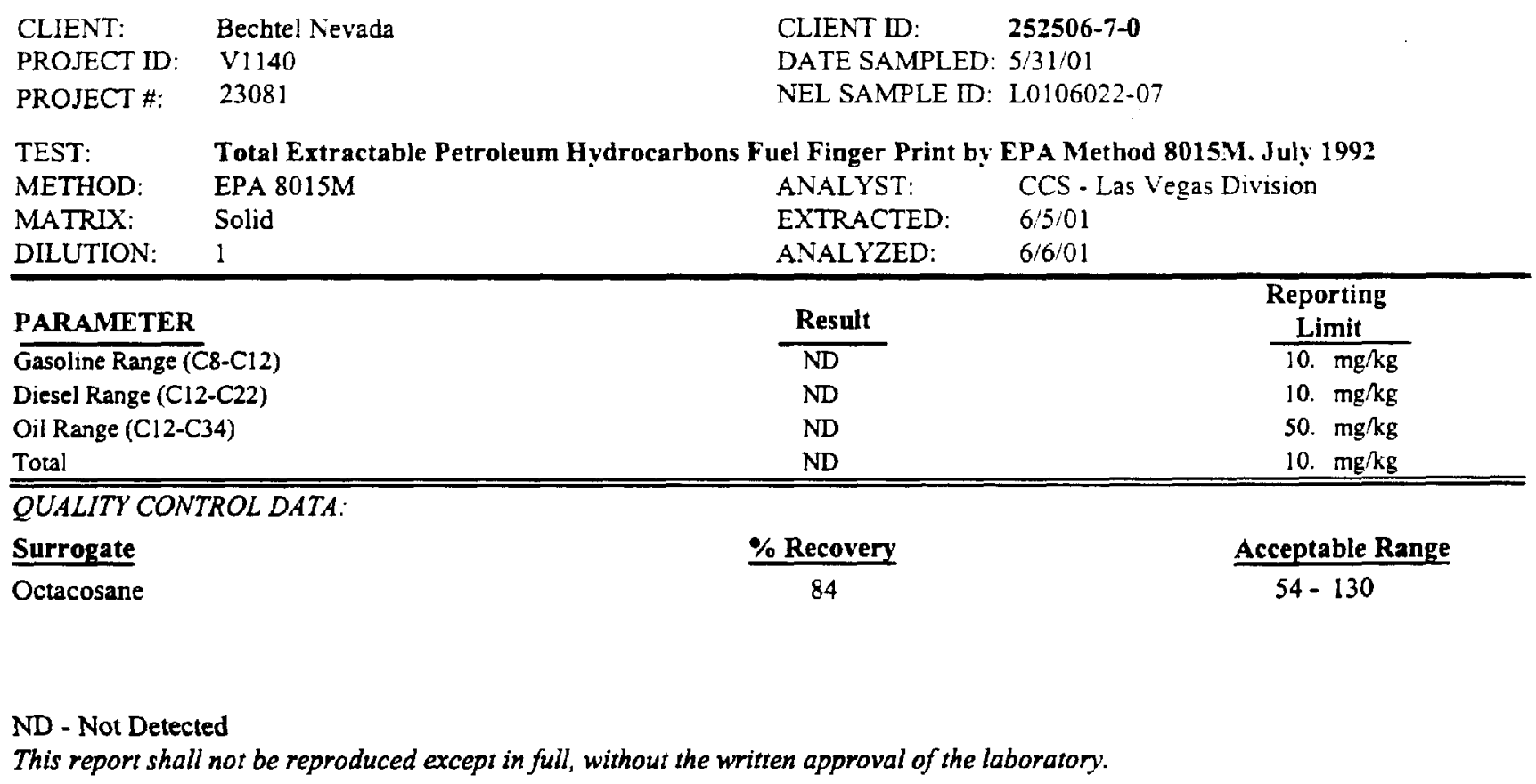




\begin{tabular}{|c|c|c|}
\hline CLIENT: & Bechtel Nevada & CLIENT ID: \\
\hline PROJECT ID: & $V 1140$ & DATE SAMPLED: 5/31/01 \\
\hline PROJECT \#: & 23081 & NEL SAMPLE ID: L0106022-08 \\
\hline
\end{tabular}

TEST: $\quad$ Total Extractable Petroleum Hydrocarbons Fuel Finger Print by EPA Method 8015M. July 1992

METHOD: EPA 8015M ANALYST: CCS - Las Vegas Division

MATRIX: Solid EXTRACTED: 6/5/01

DILUTION: 1 ANALYZED: $\quad 6 / 6 / 01$

\begin{tabular}{lcc}
\hline PARAMETER & Result & Reporting \\
Limit \\
\cline { 2 - 3 } & $\mathrm{ND}$ & $\frac{10 . \mathrm{mg} / \mathrm{kg}}{10}$ \\
Diesel Range (C12-C22) & $\mathrm{ND}$ & $10 . \mathrm{mg} / \mathrm{kg}$ \\
Oil Range (C12-C34) & $\mathrm{ND}$ & $50 . \mathrm{mg} / \mathrm{kg}$ \\
Total & $\mathrm{ND}$ & $10 . \mathrm{mg} / \mathrm{kg}$ \\
\hline
\end{tabular}

QUALITY CONTROL DATA:

Surrogate

Octacosane

\section{Acceptable Range}

$54-130$

ND - Not Detected

This report shall not be reproduced except in full, without the written approval of the laboratory. 


$\begin{array}{llll}\text { CLIENT: } & \text { Bechtel Nevada } & \text { CLIENT ID: } & \mathbf{2 5 2 5 0 6 - 9 - 0} \\ \text { PROJECT ID: } & \text { V1140 } & \text { DATE SAMPIED: 5/31/01 } \\ \text { PROJECT \#: } & 23081 & \text { NEL SAMPLE ID: L0106022-09 }\end{array}$

TEST: $\quad$ Total Extractable Petroleum Hydrocarbons Fuel Finger Print by EPA Method 8015N1. July 1992

METHOD: EPA 8015M ANALYST: CCS - Las Vegas Division

MATRIX: Solid EXTRACTED: 6/5/01

DILUTION: 1 ANALYZED: $\quad 6 / 5 / 01$

\begin{tabular}{|c|c|c|}
\hline PARAMETER & Result & $\begin{array}{l}\text { Reporting } \\
\text { Limit }\end{array}$ \\
\hline$\overline{\text { Gasoline Range ( } \mathrm{C}} 8-\mathrm{Cl} 2)$ & $\mathrm{ND}$ & 10. $\mathrm{mg} / \mathrm{kg}$ \\
\hline Diesel Range (C12-C22) & ND & 10. $\mathrm{mg} / \mathrm{kg}$ \\
\hline Oil Range (C12-C34) & ND & 50. $\mathrm{mg} / \mathrm{kg}$ \\
\hline Total & ND & 10. $\mathrm{mg} / \mathrm{kg}$ \\
\hline
\end{tabular}

QUALITY CONTROL DATA:

Surrogate

\% Recovery

Octacosane

89

Acceptable Range

$54-130$

ND - Not Detected

This report shall not be reproduced except in full, without the written approval of the laboratory. 


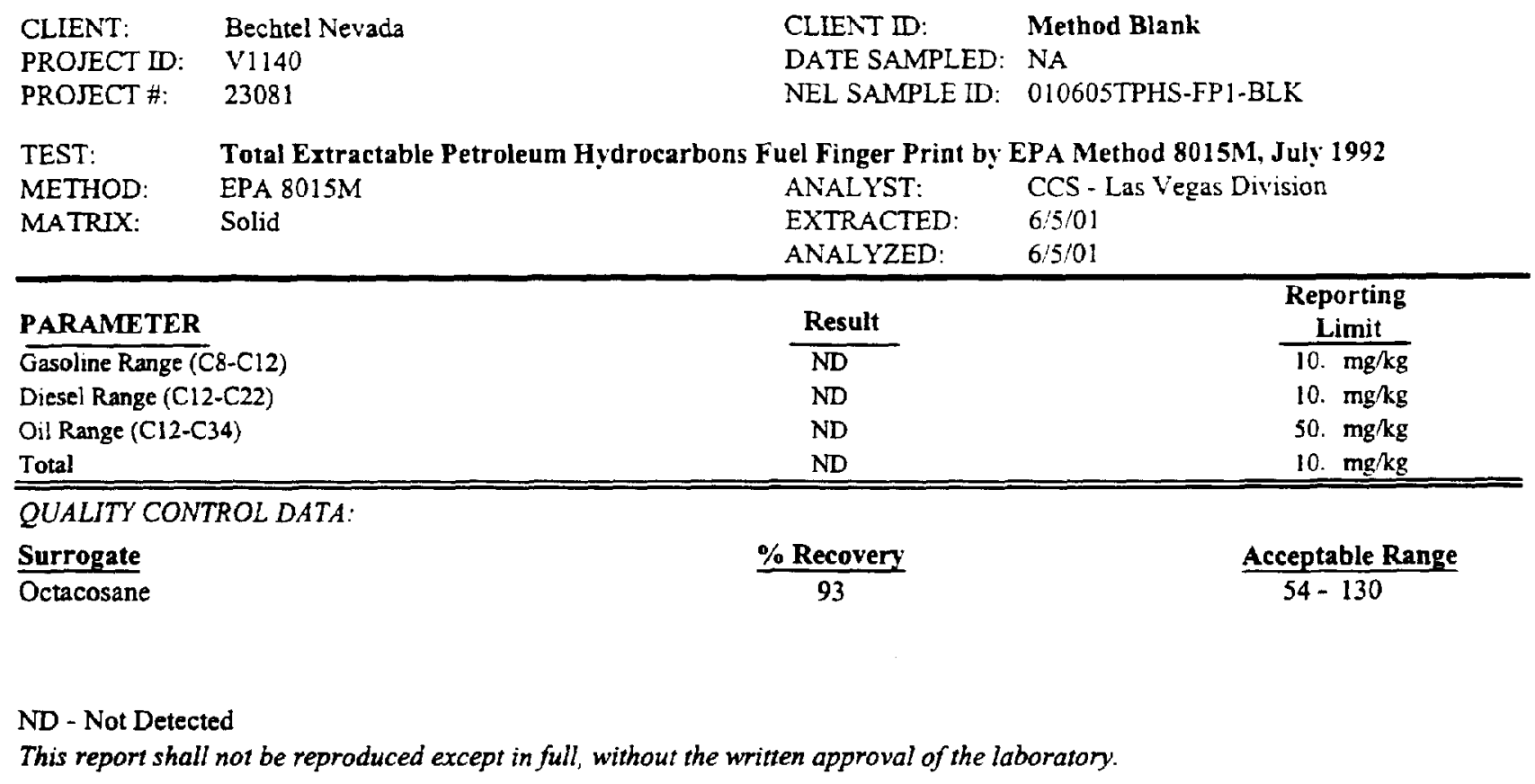




\section{NEL LABORATORIES}

CLIENT: Bechtel Nevada

PROJECT ID: V1140

PROJECT \#: 23081

TEST: $\quad$ Total Extractable Petroleum Hydrocarbons Fuel Finger Print by EPA Method 8015M, July 1992

MATRJX: Solid

\begin{tabular}{|c|c|c|c|c|c|c|}
\hline PARAMETER & NEL Sample ID & $\begin{array}{c}\text { Spike } \\
\text { Amount }\end{array}$ & $\begin{array}{l}\text { Spike } \\
\text { Result }\end{array}$ & $\frac{\text { Percent }}{\text { Recovery }}$ & $\frac{\text { Acceptable }}{\text { Range }}$ & $\underline{\text { RPD }}$ \\
\hline Diesel Range (C12-C22) & 010605TPHS-FP1-LCS & 166.7 & 154 & 92 & $53-91$ & \\
\hline Diesel Range (C12-C22) & 010605TPHS-FP1-LCSD & 166.7 & 160 & 96 & $53-91$ & 3.8 \\
\hline Total & 010605TPHS-FP1-LCS & 166.7 & 154 & 92 & $53-91$ & \\
\hline Total & 010605TPHS-FPI-LCSD & 166.7 & 160 & 96 & $53-91$ & 3.8 \\
\hline
\end{tabular}

ND - Not Detected

This report shall not be reproduced except in full, without the written approval of the laboratory. 


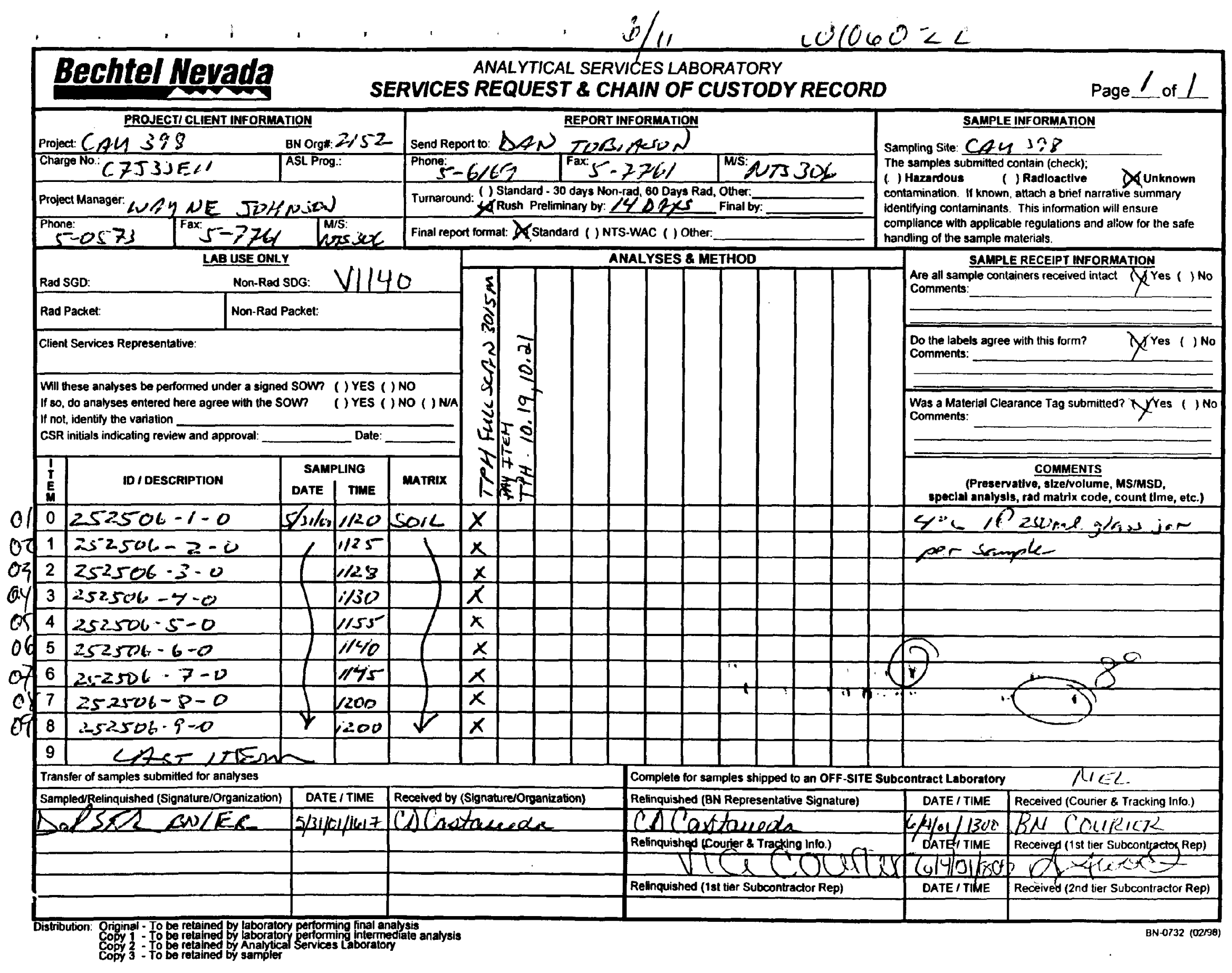


CLIENT: Bechtel Nevada

P.O. Box $98521, \mathrm{M} / \mathrm{S}$ NTS273

Las Vegas, NV 89193-8521

ATTN: $\quad$ Ted Redding

PROJECT NAME: $\quad$ V1140

NEL ORDER ID: L0106023

PROJECT NUMBER: 23081

Attached are the analytical results for samples in support of the above referenced project.

Samples submitted for this project were not sampled by NEL Laboratories. Samples were received by NEL in good condition, under chain of custody on 6/4/01.

Should you have any questions or comments, please feel free to contact our Client Services department at (702) $657-1010$.

Some results have been flagged as follows:

$\mathrm{Di}$ - Results reported from analysis at a higher dilution.

Some $Q A$ results have been flagged as follows:

C - Sample concentration is a least 5 times greater than spike contribution. Spike recovery criteria do not apply. Some surrogate results have been flagged as follows:

D - Sample required dilution. Sample QC results were diluted outside the calibrated range.

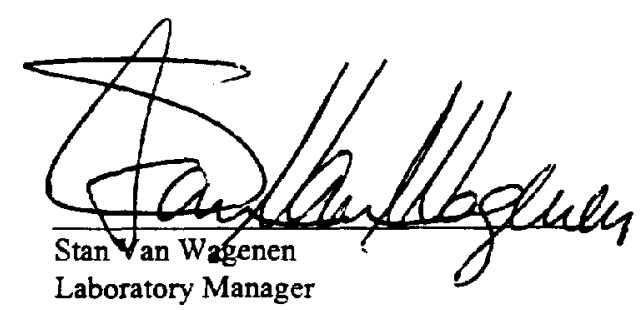

\section{CERTIFICATIONS:}

\begin{tabular}{llll}
\hline & Reno & Las Vegas & S. California \\
\cline { 2 - 4 } AZizona & AZ0520 & AZ0518 & AZ0605 \\
California & 1707 & 2002 & 2264 \\
$\begin{array}{l}\text { US Army Corps } \\
\text { of Engineers }\end{array}$ & Certified & Certified & \\
& & &
\end{tabular}

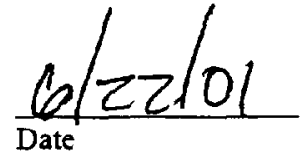

Idaho

Montana

Nevada

L.A.C.S.D.

\begin{tabular}{lll} 
Reno & Las Vegas & S. California \\
\hline Certified & Certified & \\
Certified & Certified & \\
NV033 & NV052 & CA084 \\
& & 10228
\end{tabular}


NEL LABORATORIES

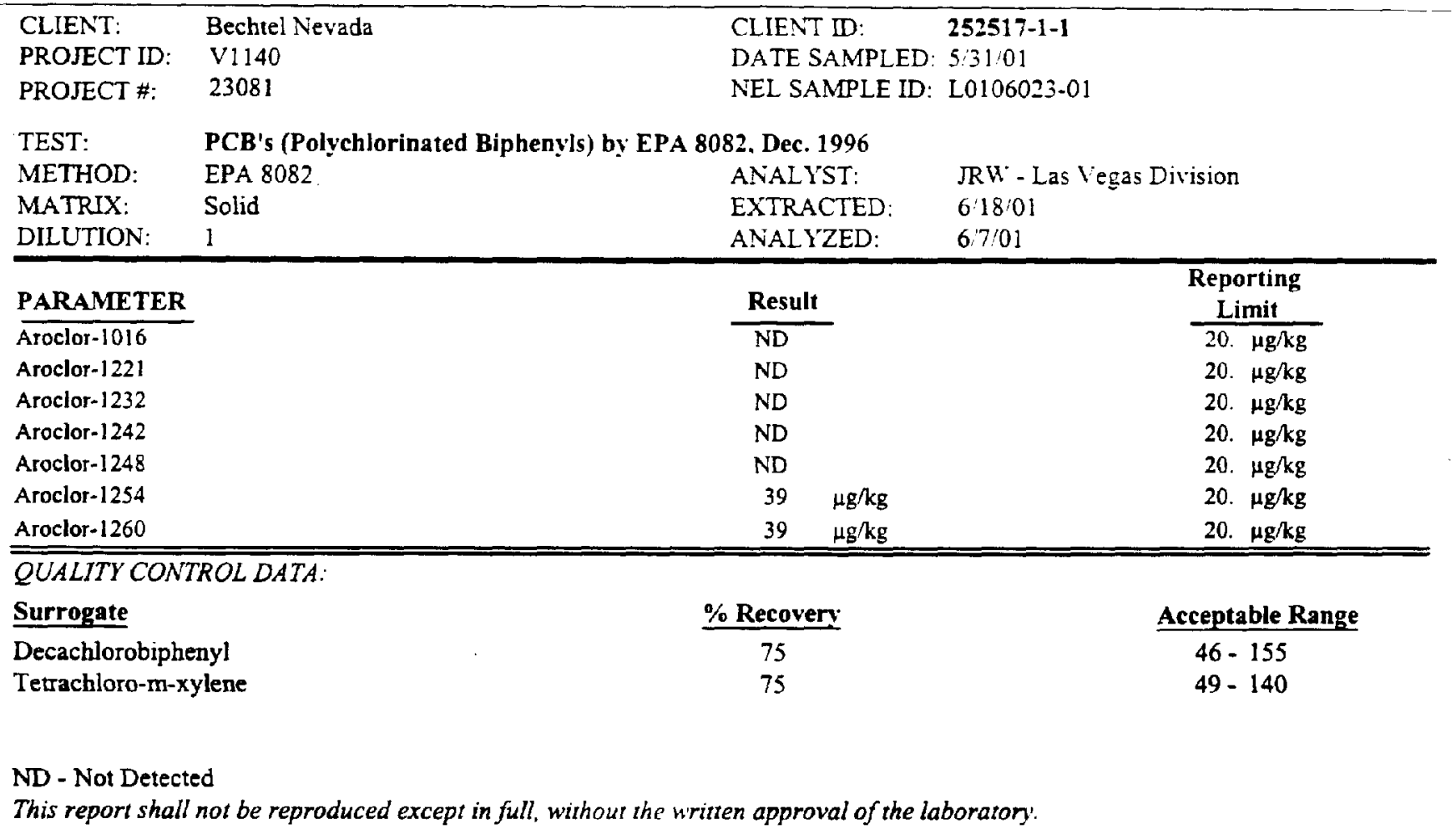


NEL LABORATORIES

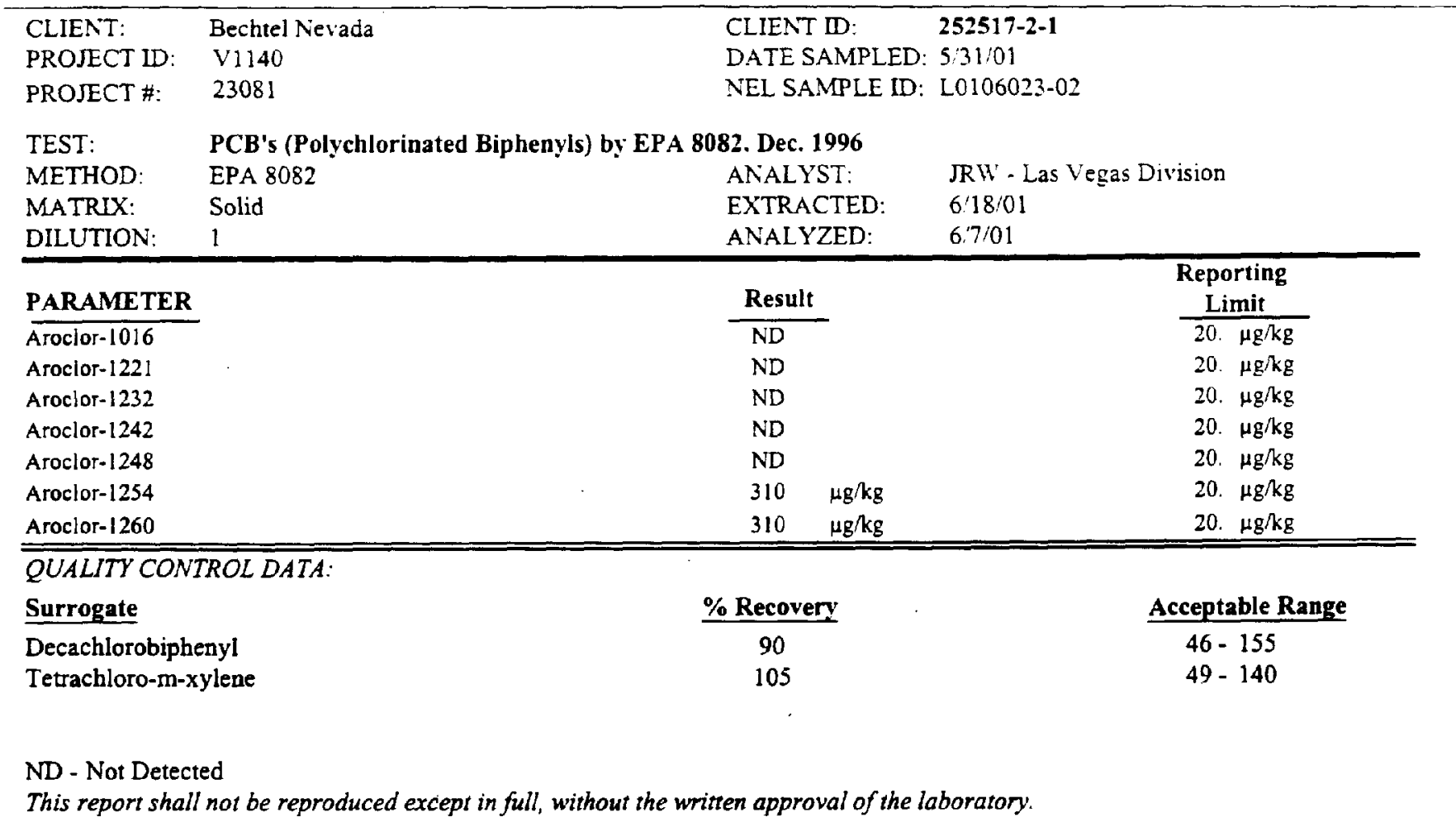


NEL LABORATORIES

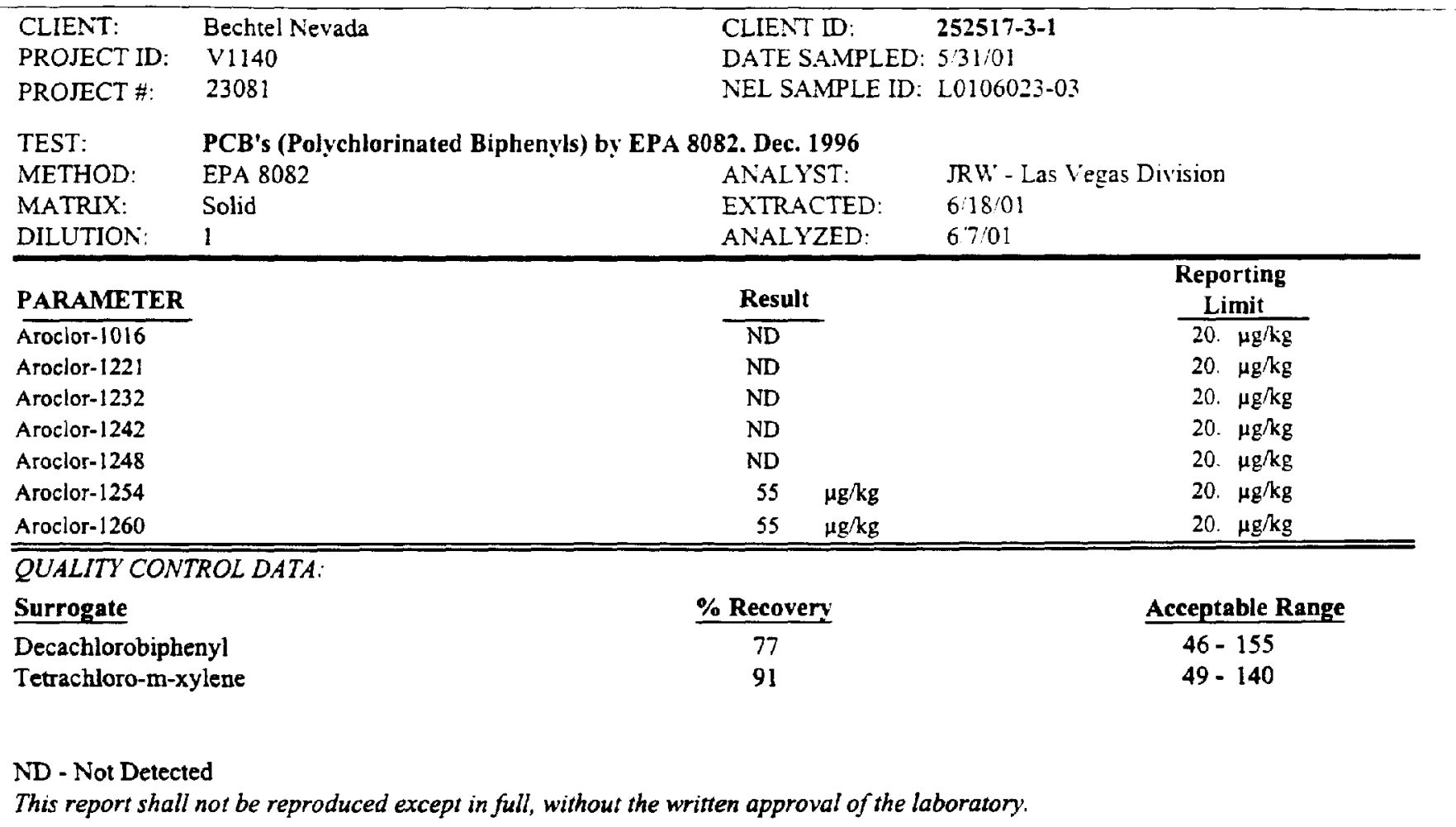


NEL LABORATORIES

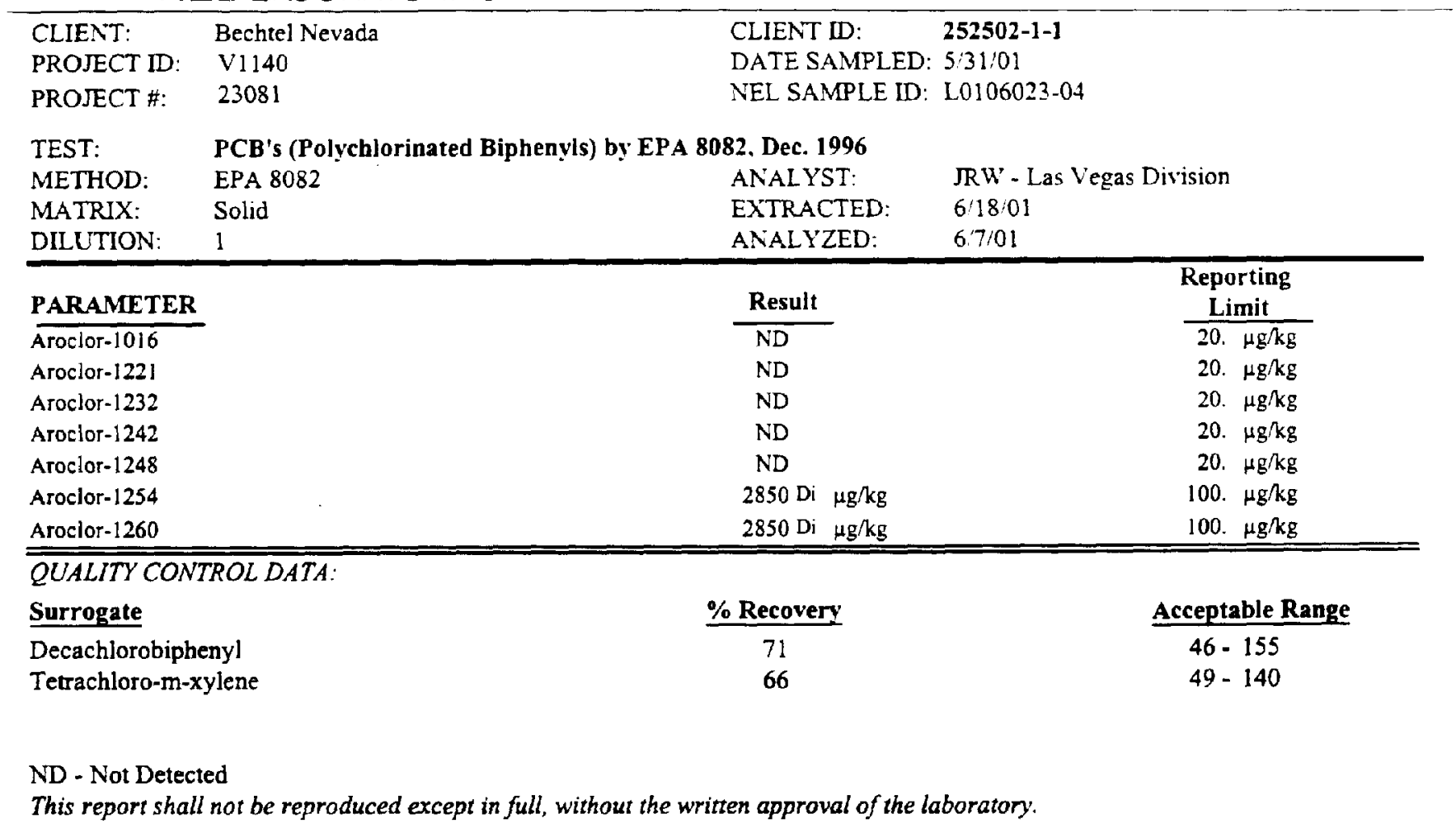


NEL LABORATORIES

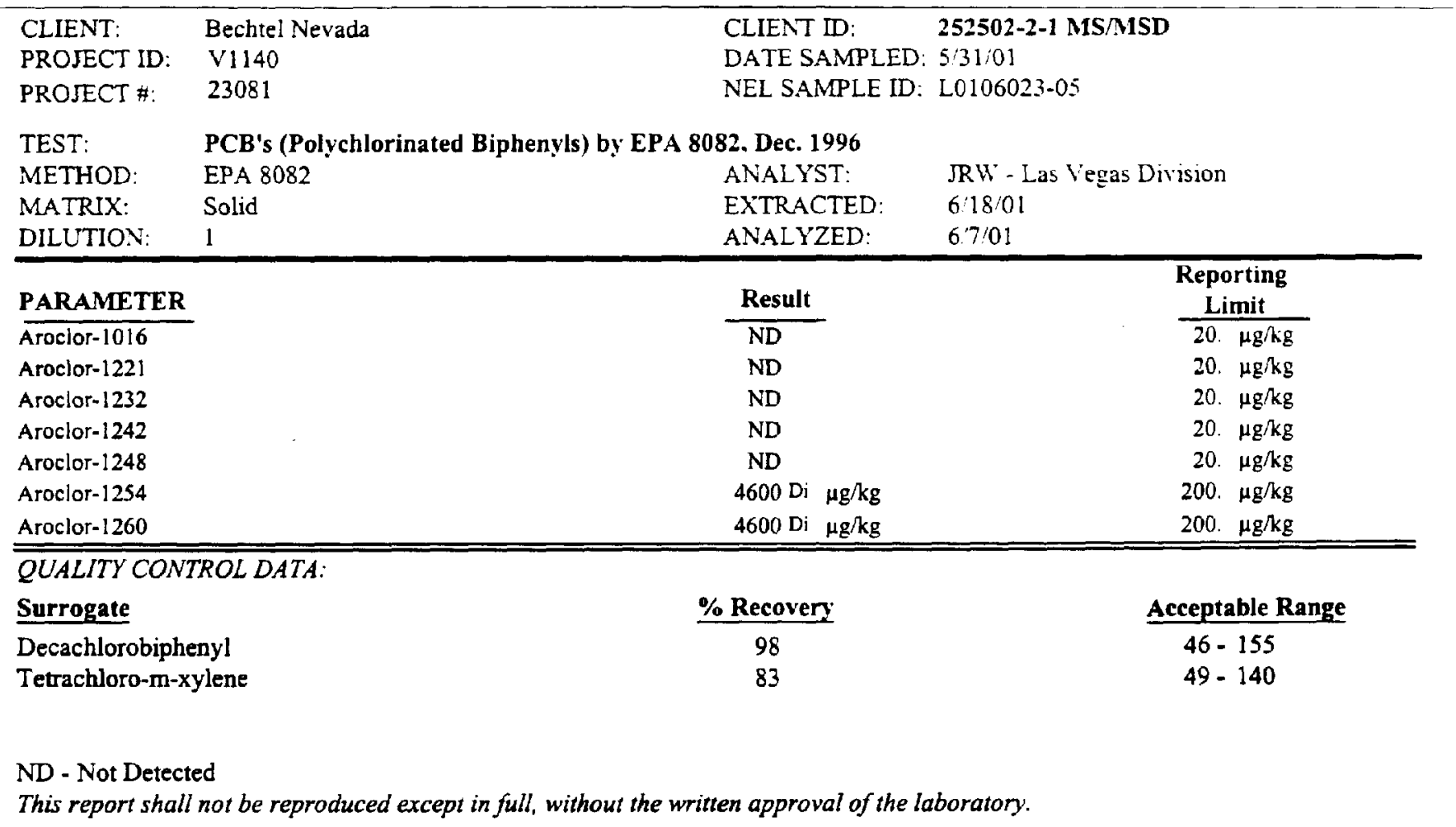


NEL LABORATORIES

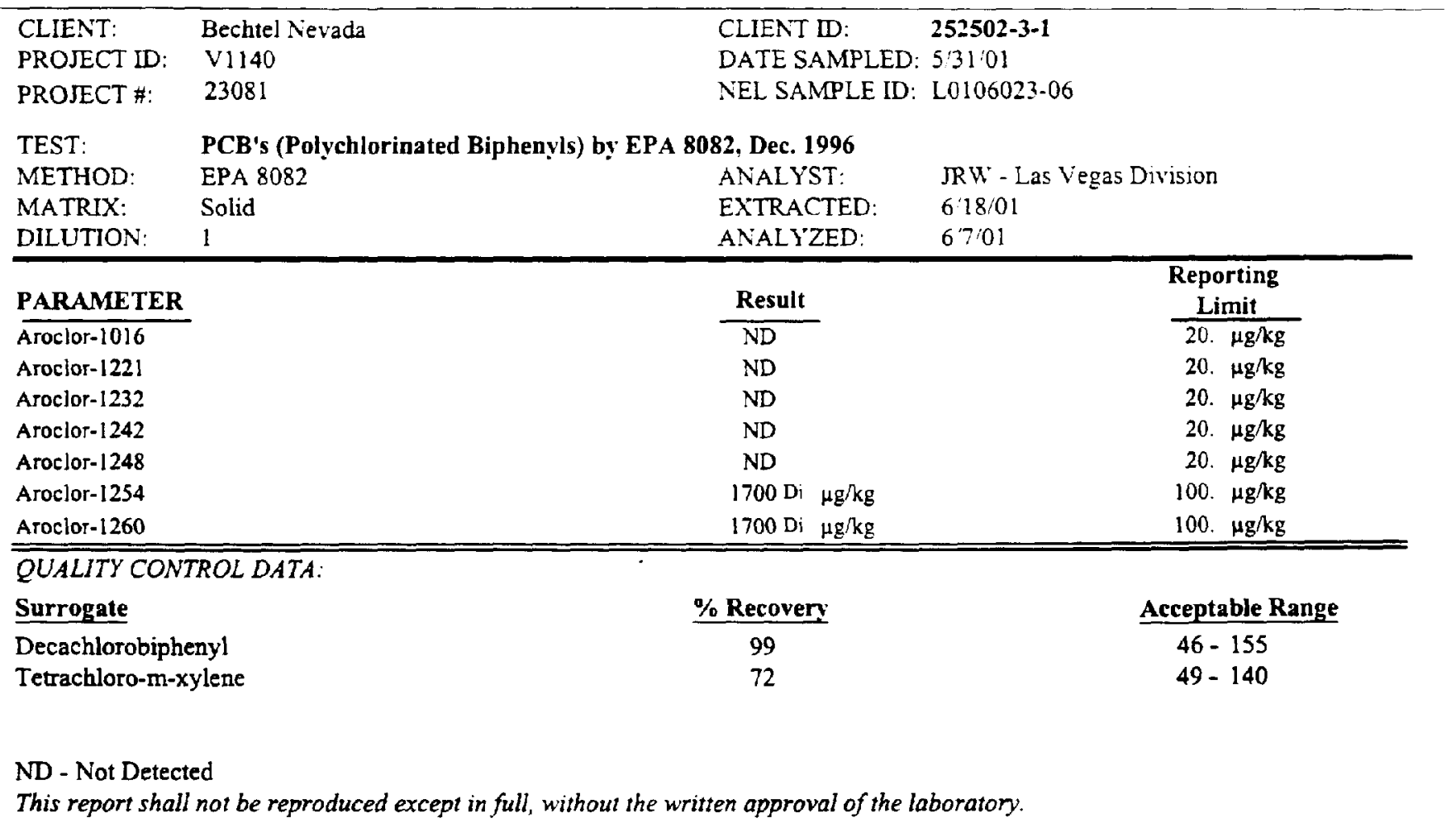


NEL LABORATORIES

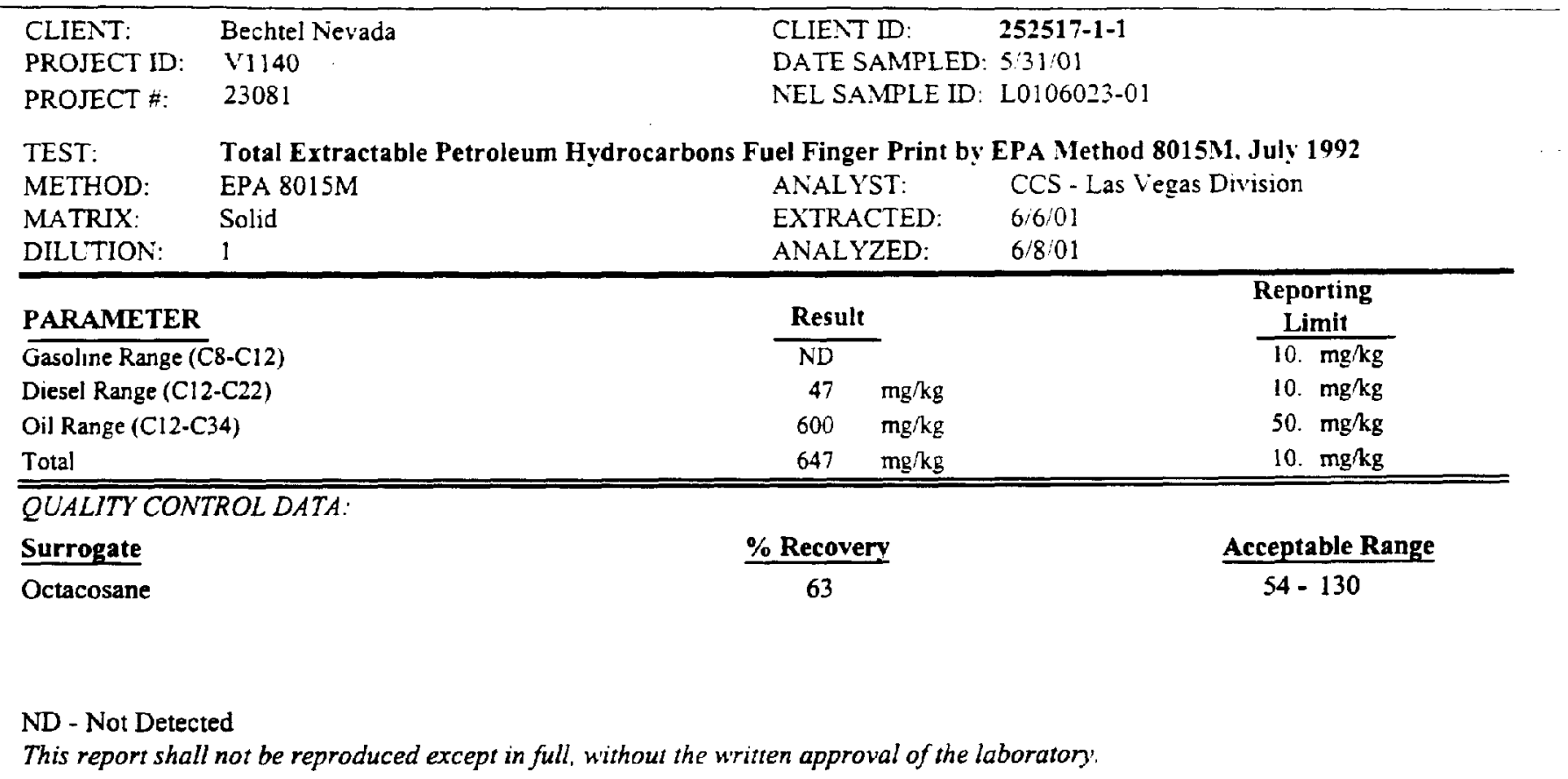


NEL LABORATORIES

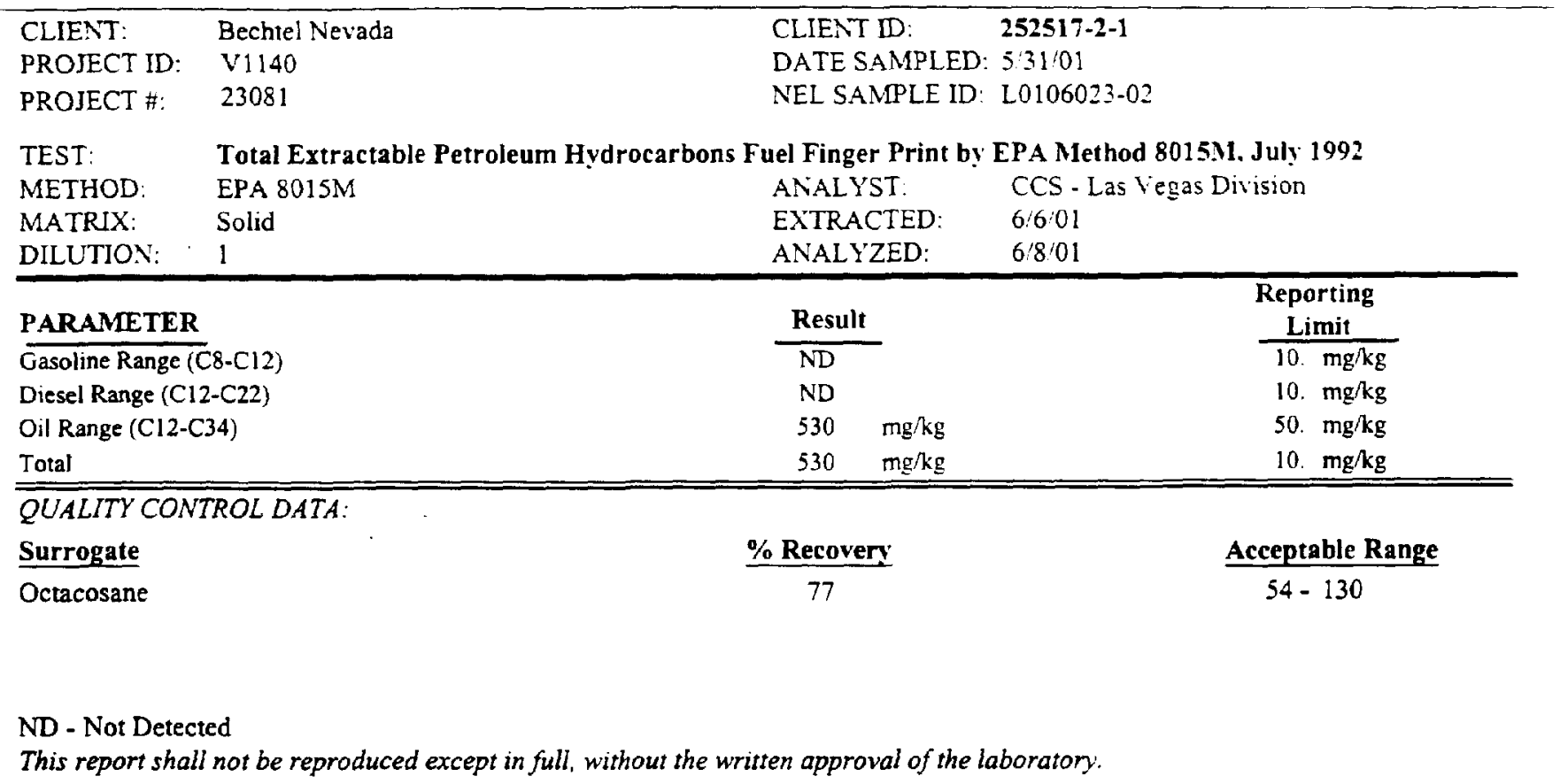


NEL LABORATORIES

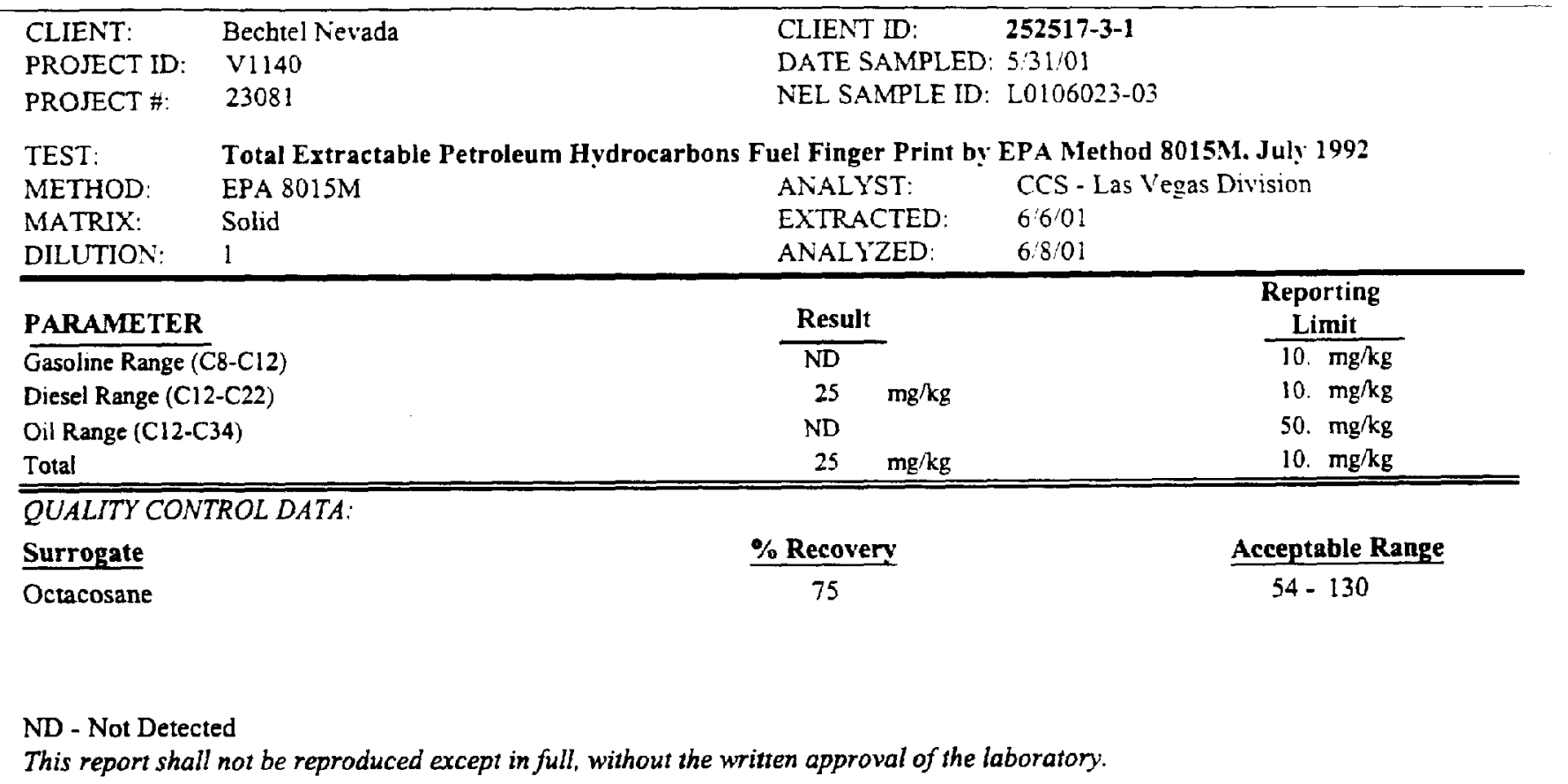


NEL LABORATORIES

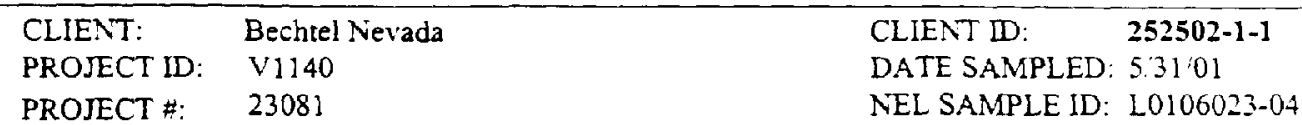

TEST: $\quad$ Total Extractable Petroleum Hydrocarbons Fuel Finger Print by EPA Method 8015M. July 1992

METHOD: EPA 8015M ANALYST: CCS - Las Vegas Division

MATRIX: Solid $\quad$ EXTRACTED: $6 \% 601$

DILUTION: 1 ANALYZED: 6\%:01

\begin{tabular}{|c|c|c|}
\hline PARAMETER & Result & $\begin{array}{l}\text { Reporting } \\
\text { Limit }\end{array}$ \\
\hline$\overline{\text { Gasoline Range ( }}(\mathrm{C}-\mathrm{C} 12)$ & ND & $10 . \mathrm{mg} / \mathrm{kg}$ \\
\hline Diesel Range (C12-C22) & $\mathrm{mg} / \mathrm{kg}$ & 10. $\mathrm{mg} / \mathrm{kg}$ \\
\hline Oil Range (Cl2-C34) & $\mathrm{mg} / \mathrm{kg}$ & 50. $\mathrm{mg} / \mathrm{kg}$ \\
\hline Total & $\mathrm{mg} / \mathrm{kg}$ & 10. $\mathrm{mg} / \mathrm{kg}$ \\
\hline \multicolumn{3}{|c|}{ QUALITY CONTROL DATA: } \\
\hline Surrogate & $\%$ Recovery & Acceptable Range \\
\hline Octacosane & 77 & $54-130$ \\
\hline
\end{tabular}

ND - Not Detected

This report shall not be reproduced except in full, without the written approval of the laboratory. 
NEL LABORATORIES

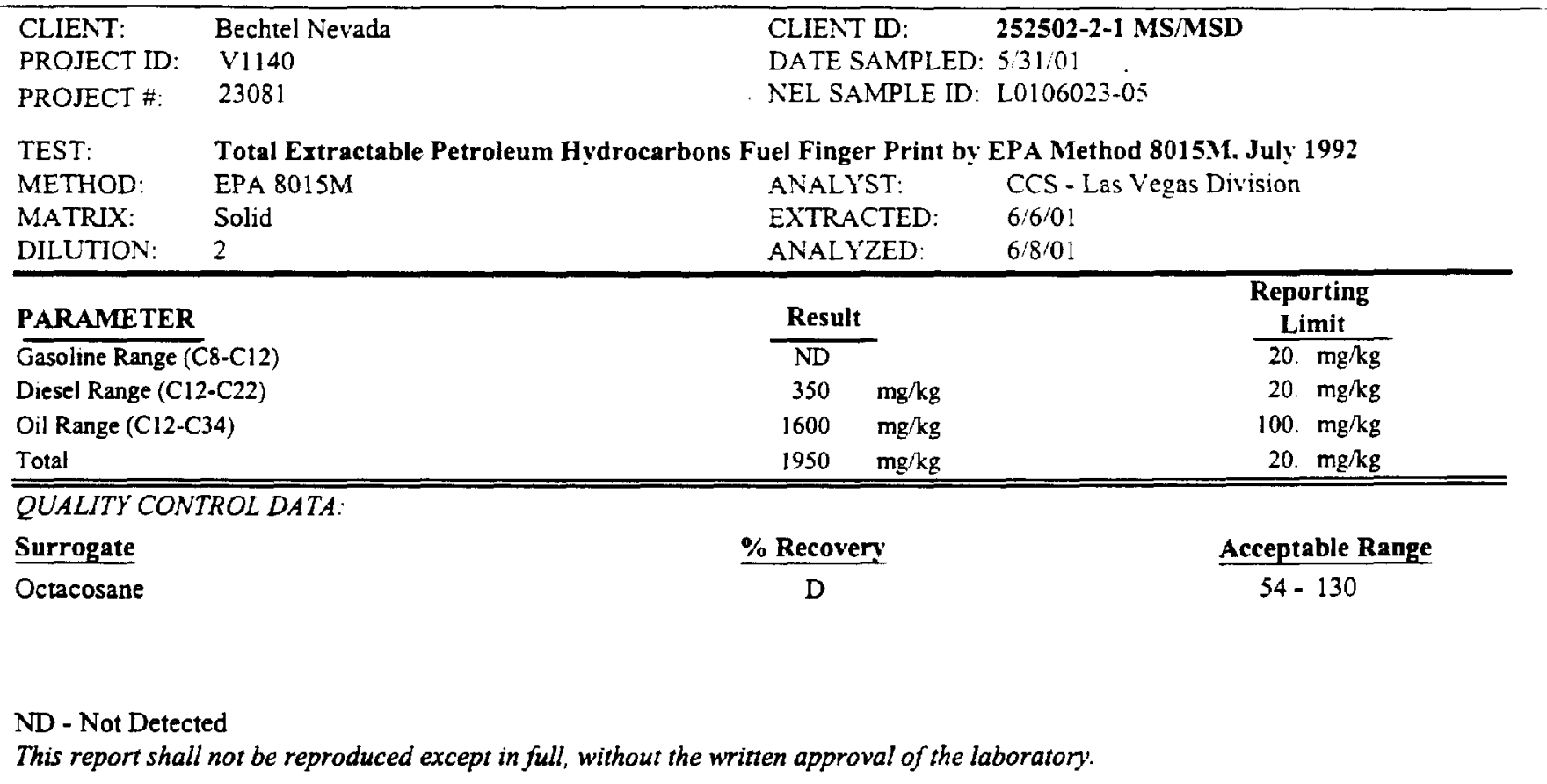


NEL LABORATORIES

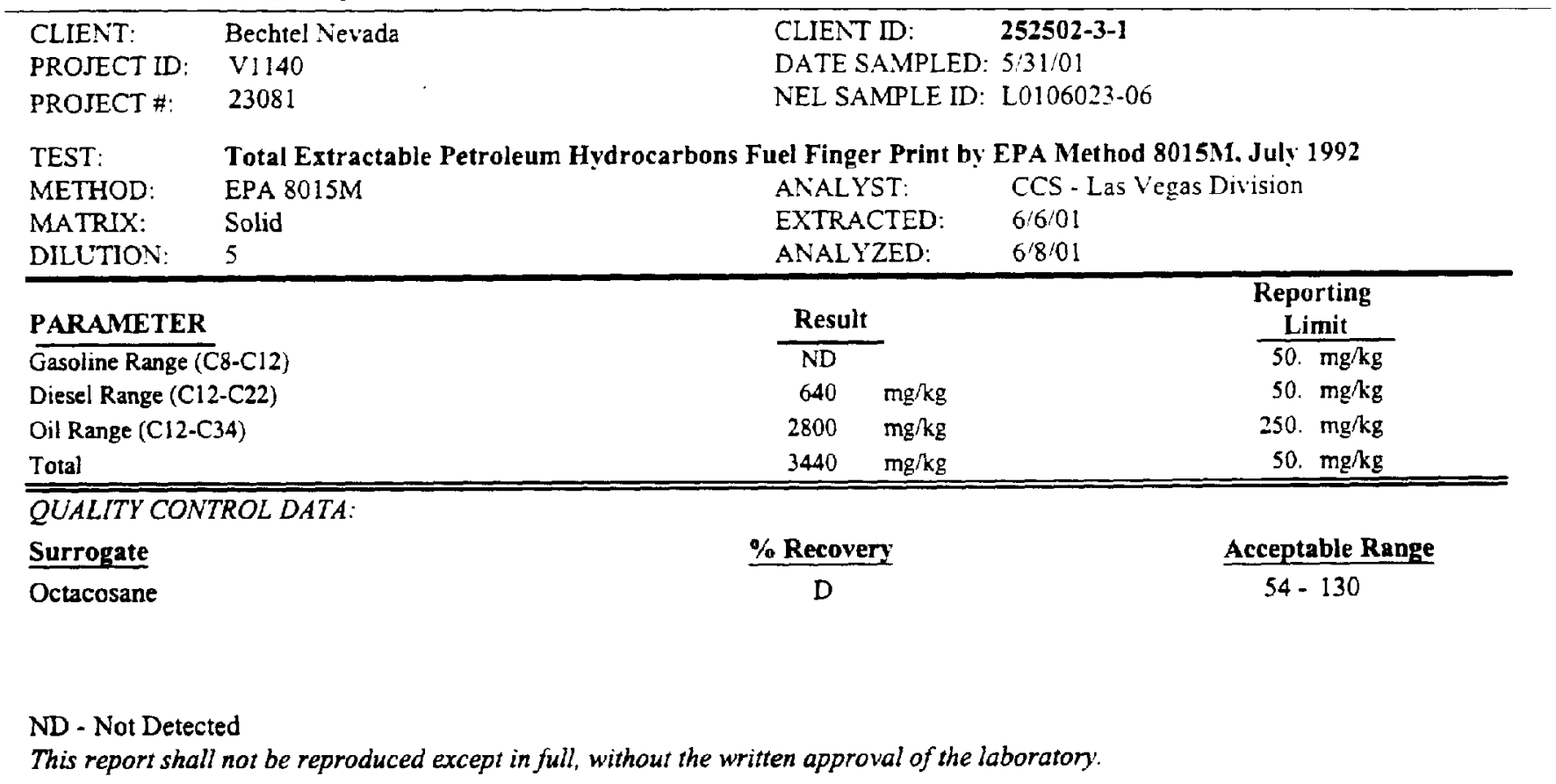


NEL LABORATORIES

\begin{tabular}{llll}
\hline CLIENT: & Bechtel Nevada & CLIENT ID: & Method Blank \\
PROJECT ID: & V1140 & DATE SAMPLED: & NA \\
PROJECT \#: & 23081 & NEL SAMPLE ID: & 010605PCBS-BLK \\
& & & \\
TEST: & PCB's (Polychlorinated Biphenyls) by EPA 8082. Dec. 1996 & \\
METHOD: & EPA 8082 & ANALYST: & JRW - Las Vegas Division \\
MATRIX: & Solid & EXTRACTED: & $6 / 18 / 01$ \\
& & ANALYZED: & $67 / 01$ \\
\hline
\end{tabular}

\section{PARAMETER}

Aroclor-1016

Aroclor-1221

Arocior-1232

Aroclor- 1242

Aroclor- 1248

Aroclor-1254

Aroclor -1260

ANAIYZED:

QUALITY CONTROL DATA:

Surrogate

Decachlorobiphenyl

Tetrachloro-m-xylene

\begin{tabular}{l} 
Result \\
\hline ND \\
ND \\
ND \\
ND \\
ND \\
ND \\
ND
\end{tabular}

$\%$ Recovery

83

87
Reporting

Limit

20. $\mu \mathrm{g} / \mathrm{kg}$

20. $\mu \mathrm{g} / \mathrm{kg}$

20. $\mu \mathrm{g} / \mathrm{kg}$

20. $\mu \mathrm{g} / \mathrm{kg}$

20. $\mu \mathrm{g} / \mathrm{kg}$

20. $\mu \mathrm{g} / \mathrm{kg}$

20. $\mu \mathrm{g} / \mathrm{kg}$

ND - Not Detected

This report shall not be reproduced except in full, without the written approval of the laboratory.
CLIENT: Bechtel Nevada
CLIENT ID:
Method Blank
PROJECT ID: V1140
DATE SAMPLED: NA
PROJECT \#: 23081
NEL SAMPLE ID： 010606TPHS-FP-BLK

TEST:

METHOD:

MATRIX:
Total Extractable Petroleum Hydrocarbons Fuel Finger Print by EPA Method 8015M, July 1992 EPA 8015M Solid
ANALYST: EXTRACTED: ANALYZED:

\begin{tabular}{|c|c|c|}
\hline PARAMETER & Result & $\begin{array}{c}\text { Reporting } \\
\text { Limit } \\
\end{array}$ \\
\hline$\overline{\text { Gasoline Range (C} 8-C l 2)}$ & ND & 10. $\mathrm{mg} / \mathrm{kg}$ \\
\hline Diesel Range ( $\mathrm{C} 12-\mathrm{C} 22)$ & ND & 10. $\mathrm{mg} / \mathrm{kg}$ \\
\hline Oil Range (C12-C34) & ND & 50. $\mathrm{mg} / \mathrm{kg}$ \\
\hline Total & ND & 10. $\mathrm{mg} / \mathrm{kg}$ \\
\hline
\end{tabular}

CCS - Las Vegas Division 6/6/01 $6 / 8 / 01$
QUALITY CONTROL DATA:

\section{Surrogate}

Octacosane

\section{$\%$ Recovery}

80
Acceptable Range

$54-130$

ND - Not Detected

This report shall not be reproduced except in full, without the written approval of the laboratory. 
NEL LABORATORIES

\begin{tabular}{|c|c|c|c|c|c|c|c|}
\hline $\begin{array}{l}\text { CLIENT: } \\
\text { PROJECT ID: } \\
\text { PROJECT \#: }\end{array}$ & $\begin{array}{l}\text { Bechtel Nevada } \\
\text { V1140 } \\
23081\end{array}$ & & & $\begin{array}{l}\text { CLIENT II } \\
\text { DATE SAI } \\
\text { NEL SAM }\end{array}$ & $\begin{array}{l}\text { 252502- } \\
\text { MPLED: } 5 / 31 / 01 \\
\text { PLE ID: L01060 }\end{array}$ & $\begin{array}{l}1-1 \\
23-04\end{array}$ & \\
\hline $\begin{array}{l}\text { TEST: } \\
\text { MATRIX: }\end{array}$ & $\begin{array}{l}\text { TCLP-8 Metals } \\
\text { Solid }\end{array}$ & & & & & & \\
\hline PARAMETER & $\begin{array}{c}\text { RESULT } \\
\mathrm{mg} / \mathrm{L} \\
\end{array}$ & $\begin{array}{c}\text { REPORTING } \\
\text { LIMIT } \\
\end{array}$ & D. F. & METHOD & $\begin{array}{c}\text { TCLP/STLC } \\
\text { EXTRACTION } \\
\text { DATE } \\
\end{array}$ & DIGESTED & ANAL YZED \\
\hline Arsenic & ND & $0.1 \mathrm{mg} / \mathrm{L}$ & 1 & EPA 6010 & $6 / 6 / 01$ & $6 / 7 / 01$ & $6 / 8 / 01$ \\
\hline Barium & ND & 1. $\mathrm{mg} / \mathrm{L}$ & 1 & EPA 6010 & $6 / 6 / 01$ & $6 / 7 / 01$ & $6 / 8 / 01$ \\
\hline Cadmium & 0.029 & $0.01 \mathrm{mg} / \mathrm{L}$ & 1 & EPA 6010 & $6 / 6 / 01$ & $6 / 7 / 01$ & $6 / 8 / 01$ \\
\hline Chromium & ND & $0.01 \mathrm{mg} / \mathrm{L}$ & 1 & EPA 6010 & $6 / 6 / 01$ & $6 / 7 / 01$ & $6 / 8 / 01$ \\
\hline Lead & 3.5 & $0.05 \mathrm{mg} / \mathrm{L}$ & 1 & EPA 6010 & $6 / 6 / 01$ & $6: 7 / 01$ & $6 / 8 / 01$ \\
\hline Mercury & ND & $0.002 \mathrm{mg} / \mathrm{L}$ & 10 & EPA $7470 A$ & $6 / 6 / 01$ & $6 / 7 / 01$ & $6 / 7 / 01$ \\
\hline Selenium & ND & $0.1 \mathrm{mg} / \mathrm{L}$ & 1 & EPA 6010 & $6 / 6 / 01$ & $6 / 7 / 01$ & $6 / 8 / 01$ \\
\hline Silver & ND & $0.02 \mathrm{mg} / \mathrm{L}$ & 1 & EPA 6010 & $6 / 6 / 01$ & $6 / 7 / 01$ & $6 / 8 / 01$ \\
\hline
\end{tabular}

D.F. - Dilution Factor

ND - Not Detected

This report shall not be reproduced except in full, without the written approval of the laboratory. 
NEL LABORATORIES

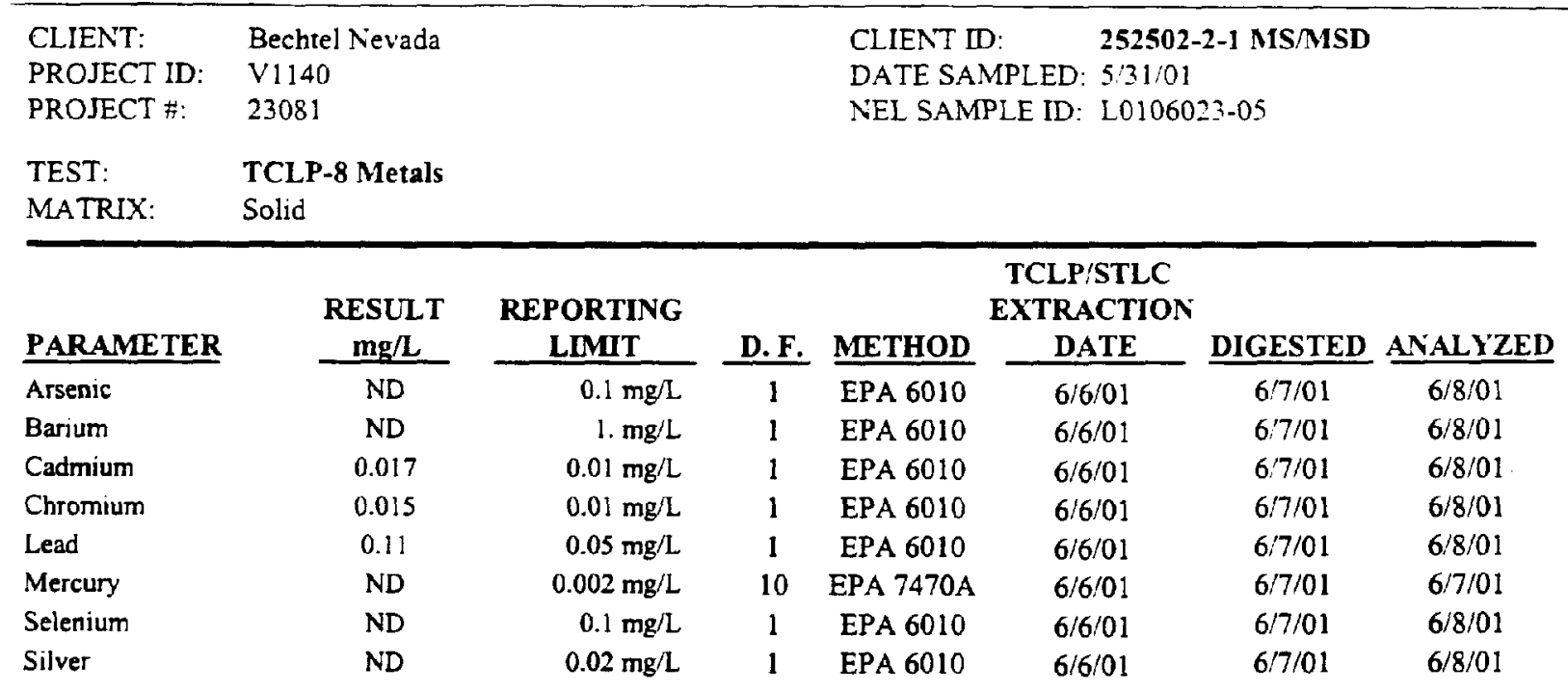

\section{D.F. - Dilution Factor}

ND - Not Detected

This repart shall not be reproduced except in full, without the written approval of the laboratory. 
NEL LABORATORIES

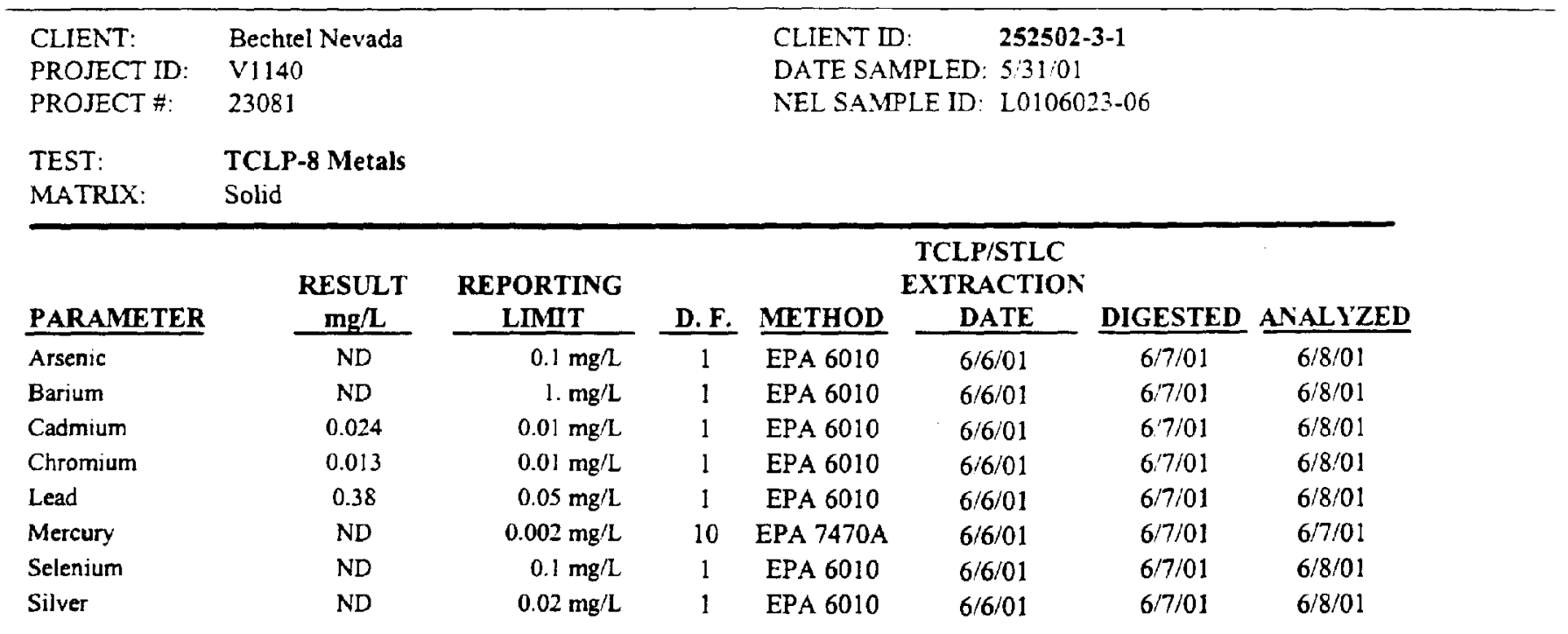

D.F. - Dilution Factor

ND - Not Detected

This report shall not be reproduced except in full, without the written approval of the laboratory. 
NEL LABORATORIES

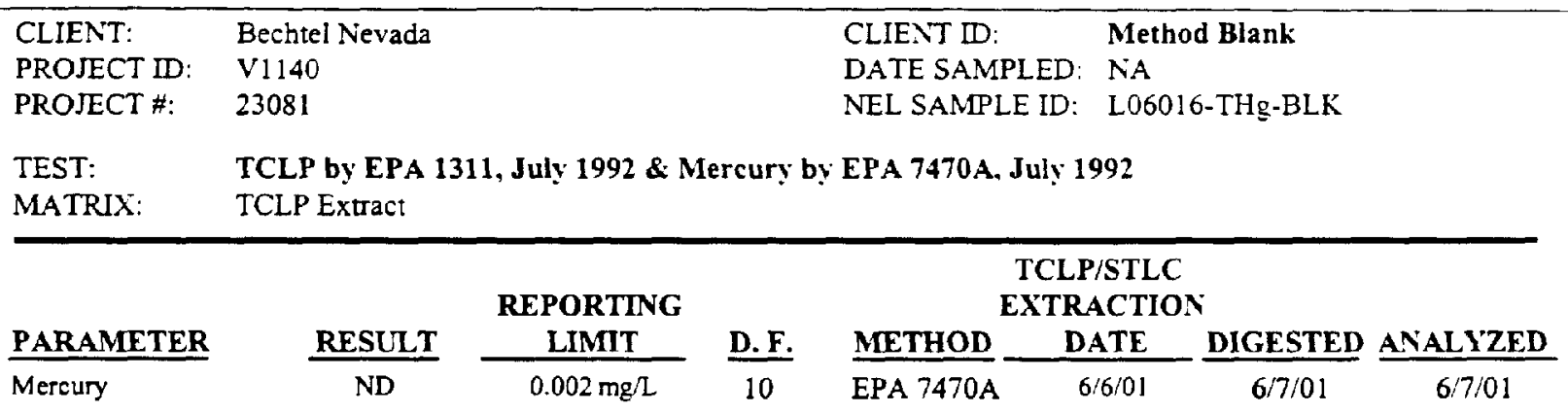

D.F. - Dilution Factor

ND - Not Detected

This report shall not be reproduced except in full. without the nrtten approval of the laboratory. 
NEL LABORATORIES

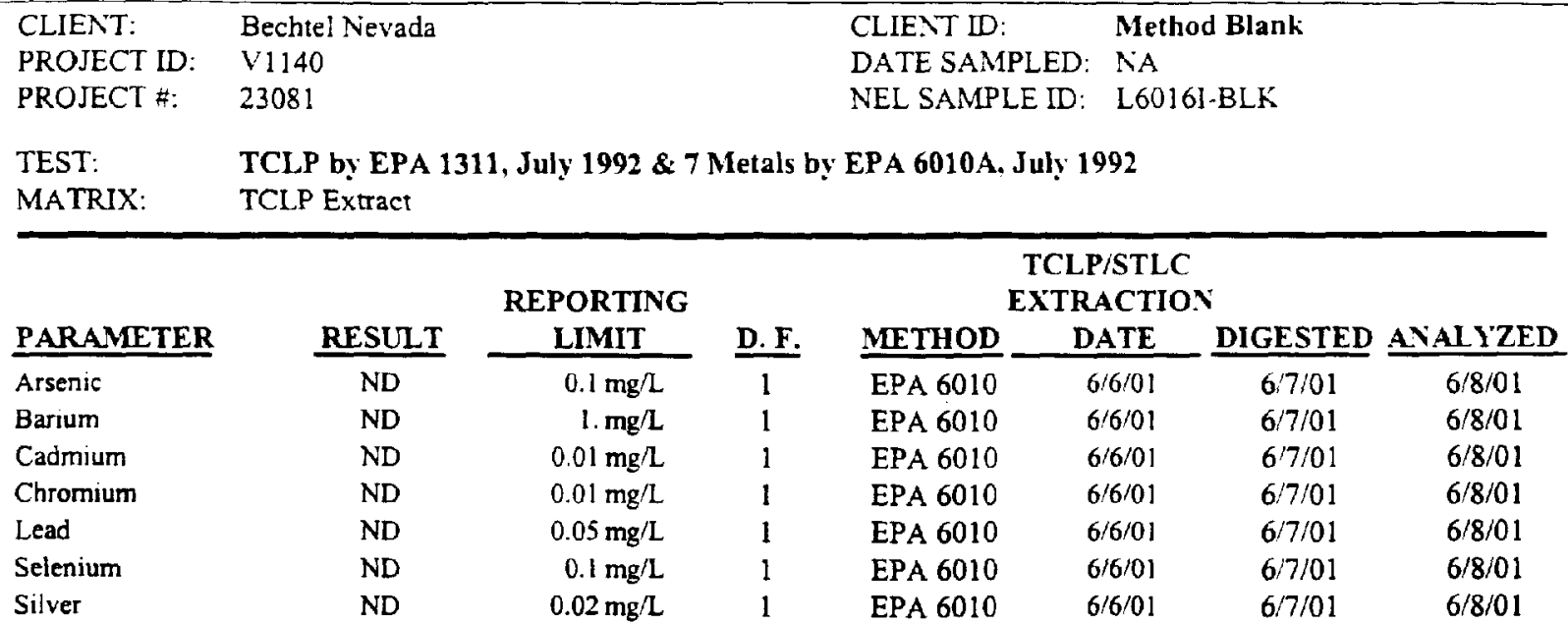

D.F. - Dilution Factor

ND - Not Detected

This report shall not be reproduced except in full, without the written approval of the laboratory. 
NEL LABORATORIES

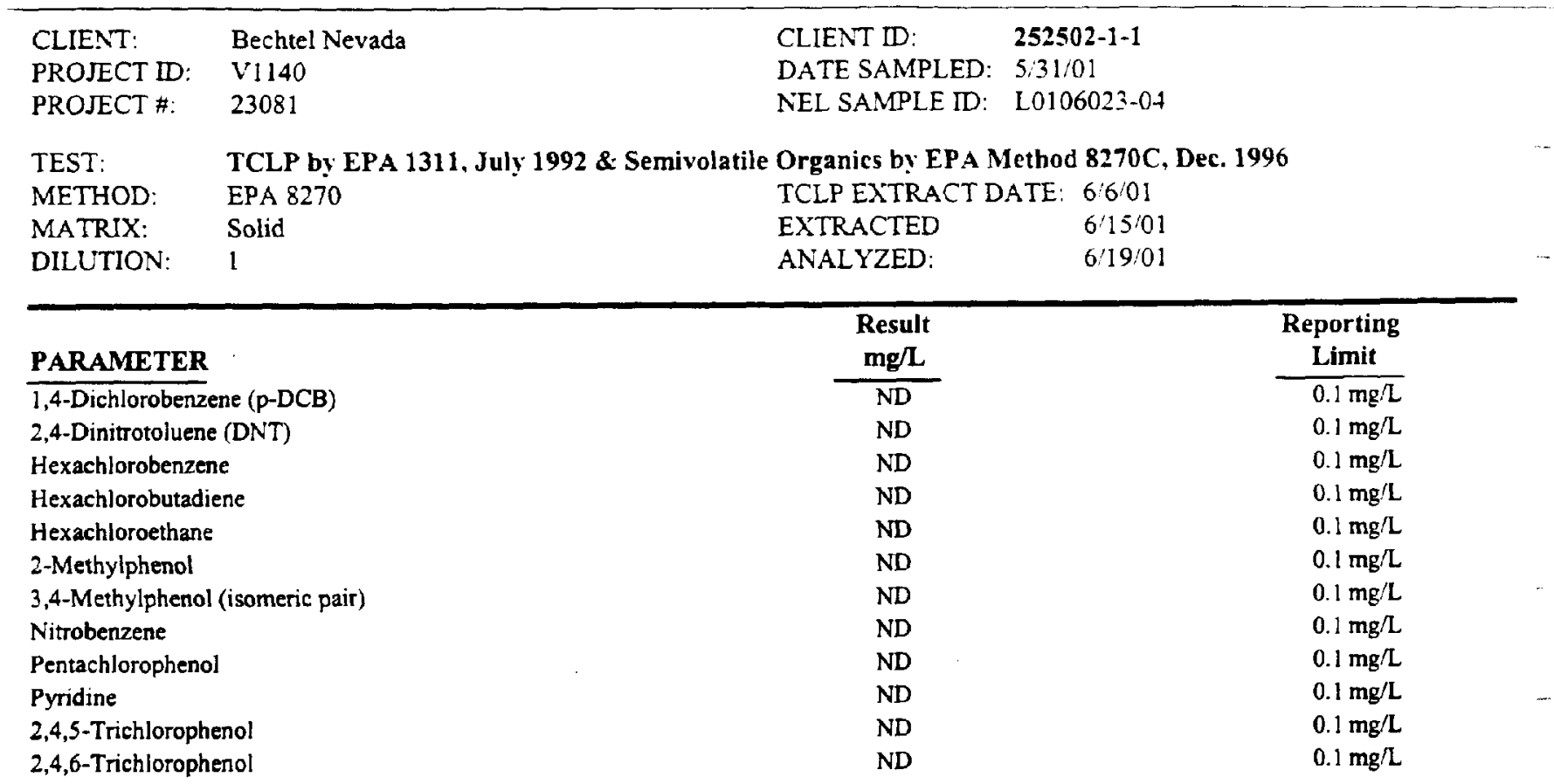

\section{QUALITY CONTROL DATA:}

\section{Surrogate}

2,4,6-Tribromophenol

2-Fluorobiphenyl

2-Fluorophenol

Nitrobenzene-d5

p-Terphenyl-d14

Phenol-ds

\section{\% Recovery}

36
19
18
23
34
14

36

19

23

14
Acceptable Range

$0-161$

$16-127$

0 - 88

9- 132

$16-163$

0.63

ND - Not Detected

This report shall not be reproduced except in full, without the written approval of the laboratory. 
NEL LABORATORIES

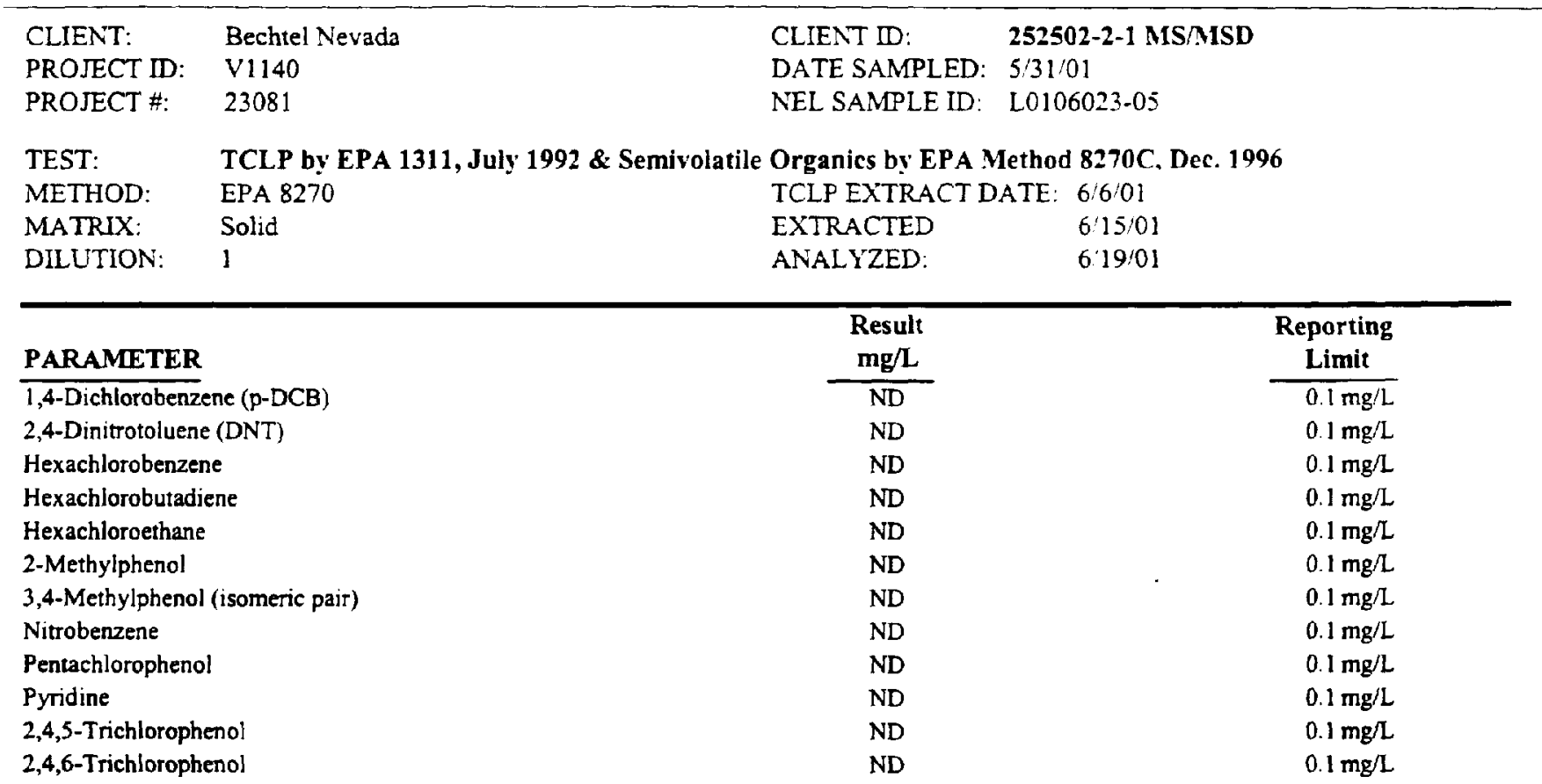

\section{QUALITY CONTROL DATA:}

\section{Surrogate}

2,4,6-Tribromophenol

2-Fluorobiphenyl

2-Fluorophenol

Nitrobenzene-d5

p-Terphenyl-d14

Phenol-d5
$\%$ Recovery

44
22
18
24
32
16

Acceptable Range

$0-161$

$16-127$

$0-88$

9- 132

$16-163$

$0-63$

ND - Not Detected

This report shall not be reproduced except in full, without the written approval of the laboratory. 
NEL LABORATORIES

$\begin{array}{llll}\text { CLIENT: } & \text { Bechtel Nevada } & \text { CLIENT ID: } & \text { 252502-3-1 } \\ \text { PROJECT ID: } & \text { V1140 } & \text { DATE SAMPLED: } & 5 / 31 / 01 \\ \text { PROJECT \#: } & 23081 & \text { NEL SAMPLE ID: } & \text { L0106023-06 }\end{array}$

TEST:

METHOD:

MATRIX:

TCLP by

EPA 8270

Solid

DILUTION:

DATE SAMPLED: 5/31/0

NEL SAMPLE ID: L0106023-06

\begin{tabular}{|c|c|c|}
\hline PARAMETER & $\begin{array}{c}\text { Result } \\
\text { mg/L }\end{array}$ & $\begin{array}{c}\text { Reporting } \\
\text { Limit } \\
\end{array}$ \\
\hline$\overline{\text { 1,4-Dichlorobenzene (p-DCB) }}$ & ND & $0.1 \mathrm{mg} / \mathrm{L}$ \\
\hline 2,4-Dinitrotoluene (DNT) & ND & $0.1 \mathrm{mg} / \mathrm{L}$ \\
\hline Hexachlorobenzene & ND & $0.1 \mathrm{mg} / \mathrm{L}$ \\
\hline Hexachlorobutadiene & ND & $0.1 \mathrm{mg} / \mathrm{L}$ \\
\hline Hexachloroethane & ND & $0.1 \mathrm{mg} / \mathrm{L}$ \\
\hline 2-Methyiphenol & ND & $0.1 \mathrm{mg} / \mathrm{L}$ \\
\hline 3,4-Methylphenol (isomeric pair) & ND & $0.1 \mathrm{mg} / \mathrm{L}$ \\
\hline Nitrobenzene & ND & $0.1 \mathrm{mg} / \mathrm{h}$ \\
\hline Pentachlorophenol & ND & $0.1 \mathrm{mg} / \mathrm{L}$ \\
\hline Pyridine & ND & $0.1 \mathrm{mg} / \mathrm{L}$ \\
\hline 2,4,5-Trichlorophenol & ND & $0.1 \mathrm{mg} / \mathrm{L}$ \\
\hline 2,4,6-Trichlorophenol & ND & $0.1 \mathrm{mg} / \mathrm{L}$ \\
\hline
\end{tabular}

QUALITY CONTROL DATA:

\section{Surrogate}

2,4,6-Tribromophenol

2-Fluorobiphenyl

2-Fluorophenol

Nitrobenzene-d5

p-Terphenyl-d14

Phenol-d5

\section{$\%$ Recovery}

47

22

19

24

32

17

\section{Acceptable Range}

$0-161$

$16-127$

$0-88$

$9-132$

$16-163$

$0-63$

ND - Not Detected

This report shall not be reproduced except in full, without the written approval of the laboratory. 
NEL LABORATORIES

\begin{tabular}{llll}
\hline CLIENT: & Bechtel Nevada & CLIENT ID: & Method Blank \\
PROJECT ID: & V1140 & DATE SAMPLED: NA \\
PROJECT \#: & 23081 & NEL SAMPLE ID: & $0615 E 1$ TCLP8270-BLK
\end{tabular}

TEST: $\quad$ TCLP by EPA 1311, July 1992 \& Semivolatile Organics by EPA Method 8270C. Dec. 1996

METHOD: EPA 8270 TCLP EXTRACT DATE: 6:601

MATRIX: TCLPExtract EXTRACTED

ANALYZED: $\quad 6 \% 19 / 01$

\section{PARAMETER}

1,4-Dichlorobenzene (p-DCB)

2,4-Dinitrotoluene (DNT)

Hexachlorobenzene

Hexachlorobutadiene

Hexachloroethane

2-Methylphenol

3,4-Methylphenol (isomeric pair)

Nitrabenzene

Pentachlorophenol

Pyridine

2,4,5-Trichlorophenol

2,4,6-Trichlorophenol

\begin{tabular}{c}
$\begin{array}{c}\text { Result } \\
\mathbf{m g} \mathbf{L}\end{array}$ \\
\hline ND \\
ND \\
ND \\
ND \\
ND \\
ND \\
ND \\
ND \\
ND \\
ND \\
ND \\
ND
\end{tabular}

Reporting

Limit

$0.1 \mathrm{mg} / \mathrm{L}$

$0.1 \mathrm{mg} / \mathrm{L}$

$0.1 \mathrm{mg} / \mathrm{L}$

$0.1 \mathrm{mg} / \mathrm{L}$

$0.1 \mathrm{mg} / \mathrm{L}$

$0.1 \mathrm{mg} / \mathrm{L}$

$0.1 \mathrm{mg} / \mathrm{L}$

$0.1 \mathrm{mg} / \mathrm{L}$

$0.1 \mathrm{mg} / \mathrm{L}$

$0.1 \mathrm{mg} /$

$0.1 \mathrm{mg} / \mathrm{L}$

$0.1 \mathrm{mg} / \mathrm{h}$

QUALITY CONTROL DATA:

\section{Surrogate}

2,4,6-Tribromophenol

2-Fluorobiphenyl

2-Fluorophenol

Nitrobenzene-d5

p-Terphenyl-d14

Phenol-d5

ND - Not Detected

\section{$\%$ Recovery}

32

18

20

22

30

16
Acceptable Range

$0-161$

$16-127$

$0-88$

$9-132$

$16-163$

$0-63$

This report shall not be reproduced except in full, without the written approval of the laboratory. 
NEL LABORATORIES

$\begin{array}{ll}\text { CLIENT: } & \text { Bechtel Nevada } \\ \text { PROJECT ID: } & \text { V1140 } \\ \text { PROJECT \#: } & 23081 \\ \text { TEST: } & \text { PCB's (Polychlorinated Biphenyls) by EPA 8082, Dec. } 1996 \\ \text { MATRIX: } & \text { Solid }\end{array}$

\begin{tabular}{|c|c|c|c|c|c|c|}
\hline PARAMETER & NEL Sample ID & $\begin{array}{c}\text { Spike } \\
\text { Amount }\end{array}$ & $\frac{\text { Spike }}{\text { Result }}$ & $\frac{\text { Percent }}{\text { Recovery }}$ & $\frac{\text { Acceptable }}{\text { Range }}$ & $\underline{\text { RPD }}$ \\
\hline Aroclor-1016 & 010605 PCBS-LCS & 333 & 283 & 85 & 63.127 & \\
\hline Aroclor-1016 & 010605PCBS-LCSD & 333 & 226 & 68 & $63-127$ & 22.4 \\
\hline Aroclor-1016 & L0106023-06-MS & 333 & 355 & 107 & $55-142$ & \\
\hline Aroclor-1016 & L0106023-06-MSD & 333 & 306 & 92 & $55-142$ & 14.8 \\
\hline Aroclor- 1260 & 010605PCBS-LCS & 333 & 332 & 100 & $57-138$ & \\
\hline Aroclor- 1260 & 010605PCBS-LCSD & 333 & 264 & 79 & $57-138$ & 22.8 \\
\hline Aroclor- 1260 & L0106023-06-MS & 333 & 1810 & 33 & $48-129$ & \\
\hline Aroclor- 1260 & L0106023-06-MSD & 333 & 2040 & 102 & $48-129$ & 102.2 \\
\hline
\end{tabular}

ND - Not Detected

This report shall not be reproduced except in full, without the written approval of the laboratory. 
NEL LABORATORIES

CLIENT: Bechtel Nevada

PROJECT ID: V1140

PROJECT \#: 23081

TEST: $\quad$ Total Extractable Petroleum Hydrocarbons Fuel Finger Print by EPA Method 8015M. July 1992

MATRIX: Solid

\begin{tabular}{|c|c|c|c|c|c|c|}
\hline PARAMETER & NEL Sample ID & $\frac{\text { Spike }}{\text { Amount }}$ & $\begin{array}{l}\text { Spike } \\
\text { Result }\end{array}$ & $\frac{\text { Percent }}{\text { Recovery }}$ & $\frac{\text { Acceptable }}{\text { Range }}$ & $\underline{\text { RPD }}$ \\
\hline Diesel Range (C12-C22) & 010606TPHS-FP-LCS & 166.7 & 138 & 83 & $53-91$ & \\
\hline Diesel Range (C12-C22) & 010606TPHS-FP-LCSD & 166.7 & 145 & 87 & $53-91$ & 4.9 \\
\hline Total & 010606TPHS-FP-LCS & 166.7 & 138 & 83 & $53-91$ & \\
\hline Total & 010606TPHS-FP-LCSD & 166.7 & 145 & 87 & $53-91$ & 4.9 \\
\hline
\end{tabular}

ND - Not Detected

This report shall not be reproduced except in full. without the written approval of the laboratory. 


$\begin{array}{ll}\text { CLIENT: } & \text { Bechtel Nevada } \\ \text { PROJECT D: } & \text { V1140 } \\ \text { PROJECT \#: } & 23081 \\ \text { TEST: } & \text { TCLP by EPA 1311, July } 1992 \text { \& Semivolatile Organics by EPA Method 8270C. Dec. } 1996 \\ \text { MATRIX: } & \text { Solid }\end{array}$

\begin{tabular}{|c|c|c|c|c|c|c|}
\hline PARAMETER & NEL Sample ID & $\begin{array}{c}\text { Spike } \\
\text { Amount }\end{array}$ & $\frac{\text { Spike }}{\text { Result }}$ & $\frac{\text { Percent }}{\text { Recovery }}$ & $\frac{\text { Acceptable }}{\text { Range }}$ & RPD \\
\hline Pyridine & 0615E1 TCLP8270-LCS & 80 & 56.5 & 71 & $10-130$ & \\
\hline Pyridine & 0615E1 TCLP8270-LCSD & 80 & 72.8 & 91 & $10-130$ & 25.2 \\
\hline Pyridine & L0106023-04-MS & 80 & 61.8 & 77 & $10-130$ & \\
\hline 1,4-Dichlorobenzene (p-DCB) & 0615E1 TCLP8270-LCS & 80 & 67.4 & 84 & $7-105$ & \\
\hline 1,4-Dichlorobenzene (p-DCB) & 0615E1 TCLP8270-LCSD & 80 & 74.5 & 93 & $7-105$ & 10. \\
\hline 1,4-Dichlorobenzene (p-DCB) & L0106023-04-MS & 80 & 56 & 70 & $7-105$ & \\
\hline Hexachloroethane & 0615E1 TCLP8270-LCS & 80 & 50.6 & 63 & $43-104$ & \\
\hline Hexachloroethane & 0615E1 TCLP8270-LCSD & 80 & 54 & 68 & $43-104$ & 6.5 \\
\hline Hexachloroethane & L0106023-04-MS & 80 & 43.5 & 54 & $43-104$ & \\
\hline Nitrobenzene & 0615E1 TCLP8270-LCS & 80 & 96.4 & 121 & $28-124$ & \\
\hline Nitrobenzene & 0615E1 TCLP8270-LCSD & 80 & 82.9 & 104 & $28-124$ & 15.1 \\
\hline Nitrobenzene & L0106023-04-MS & 80 & 84.4 & 106 & $28-124$ & \\
\hline Hexachlorobutadiene & 0615E1 TCLP8270-LCS & 80 & 53 & 66 & $39-111$ & \\
\hline Hexachlorobutadiene & 0615E1 TCLP8270-LCSD & 80 & 57 & 71 & $39-111$ & 7.3 \\
\hline Hexachlorobutadiene & L0106023-04-MS & 80 & 46.6 & 58 & $39-111$ & \\
\hline 2-Methylphenol & 0615E1 TCLP8270-LCS & 80 & 76.8 & 96 & $30-130$ & \\
\hline 2-Methylphenol & 0615E1 TCLP8270-LCSD & 80 & 82.9 & 104 & $30-130$ & 7.6 \\
\hline 2-Methylphenol & L0106023-04-MS & 80 & 64.5 & 81 & $30-130$ & \\
\hline 3,4-Methylphenol (isomeric pair) & 0615E1 TCLP8270-LCS & 80 & 67.6 & 85 & $30-130$ & \\
\hline 3,4-Methylphenol (isomeric pair) & 0615E1 TCLP8270-LCSD & 80 & 71.8 & 90 & $30-130$ & 6. \\
\hline 3,4-Methylphenol (isomeric pair) & L0106023-04-MS & 80 & 56.3 & 70 & $30-130$ & \\
\hline 2,4,6-Trichlorophenol & 0615E1 TCLP8270-LCS & 80 & 102.7 & 128 & $43-110$ & \\
\hline 2,4,6-Trichlorophenol & 0615E 1 TCLP8270-LCSD & 80 & 93.8 & 117 & $43-110$ & 9.1 \\
\hline 2,4,6-Trichlorophenol & L0106023-04-MS & 80 & 88.4 & 111 & $43-110$ & \\
\hline 2,4,5-Trichlorophenol & 0615E1 TCLP8270-LCS & 80 & 70.1 & 88 & $30-130$ & \\
\hline 2,4,5-Trichlorophenol & 0615E1 TCLP8270-LCSD & 80 & 97.5 & 122 & $30-130$ & 32.7 \\
\hline 2,4,5-Trichlorophenol & L0106023-04-MS & 80 & 97.4 & 122 & $30-130$ & \\
\hline 2,4-Dinitrotoluene (DNT) & 0615E1 TCLP8270-LCS & 80 & 101.8 & 127 & $50-111$ & \\
\hline 2,4-Dinitrotoluene (DNT) & 0615E1 TCLP8270-LCSD & 80 & 95.8 & 120 & $50-111$ & 6.1 \\
\hline 2,4-Dinitrotoluene (DNT) & L0106023-04-MS & 80 & 86.1 & 108 & $50-111$ & \\
\hline Hexachlorobenzene & 0615E1 TCLP8270-LCS & 80 & 96.7 & 121 & $41-125$ & \\
\hline Hexachlorobenzene & 0615E1 TCLP8270-LCSD & 80 & 92.1 & 115 & $41-125$ & 4.9 \\
\hline Hexachlorobenzene & L0106023-04-MS & 80 & 76.8 & 96 & $41-125$ & \\
\hline Pentachlorophenol & 0615E1 TCLP8270-LCS & 80 & 63.1 & 79 & $47-127$ & \\
\hline Pentachlorophenol & 0615E1 TCLP8270-LCSD & 80 & 73.1 & 91 & $47-127$ & 14.7 \\
\hline Pentachlorophenol & L0106023-04-MS & 80 & 67.7 & 85 & $47-127$ & \\
\hline
\end{tabular}

ND - Not Detected

This report shall not be reproduced except in full, without the written approval of the laboratory. 
NEL LABORATORIES

\begin{tabular}{|c|c|c|c|c|c|c|c|}
\hline $\begin{array}{l}\text { CLIENT: } \\
\text { PROJECT ID: } \\
\text { PROJECT \#: }\end{array}$ & $\begin{array}{l}\text { Bechtel Nevada } \\
\text { V1140 } \\
23081\end{array}$ & & & & & & \\
\hline $\begin{array}{l}\text { TEST: } \\
\text { MATRIX: }\end{array}$ & $\begin{array}{l}\text { TCLP/STLC Metals } \\
\text { Solid }\end{array}$ & & & & & & \\
\hline PARAMETER & & NEL Sample ID & $\frac{\text { Spike }}{\text { Amount }}$ & $\frac{\text { Spike }}{\text { Result }}$ & $\frac{\text { Percent }}{\text { Recovery }}$ & $\frac{\text { Acceptable }}{\text { Range }}$ & $\underline{\text { RPD }}$ \\
\hline Mercury & & L06016-THg-LCS & 0.05 & 0.0495 & 99 & $85-115$ & \\
\hline Mercury & & L0106016-01-MS & 0.05 & 0.045 & 90 & $75-125$ & \\
\hline Mercury & & L0106016-01-MSD & 0.05 & 0.0453 & 91 & $75-125$ & 0.7 \\
\hline
\end{tabular}

ND - Not Detected

This report shall not be reproduced except in full, without the written approval of the laboratory. 
NEL LABORATORIES

$\begin{array}{ll}\text { CLIENT: } & \text { Bechtel Nevada } \\ \text { PROJECT ID: } & \text { V1140 } \\ \text { PROJECT \#: } & 23081 \\ \text { TEST: } & \text { TCLP/STLC Metals } \\ \text { MATRIX: } & \text { Solid }\end{array}$

\begin{tabular}{|c|c|c|c|c|c|c|}
\hline PARAMETER & NEL Sample ID & $\frac{\text { Spike }}{\text { Amount }}$ & $\frac{\text { Spike }}{\text { Result }}$ & $\frac{\text { Percent }}{\text { Recovery }}$ & $\frac{\text { Acceptable }}{\text { Range }}$ & $\underline{\text { RPD }}$ \\
\hline Arsenic & L6016I-LCS & 0.5 & 0.498 & 100 & $85-115$ & \\
\hline Arsenic & L0106016-01-MS & 0.5 & 0.505 & 101 & $75-125$ & \\
\hline Arsenic & L0106016-01-MSD & 0.5 & 0.508 & 102 & $75-125$ & 0.6 \\
\hline Silver & L60161-LCS & 0.5 & 0.45 & 90 & $85-115$ & \\
\hline Silver & L0106016-01-MSD & 0.5 & 0.466 & 93 & $75-125$ & 22.2 \\
\hline Barium & L6016I-LCS & 1 & 0.991 & 99 & $85-115$ & \\
\hline Barium & L0106016-01-MS & 1 & 0.97 & -43 & $75-125$ & \\
\hline Barium & L0106016-01-MSD & 1 & 2.91 & 151 & $75 \cdot 125$ & 359.3 \\
\hline Cadmium & L60161-LCS & 0.5 & 0.504 & 101 & $85-115$ & \\
\hline Cadmium & L0106016-01-MS & 0.5 & 0.587 & 87 & $75-125$ & \\
\hline Cadmium & L0106016-01-MSD & 0.5 & 0.58 & 86 & $75-125$ & 1.6 \\
\hline Chromium & L6016I-LCS & 0.5 & 0.496 & 99 & $85-115$ & \\
\hline Chromium & L0106016-01-MS & 0.5 & 0.554 & 99 & $75-125$ & \\
\hline Chromium & L0106016-01-MSD & 0.5 & 0.551 & 98 & $75-125$ & 0.6 \\
\hline Lead & L6016I-LCS & 1 & 1.03 & 103 & $85 \cdot 115$ & \\
\hline Lead & L0106016-01-MS & 1 & 1.65 & 104 & $75-125$ & \\
\hline Lead & L0106016-01-MSD & 1 & 1.67 & 106 & $75-125$ & 1.9 \\
\hline Selenium & L6016I-LCS & 0.5 & 0.553 & 111 & $85-115$ & \\
\hline Selenium & L0106016-01-MS & 0.5 & 0.463 & 93 & $75-125$ & \\
\hline Selenium & L0106016-01-MSD & 0.5 & 0.417 & 83 & $75-125$ & 10.5 \\
\hline
\end{tabular}

ND - Not Detected

This report shall not be reproduced except in full, without the written approval of the laboratory. 
$61^{\prime} 1$

10,06023

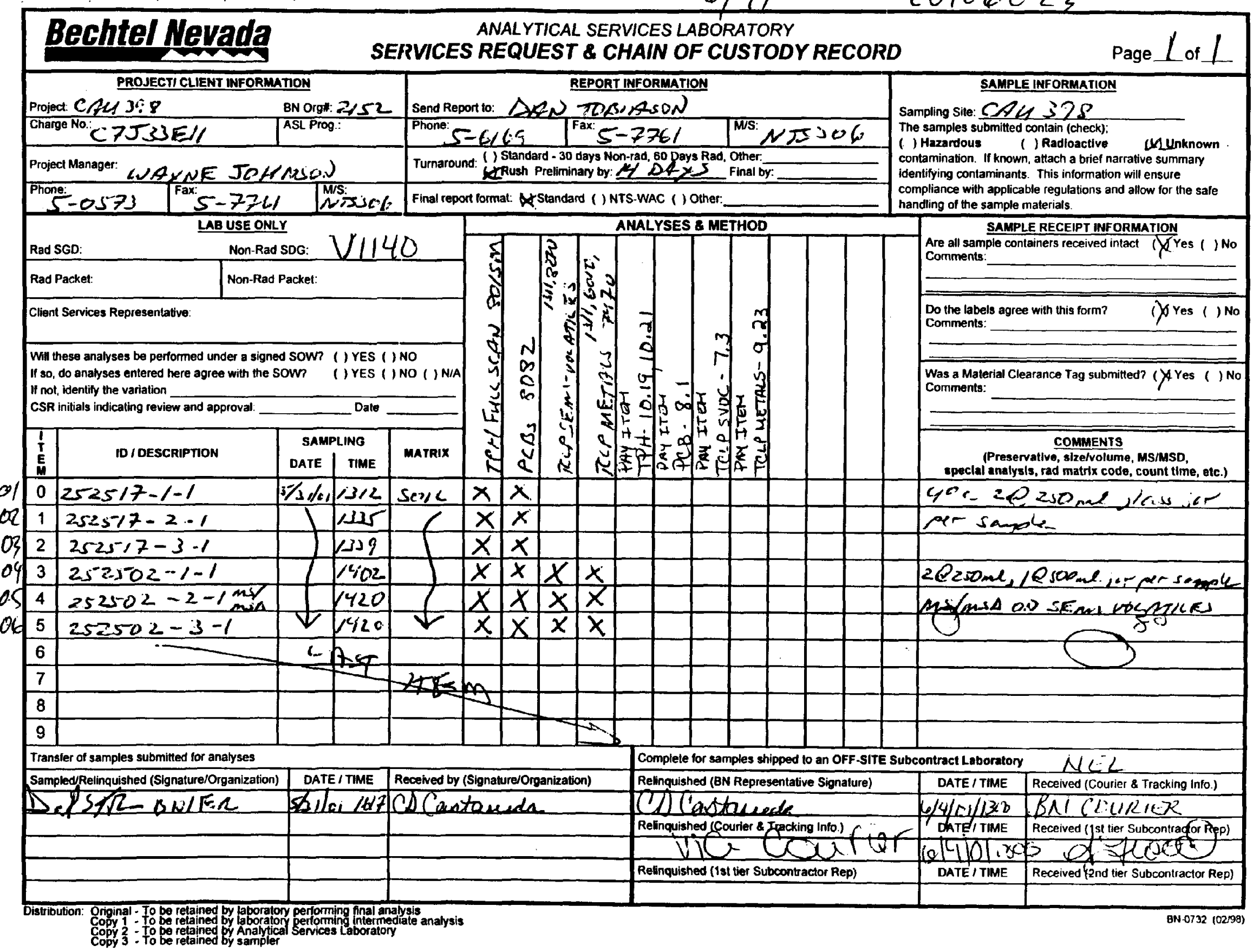




\title{
SAMPLE DELIVERY GROUP
}

\author{
V1169
}


CLOSURE REPORT - CAU 398

Section: Appendix B

Revision: 1

Date: April 2003

THIS PAGE INTENTIONALLY LEFT BLANK 
GENERAL
NARRATIVE 


\section{GENERAL ENGINEERING LABORATORIES}

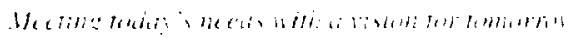

\section{CASE NARRATIVE \\ for \\ Bechtel Nevada \\ Clark County, Nevada \\ SDG\# V1169}

July 21, 2001

Laboratory Identification:

General Engineering Laboratories, Inc. (GEL)

Mailing Address:

P.O. Box 30712

Charleston, SC 29414

Express Mail Delivery and Shipping Address:

2040 Savage Road

Charleston, SC 29414

Telephone Number:

(843) 556-8171

\section{Summary:}

\section{Sample Receipt}

The sample for SDG\# V1169 arrived at GEL located in Charleston, South Carolina on June 22, 2001 for environmental analyses.

The sample containers arrived without any visible signs of tampering or breakage. The samples were delivered with chain of custody documentation and signatures.

The laboratory received the following samples:

\begin{tabular}{l}
$\begin{array}{l}\text { Laboratory } \\
\text { Identification }\end{array}$ \\
\hline 44601001 \\
44601002 \\
44601003 \\
44601004 \\
44601005
\end{tabular}

Sample

Description

252507-1-0

$252507-2-0$

252507-3-0

252508-1-0

252508-2-0 


\section{Case Narrative}

Sample analyses were conducted using methodology as outlined in GEL Standard Operating Procedures. Any technical or administrative problems during analysis, data review and reduction are listed by analytical parameter in the applicable case narrative.

\section{Internal Chain of Custodv:}

Custody was maintained for all samples.

\section{Items of Note:}

There are no items of note.

\section{Data Package:}

The enclosed data package contains the following sections: Case Narrative, Chain of Custody, Cooler Receipt Checklist, Data Review Definition Sheet, and Radiological parameters.

This data package, to the best of my knowledge, is in compliance with technical and administrative requirements.

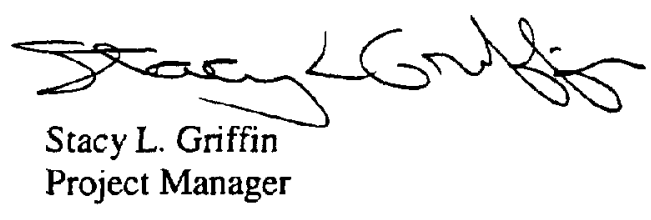




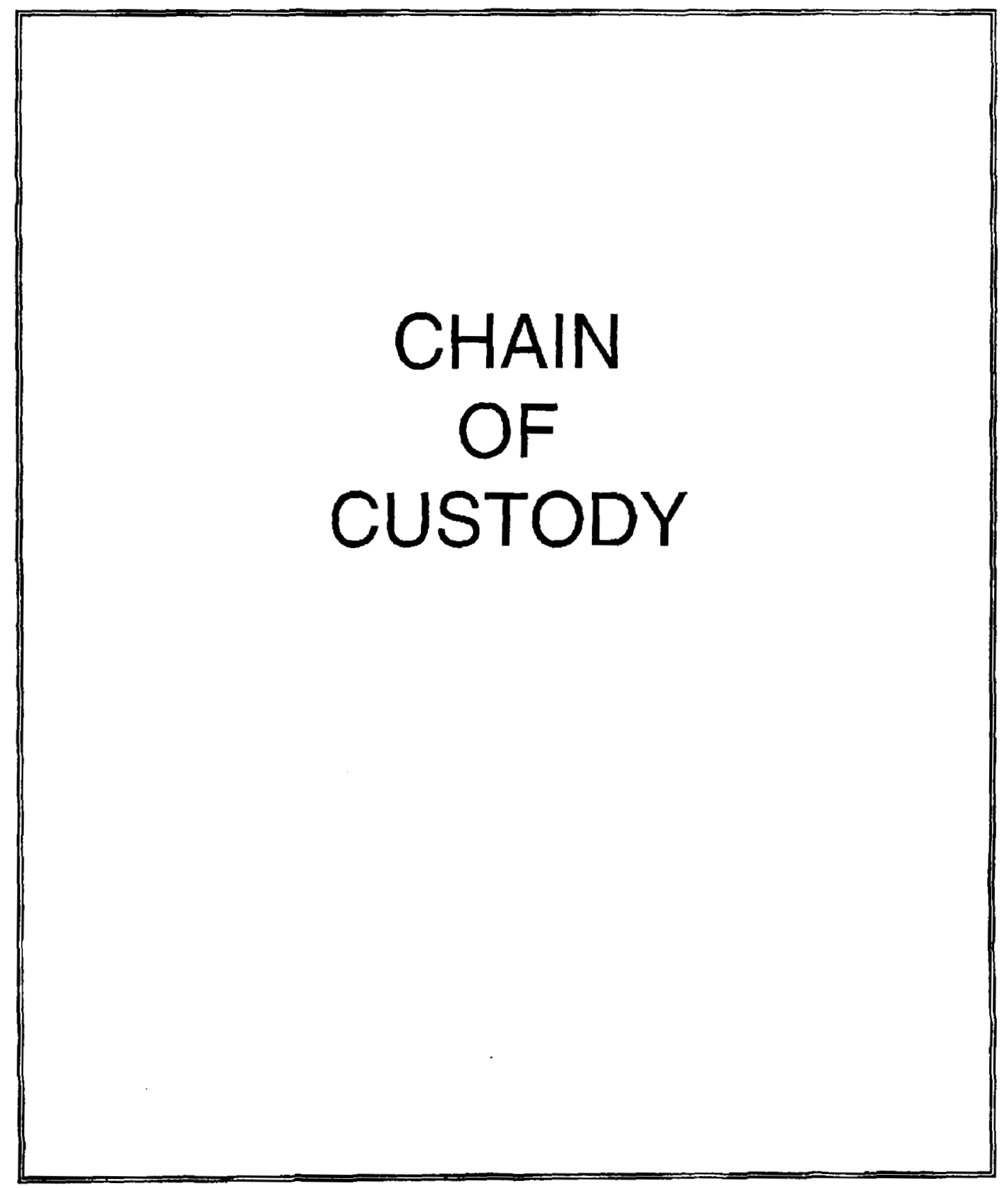


" "Hb-"

\section{Bechtel Nevada}

ANALYTICAL SERVICES LABORATORY

SERVICES REQUEST \& CHAIN OF CUSTODY RECORD

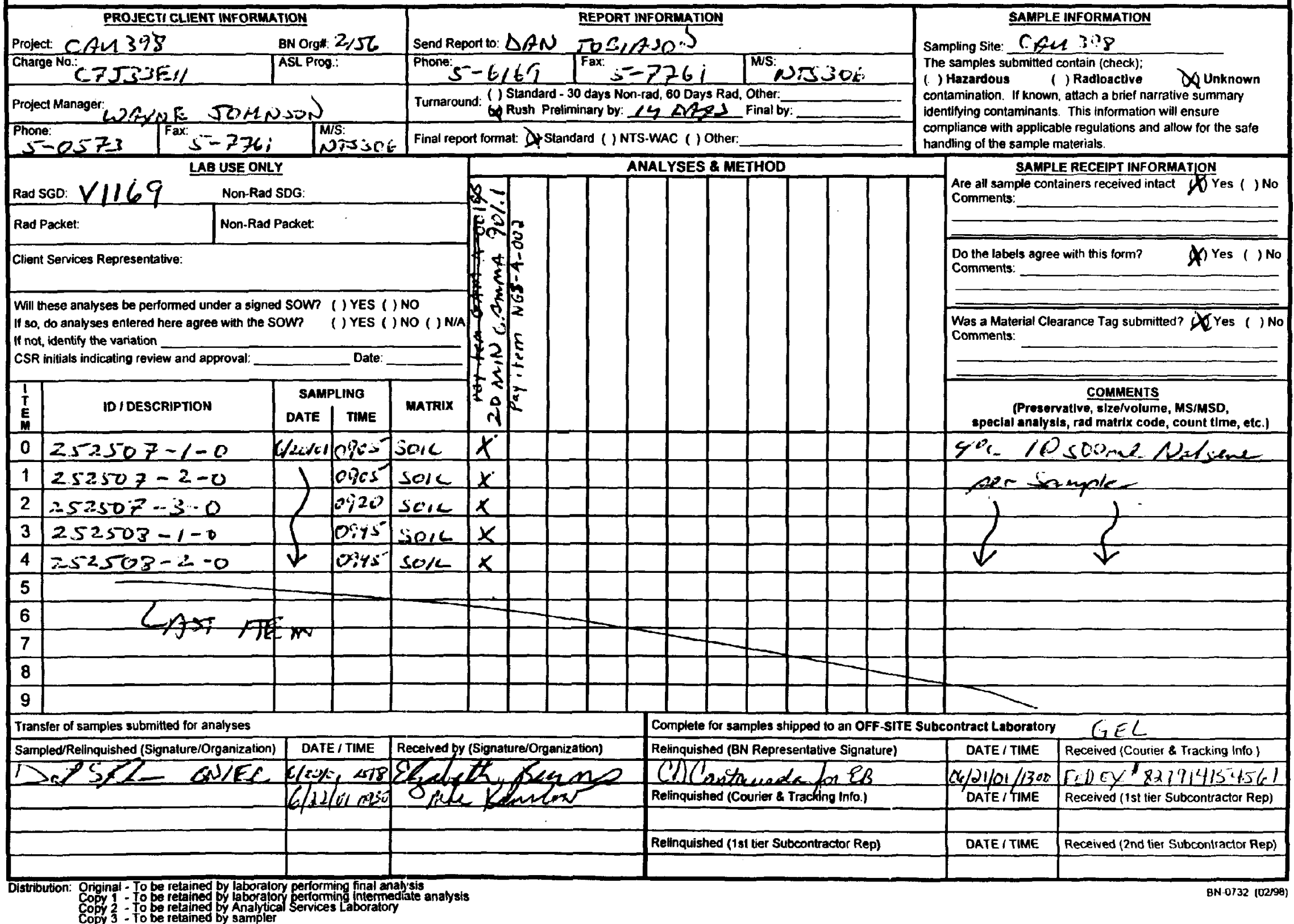




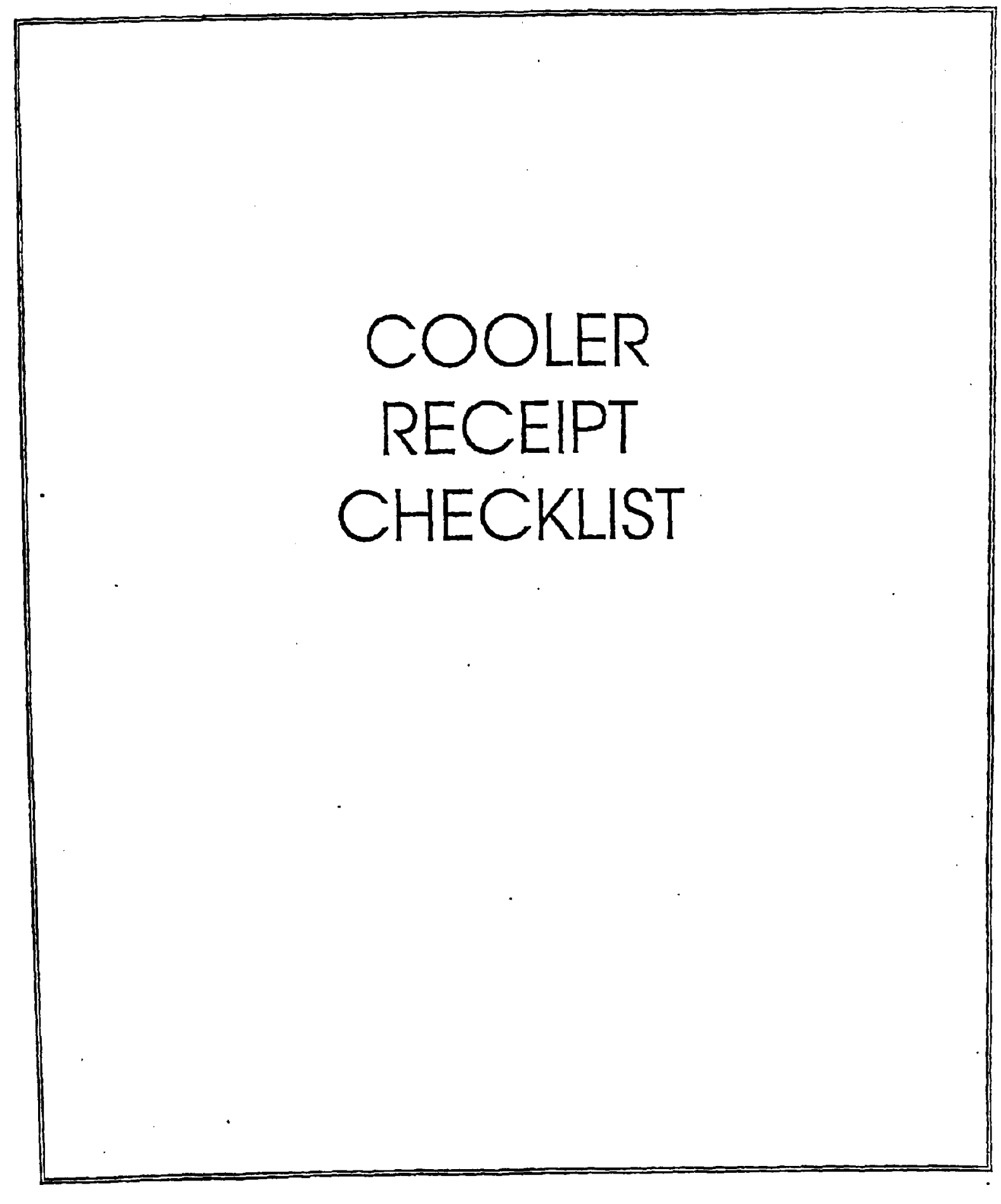




$$
\text { Dale- } \frac{6-\alpha \alpha-O 1}{\text { Becktel NeN }}
$$

SAMPLE RECEIPT REVIEW

Recelved by $m k$

SAMPLEREMEN CPITERIA

1 Were shipping contalners received inlact and sealed? if no. notly the Project Manager 2 Were chain of cuslady documents included?

3 Shipping container temperature(s) checked:

4 Is temperature documenled on Chain of Custody

5 Was shipping container temperature within specifications $(4+1-2 \mathrm{C})$ if no, nolify Project Manager

6 Are any of the samples idenulfed by the client as radioactive? If yes, complete radioactive receipt form

Any samples not indentified by the client as radioaclive must be screened for radioactivity.

If screening results indicate $>x 2$ background infom the RSO.

7 Wese chain of cuslody documents compleled corlectyr? (lnk, signed, match containers)

a Were sample containers recelved intact and sealed? If no, nolity the Project Manager

9 Were all sample containers properly labeled?

10 Were correct sample containers received?

11 Preserved samples chlecked for pH?

12. Were samples preserved carroctly? If no, nolily Project Manager

13 Were samples received within holding time? if $\mathrm{Na}_{2}$ natify Project Manager

14 Were VOA vials free of headspace?

15 ARCOC\#

16 SDG\#

No NA COMMENTSIQUALFIERS

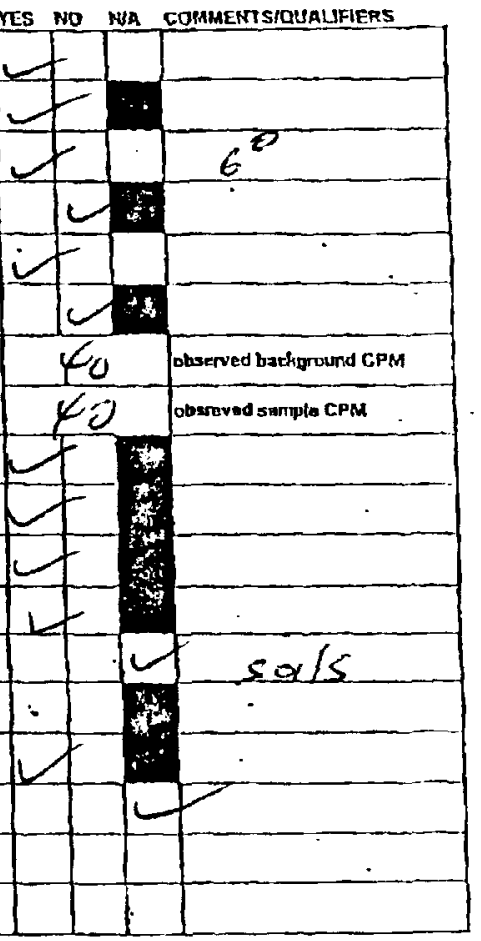

PM(A) Review.

Date kevlewed.

Addilional Comments: 


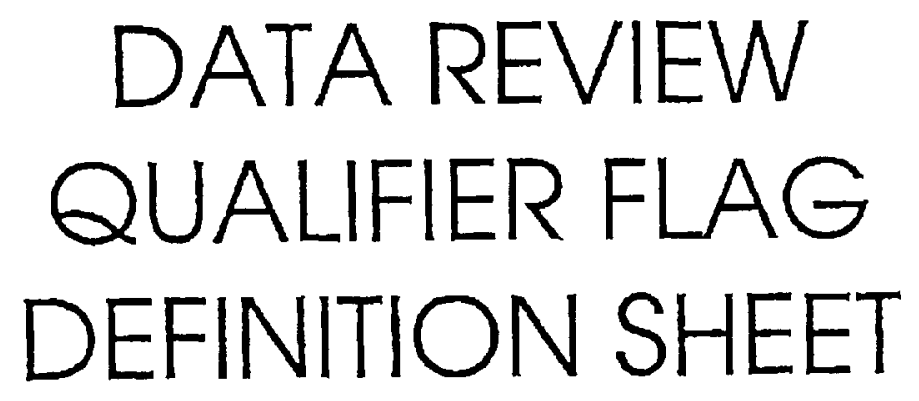




\section{General Enginesing Laboratories. Inc. \\ DÄTA QUALIFIERS FDR INORGANIC ANALYSES}

Dara Qualiñers used on Form 15 or Ceriñcates of Anaiysis ( $C \mathrm{O}_{\mathrm{f}} \mathrm{A}$ ) follow the speciñcarions se: forth in the technical soevinications of the mosi curreat C.P Siatement of Work and are deriner as follows.

\begin{tabular}{|c|c|c|}
\hline Seccion & Eroianation & Location \\
\hline $\bar{E}$ & 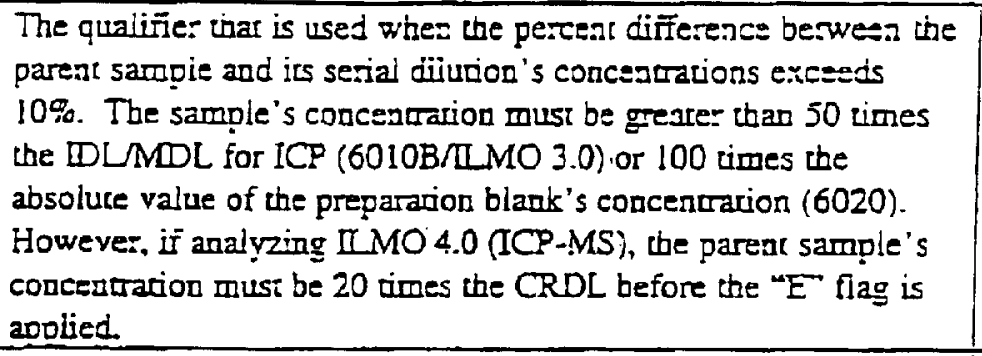 & Form 1. \\
\hline * & $\begin{array}{l}\text { The qualiner thar is used to indicare thar the duplicare sample } \\
\text { anaiysis for an anaive is out of control. }\end{array}$ & $\begin{array}{l}\text { Form I. } \\
\text { and EDD }\end{array}$ \\
\hline$\div$ & $\begin{array}{l}\text { Corretarion coefficieat the Method of Standard Addition (MSA) } \\
\text { is less than } 0.095 \text {. }\end{array}$ & $\begin{array}{l}\text { Form } 2 \\
\text { and EDD }\end{array}$ \\
\hline $\mathrm{B}$ & $\begin{array}{l}\text { The qualifie: is used to indicare that the reported result fell above } \\
\text { the IDLMDL but below the } C R D L \text {. }\end{array}$ & $\begin{array}{l}\text { Form } 1, \\
\text { and EDD }\end{array}$ \\
\hline $\bar{M}$ & $\begin{array}{l}\text { The qualifie: is used to indicare thar the replicate injection } \\
\text { readings of the GFAA sample analysis do not agree within } 20 \% \text {. } \\
\text { relarive standard deviation (RSD) or coefficient of variation (CV). }\end{array}$ & $\begin{array}{l}\text { Form l. } \\
\text { and EDD }\end{array}$ \\
\hline $\bar{N}$ & $\begin{array}{l}\text { This qualifier is used to indicare thar the marix or pre-digested } \\
\text { spike sample recovery for an analyce is not within the specified } \\
\text { consrol limit }\end{array}$ & $\begin{array}{l}\text { Form l. } \\
\text { and EDD }\end{array}$ \\
\hline$S$ & $\begin{array}{l}\text { The reported value was desermined by the Mechod of Standard } \\
\text { Addicion (MSA). }\end{array}$ & $\begin{array}{l}\text { Form } 1 \text {, } \\
\text { and EDD }\end{array}$ \\
\hline $\mathrm{U}$ & The anaiyre's result was less than the IDLMDL. & $\begin{array}{l}C \text { of } A \text { Form } 1 . \\
\text { and EDD }\end{array}$ \\
\hline $\bar{W}$ & $\begin{array}{l}\text { Posi-digestion spike for GFAA analysis is out of concrol limits } \\
(85 \%-115 \%) \text {, while sample results are less than } 50 \% \text { of the spike } \\
\text { absorbance. }\end{array}$ & $\begin{array}{l}\text { EDD, and } \\
\text { Form 5. par } 2\end{array}$ \\
\hline $\bar{x}$ & Othe: reporing tag as defined in repor narauve. & $\begin{array}{l}\text { Form } 1 . \\
\text { and EDD }\end{array}$ \\
\hline$= \pm$ & $\begin{array}{l}\text { Thus qualifier is used to indicate that the Laboratory Concrol } \\
\text { Sampie (LCS) recovery for an analyre is outside of the speeified } \\
\text { limits. }\end{array}$ & $\begin{array}{l}\text { QC Summary } \\
\text { Repor }\end{array}$ \\
\hline
\end{tabular}

All surogate recoveries and acesplanes ranges are reponed as the bocom of Form 2 or $C$ of $A$. Any recoveries falling ourside the accepcance range will be flagged with a -All flags do not aopiy to QC Summary and Cercinicate of Anaiysis packenges. 


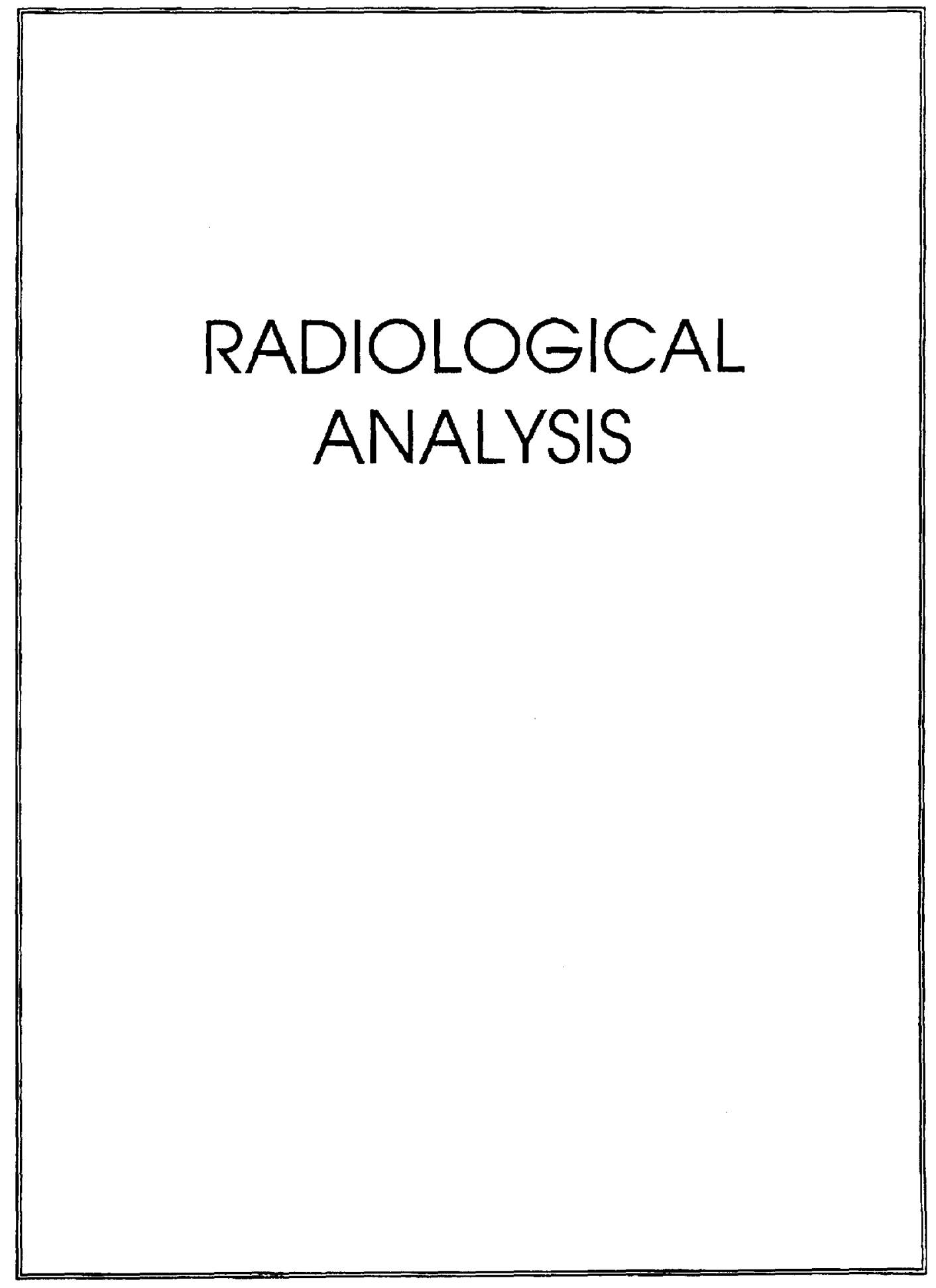




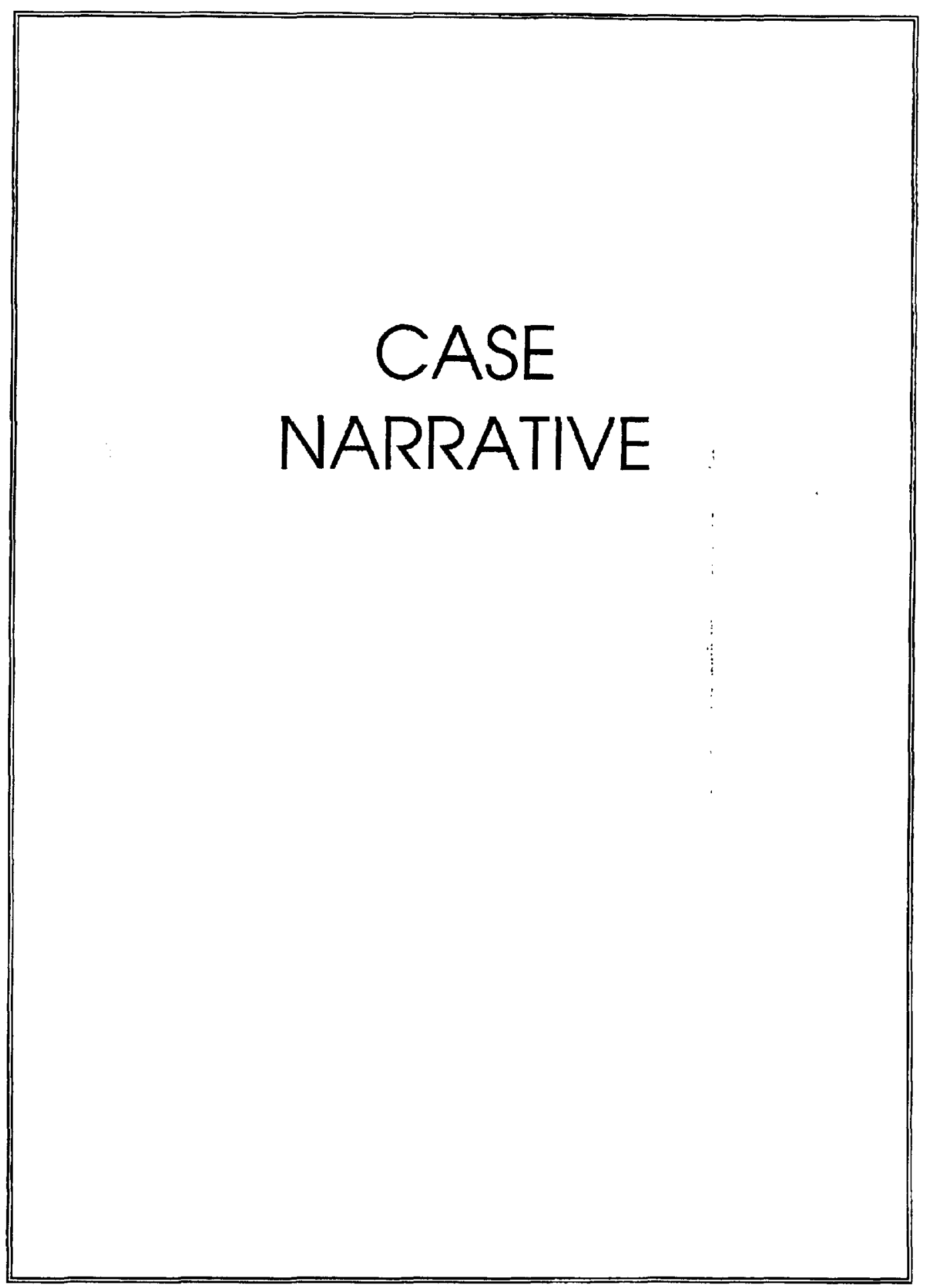




\section{Radiochemistry Case Narrative \\ Bechtel Nevada (NEVA) \\ SDG V1169}

Method/Analysis Information

Batch Number:

86288

Procedure:

Analytical Method:

Determination of Gamma Isotopes in Water and Soil

DOE EML HASL 300

Sample ID
44601001
44601002
44601003
44601004
44601005
1200027924
1200027925
1200027926

Client ID

$252507-1-0$

$252507-2-0$

252507-3-0

252508-1-0

252508-2-0

MB tor batch 86288

044403-0-1(44379001DLP)

LCS for batch 86288

SOP Reference

Procedures for preparation, analysis and reporting of analytical data are controlled by General Engineering Laboratories, Inc. as Standard Operating Procedures (SOP). The data discussed in this narrative has been prepared and analyzed in accordance with GL-RAD-A-013.

\section{Calibration Information:}

Calibration Information

All initial and continuing calibration requirements have been met.

\section{Standards Information}

Standard solution(s) for these analyses are NIST tricieahle and used before the expiration date(s).

\section{Sample Geometry}

All counting sources were prepared in the same geometry as the calibration standards.

\section{Quality Control (OC) Information:}

Blank Information

The blank volume is representative of the sampls solume(s) in this batch.

\section{Designated QC}

The following sample(s) was used for QC: $44.37900 \%$.

\section{QC Information}

All of the $Q C$ samples met the required acceptance linits.

\section{Technical Information:}

Holding Time

All sample procedures for this sample set were performed within the required holding time.

\section{Preparation Information}

All preparation criteria have been met for these analyses. 
Sample Re-prep/Re-analysis

None of the samples in this sample set required reprep or reanalysis.

Miscellaneous Information:

NCR Documentation

No NCR were generated for the preparation or analysis of this sample set.

Manual Integration

No manual integrations were performed on data in this batch.

Additional Comments

The following data was rejected due to low abundance: Sampie $1200027924 ;$ U-238.

The following data was rejected due to no valid peak:

Sample 1200027924 ; U-235,

Sample 44601003; U-235.

Review Validation:

GEL requires all analytical data to be verified by a qualified data validator. In addition, all data designated for CLP or CLP-like packaging will receive a third level validation upon completion of the data package.

The following data validator verified the information presented in this case narrative:

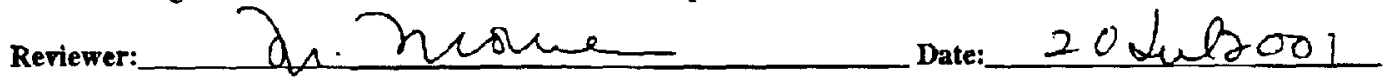




\section{GENERAL ENGINEERING LABORATORIES}

Meering today's needs with a vision for tontorm.

\section{Certificate of Analysis}

Company : Bechlel Nevada
Address: 2621 Losee Road

Contact: North Las Vegas, Nevadh 89030-4129

Report Date: July 20, 2001

Project: Environmental Rad Analysis

Page 1 of 1

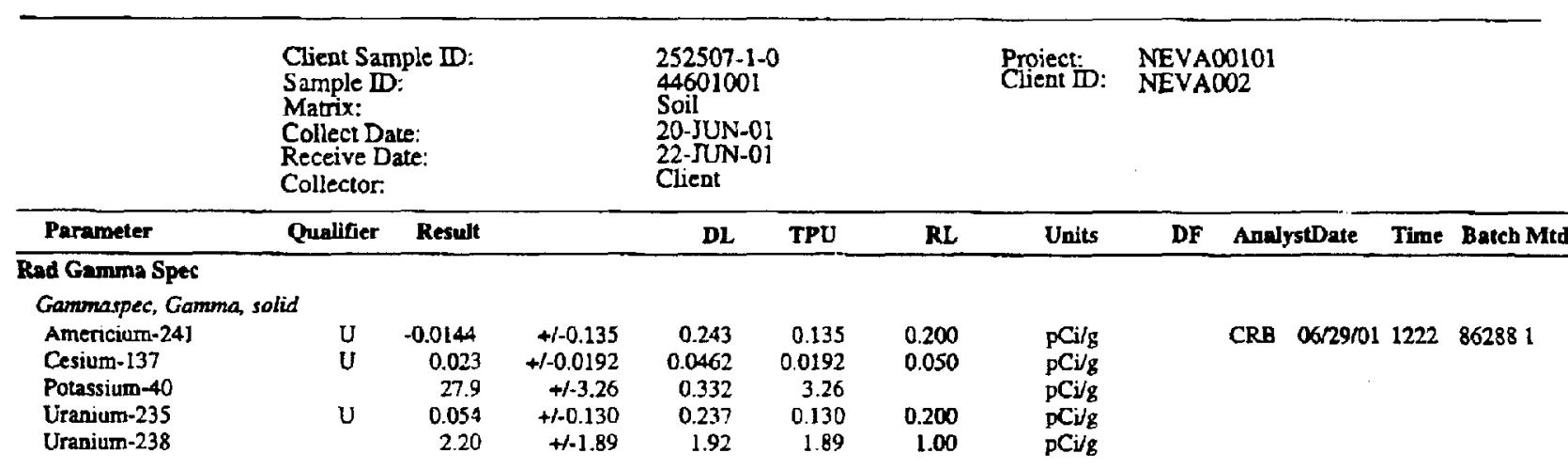

The following Prep Methods were performed

\begin{tabular}{llllll}
\hline Method & Description & Analyst & Date & Time & Prep Batch \\
\hline Dry Soil Prep & Dry Soil Prep RAD A-021,A-021B.A-026 & WEO & $06 / 25 / 01$ & 1110 & 85627 \\
The following Anglytical Methods were performed & & & & \\
\hline Method & Description & & & \\
\hline 1 & DOE EML HASL 300
\end{tabular}

Notes:

The Qualifiers in this report are defined as follows:

* Indicates the analyze is a surrogate compound.

$<$ Actual result is less than amount reported

$>$ Actual result is greater than amount reported

$J$ Indicates an estimated value. The result was greater than the detectuon limit, but less than the reporting limit

$\mathrm{U}$ Indicates the compound was analyzed for but not detected above the detection limit

The above sample is reported on an "as received" basis.

This data report has been prepared and reviewed in accordance with General Engineering L.aboratories, Inc. standard operating procedures. Please direct any questions to your Ptoject Manager, Stacy Griffn.

Reviewed by

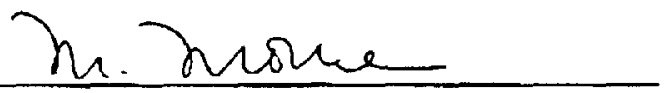




\section{GENERAL ENGINEERING LABORATORIES}

Meeing today's necds with a vision for tomorror.

\section{Certificate of Analysis}

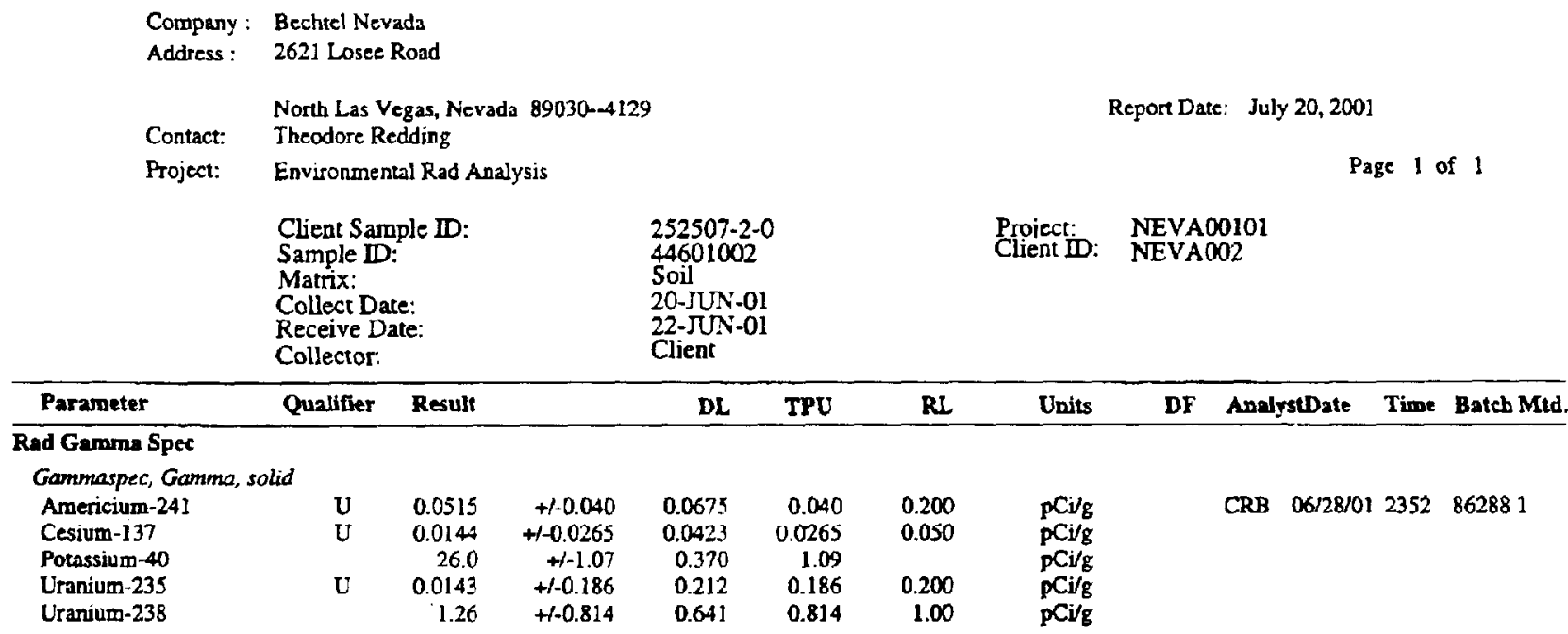

The following Prep Methods were performed

\begin{tabular}{llllll}
\hline Method & Description & Analyst & Date & Time & Prep Batch \\
\hline Dry Soil Prep & Dry Soil Prep RAD A-021,A-0218,A-026 & WEO & 06/25/01 & 1110 & 85627
\end{tabular}

The following Analytical Methods were performed

Method Description

1 DOE EML HASL 300

Nores:

The Qualifiers in this report are defined as follows :

** Indicates the analyte is a surnogate compound.

< Actual result is less than amount reported

$>$ Actual result is greater than arnount reported

J Indicates an estimated value. The result was greater than the detection limit, but less than the reporting limit.

U Indicates the compound was analyzed for but not detected above the detection limit

The above sample is reported on an "as received" basis

This data report has been prepared and reviewed in accordance with General Engineering Laboratories, Inc.

standard operating procedures. Please direct any questions to your Project Manager, Stacy Griffin.

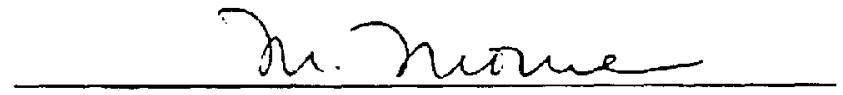

Reviewed by 


\section{GENERAL ENGINEERING LABORATORIES}

Meeting today's needs with a vision for comorrow:

\section{Certificate of Analysis}

\begin{tabular}{|c|c|c|}
\hline Company : & Becbtel Nevada & \\
\hline Address: & 2621 Losee Road & \\
\hline Contact: & $\begin{array}{l}\text { North Las Vegas, Nevada } 89030-4129 \\
\text { Theodore Redding }\end{array}$ & \\
\hline Project: & Environmental Rad Analysis & \\
\hline & $\begin{array}{l}\text { Client Sample ID: } \\
\text { Sample ID: } \\
\text { Matrix: } \\
\text { Collect Date: } \\
\text { Receive Date: } \\
\text { Collector: }\end{array}$ & $\begin{array}{l}252507-3-0 \\
44601003 \\
\text { Soil } \\
\text { 20-JUN-01 } \\
\text { 22-JUN-01 } \\
\text { Client }\end{array}$ \\
\hline
\end{tabular}

\begin{tabular}{|c|c|c|c|c|c|c|c|c|c|c|c|c|}
\hline Parameter & Qualifier & Result & & DL & TPU & $\mathbf{R L}$ & Units & DF & Anal & FstDate & Time & Batch Mtd \\
\hline \multicolumn{13}{|l|}{ Rad Gamma Spec } \\
\hline \multicolumn{13}{|c|}{ Gammaspec, Gamma, solid } \\
\hline $\begin{array}{l}\text { Americium-241 } \\
\text { Cesium-137 } \\
\text { Potassium-40 } \\
\text { Uranium-235 } \\
\text { Uranium-238 }\end{array}$ & $\begin{array}{l}\mathrm{U} \\
\mathrm{U}\end{array}$ & $\begin{array}{r}0.000859 \\
0.0282 \\
18.7 \\
0.00 \\
1.20\end{array}$ & $\begin{array}{r}+/-0.0298 \\
+/-0.0267 \\
+/-2.09 \\
+/ .0 .272 \\
+/-0.638\end{array}$ & $\begin{array}{r}0.0502 \\
0.0388 \\
0.384 \\
0.170 \\
0.488\end{array}$ & $\begin{array}{r}0.0298 \\
0.0267 \\
2.09 \\
0.272 \\
0.638\end{array}$ & $\begin{array}{r}0.200 \\
0.050 \\
0.200 \\
1.00\end{array}$ & $\begin{array}{l}\mathrm{pCi} / g \\
\mathrm{pCi} / \mathrm{g} \\
\mathrm{pCi} / g \\
\mathrm{pCi} / \mathrm{g} \\
\mathrm{pCi} / g\end{array}$ & & CRB & $06 / 28 / 01$ & 2349 & 862881 \\
\hline
\end{tabular}

The following Prep Methods were performed

\begin{tabular}{llllll}
\hline Method & Description & Analyst & Date & Time & Prep Batch \\
\hline Dry Soil Prep & Dry Soil Prep RAD A -021,A-021B,A-026 & WEO & $06 / 25 / 01$ & 1110 & 85627
\end{tabular}

The following Analytical Methods were performed

Method Description

1 DOE EML HASL 300

Notes:

The Qualifiers in this report are defined as follows :

* Indicates the analyte is a surrogate compound.

< Actual result is less than amount reported

$>$ Actual result is greater than amount reported

$\mathrm{J}$ Indicates an estimated value. The result was greater than the detection limit, but less than the reporting limit.

$\mathrm{U}$ Indicates the compound was analyzed for but not detected above the detection limit

The above sample is reported on an "as reecived" basis.

This data report has been prepared and reviewed in accordance with General Engineering Laboratories. Inc. standard operating procedures. Please direct any questions to your Project Manager, Stacy Griffin.

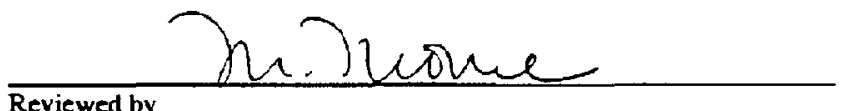




\section{GENERAL ENGINEERING LABORATORIES}

Mecting today's needs with a vision for tomorrow:

\section{Certificate of Analysis}

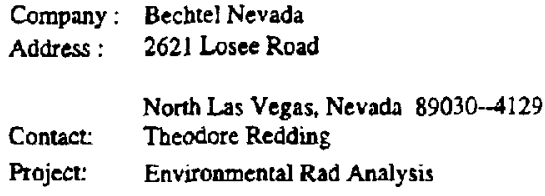

Report Date: July 20. 2001

Page 1 of 1

$$
\text { Parameter }
$$

Qualifier Result

DL TPU

RI. Units DF

AoalystDate Time Batch Mtd.

Rad Gamma Spec

Gammaspec. Gomma, solid Americium-241

Cesium-137

Potassium-40

$\begin{array}{ccc}U & 0.0159 & +1-0.0898 \\ U & -0.00148 & +1-0.0181\end{array}$

$21.1++2.4$

$0.182+/-0.173$

$1.76+1.12$

0.169
0.0278

0.018

0.252

0.164

1.28

2.41

0.173

$1.12 \quad-100$

Proiect: NEVA00101

Client ID: NEVA002

UTanium-238

The following Prep Methods were performed

Method Description Analyst Date $\quad$ Time Prep Batch

\begin{tabular}{llllll}
\hline Dry Soil Prep & Dry Soil Prep RAD A-021,A-021B,A-026 & WEO & 06/25/01 & 1110 & 85627
\end{tabular}

The following Anulytical Methods were performed

Method Description

$-1$

DOE EML HASL 300

Notes:

The Qualifiers in this report are defined as follows :

- * Indicates the analyte is a surrogate compound

$<$ Actual result is less than amount reported

$>$ Actual result is greater than amount reported

J Indicates an estimated value. The result was greater than the detection limit, but less than the reporting limit.

$\mathrm{U}$ Indicates the compound was analyzed for but not detected above the detection limit

The above sample is reported on an "as received" basis.

This data report has been prepared and reviewed in accordance with General Engineering Laboratories, Inc. standard operating procedures. Please direet any questions to your Project Manager. Stacy Griffin.

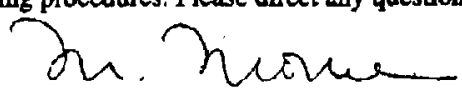

Reviewed by 


\title{
GENERAL ENGINEERING LABORATORIES
}

\author{
Meeling loday's needs with a vision for tomorm:
}

\section{Certificate of Analysis}

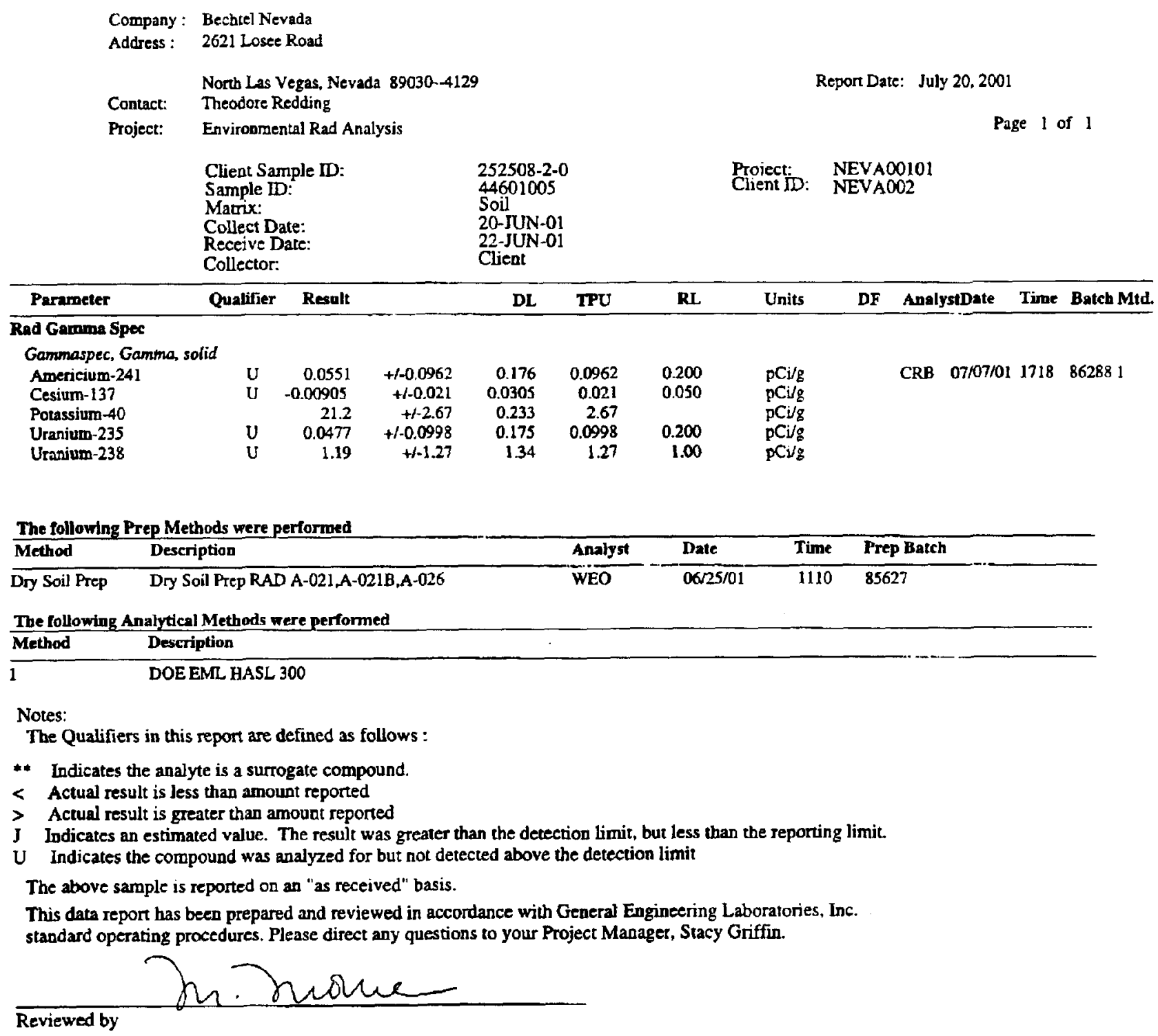




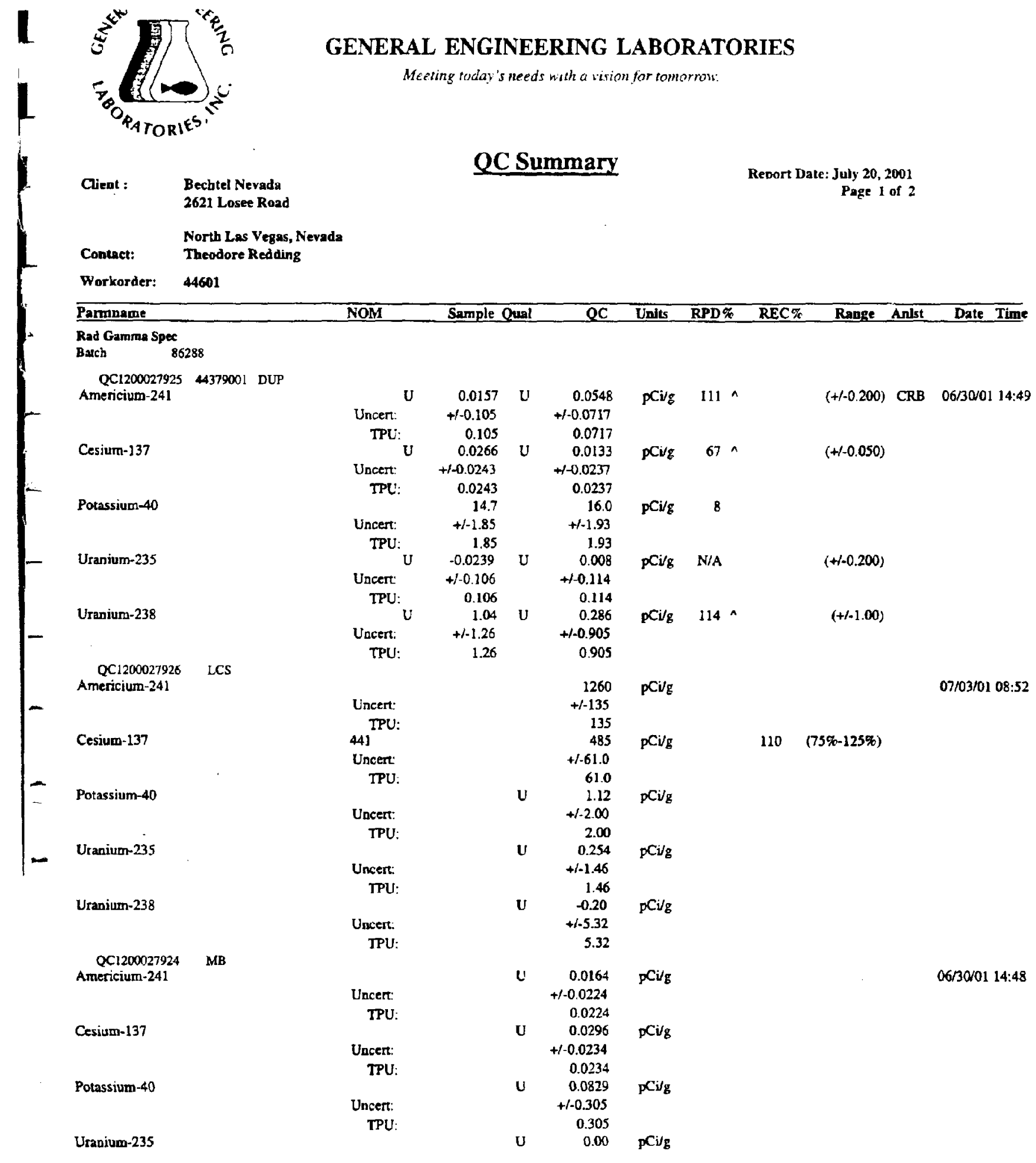




\title{
GENERAL ENGINEERING LABORATORIES
}

\author{
Mecting today's needs with a vision for tomerrow
}

\section{QC Summary}

Workorder: $\$ 4601$

Parmname

Rad Gamma Spec

Batch

86288

Uranium-238

NOM
Sample Qual

QC

Units

RPD\%

Page 2 of 2

Range Anlst Date Time

KECF Range Anls

$+/-0.0975$

Uncert:

TPU:

Uncert:

TRU:
U

0.0975

$+1-0.907$

$\mathrm{pCi} / \mathrm{g}$

Notes:

The Qualifiers in this report are defined as follows:

** Indicates the analyte is a surrogate compound.

$<\quad$ Actual result is less than amount reported

$>\quad$ Actual result is greater than amount reported

J Indicates an estimated value. The result was greater than the detection Jimit, but less than the reporting limit.

U Indicates the compound was analyzed for but not deteeted above the detection limit

N/A indicates that spike recovery limits do not apply when sample concentration exceeds spike conc. by a factor of 4 or more.

$\wedge$ The Relative Percent Difference (RPD) obtained from the sample duplicate (DUP) is cvaluated against the acceptence criteria when the sample is greater than five times ( $5 X$ ) the contract required detection limit ( $R L$ ). In cases where either the sample or duplicate value is less than $5 X$ the RL, a control limit of $+/$ the $R L$ is used to evaluate the DUP result.

For PS, PSD, and SDILT results, the values listed are the measured amounts, not firal concentrations. 
CLOSURE REPORT - CAU 398

Section: Appendix B

Revision: 1

Date: April 2003

SAMPLE DELIVERY GROUP

V1170 
CLOSURE REPORT - CAU 398

Section: Appendix B

Revision: 1

Date: April 2003

\section{THIS PAGE INTENTIONALLY LEFT BLANK}


CLIENT: $\quad$ Bechtel Nevada

P.O. Box 98521 , M/S NTS273

Las Vegas, NV 89193.8521

ATTN: $\quad$ Ted Redding

PROJECT NAME: V1170

NEL ORDER ID: L0106266

PROJECT NUMBER: 23081

Attached are the analytical results for samples in support of the above referenced project.

Samples submitted for this project were not sampled by NEL Laboratories. Samples were received by NEL in good condition, under chain of custody on $6 / 21 / 01$.

Should you have any questions or comments, please feel free to contact our Client Services department at (702) $657-1010$.

Some results have been flagged as follows:

Jc - This concentration may be biased because the continuing calibration verification (CCV) standard did not meet $\mathrm{QC}$ requirements for this analyte. However, overall CCV standard recoveries meet method requirements and analytical results are in control.

Some surrogate results have been flagged as follows:

D - Sample required dilution. Sample QC results were diluted outside the calibrated range.
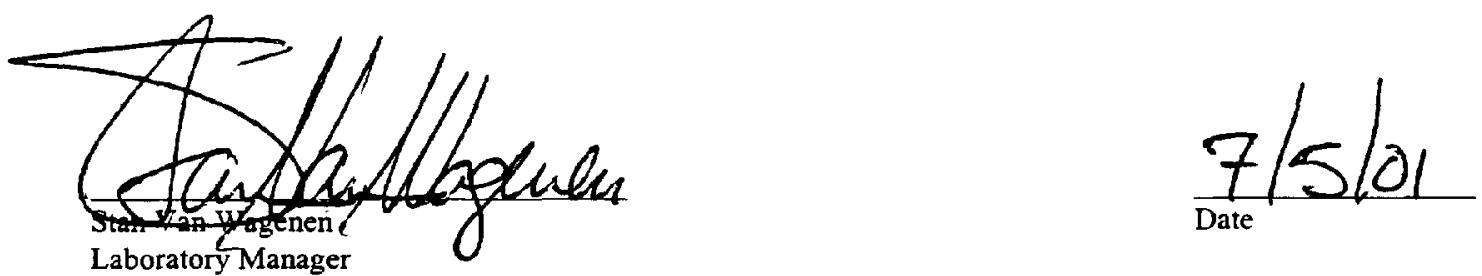

\section{CERTIFICATIONS}

\begin{tabular}{llll}
\hline & Reno & Las Vegas & S. California \\
\cline { 2 - 4 } $\begin{array}{l}\text { Arizona } \\
\text { California }\end{array}$ & 170520 & AZ0518 & AZ0605 \\
$\begin{array}{l}\text { US Army Corps } \\
\text { of Engineers }\end{array}$ & Certified & Certified & \\
A & & &
\end{tabular}

Idaho

Montana

Nevada

L.A.C.S.D.

\begin{tabular}{lll} 
Reno & Las Vegas & S. California \\
\hline Certified & Certified & \\
Certified & Certified & \\
NV033 & NV052 & CA084 \\
& & 10228
\end{tabular}


NEL LABORATORIES

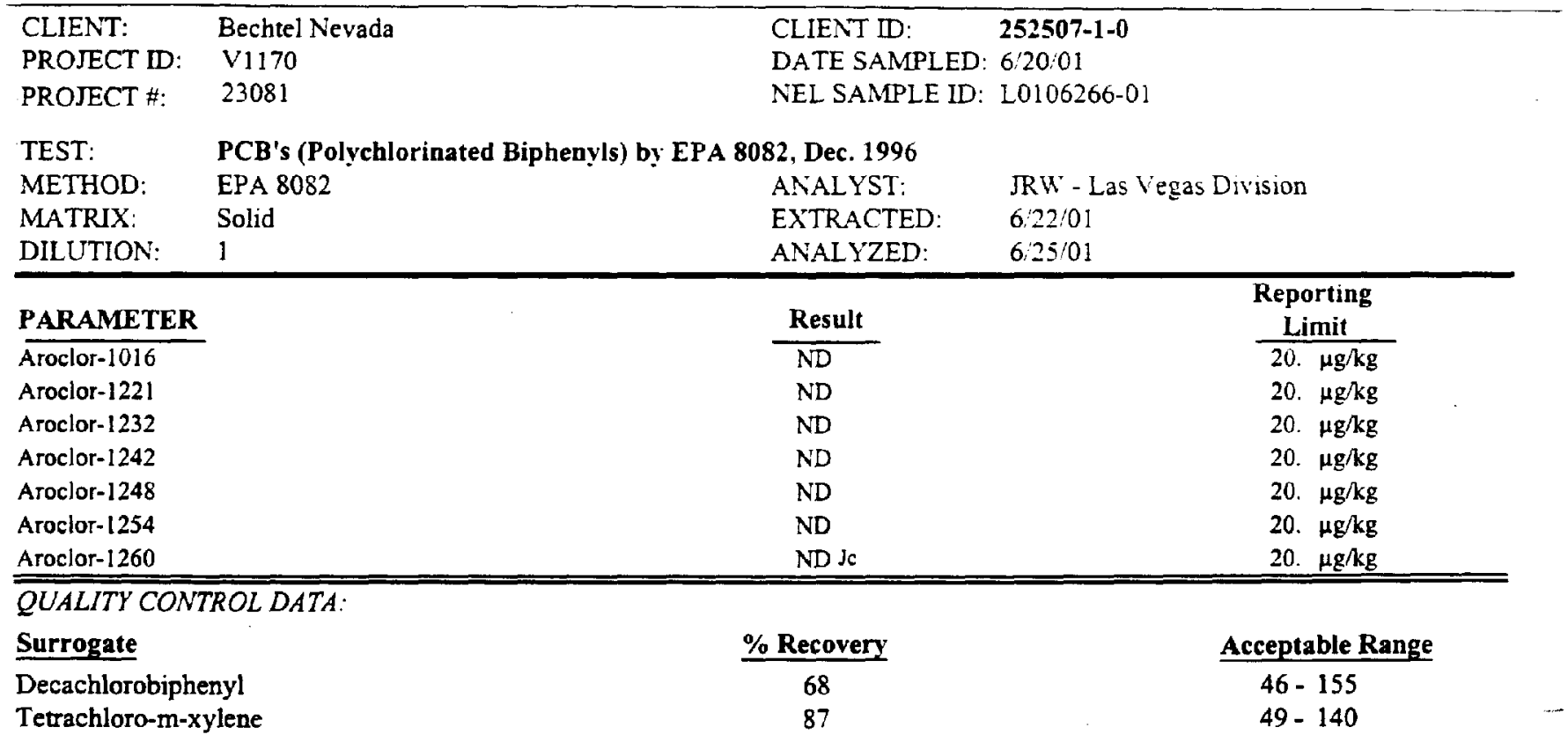

ND - Not Detected

This report shall not be reproduced except in full, without the written approval of the laboratory. 
NEL LABORATORIES

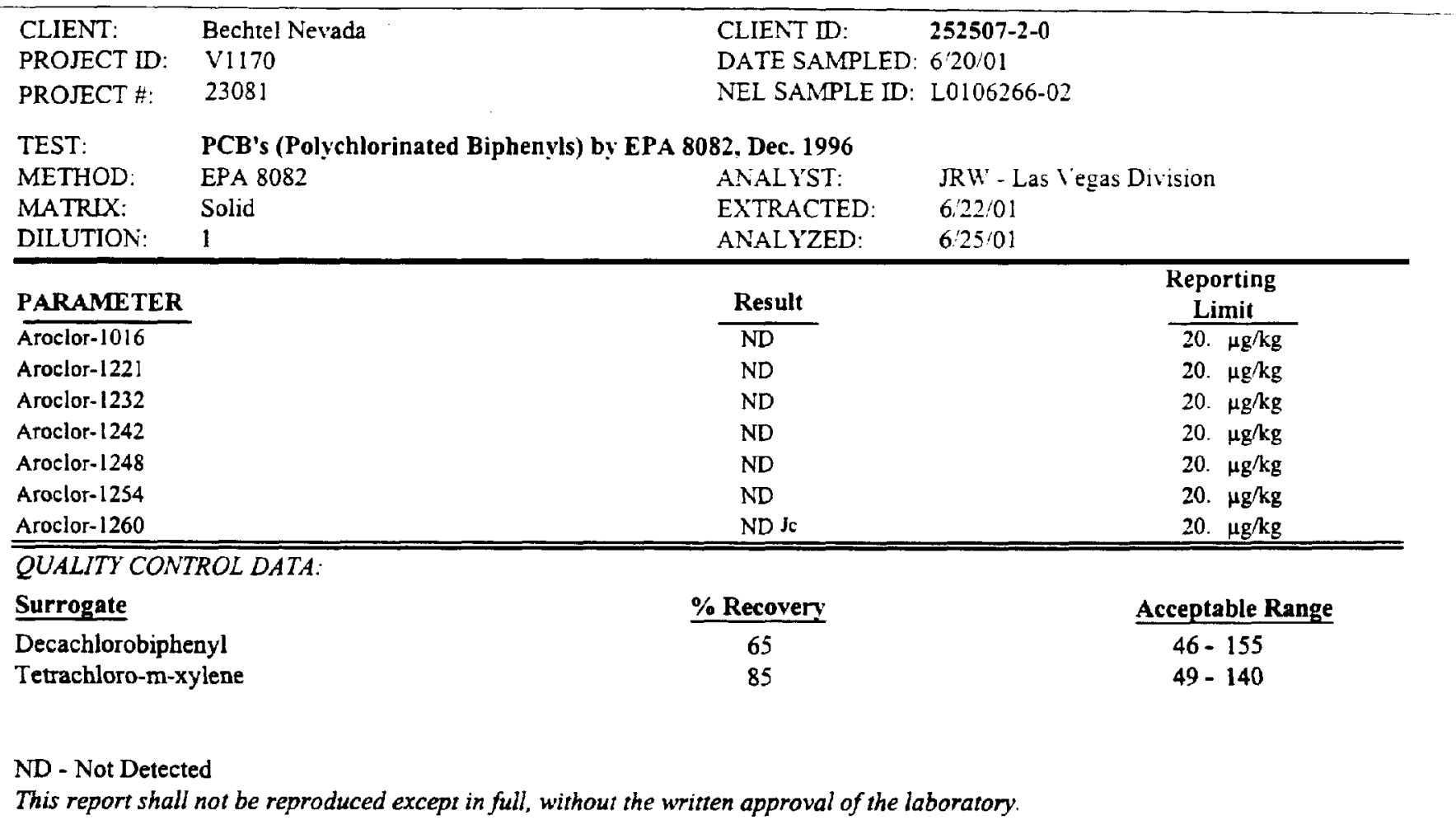


NEL LABORATORIES

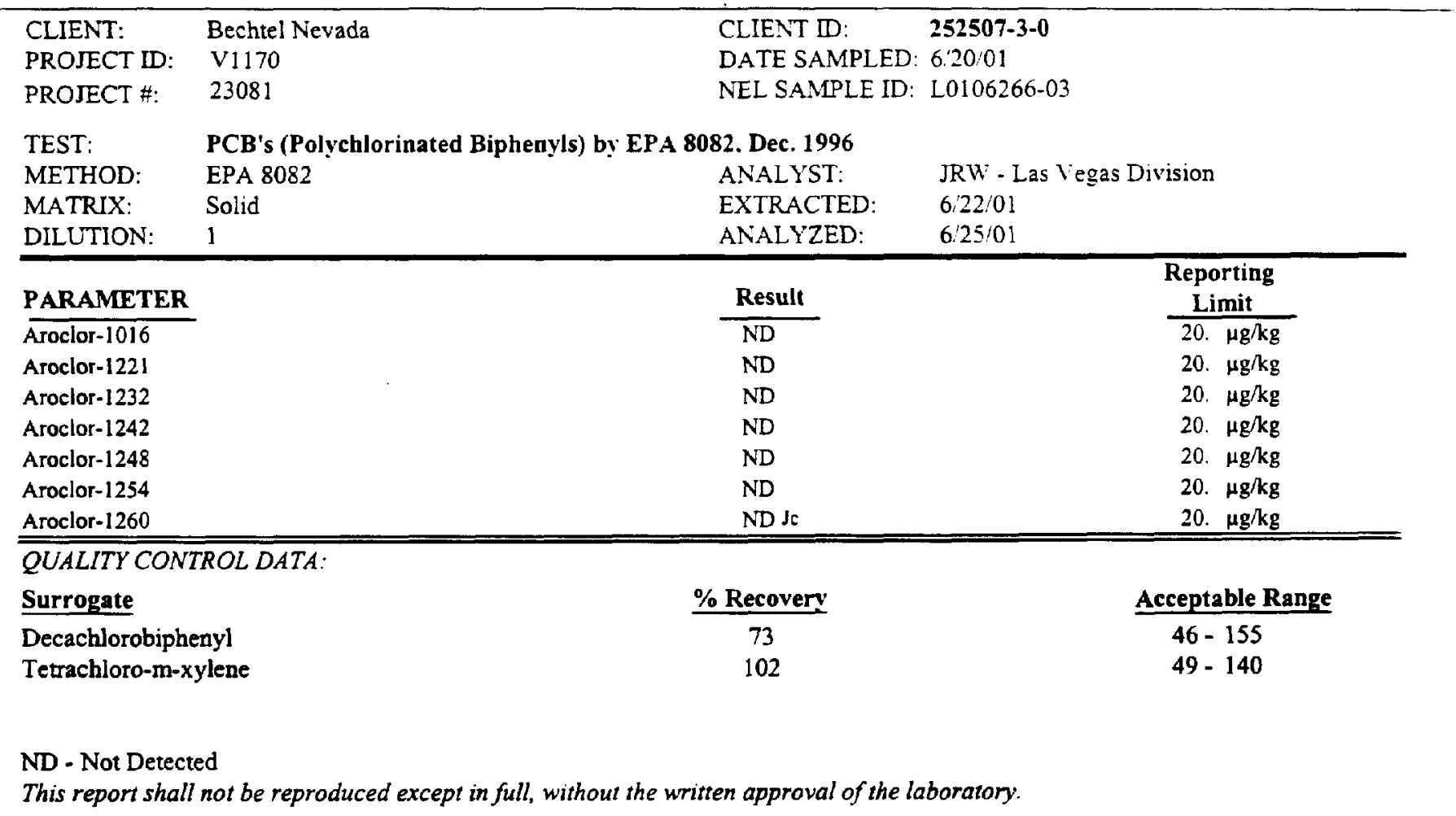


NEL LABORATORIES

$\begin{array}{llll}\text { CLIENT: } & \text { Bechtel Nevada } & \text { CLIENT ID: } & \mathbf{2 5 2 5 0 8 - 1 - 0} \\ \text { PROJECT ID: } & \text { V1170 } & \text { DATE SAMPLED: } 6.2001 \\ \text { PROJECT \#: } & 23081 & \text { NEL SAMPLE ID: } & \text { L0106266-04 }\end{array}$

TEST: $\quad$ PCB's (Polychlorinated Biphenyls) by EPA 8082. Dec. 1996

METHOD: $\quad$ EPA 8082

MATRIX: Solid

ANALYST:

EXTRACTED:

JRW - Las Vegas Division

DILUTION:

1

ANALYZED

$6.22 / 01$

$625 \% 01$

PARAMETER

Aroclor-1016

Aroclor-1221

Aroclor-1232

Aroclor-1242

Aroclor-1248
Result

ND

ND

ND

ND

ND

ND

ND Jc

\% Recovery

49

65
Reporting

Limit

20. $\mu \mathrm{g} / \mathrm{kg}$

20. $\mu \mathrm{g} / \mathrm{kg}$

20. $\mu \mathrm{g} / \mathrm{kg}$

20. $\mu \mathrm{g} / \mathrm{kg}$

20. $\mu \mathrm{g} / \mathrm{kg}$

20. $\mu \mathrm{g} / \mathrm{kg}$

20. $\mu \mathrm{g} / \mathrm{kg}$

QUALITY CONTROL DATA.

Surrogate

Decachlorobiphenyl

Tetrachloro-m-xylene

ND - Not Detected

This report shall not be reproduced except in full. without the written approval of the laboratory.
Acceptable Range

$46-155$

$49-140$ 
NEL LABORATORIES

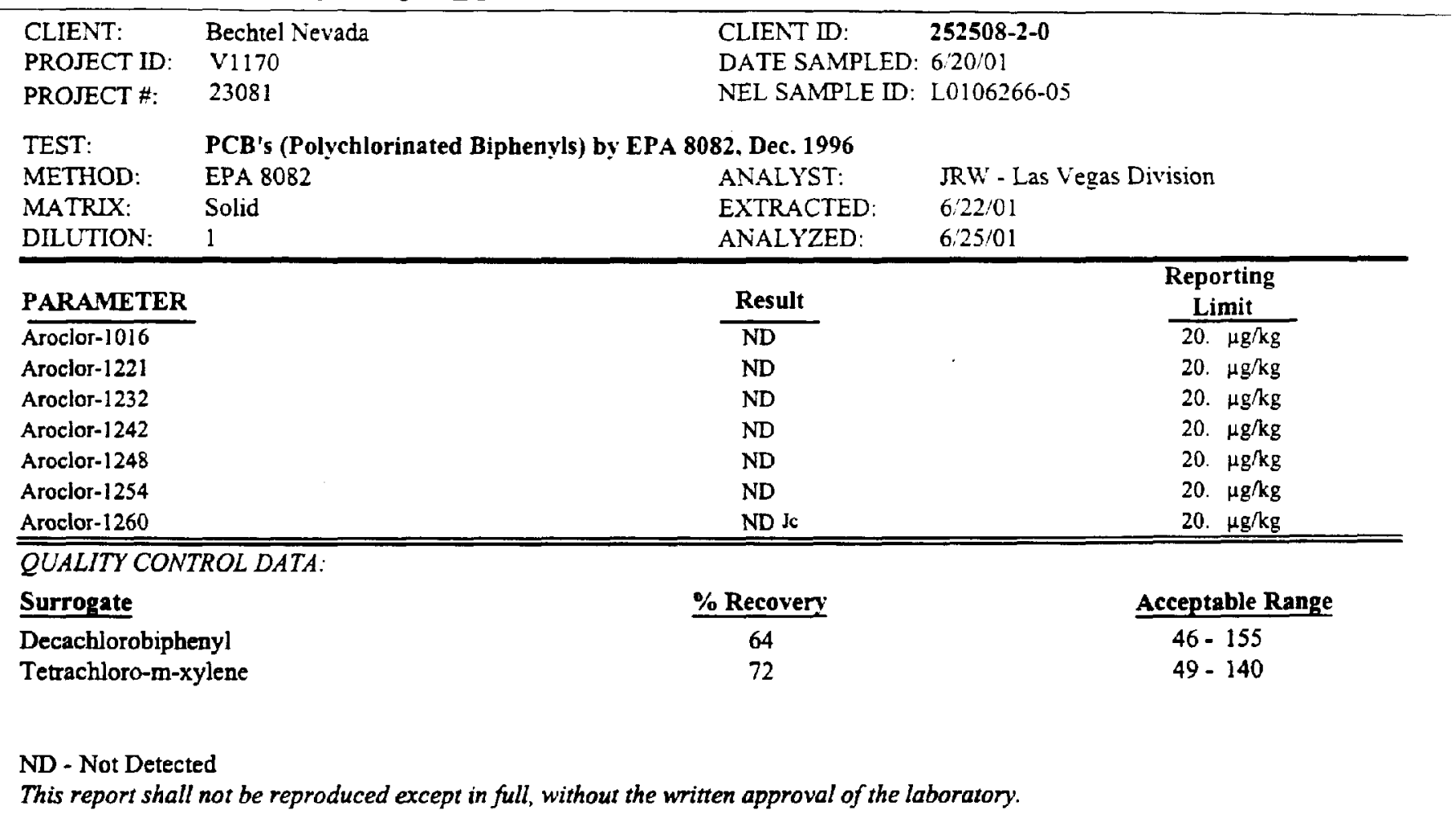


NEL LABORATORIES

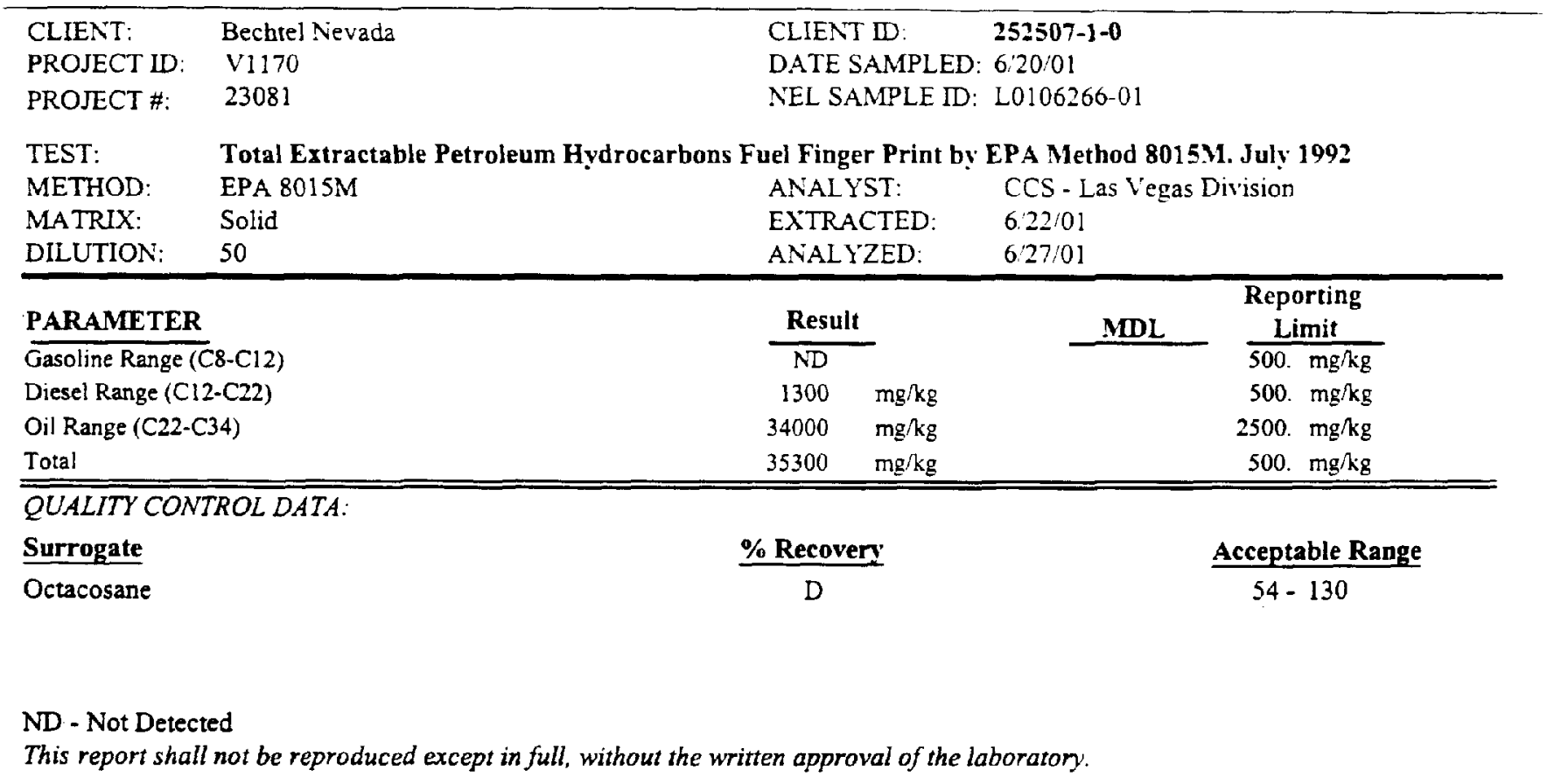


NEL LABORATORIES

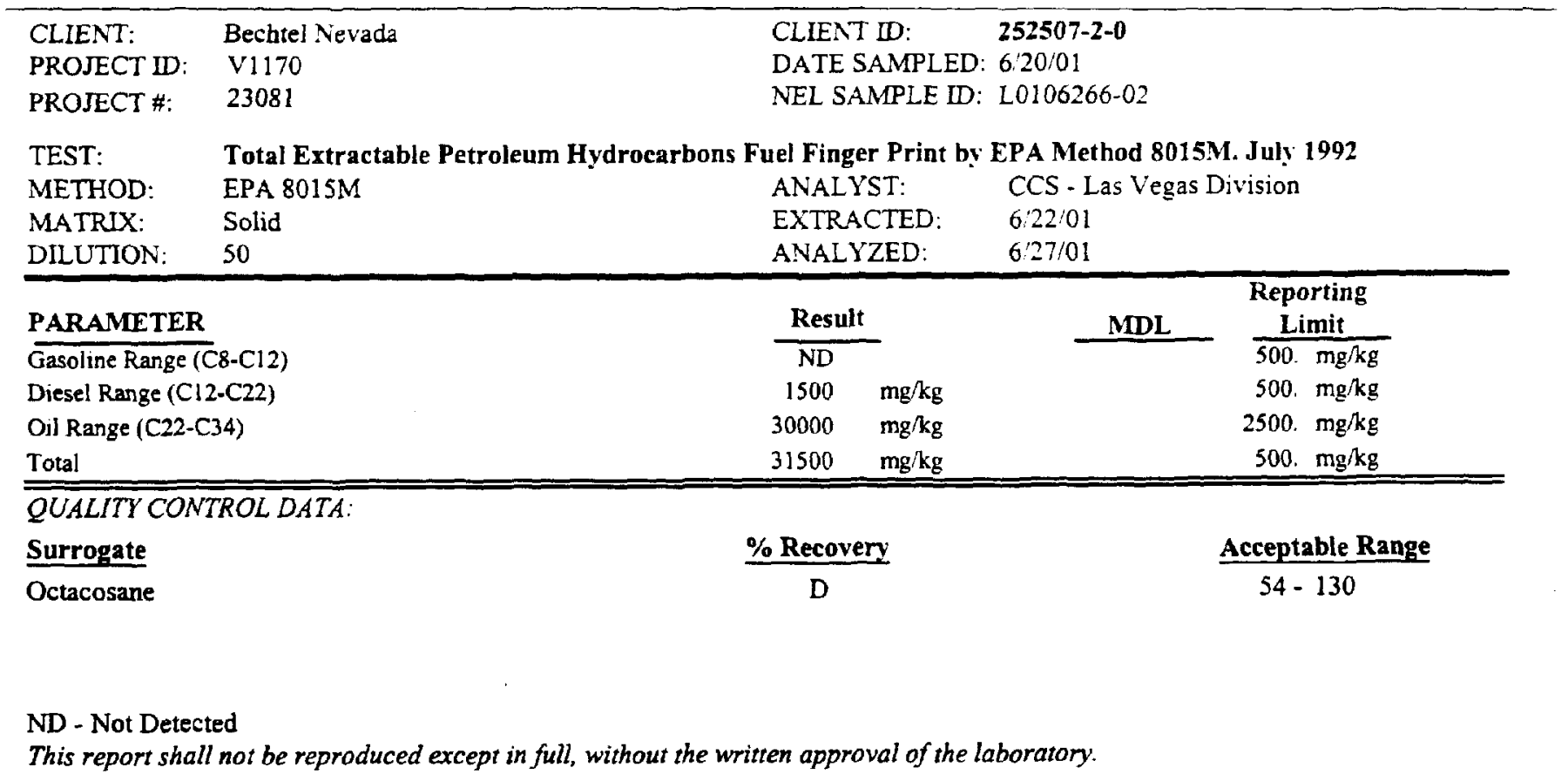


NEL LABORATORIES

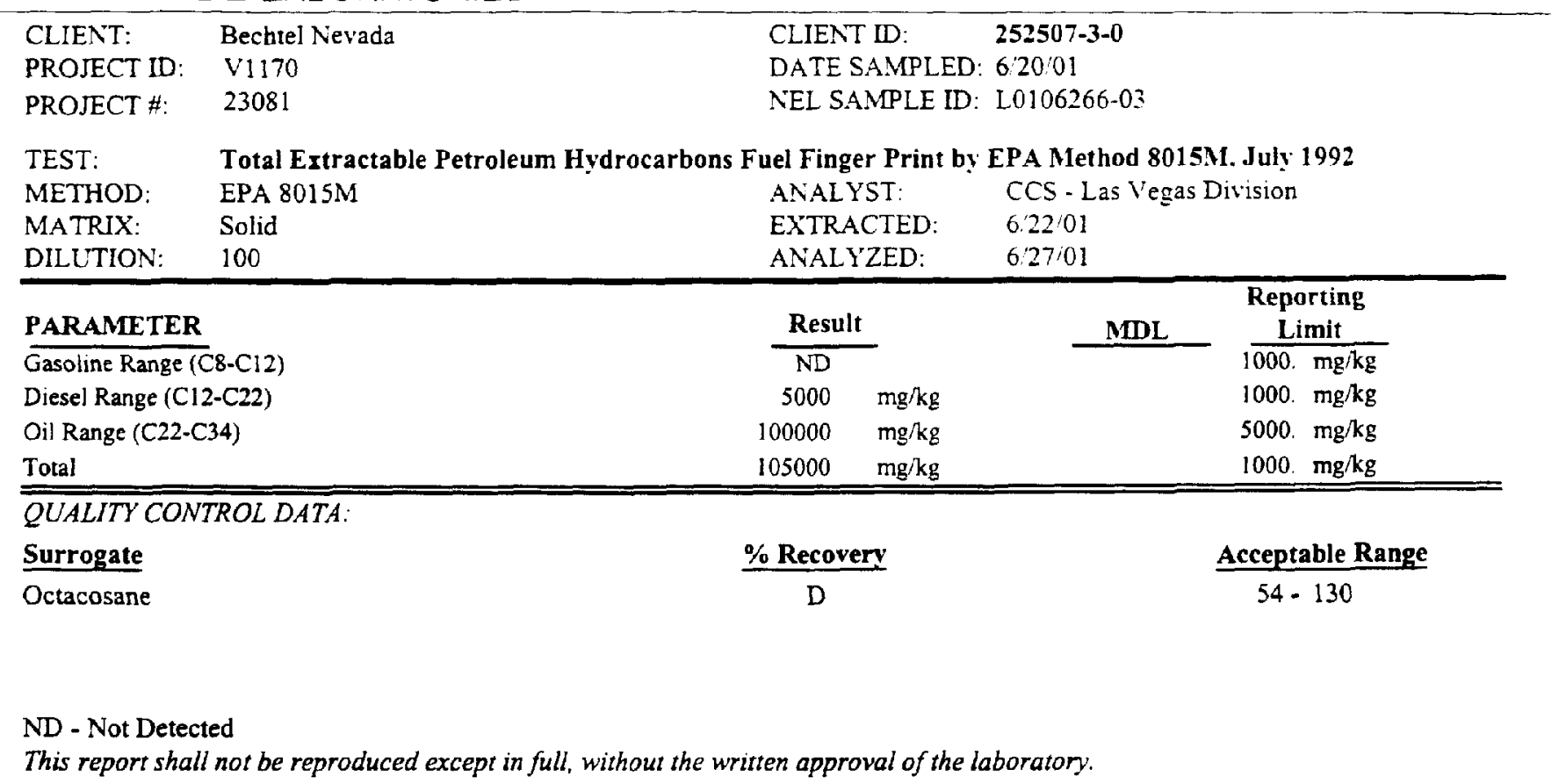


NEL LABORATORIES

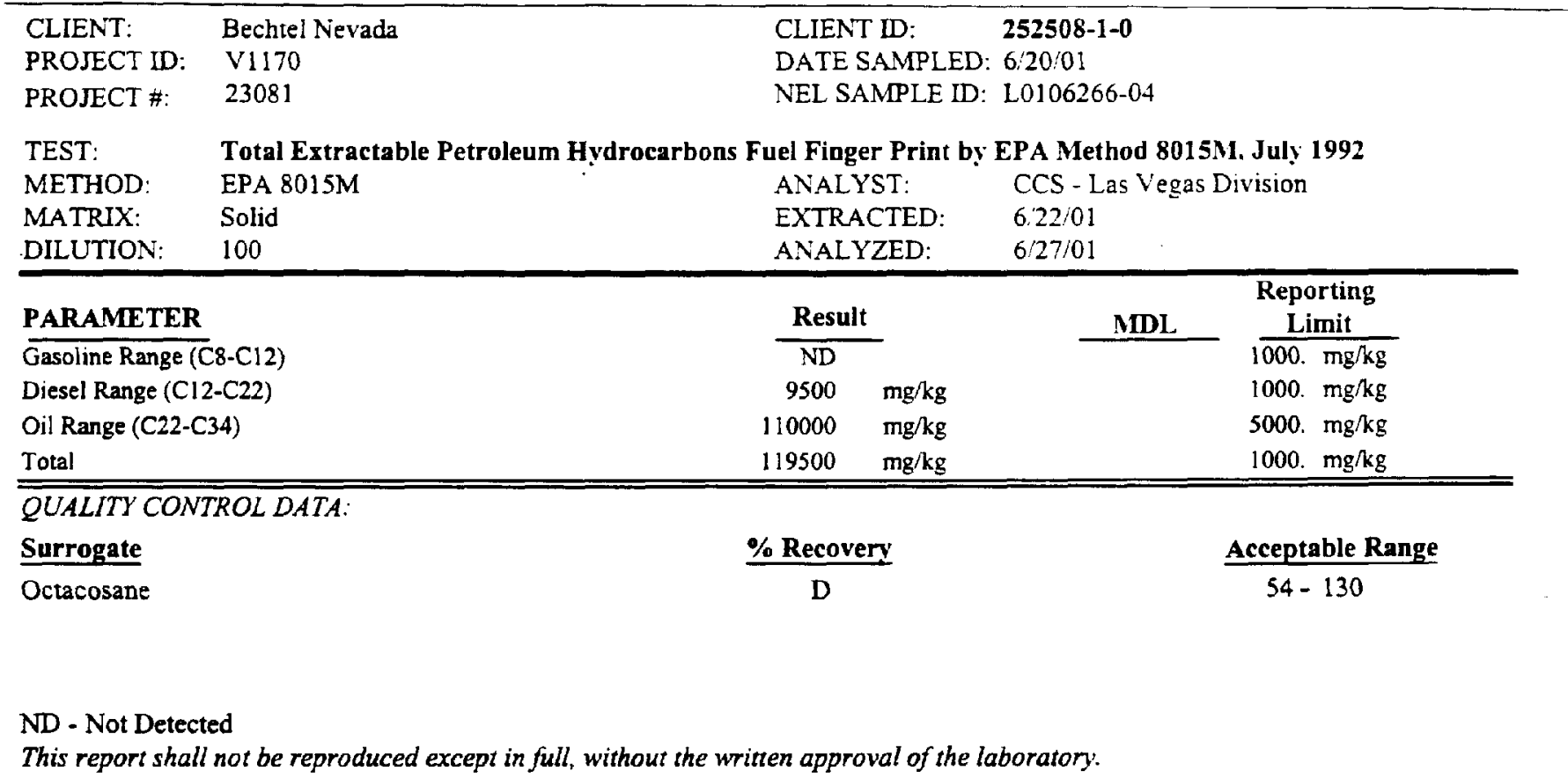


NEL LABORATORIES

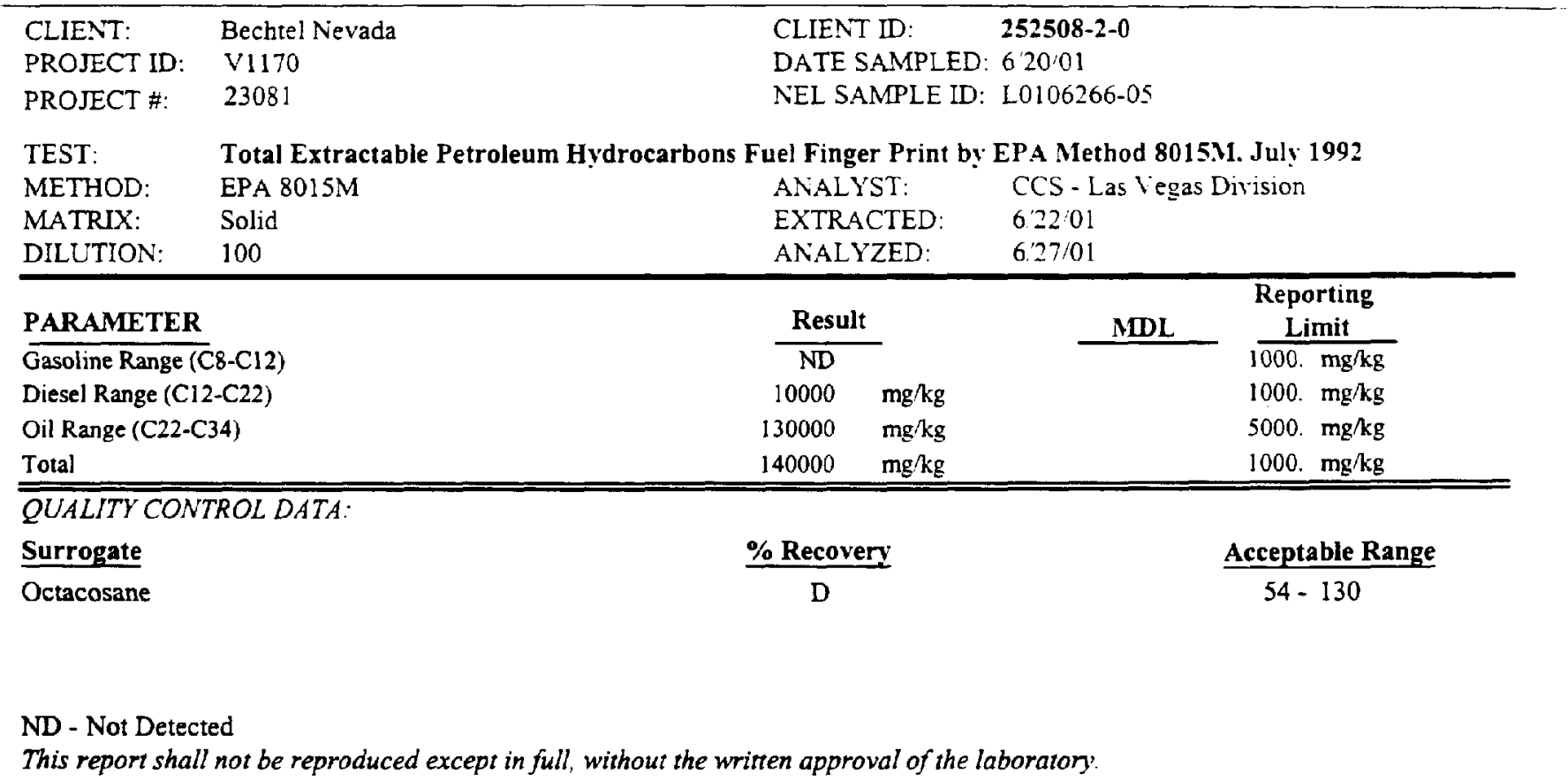




\section{NEL LABORATORIES}

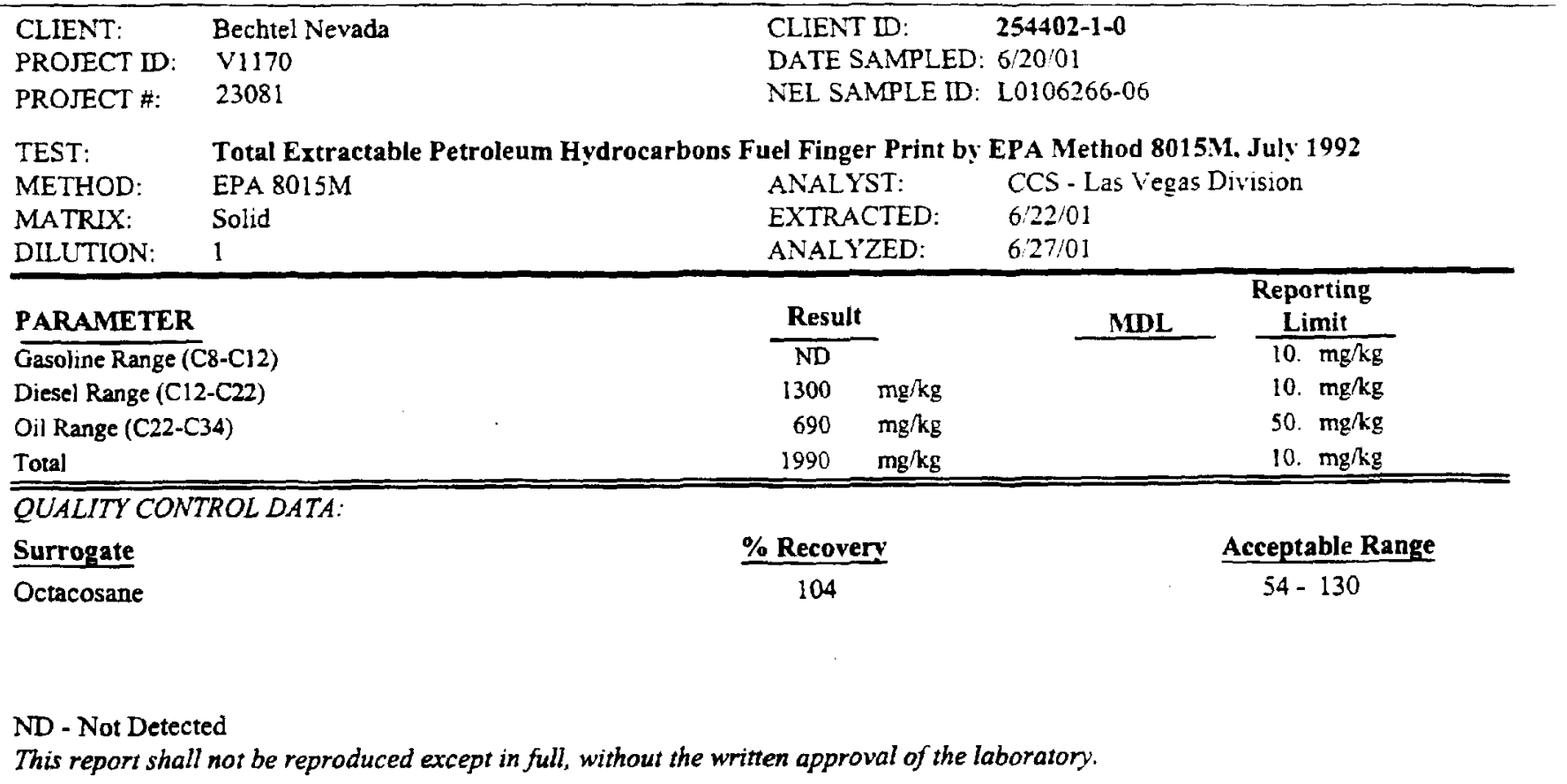


NEL LABORATORIES

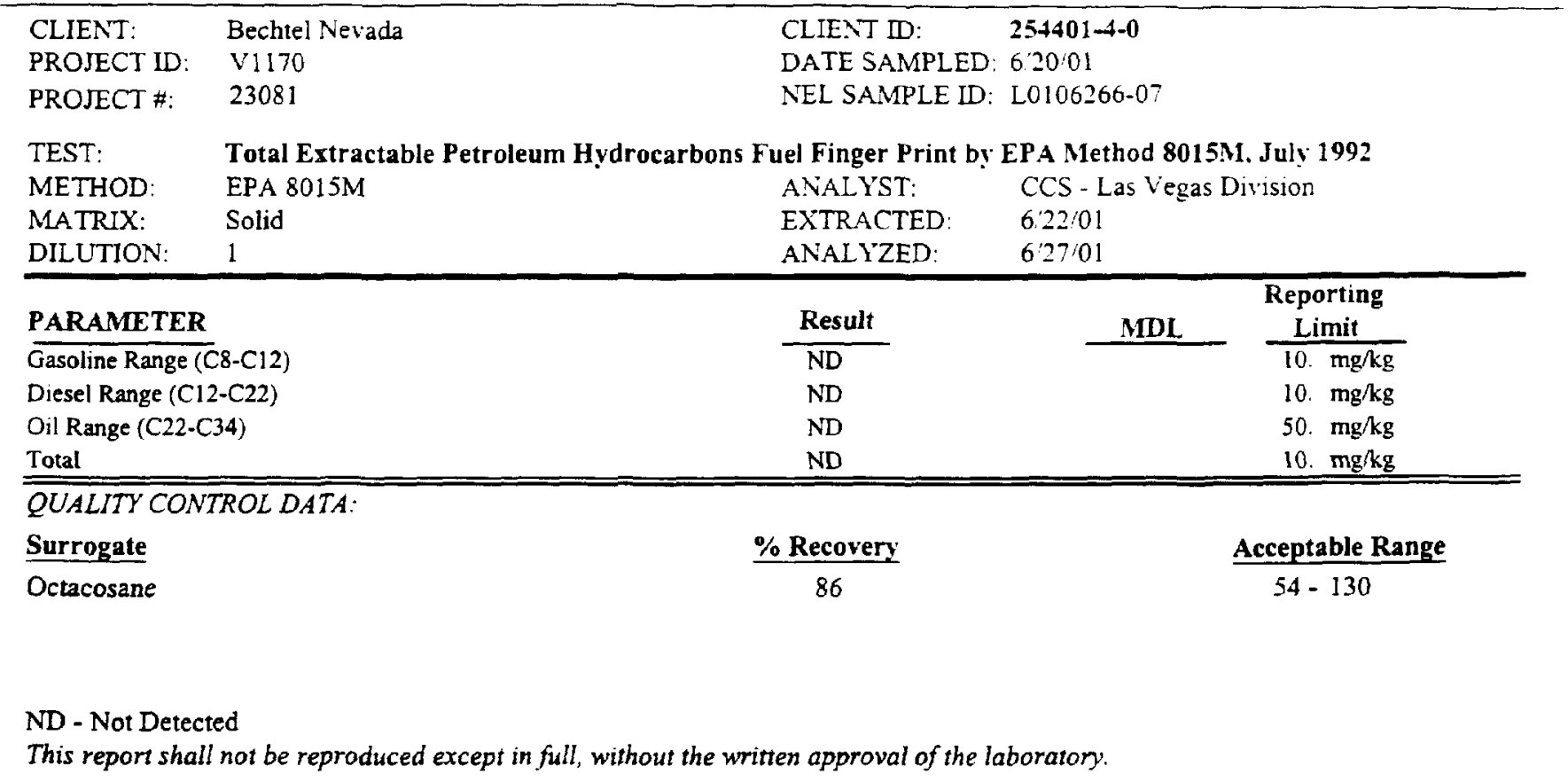


NEL LABORATORIES

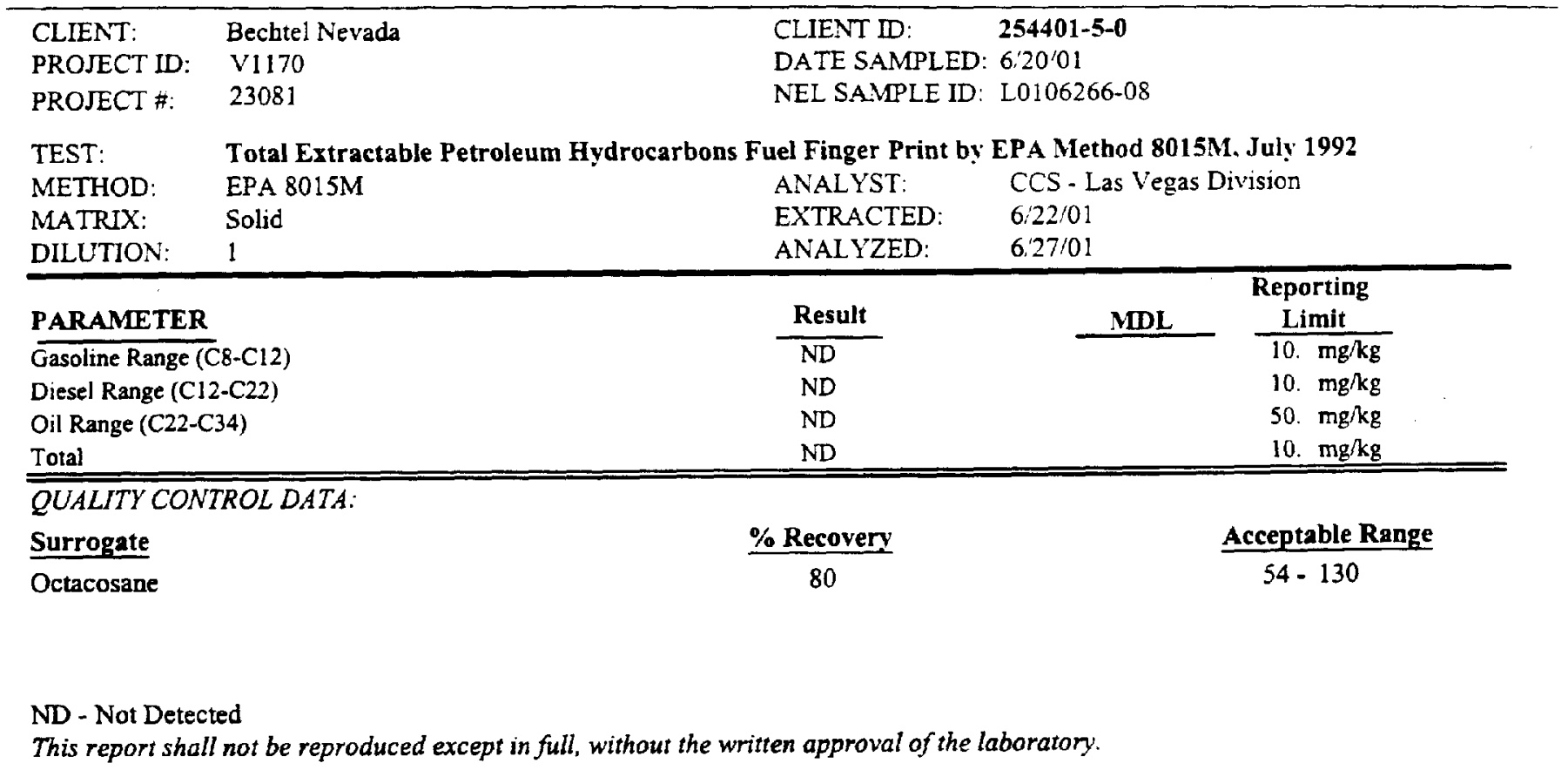


NEL LABORATORIES

$\begin{array}{llll}\text { CLIENT: } & \text { Bechtel Nevada } & \text { CLIENT ID: } & \mathbf{2 5 4 4 0 1 - 6 - 0} \\ \text { PROJECT ID: } & V 1170 & \text { DATE SAMPLED: } 6 / 20 / 01 \\ \text { PROJECT \#: } & 23081 & \text { NEL SAMPLE ID: } & \text { L0106266-09 }\end{array}$

TEST: Total Extractable Petroleum Hydrocarbons Fuel Finger Print by EPA Method 8015M. July 1992

METHOD: EPA 8015M

MATRIX: Solid

DILUTION: 1

\section{PARAMETER}

Gasoline Range (C8-C12)

Diesel Range (C12-C22)

Oil Range (C22-C34)

Total

QUALITY CONTROL DATA:

Surrogate

Octacosane
ANALYST: CCS - Las Vegas Division

EXTRACTED: $\quad 6 \% 22 \% 1$

ANALYZED: $\quad 627 / 01$

ANAL IZED: $\quad 6270$

$\begin{array}{lll}\text { Result } & \text { MDL } & \begin{array}{c}\text { Reporting } \\ \text { Limit }\end{array} \\ & 10 . \mathrm{mg} / \mathrm{kg} \\ \mathrm{ND} & 10 . \mathrm{mg} / \mathrm{kg} \\ \mathrm{ND} & 50 . \mathrm{mg} / \mathrm{kg} \\ \mathrm{ND} & 10 . \mathrm{mg} / \mathrm{kg}\end{array}$

\% Recovery

79

Acceptable Range

$54-130$

ND - Not Detected

This report shall not be reproduced except in full, without the written approval of the laboratory. 
NEL LABORATORIES

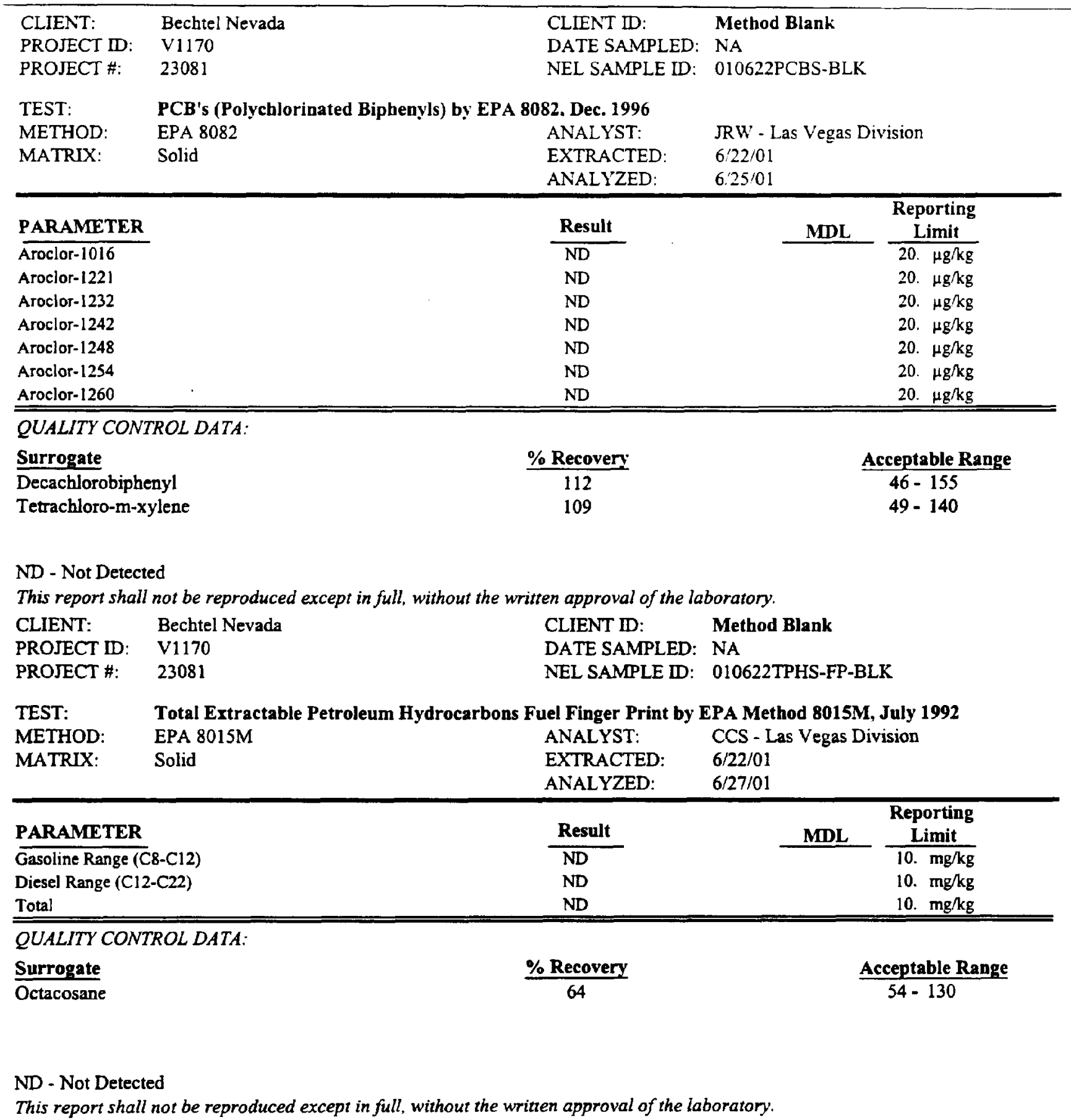

This report shall not be reproduced except in full, without the written approval of the laboratory. 


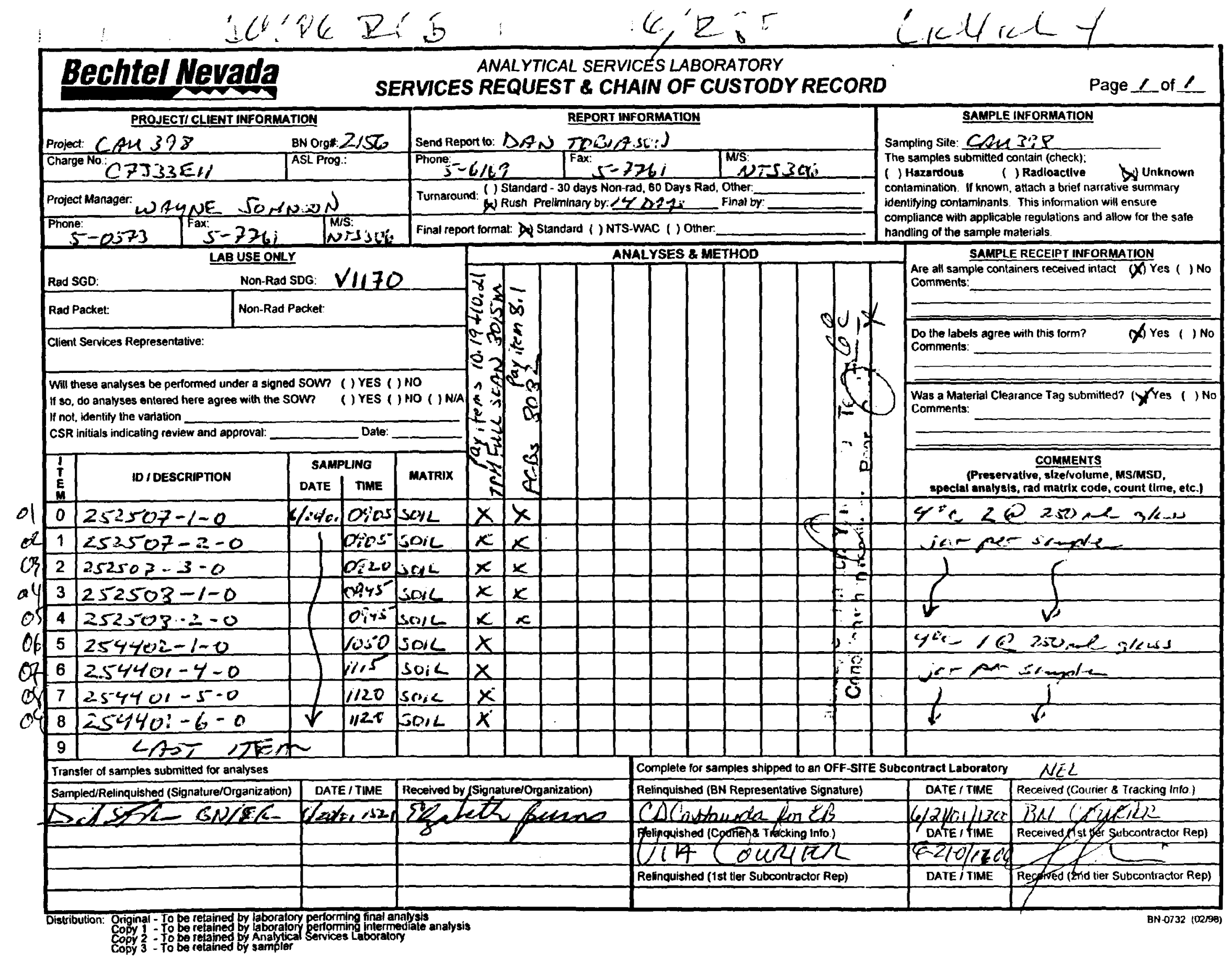


CLOSURE REPORT - CAU 398

Section: Appendix B

Revision: 1

Date: April 2003

\section{SAMPLE DELIVERY GROUP}

\section{V1565}


CLOSURE REPORT - CAU 398

Section: Appendix B

Revision: 1

Date: April 2003

\section{THIS PAGE INTENTIONALLY LEFT BLANK}


Ted Redding

Bechtel Nevada

P.O. Box 98521 , M/S NTS273

Las Vegas, NV 89193-8521

TEL: 702-295-7220

RE Project: V1565

Order No.: L0204394

Dear Ted Redding:

NEL Laboratories, Las Vegas received 5 samples on 4/25/02 for the analyses presented in the following report.

There were no problems with the analyses and all data for associated QC met EPA or laboratory specifications unless noted in the Case Narrative.

If you have any questions regarding these tests results, please feel free to call.
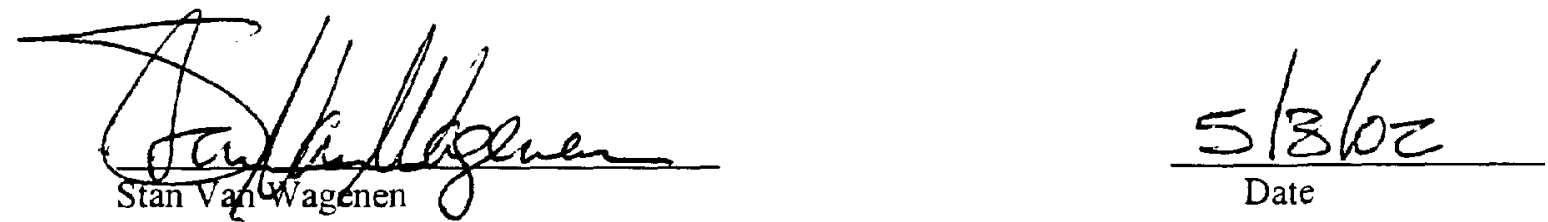

Laboratory Manager

$\begin{array}{lll}\text { Certifications: } & \text { Reno } & \text { Las Vegas } \\ \text { Arizona } & \text { AZ0520 } & \text { AZ0518 } \\ \text { California } & 1707 & 2002 \\ \text { Idaho } & \text { Certified } & \text { Certified } \\ \text { Montana } & \text { Certified } & \text { Certified } \\ \text { Nevada } & \text { NV033 } & \text { NV052 } \\ \text { New Mexico } & \text { Certified } & \text { Certified } \\ \text { US Army Corps of Engineers } & & \text { Certified }\end{array}$


NEL LABORATORIES

\begin{tabular}{|c|c|c|c|c|c|c|c|c|c|}
\hline CLIENT: & \multicolumn{4}{|c|}{ Bechtel Nevada } & \multicolumn{5}{|c|}{ CLIENT ID: $\quad 252503-1$} \\
\hline PROJECT ID: & \multicolumn{4}{|l|}{11565} & \multicolumn{5}{|c|}{ DATE SAMIPLED: 42402} \\
\hline PROJECT \#: & \multicolumn{4}{|l|}{30033} & \multicolumn{5}{|c|}{ NEL SAMPLE ID: L0204394-001A } \\
\hline MATRIX: & \multicolumn{9}{|l|}{ SOLID } \\
\hline \multicolumn{10}{|c|}{ Reporting } \\
\hline Gasolıne Range Or & $\operatorname{ses}(\mathrm{C} 8-\mathrm{C} 12)$ & ND & $\mathrm{mg} / \mathrm{Kg}$ & 10 & 1 & SW8015Ext & $0425: 02$ & 0430,02 & PXC.LY \\
\hline Diesel Range Orga & $(\mathrm{Cl}-\mathrm{C} 22)$ & ND & $\mathrm{mg} / \mathrm{Kg}$ & 10 & 1 & SW8015Ext & $04: 2502$ & $0430 \% 02$ & PXC-1Y \\
\hline Oil Range Organics & $22 \cdot(34)$ & ND & $\mathrm{mg} / \mathrm{Kg}$ & 50 & 1 & SW80!5Ext & $0+125 / 02$ & $0+30 / 02$ & PXC-L!' \\
\hline Total TPH & & ND & $\mathrm{mg} / \mathrm{Kg}$ & 10 & 1 & SW8015Ext & $04 / 25 / 02$ & $04: 30 / 02$ & $P X C-L Y$ \\
\hline Surr: n-Octacos & & 60.1 & $\%$ REC & $55-130$ & 1 & SW8015Exi & $04 / 25 / 02$ & $04 / 30 / 02$ & PXC-LV \\
\hline
\end{tabular}

ND - Not Detected at the Reporting Limit

DF - Dilution Factor

Date: $03-M a y-02$
B - Analyte detected in the associated Method Blank

S - Spike Recovery outside accepted recovery limits

$E$ - Value above quantitation range
Page 1 of 5 
NEL LABORATORIES

\begin{tabular}{lll}
\hline CLIENT: & Bechtel Nevada & CLIENT ID: \\
PROJECT ID: & 11565 & DATE SAM-2 \\
PROJECT \#: & 30033 & NEL SAIIPLE ID: L0204304-002A \\
MATRIX: & SOLID &
\end{tabular}

\begin{tabular}{|c|c|c|c|c|c|c|c|c|}
\hline Parameter & $\underline{\text { Result }}$ & Enit & $\begin{array}{l}\text { Reporting } \\
\text { Limit }\end{array}$ & $\underline{\text { DF }}$ & Method & Prep Date & Analyzed & Analyst \\
\hline Gasoline Range Organics (C8-C12) & ND & $\mathrm{mg} / \mathrm{kg}$ & 10 & 1 & SW8015Ex: & $04.25 / 02$ & 043002 & PXC-LY \\
\hline Diesel Range Organics (C 12-C22) & ND & $\mathrm{mg} / \mathrm{Kg}$ & 10 & 1 & SW8015Ext & $04 / 25 / 02$ & $04: 30 / 0 ?$ & PXC-LY \\
\hline Oil Range Organies (C22-C34) & ND & $\mathrm{mg} / \mathrm{Kg}$ & 50 & 1 & SW80:5Ext & $04.25 \% 02$ & $04 / 30 / 02$ & PXC-LY \\
\hline Total TPH & ND & $\mathrm{mg} / \mathrm{Kg}$ & 10 & 1 & SW'8015Ext & $04 / 25 / 02$ & 0430.02 & PXC-LV \\
\hline Surr: n-Octacosane & 68.1 & $\%$ REC & $55-130$ & 1 & SW8015Ext & $04 / 25 / 02$ & $04: 30 / 02$ & PXC-LY \\
\hline
\end{tabular}

ND - Not Detected at the Reporting Limit

DF - Dilution Factor

Date: $03-M a y-02$
B - Analyte detected in the associated Method Blank

S - Spike Recovery outside accepted recovery limits

E - Value above quantitation range
Page 2 of 5 


\section{NEL LABORATORIES}

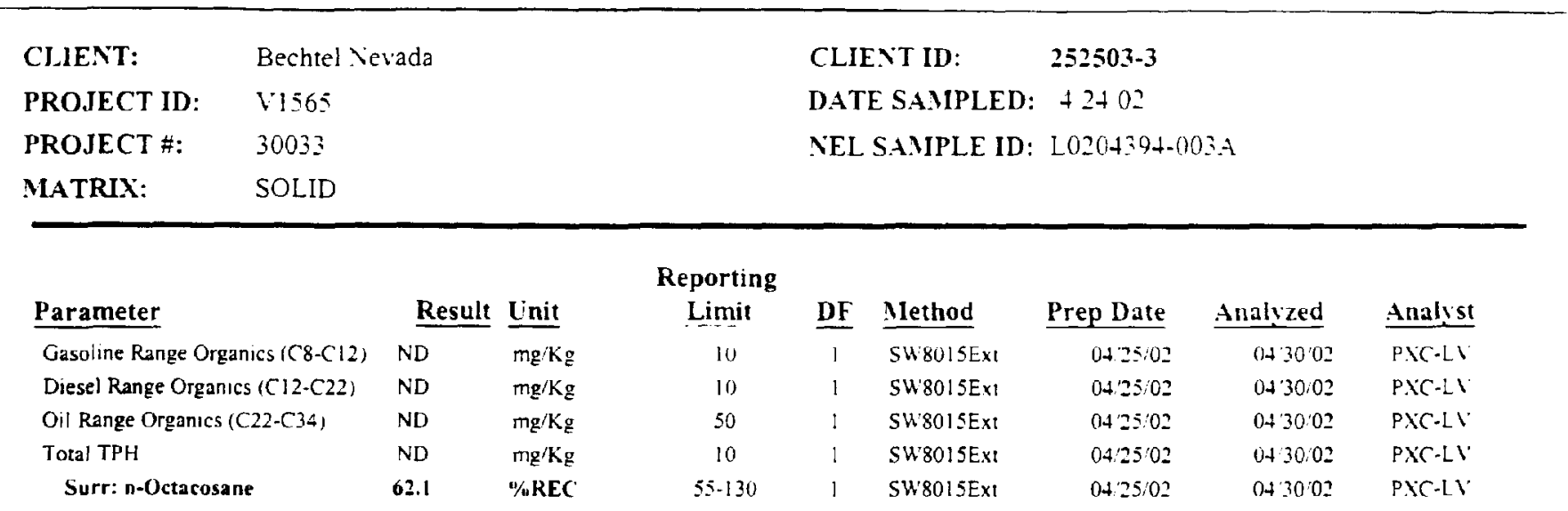

ND - Not Detected at the Reporting Limit

DF - Dilution Factor

Date: $0.3-M a y-02$
B - Analyte detected in the associated Method Blank

S - Spike Recovery outside accepted recovery limits

E - Value above quantitation range
Page 3 of 5 
NEL LABORATORIES

\begin{tabular}{|c|c|c|}
\hline CI.IENT: & Bechrel Nevada & CLIENT ID: \\
\hline PROJECT ID: & 11565 & DATE SAIIPLED: $+2+02$ \\
\hline PROJECT \#: & 30033 & NEL SAIPLE ID: $1020439+-00$ \\
\hline MATRIX: & SOLID & \\
\hline
\end{tabular}

\begin{tabular}{|c|c|c|c|c|c|c|c|c|}
\hline Parameter & Result & $\underline{\text { Unit }}$ & $\begin{array}{c}\text { Reporting } \\
\text { Limit }\end{array}$ & $\underline{\mathbf{D F}}$ & Method & Prep Date & Analyzed & Analyst \\
\hline Gasoline Range Organics (C8-C12) & ND & $\mathrm{mg} / \mathrm{Kg}$ & 10 & 1 & SW8015Ext & 042503 & $0430: 02$ & $P X C-L)$ \\
\hline Diesel Range Organics (C12-C22) & ND & $\mathrm{mg} / \mathrm{Kg}$ & 10 & 1 & SW80! 5Ext & $04: 25 / 02$ & $04: 30: 02$ & PXC-LY \\
\hline Oil Range Organics (C22-C34) & ND & $\mathrm{mg} / \mathrm{Kg}$ & 50 & 1 & SW8015Ext & 0425102 & 04.30 .02 & PXC-1 Y \\
\hline Total TPH & ND & $\mathrm{mg} / \mathrm{Kg}$ & 10 & 1 & SW8015Ext & $04: 25.02$ & $0.30 / 02$ & PXC-LY \\
\hline Surr: n-Detacosane & 71.1 & \%REC & $55-130$ & 1 & SW8015Ext & 04225.02 & $04: 30: 02$ & PXC-LV \\
\hline
\end{tabular}

ND - Not Detected at the Reporting Limit

DF - Dilution Factor

Date: 03-May- 02
B - Analyte delected in the associated Method Blank

S - Spike Recovery outside accepted recovery limits

$\mathrm{E}$ - Value above quantitation range
Page 4 of 5 
NEL LABORATORIES

\begin{tabular}{|c|c|c|c|c|c|c|c|c|c|}
\hline CLIENT: & \multicolumn{4}{|c|}{ Bechtel Nerada } & \multicolumn{4}{|c|}{ CLIENT ID: $\quad 252503-5$} & \\
\hline PROJECT ID: & \multicolumn{4}{|l|}{1565} & \multicolumn{4}{|c|}{ DATE SAMPLED: $\$ 2402$} & \\
\hline PROJECT \#: & \multicolumn{4}{|l|}{30033} & \multicolumn{4}{|c|}{ NEL SAMIPLE ID: L0204394-005A } & \\
\hline MATRIX: & \multicolumn{4}{|l|}{ SOLID } & & & & & \\
\hline \multicolumn{2}{|l|}{ Parameter } & Result & Unit & $\begin{array}{l}\text { Reporting } \\
\text { Limit }\end{array}$ & DF & Method & Prep Date & Analyzed & Analyst \\
\hline \multicolumn{2}{|c|}{ Gasoline Range Organics $\{\mathrm{C} 8-\mathrm{Cl}$, } & ND & $\mathrm{mg} / \mathrm{Kg}$ & 10 & $!$ & SW8015Ext & $04: 25: 02$ & 043002 & PXC.LY \\
\hline \multicolumn{2}{|c|}{ Diesel Range Organics (C12-C22) } & 57 & $\mathbf{m g} / \mathbf{k g}$ & 10 & 1 & SW8015Ext & $04 / 25 / 02$ & 04,3002 & PXC-LV \\
\hline \multicolumn{2}{|c|}{ Oil Range Organics (C22-C34) } & 530 & $\mathrm{mg} / \mathrm{hg}$ & 50 & 1 & SW8015Ext & $04: 25: 02$ & $04: 30: 02$ & PXC-LY \\
\hline \multicolumn{2}{|l|}{ Total TPH } & 590 & $\mathrm{mg} / \mathrm{hg}$ & 10 & 1 & SW8015Ext & $04 / 25,02$ & 0430.02 & $P \lambda C \cdot L Y$ \\
\hline \multicolumn{2}{|c|}{ Surr: n-Octacosane } & 66.1 & $\%$ REC & $55-130$ & 1 & SW8015Ext & $0+25 / 02$ & $04 / 30 / 02$ & PXC-LV \\
\hline
\end{tabular}

ND - Not Detected at the Reporting Limit

DF - Dilutron Factor

Date: $03-M a y-02$
B - Analyte detected in the associated Method Blank

$S$ - Spike Recovery outside accepted recovery limits

E - Value above quantitation range
Page 5 of 5 


\section{NEL LABORATORIES}
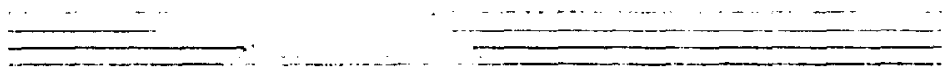

CliEnT: Bechtel Nevada

Work Order: L0204394

ANALYTICAL QC SUMNIARY REPORT

Project:

V1565

Test Method:

SW8015Ext

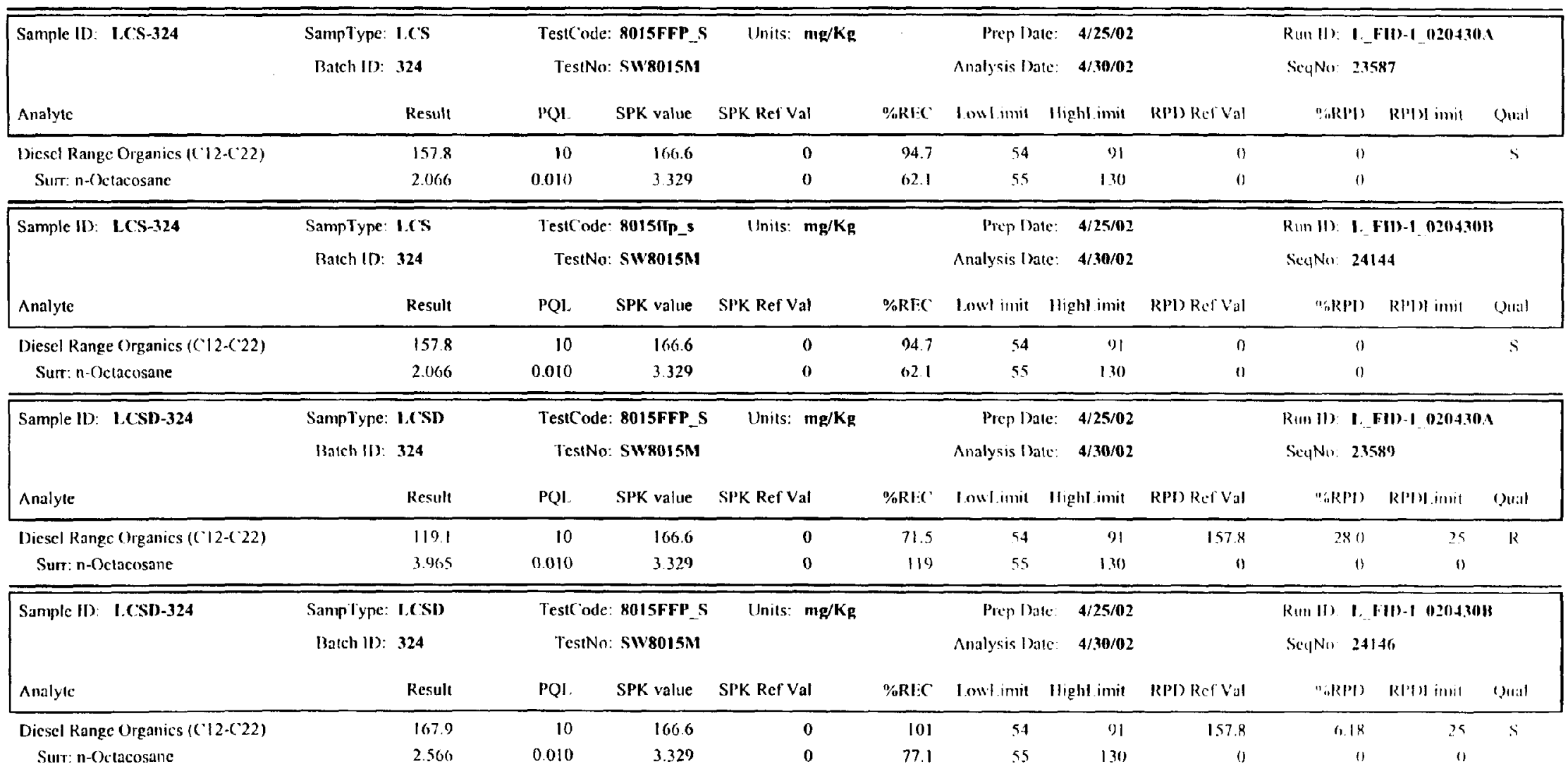

Qualifiers:

N1) - Not Detected at the Reporting L imit

C - Uıspiked sample $>5$ times the anoumt spiked

B - Analyte detected in the associanced Methend Bs:ank

JI - MS or MSD outside accepance limits. IISS acceptable.

$R-R P l)$ outside accepted recovery limits

I'tuge' $\mid$ of 1

$J$ - This concentration is considered an estimate due to L.CS failure

Jat(1: $11.3 .1961 \cdot 112$ ? 


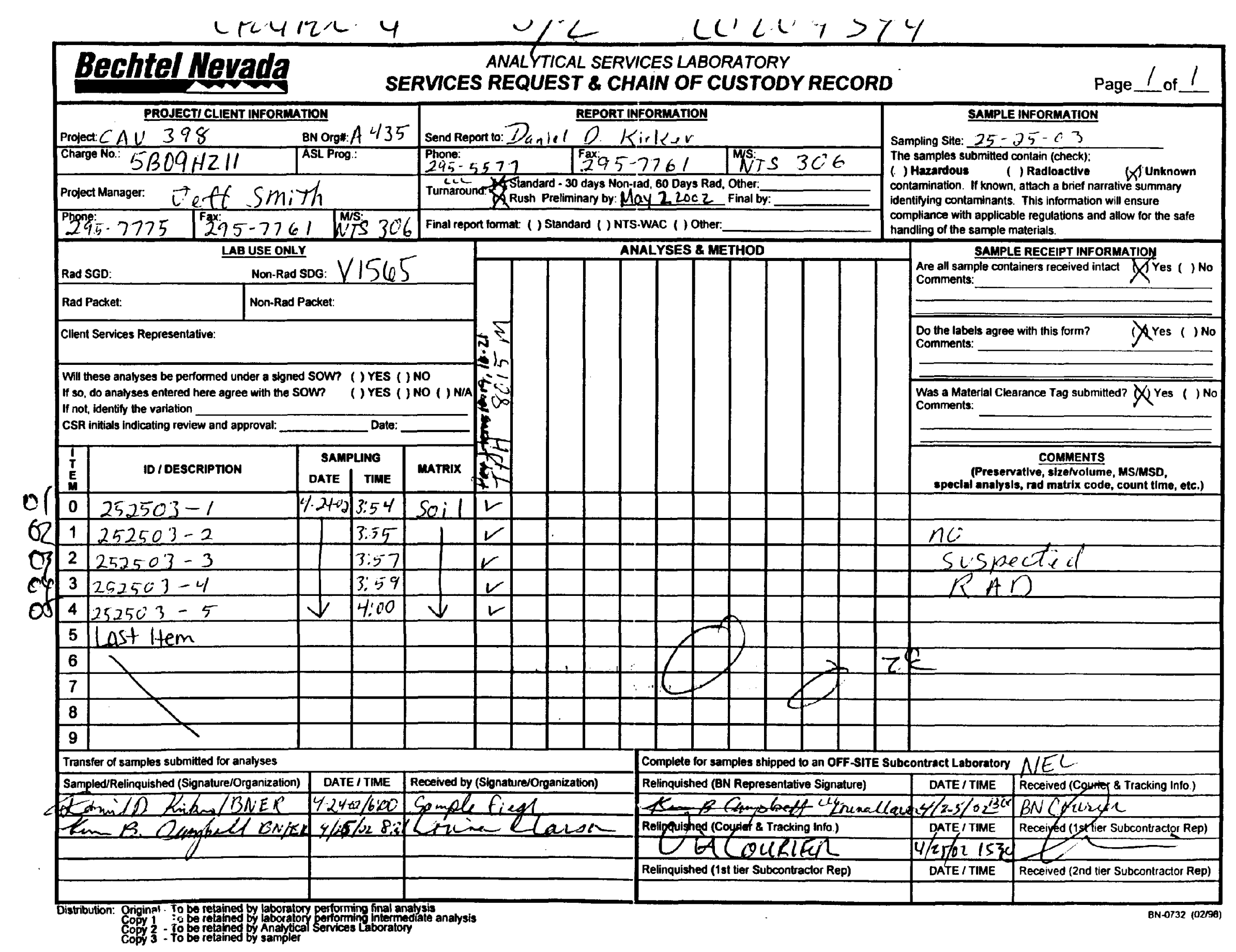


CLOSURE REPORT - CAU 398

Section: Appendix B

Revision: 1

Date: April 2003

\section{THIS PAGE INTENTIONALLY LEFT BLANK}




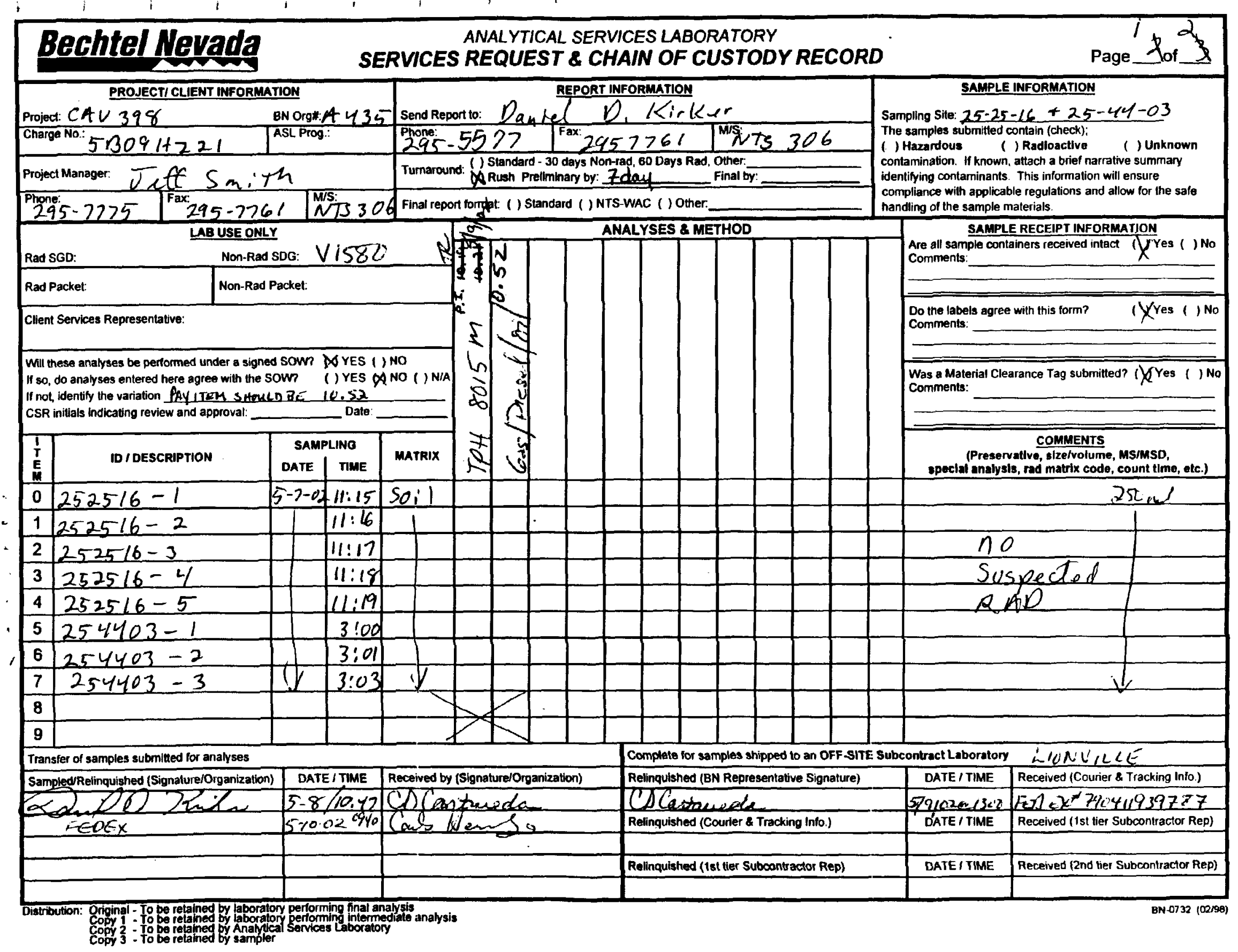




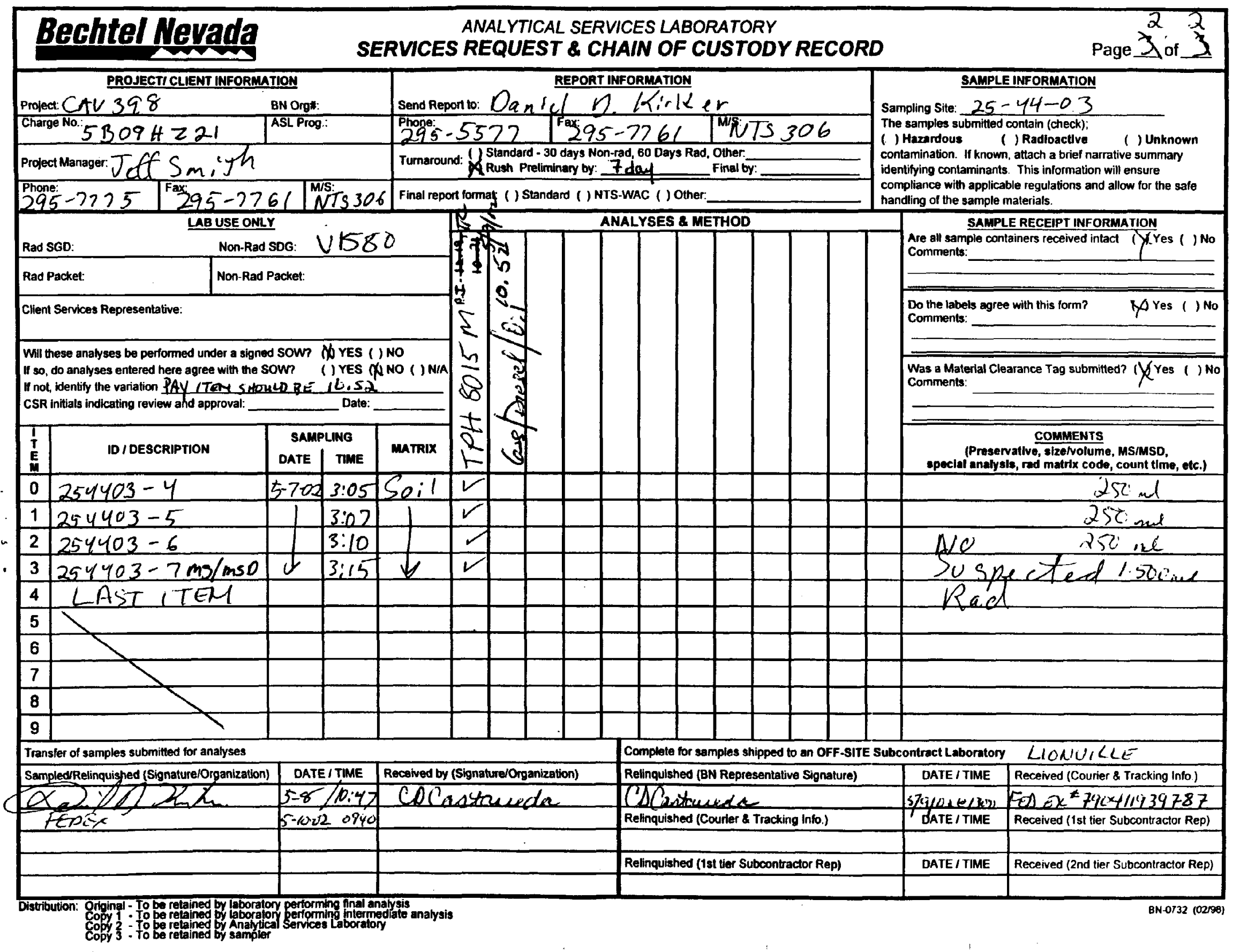


Lionville Laboratory, Inc.

GAS RANGE ORGANICS

Report Date: 05/23/02 15:06

RFW Batch Number: $0205 \mathrm{~L} 638$ Client: BECHTEL NEVADA V1580

Work Order: 60052001001 Page: 1

Cust ID: $252516-1 \quad 252516-2 \quad 252516-3 \quad 252516-4 \quad 252516-5 \quad 254403-1$

Sample

Cust ID: 252516

$252516-2$

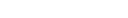

005

$\begin{array}{ccc}004 & 005 & 006 \\ \text { SOIL } & \text { SOIL } & \text { SOIL } \\ 1.00 & 1.00 & 1.00 \\ \text { UG/KG } & \text { UG/KG } & \text { UG } / \text { KG }\end{array}$

Information

$\begin{aligned} \text { RFW\# : } & \text { SoI } \\ \text { Matrix: } & \text { SoI }\end{aligned}$

$\begin{array}{rr}\text { Matrix: } & \text { SOIL } \\ \text { D.F.: } & 1.00\end{array}$

002

003

Units:

UG/KG

1.00

UG/KG

SOIL

1.00
$\mathrm{UG} / \mathrm{KG}$

$\mathrm{UG} / \mathrm{KG}$

UG/KG

1.00

2,5-Dibromotoluene

14

Gasoline Range Organics (GRO)

$=====\mathrm{f}$

80 \%

99 \%

$30 \mathrm{U}$

$30 \mathrm{U}$

$30 \mathrm{U}$

$=====\mathrm{f}$

73 \%

$33 \mathrm{U}$

$33 \mathrm{U}$

$91 \div$

\begin{tabular}{|c|c|c|c|c|c|c|c|}
\hline & Cust ID: & $254403-2$ & $254403-3$ & $254403-4$ & $254403-5$ & $254403-6$ & $254403-7$ \\
\hline Sample & RFW\# : & 007 & OOB & 009 & 010 & 011 & 012 \\
\hline \multirow[t]{4}{*}{ Information } & Matrix: & SOIL & SOIL & SOIL & SOIL & SOIL & SOIL \\
\hline & D.F.: & 1.00 & 1.00 & 1.00 & 1.00 & 1.00 & 1.00 \\
\hline & Units: & UG/KG & UG/KG & UG/KG & $\mathrm{UG} / \mathrm{KG}$ & $\mathrm{UG} / \mathrm{KG}$ & $\mathrm{UG} / \mathrm{KG}$ \\
\hline & 2,5 -Dibromotoluene & 96 & 122 & 126 & 90 & 88 & $113 \%$ \\
\hline \multicolumn{8}{|c|}{ 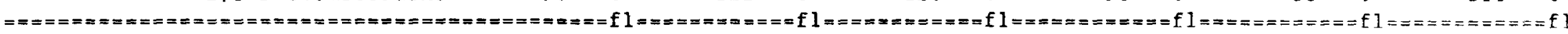 } \\
\hline Gasoline Ran & Organics $\{\mathrm{GRO}\}$ & $33 \mathrm{u}$ & $30 \mathrm{U}$ & $29 \mathrm{U}$ & $29 \mathrm{U}$ & $28 \quad \mathrm{U}$ & $33 \mathrm{U}$ \\
\hline
\end{tabular}

$\mathrm{U}=$ Analyzed, not detected. $\mathrm{J}=$ present below detection limit. $\mathrm{B}=$ Present in blank. NR= Not reported. NS $=$ Not spiked.

$\because=$ Percent recovery. $D=$ Diluted out. $I=$ Interference. $N A=$ Not Applicable. $\quad *=$ Outside of EPA CLP $Q C$ 
Lionville Laboratory, Inc.

GAS RANGE ORGANICS

Report Date: 05/23/02 15:06

RFW Batch Number: 0205L638 Client: BECHTEL NEVADA V1580 work Order: 60052001001 Page: 2

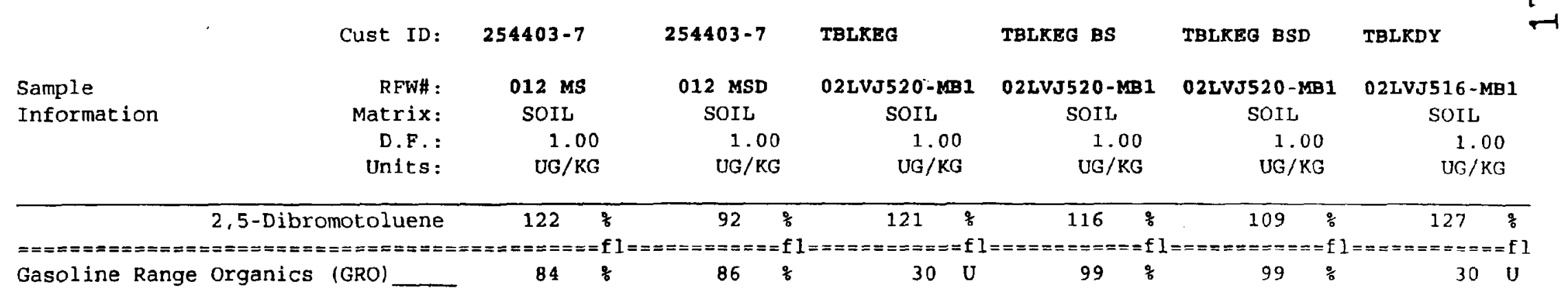

Cust ID: TBLRDY BS

Sample

Information

RFW\#: 02LVJ516-MB1

Matrix: SOIL

D.F.: $\quad 1.00$

Units : UG/KG

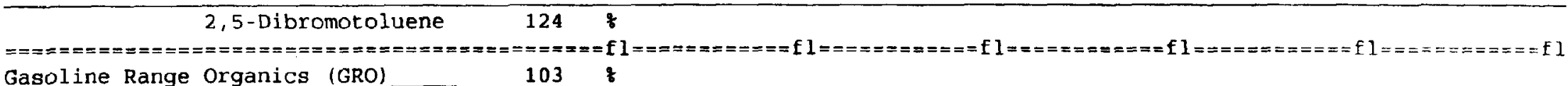

Gasoline Range Organics (GRO)

103 t

$\mathrm{U}=$ Analyzed, not detected. $\mathrm{J}=$ Present below detection limit. $\mathrm{B}=$ Present in blank. NR $=$ Not reported. NS $=$ Not $\mathrm{spiked.}$ $\%=$ percent recovery. $\mathrm{D}=$ Diluted out. $\mathrm{I}=$ Interference. NA = Not Applicable. * Outside of EPA CLP QC 
LLonville Laboratory, Inc.

DIESEL RANGE ORGANICS BY GC

Report Date: 05/23/02 15:52 RFW Batch Number: $0205 \mathrm{~L} 638$ Client: BECHTEL MEVADA V1580 Work Order: 60052001001 Page: 1

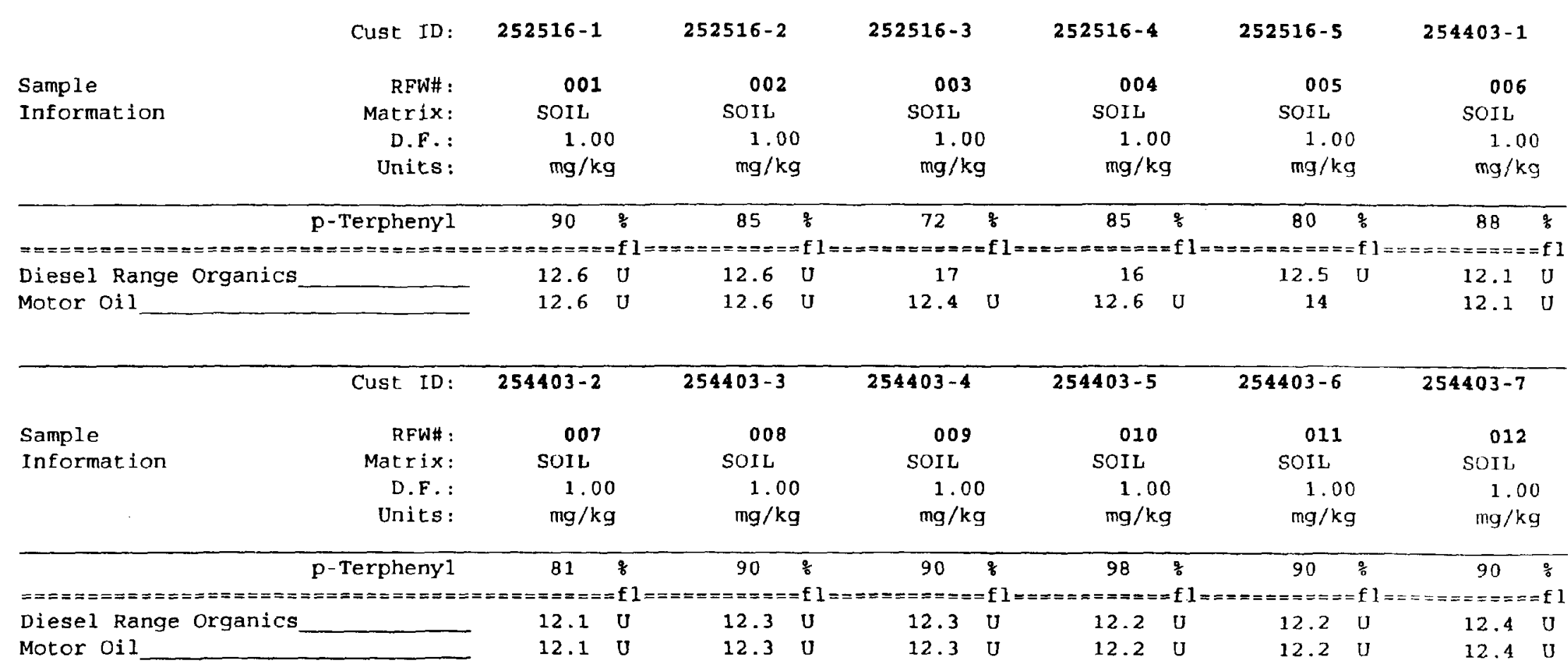

$U=$ Analyzed, not detected. $J=$ Present below detection limit. B = Present in blank. NR= Not reported. NS= Not spiked.

$\frac{2}{b}=$ Percent recovery. $D=$ Diluted out. $I=$ Interference. NA $=$ Not Applicable. $*=$ Outside of EPA CLP QC 
Lionville Laboratory, Inc.

DIESEL RANGE ORGANICS BY GC

Report Date: 05/23/02 15:52

RFW Batch Number: 0205L638 Client: BECHTEL NEVADA V1580 Work Order: 60052001001 Page: 2

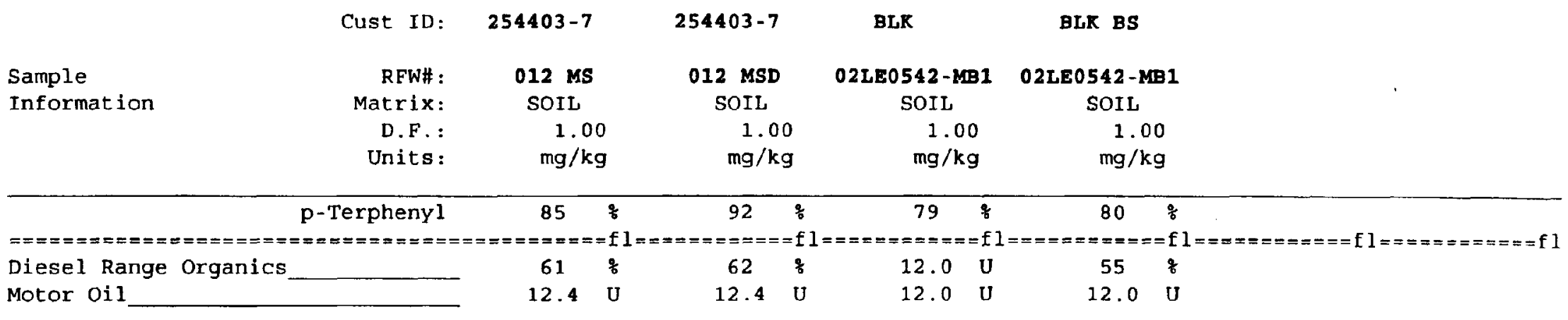

$\mathrm{U}=$ Analyzed, not detected. $\mathrm{J}=$ Present below detection limit. $\mathrm{B}=$ Present in blank. NR= Not reported. NS= Not spiked. $\because=$ Percent recovery. $D=$ Diluted out. $I=$ Interference. NA $=$ Not Applicable. ${ }^{*}$ Outside of EPA CLP QC

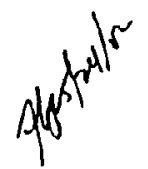


CLOSURE REPORT - CAU 398

Section: Appendix B

Revision: 1

Date: April 2003

\section{SAMPLE DELIVERY GROUP}

\section{V1581}


CLOSURE REPORT - CAL 398

Section: Appendix B

Revision: 1

Date: April 2003

THIS PAGE INTENTIONALLY LEFT BLANK 


\section{NEL LABORATORIES}

Ted Redding

Bechtel Verada

P.O. Box 98521. M'S NTS273

Las Vegas, NV 89193-8521

TEL: 702-295-7220

RE Project: V1581

Order No.: L0205125

Dear Ted Redding:

NEL Laboratories, Las Vegas received 20 samples on 5/9/02 for the analyses presented in the following report.

There were no problems with the analyses and all data for associated QC met EPA or laboratory specifications unless noted in the Case Narrative.

If you have any' questions regarding these tests results, please feel free to call.

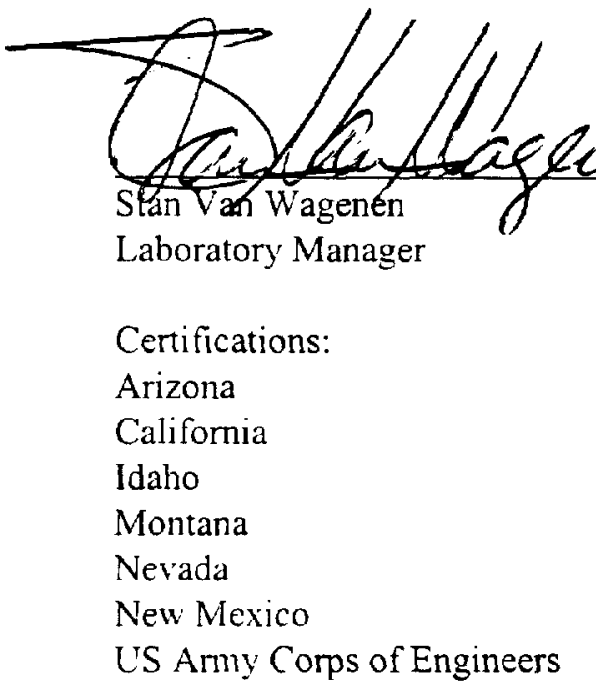

$\begin{array}{ll}\text { Reno } & \text { Las Vegas } \\ \text { AZ0520 } & \text { AZ0518 } \\ 1707 & 2002 \\ \text { Certified } & \text { Certified } \\ \text { Certified } & \text { Certified } \\ \text { NV033 } & \text { NV052 } \\ \text { Certified } & \text { Certified } \\ & \text { Certified }\end{array}$

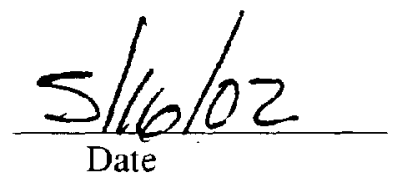


NEL LABORATORIES

\begin{tabular}{lll}
\hline CLIENT: & Bechtel Nevada & CLIENT ID: \\
PROJECT ID: & 11581 & DATE-2505-1 \\
PROJECT \#: & 30033 & NEL SAMPLE ID: L0205125-001A \\
MATRIX: & SOLID &
\end{tabular}

\begin{tabular}{|c|c|c|c|c|c|c|c|c|}
\hline Parameter & Result & Unit & $\begin{array}{l}\text { Reporting } \\
\text { Limit }\end{array}$ & $\underline{\mathrm{DF}}$ & Method & Prep Date & Analyzed & Analyst \\
\hline Gasoline Kange Organics ( $C 8-\mathrm{C}: 2$ ) & ND & $\mathrm{mg} / \mathrm{kg}$ & 10 & 1 & SW8015EX1 & 051302 & 051502 & PXC-1.Y \\
\hline Diesel Range Organics ( $\mathrm{C} 12-\mathrm{C} 22)$ & ND & $\operatorname{mg} i \mathrm{Kg}$ & 10 & 1 & SW8015Ext & $05: 13: 02$ & $05 \cdot 150 ?$ & PXC-LY \\
\hline Oil Range Organics (C22-C34) & ND & $\mathrm{mg} / \mathrm{Kg}$ & 50 & 1 & SW8015Ext & $05: 13: 02$ & $0515 / 02$ & PXC-LY \\
\hline Total Perroleum Hydrocarbons & ND & $\mathrm{mg} / \mathrm{Kg}$ & 10 & 1 & SW8015EXI & $05 / 13 / 02$ & 051502 & PXC-LV \\
\hline Surr: $n$-Octa cosane & 80.1 & $\%$ REC & $55-130$ & 1 & SW80ISEXt & $05: 13: 02$ & $05 \div 15: 02$ & PXC-LV \\
\hline
\end{tabular}

\footnotetext{
ND - Not Detected at the Reporting Limit

DF - Dilution Factor
}

Date: $16-M a y-02$
B - Analyte detected in the associated Method Blank

S. Spike Recovery outside accepted recovery limits

E - Value above quantitation sange
Page 1 of 46 
NEL LABORATORIES

\begin{tabular}{|c|c|c|c|c|c|c|c|c|c|}
\hline PROJECT ID: & \multicolumn{4}{|l|}{$\because 1581$} & \multicolumn{5}{|c|}{ DATE SAMPLED: $:-02$} \\
\hline PROJECT \#: & \multicolumn{4}{|l|}{30033} & \multicolumn{5}{|c|}{ NEL SAMPLE ID: L0205125.002A } \\
\hline MATRIX: & \multicolumn{4}{|l|}{ SOLID } & & & & & \\
\hline \multicolumn{2}{|c|}{ Gasoline Range Organics (C8-C12) } & ND & $\mathrm{mg} / \mathrm{Kg}$ & 10 & 1 & SW80!5Ex: & $05 / 12 / 02$ & 051402 & PXC.LV \\
\hline \multicolumn{2}{|c|}{ Diesel Range Organics (C 12-C22) } & ND & $\mathrm{mg} / \mathrm{Kg}$ & 10 & 1 & SW8015Ext & $05 / 13 / 02$ & $05: 14 / 02$ & PXC-LV \\
\hline \multicolumn{2}{|c|}{ Oil Range Organics (C22-C34) } & 68 & $\mathbf{m g} / \mathbf{K g}$ & 50 & 1 & SW8015Ext & $05 / 13 / 02$ & 051402 & PXC-LY \\
\hline \multicolumn{2}{|c|}{ Tatal Petroleum Hydrocarbons } & 68 & $\mathrm{mg} / \mathrm{hg}$ & 10 & 1 & SW8015Ext & $05: 13 / 02$ & $0514 / 02$ & $\mathrm{PXC}-\mathrm{LY}$ \\
\hline \multicolumn{2}{|c|}{ Surr: $n$-Octacosane } & 94.1 & $\% \mathrm{REC}$ & $55-130$ & 1 & SW8015Ext & $05 / 13 / 02$ & $05 / 1402$ & PXC-LV \\
\hline
\end{tabular}

ND - Not Detected at the Reporting L imit

DF - Dilution Factor

Date: 16-Mav-02
B - Analyte detected in the associated Method Blank

S - Spike Recovery outside accepted recovery limits

E - Value above quantitation range
Page 2 of 46 
NEL LABORATORIES

\begin{tabular}{|c|c|c|c|c|c|c|c|c|c|}
\hline CLIENT: & \multicolumn{4}{|c|}{ Bechtel Nevada } & \multicolumn{4}{|c|}{ CLIENT ID: $\quad 252505-3$} & \\
\hline PROJECT ID: & \multicolumn{4}{|l|}{ '’1581 } & \multicolumn{4}{|c|}{ DATE SAMPLED: 5702} & \\
\hline PROJECT \#: & \multicolumn{4}{|l|}{30033} & \multicolumn{5}{|c|}{ NEL SAMPLE ID: L0205125-003A } \\
\hline MATRIX: & SOLID & & & & & & & & \\
\hline \multicolumn{2}{|l|}{ Parameter } & Result & Unit & $\begin{array}{c}\text { Reporting } \\
\text { Limit }\end{array}$ & DF & Method & Prep Date & Analyzed & Analyst \\
\hline \multicolumn{2}{|c|}{ Diesel Range Organics (C12-C22) } & ND & $\mathrm{mg} / \mathrm{kg}$ & 10 & 1 & SW8015Ext & $05 / 13: 02$ & 051502 & PXC-LY \\
\hline \multicolumn{2}{|c|}{ Gasoline Range Organics iCs-C12) } & ND & $\mathrm{mg} / \mathrm{Kg}$ & 10 & 1 & SW8015Ext & $05 / 13 / 02$ & $0515 \% 2$ & PXC-LV \\
\hline \multicolumn{2}{|c|}{ Oil Range Organics (C22-C34) } & ND & $\mathrm{mg} / \mathrm{Kg}$ & 50 & 1 & SW8015Ex1 & $05: 1302$ & $05.15 \% 2$ & PXC-LY \\
\hline \multicolumn{2}{|c|}{ Total Petroleum Hydrocarbons } & ND & $\mathrm{mg} / \mathrm{Kg}$ & 10 & 1 & SW'8015Ext & $05: 1302$ & 051502 & PXC-LY \\
\hline \multicolumn{2}{|c|}{ Surr: n-Octacosane } & 86.1 & $\%$ REC & $55-130$ & 1 & SW8015Ext & $05 / 13 / 02$ & $05 \cdot 15 \% 2$ & $\mathrm{PXC}-\mathrm{LV}$ \\
\hline
\end{tabular}

ND - Not Detected at the Reporting Limit DF - Dilution Factor

Date: $10-\mathrm{May}-02$
B - Analyte detected in the associated Method Blank

S - Spike Recovery outside accepted recovery limits

$E$ - Value above quantitation range
Page 3 of 46 
NEL Laboratories

\begin{tabular}{|c|c|c|c|c|c|c|c|c|c|}
\hline CLIENT: & \multicolumn{3}{|c|}{ Bechtel Nevada } & & CLI & NT ID: & \multicolumn{2}{|l|}{$252505-4$} & \\
\hline PROJECT ID: & \multicolumn{3}{|l|}{$V 1581$} & & \multicolumn{4}{|c|}{ DATE SAIIPLED: $5>02$} & \\
\hline I'ROJECT \#: & \multicolumn{3}{|l|}{30033} & & \multicolumn{4}{|c|}{ NEL SAIIPLE ID: L0205125-004A } & \\
\hline MATRIX: & SOLID & & & & & & & & \\
\hline \multicolumn{2}{|l|}{ Parameter } & $\underline{\text { Result }}$ & Linit & $\begin{array}{l}\text { Reporting } \\
\text { Limit }\end{array}$ & $\underline{\mathbf{D F}}$ & Method & Prep Date & Analyzed & Analyst \\
\hline \multicolumn{2}{|c|}{ Diesel Range Organics (C12-C22) } & ND & $\mathrm{mg} / \mathrm{Kg}$ & 10 & 1 & SW8015Ext & $05: 13: 02$ & 051402 & $\overline{P X C-L Y}$ \\
\hline \multicolumn{2}{|c|}{ Gasoline Range Organics ( $\mathrm{C} 8-\mathrm{Cl}$ ) } & ND & $\mathrm{mg} / \mathrm{Kg}$ & 10 & 1 & SW8015Ext & $05: 13 / 02$ & $05.1 \pm 02$ & PXC-LV \\
\hline \multicolumn{2}{|c|}{ Oil Range Organics (C22-C34) } & ND & $\mathrm{mg} / \mathrm{Kg}$ & 50 & $t$ & SW801SEX1 & $05 / 13 / 02$ & $05^{\prime} 14 / 02$ & $P X C-L V$ \\
\hline \multicolumn{2}{|c|}{ Total Petroleum Hydrocarbons } & ND & $\mathrm{mg} / \mathrm{Kg}$ & 10 & 1 & SW8015Ex1 & $05 / 13 / 02$ & 051402 & PXC-LV \\
\hline \multicolumn{2}{|c|}{ Surr: n-Octacosane } & 75.1 & $\%$ REC & $55-130$ & 1 & SW8015Ext & $05 / 13 / 02$ & $05114 / 02$ & PXC-LV \\
\hline
\end{tabular}

ND - Not Detcited at the Reporting Limit DF - Dilution Fuctor

Date: $16-\mathrm{May}-02$
B - Analyte detected in the associated Method Blank

S - Spike Recovery outside accepted recovery limits

E - Value above quantitation range
Page 4 of 46 
NEL LABORATORIES

\begin{tabular}{lll}
\hline CLIENT: & Bechtel Nevada & CLIENT ID: 2 252505-5 \\
PROJECT ID: & V1581 & DATE SAMPLED: 5702 \\
PROJECT \#: & 30033 & NEL SAMIPLE ID: L0205125.005A \\
MATRIX: & SOLID &
\end{tabular}

Parameter
Diesel Range Organics (C12-C22)
Gasoline Range Organics $(C 8-C 12)$
Oil Range Organics $(C 22-C 34)$
Total Petroleum Hydrocarbons
Surr: n-Octacosane

$\begin{array}{ccc}\frac{\text { Result }}{46} & \text { Linit } \\ \mathrm{mg} / \mathrm{kg} \\ \mathrm{ND} & \mathrm{mg} / \mathrm{Kg} \\ \mathrm{ND} & \mathrm{mg} / \mathrm{Kg} \\ 46 & \mathrm{mg} / \mathrm{Kg} \\ 83.1 & 11 \mathrm{REC}\end{array}$

\section{Reporting}

Limit

$\begin{array}{ll}\frac{\text { DF }}{1} & \text { Method } \\ 1 & \text { SW8015Ext } \\ 1 & \text { SW8015Ext } \\ 1 & \text { SW8015Ext } \\ 1 & \text { SW8015Exi } \\ 1 & \text { SW8015Ext }\end{array}$

Prep Date
051302
051302
051302
051302
$0513 \% 02$
Analyzed
051402
051402
$051+02$
051402
$051+102$

Analyst

10

PXC-LY

PXC-LV

$P X C-L 1$

PXC-LV

$55-130$

$0=13 / 02$

PXC-LY

\footnotetext{
ND - Not Detected at the Reporting I.imit

DF - Dilurion Facin
}

Date: $(6-M a)-02$
B - Analyte detected in the associated Method Blank

S - Spike Recovery outside accepted recovery limus

$\mathrm{E}$ - Volue above quantitation range 
NEL LABORATORIES

\begin{tabular}{|c|c|c|c|c|c|c|c|c|}
\hline CLIENT: & \multirow{4}{*}{$\begin{array}{l}\text { Bechtel Nevada } \\
11581 \\
30033 \\
\text { SOLID (TCLP) }\end{array}$} & & & \multicolumn{4}{|c|}{ CLIENT ID: $\quad 252505-5$} & \\
\hline PROJECT ID: & & & & \multicolumn{5}{|c|}{ DATE SAMPLED: 5702} \\
\hline PROJECT \#: & & & & \multicolumn{5}{|c|}{ NEL SAMPLE ID: $10205125005 B$} \\
\hline MATRIX: & & & & & & & & \\
\hline Parameter & Result & $\underline{\text { Unit }}$ & $\begin{array}{l}\text { Reporting } \\
\text { Limit }\end{array}$ & $\underline{\mathrm{DF}}$ & Method & Prep Date & Analyzed & Analyst \\
\hline Cadmium & ND & $\mathrm{mg} \mathrm{L}$ & 0.0050 & 1 & SW 6010B-To & $05 / 1402$ & $05.14: 02$ & FIF-Reno \\
\hline
\end{tabular}

ND - No: Detected at the Reporting L Imit DF - Dilution Factor

Date: 16-May-02
B - Analyte detected in the associated Method Blank

S - Spike Recovery outside accepted recovery himits

$E$ - Value above quantitation range
Page 6 of 46 
NEL LABORATORIES

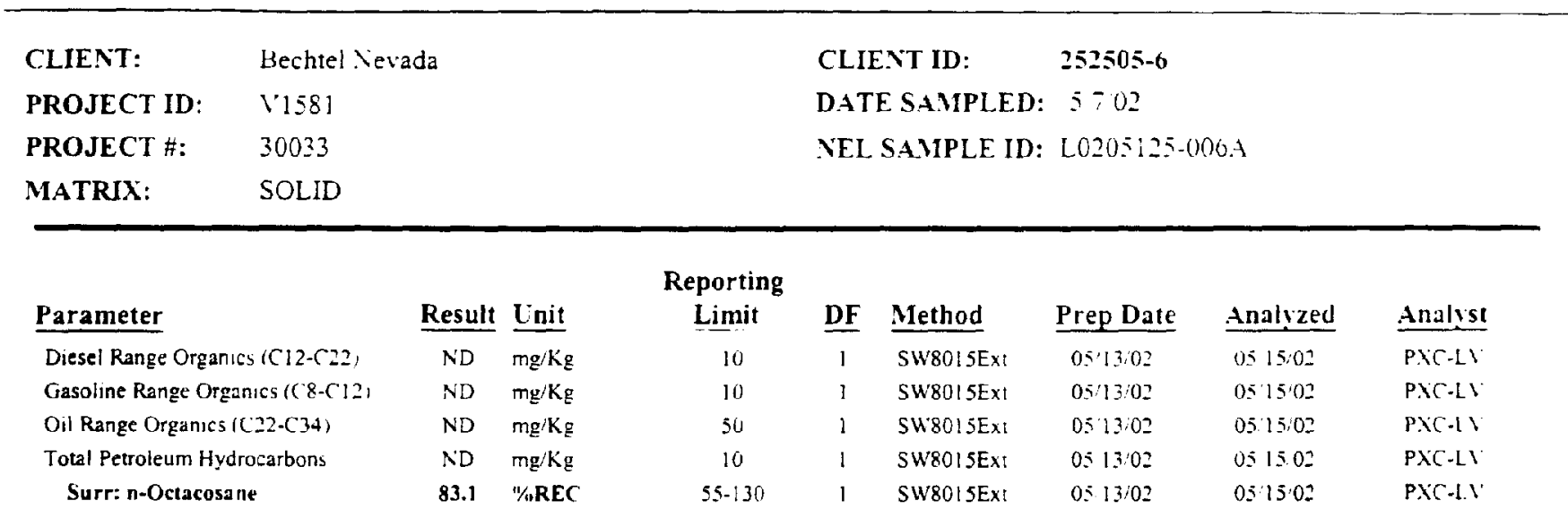

ND - Not Detected at the Reparting Lim!

DF - Dilution Factor

Date: /6-May-02
B - Analyte detected in the associated Method Blank

S - Spike Recovery outside accepted recovery limits

$E$ - Value above quantitation range
Page 7 of 46 
NEL LABORATORIES

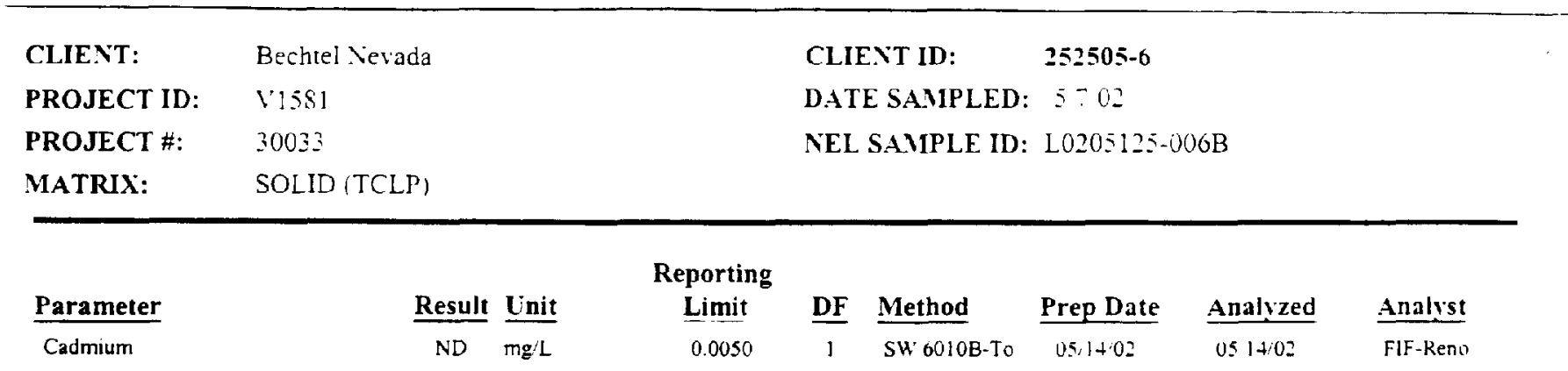

ND - Not Detected at the Reporting Limit DF - Dilution Factor

Date: 16-May-02
B - Analyte detected in the associated Method Blank S - Spike Recovery outside accepted recovery limits $E$ - Value above quantitation range
Page 8 of 46 
NEL LABORATORIES

\begin{tabular}{|c|c|c|c|c|c|c|c|c|c|}
\hline CLIENT: & \multicolumn{3}{|c|}{ Bechrel Nevada } & & \multicolumn{3}{|c|}{ CLIENT ID: $\quad 252505-7$} & & \\
\hline PROJECT ID: & \multicolumn{3}{|l|}{$\vee 1581$} & & \multicolumn{4}{|c|}{ DATE SAMIPLED: $5: 02$} & \\
\hline PROJECT \#: & \multicolumn{3}{|l|}{30033} & & \multicolumn{4}{|c|}{ NEL SAMPLE ID: L0205125.00-A } & \\
\hline MATRIX: & SOLID & & & & & & & & \\
\hline \multicolumn{2}{|l|}{ Parameter } & Result & Unit & $\begin{array}{c}\text { Reporting } \\
\text { Limit }\end{array}$ & DF & Method & Prep Date & Analyzed & Analyst \\
\hline \multicolumn{2}{|c|}{ Diesel Range Organics (C12-C22) } & ND & $\mathrm{mg} / \mathrm{Kg}$ & 10 & 1 & SW8015Ex: & 0.51302 & $051+02$ & PXC-LI \\
\hline \multicolumn{2}{|c|}{ Gasoline Range Organics ic $8-C 12$, } & ND & $\mathrm{mg} / \mathrm{Kg}$ & 10 & 1 & SW8015EX1 & 0513.02 & $051+02$ & PXC-LV \\
\hline \multicolumn{2}{|c|}{ Oil Range Organics ( $\mathrm{C} 22-\mathrm{C}^{24}$; } & ND & $\mathrm{mg} \times \mathrm{kg}$ & 50 & 1 & SW801SEX: & $0 \div 1: 02$ & $0 \leq 1+02$ & PXC-LY \\
\hline \multicolumn{2}{|c|}{ Tota! Petroleum Hydrocarbons } & $\mathrm{ND}$ & $\mathrm{mg} \cdot \mathrm{kg}$ & 10 & 1 & SW8015Ex: & 051302 & 051402 & $P X C-L Y$ \\
\hline \multicolumn{2}{|c|}{ Surr: n-Octacosane } & 57.1 & $\%$ REC & $55-130$ & 1 & SW8015Ex: & $05: 13 / 02$ & 051402 & PXC-LV \\
\hline
\end{tabular}

ND - Not Detectud at the Reporting limit

DF - Dilutwn Facior

Date: 16-.Mar-0)
B - Analyte detected in the associated Method Blank

S - Spike Recovery outside accepted recovery limits

$E$ - Value above quantitation range 
NEL LABORATORIES

\begin{tabular}{|c|c|c|c|c|c|c|c|c|}
\hline CLIENT: & \multicolumn{3}{|l|}{ Bechtel Vevada } & \multicolumn{5}{|c|}{ CLIENT ID: $\quad 252505-7$} \\
\hline PROJECT ID: & \multicolumn{3}{|l|}{$V 1581$} & \multicolumn{5}{|c|}{ DATE SAMPLED: 5702} \\
\hline PROJECT \#: & \multicolumn{3}{|l|}{30033} & \multicolumn{5}{|c|}{ NEL SAMPLE ID: L0205125-007B } \\
\hline MATRIX: & SOLID (TCLP) & & & & & & & \\
\hline Parameter & Result & Unit & $\begin{array}{l}\text { Reporting } \\
\text { Limit }\end{array}$ & $\underline{\mathbf{D F}}$ & Method & Prep Date & Analvzed & Analysi \\
\hline Cadmium & ND & $\mathrm{mg} / \mathrm{L}$ & 0.0050 & 1 & SW 6010B-To & $0511+02$ & 051402 & Fif-Reno \\
\hline
\end{tabular}

ND - Not Detected at the Reporting Limit DF - Dilution Factor

Date: 16-May-02
B - Analyte detected in the associated Method Blank

S - Spike Recovery outside accepted recovery limits

E - Value above quantitation range

Page 10 of 46 
NEL LABORATORIES

\begin{tabular}{lll}
\hline CLIENT: & Bechre! Nevada & CLIENT ID: $252505-8$ \\
PROJECT ID: & 11581 & DATE SAMPLED: $5-02$ \\
PROJECT \#: & 30033 & NEL SAIIPLE ID: L0205125-00SA \\
MATRIX: & SOLID & \\
\hline
\end{tabular}

\begin{tabular}{|c|c|c|c|c|c|c|c|c|}
\hline Parameter & Result & $\underline{\text { Unit }}$ & $\begin{array}{l}\text { Reporting } \\
\text { Limit }\end{array}$ & $\underline{\mathrm{DF}}$ & Method & Prep Date & Analyzed & Analyst \\
\hline Diesel Range Organics (C12-C22) & ND & $\mathrm{mg} / \mathrm{Kg}$ & 10 & 1 & SW80:5Ex: & 051302 & $0 \leq 1+02$ & PXCOA \\
\hline Gasoline Range Organics (C8-CI2) & ND & $\mathrm{mg} / \mathrm{Kg}$ & 10 & 1 & SW8015Ext & $0513 / 02$ & $0 \leq 14.02$ & PSC-11 \\
\hline Oil Range Organics $(\mathrm{C} 22-\mathrm{C} 34)$ & ND & $\mathrm{mg} / \mathrm{Kg}$ & 50 & 1 & SW8015Ext & $0513 / 02$ & $05: 4 / 02$ & $P X C-L$ \\
\hline Total Petroleum Hydrocarbons & ND & $\mathrm{mg} / \mathrm{Kg}$ & 10 & 1 & SW'80:5Ex: & $05: 13: 02$ & $0 \leq 1402$ & PXC.LY \\
\hline Surr: n-Octacosane & 77.1 & $1 \%$ REC & $55-130$ & 1 & SW8015Ex: & $0513 / 02$ & $0514 / 02$ & PXC-LY' \\
\hline
\end{tabular}

ND - Not Detecied at the Reporisng L.mit

DF - Dilutuon Fuctor

Date: $16-\mathrm{May}-02$
B - Analyte detected in the associated Method Blank

S - Spike Recovery outside accepted recovery limuls

$E$ - Value above quantitation range
Page 11 of 46 
NEL LABORATORIES

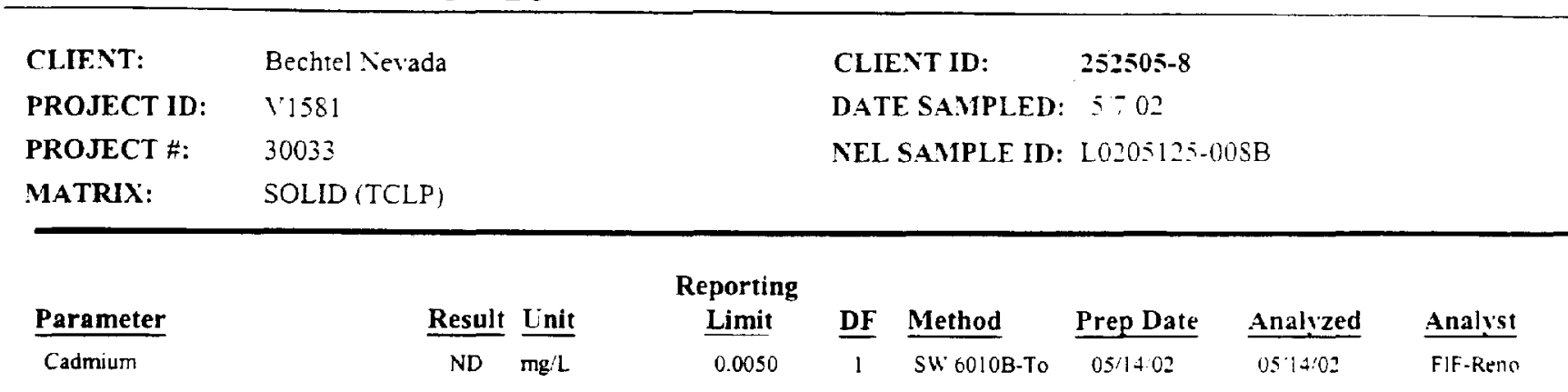

ND - Not Detected at the Reporting Limit

DF - Dilution Factor

Date: $16-M a y-02$
B - Analyte detected in the associated Method Blank

S - Spike Recovery outside accepted recovery limits

$E$ - Value above quantitation range
Page 12 of 46 
NEL LABORATORIES

\begin{tabular}{lll}
\hline CLIENT: & Bechtel levada & CLIENT ID: \\
PROJECT ID: & 11581 & DATE SAMO5-9 \\
PROJECT \#: & 30033 & NEL SAMPLE ID: L0205125-009A \\
MATRIX: & SOLID &
\end{tabular}

\begin{tabular}{|c|c|c|c|c|c|c|c|c|}
\hline Parameter & Result & Unit & $\begin{array}{c}\text { Reporting } \\
\text { Limit }\end{array}$ & $\underline{\text { DF }}$ & Method & Prep Date & Analyzed & Analyst \\
\hline Diesel Range Organics iC $12-\mathrm{C} 22$, & ND & $\mathrm{mg} / \mathrm{Kg}$ & 10 & 1 & SW8015Ex1 & 051302 & $051+0 ?$ & P.CC-LY \\
\hline Gasoline Range Organics (C8-C12) & ND & $\mathrm{mg} / \mathrm{Kg}$ & 10 & 1 & SW80isExi & $05 / 13 / 02$ & 051402 & PXC-LY \\
\hline Oil Range Organics $(\mathrm{C} 22-\mathrm{C} 34 \mathrm{r}$ & $N D$ & $\mathrm{mg} / \mathrm{Kg}$ & so & 1 & SW8015Ext & 051302 & 051402 & PXC.LI' \\
\hline Total Petroleum Hydrocarbons & ND & $\mathrm{mg} / \mathrm{Kg}$ & 10 & 1 & SW8015Ex: & $05 \div 13 / 02$ & 051402 & PXC-LY \\
\hline Surr: n-Octacosane & 85.1 & $\%$ REC & $55-130$ & 1 & SW8015Ext & $05 / 13 / 02$ & $05 / 1+02$ & $P X C-L Y$ \\
\hline
\end{tabular}

ND - Not Detecied at :he Repurang Limi

DF - Dihtion Futw

Date: $/(1-.1 / a, 1-02$
B. Analyte detected in the associated Method Blank

S - Spike Recovery outside accepted recovery limits

$E$ - Value above quantitation range
Page 13 of 46 
NEL LABORATORIES

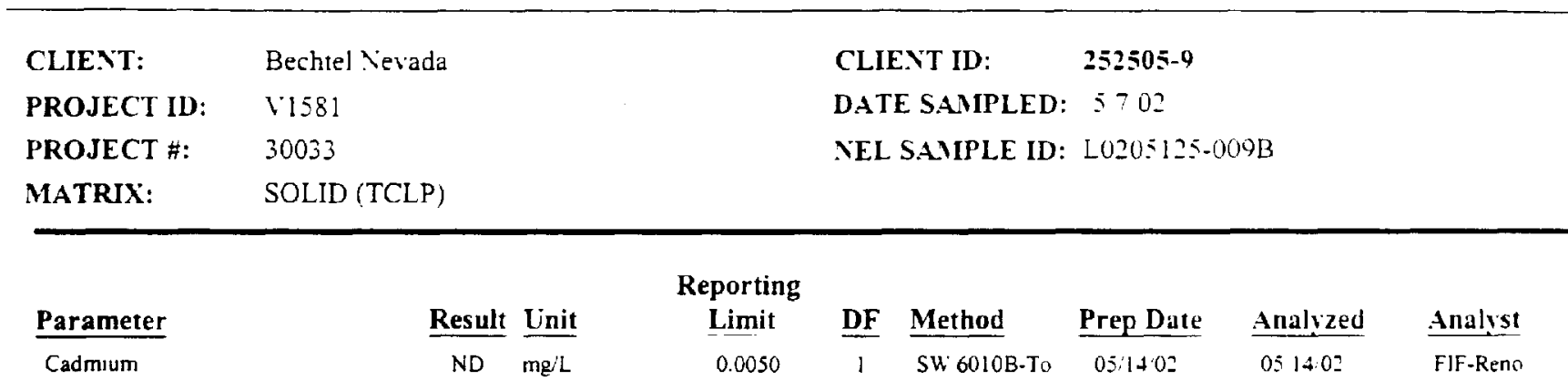

ND - Not Detected at the Reporting Limit DF - Dilution Factor

Date: 16-May-02
B - Analyte detected in the associated Method Blank

S - Spike Recovery outside accepted recovery timits

E - Value above quantitation range 
NEL LABORATORIES

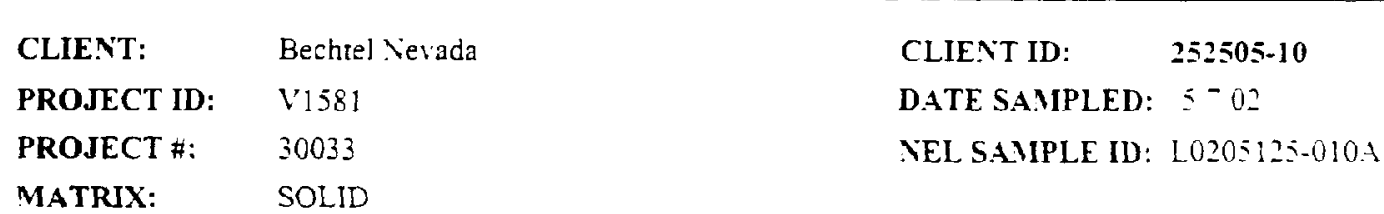

\begin{tabular}{|c|c|c|c|c|c|c|c|c|}
\hline Parameter & Result & Unit & $\begin{array}{l}\text { Reporting } \\
\text { Limit }\end{array}$ & DF & Method & Prep Date & Analized & Analyst \\
\hline Diesel Range Organics (C12-C22) & ND & $\overline{\mathrm{mg}_{\mathrm{g}} \mathrm{g}}$ & 10 & 1 & $\overline{\text { SW8015EX1 }}$ & $0513: 02$ & $051+02$ & $\overline{P X C-L Y}$ \\
\hline Gasoline Range Organucs ( $(8-\mathrm{C} 12)$ & ND & $\mathrm{mg} / \mathrm{Kg}$ & 10 & 1 & SW8015Ext & $0513 \% 02$ & 051402 & PXC-LI \\
\hline Oil Range Organics (C22-C34) & $\mathrm{ND}$ & $\mathrm{mg} / \mathrm{Kg}$ & 50 & 1 & SW'8015Ext & $0513: 02$ & $0514: 02$ & PXC.LI \\
\hline Total Petroleum Hydrocarbons & ND & $\mathrm{mg} \cdot \mathrm{Kg}$ & 10 & l & SW8015Ex1 & $05 / 13 / 02$ & $051+02$ & PXC.LY \\
\hline Surr: n-Octacosane & 78.1 & $\%$ REC & $55-130$ & 1 & SW8015EXt & $05: 13 / 02$ & $0514 / 02$ & PXC-LY \\
\hline
\end{tabular}

ND - Not Detected at the Reporting Limit

DF - Dilution Factor

Date: /6-May-02
B - Analyte detected in the associated Method Blank

S - Spike Recovery outsıde accepted recovery imits

$E$ - Value above quantitation range
Page 15 of 46 


\section{NEL LABORATORIES}

\begin{tabular}{|c|c|c|}
\hline CLIENT: & Bechtel Nevada & CLIENT ID: \\
\hline PROJECT ID: & 11581 & DATE SAMPLED: $5-02$ \\
\hline PROJECT $\#:$ & 30033 & NEL SAIIPLE ID: L0205125-010 \\
\hline MATRIX: & SOLID (TCLP) & \\
\hline
\end{tabular}

\begin{tabular}{|c|c|c|c|c|c|c|c|c|}
\hline Parameter & Result & $\underline{\text { Unit }}$ & $\begin{array}{l}\text { Reporting } \\
\text { Limit }\end{array}$ & DF & Method & Prep Date & Analyzed & Analyst \\
\hline Cadmium & $\mathrm{ND}$ & $\mathrm{mg} / \mathrm{L}$ & 0.0050 & 1 & SW: $6010 \mathrm{~B}-\mathrm{T}_{0}$ & $051+02$ & $0 \leq 1+02$ & FIF-Renw \\
\hline
\end{tabular}

ND - Not Detected at the Reportıng Limit

DF - Dilutinn Factor

Date: 16-Mav-0?
B-Analyte detected in the associated Method Blank

S - Spike Recovery outside accepted recovery limits

E - Value above quantitation range
Page 16 of 46 
NEL LABORATORIES

\begin{tabular}{lll} 
CLIENT: & Bechiel Nevada & CLIENT ID: $252504-1 W$ \\
PROJECT ID: & 11581 & DATE SAMPLED: 5202 \\
PROJECT \#: & 30033 & NEL SAMPLE ID: L0205125-011A \\
MATRIX: & SOLID & \\
\hline
\end{tabular}

\begin{tabular}{|c|c|c|c|c|c|c|c|c|}
\hline Parameter & Result & Unit & $\begin{array}{l}\text { Reporting } \\
\text { Limit }\end{array}$ & DF & Method & Prep Date & Analyzed & Analys \\
\hline Diesel Range Organics ( $\mathrm{Cl} 2-\mathrm{C} 22)$ & ND & $\mathrm{mg} / \mathrm{Kg}$ & 10 & 1 & SW8015Ex: & $05 / 13 / 02$ & 05.1402 & PXC-LY \\
\hline Gasoline Range Organics (C8-C12) & ND & $\mathrm{mg} / \mathrm{Kg}$ & 10 & 1 & SW80I5Ex: & $05 / 13 / 02$ & 051402 & PXC-LY \\
\hline Oil Range Organics (C22-C341) & ND & $\mathrm{mg} / \mathrm{Kg}$ & 50 & 1 & SW80!5Ext & $05 / 13 / 02$ & $05 / 14 / 02$ & PXC-LY \\
\hline Total Petroleum Hydrocarbons & ND & $\mathrm{mg} / \mathrm{Kg}$ & 10 & 1 & SW801SExI & $05: 13: 02$ & 051402 & PXC-LY \\
\hline Surr: n-Ostacosane & 92.1 & $\% \mathbf{R E C}$ & $55-130$ & 1 & SW8015Ext & $05 / 13 / 02$ & $05: 14: 02$ & PXC-LY \\
\hline
\end{tabular}

ND - Not Detected a! ihe Repurting l.. imil

DF - Dilution lastor

Date: /6-May-0?
B - Analyte detected in the associated Method Blank

S - Spike Recovery outside accepted recovery limits

E - Value above quantitation range
Page 17 of 46 
NEL LABORATORIES

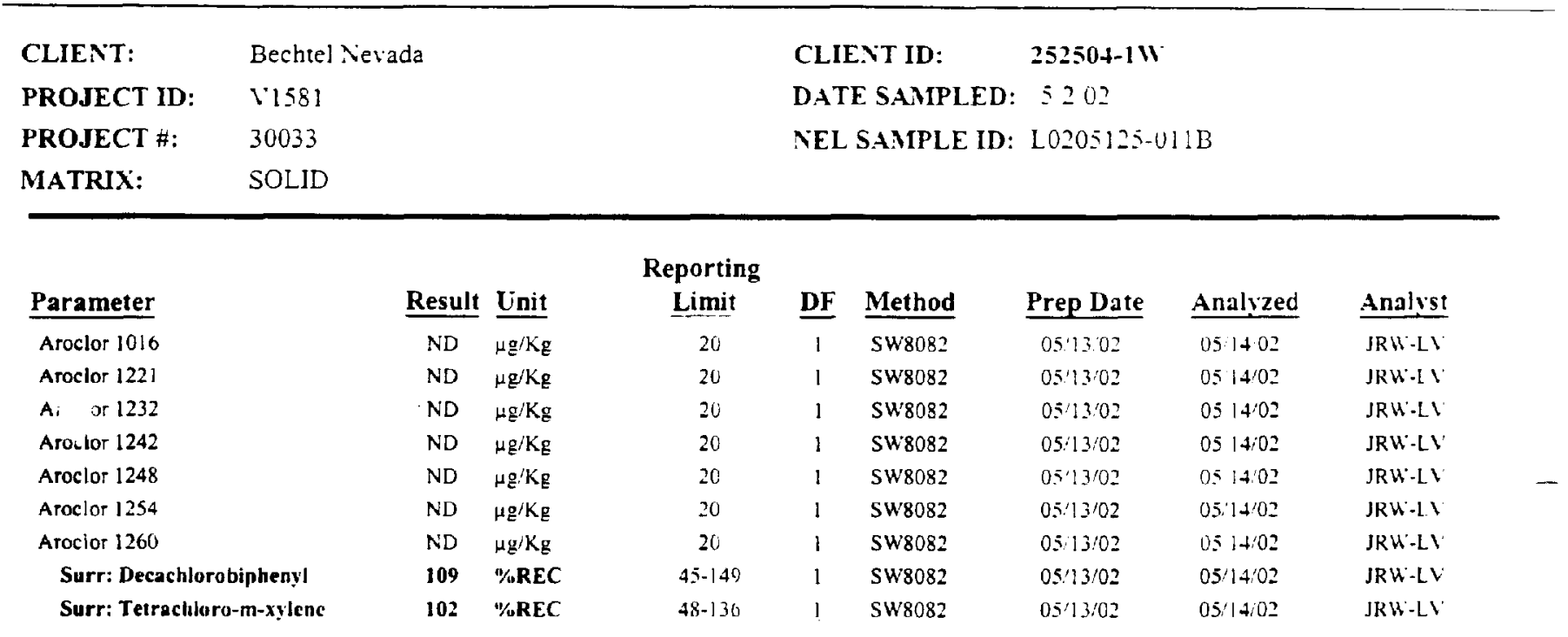

ND - Not Detected at the Reporting Limit DF - Dilution Factor

Date: /6-May-02
B - Analyte detected in the associated Method Blank

S - Spike Recovery outside accepted recovery limıts

E - Value above quantitation range
Page 18 of 46 
NEL LABORATORIES

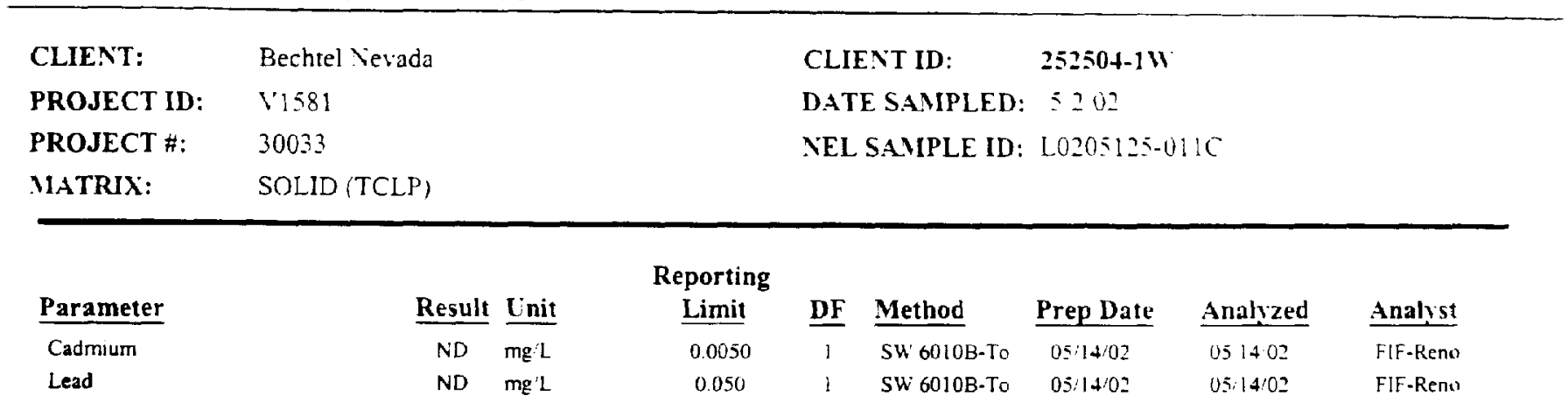

ND - Not Detected at the Reporting Limit

DF - Dilutuon Factor

Date: 16-May-02
B - Analyte detected in the associated Method Blank

S. Spike Recovery outside accepted recovery limits

$E$ - Value above quantitation range
Page 19 of 46 
NEL LaBoratories

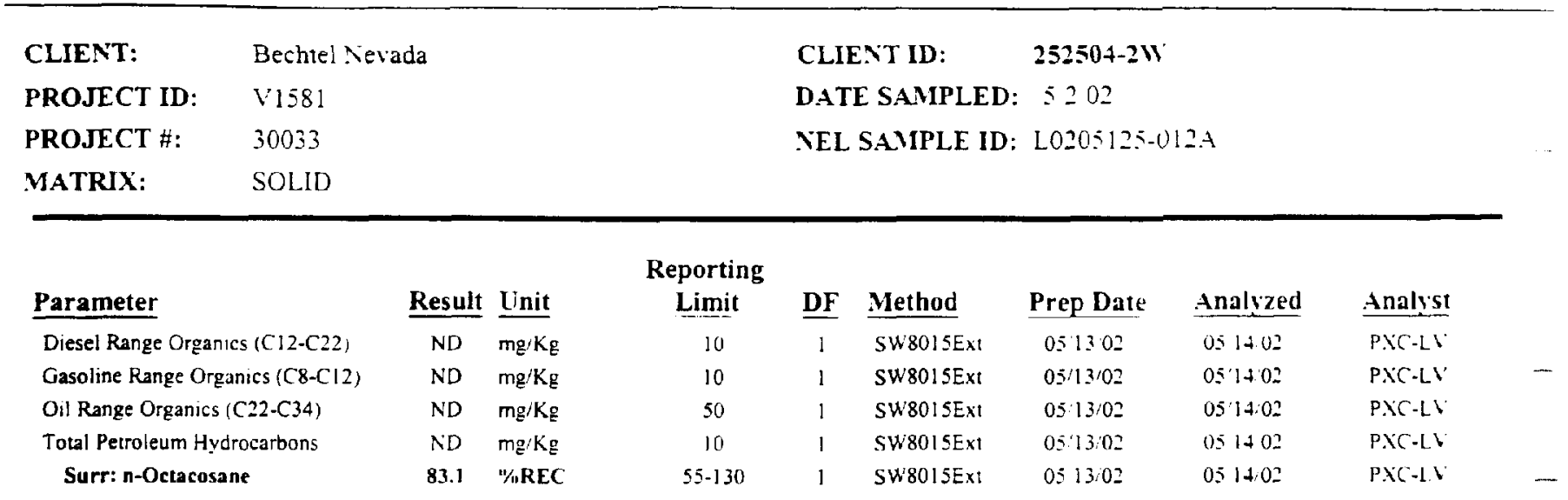

ND - Not Detected at the Reportung Limit

DF - Dilution Factor

Date: 16-May-02
B - Analyte detected in the associated Method Blank

S - Splke Recovery outside accepted recovery lımıs

E- Value above quantitation range
Page 20 of 46 
NEL LABORATORIES

\begin{tabular}{lll}
\hline CLIENT: & Bechiel Nevada & CLIENT ID: $252504-2 W$ \\
PROJECT ID: & V1581 & DATE SAMPLED: 52 02 \\
PROJECT \#: & 30033 & NEL SAMPLE ID: L0205125-012B \\
MATRIX: & SOLID &
\end{tabular}

\begin{tabular}{|c|c|c|c|c|c|c|c|c|}
\hline Parameter & $\underline{\text { Result }}$ & $\underline{\text { Unit }}$ & $\begin{array}{c}\text { Reporting } \\
\text { Limit }\end{array}$ & $\underline{\mathrm{DF}}$ & Method & Prep Date & Analyzed & Analyst \\
\hline Aroclor 1016 & ND & $\mu \mathrm{g} / \mathrm{Kg}$ & 20 & 1 & SW8082 & $0513 \% 02$ & $0 \leqslant 14 / 02$ & $J R W-L Y$ \\
\hline Aroclor 1221 & ND & $\mu \mathrm{g} / \mathrm{Kg}$ & 20 & 1 & SW8082 & $05: 13 / 02$ & 05.1402 & $J R U-L Y$ \\
\hline Aroclor 1232 & ND & $\mu g / K g$ & 20 & 1 & SW8082 & $05,13: 02$ & 051202 & JRH-LI \\
\hline Aroclor 1242 & ND & $\mu \mathrm{g} / \mathrm{Kg}$ & 20 & 1 & SW8082 & $0513 \cdot 02$ & 051402 & $J R W-L Y$ \\
\hline Arocior 1248 & ND & $\mu g / K g$ & 20 & 1 & SW8082 & $05 / 13 / 02$ & $05 / 4 / 02$ & $J R W^{\prime}-L Y$ \\
\hline Aroclor 1254 & ND & $\mu g / K g$ & 20 & 1 & SW8082 & $05: 13: 02$ & $051+02$ & $J R H-L Y$ \\
\hline Aroclor 1260 & ND & $\mu \mathrm{g} / \mathrm{Kg}$ & 20 & 1 & SW8082 & $05 \div 13 \% 02$ & $0514 / 02$ & $J R H-L I$ \\
\hline Surr: Decachlorobiphenyl & 111 & $\%$ REC & $45-149$ & 1 & SW808I & $05: 13 / 02$ & 05.1402 & $J R W-1 \mathrm{I}$ \\
\hline Surr: Tetrachloro-m-xylene & 107 & $\%$ REC & $48-136$ & 1 & SW8082 & $0 \leq 13: 02$ & $05: 14: 02$ & $J R W^{\prime}-L Y^{\prime}$ \\
\hline
\end{tabular}

ND - Not Detected at the Reporting Limit

DF - Dihution Factor

Date: $16-M a y-02$
B - Analyte detected in the associated Method Blank

S - Spike Recovery outside accepted recovery limits

$E$ - Value above quantitation range
Page 21 of 46 
NEL LABORATORIES

\begin{tabular}{|c|c|c|c|c|c|c|c|c|}
\hline CLIENT: & \multicolumn{3}{|l|}{ Bechtel Nevada } & \multicolumn{4}{|c|}{ CLIENT ID: $\quad 25250+-2 W$} & \\
\hline PROJECT ID: & \multicolumn{3}{|l|}{1581} & \multicolumn{4}{|c|}{ DATE SAMIPLED: 5202} & \\
\hline PROJECT \#: & \multicolumn{3}{|l|}{30033} & \multicolumn{5}{|c|}{ NEL SAMPLE ID: L0205125-012C } \\
\hline MATRIX: & SOLID (TCLP) & & & & & & & \\
\hline Parameter & $\underline{\text { Result }}$ & $\underline{\text { Unit }}$ & $\begin{array}{c}\text { Reporting } \\
\text { Limit }\end{array}$ & $\underline{\mathrm{DF}}$ & Method & Prep Date & Analyzed & Analyst \\
\hline Cadmium & $N D$ & $\mathrm{mg} / \mathrm{L}$ & 0.0050 & 1 & SW 6010B-To & $051+02$ & $051+02$ & FIF-Reno \\
\hline Lead & ND & $\mathrm{mg} / \mathrm{L}$ & 0.050 & 1 & SW 6010B-To & $051+02$ & $051+02$ & FIF-Reno \\
\hline
\end{tabular}

ND - Not Detcetcd at the Reporting Limit DF - Dilution Factor

Date: /6-May-02
B - Analyte detected in the associated Method Blank

S - Spike Recovery outside accepted tecovery limits

E - Value above quamtitation range
Page 22 of 46 
NEL LABORATORIES

\begin{tabular}{|c|c|c|c|c|c|c|c|c|c|}
\hline CLIENT: & \multicolumn{3}{|c|}{ Bechtel Nevada } & & \multicolumn{2}{|c|}{ CLIENT ID: } & \multicolumn{2}{|c|}{$25250+-3 w$} & \\
\hline PROJECT ID: & \multicolumn{3}{|l|}{$V 1581$} & & \multicolumn{4}{|c|}{ DATE SAAIPLED: $: 202$} & \\
\hline PROJECT \#: & \multicolumn{3}{|l|}{30033} & & \multicolumn{4}{|c|}{ NEL SAMIPLE ID: L0205125-01:A } & \\
\hline MATRIX: & \multicolumn{4}{|l|}{ SOI.IT } & & & & & \\
\hline \multicolumn{2}{|l|}{ Parameter } & Result & $\underline{\text { Unit }}$ & $\begin{array}{l}\text { Reporting } \\
\text { Limit }\end{array}$ & $\underline{\mathrm{DF}}$ & Method & Prep Date & Analyzed & Analyst \\
\hline \multicolumn{2}{|c|}{ Diesel Range Organics $\left(\mathrm{C}_{12}-\mathrm{C}_{22}\right)$} & $\mathrm{ND}$ & $\mathrm{my} / \mathrm{kg}$ & 10 & 1 & $\overline{S W 8015 E \times 1}$ & 051302 & $0 \leq 140 ?$ & PXC.LY \\
\hline \multicolumn{2}{|c|}{ Gasoline Range Organics (C8-C12) } & ND & $\mathrm{mg} / \mathrm{Kg}$ & 10 & 1 & SW8015Ext & 051302 & $051+02$ & PXC.LY \\
\hline \multicolumn{2}{|c|}{ Oil Range Organics ( $\mathrm{C} 22 \cdot \mathrm{C} 34$ ) } & ND & $\mathrm{mg} / \mathrm{Kg}$ & so & $i$ & SW8015Ex1 & $05: 13: 02$ & 051402 & PXC-LY \\
\hline \multicolumn{2}{|c|}{ Total Petroleum Hydrocarbons } & ND & $\mathrm{mg} \mathrm{Kg}$ & $: 0$ & 1 & SW8015Ext & $05: 1302$ & $051+02$ & PXC.LX' \\
\hline \multicolumn{2}{|c|}{ Surr: n-Octacosane } & 93.1 & $\%$ REC & $55-130$ & 1 & SW8015Ex1 & $0513 / 02$ & $051+02$ & PXC-LV \\
\hline
\end{tabular}

ND - Not Detected at the Reportıng Limit

DF - Dilutuon Factor

Date: 16-May-02
B - Analyte detected in the associated Method Blank

S - Spike Recovery outside accepted recovery limits

E - Value above quantitation range 
NEL LABORATORIES

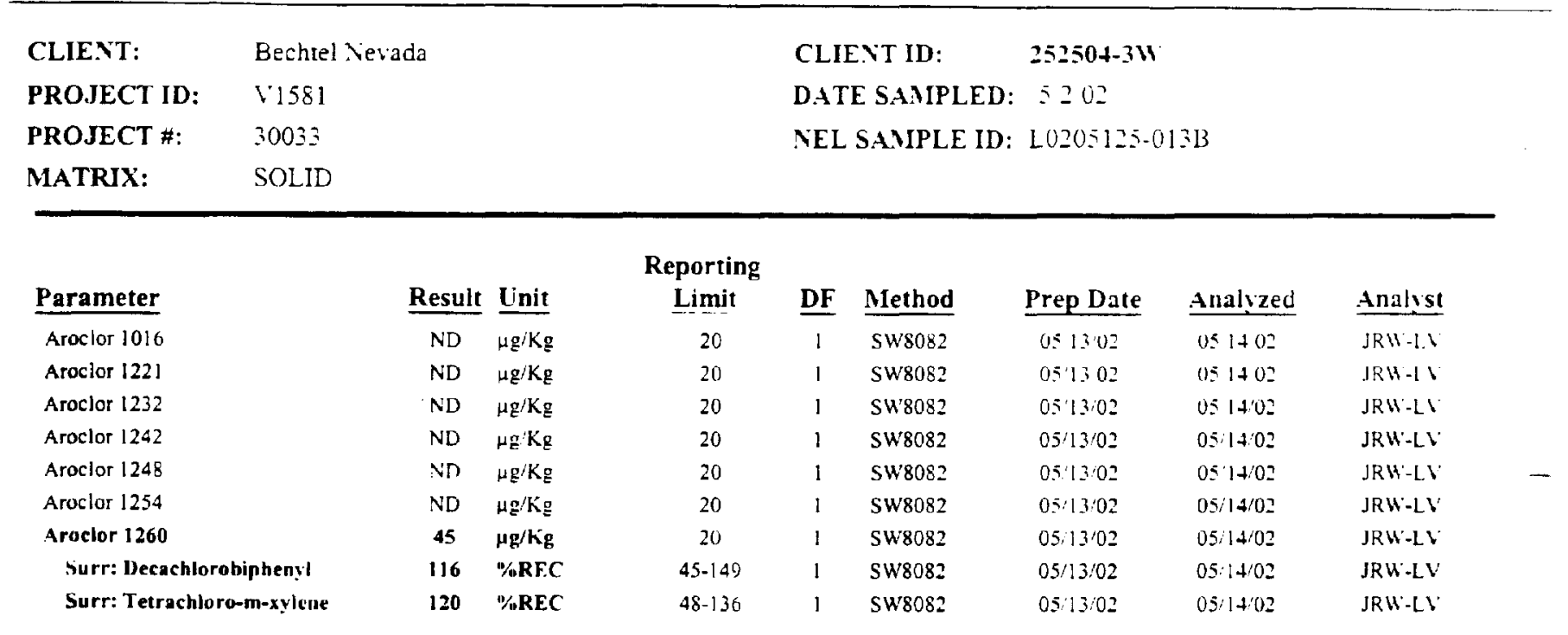

ND - Not Detected at the Reporting Limit

DF - Dilution Facin

Date: $16-M a v-n 2$
B - Analyte detected in the associated Method Blank

S - Spike Recovery outside accepted recovery lımıts

$E$ - Value above quantitation range
Page 24 of 46 


\section{NEL LABORATORIES}

$\begin{array}{ll}\text { CLIENT: } & \text { Bechtel levada } \\ \text { PROJECT ID: } & 11581 \\ \text { PROJECT \#: } & 30033 \\ \text { MATRIX: } & \text { SOLID (TCLP) }\end{array}$

CLIENT ID: $\quad 252504-3 W$

DATE SAMPLED: 5202

NEL SAIIPLE ID: L0205125-013C

\begin{tabular}{|c|c|c|c|c|c|c|c|c|}
\hline Parameter & Result & Unit & $\begin{array}{c}\text { Reporting } \\
\text { Limit }\end{array}$ & $\underline{\mathrm{DF}}$ & Method & Prep Date & Analyzed & Analyst \\
\hline Cadmium & $\mathrm{ND}$ & $\overline{\mathrm{mg} / \mathrm{L}}$ & 0.0050 & I & SW $6010 \mathrm{~B}-\mathrm{To}_{0}$ & 051402 & 051402 & FIF-Reni \\
\hline Lead & ND & $\mathrm{mg} / \mathrm{L}$ & 0.050 & 1 & SW 6010B-To & $05 / 140 ?$ & $0514 / 02$ & FIF-Renis \\
\hline
\end{tabular}

ND - Not Detected ist the Repurting Limit

DF - Dilution Factor

Date: 16-May-02
B - Analyte detected in the associated Method Blank

S - Spike Recovery outside accepted recovery limits

$E$ - Value above quantitation range
Page 25 of 46 
NEL LABORATORIES

\begin{tabular}{|c|c|c|c|c|c|c|c|c|c|}
\hline CLIENT: & \multicolumn{3}{|c|}{ Bechtel Vevada } & & CLII & NT In: & \multicolumn{2}{|l|}{$252504-4 W$} & \\
\hline PROJECT ID: & \multicolumn{3}{|l|}{$v 1581$} & & \multicolumn{4}{|c|}{ DATE SAMPLED: 5202} & \\
\hline PROJECT \#: & \multicolumn{3}{|l|}{30033} & & \multicolumn{4}{|c|}{ NEL SAMPLE ID: L020S125.014A } & \\
\hline MATRIX: & \multicolumn{4}{|l|}{ SOLID } & & & & & \\
\hline \multicolumn{2}{|l|}{ Parameter } & Result & Enit & $\begin{array}{l}\text { Reporting } \\
\text { Limit }\end{array}$ & $\underline{\mathbf{D F}}$ & Method & Prep Date & Analyzed & Analyst \\
\hline \multicolumn{2}{|c|}{ Dresel Range Organıcs (C12-C22। } & ND & $m g K g$ & 10 & 1 & SW80ljExi & $0513: 02$ & $0 \leq 1+02$ & PXC-LV \\
\hline \multicolumn{2}{|c|}{ Gasoline Range Organics ( $\mathrm{C} 8-\mathrm{C} / 2)$} & ND & $\mathrm{mg} / \mathrm{Kg}$ & 10 & 1 & SW8015Ex: & 051302 & 051402 & PAC-LI \\
\hline \multicolumn{2}{|c|}{ Oil Range Organcs ( $(22-C 34)$} & ND & $m g / K g$ & 50 & $i$ & SW'80:5Ex: & 051302 & 051202 & PXC-LX \\
\hline \multicolumn{2}{|c|}{ Total Petroleum Hydrocarbon: } & ND & $m g \cdot K g$ & 10 & $i$ & SW'80:5Ex: & $0513: 02$ & $051+02$ & PXC.LI \\
\hline \multicolumn{2}{|c|}{ Surr: n-Octacosane } & 72.1 & \%REC & $55-130$ & 1 & SW8015Ext & $05 / 13 / 02$ & $05 / 14102$ & PXC-LU \\
\hline
\end{tabular}

ND - Not Detectel at the Reportıng Limıt DF - Dilution Factor

Date: 6 6-May-02
B - Analyte detected in the associated Method Blank

S - Spike Recovery outside accepted recovery limıts

$\mathrm{E}$. Value above quantitation range
Page 26 of 46 


\begin{tabular}{|c|c|c|c|c|c|c|c|c|c|}
\hline CLIENT: & \multicolumn{4}{|c|}{ Bechrel Nevada } & \multicolumn{4}{|c|}{ CLIENT ID: $\quad 252504-41 W$} & \\
\hline PROJECT ID: & \multicolumn{4}{|l|}{11581} & \multicolumn{4}{|c|}{ DATE SAMIPLED: 5202} & \\
\hline PROJECT \#: & \multicolumn{4}{|l|}{30033} & \multicolumn{5}{|c|}{ NEL SAMPLE ID: L0205125-01+B } \\
\hline MATRIX: & \multicolumn{4}{|l|}{ SOLID } & & & & & \\
\hline Parameter & & Result & Unit & $\begin{array}{l}\text { Reporting } \\
\text { Limit }\end{array}$ & $\underline{\mathrm{DF}}$ & Method & Prep Date & Analized & Analyst \\
\hline Aroclor 1010 & & ND & $\mu g / K g$ & 20 & 1 & SW'8082 & 0511302 & $0 \div 1+02$ & JRW-LV \\
\hline Aroclor 1221 & & ND & $\mu \mathrm{g} / \mathrm{Kg}$ & 20 & 1 & SW8082 & $05: 13 ; 02$ & $051+02$ & JRW'-1:? \\
\hline Aroclor 1232 & & ND & $\mu g / \mathrm{Kg}$ & 20 & 1 & SW8082 & $05: 1302$ & $051+02$ & $J R W-L Y$ \\
\hline Aroclor 1242 & & ND & $\mu g^{\prime} \mathrm{Kg}$ & 20 & 1 & SW8082 & $05: 13 / 02$ & 051402 & $J R W-1$ \\
\hline Aroclor 1248 & & ND & $\mu \mathrm{g} / \mathrm{Kg}$ & 20 & 1 & SW8082 & $0513 / 02$ & 05.1402 & $J R H-1 \backslash$ \\
\hline Aroclor 1254 & & $\mathrm{ND}$ & $\mu \mathrm{g} / \mathrm{Kg}$ & 20 & 1 & SW'8082 & $05 / 13 / 02$ & $05.14 / 02$ & $J R H-L V$ \\
\hline Aroclor 1260 & & ND & $\mu \mathrm{g} / \mathrm{Kg}$ & 20 & 1 & Sw8082 & $05: 13 / 02$ & $05: 1402$ & IRW-IX \\
\hline Surr: Decachito & oipheny! & 95.5 & \%REC & 45.149 & 1 & Sw808? & 0513,02 & $05,14 / 02$ & $J R W-L Y$ \\
\hline Surr: Tetrachio & -m-xylens & 96.0 & $\% R E C$ & 48.130 & 1 & SW8082 & 051302 & 051402 & $J R M-\{\}$ \\
\hline
\end{tabular}

ND - Not Detected at the Reporting Limit

DF - Dilution Factor

Date: /6-May-02
B - Analyte detected in the associated Method Blank

S - Spike Recovery outside accepted recovery limits

$E$ - Value above quantitation range
Page 27 of 46 
NEL LABORATORIES

\begin{tabular}{ll} 
CLIENT: & Bechtel Nevada \\
PROJECT ID: & V'1581 \\
PROJECT \#: & 30033 \\
MATRIX: & SOLID (TCLP) \\
\hline
\end{tabular}

CLIENT ID: $\quad 252504-411$

DATE SAMIPLED: 5202

NEL SAMPLE ID: L0205125-014C

\begin{tabular}{|c|c|c|c|c|c|c|c|c|}
\hline Parameter & Result & Unit & $\begin{array}{l}\text { Reporting } \\
\text { Limit }\end{array}$ & $\underline{\mathrm{DF}}$ & Method & Prep Date & Analyzed & Analyst \\
\hline Cadmuum & $\mathrm{ND}$ & $\mathrm{mg} \cdot \mathrm{L}$ & 0.0050 & 1 & SW' $6010 \mathrm{~B}-\mathrm{TO}_{0}$ & $051 \div 02$ & 051402 & FIF-Rent \\
\hline Lead & ND & $\mathrm{mg} / \mathrm{L}$ & 0.050 & 1 & SH $6010 \mathrm{~B}-\mathrm{To}_{0}$ & 051402 & 05.1402 & FIF-Rent \\
\hline
\end{tabular}

ND - Not Detected at the Reportng Limit

DF - Dilutun Factor

Date: $16 \cdot 1 /(11-1) ?$
B - Analyte detected in the associated Method Blank

S - Spike Recovery outside accepted recovery lımits

$E$ - Value above quantitation range 
NEL LABORATORIES

\begin{tabular}{lll} 
CLIENT: & Bechiel Nevada & CLIENT ID: \\
PROJECT ID: & V'1581 & DATE SAMP4-5W \\
PROJECT \#: & 30033 & NEL SANIPLE ID: L0205125-015.t \\
MATRIX: & SOLID & \\
\hline
\end{tabular}

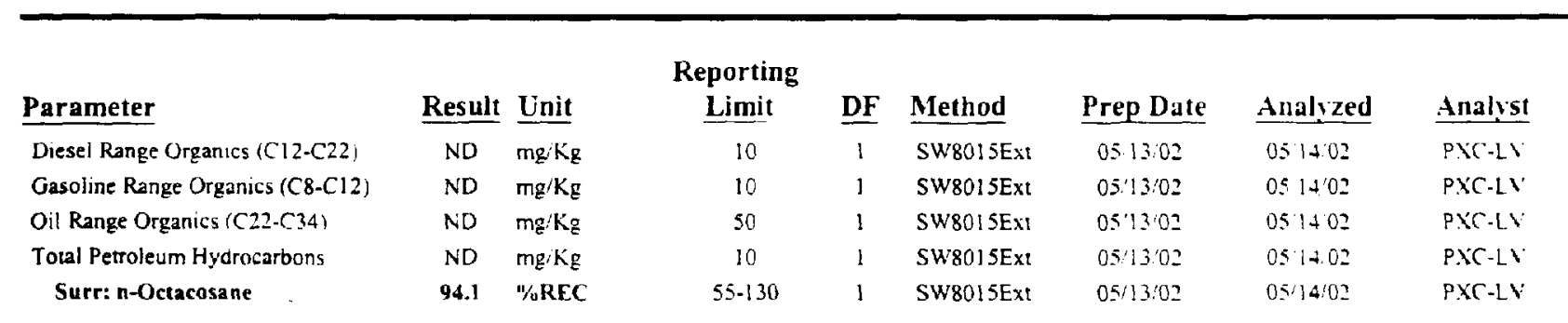

\footnotetext{
NS - Not Detected at the Reporing Limit

DF - Dilution Factor
}

Date: $/ 6-M a y-02$
B - Analyte detected in the associated Method Blank

S - Spike Recovery outside accepted recovery limits

$\mathrm{E}$ - Value above quantitation range 
NEL LABORATORIES

\begin{tabular}{lll}
\hline CLIENT: & Bechtel Nevada & CLIENT ID: \\
PROJECT ID: & 11581 & DATE SAIIPLED: 5 W \\
PROJECT \#: & 30033 & NEL SAIPLE ID: L0205125-015B \\
MATRIX: & SOLID &
\end{tabular}

\begin{tabular}{|c|c|c|c|c|c|c|c|c|}
\hline Parameter & Result & Init & $\begin{array}{l}\text { Reporting } \\
\text { Limit }\end{array}$ & $\underline{\text { DF }}$ & Method & Prep Date & Analyzed & Analyst \\
\hline Aroclor 1016 & ND & $\mu g, K g$ & 20 & $i$ & SW8082 & 0.513 .02 & $0 \leq 1 \div 03$ & $J R W-L V$ \\
\hline Aroclor 1221 & ND & $\mu g / \mathrm{Kg}$ & 20 & 1 & SW8082 & $05 / 13: 02$ & $0514 / 02$ & $J R H-L V$ \\
\hline Aroclor 1232 & ND & $\mu \mathrm{g} / \mathrm{Kg}$ & 20 & 1 & SW8082 & 051302 & $0511 \cdot 02$ & $J R H-L Y$ \\
\hline Aroclor 1242 & ND & $\mu \mathrm{g} / \mathrm{Kg}$ & 20 & 1 & SW8082 & 0513102 & $0514: 02$ & $J R W-1 Y$ \\
\hline Aroclor 1248 & ND & $\mu \mathrm{g} / \mathrm{Kg}$ & 20 & J & SW8082 & 0513102 & $051+102$ & $J R W-L V$ \\
\hline Aroclor 1254 & ND & $\mu g / K g$ & 20 & 1 & SW8082 & $05 / 13 / 02$ & $05 / 14 / 02$ & $J R W-L V$ \\
\hline Aroclor 1260 & ND & $\mu g / \mathrm{Kg}$ & 20 & 1 & SW'8082 & $0513: 02$ & 051402 & $J R W '-L V$ \\
\hline Surr: Decachlorobiphenyl & 105 & $\%$ REC & $45-149$ & 1 & SW8082 & $05 / 13 / 02$ & $05 / 1+102$ & $J R W-1 Y$ \\
\hline Surr: Tetrachioro-m-xylene & 103 & $\%$ REC & $48-136$ & 1 & SW8082 & $05: 13: 02$ & $05: 14: 02$ & $J R W-L V$ \\
\hline
\end{tabular}

ND - Not Detecled á llike Repurting 1 . Im

DF - Dilution Factor

Date: $10-M a y-02$
B - Analyte detected in the associated Method Blank

S - Spike Recovery outside accepted recovery immts

$\mathrm{E}$ - Value above quantitation range
Page 30 of 46 
NEL LABORATORIES

\begin{tabular}{lll}
\hline CLIENT: & Bechtel Nevada & CLIENT ID: $252504-5 W$ \\
PROJECT ID: & V1581 & DATE SAMPLED: 5202 \\
PROJECT \#: & 30033 & NEL SAMPLE ID: L0205125-0 $55 \mathrm{C}$ \\
MATRIX: & SOLID (TCLP) & \\
\hline
\end{tabular}

\begin{tabular}{|c|c|c|c|c|c|c|c|c|}
\hline Parameter & $\underline{\text { Result }}$ & Unit & $\begin{array}{l}\text { Reporting } \\
\quad \text { Limit }\end{array}$ & $\underline{\mathrm{DF}}$ & Method & Prep Date & Analyzed & Analyst \\
\hline Cadmium & ND & $m g / L$ & 0.0050 & 1 & SW $6010 \mathrm{~B}-\mathrm{To}$ & $0514 / 02$ & $051+02$ & FIF-Reno \\
\hline Lead & ND & $\mathrm{mg} / \mathrm{L}$ & 0.050 & 1 & SW $6010 \mathrm{~B}-\mathrm{TO}_{0}$ & 0514.02 & ביב 0514 & FIF-Renu \\
\hline
\end{tabular}

ND - Not Detected at the Reporting Limit DF - Dilution Factor

Date: $16-\mathrm{May}=0$ ?
B - Analyte detected in the associated Method Blank

S - Spike Recovery outside accepted recovery limits

E - Value above quantitation range 
NEL LABORATORIES

\begin{tabular}{|c|c|c|c|c|c|c|c|c|c|}
\hline CLIENT: & \multicolumn{4}{|c|}{ Bechtel Vevada } & \multicolumn{4}{|c|}{ CLIENT ID: $\quad 252504-1 \mathrm{E}$} & \\
\hline PROJECT ID: & \multicolumn{4}{|l|}{11581} & \multicolumn{5}{|c|}{ DATE SAMPLED: 5202} \\
\hline PROJECT \#: & \multicolumn{4}{|l|}{30033} & \multicolumn{5}{|c|}{ NEL SAMPLE ID: L0205125-016 A } \\
\hline MATRIX: & \multicolumn{9}{|l|}{ SOLID } \\
\hline \multicolumn{2}{|l|}{ Parameter } & $\underline{\text { Result }}$ & $\underline{\text { Lnit }}$ & $\begin{array}{c}\text { Reporting } \\
\text { Limit }\end{array}$ & $\underline{\text { DF }}$ & Method & Prep Date & Analyzed & Analyst \\
\hline \multicolumn{2}{|c|}{ Diesel Range Organics ( $\mathrm{Cl} 2-\mathrm{C} 22)$} & ND & $\mathrm{mg} / \mathrm{Kg}$ & 10 & 1 & SW8015Ext & 051302 & $05: 1402$ & P.SCLI \\
\hline \multicolumn{2}{|c|}{ Gasoline Range Organics $(\mathrm{C} 8-\mathrm{Cl}$ ) } & ND & $\mathrm{mg} / \mathrm{Kg}$ & 10 & 1 & SW8015Ext & $0513 / 02$ & $05: 1+02$ & PXC-LY \\
\hline \multicolumn{2}{|c|}{ Oil Range Organics (C22-C34) } & ND & $\mathrm{mg} / \mathrm{kg}$ & 50 & 1 & SW8015Ext & $05 / 13 / 02$ & $05^{\prime} 14,02$ & PXC-LY \\
\hline \multicolumn{2}{|c|}{ Total Petroleum Hydrocarbons } & ND & $\mathrm{mg} / \mathrm{Kg}$ & 10 & 1 & SW8015Ext & 051302 & $05: 14: 02$ & PXC-LV \\
\hline \multicolumn{2}{|c|}{ Surr: n-Octacosane } & 80.1 & "/nECC & $55-130$ & 1 & SW8015Ext & $05 / 13: 02$ & 0 (0)1402 & PXC-LY \\
\hline
\end{tabular}

ND - Not Detected at the Reporing L Imit

DF: - Dilutuon Factor

Date: /6-1/4y:02
B - Analyte detected in the associated Method Blank

S - Spike Recovery outside accepted recovery limits

E. Value above quantitation range
Page 32 of 46 
NEL LABORATORIES

\begin{tabular}{lll}
\hline CLIENT: & Bechtel Nevada & CLIENT ID: $\quad 252504-1 \mathrm{E}$ \\
PROJECT ID: & V1581 & DATE SAMPLED: 5202 \\
PROJECT \#: & 30033 & NEL SAIIPLE ID: $20205125-016 \mathrm{~B}$ \\
MATRIX: & SOLID & \\
\hline
\end{tabular}

\begin{tabular}{|c|c|c|c|c|c|c|c|c|}
\hline Parameter & $\underline{\text { Result }}$ & $\underline{\text { Unit }}$ & $\begin{array}{l}\text { Reporting } \\
\text { Limit }\end{array}$ & $\underline{\mathrm{DF}}$ & Method & Prep Date & Analyzed & Analyst \\
\hline Arocior 1016 & ND & $\mu \mathbf{g} / \mathrm{Kg}$ & 20 & 1 & SW8082 & $05: 1302$ & $0 \leq 1402$ & $J R W \cdot L V$ \\
\hline Aroclor 1221 & ND & $\mu \mathrm{g} / \mathrm{Kg}$ & 20 & 1 & SW8082 & $05 / 13102$ & $051+102$ & $J R K-L Y$ \\
\hline Arocior 1232 & ND & $\mu g^{\prime} \mathrm{kg}$ & 20 & 1 & SW8082 & $0513 / 02$ & $05: 14: 02$ & $J R W-L Y$ \\
\hline Aroclor 1242 & ND & $\mu \underline{g} / \mathrm{Kg}$ & 20 & 1 & SW8082 & $05: 13: 02$ & $051+02$ & $J R U-1 V$ \\
\hline Aroclor 1248 & ND & $\mu \mathrm{g}^{\prime} \mathrm{Kg}$ & 20 & 1 & Sw8082 & 051302 & $0514 / 02$ & $J R W^{\prime}-1 V^{\prime}$ \\
\hline Aroclor 1254 & ND & $\mu g / \mathrm{Kg}$ & 20 & 1 & sw8082 & 0513102 & $05: 14102$ & JRWELS \\
\hline Arocior 1260 & ND & $\mu \mathrm{g} / \mathrm{Kg}$ & 20 & 1 & SW8082 & $0513 / 02$ & 051402 & $J R H-L V$ \\
\hline Surr: Decachlorobiphenyl & 117 & $1 / 1 \mathrm{REC}$ & 45.149 & 1 & SW8082 & $0513 / 02$ & 051402 & $J R W-L$ \\
\hline Surr: Tetrachloro-m-xylenc & 116 & "/॥REC & 48.136 & 1 & Sw808? & $0513 / 02$ & $0514 / 02$ & IRW-L.V \\
\hline
\end{tabular}

ND - Not Detected at the Reporting Limit

DF - Dilution facior

Date: 16-May-O?
B - Analyte detected in the associated Method Blank

S - Spike Recovery outside accepted recovery hmits

E - Value above quantitation range 
NEL LA.EORATORIES

\begin{tabular}{lll}
\hline CLIENT: & Bechtel Nevada & CLIENT ID: \\
PROJECT ID: & 11581 & DATE SAMPLE4-1E \\
PROJECT \#: & 30033 & NEL SAMIPLE ID: L0205125-016C \\
MATRIX: & SOLID (TCLP) & \\
\hline
\end{tabular}

\begin{tabular}{|c|c|c|c|c|c|c|c|c|}
\hline Parameter & $\underline{\text { Result }}$ & Unit & $\begin{array}{l}\text { Reporting } \\
\text { Limit }\end{array}$ & $\underline{\mathrm{DF}}$ & Method & Prep Date & Analyzed & Analyst \\
\hline Cadmium & 0.012 & $\mathrm{mg} / \mathbf{L}$. & 0.0050 & 1 & SW 6010B-To & $05.14 / 02$ & 05.1402 & FIF-Renu \\
\hline Lead & ND & $\mathrm{mg} \mathrm{L}$ & 0.050 & 1 & SW $6010 \mathrm{~B}-\mathrm{TO}_{0}$ & 051402 & 0514102 & FIF-Reno \\
\hline
\end{tabular}

ND - Nor Detected a inc Reporting limit

DF - Dilution Fackor

Date: 16-May-0?
B - Analyte detected in the associated Method Blank

S - Spike Recovery outside accepted recovery limits

E - Value above quantitation range 
NEL LABORATORIES

\begin{tabular}{|c|c|c|}
\hline CLIENT: & Bechrel Nevada & CLIENT ID: \\
\hline PROJECT ID: & V'1581 & DATE SAMTPLED: $520 ?$ \\
\hline PROJECT \#: & 30033 & NEL SAIIPLE ID: L0205125-017A \\
\hline MATRIX: & SOLID & \\
\hline
\end{tabular}

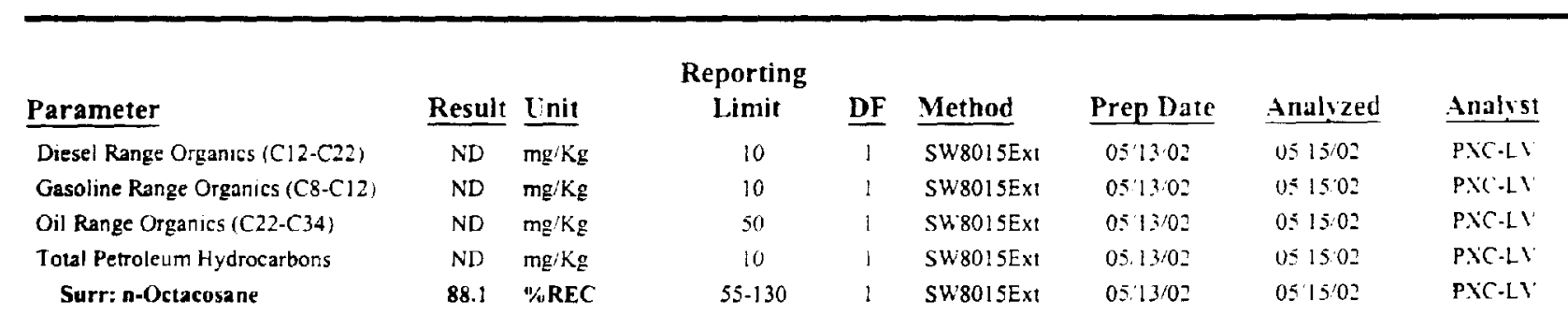

ND - Not Detected at the Reporting I.imit

DF - Dilution Factor

Date: 16-May-02
B - Analytc detected in the associated Method Blank

S - Spike Recovery outside accepted recovery limits

$E$ - Value above quantutation range
Page 35 of 46 
NEL LABORATORIES

\begin{tabular}{|c|c|c|}
\hline CLIENT: & Bechtel Nevada & CLIENT ID: \\
\hline PROJECT ID: & $V 1581$ & DATE SAMIPLED: 5202 \\
\hline PROJECT & 30033 & NEL SAMPLE ID: LO2(05125-01? \\
\hline MATRIX: & SOLID & \\
\hline
\end{tabular}

\begin{tabular}{|c|c|c|c|c|c|c|c|c|}
\hline Parameter & Result & Unit & $\begin{array}{c}\text { Reporting } \\
\text { Limit }\end{array}$ & $\underline{\text { DF }}$ & Method & Prep Dare & Analyzed & Analyst \\
\hline Aroclor 1016 & ND & $\mu g / K_{g}$ & 20 & 1 & SW'8082 & $05130 ?$ & 051402 & JRH-L \\
\hline Aroclor $122 !$ & ND & $\mu \mathrm{g} / \mathrm{kg}$ & 20 & 1 & SW8082 & $0513: 02$ & 051402 & JRW-LV \\
\hline Arocior 1232 & ND & $\mu \mathrm{g} / \mathrm{Kg}$ & 20 & 1 & SW8082 & $0513 / 02$ & $05: 14 / 02$ & JRW $W$ L V \\
\hline Arocior 1242 & 29 & $\mu g / \mathbf{k g}$ & 20 & 1 & Sw8082 & $05: 1302$ & 051402 & $J R W-L V$ \\
\hline Arocior 1248 & ND & $\mu \mathrm{g} / \mathrm{Kg}$ & 20 & 1 & SW8082 & $05.13 \% 02$ & $051+02$ & JRW-LI \\
\hline Aroclor 1254 & ND & $\mu \mathrm{g} / \mathrm{Kg}$ & 20 & 1 & SW8082 & $0: 13 / 02$ & 051402 & $J R W-L V$ \\
\hline Aroclor 1260 & ND & $\mu \mathrm{g} / \mathrm{Kg}$ & 20 & 1 & SW8082 & $05: 13 / 02$ & 051402 & JRW-LV \\
\hline Surr: Decachlorobiphenyl & 105 & $\%$ REC & $45-149$ & 1 & SW8082 & $05: 13 / 02$ & 051402 & $J R W \cdot L V$ \\
\hline Surr: Tetrachioro-m-xylene & 101 & $\%$ REC & $48-136$ & 1 & Sw8082 & $0513: 02$ & 051402 & $.1 R H: 1.1$ \\
\hline
\end{tabular}

ND - Not Detected at the Reporting Limit

DF - Dilution Factor

Date: /6-Mali-02
B - Analyte detected in the associated Method Blank

S - Spike Recovery outside accepted recovery limits

E - Value above quantitation range
Page 36 of 46 
NEL LABORATORIES

$\begin{array}{lll}\text { CLIENT: } & \text { Bechtel Nevada } & \text { CLIENT ID: } 252504-2 E \\ \text { PROJECT ID: } & 11581 & \text { DATE SAMIPLED: } 5202 \\ \text { PROJECT \#: } & 30033 & \text { NEL SAIIPLE ID: L0205125-1.17.C } \\ \text { MATRIX: } & \text { SOLID (TCLP) } & \end{array}$

\begin{tabular}{|c|c|c|c|c|c|c|c|c|}
\hline Parameter & $\underline{\text { Result }}$ & Unit & $\begin{array}{l}\text { Reporting } \\
\text { Limit }\end{array}$ & $\underline{\mathrm{DF}}$ & Method & Prep Date & Analyzed & Analyst \\
\hline Cadmium & ND & $m g^{\prime} L$ & 0.0050 & 1 & SW 6010B-To & $051+02$ & $0 \leq 1402$ & Fif-Keno \\
\hline Lead & ND & $\mathrm{mg} / \mathrm{L}$ & 0.050 & i & SW 6010B-To & 051402 & $0514 / 02$ & FIF-Reno \\
\hline
\end{tabular}

ND - Not Detected at the Repirting Limit DF - Dilution Factor

Date: 16-May-02
B - Analyte detected in the associated Method Biank

S - Spike Recovery outside accepted recovery limits

E - Value above quantitation range 
NEL LABORATORIES

$\begin{array}{lll}\text { CLIENT: } & \text { Bechtel Nevada } & \text { CLIENT ID: } \\ \text { PROJECT ID: } & 11581 & \text { 252504-3E } \\ \text { PROJECT \#: } & 30033 & \text { DATE SAMIPLED: } 5202 \\ \text { MATRIX: } & \text { SOLID } & \text { NEL SAMIPLE ID: L0205125-01SA }\end{array}$

\begin{tabular}{|c|c|c|c|c|c|c|c|c|}
\hline Parameter & Result & Unit & $\begin{array}{c}\text { Reporting } \\
\text { Limit }\end{array}$ & $\underline{\mathbf{D F}}$ & Method & Prep Date & Analyzed & Analyst \\
\hline Diesel Range Organics ( $\mathrm{Cl} 2-\mathrm{C} 22$ ) & ND & $\mathrm{mg} / \mathrm{Kg}$ & 10 & 1 & SW80ISExt & 0513102 & 051502 & $P X C-11$ \\
\hline Gasoline Range Organics $(\mathrm{C} 8-\mathrm{Cl} 2)$ & ND & $\mathrm{mg} / \mathrm{Kg}$ & 10 & 1 & SW8015Ext & $05 / 13 / 02$ & $0=15 / 02$ & PXC-IV' \\
\hline Oil Range Organies $\left(\mathrm{C}_{2} 2 \cdot \mathrm{C}_{2} \mathrm{~A}\right)$ & ND & $\mathrm{mg} / \mathrm{Kg}$ & 50 & 1 & SW80!5Ext & $05: 13 / 02$ & 051502 & PXC-LX \\
\hline Total Petroleum Hydrocarbons & ND & $\mathrm{mg} / \mathrm{Kg}$ & 10 & 1 & SW8015Ext & $05: 13: 02$ & 051502 & PXC-LV \\
\hline Surr: n-Octacosane & 75.1 & $\%$ REC & $55-130$ & 1 & SW8015Ext & $0513: 02$ & $05 \times 15 / 02$ & PXC-1Y \\
\hline
\end{tabular}

ND - Not Detected at the Reportıng I.ımı!

DF - Dilution Factor

Date: 16-Mav-02
B - Aralyte detected in the associated Method Blanti

S - Spike Recovery outside accepted recovery limits

E - Value above quanitation range
Page 38 of 46 
NEL LABORATORIES

\begin{tabular}{|c|c|c|c|c|c|c|c|c|c|}
\hline CLIENT: & \multicolumn{4}{|c|}{ Bechrel Nevada } & \multicolumn{4}{|c|}{ CLIENT ID: $\quad 252504-3 E$} & \\
\hline PROJECT ID: & \multicolumn{4}{|l|}{$\vee 1581$} & \multicolumn{4}{|c|}{ DATE SAMPLED: 5202} & \\
\hline PROJECT \#: & \multicolumn{4}{|l|}{30033} & \multirow{2}{*}{\multicolumn{4}{|c|}{ NEL SAIIPLE ID: L0205125-01SB }} & \\
\hline MATRIX: & SOLID & & & & & & & & \\
\hline \multicolumn{2}{|l|}{ Parameter } & Result & Unit & $\begin{array}{l}\text { Reporting } \\
\text { Limit }\end{array}$ & $\underline{\mathbf{D F}}$ & Method & Prep Date & Analyzed & Analyst \\
\hline \multicolumn{2}{|l|}{$\overline{\text { Aroclor } 1016}$} & ND & $\mu g^{\prime} \mathrm{kg}$ & 20 & 1 & Sw'808z & 051502 & 051402 & $I R W \cdot L$ \\
\hline \multicolumn{2}{|l|}{ Aroclor 1221} & ND & $\mu g^{\prime} \mathrm{Kg}$ & 20 & 1 & SW8082 & 0513102 & $051+02$ & $J R W-L Y$ \\
\hline \multicolumn{2}{|l|}{ Aroclor 1232} & ND & $\mu \mathrm{g} / \mathrm{Kg}$ & 20 & 1 & SW8082 & 051302 & 051402 & JRH-LI \\
\hline \multicolumn{2}{|l|}{ Aroclor 1242} & ND & $\mu \mathrm{g} / \mathrm{Kg}$ & 20 & 1 & SW8082 & 051302 & 051402 & $J R U-L Y$ \\
\hline \multicolumn{2}{|l|}{ Aroclor 1248} & ND & $\mu g / \mathrm{Kg}$ & 20 & 1 & SW8082 & $0.5: 13 / 02$ & $051+02$ & JRW-LY \\
\hline \multicolumn{2}{|l|}{ Aroclor 1254} & ND & $\mu g / K g$ & 20 & 1 & SW8082 & $05 / 13 / 02$ & $0514: 02$ & $J R W^{\prime}-L V^{\prime}$ \\
\hline \multicolumn{2}{|l|}{ Arocior 1260} & ND & $\mu g / K_{E}$ & 20 & 1 & SW808? & $05 / 13 / 02$ & $05 \cdot 1402$ & $J R W \cdot L V$ \\
\hline \multicolumn{2}{|c|}{ Surr: Decachlorobiphenyl } & 104 & "\%REC & $45-149$ & 1 & SW8082 & $05 / 13 / 02$ & $05: 14: 02$ & JRW-LY \\
\hline \multicolumn{2}{|c|}{ Surr: Tetrachloro-m-xylene } & 110 & $1 \%$ REC & $48-136$ & 1 & SW8082 & 051302 & $05: 1+102$ & $J R U^{\prime}-L Y$ \\
\hline
\end{tabular}

ND - Not Detected at the Reporting Limit

DF - Dilution Factor

Date: $16-\mathrm{May}-02$
B - Analyte detected in the associated Method Blank

S - Spıke Recovery outsıde accepted recovery linits

$E$ - Value above quantitation range
Page 39 of 46 
NEL LABORATORIES

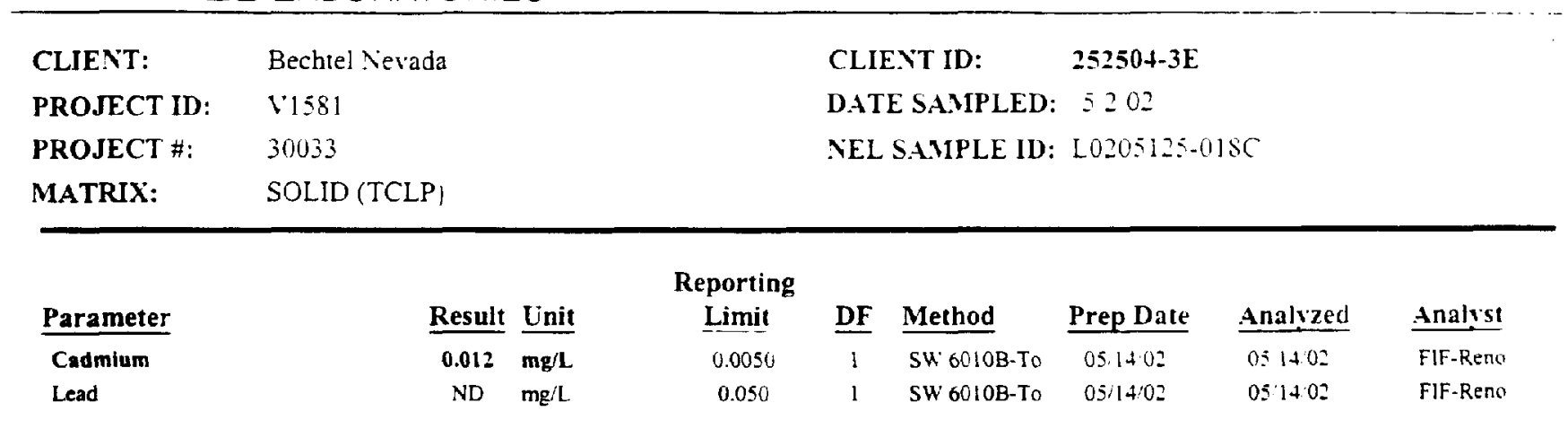

ND - Not Detected at the Reporting Limit DF - Dilution Factor

Date: 16-May-02
B - Analyte detected in the associated Method Blank

S - Spike Recovery outside accepted recovery limits

$\mathrm{E}$ - Value above quantitation range
Page 40 of 46 
NEL LABORATORIES

$\begin{array}{lll}\text { CLIENT: } & \text { Bechtel Nevada } & \text { CLIENT ID: } \\ \text { PROJECT ID: } & 11581 & \text { DATE SAM04-4E } \\ \text { PROJECT \#: } & 30033 & \text { NEL SAMIPLE ID: L0205125-0:9-A } \\ \text { MATRIX: } & \text { SOLID } & \end{array}$

\begin{tabular}{|c|c|c|c|c|c|c|c|c|}
\hline Parameter & Result & Unit & $\begin{array}{l}\text { Reporting } \\
\text { Limit }\end{array}$ & $\underline{\mathrm{DF}}$ & Method & Prep Date & Analyzed & Analisi \\
\hline Diesel Range Organics (C12-C22) & ND & $\mathrm{mg} \mathbf{\prime}^{\prime} \mathrm{Kg}$ & 10 & 1 & $S W 8015 E \times 1$ & 051502 & 051502 & $\mathrm{PXC-LY}$ \\
\hline Gasoline Range Organics (C8-C 12 ) & ND & $\mathrm{mg} / \mathrm{Kg}$ & 10 & 1 & SW8015Exi & $05^{\prime} 1302$ & 051502 & $P X C-1 Y$ \\
\hline Oil Range Organics (C22-C34) & ND & $\mathrm{mg} / \mathrm{Kg}$ & 50 & 1 & SW8015Ext & $05^{\prime} 1302$ & $0515: 02$ & $P X C-L V^{\circ}$ \\
\hline Total Petroleum Hydrocarbons & ND & $\mathrm{mg} / \mathrm{kg}$ & 10 & 1 & SW801 SExt & $05 / 13 / 02$ & $05: 1502$ & PXC-LY' \\
\hline Surr: n-Octacosane & 89.1 & "/IREC & $55-130$ & 1 & SW8015Ext & $05 / 13 / 02$ & $05: 15 / 02$ & $\mathrm{P} \times \mathrm{C}-\mathrm{LV}$ \\
\hline
\end{tabular}

ND - Not Detected at the Reportune Limit

DF - Dilution Fuctor

Date: 16-May-02
B - Analyte detected in the associated Method Blank

$S$ - Spike Recovery outside accepted recovery limits

$E$ - Value above quantitation range 
NEL LABORATORIES

\begin{tabular}{lll}
\hline CLIENT: & Bechtel Vevada & CLIENT ID: $252504-4 E$ \\
PROJECT ID: & $V 1581$ & DATE SAMPLED: 5202 \\
PROJECT \#: & 30033 & NEL SAMPLE ID: L0205125-019B \\
MAT:IX: & SOLID &
\end{tabular}

\begin{tabular}{|c|c|c|c|c|c|c|c|c|}
\hline Parameter & Result & Unit & $\begin{array}{l}\text { Reporting } \\
\text { Limit }\end{array}$ & DF & Method & Prep Date & Analyzed & Analyst \\
\hline Aroclor 1016 & ND & $\mu \mathrm{g} / \mathrm{Kg}$ & 20 & 1 & SW8082 & $0513 / 02$ & 051402 & $J R W-L Y$ \\
\hline Aroclor 1221 & ND & $\mu g / K_{g}$ & 20 & 1 & SW8082 & $05: 13: 02$ & $0514 / 02$ & JRW'LY \\
\hline Arnclor 1232 & ND & $\mu \mathrm{g} / \mathrm{Kg}$ & 20 & 1 & Su'8082 & $05: 13: 02$ & $0514: 02$ & $J R W^{\prime}-L Y$ \\
\hline Aroclor 1242 & ND & $\mu \mathrm{g} / \mathrm{Kg}$ & 20 & 1 & sw8082 & 051302 & 051402 & JRW:LI \\
\hline Aroclor 1248 & ND & $\mu \mathrm{g} / \mathrm{Kg}$ & 20 & 1 & SW8082 & $0513 / 02$ & $0514 / 02$ & $J R W-L V^{\prime}$ \\
\hline Aroclor 1254 & ND & $\mu g / K g$ & 20 & 1 & SW8082 & $05: 13 / 02$ & $05 / 14 / 02$ & JRW'LV' \\
\hline Aroclor 1260 & ND & $\mu g / \mathrm{Kg}$ & 20 & 1 & SW8082 & $05 / 13 / 02$ & $05 / 14 / 02$ & $J R W^{\prime}-L V$ \\
\hline Surr: Decachlorobiphenyl & 95.5 & $\%$ REC & 45.149 & 1 & SW8082 & $05 / 13 / 02$ & $05 / 14 / 02$ & $J R W-L V$ \\
\hline Surr: Tetrachloro-m-xylene & 99.0 & $11 / 1 \mathrm{REC}$ & $48-136$ & 1 & SW'8082 & $05113 / 02$ & 051402 & JRW'LY \\
\hline
\end{tabular}

ND - Not Detected at the Reporting Limit

DF - Dilution Factor

Date: 16-May-02
B - Analyte detected in the associated Method Blank

S - Spike Recovery outside accepted recovery iimits

$E$ - Value above quantitation range
Page 42 of 46 
NEL LABORATORIES

\begin{tabular}{|c|c|c|c|c|c|c|c|c|}
\hline CLIENT: & \multicolumn{3}{|l|}{ Bechtel Nevada } & \multicolumn{4}{|c|}{ CLIENT ID: $\quad 252504-4 E$} & \\
\hline PROJECT ID: & \multicolumn{3}{|l|}{$V 1581$} & \multicolumn{4}{|c|}{ DATE SAMIPLED: 5202} & \\
\hline PROJECT \#: & \multicolumn{3}{|l|}{30033} & \multirow{2}{*}{\multicolumn{4}{|c|}{ NEL SAMPLE ID: L020ミ125-019C }} & \\
\hline MATRIX: & SOLID (TCLP) & & & & & & & \\
\hline Parameter & Result & $\underline{\text { Linit }}$ & $\begin{array}{l}\text { Reporting } \\
\text { Limit }\end{array}$ & $\underline{\text { DF }}$ & Method & Prep Date & Analyzed & Analyst \\
\hline Cadmium & ND & $\mathrm{mg} / \mathrm{L}$ & 0.0050 & 1 & SW 6010B-To & $05: 14: 02$ & 051402 & FIF-Reno \\
\hline Lead & ND & $\mathrm{mg} / \mathrm{L}$ & 0.050 & 1 & SW 6010B-To & $05 / 1402$ & 0511102 & FIF-Renu \\
\hline
\end{tabular}

ND - Not Detected at the Reporting L_imit

DF - Dilution Factor

Date: /6-May-02
B - Aralyte detected in the associated Method Blank

S - Spike Recovery outside accepted recovery limits

$E$ - Value above quantitation range
Page 43 of 46 


\section{NEL LABORATORIES}

\begin{tabular}{|c|c|c|c|c|c|c|c|c|c|}
\hline CLIENT: & \multicolumn{4}{|c|}{ Bechtel Nevada } & \multicolumn{4}{|c|}{ CLIENT ID: $\quad 252504-5 E$} & \\
\hline PROJECT ID: & \multicolumn{4}{|l|}{ V1581 } & \multicolumn{4}{|c|}{ DATE SAMPLED: 5202} & \\
\hline PROJECT \#: & \multicolumn{4}{|l|}{30033} & \multicolumn{4}{|c|}{ NEL SAMPLE ID: L0205125.020A } & \\
\hline MATRIX: & SOLID & & & & & & & & \\
\hline \multicolumn{2}{|l|}{ Parameter } & $\underline{\text { Result }}$ & $\underline{\text { Unit }}$ & $\begin{array}{l}\text { Reporting } \\
\text { Limit }\end{array}$ & $\underline{\mathrm{DF}}$ & Method & Prep Date & Analyzed & Analyst \\
\hline \multicolumn{2}{|c|}{ Diesel Range Organics (C12-C22) } & ND & $\mathrm{mg} / \mathrm{Kg}$ & 10 & 1 & SW8015Exı & $0.5 / 13 / 02$ & 051502 & PXC.LY \\
\hline \multicolumn{2}{|c|}{ Gasoline Range Organics (C8- $\mathrm{C} 12$ ) } & ND & $\mathrm{mg} / \mathrm{Kg}$ & 10 & 1 & SW80ISExt & $05^{\prime} 13 \cdot 02$ & 051502 & PXC-LY \\
\hline \multicolumn{2}{|c|}{ Oil Range Organics (C22-C34) } & ND & $\mathrm{mg} / \mathrm{Kg}$ & 50 & 1 & SW8015Ext & $05 / 13: 02$ & 051502 & PXC-LY \\
\hline \multicolumn{2}{|c|}{ Total Petroleum Hiydrocarbons } & ND & $\mathrm{mg} / \mathrm{Kg}$ & 10 & 1 & SW8015Ext & $0513: 02$ & 051502 & $P X C-L$ \\
\hline \multicolumn{2}{|c|}{ Surr: n-Octacosane } & 79.1 & $\% \operatorname{REC}$ & 55.130 & 1 & SWBOISEXt & $05: 1302$ & 0515,02 & $P X C \cdot L Y$ \\
\hline
\end{tabular}

ND - Not Detected at the Reporting Limit

DF - Dilution Factor

Date: $16-\mathrm{May}-02$
B - Analyte detected in the associated Method Blank

S - Spike Recovery outside accepted recovery limits

$E$ - Value above quantitation range
Page 44 of 46 
NEL LABORATORIES

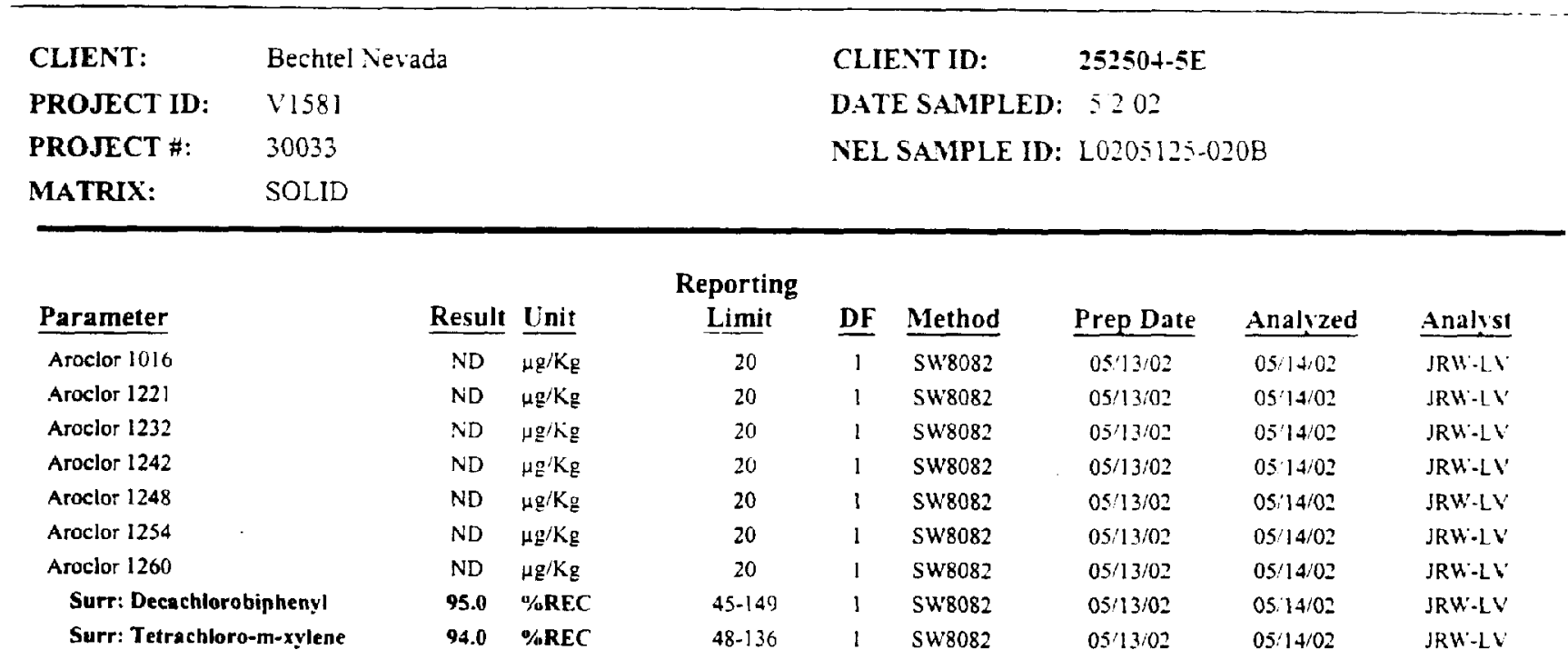

ND - Not Deteited at the Reponng 1 imu

DF - Dilution factor

Date: 10-May-02
B - Analyte delected in the associated Method Blank

S - Spike Recovery outside accepted recovery linits

$\mathrm{E} \cdot \mathrm{Value}$ above quantitation tange.
Page 45 of 46 
NEL LABORATORIES

\begin{tabular}{lll}
\hline CLIENT: & Bechiel Nevada & CLIENT ID: \\
PROJECT ID: & VI52504-5E \\
PROJECT \#: & 30033 & DATE SAMPLED: 52202 \\
MATRIX: & SOLID (TCLP) & NEL SAMPLE ID: L0205125-020C
\end{tabular}

\begin{tabular}{|c|c|c|c|c|c|c|c|c|}
\hline Parameter & Result & Unit & $\begin{array}{l}\text { Reporting } \\
\text { Limit }\end{array}$ & $\underline{\mathrm{DF}}$ & Method & Prep Date & Analyzed & Analyst \\
\hline Cadmium & ND & $\mathrm{mg} / \mathrm{L}$ & 0.0050 & 1 & SW 6010B-To & $05 / 11 / 02$ & 051402 & FIF-Renu \\
\hline Lead & ND & $\mathrm{mg} / \mathrm{L}$ & 0.050 & $i$ & SW $6010 \mathrm{~B}-\mathrm{To}$ & $05 / 14 / 02$ & $05: 14 / 02$ & FIF-Reno \\
\hline
\end{tabular}

ND - Not Delected at the Reporting Limit

DF - Dilution Factor

Date: 16-Mav-02
B - Analyte detected in the associated Method Blank

S - Spike Recovery outside accepted recovery limits

E. Value above quantiation range 
CLIENT: Bechtel Nevada

Work Order: L0205125

Project:
ANALYTICAL QC SUMMARY REPORT

BatchID: 383

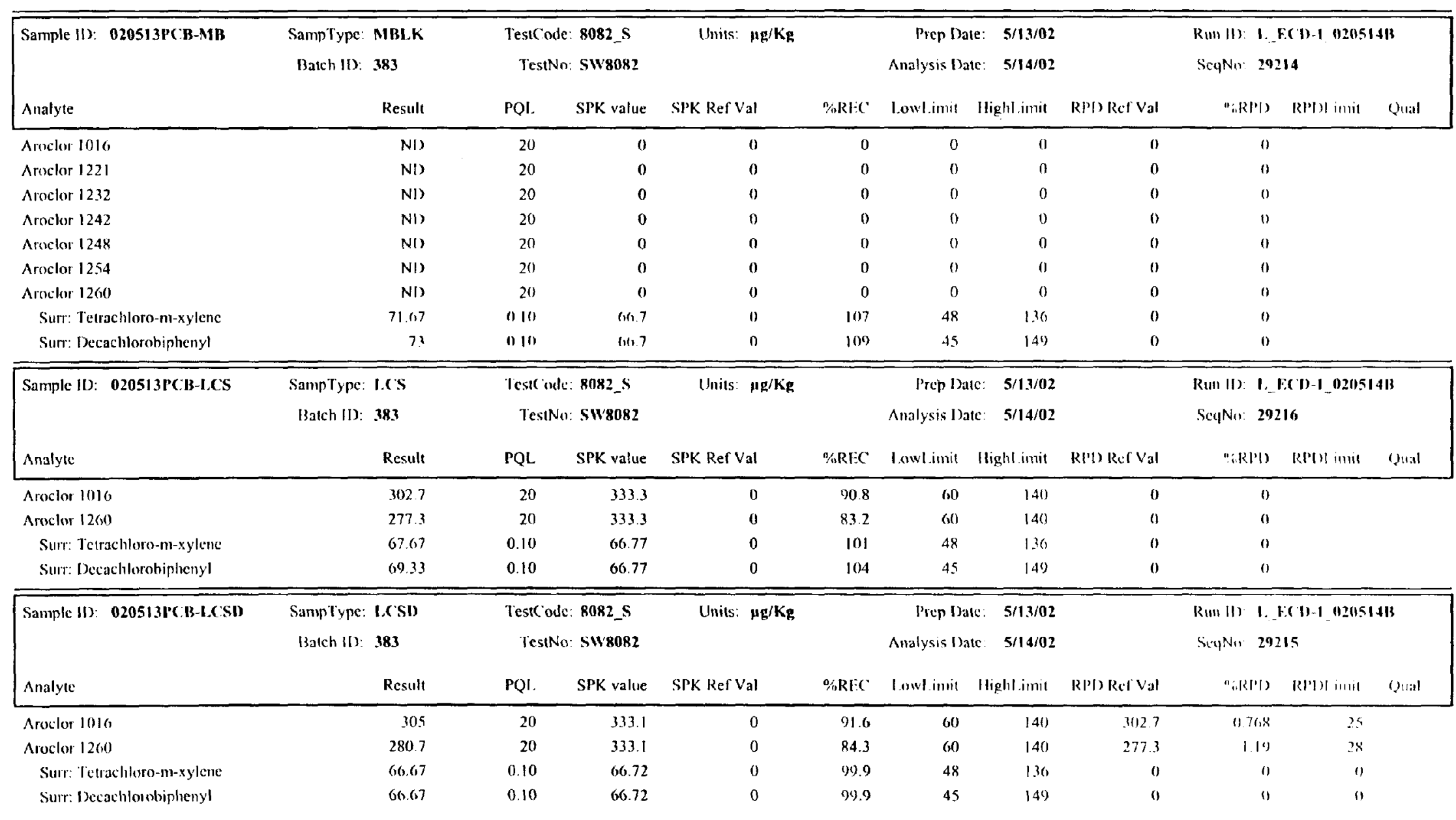

Qualifiers:

ND - Not Detected at the Reporting L init

1- Analyte delected below quantitation limits
S - Spike Recovery outside accepted recovery limits

R - RPD outside accepted recovery limits

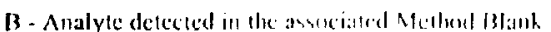

Page 1 of 5 
CLIENT:

ANALYTICAL QC SUMMARY REPORT

Work Order:

BatchID: $\quad 383$

\begin{tabular}{|c|c|c|c|c|c|c|c|c|c|c|c|c|c|}
\hline \multirow{2}{*}{$\begin{array}{l}\text { Sample ID I.0205125-018BMS } \\
\text { Analyte }\end{array}$} & \multirow{2}{*}{$\begin{array}{l}\text { SampType: } \\
\text { Batch ID: }\end{array}$} & \multirow{2}{*}{$\begin{array}{l}\text { MS } \\
383 \\
\text { Result }\end{array}$} & \multicolumn{2}{|c|}{$\begin{array}{l}\text { Test('ode: } 8082 \text { S } \\
\text { TesiNo: SW8082 }\end{array}$} & \multicolumn{2}{|c|}{ Inits: $\mu \mathrm{g} / \mathrm{Kg}$} & \multirow[b]{2}{*}{ \%Rl:C } & \multicolumn{2}{|c|}{$\begin{array}{rr}\text { Prep Date: } & 5 / 13 / 02 \\
\text { Analysis Date: } & 5 / 14 / 02\end{array}$} & \multirow[b]{2}{*}{ RPII) Ref Val } & \multicolumn{3}{|c|}{ 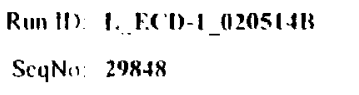 } \\
\hline & & & PQL. & SPK value & SPK Ref Val & & & Iowlimit & JighL imit & & $\%(R P \mid)$ & RPllt imit & Qual \\
\hline Aroclor 1016 & & 325.5 & 20 & 333.6 & & 0 & 97.6 & 60 & 140 & 0 & 11 & & \\
\hline Aroclor 1260 & & 289.1 & 20 & 333.6 & & 0 & 86.7 & 60 & 140 & 0 & 0 & & \\
\hline SuIt: Tetrachloro-m-xylene & & 68.45 & 0.10 & 66.81 & & 0 & 102 & 48 & 130 & 0 & 0 & & \\
\hline Surt: Decachlorobiphenyl & & 67.45 & 0.10 & 66.81 & & 0 & 101 & 45 & 149 & 0 & 11 & & \\
\hline Sample ID: $\quad$ L.02051 25-018BMS & $\begin{array}{l}\text { Sampitype: } \\
\text { Batch lD: }\end{array}$ & $\begin{array}{l}\text { MSO } \\
383\end{array}$ & $\begin{array}{r}\text { TestC } \\
\text { Tes }\end{array}$ & $\begin{array}{l}\text { 8082_S } \\
\text { SWR082 }\end{array}$ & Units: $\mu$ & $\mu \mathrm{g} / \mathrm{Kg}$ & & $\begin{array}{r}\text { Prep Da } \\
\text { Analysis Daa }\end{array}$ & $\begin{array}{l}\text { c: } 5 / 13 / 02 \\
\text { lc: } 5 / 14 / 02\end{array}$ & & $\begin{array}{l}\text { Run 11): 1. } \\
\text { SeqNa: } 208\end{array}$ & 49 & \\
\hline Analyte & & Result & PQI & SPK value & SPK Ref Val & & $\because R \Gamma C$ & Iowlimit & Ilight imit & RPD Ref Val & $\because R P I)$ & RP'Pl innit & Gual \\
\hline Aroclor 1016 & & 308.5 & 20 & 333.6 & & 0 & 92.5 & 60 & 140 & 325.5 & 5.37 & 25 & \\
\hline Aroclor 1260 & & 271.1 & 20 & 333.6 & & $\mathbf{0}$ & 81.3 & 60 & 140 & 289.1 & 6.44 & 25 & \\
\hline Surr: Tetrachloro-m-xylene & & 69.78 & 0.10 & 66.81 & & 0 & 104 & 48 & 136 & 0 & 0 & 0 & \\
\hline Surr: Decachlorobiphenyl & & 64.11 & 0.10 & 66.81 & & 0 & 96 & 45 & 149 & 0 & 0 & 0 & \\
\hline
\end{tabular}


CLIENT:

BatchID: 385

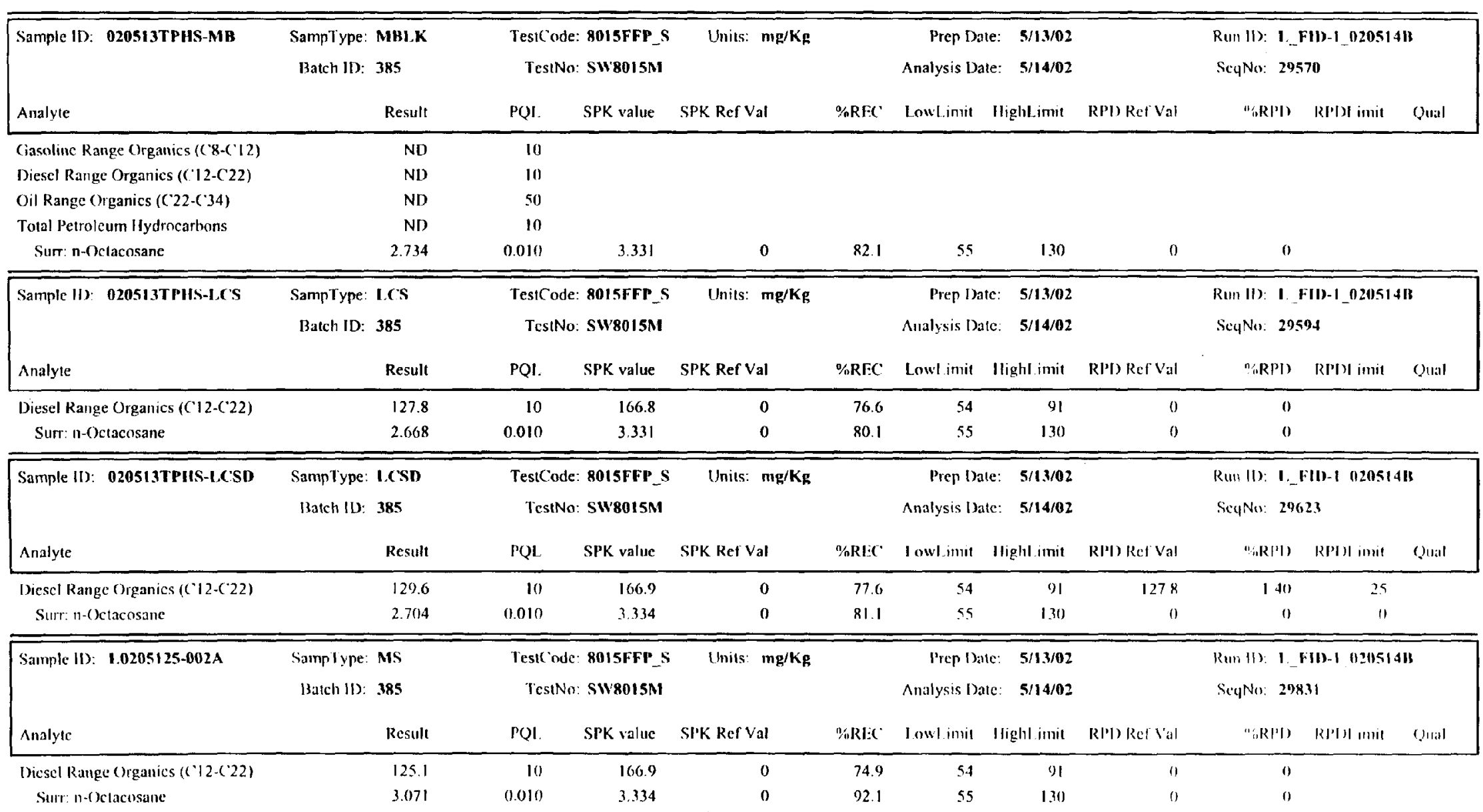



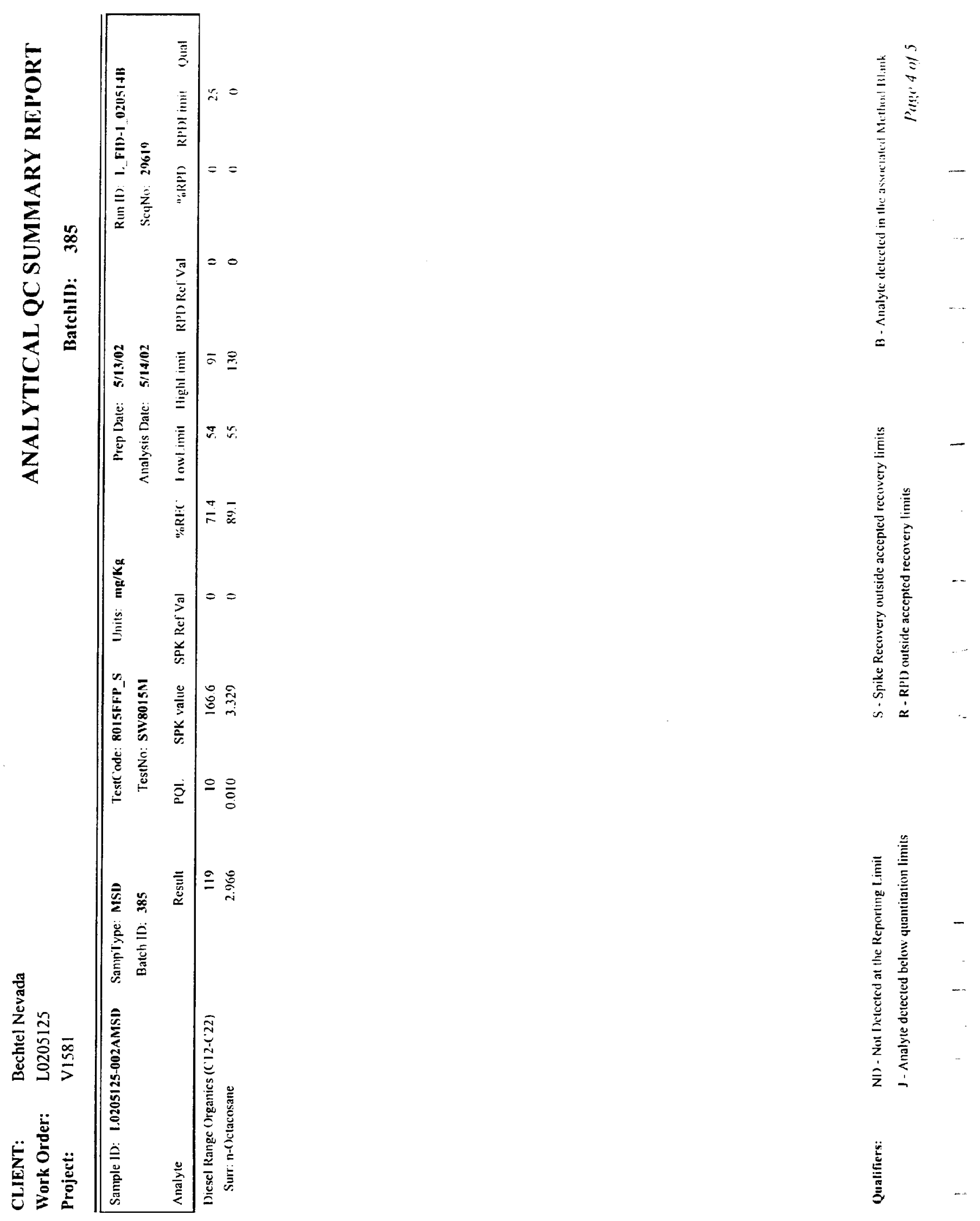
CLIENT: Bechtel Nevada

Work Order: I.0205I25

ANALYTICAL QC SUMMARY REPORT

Project: V1581

BatchII): R 986

\begin{tabular}{|c|c|c|c|c|c|c|c|c|c|c|c|}
\hline \multirow{2}{*}{$\begin{array}{l}\text { Sample ID: } \\
\text { Analyte }\end{array}$} & \multirow{2}{*}{$\begin{array}{r}\text { SampType: } \text { MBI.K } \\
\text { Batch ID: R_986 } \\
\text { Result }\end{array}$} & \multicolumn{2}{|c|}{$\begin{array}{r}\text { TesiCode: } 6010 W_{-} T \\
\text { TesiNo: Sw6010B }\end{array}$} & \multicolumn{2}{|c|}{ Units: $\mathbf{m g} / \mathbf{L}$} & \multicolumn{3}{|c|}{$\begin{array}{rr}\text { Prep Date: } & 5 / 14 / 02 \\
\text { Analysis Date: } & 5 / 14 / 02\end{array}$} & \multicolumn{3}{|c|}{$\begin{array}{l}\text { Run 11): } \\
\text { SeqNot(3-2.314 } \\
29660\end{array}$} \\
\hline & & $\mathrm{PQL}$ & SPK value & SP'K RerVal & $\because R E C$ & Iowlimit & Highl imit & RPI) Ref Val & $\because R P I$ & Rl'M imil & Ounl \\
\hline
\end{tabular}

\begin{tabular}{|c|c|c|c|c|c|c|c|c|c|c|c|}
\hline Sample II: LCS-986 & $\begin{array}{l}\text { SampType: LCS } \\
\text { Batch II): R_986 }\end{array}$ & $\begin{array}{r}\text { TesiCode } \\
\text { TestNo }\end{array}$ & $\begin{array}{l}6010 W_{-} T \\
\text { SW6010B }\end{array}$ & Unis: $\mathbf{m g} / \mathbf{l}$. & & $\begin{array}{l}\text { Prep Da } \\
\text { Analysis D. }\end{array}$ & $\begin{array}{l}\text { te: } \quad 5 / 14 / 02 \\
\text { te: } 5 / 14 / 02\end{array}$ & & $\begin{array}{l}\text { Run II): SI } \\
\text { SeyNo: } 29\end{array}$ & $18-2314$ & \\
\hline Analyte & Result & $\mathrm{POI}$. & SPK value & SPK Ref Val & $\% R F C$ & Lowlimit & Ilighl imit & RPID Ref Val & $\% R(D)$ & RPIM & Qual \\
\hline Cadmium & 05230 & 000501 & 05 & 0 & 105 & 85 & 115 & 0 & (1) & & \\
\hline Lcad & 1024 & $0(150)$ & 1 & 0 & 102 & 85 & 115 & 0 & () & & \\
\hline
\end{tabular}

\begin{tabular}{|c|c|c|c|c|c|c|c|c|c|c|c|c|c|}
\hline Sample (I): & $1.0205145-001 B$ & $\begin{array}{r}\text { Sampiype } \\
\text { Batch II). }\end{array}$ & $\begin{array}{l}\text { MSS } \\
\text { R } 986\end{array}$ & $\begin{array}{l}\text { Ienll inde } \\
\text { Iesino }\end{array}$ & $\begin{array}{l}\text { 6010W T } \\
\text { SW6010B }\end{array}$ & Innts & $m g / L$. & & $\begin{array}{r}\text { Prip Dat } \\
\text { Analysis Dat }\end{array}$ & $\begin{array}{ll}\text { te: } & 5 / 14 / 02 \\
\text { te: } & 5 / 14 / 02\end{array}$ & & $\begin{array}{l}\text { Rum II): } 5113-2314 \\
S_{c 4} N_{1}: 29661\end{array}$ & \\
\hline Analyte & & & Result & PQI. & SPK value & Si'K Rel V & & $\% R I: C^{\circ}$ & I owl imit & Ilight imit & RPI Ref Val & 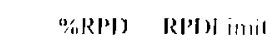 & Qual \\
\hline Cadnium & & & 0.5172 & 0.0050 & 0.5 & & 0 & 163 & 75 & 125 & 0 & 1) & \\
\hline t cad & & & 1.005 & 0.050 & 1 & & 0 & $m$ & 75 & 125 & 0 & ) & \\
\hline \multirow[t]{2}{*}{ Sample (I): } & I.0205145-001 B & \multirow{3}{*}{$\begin{array}{r}\text { Sampiype: } \\
\text { Batch ID: }\end{array}$} & MSD & TestCode: & 6010W_T & Units: & mg/L. & & Prep Dat & te: $\quad 5 / 14 / 02$ & & \multirow{2}{*}{$\begin{array}{l}\text { Run ID: } 51(18-2314 \\
\text { ScyNo: } 29602\end{array}$} & \\
\hline & & & R 986 & TestNo: & SW6010B & & & & Analysis Da! & le: $\quad 5 / 14 / 02$ & & & \\
\hline Aralyte & & & Result & PQL & SPK value & SPK Ref $V:$ & & 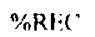 & lowl imit & Migh imit & RPID Ref Val & 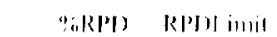 & Qual \\
\hline Cadmium & & & 0.5116 & 0.0050 & 0.5 & & 0 & 102 & & & 0 & $a$ & \\
\hline 1.ead & & & 1 & 0.050 & 1 & & 0 & 100 & & & (1) & 11 & \\
\hline
\end{tabular}




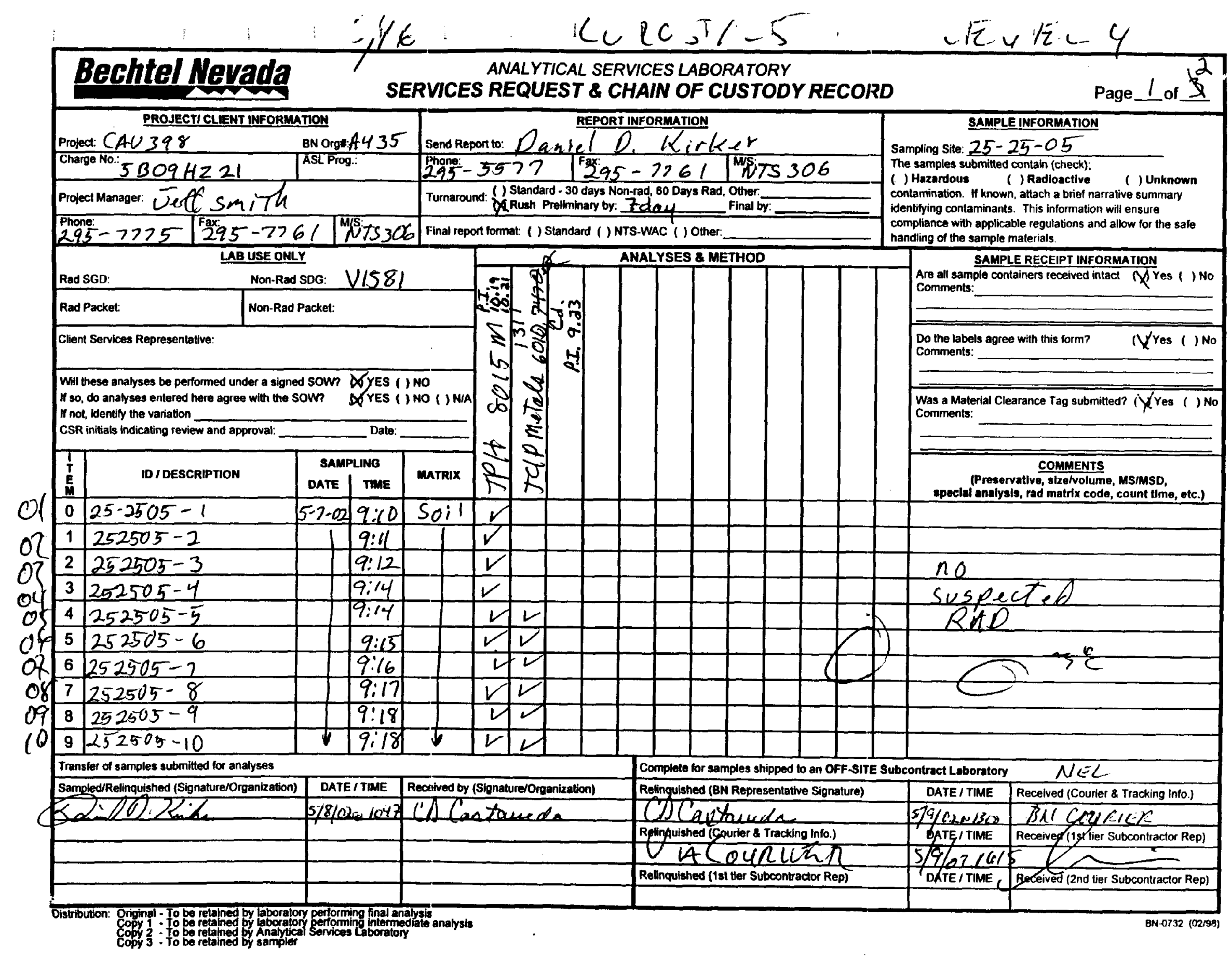




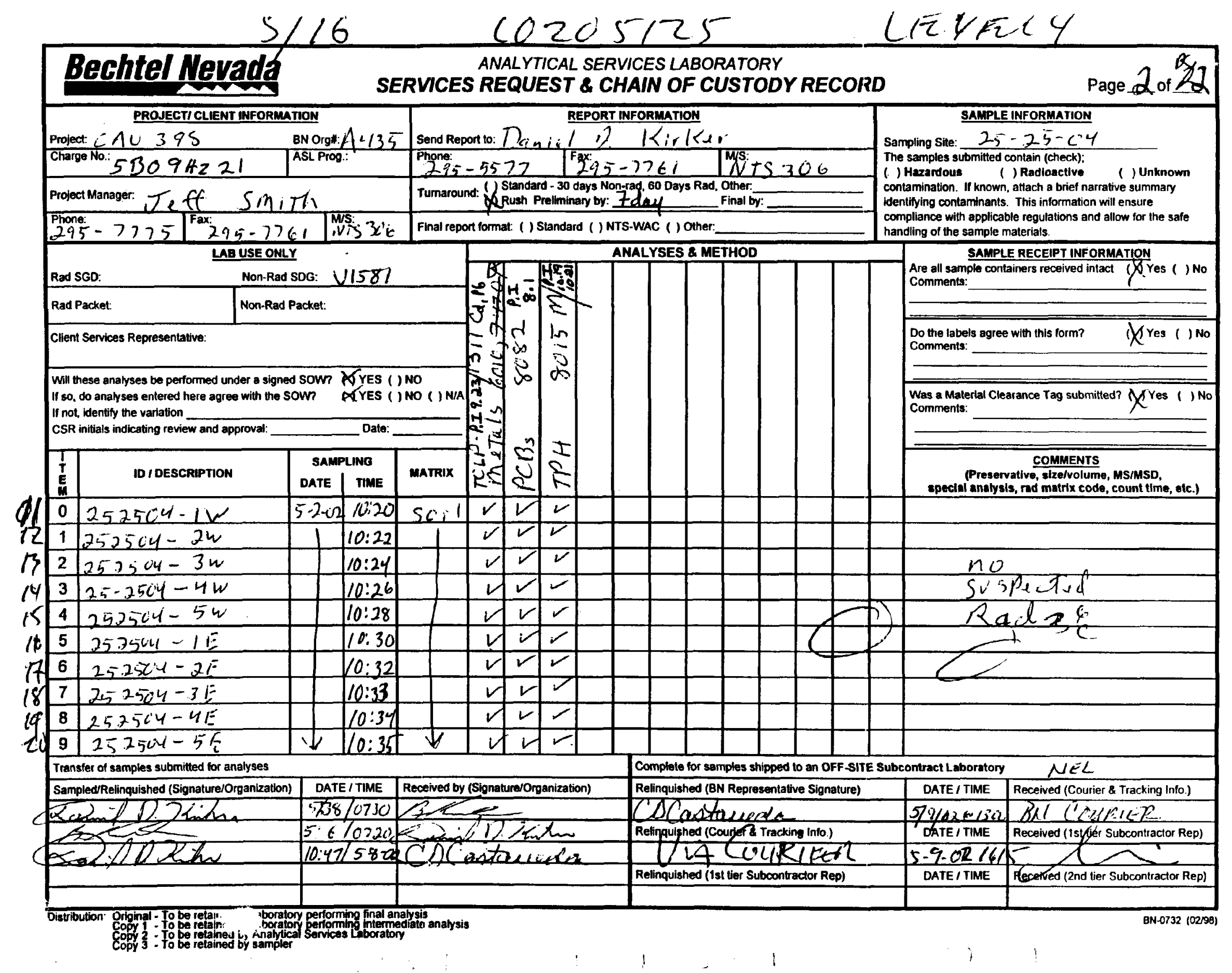


Date: April 2003

\title{
SAMPLE DELIVERY GROUP
}

\author{
V1596
}


CLOSURE REPORT - CAU 398

Section: Appendix B

Revision: 1

Date: April 2003

THIS PAGE INTENTIONALLY LEFT BLANK 
Ted Redding

Bechtel Nevada

P.O. Box 98521 , M/S NTS273

Las Vegas, NV 89193-8521

TEL: 702-295-7220

RE Project: v1596

Order No.: L0205290

Dear Ted Redding:

NEL Laboratories, Las Vegas received 12 samples on $5 / 22 / 02$ for the analyses presented in the following report.

There were no problems with the analyses and all data for associated QC met EPA or laboratory specifications unless noted in the Case Narrative.

If you have any questions regarding these tests results, please feel free to call.

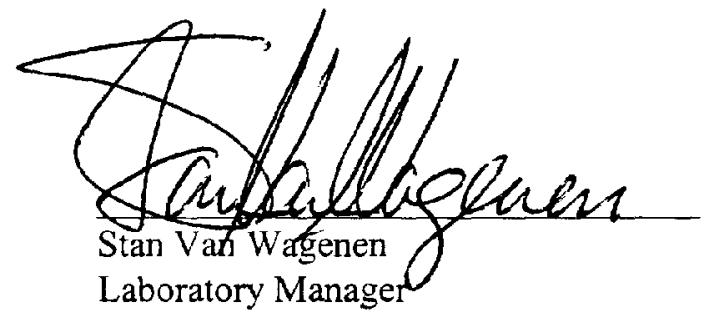

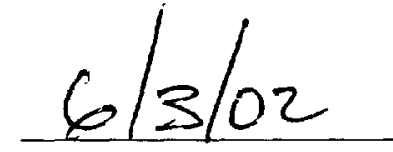

Date

$\begin{array}{lll}\text { Certifications: } & \text { Reno } & \text { Las Vegas } \\ \text { Arizona } & \text { AZ0520 } & \text { AZ0518 } \\ \text { California } & 1707 & 2002 \\ \text { Idaho } & \text { Certified } & \text { Certified } \\ \text { Montana } & \text { Certified } & \text { Certified } \\ \text { Nevada } & \text { NV033 } & \text { NV052 } \\ \text { New Mexico } & \text { Certified } & \text { Certified }\end{array}$


NEL LABORATORIES

\begin{tabular}{|c|c|c|c|c|c|c|c|c|c|}
\hline CLIENT: & \multicolumn{3}{|c|}{ Bechtel Nevada } & & \multicolumn{4}{|c|}{ CLIENT ID: $\quad$ - $\quad 254402-1$} & \\
\hline PROJECT ID: & \multicolumn{3}{|l|}{$\vee 1596$} & & \multicolumn{4}{|c|}{ DATE SAMIPLED: $5: 20: 02$} & \\
\hline PROJECT \#: & \multicolumn{3}{|l|}{30033} & & \multicolumn{4}{|c|}{ NEL SAMPLE ID: L0205290-001A } & \\
\hline MATRIX: & SOIL & & & & & & & & \\
\hline \multicolumn{2}{|l|}{ Parameter } & Result & Unit & $\begin{array}{c}\text { Reporting } \\
\text { Limit }\end{array}$ & $\underline{\text { DF }}$ & Method & Prep Date & Analyzed & Analist \\
\hline \multicolumn{2}{|c|}{ Diesel Range Organics (Cl2-C22) } & ND & $\mathrm{mg} / \mathrm{Kg}$ & 10 & 1 & SW8015Ext & $05 / 31 / 02$ & $05: 31 / 02$ & PXC-LY \\
\hline \multicolumn{2}{|c|}{ Gasoline Range Organics (C8-C12) } & ND & $\mathrm{mg} / \mathrm{Kg}$ & 10 & 1 & SW8015Ext & $05 / 31 / 02$ & $05: 31 / 02$ & PXC.LY \\
\hline \multicolumn{2}{|c|}{ Oil Range Organics (C22-C34) } & ND & $\mathrm{mg} / \mathrm{Kg}$ & 50 & 1 & SW8015Ext & $05 / 31 / 02$ & $05 / 31 / 02$ & PXC-LI \\
\hline \multicolumn{2}{|c|}{ Total Petroleum Hydrocarbons } & ND & $\mathrm{mg} / \mathrm{Kg}$ & 10 & 1 & SW8015Ext & $05 / 31 / 02$ & $05 / 31 / 02$ & $P X C-L V$ \\
\hline \multicolumn{2}{|c|}{ Surr: n-Octacosane } & 64.1 & $\%$ REC & $55-130$ & 1 & SW8015Ext & $05 / 31 / 02$ & $05 / 31 / 02$ & PXC-LV \\
\hline
\end{tabular}

ND - Not Detected at the Reporting Limit

DF - Dilution Factor

Date: 03-Jun-02
B - Analyte detected in the associated Method Blank

S - Spike Recovery outside accepted recovery limits

E - Value above quantitation range
Page 1 of 17 
NEL LABORATORIES

\begin{tabular}{|c|c|c|c|c|c|c|c|c|c|}
\hline CLIENT: & \multicolumn{3}{|c|}{ Bechrel Nevada } & & \multicolumn{3}{|c|}{ CLIENT ID: $\quad 254402-2$} & & \\
\hline PROJECT ID: & \multicolumn{3}{|l|}{$v 1596$} & & \multicolumn{4}{|c|}{ DATE SAMPLED: 5,2002} & \\
\hline PROJECT \#: & \multicolumn{3}{|l|}{30033} & & \multicolumn{4}{|c|}{ NEL SAMPLE ID: L0205290-002A } & \\
\hline MATRIX: & SOIL & & & & & & & & \\
\hline \multicolumn{2}{|l|}{ Parameter } & Result & Unit & $\begin{array}{c}\text { Reporting } \\
\text { Limit }\end{array}$ & DF & Method & Prep Date & Analyzed & Analyst \\
\hline \multicolumn{2}{|c|}{ Diesel Range Organics (C12-C22) } & ND & $\mathrm{mg} / \mathrm{Kg}$ & 10 & 1 & SW8015Ext & $05 / 24 / 02$ & $05: 30 / 02$ & $P X C-L Y$ \\
\hline \multicolumn{2}{|c|}{ Gasoline Range Organies (C8-Cl2) } & ND & $\mathrm{mg} / \mathrm{Kg}$ & 10 & 1 & SW8015Ext & $05 / 24 / 02$ & $05 / 30 / 02$ & PXC-LY \\
\hline \multicolumn{2}{|c|}{ Oil Range Organics $(\mathrm{C} 22-\mathrm{C} 34)$} & ND & $\mathrm{mg} / \mathrm{Kg}$ & 50 & 1 & SW8015Ext & $05 / 24 / 02$ & $05 / 30 / 0 ?$ & PXC-LY \\
\hline \multicolumn{2}{|c|}{ Total Petroleum Hydrocarbons } & ND & $\mathrm{mg} / \mathrm{Kg}$ & 10 & ] & SW8015Ext & $05 / 24 / 02$ & $05 / 30 / 02$ & PXC-LV \\
\hline \multicolumn{2}{|c|}{ Surr: n-Octacosane } & 65.1 & $\%$ REC & $55-130$ & 1 & SW80!5Ext & $05 / 24 / 02$ & $05 / 30 / 02$ & PXC-LV \\
\hline
\end{tabular}

ND - Not Detected at the Reporting Limit DF - Dilution Factor

Date: $03-J u n-02$
B - Analyte detected in the associated Method Blank

$S$ - Spike Recovery outside accepted recovery limits

E - Value above quantitation range
Page 2 of 17 
NEL LABORATORIES

$\begin{array}{lll}\text { CLIENT: } & \text { Bechtel Nevada } & \text { CLIENT ID: } \\ \text { PROJECT ID: } & v 1596 & \text { DATE SAMPLED: } 52002 \\ \text { PROJECT \#: } & 30033 & \text { NEL SAMPLE ID: L0205290-003A } \\ \text { MATRIX: } & \text { SOIL } & \end{array}$

\begin{tabular}{|c|c|c|c|c|c|c|c|c|}
\hline Parameter & $\underline{\text { Result }}$ & Unit & $\begin{array}{c}\text { Reporting } \\
\text { Limit }\end{array}$ & $\underline{\mathrm{DF}}$ & Method & Prep Date & Analyzed & Analyst \\
\hline Diesel Range Organics (C12-C22) & ND & $\mathrm{mg} / \mathrm{Kg}$ & 10 & 1 & SW8015Ext & $05 / 24 / 02$ & $05: 31 / 02$ & $P X C-L Y$ \\
\hline Gasoline Range Organics ( $\mathrm{C} 8-\mathrm{C} 12)$ & ND & $\mathrm{mg} / \mathrm{Kg}$ & 10 & 1 & SWBO15Ext & $05: 24 / 02$ & $05 / 31 / 02$ & PXC-LY \\
\hline Oil Range Organics ( $\mathrm{C} 22-\mathrm{C} 34$ ) & $\mathrm{ND}$ & $\mathrm{mg} / \mathrm{Kg}$ & 50 & 1 & SW8015Ext & $05 / 24 / 02$ & $05 / 31 / 02$ & PAC-LY \\
\hline Total Petroleum Hydrocarbons & $\mathrm{ND}$ & $\mathrm{mg} / \mathrm{Kg}$ & 10 & 1 & SW8015Ext & $05 / 24 / 02$ & $05 / 31 / 02$ & $\mathrm{PXC}-\mathrm{LV}$ \\
\hline Surr: n-Octacosane & 71.1 & $\%$ REC & $55-130$ & 1 & SW8015Ext & $05 / 24 / 02$ & $05 / 31 / 02$ & PXC-LY \\
\hline
\end{tabular}

ND - Not Detected at the Reporting Limit DF - Dilution Factor

Date: 03-Jun-02
$B$ - Analyte detected in the associated Method Blank

S - Spike Recovery outside accepted recovery limits

$E$ - Value above quantitation range
Page 3 of 17 
NEL LABORATORIES

\begin{tabular}{|c|c|c|c|c|c|c|c|c|c|}
\hline CLIENT: & \multicolumn{4}{|c|}{ Bechtel Nevada } & \multicolumn{4}{|c|}{ CLIENT ID: $\quad 254402-4$} & \\
\hline PROJECT ID: & \multicolumn{4}{|l|}{$v 1596$} & \multicolumn{5}{|c|}{ DATE SAMIPLED: $\quad 5,2002$} \\
\hline PROJECT \#: & \multicolumn{4}{|l|}{30033} & \multicolumn{5}{|c|}{ NEL SAMPLE ID: L0205290-004A } \\
\hline MATRIX: & SOIL & & & & & & & & \\
\hline Parameter & & $\underline{\text { Result }}$ & Unit & $\begin{array}{l}\text { Reporting } \\
\text { Limit }\end{array}$ & $\underline{\text { DF }}$ & Method & Prep Date & Analyzed & Analyst \\
\hline \multicolumn{2}{|c|}{ Diesel Range Organics (C12-C22) } & ND & $\mathrm{mg} / \mathrm{Kg}$ & 10 & 1 & SW8015Exi & $05 / 24 / 02$ & $05 / 30 / 02$ & PXC-LY \\
\hline \multicolumn{2}{|c|}{ Gasoline Range Organics (C8-C12) } & ND & $\mathrm{mg} / \mathrm{Kg}$ & 10 & 1 & SW8015Ext & $05 / 24 / 02$ & $05 / 30 / 02$ & PXC-LI \\
\hline \multicolumn{2}{|c|}{ Oil Range Organics (C22-C34) } & ND & $\mathrm{mg} / \mathrm{Kg}$ & 50 & 1 & SW8015Ext & $05 / 24 / 02$ & $05 / 30 / 02$ & PXC-LY \\
\hline \multicolumn{2}{|c|}{ Total Petroleum Hydrocarbons } & ND & $\mathrm{mg} / \mathrm{Kg}$ & 10 & 1 & Sw8015Ext & $05 / 24 / 02$ & $05 / 30 / 02$ & PXC-LY \\
\hline \multicolumn{2}{|c|}{ Surr: n-Octacosane } & 84.1 & $\%$ REC & $55-130$ & 1 & SW8015Ext & $05 / 24 / 02$ & $05 / 30 / 02$ & PXC-LV \\
\hline
\end{tabular}

ND - Not Detected at the Reporting Limit

DF - Dilution Factor

Date: 03-Jun-02
B - Analyte detected in the associated Method Blank

S - Spike Recovery outside accepted recovery limits

$E$ - Value above quantitation range
Page 4 of 17 
NEL LABORATORIES

\begin{tabular}{|c|c|c|c|}
\hline CLIENT: & Bechtel Sevada & CLIENT ID: & $254402-5$ \\
\hline PROJECT ID: & $v 1596$ & DATE SAMPLED & 52002 \\
\hline PROJECT \#: & 30033 & NEL SAMPLE ID: & L0205290-005A \\
\hline
\end{tabular}

MATRIX: SOIL

\begin{tabular}{|c|c|c|c|c|c|c|c|c|}
\hline Parameter & $\underline{\text { Result }}$ & Lnit & $\begin{array}{c}\text { Reporting } \\
\text { Limit }\end{array}$ & $\underline{\text { DF }}$ & Method & Prep Date & Analyzed & Analyst \\
\hline Diesel Range Organics $(\mathrm{C} 12-\mathrm{C} 22)$ & ND & $\mathrm{mg} / \mathrm{Kg}$ & 10 & 1 & SW8015Ex1 & $05 / 24 / 02$ & $05 / 30 / 02$ & $P X C-L Y$ \\
\hline Gasoline Range Organics (C8-C 12 ) & ND & $\mathrm{mg} / \mathrm{Kg}$ & 10 & 1 & SW8015EX: & $05 / 24 / 02$ & $05 / 30 / 02$ & PXC-LY \\
\hline Oil Range Organics (C22-C34) & ND & $\mathrm{mg} / \mathrm{Kg}$ & 50 & 1 & SW801SExt & $05 / 24 / 02$ & $05 / 30 / 02$ & $P \times C-L V$ \\
\hline Total Petroleum Hydrocarbons & ND & $\mathrm{mg} / \mathrm{Kg}$ & 10 & 1 & SW8015Ext & $05 / 24 / 02$ & $05 / 30 / 02$ & $\mathrm{PAC} \cdot \mathrm{LI}$ \\
\hline Surr: n-Octacosane & 75.1 & $\%$ REC & $55-130$ & 1 & SW8015Ex1 & $05 / 24 / 02$ & $05 / 30 / 02$ & PXC-LV \\
\hline
\end{tabular}

ND - Not Detected at the Reporting Limit

DF - Dilution Factor

Date: $03-J u n-02$
B - Analyte detected in the associated Method Blank

S - Spike Recovery outside accepted recovery limits

E - Value above quantitation range
Page 5 of 17 
NEL LABORATORIES

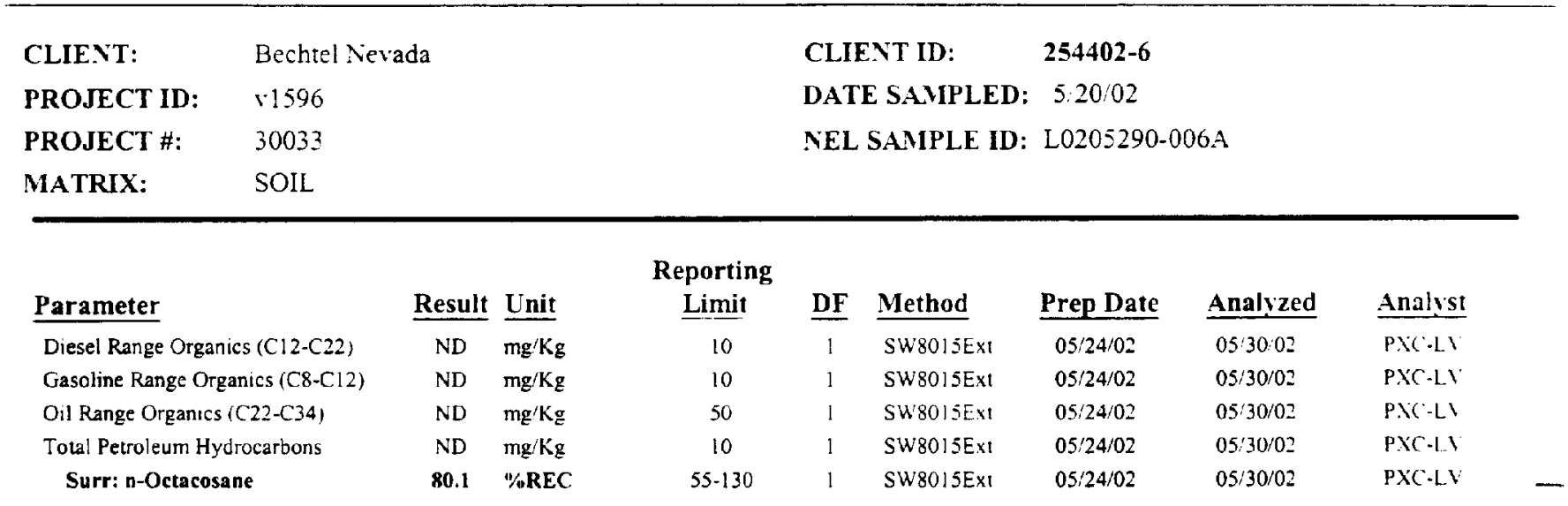

ND - Not Detected at the Reporting Limit

DF - Dilution Factor

Date: 03-Jun-02
B - Analyte detected in the associated Method Blank

S - Spike Recovery outside accepted recovery limits

E - Value above quantitation range
Page 6 of 17 
NEL LABORATORIES

\begin{tabular}{|c|c|c|c|c|c|c|c|c|c|}
\hline CLIENT: & \multicolumn{4}{|c|}{ Bechtel Nevada } & \multicolumn{4}{|c|}{ CLIENT ID: $\quad$ 252503-1 } & \\
\hline PROJECT ID: & \multicolumn{4}{|l|}{$\vee 1596$} & \multicolumn{4}{|c|}{ DATE SAMPLED: 5.2002} & \\
\hline PROJECT \#: & \multicolumn{4}{|l|}{30033} & \multicolumn{5}{|c|}{ NEL SAMPLE ID: L0205290-007A } \\
\hline MATRIX: & SOIL & & & & & & & & \\
\hline \multicolumn{2}{|l|}{ Parameter } & Result & Unit & $\begin{array}{l}\text { Reporting } \\
\text { Limit }\end{array}$ & $\underline{\text { DF }}$ & Method & Prep Date & Analyzed & Analyst \\
\hline \multicolumn{2}{|c|}{ Diesel Range Organics (C12-C22) } & ND & $\mathrm{mg} / \mathrm{Kg}$ & 10 & 1 & SW8015Ext & $05 / 31 / 02$ & $06.01 / 02$ & PXCLLI \\
\hline \multicolumn{2}{|c|}{ Gasoline Range Organics (C8-Cl2) } & ND & $\mathrm{mg} / \mathrm{Kg}$ & 10 & 1 & SW8015Ext & $05 / 31 / 02$ & $06 / 01 / 02$ & PXC-LY \\
\hline \multicolumn{2}{|c|}{ Oil Range Organics (C22-C34) } & ND & $\mathrm{mg} / \mathrm{Kg}$ & 50 & 1 & SW8015Ext & $05 / 31 / 02$ & $06 / 01 / 02$ & $P X C-L Y$ \\
\hline \multicolumn{2}{|c|}{ Total Petroleum Hydrocarbons } & ND & $\mathrm{mg} / \mathrm{Kg}$ & 10 & 1 & SW8015Ext & $05 / 31 / 02$ & $06 / 01 / 02$ & PXC-LV \\
\hline \multicolumn{2}{|c|}{ Surr: n-Octacosane } & 67.1 & $\%$ REC & $55-130$ & 1 & SW80I 5 Ext & $05 / 31 / 02$ & $06 / 01 / 02$ & PXC-LV \\
\hline
\end{tabular}

ND - Not Detected at the Reporting Limit

DF - Dilution Factor

Date: $03-J u n-02$
B - Analyte detected in the associated Method Blank

S - Spike Recovery outside accepted recovery limits

E - Value above quantitation range
Page 7 of 17 
NEL LABORATORIES

\begin{tabular}{|c|c|c|c|c|c|c|c|c|c|}
\hline CLIENT: & \multicolumn{3}{|c|}{ Bechtel Nerada } & & \multicolumn{3}{|c|}{ CLIENT ID: $\quad 252502-1$} & & \\
\hline PROJECT ID: & \multicolumn{3}{|l|}{ v1596 } & & \multicolumn{4}{|c|}{ DATE SAMPLED: $5: 211^{\prime} 02$} & \\
\hline PROJECT \#: & \multicolumn{3}{|l|}{30033} & & \multicolumn{4}{|c|}{ NEL SAMIPLE ID: L0205290-008 A } & \\
\hline MATRIX: & SOIL & & & & & & & & \\
\hline \multicolumn{2}{|l|}{ Parameter } & $\underline{\text { Result }}$ & $\underline{\text { Unit }}$ & $\begin{array}{l}\text { Reporting } \\
\text { Limit }\end{array}$ & $\underline{\mathrm{DF}}$ & Method & Prep Date & Analyzed & Analyst \\
\hline \multicolumn{2}{|c|}{ Diesel Range Organics (C12-C22) } & ND & $\mathrm{mg} / \mathrm{Kg}$ & 10 & 1 & SW8015Ext & $05 / 24 / 02$ & $0530 / 02$ & PXC-LI \\
\hline \multicolumn{2}{|c|}{ Gasoline Range Organics ( $\mathrm{C} 8-\mathrm{C} 12$ ) } & ND & $\mathrm{mg} / \mathrm{Kg}$ & 10 & 1 & SW8015Ext & $05 / 24 / 02$ & $05 / 30 / 02$ & $P X C-1 \times$ \\
\hline \multicolumn{2}{|c|}{ Oil Range Organics $(\mathrm{C} 22-\mathrm{C} 34)$} & ND & $\mathrm{mg} / \mathrm{Kg}$ & 50 & 1 & SW8015Ext & $05 / 24 / 02$ & $05: 30: 02$ & PXC-LS \\
\hline \multicolumn{2}{|c|}{ Total Petroleum Hydrocarbons } & ND & $\mathrm{mg} / \mathrm{Kg}$ & 10 & I & SW8015Ext & $05 / 24 / 02$ & $05 / 30 / 02$ & $P X C-L I$ \\
\hline \multicolumn{2}{|c|}{ Surr: n-Octacosane } & 66.1 & $\%$ REC & $55-130$ & 1 & SWBOISExt & $05 / 24 / 02$ & $05 / 30 / 02$ & $P \times C-L Y$ \\
\hline
\end{tabular}

ND - Not Detected at the Reporting Limit

DF - Dilution Factor

Date: $03-J u n-02$
B - Analyte detected in the associated Method Blank

S - Spike Recovery outside accepted recovery limits

E - Value above quantitation range
Page 8 of 17 
NEL LABORATORIES

\begin{tabular}{|c|c|c|c|c|c|c|c|c|c|c|}
\hline CLIENT: & \multicolumn{5}{|c|}{ Bechtel Nevada } & CLI & NT ID: & \multicolumn{2}{|l|}{ 252502-1 } & \\
\hline PROJECT ID: & \multicolumn{5}{|l|}{$v 1596$} & \multicolumn{4}{|c|}{ DATE SAMPLED: 52102} & \\
\hline PROJECT \#: & \multicolumn{5}{|l|}{30033} & \multicolumn{4}{|c|}{ NEL SAMPLE ID: L0205290-008B } & \\
\hline MATRIX: & SOIL & & & & & & & & & \\
\hline \multicolumn{2}{|l|}{ Parameter } & Result & Unit & & $\begin{array}{l}\text { Reporting } \\
\text { Limit }\end{array}$ & $\underline{D F}$ & Method & Prep Date & Analyzed & Analyst \\
\hline \multicolumn{2}{|l|}{ Araclor 1016} & ND & $\mu \mathrm{g} / \mathrm{Kg}$ & & 20 & 1 & SW8082 & $05 / 28 / 02$ & $05 / 31 / 02$ & $J R W-L W$ \\
\hline \multicolumn{2}{|l|}{ Aroclor 1221} & ND & $\mu \mathrm{g} / \mathrm{Kg}$ & & 20 & 1 & SW8082 & $05 / 28 / 02$ & $05 / 31 / 02$ & $J R W-L Y$ \\
\hline \multicolumn{2}{|l|}{ Aroclor 1232} & ND & $\mu \mathrm{g} / \mathrm{Kg}$ & & 20 & 1 & SW8082 & $05 / 28 / 02$ & $05 / 31 / 02$ & $J R W-L V$ \\
\hline \multicolumn{2}{|l|}{ Aroclor 1242} & ND & $\mu g / \mathrm{Kg}$ & & 20 & 1 & Sw8082 & $05 / 28 / 02$ & $05 / 31 / 02$ & $J R W-L V$ \\
\hline \multicolumn{2}{|l|}{ Aroclor 1248} & ND & $\mu \mathrm{g} / \mathrm{Kg}$ & & 20 & 1 & SW8082 & $05 / 28 / 02$ & $05 / 31 / 0=$ & $J R W-L Y$ \\
\hline \multicolumn{2}{|l|}{ Aroclor 1254} & 870 & $\mu \mathrm{g} / \mathrm{Kg}$ & & 20 & 1 & SW8082 & $05 / 28 / 02$ & $05 / 31 / 02$ & $J R W-L V$ \\
\hline \multicolumn{2}{|l|}{ Arocior 1260} & 630 & $\mu \mathrm{g} / \mathrm{Kg}$ & & 20 & 1 & SW8082 & $05 / 28 / 02$ & $05 / 3] / 02$ & $J R H-L V$ \\
\hline \multicolumn{2}{|c|}{ Surr: Decachlorobiphenyl } & 150 & $\%$ REC & $\mathrm{s}$ & $45-149$ & l & SW8082 & $05 / 28 / 02$ & $05 / 31 / 02$ & $J R W^{\prime}-L V$ \\
\hline \multicolumn{2}{|c|}{ Surr: Tetrachloro-m-xylene } & 125 & $\%$ REC & & $48-136$ & 1 & SW8082 & $05 / 28 / 02$ & $05 / 31 / 02$ & $J R W-L V$ \\
\hline
\end{tabular}

ND - Not Detected at the Reporting Limit

DF - Dilution Factor

Date: 03-Jun-02
B - Analyte detected in the associated Method Blank

S - Spike Recovery outside accepted recovery limits

$E$ - Value above quantitation range
Page 9 of 17 
NEL LABORATORIES

\begin{tabular}{|c|c|c|c|c|c|c|c|c|c|}
\hline CLIENT: & \multicolumn{3}{|c|}{ Bechtel Nevada } & & \multicolumn{4}{|c|}{ CLIENT ID: $\quad 252502-2$} & \\
\hline PROJECT ID: & \multicolumn{3}{|l|}{$v 1596$} & & \multicolumn{4}{|c|}{ DATE SAMPLED: $5,21 / 02$} & \\
\hline PROJECT \#: & \multicolumn{3}{|l|}{30033} & & \multicolumn{4}{|c|}{ NEL SAMPLE ID: L0205290-009A } & \\
\hline MATRIX: & SOIL & & & & & & & & \\
\hline \multicolumn{2}{|l|}{ Parameter } & $\underline{\text { Result }}$ & Unit & $\begin{array}{c}\text { Reporting } \\
\text { Limit }\end{array}$ & $\underline{\mathrm{DF}}$ & Method & Prep Date & Analyzed & Analyst \\
\hline \multicolumn{2}{|c|}{ Diesel Range Organics (Cl2-C22) } & ND & $\mathrm{mg} / \mathrm{Kg}$ & 10 & 1 & SW80ISExt & $05 / 24 / 02$ & $05: 30 / 02$ & PXC-IV \\
\hline \multicolumn{2}{|c|}{ Gasoline Range Organics ( $\mathrm{C} 8-\mathrm{C} 12)$} & ND & $\mathrm{mg} / \mathrm{Kg}$ & 10 & 1 & SW8015Ex1 & $05 / 24 / 02$ & $05: 30 / 02$ & $\mathrm{PXC}-\mathrm{LY}$ \\
\hline \multicolumn{2}{|c|}{ Oil Range Organics (C22-C34) } & ND & $\mathrm{mg} / \mathrm{Kg}$ & 50 & 1 & SW8015Ext & $05 / 24 / 02$ & $05: 30 / 02$ & PXO-LY \\
\hline \multicolumn{2}{|c|}{ Total Petroleum Hydrocarbons } & ND & $\mathrm{mg} / \mathrm{Kg}$ & 10 & 1 & SW801SExt & $05 / 24 / 02$ & $05 / 30 / 02$ & $P X C \cdot L V$ \\
\hline \multicolumn{2}{|c|}{ Surr: n-Octacosane } & 65.1 & "/REC & $55-130$ & 1 & SW8015Ext & $05 / 24 / 02$ & $05 / 30 / 02$ & PXC-LY \\
\hline
\end{tabular}

ND - Not Detected at the Reporting Limit

DF - Dilution Factor

Date: 03-Jun-02
B - Analyte detected in the associated Method Blank

S - Spike Recovery outside accepted recovery limits

$E$ - Value above quantitation range
Page 10 of 17 
NEL LABORATORIES

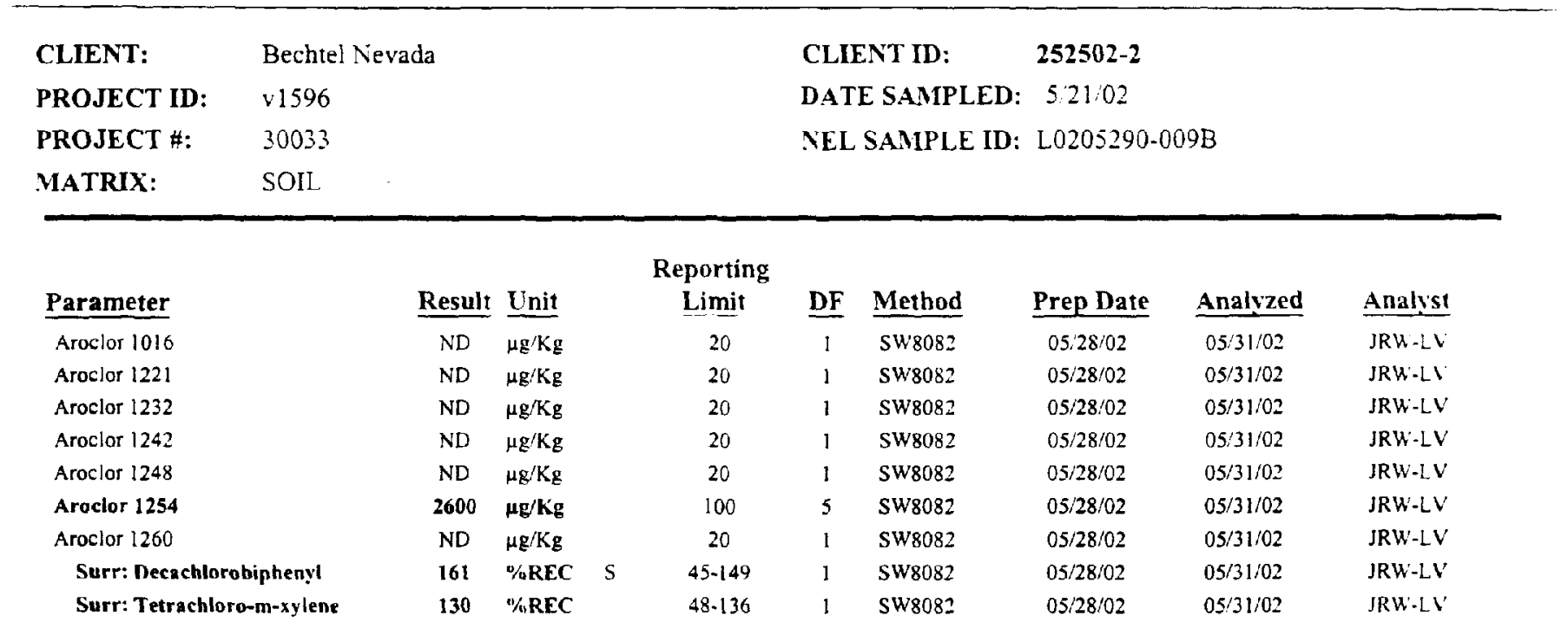

ND - Not Detected at the Reporting Limit DF - Dilution Factor

Date: 03-Jun-02
B - Analyte detected in the associated Method Blank

S - Spike Recovery outside accepted recovery limits

$E$ - Value above quantitation range
Page 11 of 17 
NEL Laboratories

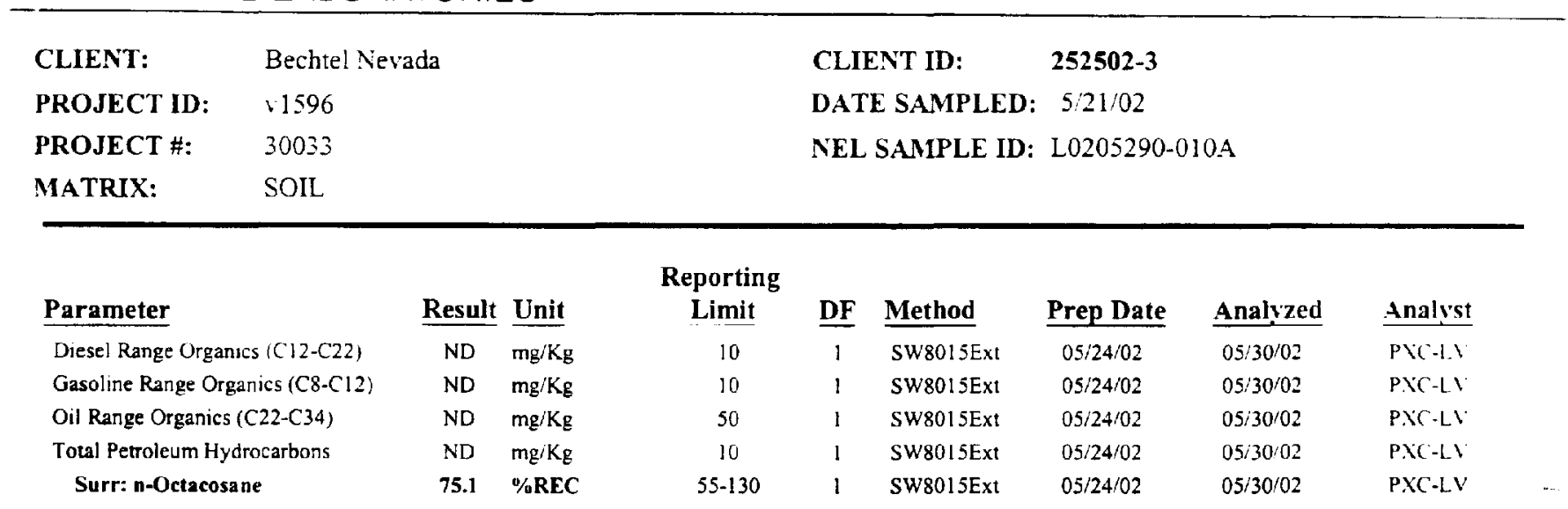

ND - Not Detected at the Reporting Limit

DF - Dilution Factor

Date: $03-J u n-02$
B - Analyte detected in the associated Method Blank

S - Spike Recovery outside accepted recovery limits

$\mathrm{E}$ - Value above quantitation range
Page 12 of 17 
NEL LABORATORIES

\begin{tabular}{|c|c|c|c|c|c|c|c|c|c|c|}
\hline CLIENT: & \multicolumn{5}{|c|}{ Bechtel Nevada } & \multicolumn{4}{|c|}{ CLIENT ID: $\quad 252502-3$} & \\
\hline PROJECT ID: & \multicolumn{5}{|c|}{$\checkmark 1596$} & \multicolumn{4}{|c|}{ DATE SAMPLED: $5: 2102$} & \\
\hline PROJECT \#: & \multicolumn{5}{|l|}{30033} & \multicolumn{4}{|c|}{ NEL SAMPLE ID: L0205290-010B } & \\
\hline MATRIX: & SOIL & & & & & & & & & \\
\hline \multicolumn{2}{|l|}{ Parameter } & $\underline{\text { Result }}$ & $\underline{\text { Lnit }}$ & & $\begin{array}{l}\text { Reporting } \\
\text { Limit }\end{array}$ & $\underline{\mathrm{DF}}$ & Method & Prep Date & Analyzed & Analyst \\
\hline \multicolumn{2}{|l|}{ Aroclor 1016} & ND & $\mu \mathrm{g} / \mathrm{Kg}$ & & 2000 & 100 & SW8082 & $05 / 28 / 02$ & $05 / 31 / 02$ & $J R U-L S$ \\
\hline \multicolumn{2}{|l|}{ Aroclor 1221} & ND & $\mu \mathrm{g} / \mathrm{Kg}$ & & 2000 & 100 & SW8082 & $05 / 28 / 02$ & $05 / 31 / 02$ & JRIS-LS \\
\hline \multicolumn{2}{|l|}{ Aroclor 1232} & ND & $\mu \mathrm{g} / \mathrm{Kg}$ & & 2000 & 100 & Sw8082 & $05 / 28 / 02$ & $05 / 31 / 02$ & $J R W \cdot L V$ \\
\hline \multicolumn{2}{|l|}{ Aroclor 1242} & ND & $\mu \mathrm{g} / \mathrm{Kg}$ & & 2000 & 100 & SW8082 & $05 / 28 / 02$ & $05 / 31 / 02$ & $J R W-L Y$ \\
\hline \multicolumn{2}{|l|}{ Aroclor 1248} & ND & $\mu \mathrm{g} / \mathrm{Kg}$ & & 2000 & 100 & Sw8082 & $05 / 28 / 02$ & $05 / 31 / 02$ & $J R W-L S^{\prime}$ \\
\hline \multicolumn{2}{|l|}{ Aroclor 1254} & 54000 & $\boldsymbol{\mu g} / \mathbf{K g}$ & & 2000 & 100 & SW8082 & $05 / 28 / 02$ & $05 / 31 / 02$ & $J R H-L I$ \\
\hline \multicolumn{2}{|l|}{ Aroclor 1260} & ND & $\mu \mathrm{g} / \mathrm{Kg}$ & & 2000 & 100 & SW8082 & $05 / 28 / 02$ & $05 / 31 / 02$ & $J R W^{\prime}-L V$ \\
\hline \multicolumn{2}{|c|}{ Sur: Decachlorobiphenyl } & 0 & $\% \mathrm{REC}$ & $\mathrm{D}$ & $45-149$ & 100 & SW8082 & $05 / 28 / 02$ & $05 / 31 / 02$ & $J R W-L V$ \\
\hline \multicolumn{2}{|c|}{ Surr: Tetrachloro-m-xylene } & 0 & $\%$ REC & $\mathrm{D}$ & $48-136$ & 100 & SW8082 & $05 / 28 / 02$ & $05 / 31 / 02$ & $J R W^{\prime}-L V^{\prime}$ \\
\hline
\end{tabular}

ND - Not Detected at the Reporting Limit

DF - Dilution Factor

Date: $03-J u n-02$
B - Analyte detected in the associated Method Blank

S - Spike Recovery outsıde accepted recovery limits

$E$ - Value above quantitation range
Page 13 of 17 
NEL LABORATORIES

\begin{tabular}{|c|c|c|c|}
\hline CLIENT: & Bechtel Nevada & CLIENT ID: & $252502-4$ \\
\hline PROJECT ID: & ₹1596 & DATE SAMPLED: & $5: 21 / 02$ \\
\hline PROJECT \#: & 30033 & NEL SAMPLE ID: & L0205290-011A \\
\hline MATRIX: & SOIL & & \\
\hline
\end{tabular}

\begin{tabular}{|c|c|c|c|c|c|c|c|c|}
\hline Parameter & Result & $\underline{\text { Unit }}$ & $\begin{array}{c}\text { Reporting } \\
\text { Limit }\end{array}$ & $\underline{\mathbf{D F}}$ & Method & Prep Date & Analyzed & Analyst \\
\hline Diesel Range Organics (C12-C22) & ND & $\mathrm{mg} / \mathrm{Kg}$ & 10 & 1 & SW8015Ext & $05 / 24 / 02$ & $05 / 30 / 02$ & PXC-LV \\
\hline Gasoline Range Organics (C8-C 12 ) & ND & $\mathrm{mg} / \mathrm{Kg}$ & 10 & 1 & SW8015Ext & $05 / 24 / 02$ & $05 / 30 / 02$ & PYC-L.V \\
\hline Oil Range Organics (C22-C34) & ND & $\mathrm{mg} / \mathrm{Kg}$ & 50 & 1 & SW801SExt & $05 / 24 / 02$ & $05 / 30: 02$ & PXC-LI \\
\hline Tota] Petroleum Hydrocarbons & ND & $\mathrm{mg} / \mathrm{Kg}$ & 10 & 1 & SW8015Ext & $05 / 24 / 02$ & $05 / 30 / 02$ & PXC-LV \\
\hline Surr: n-Octacosane & 81.1 & $\%$ REC & $55-130$ & $\mathbf{l}$ & SW8015Ext & $05 / 24 / 02$ & $05 / 30 / 02$ & PXC-LV \\
\hline
\end{tabular}

ND - Not Detected at the Reporting Limit

DF - Dilution Factor

Date: $03-J u n-02$
B - Analyte detected in the associated Method Blank

$S$ - Spike Recovery outside accepted recovery limits

E-Value above quantitation range
Page 14 of 17 
NEL LABORATORIES

\begin{tabular}{|c|c|c|c|c|c|c|c|c|c|}
\hline CLIENT: & \multicolumn{4}{|c|}{ Bechtel Nevada } & \multicolumn{4}{|c|}{ CLIENT ID: $\quad 252502-4$} & \\
\hline PROJECT ID: & \multicolumn{4}{|c|}{$\vee 1596$} & \multicolumn{4}{|c|}{ DATE SAMPLED: $\quad 5: 21 / 02$} & \\
\hline PROJECT \#: & \multicolumn{4}{|l|}{30033} & \multicolumn{5}{|c|}{ NEL SAMPLE ID: $10205290-011 \mathrm{~B}$} \\
\hline MATRIX: & \multicolumn{9}{|l|}{ SOIL } \\
\hline \multicolumn{2}{|l|}{ Parameter } & $\underline{\text { Result }}$ & Unit & $\begin{array}{l}\text { Reporting } \\
\text { Limit }\end{array}$ & $\underline{\text { DF }}$ & Method & Prep Date & Analyzed & Analyst \\
\hline \multicolumn{2}{|l|}{ Arocior 1016} & ND & $\mu g / \mathrm{Kg}$ & 20 & 1 & SW8082 & $05 / 28 / 02$ & $05 / 31 / 02$ & JRW.LS \\
\hline \multicolumn{2}{|l|}{ Arocior 1221} & ND & $\mu g / K g$ & 20 & 1 & SW8082 & $05 / 28 / 02$ & $05 / 31 / 02$ & $J R H-L Y$ \\
\hline \multicolumn{2}{|l|}{ Aroclor 1232} & ND & $\mu \mathrm{g} / \mathrm{Kg}$ & 20 & 1 & SW8082 & $05 / 28 / 02$ & $05 / 31 / 02$ & $J R U-L V$ \\
\hline \multicolumn{2}{|l|}{ Aroclor 1242} & ND & $\mu g / \mathrm{Kg}$ & 20 & 1 & SW8082 & $05 / 28 / 02$ & $05 / 31 / 02$ & $J R W-L Y$ \\
\hline \multicolumn{2}{|l|}{ Aroctor 1248} & ND & $\mu \mathrm{g} / \mathrm{Kg}$ & 20 & 1 & Sw8082 & $05 / 28 / 02$ & $05 / 31 / 02$ & $J R W-1 V$ \\
\hline \multicolumn{2}{|l|}{ Aroclor 1254} & 190 & $\mu \mathrm{g} / \mathrm{Kg}$ & 20 & 1 & SW8082 & $05 / 28 / 02$ & $05 / 31 / 02$ & $J R W-L V$ \\
\hline \multicolumn{2}{|l|}{ Arocior 1260} & 140 & $\mu \mathrm{g} / \mathrm{Kg}$ & 20 & 1 & SW8082 & $05 / 28 / 02$ & $05 / 31 / 02$ & $J R W-L V$ \\
\hline \multicolumn{2}{|c|}{ Surr: Decachlorobiphenyl } & 148 & $\%$ REC & $45-149$ & 1 & SW8082 & $05 / 28 / 02$ & $05 / 31 / 02$ & $J R W^{\prime}-L Y$ \\
\hline \multicolumn{2}{|c|}{ Surr: Tetrachloro-m-xylene } & 125 & $\%$ REC & $48-136$ & 1 & SW8082 & $05 / 28 / 02$ & $05 / 31 / 02$ & $J R W-L V$ \\
\hline
\end{tabular}

ND - Not Detected at the Reporting Limit

DF - Dilution Factor

Date: 03-Jun-02
B - Analyte detected in the associated Method Blank

S - Spike Recovery outside accepted recovery limits

E - Value above quantitation range
Page 15 of 17 
NEL LABORATORIES

$\begin{array}{lll}\text { CLIENT: } & \text { Bechtel Nevada } & \text { CLIENT ID: } \\ \text { PROJECT ID: } & v 1596 & \text { DAT2502-5 } \\ \text { PROJECT \#: } & 30033 & \text { NEL SAMPLE ID: L0205290-012A } \\ \text { MATRIX: } & \text { SOIL } & \end{array}$

\begin{tabular}{|c|c|c|c|c|c|c|c|c|}
\hline Parameter & $\underline{\text { Result }}$ & $\underline{\text { Unit }}$ & $\begin{array}{c}\text { Reporting } \\
\text { Limit }\end{array}$ & $\underline{\mathbf{D F}}$ & Method & Prep Date & Analyzed & Analrst \\
\hline Diese] Range Organics (C12.C22) & ND & $\mathrm{mg} / \mathrm{Kg}$ & 20 & 1 & SW8015Ext & $05 / 24 / 02$ & $05: 30 / 02$ & PXC-LV \\
\hline Gasoline Range Organics ( $\mathrm{C} 8-\mathrm{Cl} 2)$ & ND & $\mathrm{mg} / \mathrm{Kg}$ & 20 & 1 & SW8015Exi & $05 / 24 / 02$ & $05 / 30 / 02$ & PXC-1.Y \\
\hline Oil Range Organics (C22-C34) & ND & $\mathrm{mg} / \mathrm{Kg}$ & 100 & 1 & SW8015Ext & $05 / 24 / 02$ & $05 / 30 / 02$ & PXC-1.1 \\
\hline Total Petroleum Hydrocarbons & $\mathrm{ND}$ & $\mathrm{mg} / \mathrm{Kg}$ & 20 & 1 & SW8015Ext & $05 / 24 / 02$ & $05 / 30 / 02$ & PXC'LV \\
\hline Surr: n-Octacosane & 83.1 & $\%$ REC & $55-130$ & 1 & SW8015Ext & $05 / 24 / 02$ & $05 / 30 / 02$ & PXC-LV \\
\hline
\end{tabular}

ND - Not Detected at the Reporting Limit DF - Dilution Factor

Date: $03-J u n-02$
$\mathrm{B}$ - Analyte detected in the associated Method Blank

S - Spike Recovery outside accepted recovery limits

$E$ - Value above quantitation range
Page 16 of 17 
NEL LABORATORIES

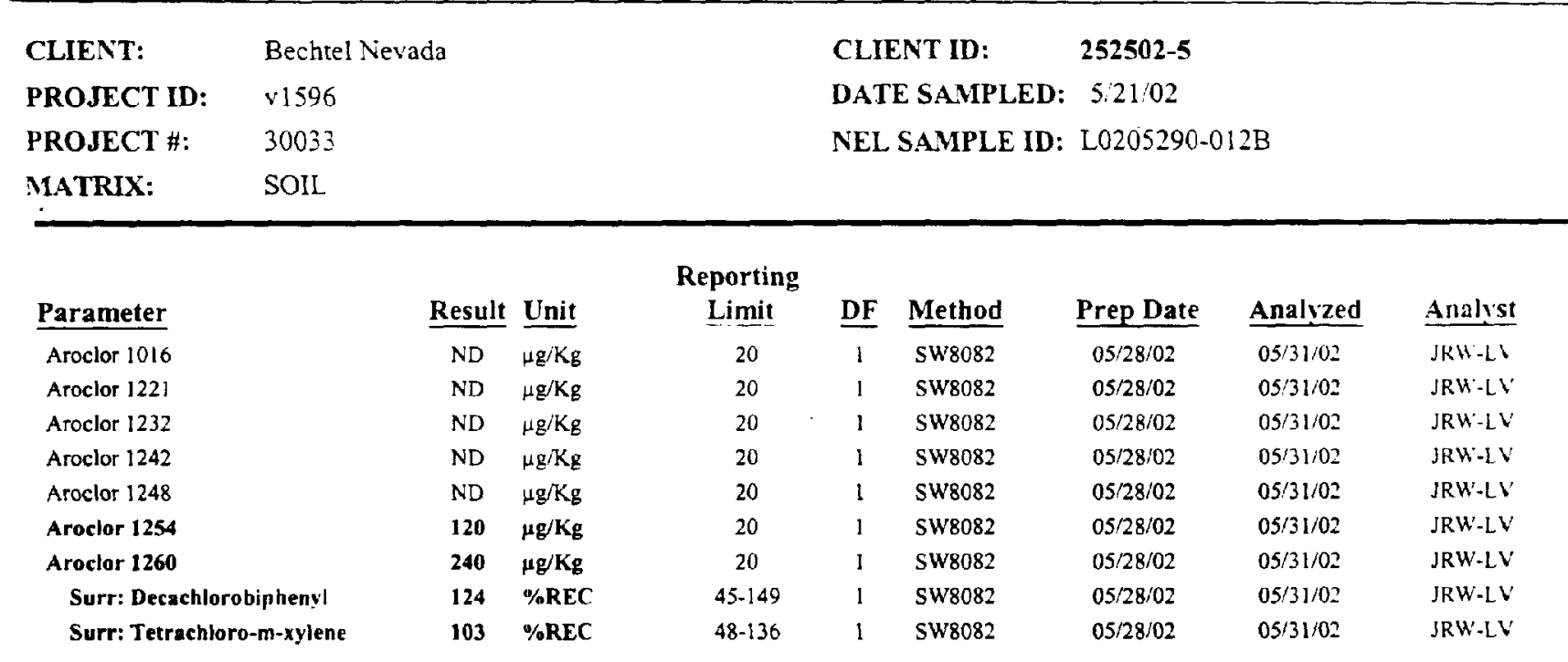

ND - Not Detected at the Reporting Limit

DF - Dilution Factor

Date: $03-J u n-02$
B - Analyte detected in the associated Method Blank

S - Spike Recovery outside accepted recovery limits

$\mathrm{E}$ - Value above quantitation range
Page 17 of 17 


\section{CLIENT: Bechtel Nevada \\ Work Order: L0205290}

Project:

v1596

\section{ANALYTICAL QC SUMMARY REPORT}

BatchlD: 430

\begin{tabular}{|c|c|c|c|c|c|c|c|c|c|c|c|c|c|}
\hline \multirow{2}{*}{$\begin{array}{l}\text { Sample ID: 020528PCBS-MB } \\
\text { Analyte }\end{array}$} & \multirow{2}{*}{$\begin{array}{r}\text { SampType: } \\
\text { Batch ID: }\end{array}$} & \multirow{2}{*}{$\begin{array}{l}\text { MBLK } \\
430 \\
\text { Result }\end{array}$} & \multicolumn{2}{|c|}{$\begin{array}{l}\text { TestCode: } \mathbf{8 0 8 2} \text { SS } \\
\text { TestNo: Sw8082 }\end{array}$} & \multicolumn{3}{|c|}{ Units: $\mu \mathbf{g} / \mathbf{K g}$} & \multicolumn{3}{|c|}{$\begin{aligned} \text { Prep Date: } & \mathbf{5 / 2 8 / 0 2} \\
\text { Analysis Date: } & \mathbf{5 / 3 1 / 0 2}\end{aligned}$} & \multicolumn{3}{|c|}{$\begin{array}{l}\text { Rum II) L_EC(1)-1_020531A } \\
\text { SeqNo: } 34019\end{array}$} \\
\hline & & & PQI & SPK value & SPK Ref $V_{a}$ & & \%REC & LowLimit I & Highl imit & Rl'I) Ref Val & "RRP & RPII_imit & Qแal \\
\hline Aroclor 1016 & & ND & 20 & & & & & & & & & & \\
\hline Aroclor 1221 & & ND & 20 & & & & & & & & & & \\
\hline Aroclor 1232 & & ND & 20 & & & & & & & & & & \\
\hline Aroclor 1242 & & ND & 20 & & & & & & & & & & \\
\hline Arnclor 1248 & & ND & 20 & & & & & & & & & & \\
\hline Aroclor 1254 & & ND & 20 & & & & & & & & & & \\
\hline Arocler 1260 & & ND & 20 & & & & & & & & & & \\
\hline Surr: Tetrachloro-m-xylene & & 74.98 & 0.10 & 66.68 & & 0 & 112 & 48 & 136 & 0 & 0 & & \\
\hline Surr: Decachlorobiphenyl & & 94.3 & 0.10 & 66.68 & & 0 & 141 & 45 & 149 & 0 & 0 & & \\
\hline Sample ID. O20528PCBS-LCS & \multirow[t]{2}{*}{$\begin{array}{r}\text { SampType: } \\
\text { Batch ID: }\end{array}$} & \multirow{2}{*}{$\begin{array}{l}\text { LCS } \\
430 \\
\text { Result }\end{array}$} & \multicolumn{2}{|c|}{$\begin{array}{l}\text { TestCode: 8082_S } \\
\text { TestNo: SW8082 }\end{array}$} & \multicolumn{2}{|c|}{ Units: $\mathbf{\mu g} / \mathbf{K g}$} & & \multicolumn{2}{|c|}{$\begin{array}{rr}\text { Prep Date: } & 5 / 28 / 02 \\
\text { Analysis Date: } & 5 / 31 / 02\end{array}$} & & \multicolumn{3}{|c|}{$\begin{array}{l}\text { Rum II): I_EC II)-1_020531A } \\
S e q N a: 34021\end{array}$} \\
\hline Analyte & & & $\mathrm{PQL}$ & SPK value & SPK Ref $V_{2}$ & & $\% \mathrm{REC}$ & LowLimit I & HighL.imit & RPD Rer Val & " & RPPl.imit & Qual \\
\hline Aroclor 1016 & & 341.6 & 20 & 332.9 & & 0 & 103 & 60 & 140 & 0 & 0 & & \\
\hline Aroclor 1260 & & 356.9 & 20 & 332.9 & & 0 & 107 & 60 & 140 & 0 & 0 & & \\
\hline Surr: Tetrachloro-m-xylene & & 75.97 & 0.10 & 66.68 & & 0 & 114 & 48 & 130 & 0 & 0 & & \\
\hline Surt: Decachlorobiphenyl & & 96.63 & 0.10 & 66.68 & & 0 & 145 & 45 & 149 & 0 & 0 & & \\
\hline \multirow[t]{2}{*}{ Sample ID: 020528PCBS-LCSD } & \multirow[t]{2}{*}{$\begin{array}{r}\text { SampType: } \\
\text { Batch ID: }\end{array}$} & $\begin{array}{l}\text { LCSD } \\
430\end{array}$ & $\begin{array}{r}\text { TestC } \\
\text { Tes }\end{array}$ & $\begin{array}{l}\text { :8082_S } \\
\text { SW8082 }\end{array}$ & Units: & $\mu \mathrm{g} / \mathrm{Kg}$ & & $\begin{array}{r}\text { Prep Date } \\
\text { Analysis Date }\end{array}$ & $\begin{array}{l}5 / 28 / 02 \\
\text { e: }\end{array}$ & & $\begin{array}{l}\text { Run II): I, } \\
\text { ScyNo: } \mathbf{9 4 0}\end{array}$ & 20 & \\
\hline & & Result & PQL & SPK value & SPK Ref $\mathrm{Va}$ & & $\%$ REC & LowLimit I & ItighLimit & RPI) Ref Val & "IRPI) & RPID init & Oual \\
\hline Aroclor 1016 & & 313.2 & 20 & 332.9 & & 0 & 94.1 & 60 & 140 & .341 .6 & 8.0 .5 & 25 & \\
\hline Aroclor 1260 & & 324.9 & 20 & 332.9 & & 0 & 97.6 & 60 & 140 & $35 r, 9$ & 9.18 & 28 & \\
\hline Surr: Tetrachloro-m-xylene & & 63.31 & 0.10 & 66.68 & & 0 & 95 & 48 & 136 & 0 & 0 & 0 & \\
\hline Surt Iecachlorobiphenyl & & 81.31 & 0.10 & 66.68 & & 0 & 122 & 4.5 & 149 & 0 & 0 & 0 & \\
\hline
\end{tabular}

Qualifien: 
CLIENT: Bechtel Nevada

ANALYTICAL QC SUMMARY REPORT

Work Order: L0205290

BatchID: $\quad 430$

v1596

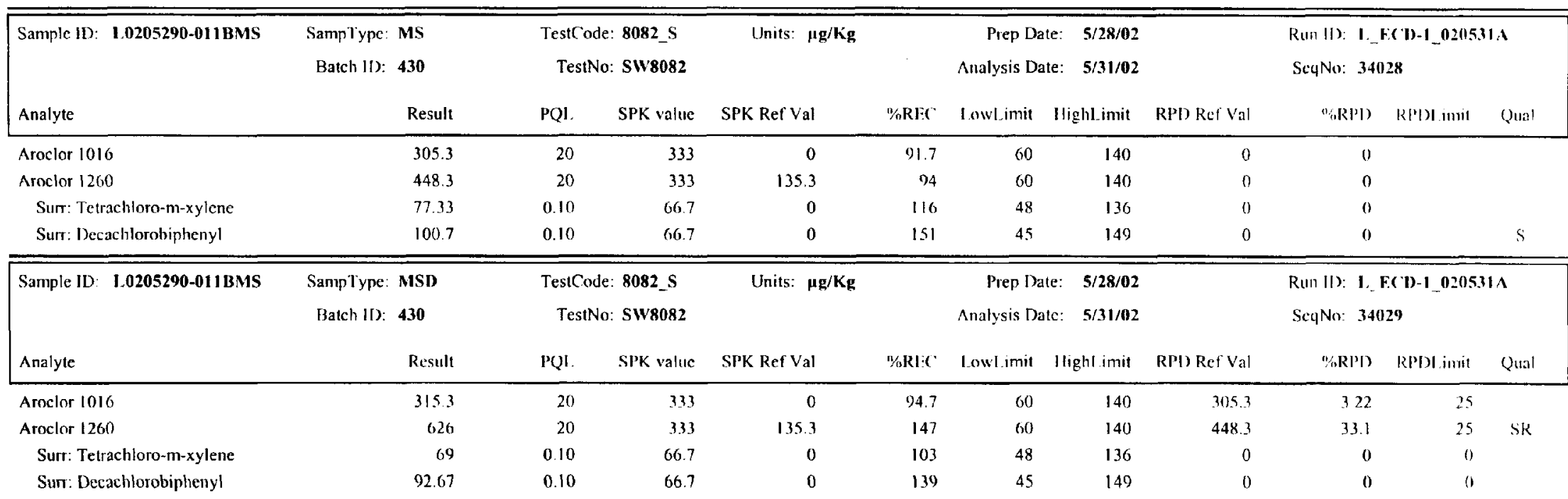


CLIENT:

Bechtel Nevada

Work Order: L0205290

Project:

v1596
ANALYTICAL OC SUMMARY REPORT

BatchID: $\quad 440$

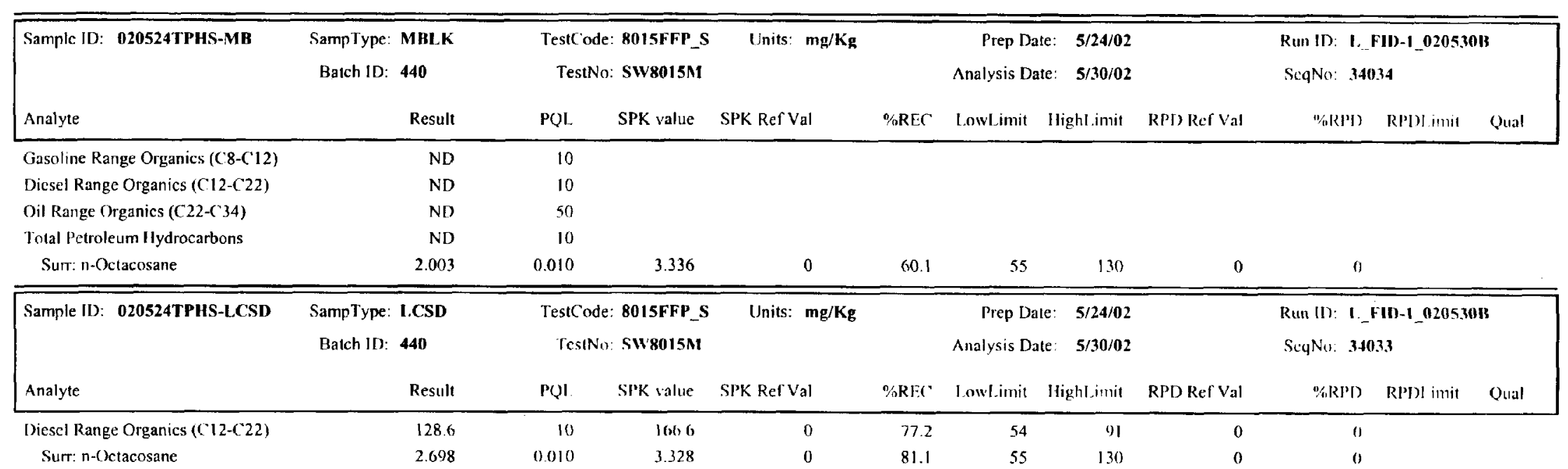

B - Analyte detected in the assictited Mithud blank 
CLIENT:

Work Order:

Project:
Bechtel Nevada

L0205290

v1596
ANALYTICAL QC SUMMARY REPORT

BatchID: 441

\begin{tabular}{|c|c|c|c|c|c|c|c|c|c|}
\hline Sample ID: 02053ITPHS-MB & $\begin{array}{l}\text { SampType: MBLK } \\
\text { Batclı ID: } \mathbf{4 4 1}\end{array}$ & $\begin{array}{l}\text { TestCode: } \\
\text { TestNo: }\end{array}$ & $\begin{array}{l}\text { 8015FFP_S } \\
\text { SIVB015M }\end{array}$ & Units: $\mathbf{m g} / \mathbf{K g}$ & & $\begin{array}{rr}\text { Prep Date: } & \mathbf{5 / 3 1 / 0 2} \\
\text { Analysis Date: } & \mathbf{5 / 3 1 / 0 2}\end{array}$ & & $\begin{array}{l}\text { Run 1D: I,FII)-1_0205.31A } \\
\text { SeyNo: } 3.3980\end{array}$ & . \\
\hline Analyte & Result & PQL & SPK value & SPK Ref Val & $\%$ REC & Lowl imit Hlight imit & RPD Ret Val & "يRPI) RP[H.imit & Qual \\
\hline Gasoline Range Organics (C8-C12) & ND & 10 & & & & & & & \\
\hline Diesel Range Organics (C12-C22) & ND & 10 & & & & & & & \\
\hline Oil Range Organics (C22-C34) & ND & 50 & & & & & & & \\
\hline Total Petroleum Hydrocarbons & ND & 10 & & & & & & & \\
\hline Surr: n-Octacosane & 2.067 & 0.010 & 3.33 & 0 & 62.1 & 130 & 0 & () & \\
\hline Sample ID: 020531TPHS-LCS & $\begin{array}{c}\text { SampType: I.CS } \\
\text { Batch ID: } \mathbf{4 4 I}\end{array}$ & $\begin{array}{r}\text { TestCode: } \\
\text { TestNo: }\end{array}$ & $\begin{array}{l}\text { :8015FFP_S } \\
\text { SWB015M }\end{array}$ & Units: $\mathbf{m g} / \mathbf{K g}$ & & $\begin{aligned} \text { Prep Date: } & 5 / 31 / 02 \\
\text { Analysis Date: } & 6 / 1 / 02\end{aligned}$ & & $\begin{array}{l}\text { Run II) } \quad \text { I_FID)-1_020531A } \\
\text { ScyNN } \quad 3.3978\end{array}$ & \\
\hline Analytc & Result & $\mathrm{PQL}$ & SPK value & SPK Ref Val & \%RFC & Lowlimit Hight.imit & RPI) Ref Val & \%RI'I RPIDI.init & Oual \\
\hline Diesel Range Organics (C12-C22) & 120.5 & 10 & 166.6 & $\mathbf{0}$ & 72.3 & 54 & 0 & 0 & \\
\hline Surr: $n$-Octacosane & 2.6 & 0.010 & 3.329 & 0 & 78.1 & 130 & 0 & 0 & \\
\hline Sample ID: O2053ITPHS-LCSD & $\begin{array}{l}\text { SampType: LCSD } \\
\text { Batch ID: } \mathbf{4 4 1}\end{array}$ & $\begin{array}{r}\text { TesiCode: } \\
\text { TestNo: }\end{array}$ & $\begin{array}{l}\text { 8015FFPSS } \\
\text { SWBo15M }\end{array}$ & Units: $\mathbf{m g} / \mathbf{K g}$ & & $\begin{array}{rr}\text { Prep Date: } & 5 / 31 / 02 \\
\text { Analysis Date: } & 5 / 31 / 02\end{array}$ & & $\begin{array}{l}\text { Run II) I_FID-1 } 1020531 \mathrm{~A} \\
\mathrm{Seq} N \mathrm{~N} \cdot 33979\end{array}$ & \\
\hline Analyte & Result & PQL & SPK value & SPK Ref Val & \%REC & LowLimit Hlighl.ımit & RPI) Ref Val & "(RPI) RPID imil & Qual \\
\hline Diesel Range Organics (C12-(22) & 96.43 & 10 & 166.6 & 0 & 57.9 & 91 & 120.5 & 22.2 & \\
\hline Surr: n-Octacosane & 2.6 & 0.010 & 3.329 & 0 & 78.1 & 130 & 0 & 0 & \\
\hline Sample ID: L0205290-001A & $\begin{array}{r}\text { SampType: MS } \\
\text { Batch ID: } \mathbf{4 4 1}\end{array}$ & $\begin{array}{r}\text { TestCode: } \\
\text { TestNo: }\end{array}$ & $\begin{array}{l}\text { 8015FFP_S } \\
\text { SW8015M }\end{array}$ & Units: $\mathbf{m g} / \mathbf{K g}$ & & $\begin{array}{rr}\text { Prep Date: } & \mathbf{5 / 3 1 / 0 2} \\
\text { Analysis Date: } & \mathbf{5 / 3 0 / 0 2}\end{array}$ & & $\begin{array}{l}\text { Run II) } 1, \text { FID-1 } 02053013 \\
\text { ScyNo: } \quad 34045\end{array}$ & \\
\hline Analyte & Result & PQL & SPK value & SPK Ref Val & $\%$ REC & LowLimit Highl imit & RPIJ Ref Val & "uRPI) RI'IJimit & Qual \\
\hline $\begin{array}{l}\text { Diesel Range Organics (C12-(22) } \\
\text { Surr: n-Octacosane }\end{array}$ & $\begin{array}{l}112.4 \\
2.164\end{array}$ & $\begin{array}{r}10 \\
0.010\end{array}$ & $\begin{array}{l}166.5 \\
3.326\end{array}$ & $\begin{array}{l}0 \\
0\end{array}$ & $\begin{array}{l}67.5 \\
65.1\end{array}$ & $\begin{array}{r}91 \\
130\end{array}$ & $\begin{array}{l}0 \\
0\end{array}$ & () & \\
\hline
\end{tabular}


CLIENT:

Bechtel Nevada

Work Order: L0205290

Project: v1596

Sample ID: L.0205290-001A SampType: MSD

Batch ID: 441

Analyte

Dicsel Range Organics (C12-C22)

Surt: п-Uctacosane

Result

Result

116.7
2.197

2.1

0.010

TestCode: 8015FFP_S

TestNo: SW8015M

PQL SPK value SPK Ref Val

$\begin{array}{rr}10 & 166.5 \\ 0.010 & 3.326\end{array}$

\section{ANALYTICAL QC SUMMARY REPORT}

BatchlD: 441 


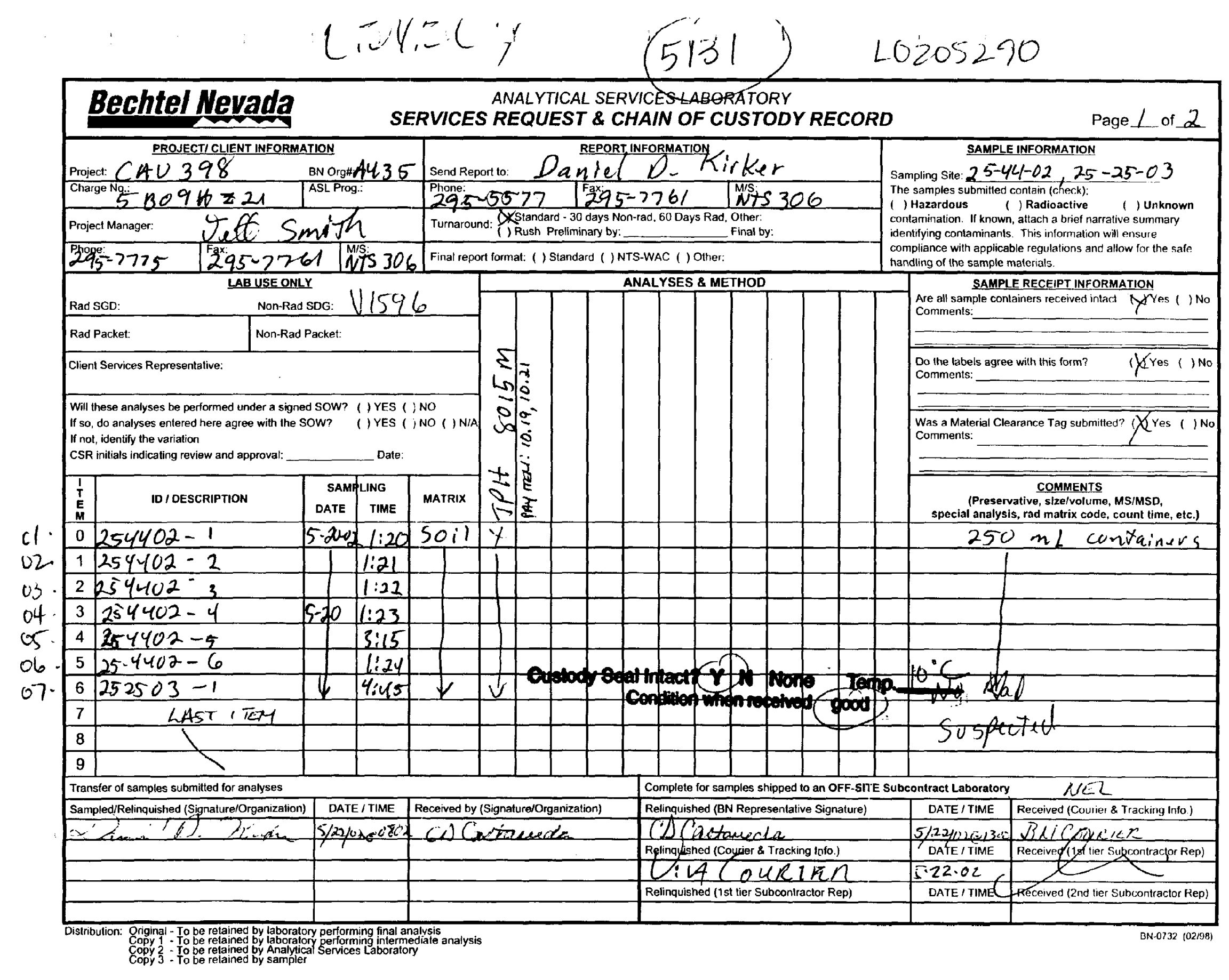




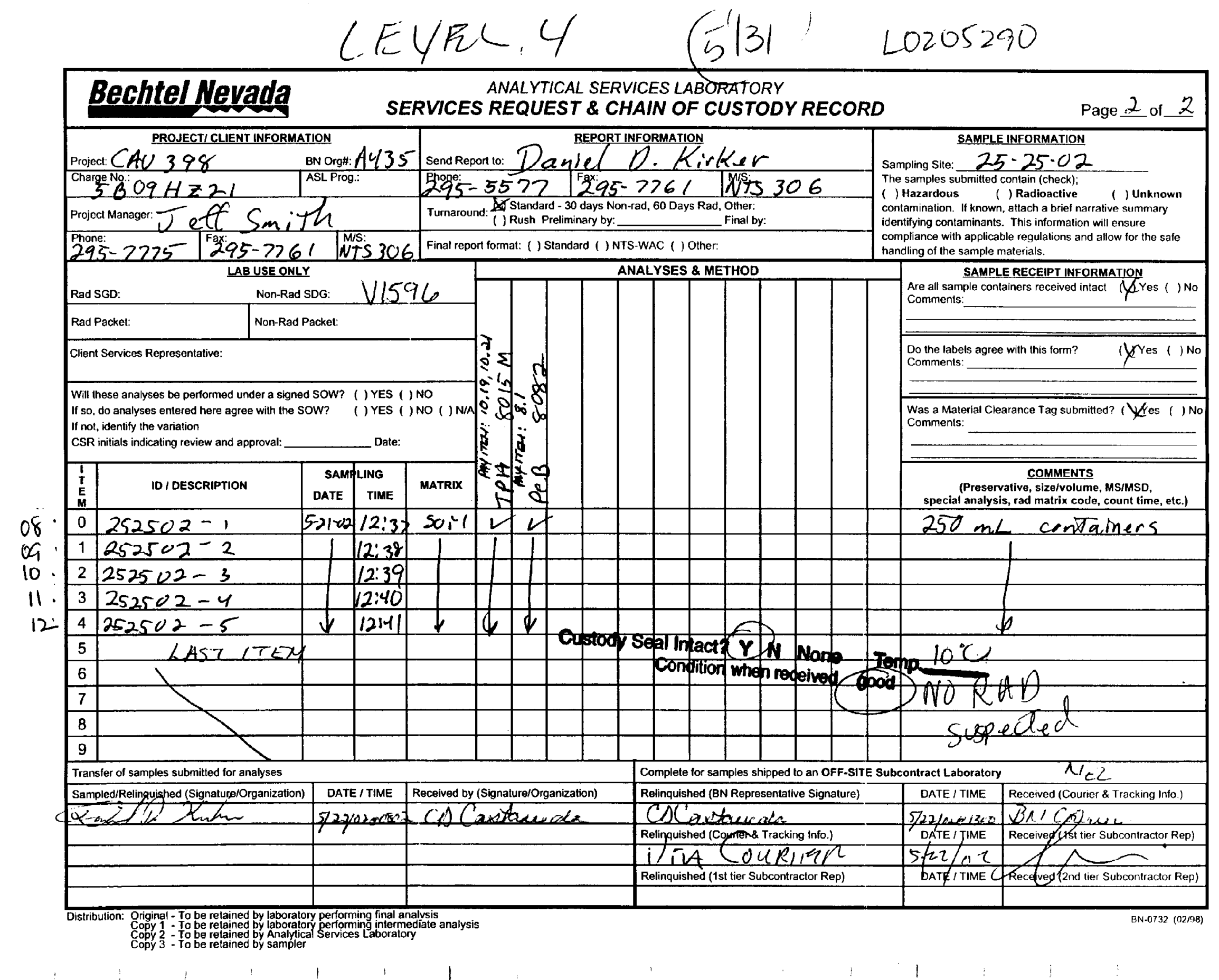


CLOSURE REPORT - CAU 398

Section: Appendix B

Revision: 1

Date: April 2003

\section{SAMPLE DELIVERY GROUP}

\section{V1609}


CLOSURE REPORT - CAU 398

Section: Appendix B

Revision: 1

Date: April 2003

THIS PAGE INTENTIONALLY LEFT BLANK 


\section{NEL LABORATORIES}

Ted Redding

Bechtel Nevada

P.O. Box 98521, M/S NTS273

Las Vegas, NV 89193-8521

TEL: 702-295-7220

RE Project: V1609

Order No.: L0206022

Dear Ted Redding:

NEL Laboratories, Las Vegas received 12 samples on 6/4/02 for the analyses presented in the following report.

There were no problems with the analyses and all data for associated QC met EPA or laboratory specifications unless noted in the Case Narrative.

If you have any questions regarding these tests results, please feel free to call.
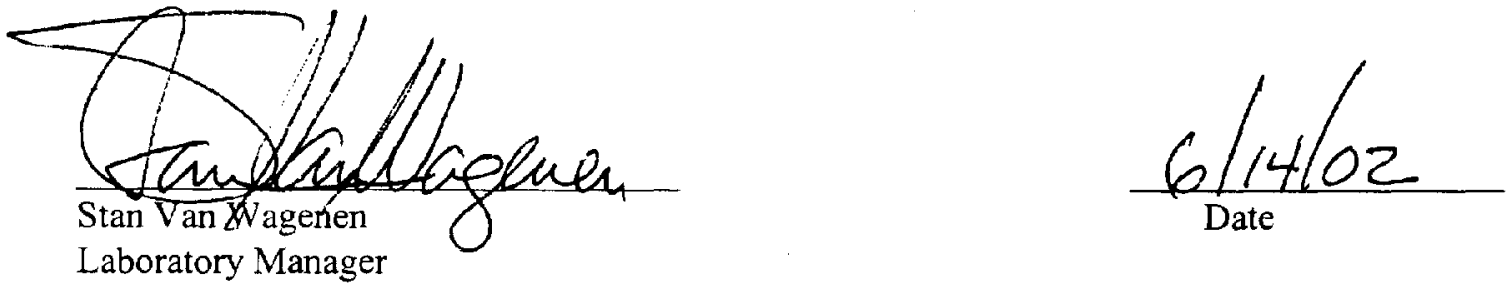

Certifications:

Arizona

California

Reno

Las Vegas

Idaho

AZ0520 AZ0518

Montana

1707

2002

Nevada

Certified Certified

Certified Certified

New Mexico

NV033 NV052

Certified Certified 
NEL LABORATORIES

\begin{tabular}{|c|c|c|c|c|c|c|c|c|c|}
\hline CLIENT: & \multicolumn{3}{|c|}{ Bechtel Nevada } & & CLI & NT ID: & \multicolumn{2}{|l|}{$252504-1$} & \\
\hline PROJECT ID: & \multicolumn{3}{|l|}{$v 1609$} & & \multicolumn{4}{|c|}{ DATE SAMPLED: 6302} & \\
\hline PROJECT \#: & \multicolumn{3}{|l|}{30033} & & \multicolumn{4}{|c|}{ NEL SAMPLE ID: L020602--001A } & \\
\hline MATRIX: & SOIL & & & & & & & & \\
\hline \multicolumn{2}{|l|}{ Parameter } & $\underline{\text { Result }}$ & Unit & $\begin{array}{l}\text { Reporting } \\
\text { Limit }\end{array}$ & $\underline{\text { DF }}$ & Method & Prep Date & Analyzed & Analyst \\
\hline \multicolumn{2}{|c|}{ Diesel Range Organics (C12-C22) } & ND & $\mathrm{mg} / \mathrm{kg}$ & 10 & 1 & SW8015Ext & $00: 05 / 02$ & 000002 & $P X C-1 X$ \\
\hline \multicolumn{2}{|c|}{ Gasoline Range Organics (CR-C12) } & ND & $\mathrm{mg} / \mathrm{Kg}$ & 10 & 1 & SW8015Ext & 00,0502 & 0600,02 & PXC-1Y \\
\hline \multicolumn{2}{|c|}{ (Gil Range Organics (C22-C 34 ) } & ND & $\mathrm{mg} / \mathrm{Kg}$ & 50 & 1 & SW8015Ext & $00 / 0502$ & 06,0602 & $P A C-1 V$ \\
\hline \multicolumn{2}{|c|}{ Total Petroleum Hydrocarbons } & ND & $\mathrm{mg} / \mathrm{Kg}$ & 10 & 1 & SW8015Ext & $06 / 05 / 02$ & 060602 & PXC-IV \\
\hline \multicolumn{2}{|c|}{ Surr: n-Octacosane } & 79.1 & " REC & $55-130$ & 1 & SW8015Ext & $00: 0502$ & $0600: 02$ & PXC-LY \\
\hline
\end{tabular}

ND - Not Detected at the Reporting Limit DF - Dilution Factor

Date: $/ /-J u n-02$
B - Analyte detected in the associated Method Blank

S. Spike Recovery outside accepted recovery limits

$E$ - Value above quantitation range
Page 1 of 12 
NEL LABORATORIES

$\begin{array}{lll}\text { CLIENT: } & \text { Bechrel Nevada } & \text { CLIENT ID: } \\ \text { PROIECT ID: } & \text { V1609 } & \text { DATE SAMIPLED: } 6302 \\ \text { IROJECT \#: } & 30033 & \text { NEL SAMPLE ID: L0200022-002A } \\ \text { MATRIX: } & \text { SOIL } & \end{array}$

\begin{tabular}{|c|c|c|c|c|c|c|c|c|}
\hline Parameter & Result & Unit & $\begin{array}{c}\text { Reporting } \\
\text { Limit }\end{array}$ & $\underline{\mathrm{DF}}$ & Method & Prep Date & Analyzed & Analyst \\
\hline Diesel Range Organics (C12-C22) & ND & $\mathrm{mg} / \mathrm{Kg}$ & 10 & 1 & SW8015Ext & $00 / 05 / 02$ & 06.0602 & PXC-LI \\
\hline Gasoline Range Organics (C8-C12) & ND & $\mathrm{mg} / \mathrm{Kg}$ & 10 & 1 & SW8015Ext & $00: 05 / 02$ & 000002 & PXC -L.S \\
\hline Oif Range Organics (C22-C 34 ) & ND & $\mathrm{mg} / \mathrm{Kg}$ & 50 & 1 & SW8015Ex1 & 060502 & $06: 0602$ & PXC-LY \\
\hline Total Petroleum Hydrocarbons & ND & $\mathrm{mg} / \mathrm{Kg}$ & 10 & 1 & SW8015Ext & $06 / 05 / 02$ & $0006 \% 2$ & PXC-LV \\
\hline Surr: n-Octacosane & 89.1 & "/REC & $55-130$ & 1 & SW8015Ext & $06 / 05 / 02$ & $06: 00 / 02$ & $\mathrm{PXC}-\mathrm{LV}$ \\
\hline
\end{tabular}

ND - Not Detected at the Reporting Limit DF - Dilution Factor

Date: $/ 1-J u n-0$ ?
$\mathrm{B}$ - Analyte detected in the associated Method Blank

$S$ - Spike Recovery outside accepted recovery limits

$E$ - Value above quantitation range
Page 2 of 12 
NEL LABORATORIES

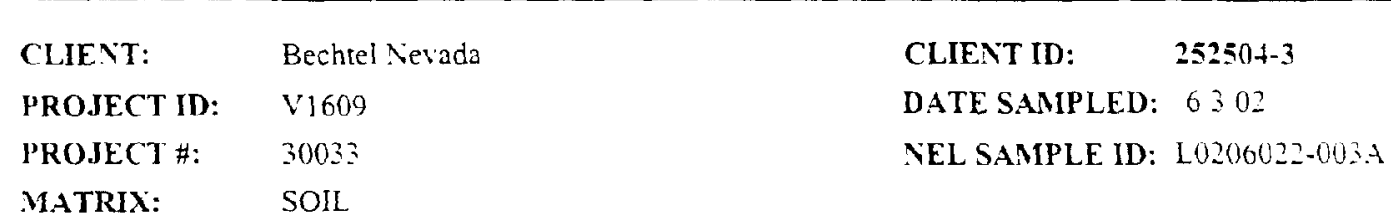

\begin{tabular}{|c|c|c|c|c|c|c|c|c|}
\hline Parameter & $\underline{\text { Result }}$ & Unit & $\begin{array}{l}\text { Reporting } \\
\text { Limit }\end{array}$ & $\underline{\text { DF }}$ & Methad & Prep Date & Analyzed & Analesi \\
\hline Diesel Range Organics (C12-C22) & ND & $\mathrm{mg} / \mathrm{Kg}$ & 10 & 1 & SW80:5Ext & $00,05 \cdot 02$ & 0000.02 & $b x-1 d$ \\
\hline Gasoline Range Organics (C8-C12) & ND & $\mathrm{mg} / \mathrm{Kg}$ & 10 & 1 & SW8015Ext & $00 / 05 / 02$ & 000602 & PXC-LY \\
\hline Oil Range Organics $(C 22-C 34)$ & $\mathrm{ND}$ & $\mathrm{mg} / \mathrm{Kg}$ & 50 & 1 & SW80I5Ext & 000502 & 0600.02 & $P X C-L Y$ \\
\hline Total Petroleum Hydrocarbons & ND & $\mathrm{mg} / \mathrm{Kg}$ & 10 & 1 & SW8015Ext & $06 / 05 / 02$ & 06,0602 & $P X C-I Y$ \\
\hline Surr: n-Octacosanc' & 102 & $11 / 1 \mathrm{REC}$ & $55-130$ & 1 & SW8015Ext & $00 / 05 / 02$ & $06 / 06 / 02$ & PXC-LV \\
\hline
\end{tabular}

ND - Not Detected at the Reporting Limit

DF - Dilution Factor

Date: I $i-J u m-02$
B - Analyte detected in the associated Method Blank

S - Spike Recovery outside accepted recovery' limits

$E$ - Value above quantitation range 
NEL LABORATORIES

\begin{tabular}{|c|c|c|c|c|c|c|c|c|c|}
\hline CLIENT: & \multicolumn{4}{|c|}{ Bechtel Nevada } & \multicolumn{4}{|c|}{ CLIENT ID: $\quad 252504-4$} & \\
\hline PROJECT ID: & \multicolumn{4}{|l|}{$\vee 1609$} & \multicolumn{4}{|c|}{ DATE SAMPLED: 6302} & \\
\hline PROJECT \#: & \multicolumn{4}{|l|}{30033} & \multicolumn{5}{|c|}{ NEL SAMPLE ID: L0206022-004A } \\
\hline MATRIX: & SOIL & & & & & & & & \\
\hline \multicolumn{2}{|l|}{ Parameter } & $\underline{\text { Result }}$ & $\underline{\text { Unit }}$ & $\begin{array}{l}\text { Reporting } \\
\text { Limit }\end{array}$ & $\underline{\mathrm{DF}}$ & Method & Prep Date & Analyzed & Analyst \\
\hline \multicolumn{2}{|c|}{ Diesel Range Organics (C12-C22) } & ND & $\mathrm{mg} / \mathrm{Kg}$ & 10 & $!$ & SW8015Ext & $06: 05 / 02$ & 060002 & PXC-II \\
\hline \multicolumn{2}{|c|}{ Gasoline Range Organics (C8-C12) } & ND & $\mathrm{mg} / \mathrm{Kg}$ & 10 & 1 & SW8015Ex1 & $06 / 05 / 02$ & 06.0602 & PXC -1.1 \\
\hline \multicolumn{2}{|c|}{ Oil Range Organics (C22-C34) } & ND & $\mathrm{mg} / \mathrm{Kg}$ & 50 & 1 & SW80 $5 E x 1$ & 06,0502 & 060602 & $P X(-L)$ \\
\hline \multicolumn{2}{|c|}{ Total Petroleum Hydrocarbons } & ND & $\mathrm{mg} / \mathrm{Kg}$ & 10 & 1 & SW8015Ext & $00 / 05 / 02$ & $06: 0602$ & $P X C \cdot L Y$ \\
\hline \multicolumn{2}{|c|}{ Surr: n-Octacosane } & 125 & $\% R E C$ & $55-130$ & 1 & SW8015Ext & $06 / 05 / 02$ & $06 / 00 / 02$ & PXC-1.' \\
\hline
\end{tabular}

ND - Not Detected at the Reporting Limit DF - Dilution Factor

Date: $1 /-J u n-02$
$\mathrm{B}$ - Analyte detected in the associated Method Blank

S - Spike Recovery outside accepted recovery limits

E - Value above quantitation range
Page 4 of 12 
NEL LABORATORIES

\begin{tabular}{|c|c|c|c|c|c|c|c|c|c|}
\hline CLIENT: & \multicolumn{4}{|c|}{ Bechtel Nevada } & \multicolumn{4}{|c|}{ CLIENT ID: $\quad 252504-5$} & \\
\hline PROJECT ID: & \multicolumn{4}{|c|}{$V 1609$} & \multicolumn{5}{|c|}{ DATE SAMPLED: 6302} \\
\hline PROJECT \#: & \multicolumn{4}{|l|}{30033} & \multicolumn{5}{|c|}{ NEL SAMIPLE ID: L0206022-005A } \\
\hline MATRIX: & SOIL & & & & & & & & \\
\hline \multicolumn{2}{|l|}{ Parameter } & $\underline{\text { Result }}$ & $\underline{\text { Unit }}$ & $\begin{array}{l}\text { Reporting } \\
\text { Limit }\end{array}$ & $\underline{\mathrm{DF}}$ & Method & Prep Date & Analyzed & Analys! \\
\hline \multicolumn{2}{|c|}{ Diesel Range Organics (C $\left.12-\mathrm{C}_{2} 2\right)$} & ND & $\mathrm{mg} / \mathrm{Kg}$ & 10 & 1 & SW8015Ext & $00: 05: 02$ & 06.0602 & PXC-LV \\
\hline \multicolumn{2}{|c|}{ Gasoline Range Organics $(\mathrm{C} 8-\mathrm{C}(2)$} & ND & $\mathrm{mg} / \mathrm{Kg}$ & 10 & 1 & SW8015Ext & $06 / 05 / 02$ & $06 / 00: 02$ & $P X C-L V$ \\
\hline \multicolumn{2}{|c|}{ Oil Range Organics $\left(\mathrm{C}_{2} 2-\mathrm{C}_{3}+\right\}$} & $N D$ & $\mathrm{mg} \mathrm{Kg}$ & 50 & 1 & SW8015Ext & $06 / 050 ?$ & 0606,02 & PXC-1.Y \\
\hline \multicolumn{2}{|c|}{ Total Petroleum Hydrocarbons } & $\mathrm{ND}$ & $\mathrm{mg} / \mathrm{Kg}$ & 10 & 1 & SW8015Ext & $06 / 05 / 02$ & $06: 06: 02$ & $P X C-L V$ \\
\hline \multicolumn{2}{|c|}{ Surr: n-Octacosane } & 99.1 & $\%$ REC & $55-130$ & 1 & SW8015Ext & $06 / 05: 02$ & $06 / 06 / 02$ & PXC-LV \\
\hline
\end{tabular}

ND - Not netected at the Reporting limit

DF - Dilution Factor

Date: $/ /-J u n-02$
B - Analyte detected in the associated Method Blank

$S$ - Spike Recovery outside accepted recovery limits

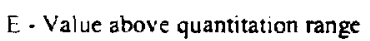

Page 5 of 12 


\section{NEL LABORATORIES}

\begin{tabular}{|c|c|c|c|c|c|c|c|c|c|}
\hline CLIENT: & \multicolumn{3}{|c|}{ Bechtel Nerada } & & \multicolumn{3}{|c|}{ CLIENT ID: $\quad 252504-6$} & & \\
\hline PROJECT ID: & \multicolumn{3}{|l|}{$V 1609$} & & \multicolumn{4}{|c|}{ DATE SAMPLED: 6302} & \\
\hline PROJECT \#: & \multicolumn{3}{|l|}{30033} & & \multicolumn{4}{|c|}{ NEL SAMPLE ID: L020602?-000A } & \\
\hline MATRIX: & SOIL & & & & & & & & \\
\hline \multicolumn{2}{|l|}{ Parameter } & Result & $\underline{\text { Unit }}$ & $\begin{array}{c}\text { Reporting } \\
\text { Limit }\end{array}$ & $\underline{\mathbf{D F}}$ & Method & Prep Date & Analyzed & Analysı \\
\hline \multicolumn{2}{|c|}{ Dicsel Range Organics (C12-C22) } & ND & $\mathrm{mg} / \mathrm{Kg}$ & 10 & 1 & SW8015Ext & $06 / 05 / 02$ & $00.00: 02$ & $P X C \cdot L Y$ \\
\hline \multicolumn{2}{|c|}{ Gasoline Range Organics ( $\mathrm{C} 8-\mathrm{Cl}$ ) } & ND & $\mathrm{mg} / \mathrm{Kg}$ & 10 & I & SW8015Ext & $06 / 05 / 02$ & $00 / 00 / 02$ & PXC-IX \\
\hline \multicolumn{2}{|c|}{ Oil Range Organics ( $(22-\mathrm{C} 34)$} & ND & $\mathrm{mg} / \mathrm{Kg}$ & 50 & 1 & SW801 SExt & $06 / 05 / 02$ & $00: 00: 02$ & PXC-LY \\
\hline \multirow{2}{*}{\multicolumn{2}{|c|}{$\begin{array}{l}\text { Total Petroleum Hydracarbons } \\
\text { Surr: } n \text {-Octacosane }\end{array}$}} & ND & $\mathrm{mg} / \mathrm{Kg}$ & 10 & 1 & SW80l SExt & $06 / 05 / 02$ & 06.0602 & $P X C-1 . Y$ \\
\hline & & 98.1 & $11 / \mathrm{RECC}$ & $55-130$ & 1 & SW8015Ext & $06 / 05 / 02$ & 060602 & PXC-11 \\
\hline
\end{tabular}

ND - Not Detected at the Reporting Limit DF - Dilution Factor

Date: $\| /-J u n-02$
B - Analyte detected in the associated Method Blank

S - Spike Recovery outside accepted recovery limits

$E$ - value above quantitation range
Page 6 of 12 
NEL LABORATORIES

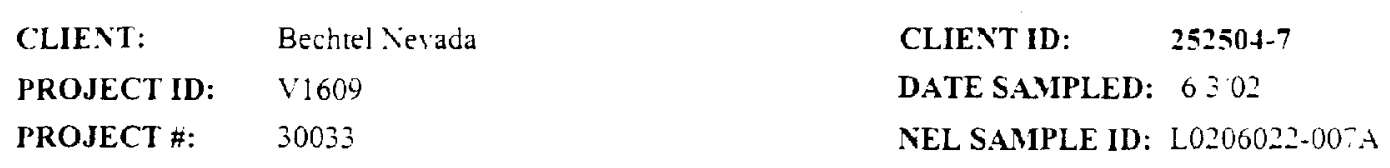

MATRIX: SOIL

\begin{tabular}{|c|c|c|c|c|c|c|c|c|}
\hline Parameter & Result & Init & $\begin{array}{c}\text { Reporting } \\
\text { Limit }\end{array}$ & $\underline{\mathrm{DF}}$ & Method & Prep Date & Analyzed & Analist \\
\hline Diesel Range Organics (C12-('22) & ND & $\mathrm{mg} / \mathrm{Kg}$ & 10 & 1 & SW8015Ex1 & $00 \% 0502$ & 0006.02 & $P X(-L 1$ \\
\hline Gasoline Range Organics $1(\mathrm{C} 8-\mathrm{C} 12$, & ND & $\mathrm{mg} / \mathrm{Kg}$ & 10 & 1 & SW8015Ex1 & $06 / 05 / 02$ & $06^{\circ} 00^{\prime} 02$ & PXC -11 \\
\hline Oil Range Organics ( $\mathrm{C} 22-\mathrm{C} 34)$ & ND & $\mathrm{mg} / \mathrm{Kg}$ & 50 & 1 & SW8015Ext & $00 / 05 / 02$ & 06.0602 & $P \times C-1$. \\
\hline Total Petroleum Hydrocarbons & ND & $\mathrm{mg} / \mathrm{Kg}$ & 10 & 1 & SW8015Ext & $06: 05: 02$ & $06: 00 / 02$ & PXC-LY \\
\hline Surr: n-Octacosane & 85.1 & $\%$ REC & $55-130$ & 1 & SW8015Ext & $06 / 05 / 02$ & $06: 06 / 02$ & PXC-LV \\
\hline
\end{tabular}

ND - Not Detected at the Reporting Limit

DF - Dilution Factor

Date: $1 /-J u n-02$
B - Analyte detected in the associated Method Blank

$S$ - Spike Recovery outside accepted recovery limits

E - Value above quantitation range
Page 7 of 12 
NEL LABORATORIES

\begin{tabular}{|c|c|c|c|c|c|c|c|c|c|}
\hline CLIENT: & \multicolumn{4}{|c|}{ Bechtel Vevada } & \multicolumn{4}{|c|}{ CLIENT ID: $\quad 252504-8$} & \\
\hline PROJECT ID: & \multicolumn{4}{|l|}{$V 1609$} & \multicolumn{5}{|c|}{ DATE SAMPLED: 6302} \\
\hline PROJECT \#: & \multicolumn{4}{|l|}{30033} & \multicolumn{5}{|c|}{ NEL SAMPLE ID: L0206022-008A } \\
\hline MATRIX: & SOII. & & & & & & & & \\
\hline \multicolumn{2}{|l|}{ Parameter } & Result & Unit & $\begin{array}{c}\text { Reporting } \\
\text { Limit }\end{array}$ & $\underline{\text { DF }}$ & Method & Prep Date & Analyzed & Analyst \\
\hline \multicolumn{2}{|c|}{ Diesel Range Organics (C12-C22) } & ND & $\mathrm{mg} / \mathrm{Kg}$ & 10 & 1 & SW8015Ext & $06 / 05 / 02$ & 160002 & PXC -LY \\
\hline \multicolumn{2}{|c|}{ Gasoline Range Otganics (C8-C12) } & ND & $\mathrm{mg} / \mathrm{Kg}$ & 10 & $i$ & SW8015Ext & $06 / 05: 02$ & 0600.02 & PXC.II \\
\hline \multicolumn{2}{|c|}{ Oil Range Organics (C22-C34) } & ND & $\mathrm{mg} / \mathrm{Kg}$ & 50 & 1 & SW8015Ext & 000502 & 060602 & PXC-1I: \\
\hline \multicolumn{2}{|c|}{ Total Petroleum Hydrncarbons } & ND & $\mathrm{mg} / \mathrm{Kg}$ & 10 & 1 & SW8015Ext & $00 / 05: 02$ & 00.0002 & PXC $-L I$ \\
\hline \multicolumn{2}{|c|}{ Surr: n-Octacosane } & 97.1 & $\%$ REC & $55-130$ & 1 & SW8015Ext & $06 / 05 / 02$ & $06 / 06 / 02$ & PXC-LY \\
\hline
\end{tabular}

ND - Not Detected at the Reporting Limit

DF - Dilution Factor

Date: IJ-Jun-02
B - Analyte detected in the associated Method Blank

S - Spike Recovery outside accepted recovery limits

$E$ - Value above quantitation range
Page 8 of 12 
NEL LABORATORIES

\begin{tabular}{|c|c|c|c|c|c|c|c|c|c|}
\hline CLIENT: & \multicolumn{3}{|c|}{ Bechtel Nevada } & & CLI & NT ID: & $252504-9$ & & \\
\hline PROJECT ID: & \multicolumn{3}{|l|}{ V1609 } & & DAT & SAMPLE & 63.02 & & \\
\hline PROJECT \#: & \multicolumn{3}{|l|}{30033} & & \multicolumn{4}{|c|}{ NEL SAMPLE 1D: L0206022-000 A } & \\
\hline MATRIX: & SOIL & & & & & & & & \\
\hline \multicolumn{2}{|l|}{ Parameter } & Result & Unit & $\begin{array}{c}\text { Reporting } \\
\text { Limit }\end{array}$ & DF & Method & Prep Date & Analyzed & Analyst \\
\hline \multicolumn{2}{|c|}{ Diesel Range Organics (C12-C22) } & ND & $\mathrm{mg} / \mathrm{Kg}$ & 10 & 1 & SW8015Ext & $00 / 05 / 02$ & $06 / 06 / 02$ & PXC.LI \\
\hline \multicolumn{2}{|c|}{ Gasoline Range Organics (C8-C12) } & ND & $\mathrm{mg} / \mathrm{Kg}$ & 10 & 1 & SW8015Ext & $06 / 05 / 02$ & $0606: 02$ & PXC-LI \\
\hline \multicolumn{2}{|c|}{ Oil Range Organics ( $\mathrm{C} 22-\mathrm{C} 34)$} & ND & $\mathrm{mg} / \mathrm{Kg}$ & 50 & 1 & SW8015Ext & $06 / 05: 02$ & $06: 06 / 02$ & $P \times(-L)$ \\
\hline \multicolumn{2}{|c|}{ Total Petroleum Hydrocarhons } & $\mathrm{ND}$ & $\mathrm{mg} \mathrm{Kg}$ & to & 1 & SWBO15Ex: & $00 / 05: 02$ & $06: 06 / 02$ & PXC-I. Y \\
\hline \multicolumn{2}{|c|}{ Surr: n-Octacosane } & 70.1 & $11 / 1 \mathrm{REC}$ & $55-130$ & 1 & SW8015Ext & $06 / 05 / 02$ & $06: 04: 02$ & PXC.LV \\
\hline
\end{tabular}

ND - Not Detected at the Reporting Limit

DF - Dilution Factor

Date: $1 /-J u n-02$
B - Analyce detected in the associated Method Blant:

S - Spike Recovery outside accepted recovery limits

E - Value above quantitation range 
NEL LABORATORIES

\begin{tabular}{|c|c|c|}
\hline CLIENT: & Bechtel Nevada & CLIENT ID: \\
\hline PROJECT ID: & 11609 & DATE SAMPLED: 6302 \\
\hline PROJECT \#: & 30033 & NEL SAMPLE ID： L0206022-010A \\
\hline
\end{tabular}

MATRIX: SOIL

\begin{tabular}{|c|c|c|c|c|c|c|c|c|}
\hline Parameter & Result & Enit & $\begin{array}{c}\text { Reporting } \\
\text { Limit }\end{array}$ & DF & Method & Prep Date & Analyzed & Analyst \\
\hline Diesel Range Organics (C12-C22) & ND & $\mathrm{mg} / \mathrm{Kg}$ & 10 & 1 & SW8015Ext & $00 / 05 / 02$ & $0606 / 02$ & PXC'L' \\
\hline Gasoline Range Organics (C8-C12) & ND & $\mathrm{mg} / \mathrm{Kg}$ & 10 & 1 & SW8015Ext & $06 / 05 / 02$ & $06 / 06 / 02$ & PXC.LY \\
\hline Oil Range Organıcs ( $C 22-\mathrm{C} 34)$ & ND & $\mathrm{mg} / \mathrm{Kg}$ & 50 & $i$ & SW8015Ext & $06 / 05 / 02$ & $06: 06 / 02$ & PXC-LV \\
\hline Total Petroleum Hydrocarbons & $\mathrm{ND}$ & $\mathrm{mg} / \mathrm{Kg}$ & 10 & l & SW8015Ext & $06 / 05 / 02$ & $06: 06: 02$ & PXC-LV \\
\hline Surr: n-Octacosane & 73.1 & $\%$ REC & $55-130$ & 1 & SW80!5Ext & $06 / 05 / 02$ & $06 / 06 / 02$ & PXC-LY \\
\hline
\end{tabular}

ND - Not Detected at the Reporing Linit

DF - Dilution Factor

Date: //-Jun-02
B - Analyre detected in the associated Method Blank

S - Spike Recovery outside accepted recovery limits

$E$ - Value above quantitation range
Page 10 of 12 
NEL LABORATORIES

$\begin{array}{lll}\text { CLIENT: } & \text { Bechtel Nevada } & \text { CLIENT ID: } \\ \text { PROJECT ID: } & \text { V1609 } & \text { DATE SAMPLED: } 11 \\ \text { PROJECT H: } & 30033 & \text { NEL SAMPLE ID: L0206022-011A } \\ \text { MATRIX: } & \text { SOIL } & \end{array}$

\begin{tabular}{|c|c|c|c|c|c|c|c|c|}
\hline Parameter & $\underline{\text { Result }}$ & Unit & $\begin{array}{c}\text { Reporting } \\
\text { Limit }\end{array}$ & $\underline{\text { DF }}$ & Method & Prep Date & Analyzed & Analys \\
\hline Diesel Range Organics $(\mathrm{C} 12-\mathrm{C} 22)$ & ND & $\mathrm{mg} / \mathrm{Kg}$ & 10 & 1 & SW8015Ext & 060502 & 06.0602 & $P X(-1)$ \\
\hline Gasoline Range Organics (C8-C12) & ND & $\mathrm{mg} / \mathrm{Kg}$ & 10 & 1 & SW8015Ext & $06 / 05 / 02$ & $00^{\circ} 06^{\prime} 02$ & PXC.1.X \\
\hline Oit Range Organics (C22-C34) & ND & $\mathrm{mg} / \mathrm{Kg}$ & 50 & 1 & SW8015Ext & $06 / 05 / 02$ & 000602 & PXC-LS \\
\hline Total Petroleum Hydrocarbuns & ND & $\mathrm{mg} / \mathrm{Kg}$ & 10 & 1 & SW8015Ext & $06 / 05 / 02$ & $06,06: 02$ & $P X C \cdot L Y$ \\
\hline Surr: n-Octacosane & 81.1 & $\%$ REC & $55 \cdot 130$ & l & SW8015Ext & $00 / 05 / 02$ & $06 / 06: 02$ & $\mathrm{PXC}-\mathrm{LY}$ \\
\hline
\end{tabular}

ND - Not Detected at the Reporing Limst

DF - Dilution Factor

Date: //-Jun 02
B - Analyte detected in the associated Method Blank

S - Spike Recovery outside accepted recovery limits

$\mathrm{E}$ - Value above quantitation range
Page 11 of 12 
NEL LABORATORIES

$\begin{array}{lll}\text { CLIENT: } & \text { Bechtel Nevada } & \text { CLIENT ID: } \\ \text { PROJECT ID: } & \text { V } 1609 & \text { DATE SANPLED: 6304-12 } \\ \text { PROJECT \#: } & 30033 & \text { NEL SAMIPLE ID: L0206022-012A } \\ \text { MATRIX: } & \text { SOIL } & \end{array}$

\begin{tabular}{|c|c|c|c|c|c|c|c|c|}
\hline Parameter & $\underline{\text { Result }}$ & $\underline{\text { Unit }}$ & $\begin{array}{c}\text { Reporting } \\
\text { Limit }\end{array}$ & $\underline{\mathbf{D F}}$ & Method & Prep Date & Analyzed & Analyst \\
\hline Diesel Range Organics (C12-C22) & ND & $\mathrm{mg} / \mathrm{Kg}$ & 10 & 1 & SW8015Ext & $06 / 05 / 02$ & $06 / 06 / 02$ & $P X C-L Y$ \\
\hline Gasoline Range Organics ( $\mathrm{C} 8-\mathrm{Cl} 2)$ & ND & $\mathrm{mg} / \mathrm{Kg}$ & 10 & 1 & SW8015Ext & $06 / 05 / 02$ & $06 / 06 / 02$ & $P X C \cdot L V$ \\
\hline Oil Range Organics (C22-C 34$)$ & ND & $\mathrm{mg} / \mathrm{Kg}$ & 50 & 1 & SW8015Ext & $06 / 05 / 02$ & $06 / 06 / 02$ & $P X C \cdot L V$ \\
\hline Total Petroleum Hydrocarbons & ND & $\mathrm{mg} / \mathrm{Kg}$ & 10 & 1 & SW8015Ext & $06 / 05 / 02$ & $06 / 06 / 02$ & PXC-IV \\
\hline Surr: n-Octacosane & 74.1 & "\%REC & $55-130$ & 1 & SW8015Ext & $06 / 05 / 02$ & $06 / 06 / 02$ & PXC-LV \\
\hline
\end{tabular}

ND - Not Detected a: the Reporturg l.Im1t DF - Dilution ractor

Date: $/ /-J u n-02$
B - Analyte detected in the associated Method Blank

S - Spike Recovery outside accepted recovery limits

E - Value above quantitation range
Page 12 of 12 
CLIENT: Bechtel Nevada

Work Order: $\quad$ L0206022

Project: $\quad$ V1609

\begin{tabular}{|c|c|c|c|c|c|c|c|c|c|}
\hline Sample ID: 020605TPHS-MB & $\begin{array}{l}\text { Samp'Type: MBI.K } \\
\text { Batch ID: } \mathbf{4 5 4}\end{array}$ & $\begin{array}{l}\text { TestCode: } \\
\text { TestNo: }\end{array}$ & $\begin{array}{l}\text { 8015FFPS } \\
\text { SW8015M }\end{array}$ & Units: $\mathbf{m g} / \mathbf{K g}$ & & $\begin{array}{rr}\text { Prep Date: } & \mathbf{6 / 5 / 0 2} \\
\text { Analysis Dale: } & \mathbf{6 / 6 / 0 2}\end{array}$ & & $\begin{array}{l}\text { Ru11 11): I. F(1)-1 } 0206051 \\
\text { SeqNo: } 35602\end{array}$ & \\
\hline Analyte & Result & PQL & SPK value & SPK Ref Val & "fRIT & Inwlimil Hight inuit & RPIJ Ref Val & "\#RPl! $\quad R P(J)$ imil & Qunil \\
\hline Gasoline Range Organics (C8-C12) & ND & 10 & & & & & & & \\
\hline Dicscl Range (Jrganics ( $12-r 22$ ) & $\mathrm{ND}$ & 10 & & & & & & & \\
\hline Oil Range (Organics (C22-C34) & ND & 50 & & & & & & & \\
\hline Total Pelroleum Hydrocarbons & ND & 10 & & & & & & & \\
\hline Surr: n-Octacosane & 2.601 & 0.010 & 3.331 & 0 & 78.1 & 130 & 0 & " & \\
\hline Sample IID: 020605 TPHS-LCS & $\begin{array}{c}\text { SampType: LCS } \\
\text { Batch ID: } 454\end{array}$ & $\begin{array}{r}\text { TestCode: } \\
\text { TestNo: }\end{array}$ & $\begin{array}{l}\text { 8015FFP_s } \\
\text { SW8015M }\end{array}$ & Units: $\mathbf{m g} / \mathbf{K g}$ & & $\begin{aligned} \text { Prep Date: } & \mathbf{6 / 5 / 0 2} \\
\text { Analysis Date: } & \mathbf{6} / \mathbf{6} / 02\end{aligned}$ & & $\begin{array}{l}\text { Run II): I. FII)-1 0206,051 } \\
\text { SeyNo: } 356001\end{array}$ & \\
\hline Analytc & Result & PQL & SPK value & SPK Ref Val & $\%$ REC & LowLimut Jlight.imit & RPD Ref Val & "inRPI RP'Dl imil & Qual \\
\hline Diesel Range Organics (C 12-C22) & 124.1 & 10 & 166.4 & 0 & 74.6 & 91 & 0 & 0 & \\
\hline Surr: n-Octacosane & 2.762 & 0.010 & 3.324 & 0 & 83.1 & 130 & 0 & 0 & \\
\hline Sample ID: 020605TPHS-I.CSD & $\begin{array}{l}\text { SampType: I.CSD } \\
\text { Batch ID: } 454\end{array}$ & $\begin{array}{r}\text { TestCode: } \\
\text { TcstNo: }\end{array}$ & $\begin{array}{l}\text { :8015FFP_S } \\
\text { SW8015M }\end{array}$ & Units: $\mathbf{m g} / \mathbf{K g}$ & & $\begin{aligned} \text { Prep Date: } & 6 / 5 / 02 \\
\text { Analysis Datc: } & 6 / 6 / 02\end{aligned}$ & & $\begin{array}{l}\text { Run II): 1_Flld-1_0206051 } \\
\text { SicuNo: } 35601\end{array}$ & \\
\hline Analyte & Result & PQI & SPK value & SP'k Ref Val & $\%$ REC & Lowl init llight imit & RPI) Ref Val & "aRPI) RPIM imil & (Miall \\
\hline Diesel Range Organics ( $\mathrm{C} 12-(22)$ & 122.7 & 10 & 166.5 & 0 & 73.7 & 91 & 124.1 & 1.1. & \\
\hline Surt: n-Octacosane & 2.73 & 0.010 & 3.326 & 0 & 82.1 & 130 & 0 & $"$ & \\
\hline Sample ID: $\quad$ 1.0206022-001A & $\begin{array}{l}\text { Samplype: MS } \\
\text { Batch II): } \mathbf{4 5 4}\end{array}$ & $\begin{array}{r}\text { TestCode: } \\
\text { TestNo: }\end{array}$ & $\begin{array}{l}\text { 8015IFP_S } \\
\text { SW8015MI }\end{array}$ & Innits: $\mathbf{m g} / \mathbf{K g}$ & & $\begin{aligned} \text { Prep 1Bate: } & 6 / 5 / 02 \\
\text { Analysis Date: } & 6 / 6 / 02\end{aligned}$ & & 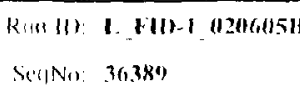 & \\
\hline Analytc & Resull & PQI & SPK value & SPK Ref Val & $\%$ RIC & Laws imit Nlighl.mit & RPlD ReS Val & 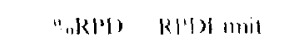 & mall \\
\hline Diesel Range ()rganics (('12-('22) & 119 & 10 & 166.8 & 0 & 71.4 & 91 & 9 & " & \\
\hline Surr: "1-tedacusanc & 2.434 & 0.010 & 3.331 & 0 & 73.1 & 130 & () & (1 & \\
\hline
\end{tabular}

Qualifiers: NID-Not Detected at the Repurting l imit

S - Spike Resorety outside accepted recorcty limits

1- Analyte delected below quantitation limits

R - RPD uulvide accepled recovery limis

13- Andy 20 ded

lilge 1 of ? 
CLIENT:

Bechtel Nevada

Work Order: L0206022

Project: V1609

\begin{tabular}{|c|c|c|c|c|c|c|c|c|c|c|c|c|}
\hline \multirow{2}{*}{$\begin{array}{l}\text { Samiple ID: } 1.0206022-001 \mathrm{~A} \\
\text { Analyte }\end{array}$} & \multirow{2}{*}{$\begin{aligned} \text { SampType: } & \text { MSD } \\
\text { Batch II): } & \mathbf{4 5 4} \\
& \text { Result }\end{aligned}$} & \multicolumn{2}{|c|}{$\begin{array}{l}\text { TestCode: 8015FFP_S } \\
\text { TestNo: Sw80I5M }\end{array}$} & \multicolumn{3}{|c|}{ Units: $\mathbf{m g} / \mathbf{K g}$} & \multicolumn{2}{|c|}{$\begin{aligned} \text { Prep Date: } & 6 / 5 / 02 \\
\text { Analysis Datc: } & 6 / 6 / 02\end{aligned}$} & & \multicolumn{3}{|c|}{$\begin{array}{l}\text { Rum II): I. FII)-1_02060SIs } \\
\text { SeqNo: } 36.388\end{array}$} \\
\hline & & $\mathrm{PQI}$ & SPK value & SPK Ref Val & & "“RIIC" & I.owlimit & Hight .mitit & RPl) Rel Val & "\#RPl & RIPI Imil & Qu:al \\
\hline Dicscl Range Organics (C $12-(22)$ & 124.2 & 10 & 166.8 & & 0 & 74.5 & 54 & 91 & 119 & 4.28 & 25 & \\
\hline Surt: $\mathbf{n}$-Uclacosane & 2.568 & 0.010 & 3.331 & & 0 & 77.1 & 55 & 130 & 0 & 0 & 0 & \\
\hline
\end{tabular}

ANALYTICAL QC SUMMARY REPORT

\section{BatchID: 454}




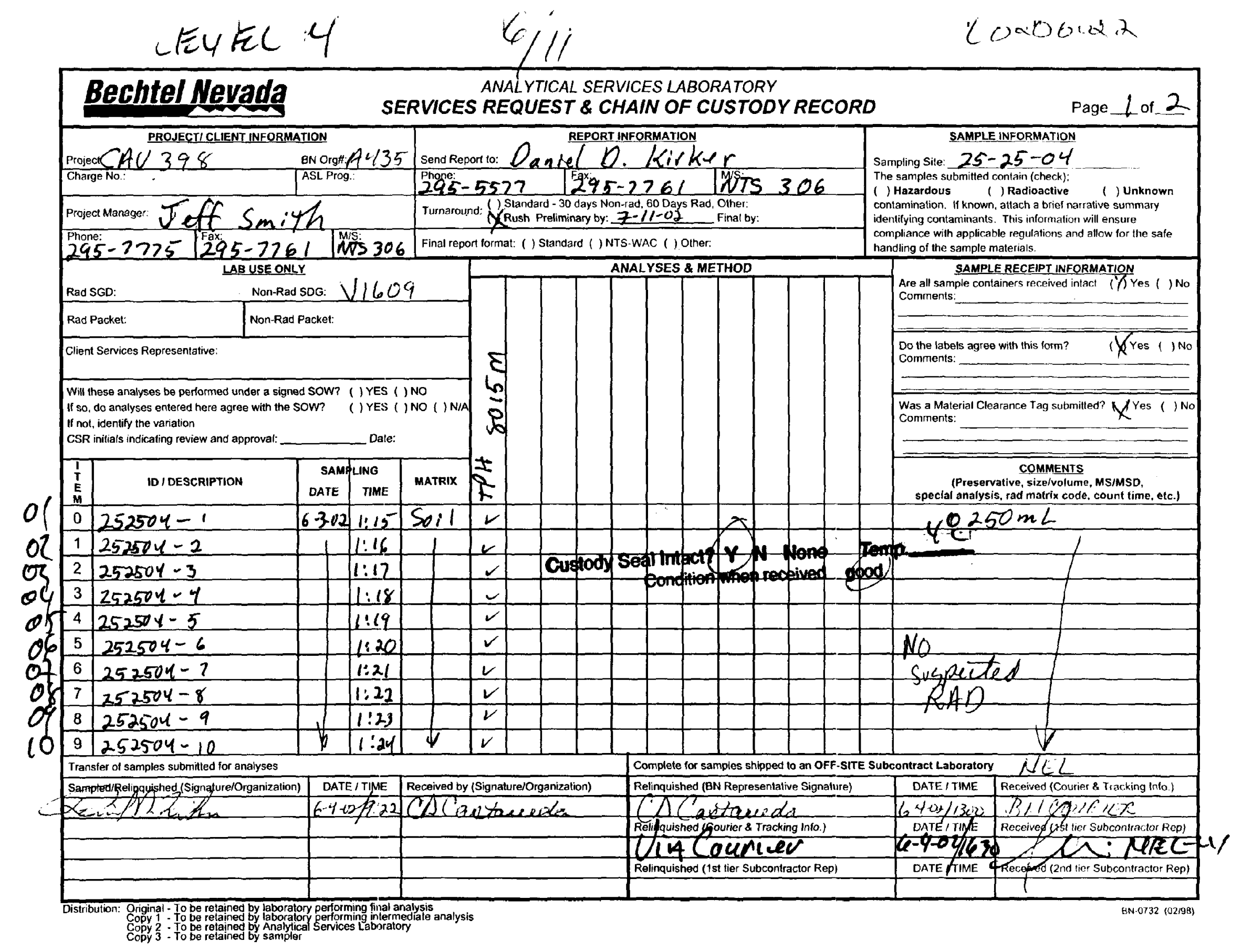




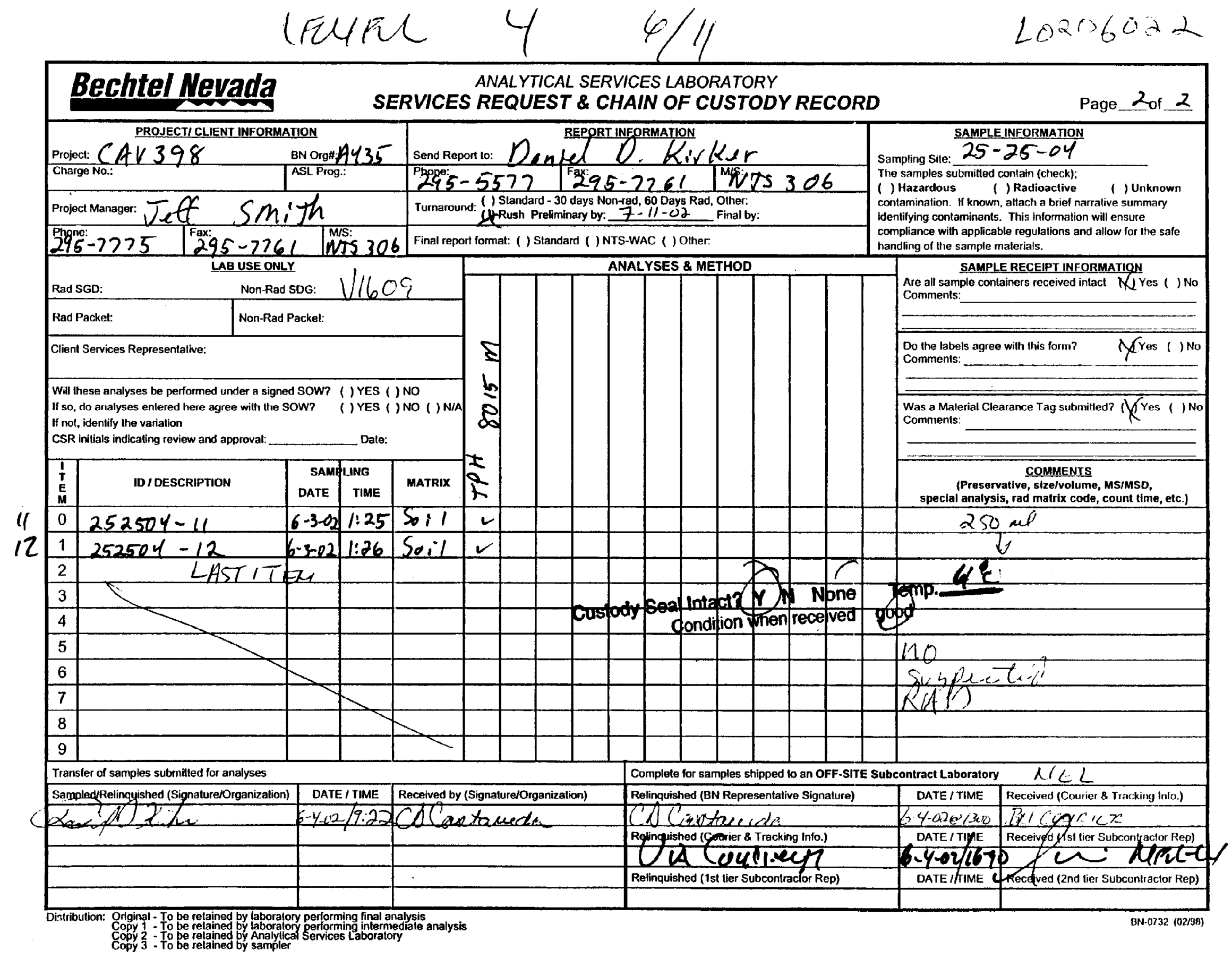


CLOSURE REPORT - CAU 398

Section: Appendix B

Revision: 1

Date: April 2003

SAMPLE DELIVERY GROUP

V1627 
CLOSURE REPORT - CAU 398

Section: Appendix B

Revision: 1

Date: April 2003

\section{THIS PAGE INTENTIONALLY LEFT BLANK}


Ted Redding

Bechtel Nerada

P.O. Box 98521, MS NTS273

Las Vegas, NV 89193-8521

TEL: 702-295-7220

RE Project: V1627

Order No.: L0206284

Dear Ted Redding:

NEL Laboratories, Las Vegas received 5 samples on 6/18/02 for the analyses presented in the following report.

There were no problems with the analyses and all data for associated QC met EPA or laboratory specifications unless noted in the Case Narrative.

If you have any guestions regarding these tests results, please feel free to call.

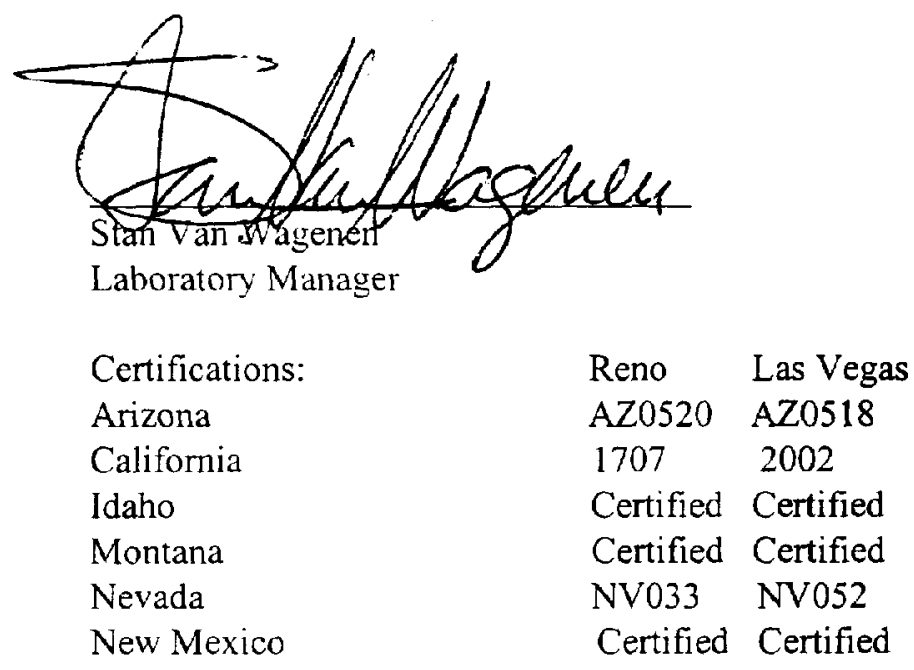


NEL LABORATORIES

\begin{tabular}{|c|c|c|c|c|c|c|c|c|c|}
\hline CLIENT: & \multicolumn{4}{|c|}{ Bechtel Nevada } & \multicolumn{4}{|c|}{ CLIENT ID: $\quad 252502-1$} & \\
\hline PROJECT ID: & \multicolumn{4}{|l|}{ V1627 } & \multicolumn{4}{|c|}{ DATE SAMPLED: $6: 17 / 02$} & \\
\hline PROJECT \#: & \multicolumn{4}{|l|}{30033} & \multicolumn{5}{|c|}{ NEL SAMPLE ID: I0206284-001A } \\
\hline MATRIX: & \multicolumn{4}{|l|}{ SOLID } & & & & & \\
\hline Parameter & & $\underline{\text { Result }}$ & Unit & $\begin{array}{c}\text { Reporting } \\
\text { Limit }\end{array}$ & $\underline{\mathbf{D F}}$ & Method & Prep Date & Anatyzed & Analyst \\
\hline Aroclor 1016 & & ND & $\mu \mathrm{g} / \mathrm{Kg}$ & 20 & 1 & Sw8082 & $06 / 20 / 02$ & $06: 24: 02$ & $J R W-L V$ \\
\hline Arocior 1221 & & ND & $\mu \mathrm{g} / \mathrm{Kg}$ & 20 & 1 & SW8082 & $06 / 20 / 02$ & $06 / 24 / 02$ & JRW-LV \\
\hline Aroclor 1232 & & ND & $\mu \mathrm{g} / \mathrm{Kg}$ & 20 & 1 & SW8082 & $06 / 20 / 02$ & $06 / 24 / 02$ & $J R W-L V$ \\
\hline Aroclor 1242 & & ND & $\mu \underline{g} / \mathrm{Kg}$ & 20 & 1 & Sw8082 & $06 / 20 / 02$ & $06 / 24 / 02$ & $\mathrm{JRW}-\mathrm{LV}$ \\
\hline Aroclor 1248 & & ND & $\mu \mathrm{g} / \mathrm{Kg}$ & 20 & 1 & SW8082 & $06 / 20 / 02$ & $06 / 24 / 02$ & $\mathrm{JRW} \cdot \mathrm{LV}$ \\
\hline Aroclor 1254 & & 960 & $\boldsymbol{\mu g} / \mathbf{K g}$ & 20 & 1 & SW8082 & $06 / 20 / 02$ & $06 / 24 / 02$ & $J R W-L V$ \\
\hline Aroclor 1260 & & $N D$ & $\mu g / K g$ & 20 & 1 & SW8082 & $06 / 20 / 02$ & $06 / 24 / 02$ & $J R W \cdot L V$ \\
\hline Surr: Decachlo & iphenyl & 131 & $\% \mathrm{REC}$ & $45-149$ & 1 & sw8082 & $06 / 20 / 02$ & $06 / 24 / 02$ & $J R W-L V$ \\
\hline Surr: Tetrachto & $-m$-xylene & 126 & " REC & $48-136$ & 1 & SW8082 & $06 / 20 / 02$ & $06 / 24 / 02$ & $J R W-L V$ \\
\hline
\end{tabular}

ND - Not Detected at the Reporting I imit

DF - Dilution Factor

Date: $26-J u(n-0) 2$
B - Analyte detected in the associated Method Blank

$S$ - Spike Recovery outside accepted recovery limits

$E$ - Value above quantitation range
Page 1 of 5 
NEL LABORATORIES

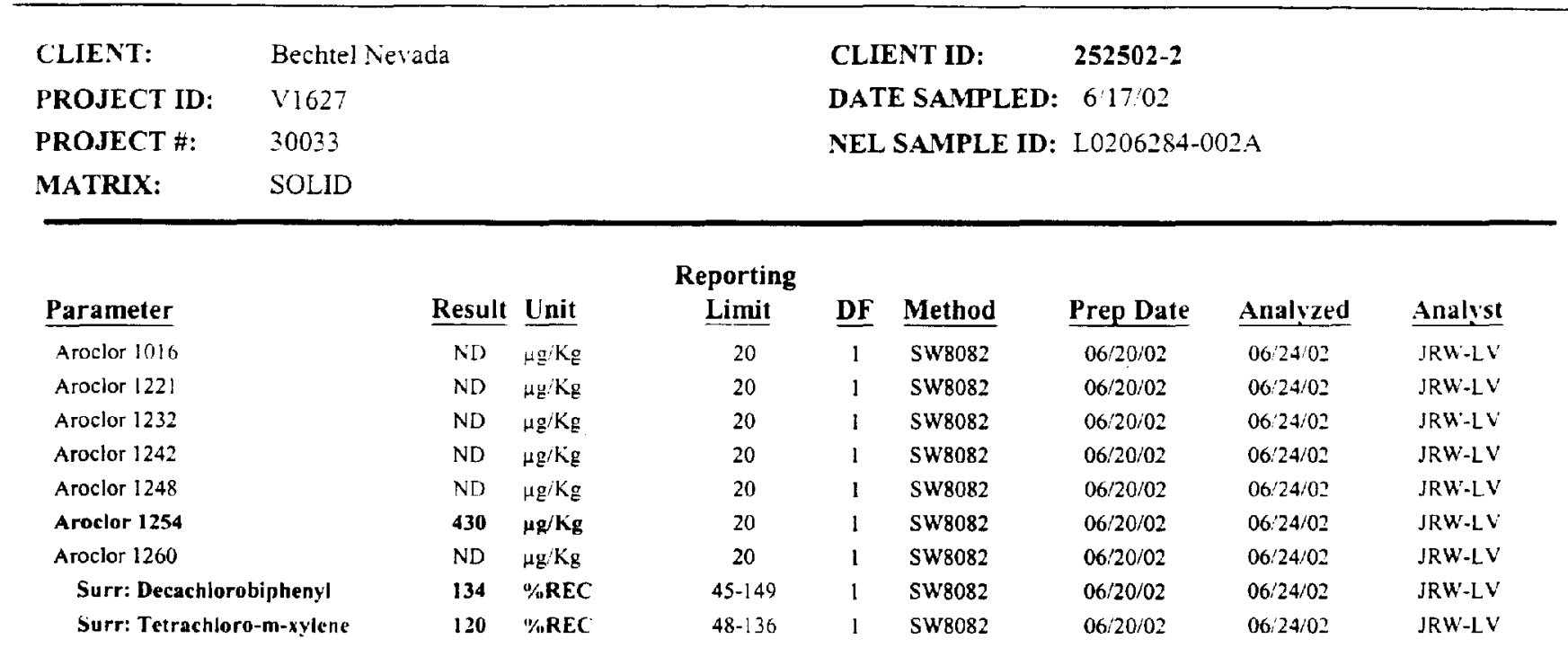

ND - Not Detected at the Reporting Limit

DF - Dilution Factor

Date: $26-J u n-02$
B - Analyte detected in the associated Method Blank

S - Spike Recovery outside accepted recovery limits

E - Value above quantitation range
Page 2 of 5 
NEL LABORATORIES

\begin{tabular}{|c|c|c|c|c|c|c|c|c|c|}
\hline CLIENT: & \multicolumn{4}{|c|}{ Bechtel Vevada } & \multicolumn{4}{|c|}{ CLIENT ID: $\quad 252502-3$} & \\
\hline PROJECT ID: & \multicolumn{4}{|l|}{ V1627 } & \multicolumn{4}{|c|}{ DATE SAMPLED: $\quad 6: 17 / 02$} & \\
\hline PROJECT \#: & \multicolumn{4}{|l|}{30033} & \multicolumn{4}{|c|}{ NEL SAMPLE ID: L0206284-003A } & \\
\hline MATRIX: & SOLID & & & & & & & & \\
\hline \multicolumn{2}{|l|}{ Parameter } & $\underline{\text { Result }}$ & Lnit & $\begin{array}{l}\text { Reporting } \\
\underline{\text { Limit }}\end{array}$ & $\underline{\text { DF }}$ & Method & Prep Date & Analyzed & Analyst \\
\hline \multicolumn{2}{|l|}{ Aroclor 1016} & ND & $\mu g i K g$ & 20 & 1 & SW8082 & $06 / 20 / 02$ & $06,24 / 02$ & $J R W^{\prime}-L V$ \\
\hline \multicolumn{2}{|l|}{ Aroclor 1221} & ND & $\mu g^{\prime} \mathrm{Kg}$ & 20 & 1 & SW8082 & $06 / 20 / 02$ & $06 / 24 / 02$ & $J R W-L V$ \\
\hline \multicolumn{2}{|l|}{ Aroclor 1232} & ND & $\mu g / \mathrm{Kg}$ & 20 & 1 & SW8082 & $06 / 20 / 02$ & $06 / 24 / 02$ & JRW-IV \\
\hline \multicolumn{2}{|l|}{ Aroclor 1242} & ND & $\mu \mathrm{g} \cdot \mathrm{Kg}$ & 20 & 1 & SW8082 & $06 / 20 / 02$ & $06 / 24 / 02$ & $J R W-L V$ \\
\hline \multicolumn{2}{|l|}{ Aroclor 1248} & ND & $\mu \mathrm{g} / \mathrm{Kg}$ & 20 & 1 & SW8082 & $06 / 20 / 02$ & $06 / 24 / 02$ & $J R W-L V$ \\
\hline \multicolumn{2}{|l|}{ Aroclor 1254} & ND & $\mu \mathrm{g} / \mathrm{Kg}$ & 20 & 1 & SW8082 & $06 / 20 / 02$ & $06 / 24 / 02$ & $J R W-L V$ \\
\hline \multicolumn{2}{|l|}{ Aroclor 1260} & 64 & $\mu \mathrm{g} / \mathrm{Kg}$ & 20 & 1 & SW8082 & $06 / 20 / 02$ & $06 / 24 / 02$ & $J R W-L V$ \\
\hline \multicolumn{2}{|c|}{ Surr: Decachlorobiphenyl } & 126 & $\%$ REC & $45-149$ & 1 & SW8082 & $06 / 20 / 02$ & $06 / 24 / 02$ & JRW-LV \\
\hline \multicolumn{2}{|c|}{ Surr: Tetrachloro-m-xylene } & 124 & $\% R E C$ & $48-136$ & 1 & SW8082 & $06 / 20 / 02$ & $06 / 24 / 02$ & JRW:LV \\
\hline
\end{tabular}

ND - Not Detected at the Repurtung L. Imit

DF - Dilution Factor

Date: 26-Jun-02
B - Analyte detected in the associated Method Blank

S - Spike Recovery outside accepted recovery limits

$\mathrm{E}$ - Value above quantitation range
Page 3 of 5 
NEL LABORATORIES

\begin{tabular}{|c|c|c|c|c|c|c|c|c|c|}
\hline CLIENT: & \multicolumn{4}{|c|}{ Bechtel Nevada } & \multicolumn{4}{|c|}{ CLIENT ID: $\quad 252502-4$} & \\
\hline PROJECT ID: & \multicolumn{4}{|l|}{ V1627 } & \multicolumn{4}{|c|}{ DATE SAMPLED: $6: 17 / 02$} & \\
\hline PROJECT \#: & \multicolumn{4}{|l|}{30033} & \multicolumn{5}{|c|}{ NEL SAMPLE ID: L0206284-004A } \\
\hline MATRIX: & SOLID & & & & & & & & \\
\hline \multicolumn{2}{|l|}{ Parameter } & $\underline{\text { Result }}$ & Unit & $\begin{array}{c}\text { Reporting } \\
\text { Limit }\end{array}$ & $\underline{\mathbf{D F}}$ & Method & Prep Date & Analyzed & Analyst \\
\hline Aroclor 1016 & & ND & $\mu \mathrm{g} / \mathrm{Kg}$ & 20 & 1 & SW8082 & $06 / 20 / 02$ & $06 / 24 / 02$ & $J R W-L V$ \\
\hline Arocior 1221 & & ND & $\mu \mathrm{g} / \mathrm{Kg}$ & 20 & 1 & SW8082 & $06 / 20 / 02$ & $06 / 24 / 02$ & JRW-LV \\
\hline Aroclor 1232 & & ND & $\mu \mathrm{g} / \mathrm{Kg}$ & 20 & 1 & SW8082 & $06 / 20 / 02$ & $06: 24 / 02$ & $J R W-L$ \\
\hline Aroclor 1242 & & ND & $\mu g^{\prime} \mathrm{Kg}$ & 20 & 1 & SW8082 & $06 / 20 / 02$ & $00: 24 / 02$ & $J R W-L V$ \\
\hline Aroclor 1248 & & ND & $\mu \mathrm{g} / \mathrm{Kg}$ & 20 & 1 & SW8082 & $06 / 20 / 02$ & $06 / 24 / 02$ & $J R W \cdot L V$ \\
\hline Aroclor 1254 & & ND & $\mu \mathrm{g} / \mathrm{Kg}$ & 20 & 1 & SW8082 & $06 / 20 / 02$ & $06 / 24 / 02$ & JRW-LV \\
\hline Aroclor 1260 & & 590 & $\mu g / \mathbf{K g}$ & 20 & 1 & SW8082 & $06 / 20 / 02$ & $06 / 24 / 02$ & $J R W-L V$ \\
\hline Surr: Decachlo & siphenyl & 127 & "\%EC & $45-149$ & 1 & SW8082 & $06 / 20 / 02$ & $06 / 24 / 02$ & $J R W-L V$ \\
\hline Surr: Tetrachlo & -m-xylene & 113 & "\#REC & $48-136$ & 1 & SW8082 & $06 / 20 / 02$ & $06 / 24 / 02$ & $J R W-L V$ \\
\hline
\end{tabular}

ND - Not Detected at the Reporting Limi DF - Dilution Factor

Date: $26-J u n-02$
B - Analyte detected in the associated Method Blank

S-Spike Recovery outside accepted recovery limits

$E$ - Value above quantitation range
Page 4 of 5 
NEL LABORATORIES

\begin{tabular}{lll}
\hline CLIENT: & Bechtel Nevada & CLIENT ID: \\
PROIECT ID: & V1627 & DATE SAMPLED: $6 / 1702$ \\
PROJECT \#: & 30033 & NEL SAMPLE ID: L0206284-005A \\
MATRIX: & SOLID & \\
\hline
\end{tabular}

\begin{tabular}{|c|c|c|c|c|c|c|c|c|}
\hline Parameter & Result & $\underline{\text { Unit }}$ & $\begin{array}{l}\text { Reporting } \\
\text { Limit }\end{array}$ & $\underline{\mathbf{D F}}$ & Method & Prep Date & Analyzed & Analyst \\
\hline Arocior 1016 & ND & $\mu \mathrm{g} / \mathrm{Kg}$ & 20 & 1 & SW8082 & $06 / 20 / 02$ & $06 / 24 / 02$ & JRR:LV \\
\hline Aroclor 1221 & ND & $\mu \mathrm{g} / \mathrm{Kg}$ & 20 & 1 & SW8082 & $06 / 20 / 02$ & $06 / 24 / 02$ & JRW-LV \\
\hline Aroclor 1232 & ND & $\mu g / K g$ & 20 & 1 & SW8082 & $06 / 20 / 02$ & $06 / 24 / 02$ & JRW-LV \\
\hline Arocior 1242 & ND & $\mu \mathrm{g} / \mathrm{Kg}$ & 20 & 1 & SW8082 & $06 / 20 / 02$ & $06 / 24 / 02$ & $J R W-L V$ \\
\hline Aroclor 1248 & ND & $\mu g / \mathrm{Kg}$ & 20 & 1 & Sw8082 & $06 / 20 / 02$ & $06 / 24 / 02$ & JRW-LV \\
\hline Aroclor 1254 & ND & $\mu \mathrm{g} / \mathrm{Kg}$ & 20 & 1 & SW8082 & $06 / 20 / 02$ & $06 / 24 / 02$ & JRW-LV \\
\hline Arocior 1260 & 480 & $\mu \mathrm{g} / \mathrm{Kg}$ & 20 & 1 & SW8082 & $06 / 20 / 02$ & $06 / 24 / 02$ & JRW-LV \\
\hline Surr: Decachlorobiphenyl & 126 & $\%$ REC & $45-149$ & 1 & SW8082 & $06 / 20 / 02$ & $06 / 24 / 02$ & JRW-LV \\
\hline Surr: Tetrachloro-m-xylene & 113 & $\%$ REC & $48-136$ & 1 & SW8082 & $06 / 20 / 02$ & $06 / 24 / 02$ & JRW-L.V \\
\hline
\end{tabular}

ND - Not Detected at the Reporting LImit

DF - Dilution Factor

Date: $26-J u n-02$
B - Analyte detected in the associated Method Blank

S - Spike Recovery outside accepted recovery limits

E - Value above quantitation range
Page 5 of 5 
$\begin{array}{ll}\text { CLIENT: } & \text { Bechtel Nevada } \\ \text { Work Order: } & \text { L0206284 }\end{array}$

Project: V1627

\section{ANALYTICAL QC SUMMARY REPORT}

BatchID: 494

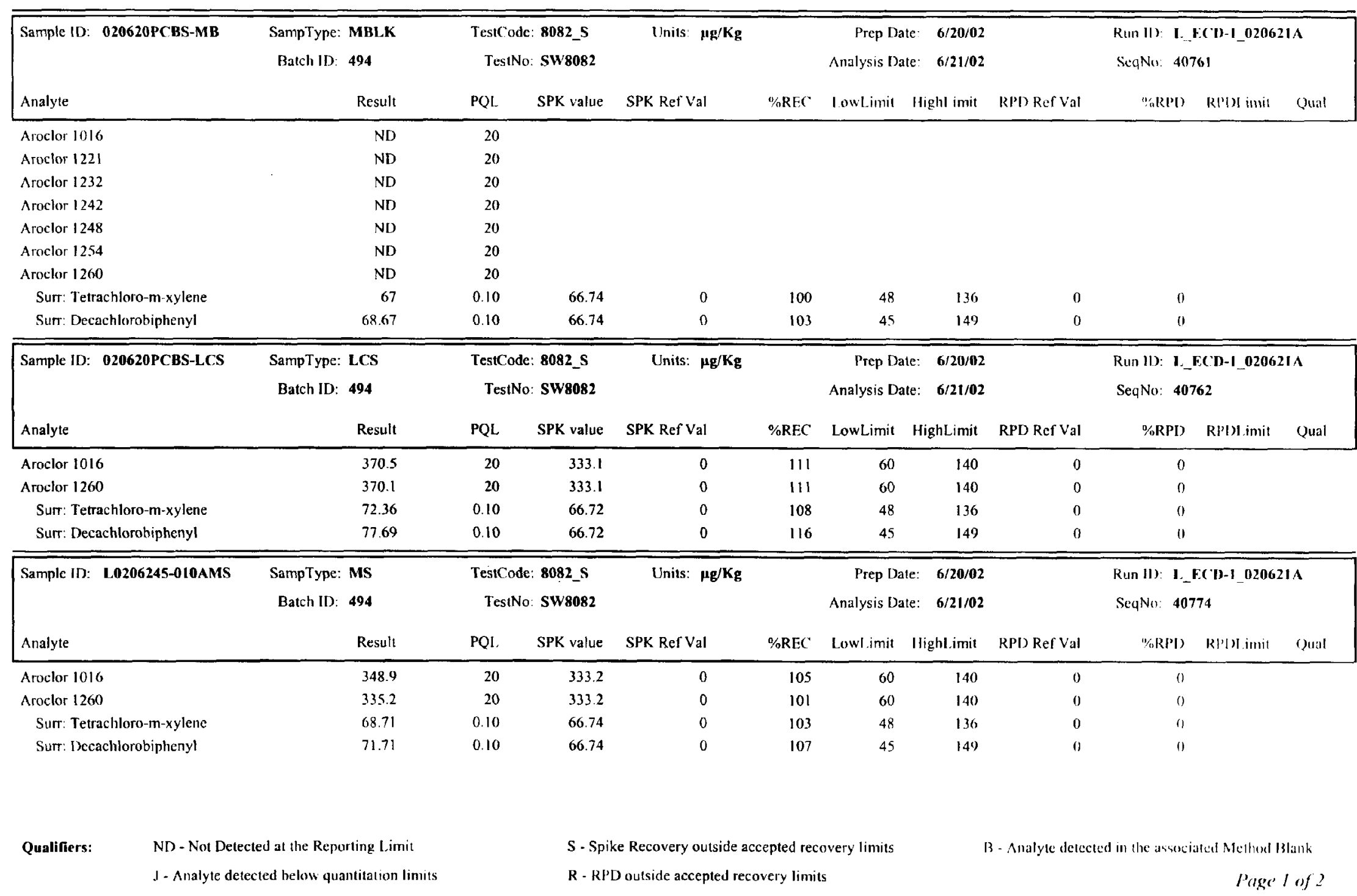


CLIENT:

Bechtel Nevada

Work Order: L0206284

ANALYTICAL QC SUMMARY REPORT

Project:

V1627

BatchID

494

\begin{tabular}{|c|c|c|c|c|c|c|c|c|c|c|c|c|}
\hline \multirow{2}{*}{$\begin{array}{l}\text { Sample ID: L0206245-010AMSD } \\
\text { Analyte }\end{array}$} & \multirow{2}{*}{$\begin{array}{l}\text { SampType: } \\
\text { Batch ID: }\end{array}$} & \multirow{2}{*}{$\begin{array}{l}\text { MSD } \\
494 \\
\text { Result }\end{array}$} & \multicolumn{2}{|c|}{$\begin{array}{l}\text { TestCode: } 8082 \text { S } \\
\text { TestNo: Sw8082 }\end{array}$} & \multicolumn{2}{|l|}{ Units: $\mu \mathrm{g} / \mathbf{K g}$} & \multicolumn{2}{|c|}{$\begin{array}{rr}\text { Prep Date: } & \mathbf{6 / 2 0 / 0 2} \\
\text { Analysis Date: } & 6 / 21 / 02\end{array}$} & \multicolumn{4}{|c|}{$\begin{array}{l}\text { Rum ID): 1,ECD-1_020621A } \\
\text { ScqNo: } 40775\end{array}$} \\
\hline & & & PQI. & SPK value & SPK Ref Val & \%RIEC & Lowl.init & Hight imit & RPI Ref Yal & $0_{\text {¿RI'l }}$ & RPIJ imil & (1) $1: 11$ \\
\hline Aroclor 1016 & & 322.9 & 20 & 333.2 & 0 & 96.9 & 60 & 140 & 348.9 & 7.75 & 25 & \\
\hline Aroclor 1260 & & 309.9 & 20 & 333.2 & 0 & 03 & 60 & 140 & 335.2 & 7.80 & 25 & \\
\hline Surr Tetrachloro-n1-xylene & & 6204 & 0.10 & 66.74 & 0 & 93 & 48 & 136 & 0 & 0 & 0 & \\
\hline Surr: Decachlorobiphenyl & & 65.04 & 0.10 & 66.74 & 0 & 97.5 & 45 & 149 & 0 & 0 & 0 & \\
\hline
\end{tabular}




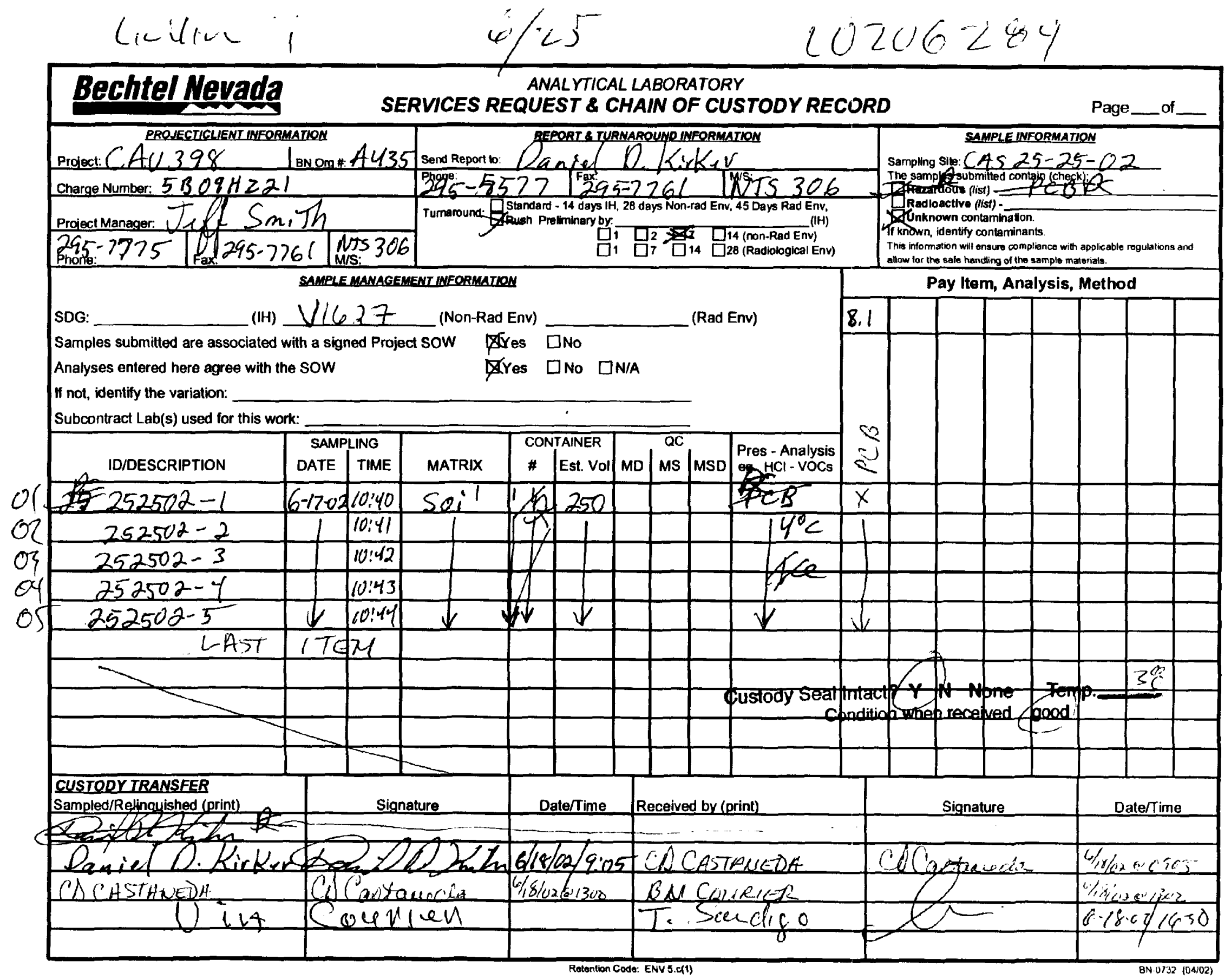


CLOSURE REPORT - CAU 398

Section: Appendix B

Revision: 1

Date: April 2003

\section{SAMPLE DELIVERY GROUP}

\section{V1815}


CLOSURE REPORT - CAU 398

Section: Appendix B

Revision: 1

Date: April 2003

THIS PAGE INTENTIONALLY LEFT BLANK 


\section{Bechtel Nevada}

ANALYTICAL LABORATORY

PROJECTICLIENT INEORMATION

SERVICES REQUEST \& CHAIN OF CUSTODY RECORD

Project: $C A 4348$

IBN Org \# BSQ2 send Report to: Brad Jackson

Charge Number: $\quad 5309 \mathrm{HZ} 30$

Project Manager: Jeffrey Smith

$702-245-7175$

Fax: $295 \cdot 7161$

\begin{tabular}{|l|l} 
\\
Nith \\
M/S:
\end{tabular}

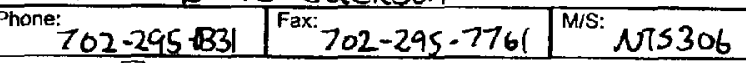
Turnaround: 9 Standard -14 days $\mathrm{IH}, 28$ days Non-rad Env, 45 Days Rad Env, Phone: SAMPLE MANAGEMENT INFORMATION SDG: (IH) 11815 (Non-Rad Env) $\begin{array}{lllll}\square 1 & \square^{2} & \square^{7} & \square & U_{14}^{14} \text { (non-Rad Env) } \\ \square & 28 \text { (Radiological Env) }\end{array}$ Tres ano Analyses entered here agree with the SOW $\square$ YYes $\square$ No $\square$ N/A

If not, identify the variation:

Subcontract Lab(s) used for this work: Lion ville

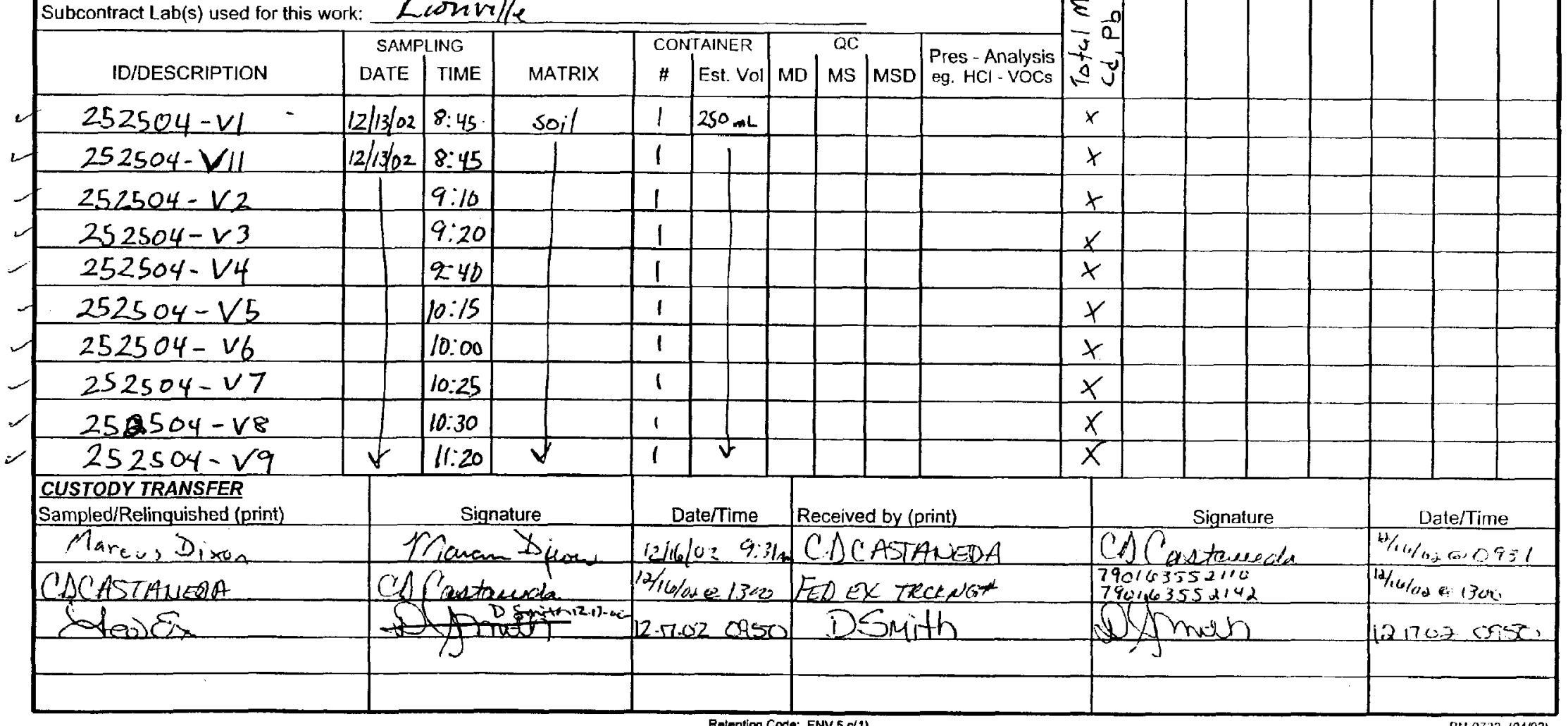

\section{SAMPLE INFORMATION}

Sampling Site: $\mathrm{CAU} 398$

The samples submitted contain (check):

Bazardous (itst) -

UUnknown conlamination.

If known, identify contarninants.

allow for the sale handing of the sample materials

Pay Item, Analysis, Method

(Rad Env)

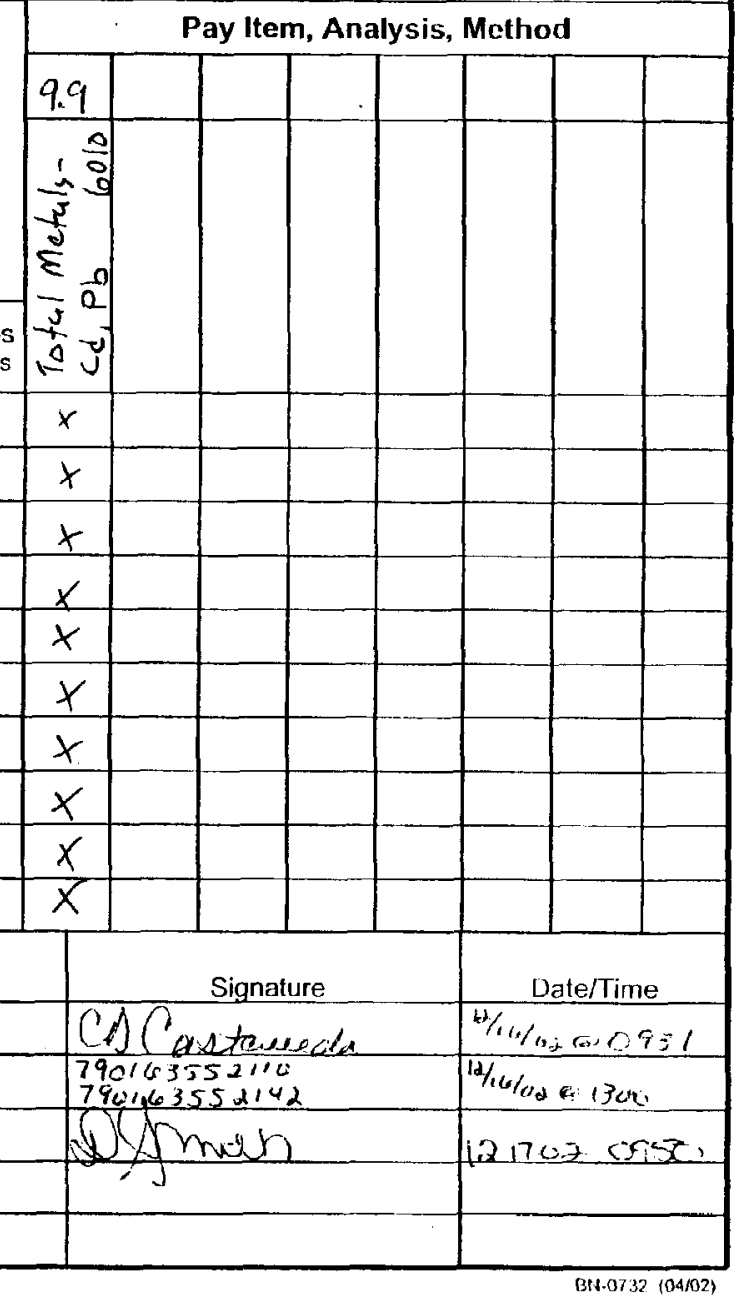




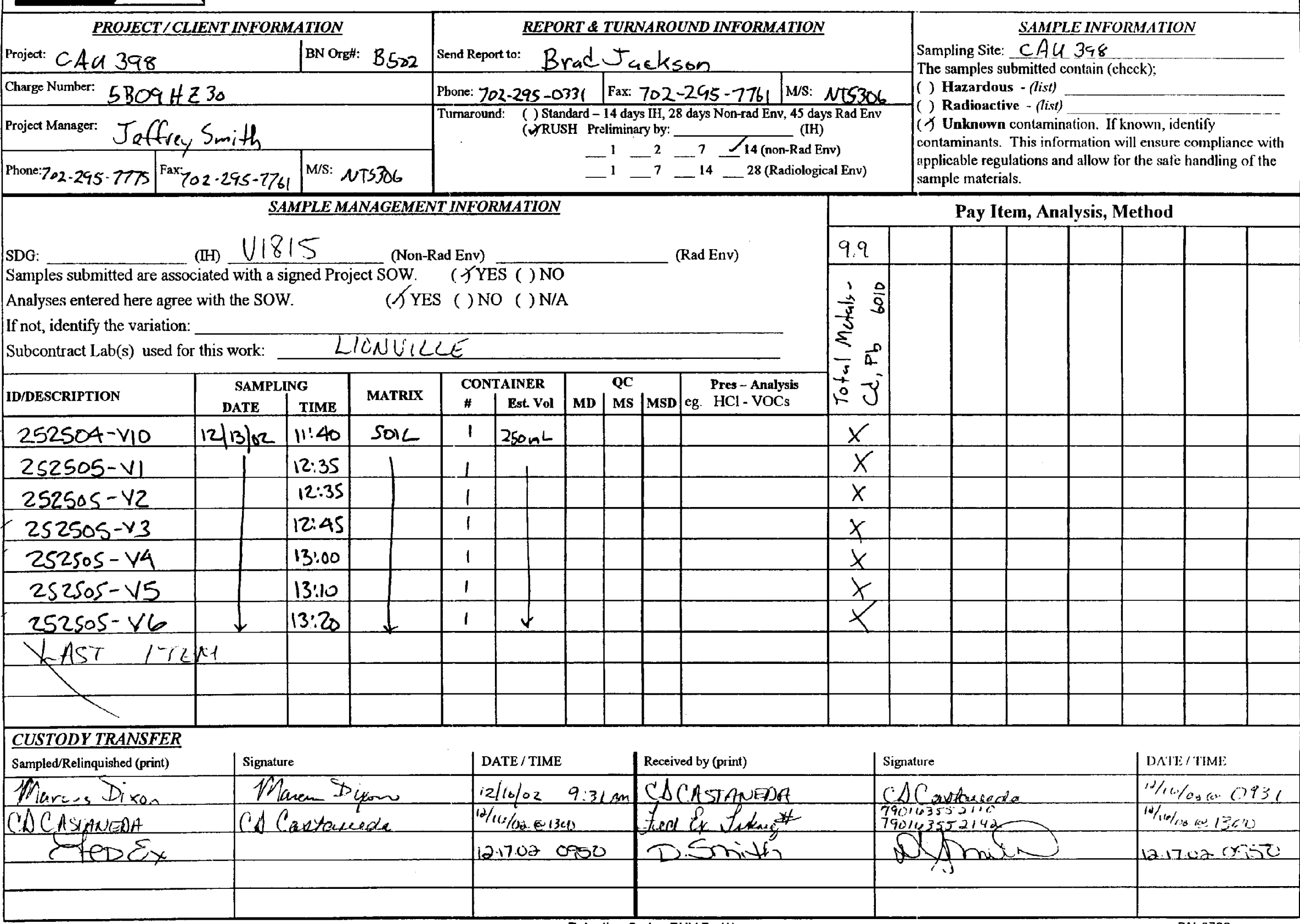


Lionville Laboracory, Ine.

INORGANICS DATA SUMMARY REPORT 22/30/02

\begin{tabular}{|c|c|c|}
\hline SAMPLE & GIIE ID & ANALYTB \\
\hline$-\varepsilon=2=-E$ & 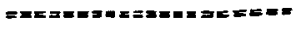 & DEn \\
\hline-001 & $252504-v_{1}$ & $\begin{array}{l}\text { Cadmium, Total } \\
\text { Lead, Total }\end{array}$ \\
\hline-002 & $252504-v 11$ & $\begin{array}{l}\text { Cadri um, Total } \\
\text { Lead, Total }\end{array}$ \\
\hline-003 & $252504-v_{2}$ & $\begin{array}{l}\text { Cadmium, Total } \\
\text { Lead, Total }\end{array}$ \\
\hline-004 & $252504-v 3$ & $\begin{array}{l}\text { Cadriut, Total } \\
\text { Lead, Totel }\end{array}$ \\
\hline-005 & $252504-v_{4}$ & $\begin{array}{l}\text { Cadmi um, Total } \\
\text { Land, Total }\end{array}$ \\
\hline-006 & $252504-V 5$ & $\begin{array}{l}\text { Cadmium, Toral } \\
\text { Lead, Totel }\end{array}$ \\
\hline-007 & $252504-v 6$ & $\begin{array}{l}\text { Cadmium, Total } \\
\text { Lead, Totel }\end{array}$ \\
\hline-008 & $252504-V 7$ & $\begin{array}{l}\text { Cadmium, Fotal } \\
\text { Lead, Total }\end{array}$ \\
\hline-009 & $252504-V 8$ & $\begin{array}{l}\text { Cadmium, Total } \\
\text { Lead, Iotal }\end{array}$ \\
\hline-010 & $252504-V 9$ & $\begin{array}{l}\text { Cadnlum, Total } \\
\text { Lead, Total }\end{array}$ \\
\hline
\end{tabular}

LVL LOT \#: 02122358

\begin{tabular}{|c|c|c|c|}
\hline & & REPORTIME & DILUTION \\
\hline RESULT & JNITS & LIMII & FACTOR \\
\hline$=x==0=n=$ & $=x===m$ & $==2=0=x=0$ & $m=n+m=0=$ \\
\hline $0.04 \mathrm{u}$ & MG/KG & 0.09 & 1.0 \\
\hline 5.1 & MG/KG & 0.24 & 1.0 \\
\hline 0.05 & $M G / K G$ & 0.04 & 1.0 \\
\hline 5.8 & $M G / K G$ & 0.24 & 1.0 \\
\hline $0.04 u$ & $M G / K G$ & 0.04 & 1.0 \\
\hline 3.6 & MG/KG & 0.24 & 1.0 \\
\hline $0.04 \mathrm{u}$ & $M G / K G$ & 0.04 & 1.0 \\
\hline 4.0 & MG/KG & 0.23 & 1.0 \\
\hline $0.04 \mathrm{u}$ & MG/KG & 0.04 & 1.0 \\
\hline 4.7 & MG/RG & 0.24 & 1.0 \\
\hline $0.04 \mathrm{u}$ & MG/KG & 0.04 & 1.0 \\
\hline 4.1 & NG/KG & 0.24 & 1.0 \\
\hline $0.04 u$ & MS/KG & 0.04 & 1.0 \\
\hline 4.8 & Ms/ke & 0.23 & 1.0 \\
\hline $0.04 \mathrm{u}$ & Mo/KG & 0.04 & 1.0 \\
\hline 3.5 & MG/Ke & 0.24 & 1.0 \\
\hline $0.04 \mathrm{u}$ & MG / KG & 0.01 & 1.0 \\
\hline 4.5 & nG/KG & 0.34 & 2.0 \\
\hline $0.04 \mathrm{v}$ & $\mathrm{MG} / \mathrm{KG}$ & 0.04 & 2.0 \\
\hline 4.2 & Mo/Ko & 0.22 & 1.0 \\
\hline
\end{tabular}


Lionvilie Laboratory, Ine.

INORGANICS DATA SUMMARY REPORT 12/30/02

\begin{tabular}{|c|c|c|}
\hline \multicolumn{3}{|c|}{ WORK ORDER: 60052-001-001-0001-00 } \\
\hline SAMPLE & SITE ID & ANALYTE \\
\hline$=\pi x==0$ & 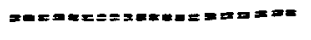 & 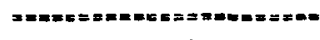 \\
\hline-011 & $252504-v_{10}$ & $\begin{array}{l}\text { Cadmium, Jotal } \\
\text { Lead, Total }\end{array}$ \\
\hline-022 & $252505-\mathrm{VI}$ & $\begin{array}{l}\text { Cadmium, Toeal } \\
\text { Iaad, Total }\end{array}$ \\
\hline-013 & $252505-v 2$ & $\begin{array}{l}\text { Cadni um, Total } \\
\text { Lead, Total }\end{array}$ \\
\hline-014 & $252505-v_{3}$ & $\begin{array}{l}\text { Cactmi um, Total } \\
\text { Lead, Total }\end{array}$ \\
\hline-015 & $252505-v_{4}$ & $\begin{array}{l}\text { Camium, Total } \\
\text { Lead, Total }\end{array}$ \\
\hline-016 & $252505-v 5$ & $\begin{array}{l}\text { Cadmi um, Total } \\
\text { Load, Total }\end{array}$ \\
\hline-017 & $252505-v 6$ & $\begin{array}{l}\text { Cadmi um, Total } \\
\text { Lead, Total }\end{array}$ \\
\hline
\end{tabular}

\begin{tabular}{|c|c|c|c|}
\hline & & REPORTING & DILUIION \\
\hline RESUI: & UNITS & IIM:I & FACTOR \\
\hline$E==\approx=-x$ & $=x= \pm x=$ & $m=m====0=0$ & $\Rightarrow=====-8$ \\
\hline 0.04 & MG/KG & 0.04 & 2.0 \\
\hline 4.6 & MG/KG & 0.23 & 1.0 \\
\hline $0.04 \mathrm{u}$ & MG/KG & 0.04 & 2.0 \\
\hline 4.6 & MG/KG & 0.24 & 1.0 \\
\hline 0.05 & MG/KG & 0.04 & 1.0 \\
\hline 5.3 & MG / KG & 0.23 & 1.0 \\
\hline 0.04 & MG/KG & 0.04 & 1.0 \\
\hline 4.6 & MG/KG & 0.21 & 1.0 \\
\hline 0.044 & MG/KG & 0.04 & 2.0 \\
\hline 4.3 & MG/KG & 0.22 & 1.0 \\
\hline 0.04 & MG/KG & 0.04 & 1.0 \\
\hline 5.1 & MG/KG & 0.23 & 1.0 \\
\hline 0.09 & MG/KG & 0.04 & 1.0 \\
\hline 4.8 & MG/KE & 0.25 & 2.0 \\
\hline
\end{tabular}


Lionvilie Laboracory, Ine.

INORGAMICS METHOD BLANK DATA SUMMARY PAGE $12 / 30 / 02$

CLIENT: BECHTEL NEVADA V $1 B 15$

WORK ORDER: 60052-001-001-0001-00

GAMPLE SITE ID

BLANR] $0220749-M B$
IVL LOT \# 02:2L35E

\begin{tabular}{|c|c|c|c|}
\hline & & REPORTING & DILUTION \\
\hline RESULT & UNETS & LIMIE & FACTOR \\
\hline$F== \pm=E=\pi$ & $\Rightarrow x=2 x= \pm$ & 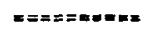 & $y==2 x=0 x$ \\
\hline $0.04 u$ & MG/KG & 0.04 & 1.0 \\
\hline $0.24 \mathrm{~L}$ & $\mathrm{MG} / \mathrm{KG}$ & 0.24 & 3.0 \\
\hline
\end{tabular}


Lionvilie Laboratory, Ine INORGANICS ACCURACY REPORT $12 / 30 / 02$

CLIENT: BECHTEL NEVADA VIBIS WORK ORDER: 60052-001-001-0001-00

SAMPLE SITE ID

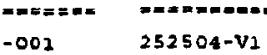

LVI LOT \# 02121358

\begin{tabular}{|c|c|c|c|c|}
\hline SPIKED & INITIAI & SPIKED & & DILUTION \\
\hline SAMPEE & RESULT & AMOUN & IRECOV & FACTOR (SPK) \\
\hline$==-x=-x$ & $=x=x=x=$ & $-m=x=0$ & 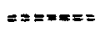 & 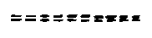 \\
\hline 4.9 & 0.040 & 5.2 & 96.2 & 1.0 \\
\hline 4.7 & 0.044 & 5.1 & 92,2 & 1.0 \\
\hline 57.4 & 5.1 & 50.7 & 203.2 & 2.0 \\
\hline 53.0 & 5.1 & 51.3 & 93.4 & 1.0 \\
\hline
\end{tabular}


Lionvilie Laboratory. Ine.

INORGRHICS DUPJICATE SPIKE REPORT 12/30/02

CLIENT: BECHTEL NEVADA VIBI5

WORK ORDER: 60052-001-001-0001-00

SAMPLE SITE ID

$-001252501-v$ :
ANALYTE

Cadmium, Total

Lead, Total
IVL LOT \#: 0212535E

\begin{tabular}{|c|c|c|}
\hline EKE\#1 & SEIKE $\# 2$ & \\
\hline RECOV & VRECOV & TDIFF \\
\hline$E=x=x$ & $=F C=m x$ & $=0$ \\
\hline 96.1 & 92.2 & 4.2 \\
\hline 03.2 & 93.4 & 10 \\
\hline
\end{tabular}




\section{Lionvilie Laboracory. Ire.}

INORGANICS PRECISION REPORT $22 / 30 / 02$

CLIENT: BECHTBI NEVADS V1G15

WORK ORDER: 60052-002-001-0001-00

SAMPLE SITE ID

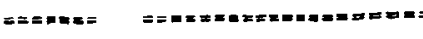

$-002 R B P \quad 252504-V 1$
LVI EOT $\$$ : 02:2L358

\begin{tabular}{|c|c|c|}
\hline INITIAL & & \\
\hline RESULT & REPLICATE & RPD \\
\hline E=EN=Ex= & 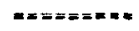 & 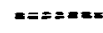 \\
\hline $0.04 \mathrm{u}$ & $0.04 \mathrm{~L}$ & NC \\
\hline 5.2 & 5.0 & 2.0 \\
\hline
\end{tabular}

DILUTION

EACTOR (REP)

1.0

$=0$
Cadnium, Total

Lead, Tota? 
Lionville Laboratory, Ine.

INORGANICS LABORATORY CONTROL STANDARDS REPORT $12 / 30 / 02$

CLIENT: BECFTEL NEVADA Vi8:5

WORK ORDEP: 60052-001-001-0001-00

SAMPLE SITR ID

LCS1 $0220749-2 C 1$
LVL LOF \#: 02121,35E

SPIKEO SPIKED

SAMPLE RMOUNT UNITS TRECOV

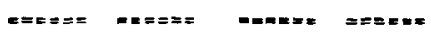

$24.2 \quad 25.0$ MG/KG $\quad 96.4$

242250 MG/KG $2 E .8$ 
CLOSURE REPORT - CAL 398

Section: Appendix C

Revision: 1

Date: April 2003

\section{APPENDIX C}

\section{USE RESTRICTION INFORMATION}


CLOSURE REPORT - CAU 398

Section: Appendix $C$

Revision: 1

Date: April 2003

THIS PAGE INTENTIONALLY LEFT BLANK 


\section{CAU Use Restriction Information}

CAU Number/Description: CAU 398: Area 25 Spill Sites, Nevada Test Site, Nevada

Applicable CAS Numbers/Descriptions: CAS 25-25-07, Hydraulic Oil Spill(s);

CAS 25-25-08, Hydraulic Oil Spill(s)/Oil spill sites located inside $X$ and $Y$ Tunnels in area 25.

Contact (organization/project): NNSA/NV Industrial Sites Project Manager

Surveyed Area (UTM coordinates, Zone 11, NDA 27):

CAS 25-25-07, Hydraulic Oil Spill(s)

NW corner: $\quad 4,064,605.16 \mathrm{~m} \mathrm{~N} \quad 560,087.66 \mathrm{~m} \mathrm{E}$

NE corner: $\quad 4,064,611.77 \mathrm{~m} \mathrm{~N} \quad 560,108.00 \mathrm{~m} \mathrm{E}$

SW corner: $\quad 4,064,595.76 \mathrm{~m} \mathrm{~N} \quad 560,091.00 \mathrm{~m} \mathrm{E}$

SE corner: $\quad 4,064,603.28 \mathrm{~m} \mathrm{~N} \quad 560,109.85 \mathrm{~m} \mathrm{E}$

CAS 25-25-08, Hydraulic Oil Spill(s)

NW corner: $\quad 4,064,454.75 \mathrm{~m} \mathrm{~N}, \quad 560,310.32 \mathrm{~m} \mathrm{E}$

NE corner: $\quad 4,064,449.82 \mathrm{~m} \mathrm{~N} \quad 560,320.18 \mathrm{~m} \mathrm{E}$

SW corner: $\quad 4,064,428.24 \mathrm{~m} \mathrm{~N} \quad 560,301.13 \mathrm{~m} \mathrm{E}$

SE corner: $\quad 4,064,425.16 \mathrm{~m} \mathrm{~N} \quad 560,310.24 \mathrm{~m} \mathrm{E}$

Survey Date $\underline{8 / 15 / 2002}$ Survey Method GPS Datum NAD 1927 Zone UTM Zone 11

Site Monitoring Requirements: NONE

Monitoring Frequency (quarterly, annually?): N/A

\section{Use Restrictions}

The future use of any land related to this Corrective Action Unit (CAU), as described by the above surveyed location, is restricted from any DOE or Air Force activity that may alter or modify the containment control as approved by the state and identified in the CAU Closure Report or other CAU documentation unless appropriate concurrence is obtained in advance.

Comments: See the CAU 398 Closure Report (Document number DOE/NV-873, 2003) for additional information on the condition of the site and any monitoring and/or inspection requirements. Note, the spill sites are within the $\mathrm{X}$ and $\mathrm{Y}$ Tunnels. Use restrictions apply to the areas inside the tunnels only, not on the surface area above the tunnels.

Submitted By: Dabavi Cuntis Date: 1/23/03 Attachments: Site Figures showing survey locations and coordinates for the $\mathrm{X}$ and $\mathrm{Y}$ Tunnel use restrictions (CAS252507_UR.cdr and CAS252508_UR.cdr). 
CLOSURE REPORT - CAU 398

Section: Appendix C

Revision: ]

Date: April 2003

THIS PAGE INTENTIONALLY LEFT BLANK 


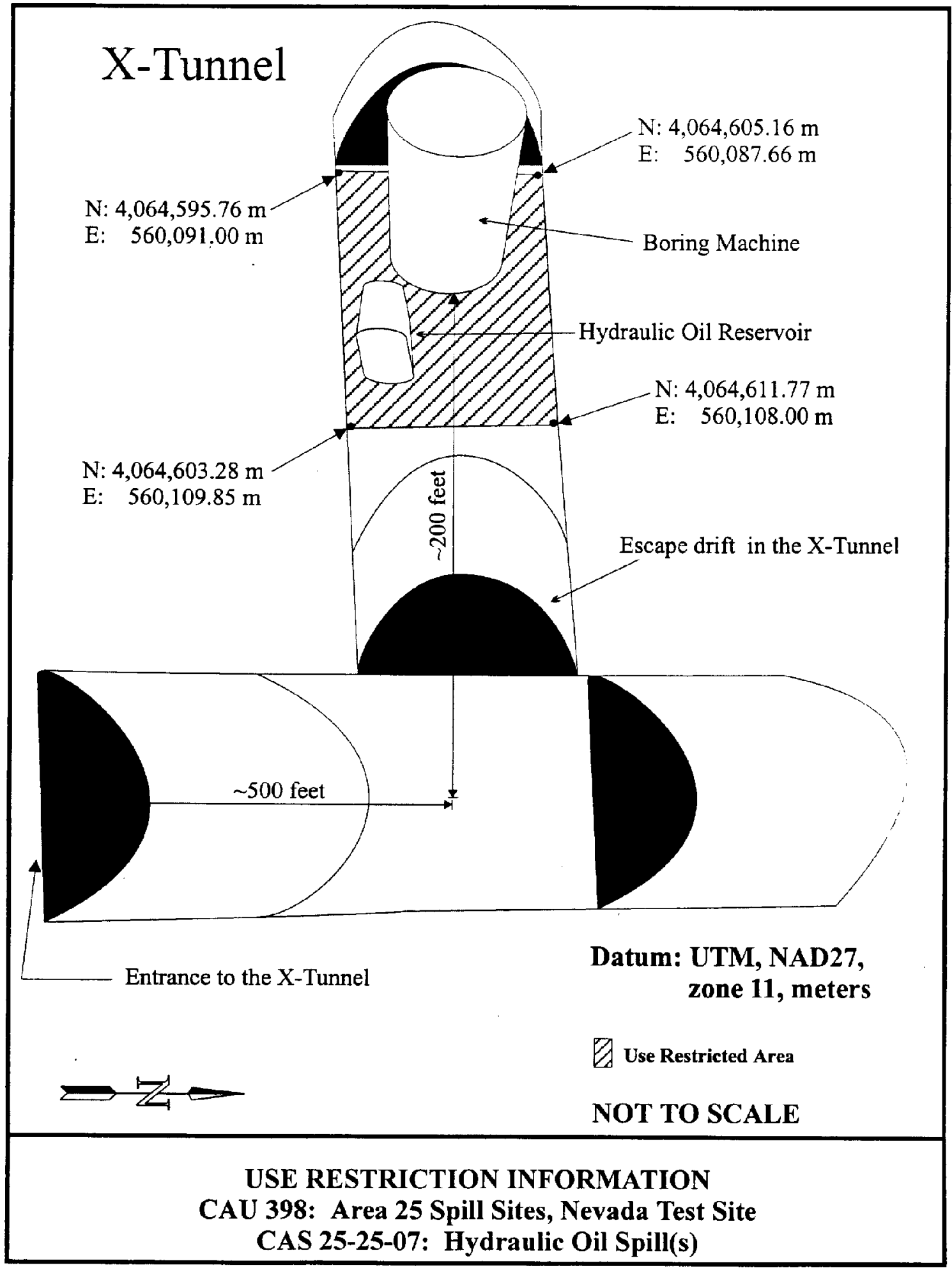




\section{Y-Tunnel}

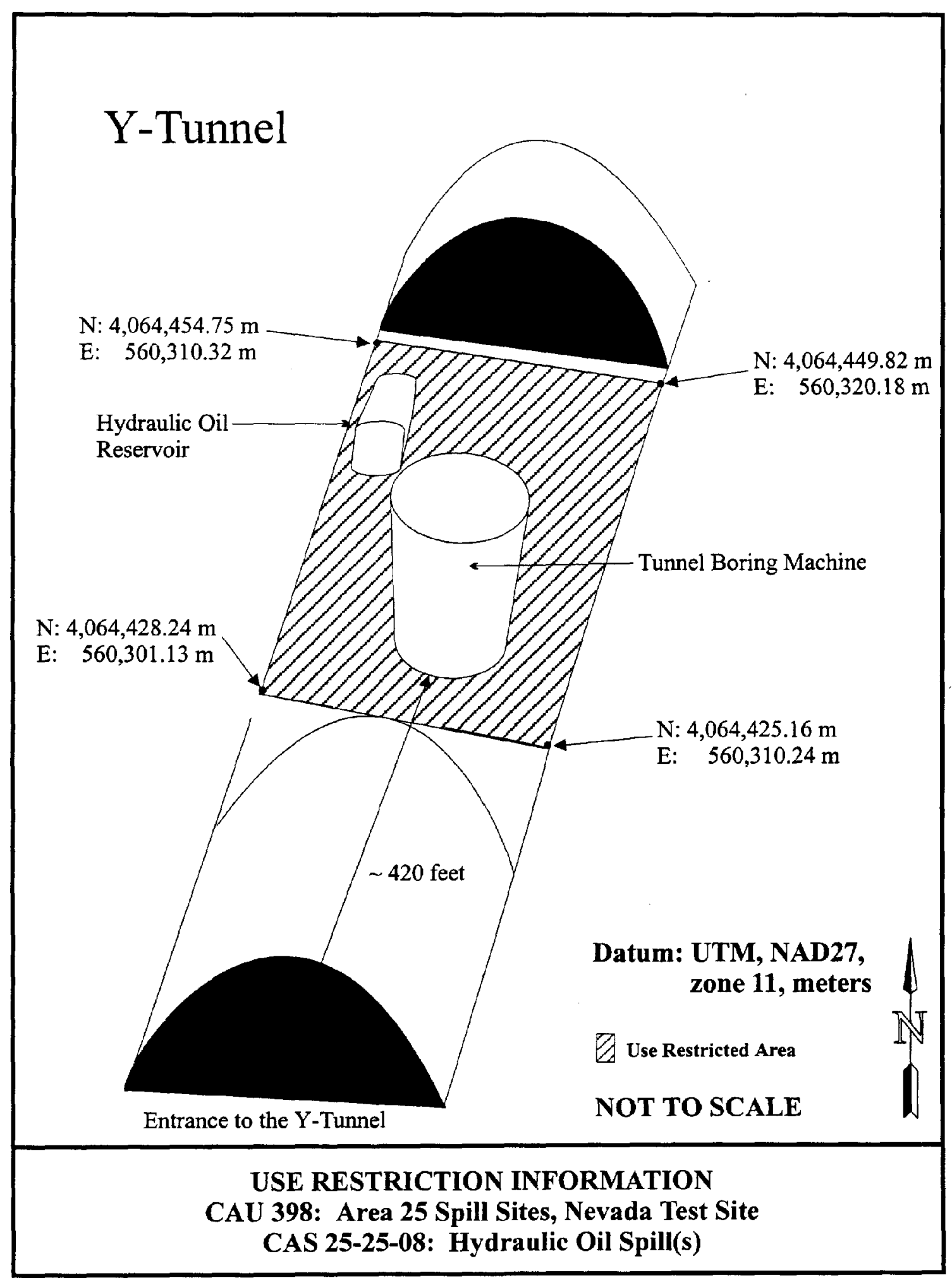




\section{CAU Use Restriction Information}

CAU Number/Description: CAU 398: Area 25 Spill Sites, Nevada Test Site, Nevada

Applicable CAS Numbers/Descriptions: CAS 25-25-17, Subsurface Hydraulic Oil Spill

Contact (organization/project): NNSA/NV Industrial Sites Project Manager

Surveyed Area (UTM coordinates, Zone 11, NAD 27):

CAS 25-25-17, Subsurface Hydraulic Oil Spill

NW corner: $4,073,416.13 \mathrm{~m} \mathrm{~N} \quad 562,107.74 \mathrm{~m} \mathrm{E}$

NE corner: $\quad 4,073,415.73 \mathrm{~m} \mathrm{~N} \quad 562,110.74 \mathrm{~m} \mathrm{E}$

SE corner: $\quad 4,073,412.73 \mathrm{~m} \mathrm{~N} \quad 562,110.14 \mathrm{~m} \mathrm{E}$

SW corner: $\quad 4,073,413.13 \mathrm{~m} \mathrm{~N} \quad 562,107.14 \mathrm{~m} \mathrm{E}$

Survey Date 12/16/2002 Survey Method Transit Datum NAD 1927 Zone UTM Zone 11

Site Monitoring Requirements: NONE

Monitoring Frequency (quarterly, annually?): N/A

\section{Use Restrictions}

The future use of any land related to this Corrective Action Unit (CAU), as described by the above surveyed location, is restricted from any DOE or Air Force activity that may alter or modify the containment control as approved by the state and identified in the CAU Closure Report or other CAU documentation unless appropriate concurrence is obtained in advance.

Comments: See the CAU 398 Closure Report (Document number DOE/NV-873, 2003) for additional information on the condition of the site and any monitoring and/or inspection requirements. Note, the spill site is within the Utility Corridor at E-MAD. Use restrictions apply to the area within the utility corridor.

Submitted By: Labini Cortis Date: $1 / 23 / 03$

Attachments: Site Figure showing survey locations and coordinates (CAS252517_UR.cdr). 
CLOSURE REPORT - CAU 398 Section: Appendix C

Revision: 1

Date: April 2003

THIS PAGE INTENTIONALLY LEFT BLANK 


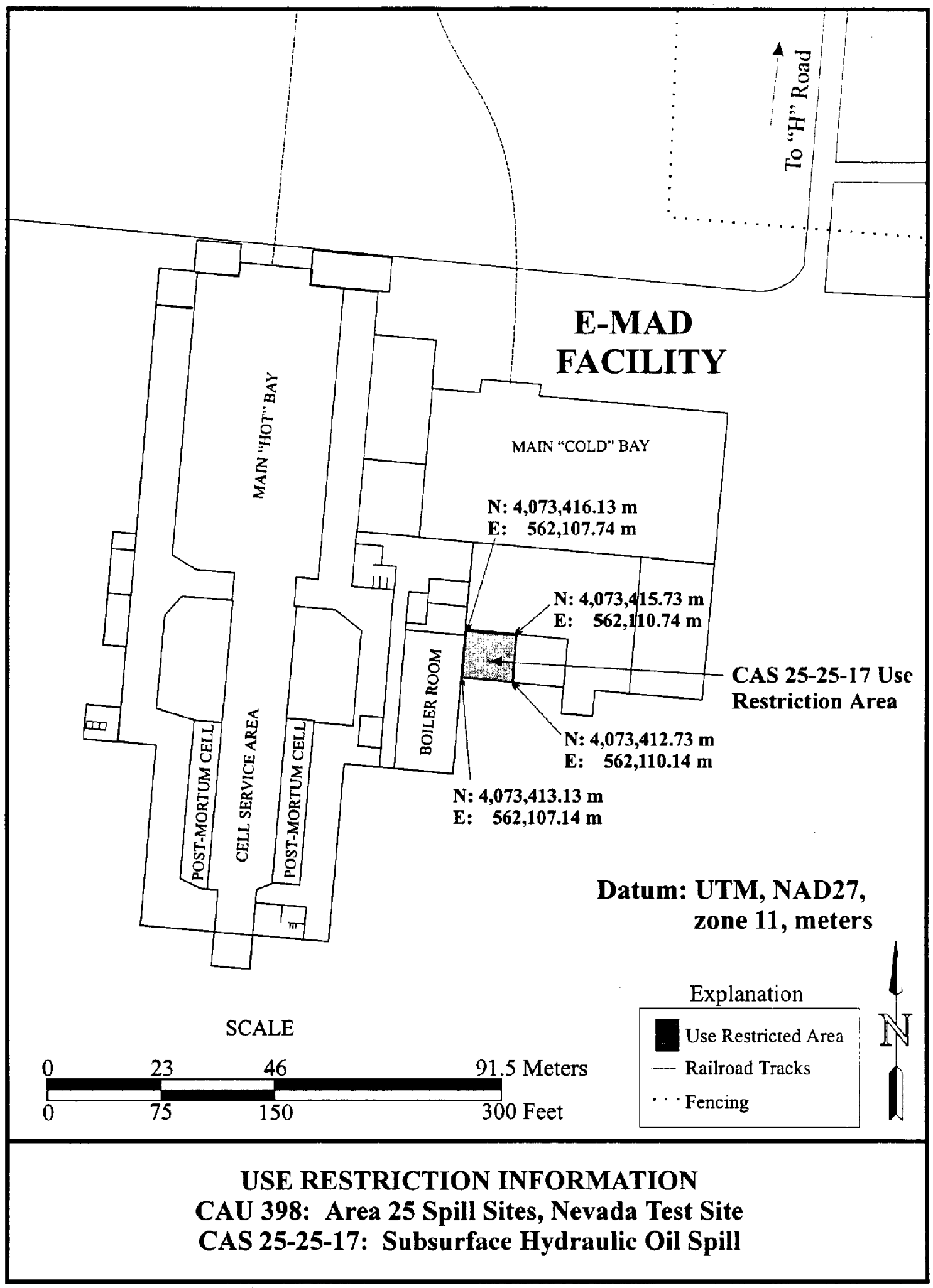


CLOSURE REPORT - CAU 398

Section: Appendix $\mathrm{C}$

Revision: 1

Date: April 2003

THIS PAGE INTENTIONALLY LEFT BLANK 
CLOSURE REPORT - CAU 398

Section: Appendix D

Revision:

Date: April 2003

\section{APPENDIX D}

\section{WASTE DISPOSITION DOCUMENTATION}


CLOSURE REPORT - CAU 398

Section: Appendix D

Revision: 1

Date: April 2003

THIS PAGE INTENTIONALLY LEFT BLANK 


\section{Bechtel Mevada

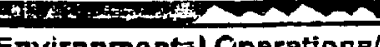 \\ Environmental Cperationgl Hazardous Wasta Operations}

\section{Re:quest for Service}

FAX 54815 or send to MS NTS 110

Date Needed: $\quad$ 6/27/02

Phone Number: $\quad 5-0331$

Phone Number: $\quad \mathbf{5 - 1 2 4 0}$

Facility Owner or Designee:

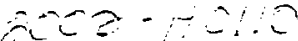

Project \#: CAU 398

Charge \#: $5 \mathrm{BOgHz2}$

Org. Name/No.: $\quad$ A435

Mail Stop: NTS306 Jeff Smith

\section{Section A - Services Raquested}

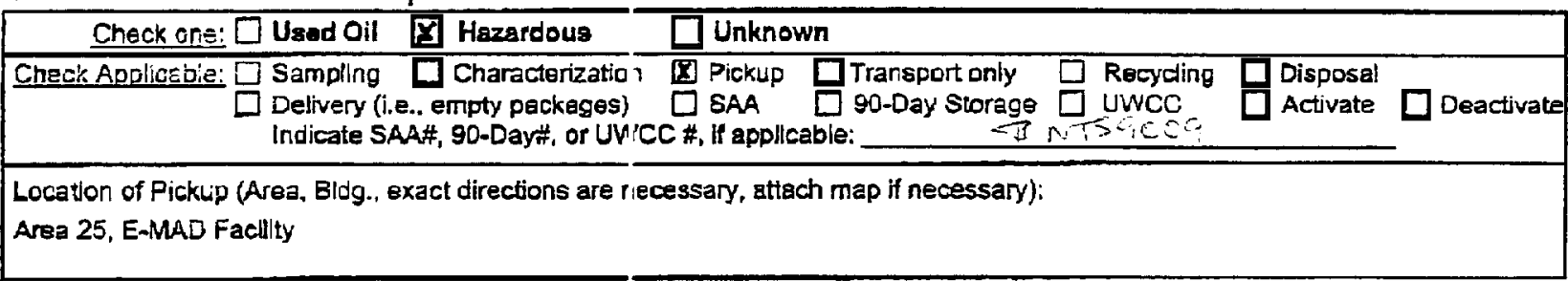

SectIon B - Gerieral Waste Information (use cor:unuaston snees i necessary)

Waste Generation Date: 6/3/02 to 6/5/02 [O One T me Generation $\square$ Routine Generation CAU/CAS If appllcable: jAS 25-25-0; Radiological Clearance provided: $\square$ BN-0121, Clearsince Sticker X BN-0488, Green Tag $\square$ BN-0002, Hazandous Waste Certification $\square$ None

Waste Amount (Gallons): Type of Container (ie., can, drum, carboy, tanker, etc.): 55 Metal

Number of Containers: 4

Detailed Description/Process Knowledge (le., Llquid, Solld, Gas; Name of material; Physleal description; How waste wes generated, Suspected contaminants, etc.); (Attach applicable MS DSs.)

Waste contalns PCBs in s0il. All waste is containeriz $9 d$ in 55 gallon drums. Waste was generated when removing bydrocarbon impacted soil from CAS 25-25-02.

I cerdfy under penalty of law, the above information is correct and additional information requlred is avallable as indicated. The material requested for p/ckup has only those materials described on this form. Contents will be verifled by process

knowledge of origin, MSDS, andor sampling and analysls.

(specify) Beswerator, $\square$ Facllyty Owner $\square$ Project Managar

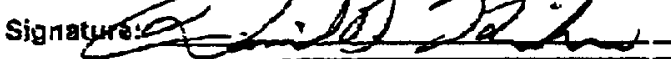

\section{Sectlon C - Work Location Information}

Facllty Point of Contact (Name. Phone, Pager):

Who will sign the Work Packege Traveler? (Name, Phone, Pager)

Jeff Smith, 5-7775, 4-5680

Dan KIrker, 5-5577, 4-6075

Facllity Access Requlrements:

EM-5 Kay to enter E-MAD facility

Known hazards in the requested service area:

Acceptabla tims period to conduct requested services:

Hours (AM/PM): 7:00 AM to 4:00 PM

Day(s): Mon-ThLir

Section D - Services Complated

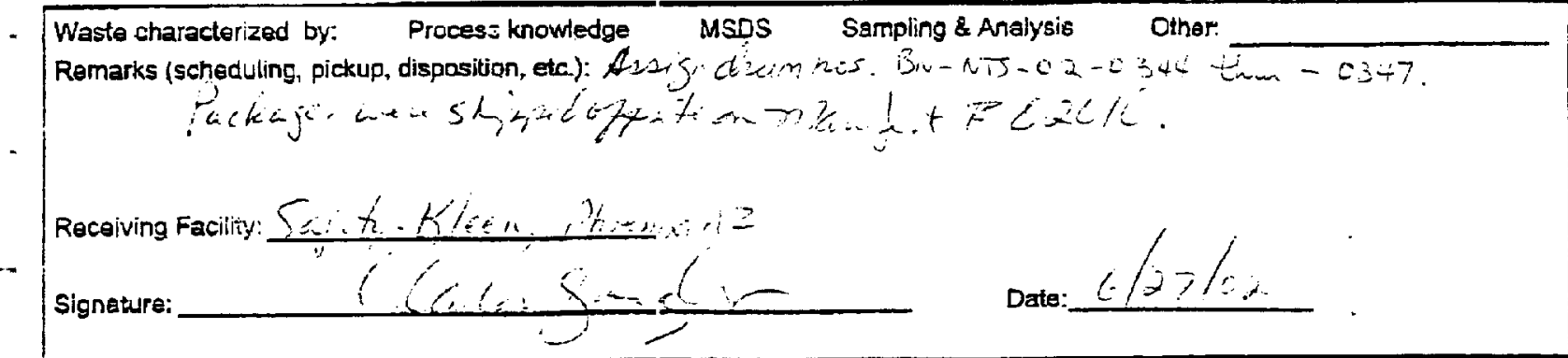


Jate of Request: $\frac{5-06 \times 02}{5-23-02}$

Date Neaded:

Requester Name:

Secondary Curitact:

Organization Nams:

Charge Number:

$23-02$

Environmental Operations / Hazardous Waste Operations

\section{Request for Service}

An acditional foe will be astessed for tme expended when charge numbers are incorrec! or are not open lo Envlronmental Opgratons Org. numbers 2150 and above. If sampling ls required the eharge $\#$ must be open.

Section A - Services Requested (Soo instructions on page 2 or request asstsrence from EO/HWO personnal)

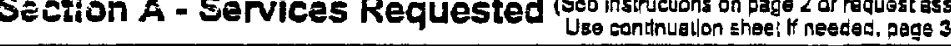

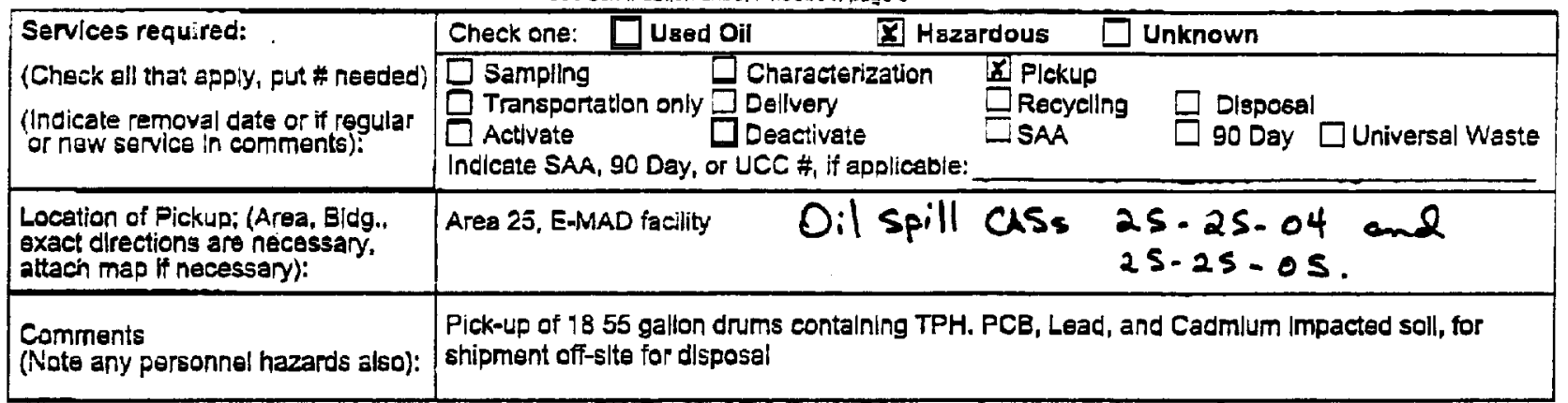

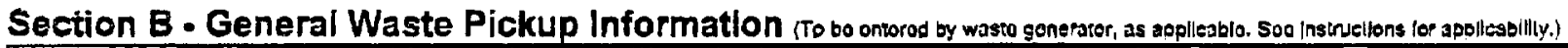

Waste Generation Data: $4 / 23$ to 5/2 _ Radiological data provided, (see instructions on page 2)? $\square$ Yes $\square$ No $\square$ Exempt

ER or hisioric cleanup?: $\mathbf{Z}$ Yes $\square$ No 'If "Y9S," describe (inelude CAU \#): CAU 398 Area 25 Soill Sites

Waste Amount (Gallons): __ Type of Container: 55 metal Nu Number of Containers: 18

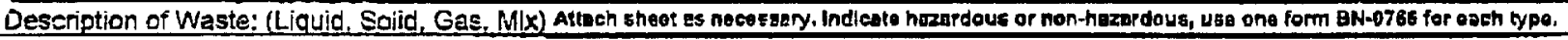

Waste contains TPH, PCBs. Lead and Cadmium in soll. All waste is containerized in 55 gallon drums

Waste origin statement (Use the continuation sheet, paga 3, if necessary, and attach applicable Intibrmatlon such as MSDS, enalyt cal resul:s, or SAA revisions.) Print, slgn and dellver thls request to EO/HWO.

Waste. is from spills associated with CAU 398. All soil was excavared from the E-MAD facility in Area 25. Spills are riom equipment leaking, and also from wastes being dumped in draining ditch after they finished using them.

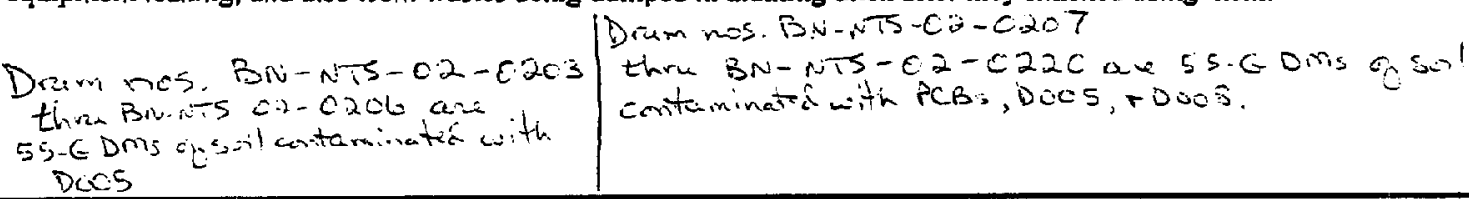

I certity under penalty of law, the above information is correot and additional information required Is avallable as indleated. The container recuested for pickup has only those materials allowed by the acceptance criteria detailed on the instructions to this form. Contents wilbeverilied by process or orlgin knowledge or sampllng and analysis.

Generator Signature:

Section C - HWO USE ONLY Completed by ( $($ OOHWO personnel initials):

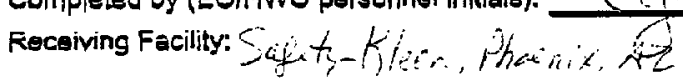

EOAHWO Femarks (scheduling, pickup, container, exceptlens, labels).

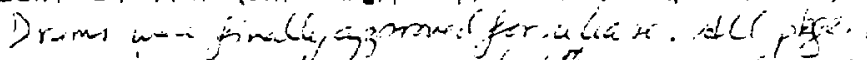

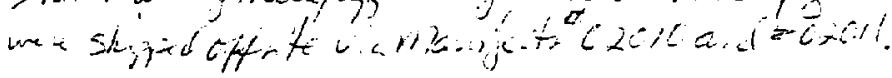

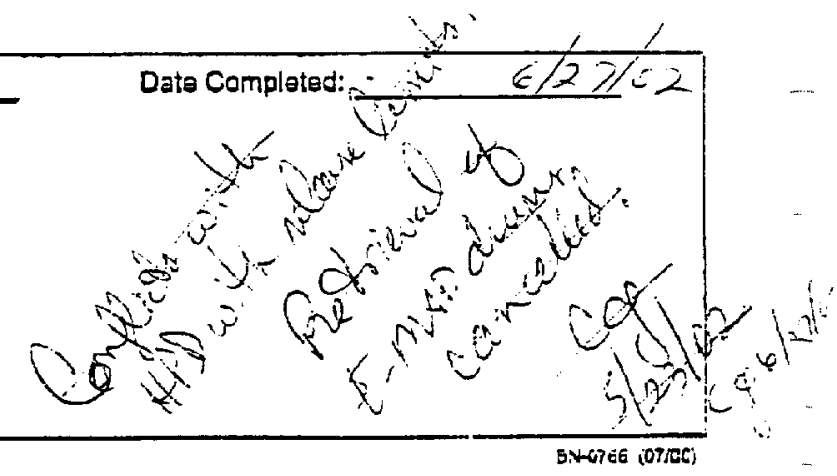




\section{Bechtel Nevada TRAVELER}

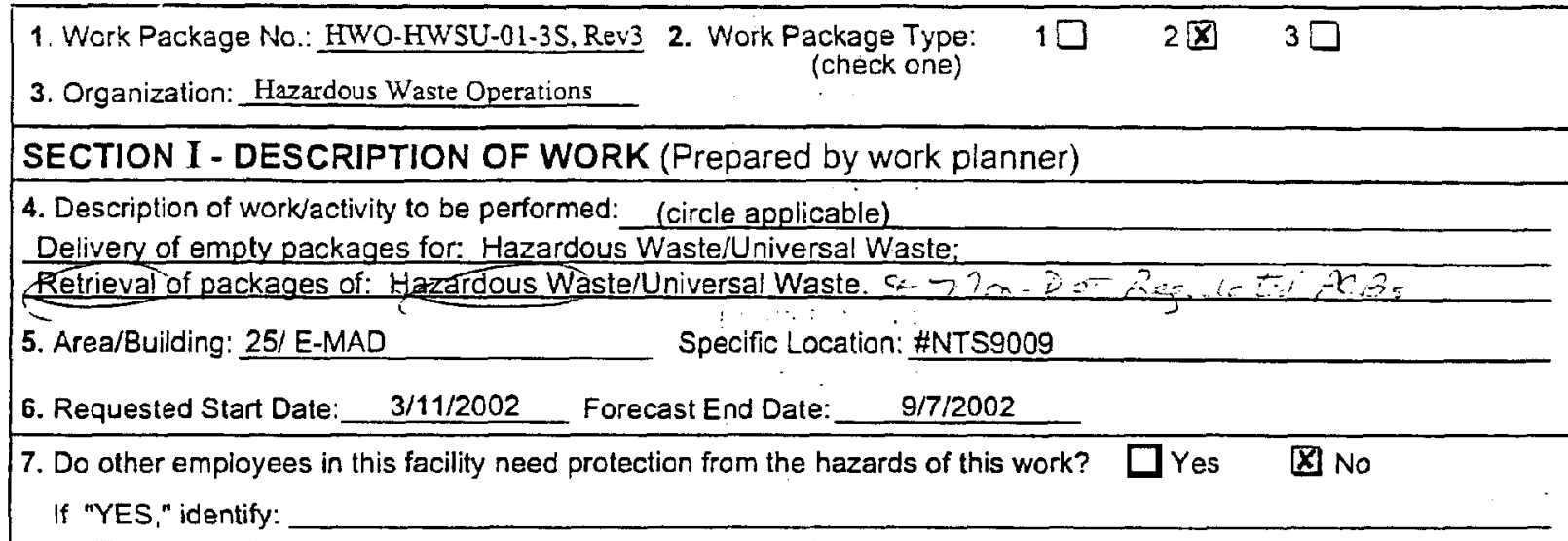
8. Permits Required?
$\square$ Yes $\quad x$ No
LO/TO Required?
$\square$ Yes $邓$ No
9. Permit Types:
None.

10. Other Requirements: Notifv orior to arrival.

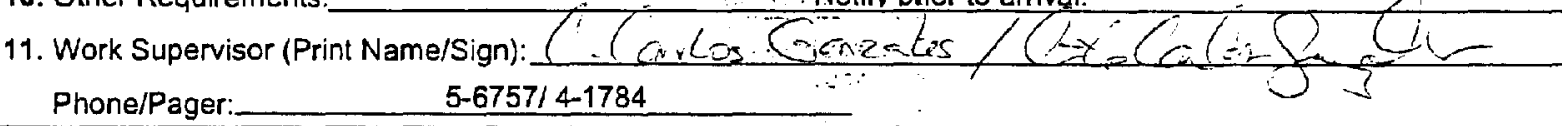

SECTION II - WORK AUTHORIZATION (Completed by facility owner or designee)

12. Point of Contact: (Name/Phone/Pager No.)

DAN KIRKER 5-5577/4-6075

13. Access requirements have been met? $Z$ Y $\square$ in $\square$

14. Pertinent hazards and controls for this work have been communicated to co-located work groups. $\square$ Yes $\bigotimes$ N/A

15. AUTHORIZATION TO PERMIT WORK - Work is within facility safety envelope and facility configuration determined. Work is authorized for these time periods, facility is ready to accept work, and work is deconflicted.

\begin{tabular}{|c|c|c|c|c|c|}
\hline Start Date & Start Time & End Date & End Time & Print Facility Owner or Designee/Phone No. & Signature \\
\hline $6 / 27 / 02$ & 0800 & $6 / 27 / 02$ & 100.0 & Dan Kirker 5-5577/4-6075 & 1 \\
\hline & & & & $\because: \ldots \cdots$ & \\
\hline & & & & & \\
\hline & & & & $\therefore$ & \\
\hline & & & & $\because \cdots$ & \\
\hline & & & & $\ldots \ldots \ldots \ldots-$ & \\
\hline
\end{tabular}

16. Comments: Retrieve Hazardous \& PCB Waste drums (22 each); to be shipped offsite via Manifest \#02010 \& 02011.

\section{SECTION III - FINAL STATUS/END OF WORK}

17. Work is completed. Area is clean and safe. Post work verification is completed.

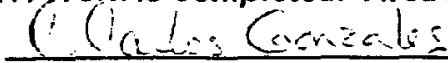
Name (work supervisor or designee)

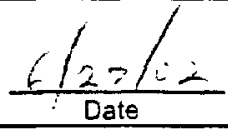

18. Applicable activity/work is accepted and Traveler is closed.

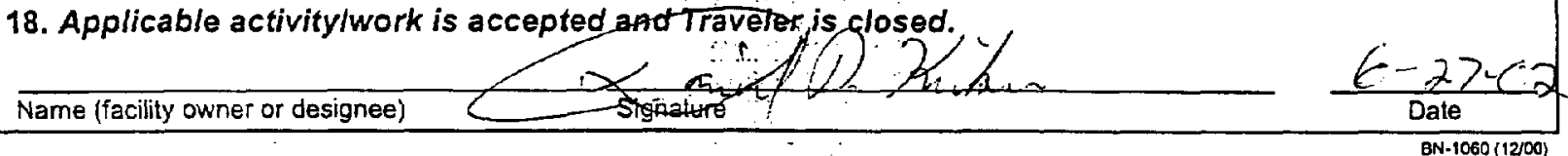


Please print or lype. (Form designed tor use on elite (12-pitch) typewriter.)

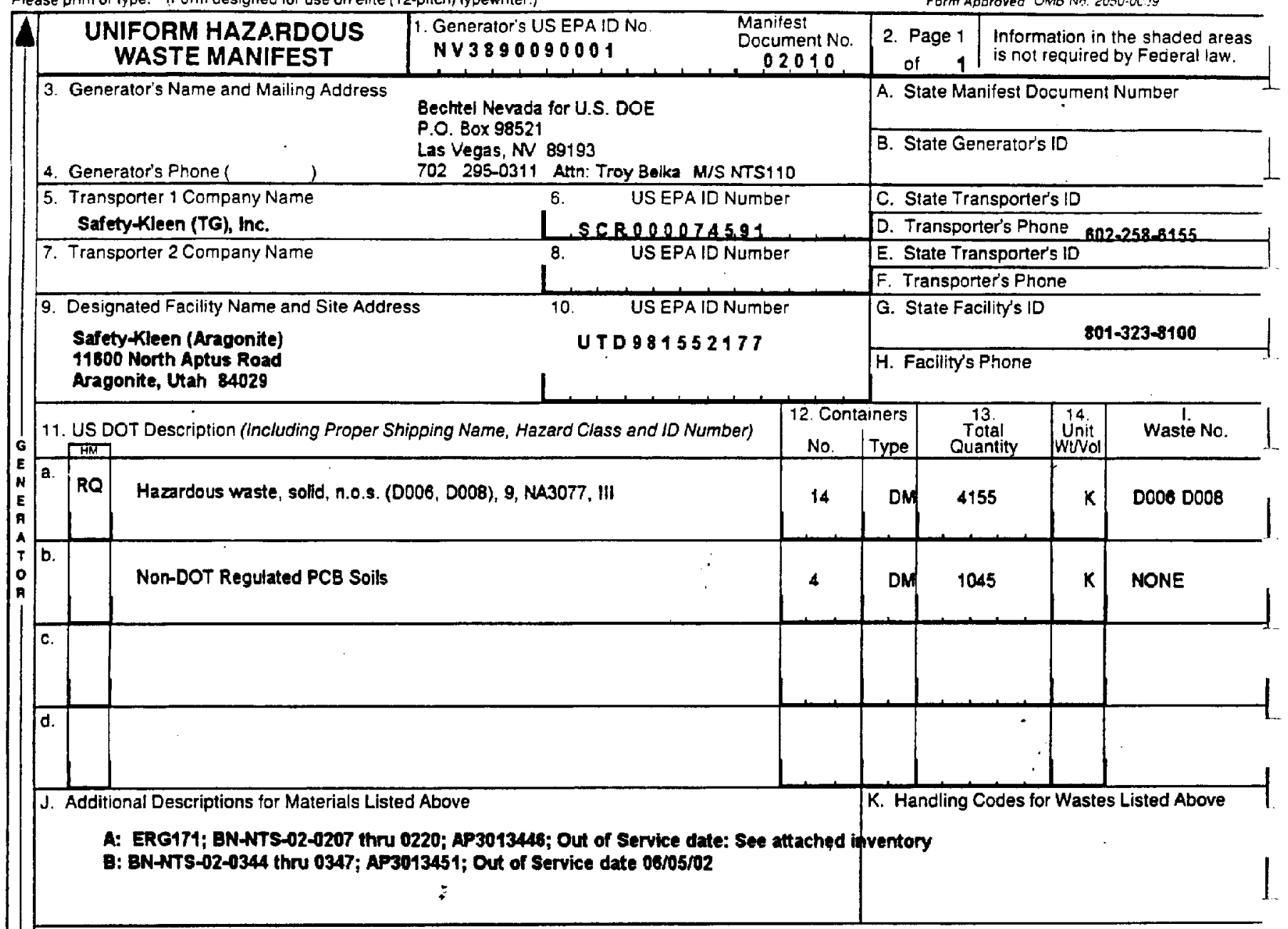

15. Specjal Handling Instructions and Additional Information

24hour emergency contact $\$(702) 205-0311$ collect

Use Proper PPE when handling containers

Certificate of Destruction is required

?

16. GENERATOR'S CERTIFICATION: I hereby declare that the contents of this consignment are lully and accurately described above by

proper shipping name and are classilied, packed, marked, and tabeled, and are in all respects in proper condilion lor transport by highway

according to applicable international and national government regulations.

II I am a large quantity generator, I certify that I have a program in place to reduce the volume and toxicity of waste generated to the degree I have determined to be economically practicable and that I have selected the practicable method of treatment, storage, or disposal currently available to me which minimizes the present and future threat to human health and the environmeni; OR, if I am a small quantity generator, I have made a good taith eflort to minimize my waste generation and select the best waste management method that is avaitable to me and that $I$ can afford.

Printed/Typed Name TRQ S. BELKA

T 17. Transporter 1 Acknowledgement of Receipt of Materials A Printed/Typed Name

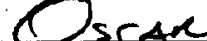

12N12

\begin{tabular}{l|l} 
Printed/Typed Name & Signature
\end{tabular}

19. Discrepancy Indication Space

E

20. Facility Owner or Operator: Certification of receipt of hazardous materials covered by this manifest except as noted in Item 19.

\begin{tabular}{l|l|l}
\hline T & Printed/Typed Name & Signature
\end{tabular}


Please print or type. (Form designed for use on elite (12-pitch) typewriter.)

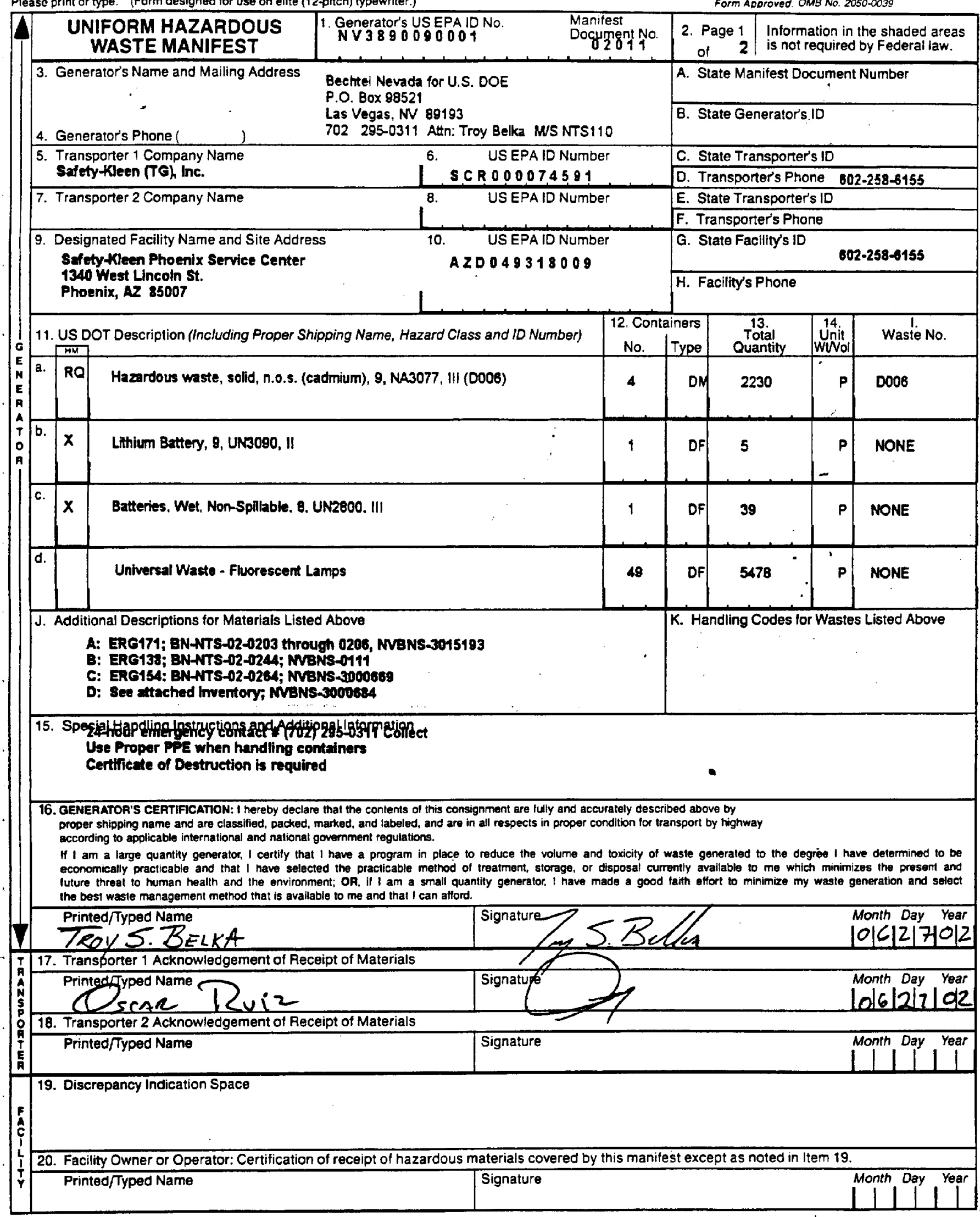




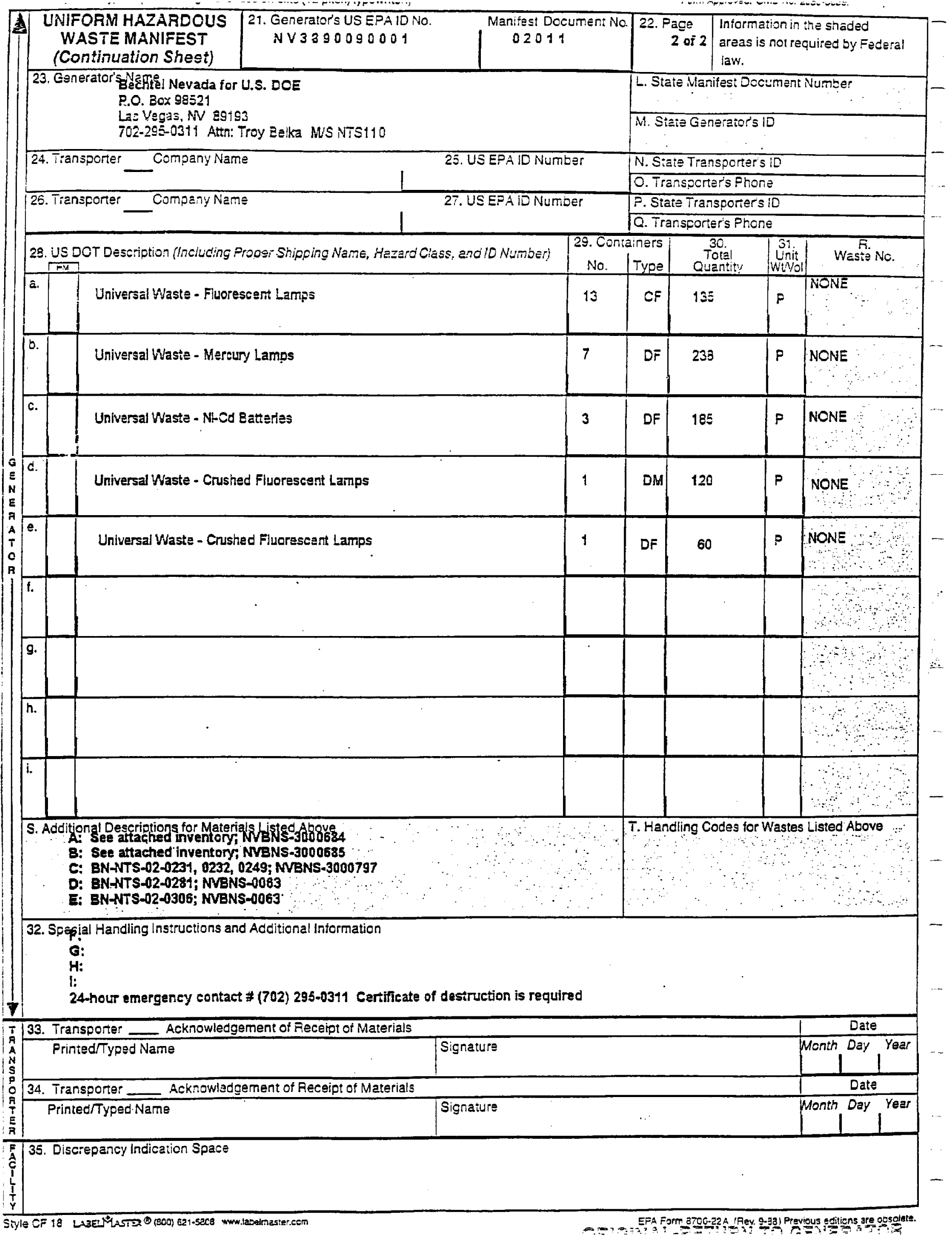


SOIUWASTE TFACKING SYSTEM

Larin! Dare Uf Wäte
IE

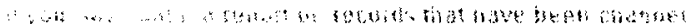

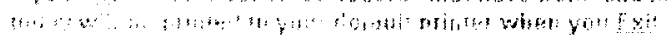

Bechtel Nevade $\leftrightarrow|<|>|\gg|$ Query $\mid$ Save $\mid$ Ext 
SOULWASTE IFACMIVE SYSTEM

\begin{tabular}{|c|c|c|c|}
\hline $\begin{array}{l}\text { Lariart: } \\
\text { IL }\end{array}$ & $\begin{array}{l}\text { Late of } \\
\text { Receipt }\end{array}$ & $\begin{array}{l}\text { Waste } \\
\text { Categor }\end{array}$ & Twe of triaste \\
\hline AREAE & p3-nut-2002 & 1 & FFACO-ONSITE \\
\hline AREAE & 30-MAY-2002 & 1 & FFACO-OANSITE \\
\hline AREA, $\varepsilon$ & 29-MAY-2002 & 1 & FFACO-ONSITE \\
\hline APEA 6 & QS-MAY-2002 & $\bar{T}$ & FFACO-ONISITE \\
\hline AFEA 6 & $23-M A Y-2002$ & $\bar{T}$ & FACOOONSITE \\
\hline AFEA 6 & $22-M A Y-2002$ & 1 & FFACOONSITE \\
\hline AREA, 6 & $21-M A Y-2002$ & 1 & FFACO-ONSITE \\
\hline AREA $\varepsilon$ & 21-MaY-2002 & 1 & FFACO-ONSITE \\
\hline AREA 6 & $21-M A Y-2002$ & $\mathrm{I}$ & FFACO-ONSITE \\
\hline AREA 6 & 16-MAY-2002 & 1 & FACO-ONSITE \\
\hline
\end{tabular}

\begin{tabular}{|c|c|c|c|c|c|}
\hline $\begin{array}{c}\text { EM o } \\
\text { DF }\end{array}$ & $\begin{array}{l}\text { Routine o } \\
\text { Clean-up }\end{array}$ & $\frac{\text { Weiaht }}{\text { Pounds }}$ & $\begin{array}{l}\text { Area } \\
\text { No. }\end{array}$ & $\begin{array}{l}\text { Building } \\
\text { No. }\end{array}$ & \\
\hline EM & CLEAN-UP & 66000 & $E s$ & CAL 396 & Comments \\
\hline$E M$ & ELEAN-IP & 80000 & 25 & 20195 & Cornments \\
\hline EN! & ELEAN-LIP & 45000 & 85 & FAL 392 & Comments \\
\hline$E M$ & CLEAN-LIF & 46.400 & 65 & $=4 \cup 39$ & Commerts \\
\hline EM & CLEANAJAF & 40000 & 5 & 204395 & Comments \\
\hline$E^{M}$ & FLEAN-UP & 48000 & 25 & EAL 398 & Commerts \\
\hline $\mathrm{FM}^{M}$ & ELEANALIP & 46500 & 25 & CAU 398 & Comments \\
\hline EM & CLEAN-UP & 48000 & 25 & CAU 398 & Commerts \\
\hline$E M$ & CLEAN-LP & 48000 & 5 & FAU 398 & Cormerts \\
\hline$E$ & CLEAN-UP & 4600 & 25 & CAU 398 & Comments \\
\hline
\end{tabular}

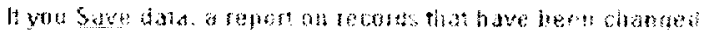

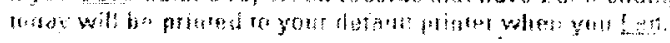

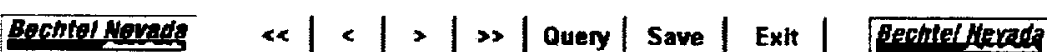

Courk 10 r 


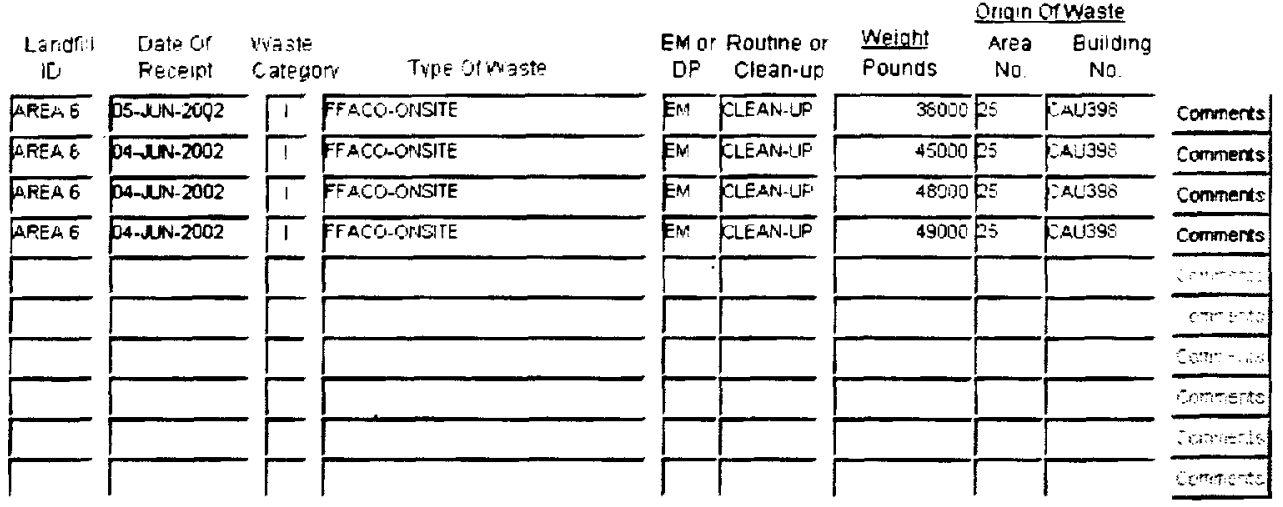

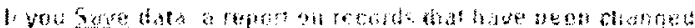

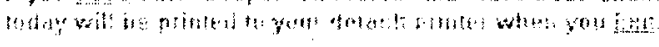

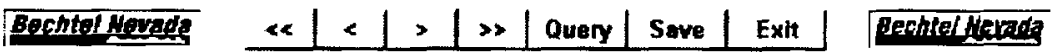




\begin{tabular}{llllll}
\hline SWO USE (Circle One Area) AREA & 23 & 6 & $(9)$ & LANDFIL \\
\hline
\end{tabular}
For waste characterization, approval, andlor assistance, contact Solid Waste Operation (SWO) at 5-7898.

\begin{tabular}{|c|}
\hline 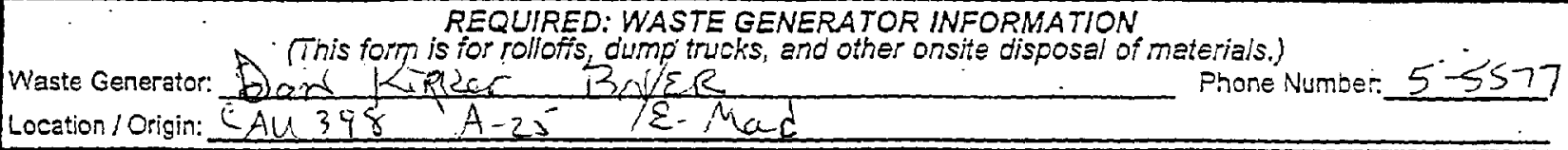 \\
\hline Waste Category: (chesk one) \\
\hline $\begin{array}{l}\square \text { Putrescible } \\
\square \text { Asbestos Containing Material } \square \text { FFACO-offite }\end{array}$ \\
\hline Environmental management $\square$ Defense Projects \\
\hline Pollution Prevention Category: (check one) \\
\hline Method of Characterization: (check one) \\
\hline $\begin{array}{l}\text { Prohibited Waste } \\
\text { at all three NTS landfilis: } \\
\text { wastes (needles, sharps, bloody dlothing). } \\
\text { Additional Prohlbited Waste Sewage Sludge; Aninal carcasses, Wet garbage (food waste); and Friable asbestos } \\
\text { at the Area } 9 \text { U10c Landfill: }\end{array}$ \\
\hline $\begin{array}{l}\text { REQUIRED: WASTE CONTENTS ALLOWABLE WASTES } \\
\text { Check all allowable waStes that are contained within this load: } \\
\text { NOTE: Waste disposed at the Area } 6 \text { Hydrocarbon Landfill must have come into contact with petroleum hydrocarbons or co } \\
\text { gasoline (no benzene, lead); jet fuel; diesel fuel; lubricants and hydraulics; kerosene; asphaltic petroleum hydrocarb }\end{array}$ \\
\hline 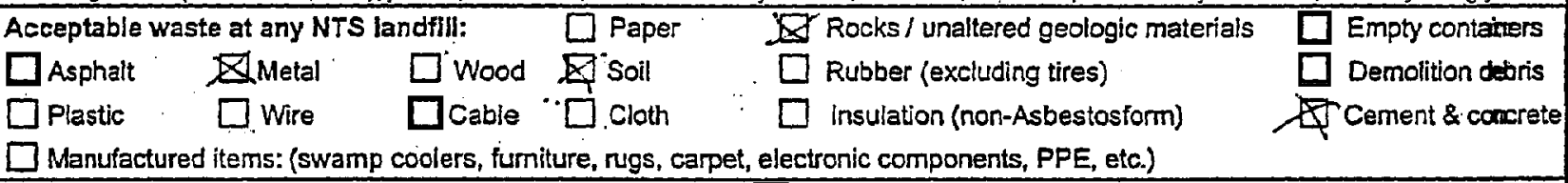 \\
\hline $\begin{array}{l}\text { Additional waste accepted at the Area } 23 \text { Mercury Landfill: } \square \text { Office waste } \square \text { Food Waste } \square \text { Animal Carcasses } \\
\square \text { Asbestos: } \square \text { Friable } \square \text { Non-Friable (contact SWO if regulated load) Quantity: }\end{array}$ \\
\hline
\end{tabular}
Additional waste accepted at the Area 9 U10c Landfill:
$\square$ Non-friable asbestos
$\square$ Drained automobiles and military vehicles
Solid fractions from sand/oil/water separators
$\square$ Light ballasts (contact SWO)
Drained fuel filters (gas \& diesel)
$\square$ Deconned Underground and Above Greund
DHydrocarbons (contact SWO)
$\square$ Tanks

Additional waste accepted at the Area 6 Hydrocarbon Landfill:
$\square$ septic sludge $\square$ Rags
$\square$ Drained fuel filters (gas \& diesel)
$\square$ Crushed non-terne plated ofl filters
$\square$ Plants
$\square$ Sludge from sand/oil/water separators
$\square$ PCBs below 50 parts per million

Initials: REQUIRED: WASTE GENER (If initialed, no radiological clearance is necessary.)

The above mentioned waste was generated outside of a Controlled Waste Management Area (CWMA) and to the best of nny knowledge, does not contain radiological materials.

To the best of my knowledge, the waste described above contains only those materials that are allowed for disposal at this site. I have verified this through the waste characterization method identified above and a review of the above-mentioned prohibited and allowable waste items.

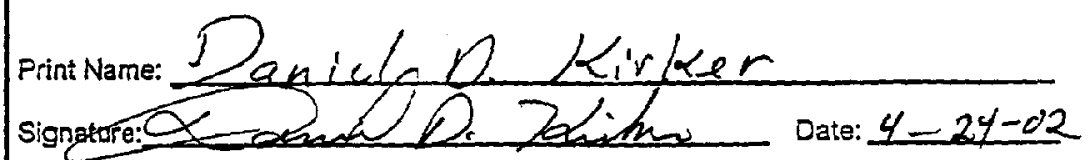

If applicable, place BN-0546, "Radiological Release Sticker" here. Onsite use only.

Note: Food waste, office trash and/or animal carcasses are considered not to contain added redioactivity, and therefore do not require a radiological clearance.

SWO USE ONLY
Load Weight (net from scale of estimate) 15,000

Signature of Certifier:

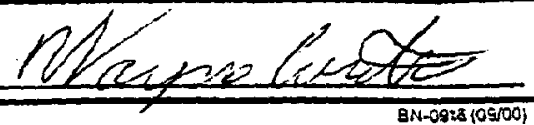




\section{Bechtel Nevada NTS Landfill Load Verification \\ Waste definitions are available on page 2)}

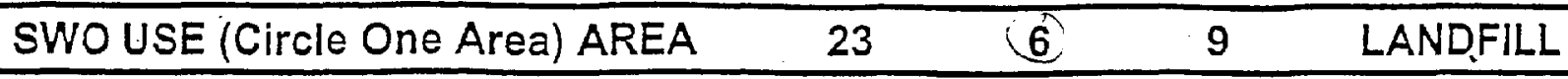

For waste characterization, approval, andlor assistance, contact Solid Waste Operation (SWO) at 5-7898.

$$
\text { REQUIRED: WASTE GENERATOR INFORMATION " }
$$

(This form is for rolloffs dump trucks, and other onsite disposal of materials.)

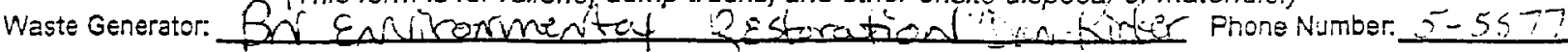
Location/Origin: A-25 E-Md CAu 398 C. CS $25-25-05$

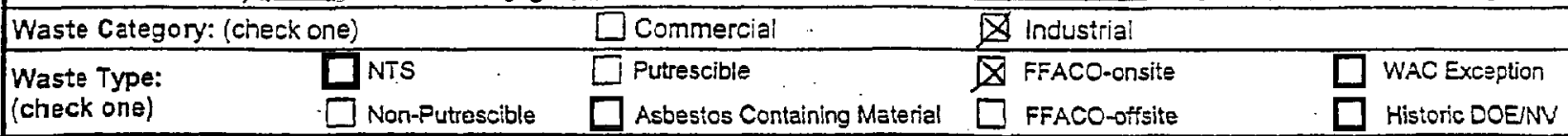

Pollution Prevention Category: (check one) $\square$ Environmental management $\square$ Defense Projects

Pollution Prevention Category: (check one) $\bigotimes$ Clean-Up $\square$ Routine

Method of Characterization: (check one) $\square$ Sampling \& Analysis $\square$ Process Knowledge $\square$ Contents

Prohibited Waste Radloactive waste; RCRA waste; Hazardous waste; Free liquids, PCBs above TSCA requlatory levels-, and Medica! at all three NTS landfills: wastes (needles, sharps, bloody clothing).

Additional Prohibited Waste Sewage Shudge; Animal carcasses., Wet garbage (food waste); and Friable asbestos at the Area 9 U10c Landfill:

REQUIRED: WASTE CONTENTS ALLOWABLE WASTES

Check all allowable wastes that are contained within this load:

NOTE: Waste disposed at the Area 6 Hydrocabon Landfill must have come into contact with petroleum hydrocarbons or coolants such as: gasoline (no benzene, lead); jet fuel; diesel fuel; lubricants and hydraulics; kerosene; asphaltic petroleum hydrocarbon; and ethylene glycol.
Acceptable waste at any NTS landfill:
$\square$ Asphalt
$\square$ Metal
$\square$ Wood
$\square$ Paper
$\square$ Rocks / unaltered geologic materials
$\square$ Empty containers
$\square$ Plastic
$\square$ Wire
$\square$ Cable
$\square$ Soil

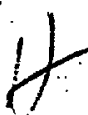
$\square$ Rubber (excluding tires)
$\square$ Demolition debris

$\square$ Manufactured items: (swamp coolers, fumiture, rugs, carpet, electronic components, PPE, etc.)

Additional waste accepted at the Area 23 Mercury Landfill: $\square$ Office waste $\square$ Food Waste $\square$ Animal Carcasses

$\square$ Asbestos: $\square$ Friable $\square$ Non-Friable (contact SWO if regulated load) Quantity.

\section{Additional waste accepted at the Area 9 U10c Landfill:}
$\square$ Non-friable asbestos
Drained automobiles and military vehicles
Solid fractions from sand/oillwater separators
$\square$ Light ballasts (contact SWO)
Drained fuel filters (gas \& diesel)
$\square$ Deconned Underground and Above Ground
Hydrocarbons (contact SWO)
$\square$ Tanks

Additional waste accepted at the Area 6 Hydrocarbon Landfill:
- $\square$ Septic sludge $\square$ Rags $\square$ Drained fuel filters (gas \& diesel)
Delants $\quad \square$ Soi
Sludge from sand/oil/water separators
REQUIRED: WASTE GENERATOR SIGNATURE
Crushed non-terne plated oil filters
PCBs below 50 parts per million

Initials: (If inithaled, no radiological clearance is necessary.)

The above mentioned waste was generated outside of a Controlled Waste Management Area (CWMA) and to the best of my knowledge, does not contain radiological materials.

To the best of my knowledge, the waste described above contains only th site. I have verified this through the waste characterization method identit prohibited and allowable waste items.

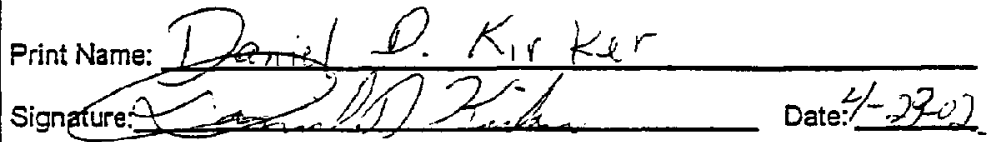

Note: Food waste, ofice trash and/or animal carcasses are considered not to $c$ require a radiological clearance.

SWO USE ONLY

Load Weight (net from scale or estimate): 2

Radiation Survey Release for Waste Disposal RCT Initials

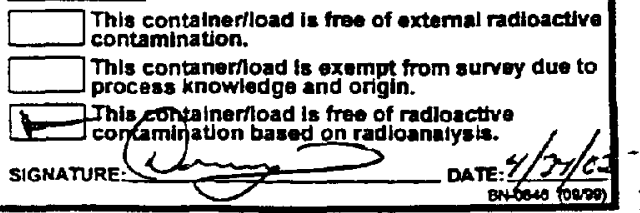

SIGNATURE: 


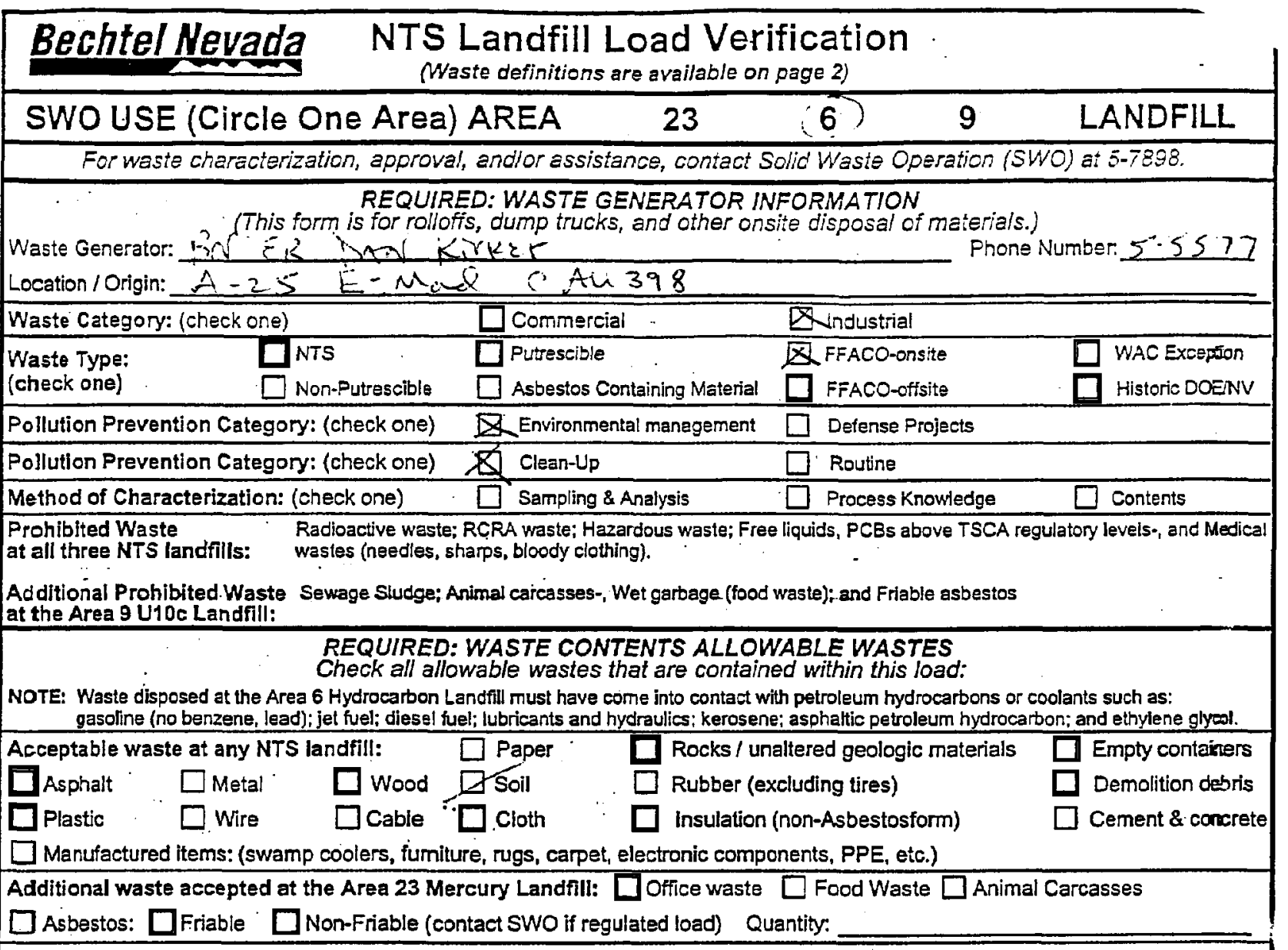

Additional waste accepted at the Area 9 U10c Landfill:
$\square$ Non-friable asbestos
$\square$ Drained automobiles and military vehicles
Solid fractions from sand/oil/water separators
$\square$ Light ballasts (contact SWO)
$\square$ Drained fuel filters (gas \& diesel)
$\square$ Deconned Underground and Above Ground
$\square$ Hydrocarbons (contact SWO)
$\square$ Tanks
Additional waste accepted at the Area 6 Hydrocarbon Landfill:
$\square$ Septic sludge $\square$ Rags
$\square$ Drained fuel filters (gas \& diesel)
$\square$ Plants $D$ SOL
$\square$ sludge from sand/oil/water separators
$\square$ Crushed non-terne plated oil filters
$\square$ PCBs below 50 parts per million
initials: REQUIRED: WASTE GENER (If initialed, no radiological clearance is necessary.)

The above mentloned waste was generated outside of a Controlled Waste Management Area (CWMA) and to the best of my knowledge, does not contain radiological materials.

To the best of my knowledge, the waste described above contains only those materials that are allowed for disposal at this site. I have verified this through the waste characterization method identified above and a review of the above-mentioned prohibited and allowable waste items.

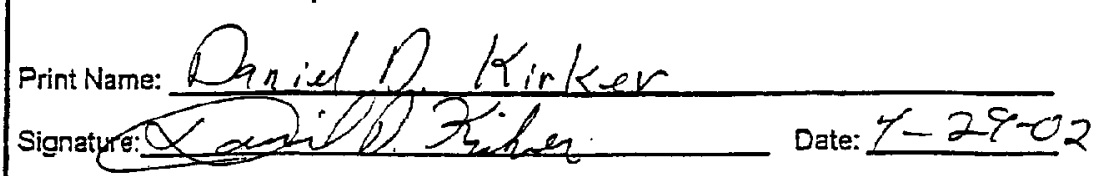

If applicable, place BN-0646 "Radiological Release Sticker" here. Onsite use only.

Note: Food waste, ofiice trash and/or animal carcasses are considered not to contain added radioactivity, and thereitore do not require a radiological clearance.

SWO USE ONLY

Load Weight (net from scale or estimate): Signature of Certifier:

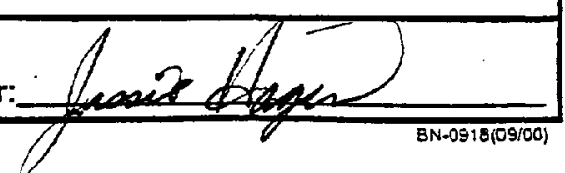




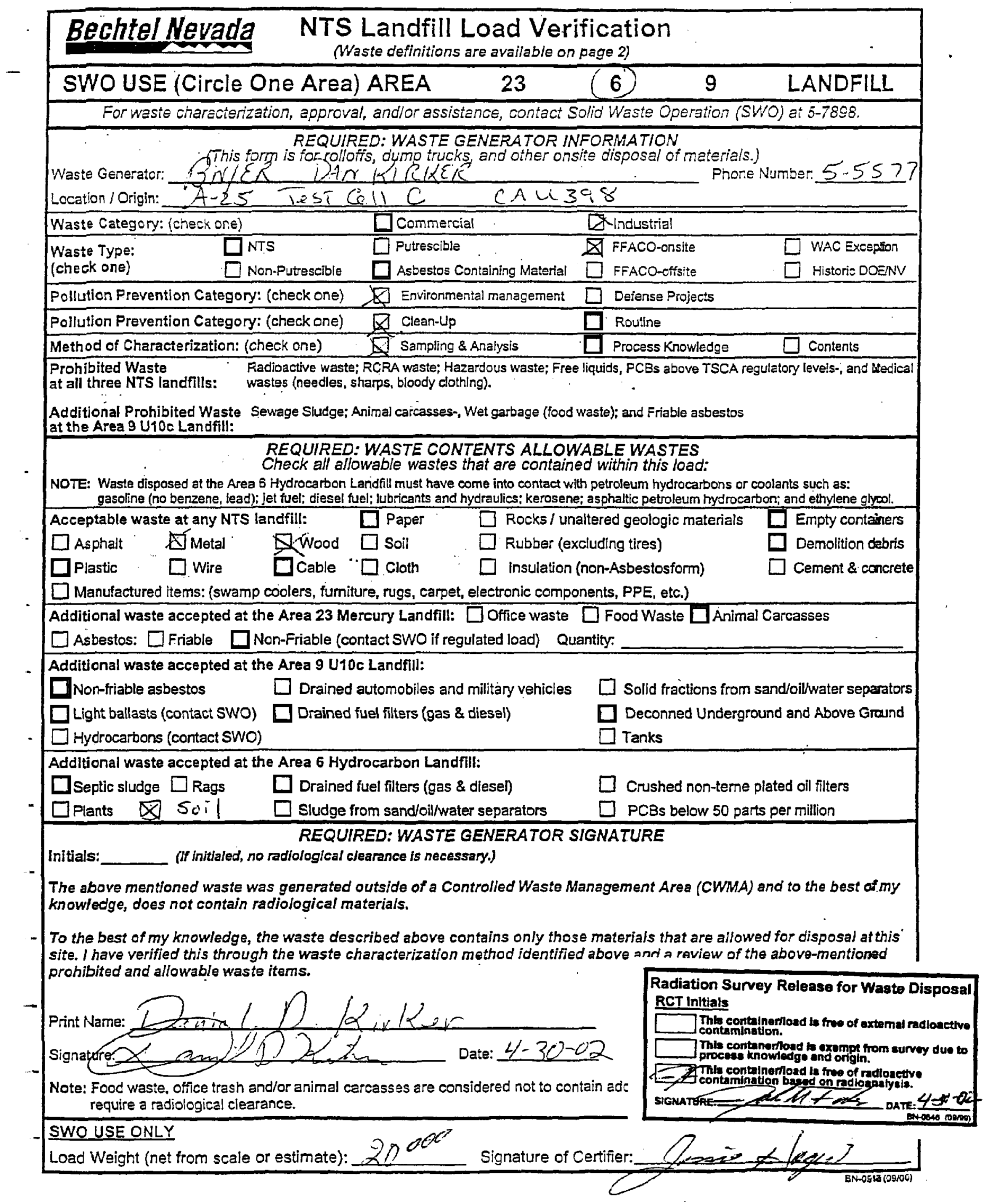




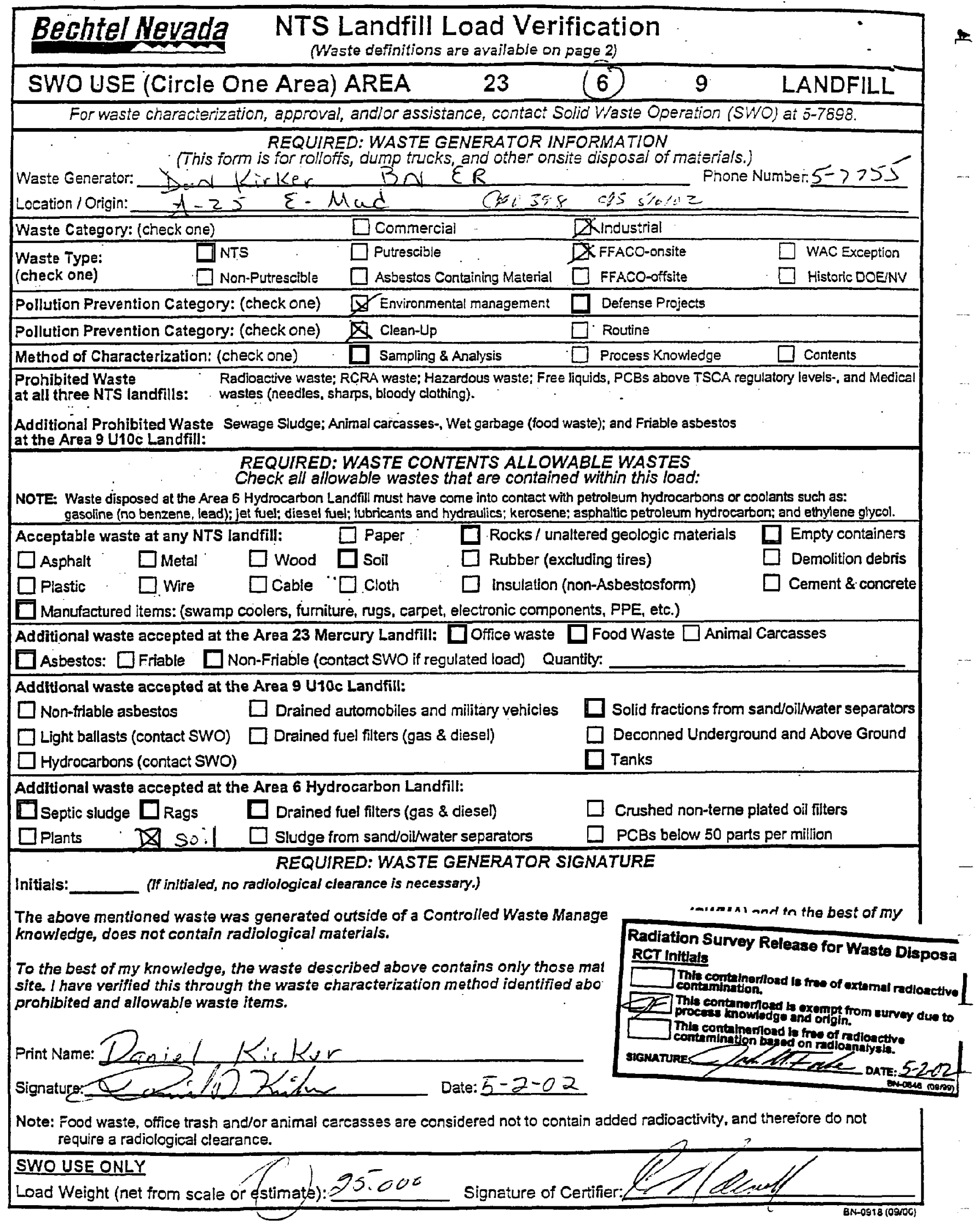




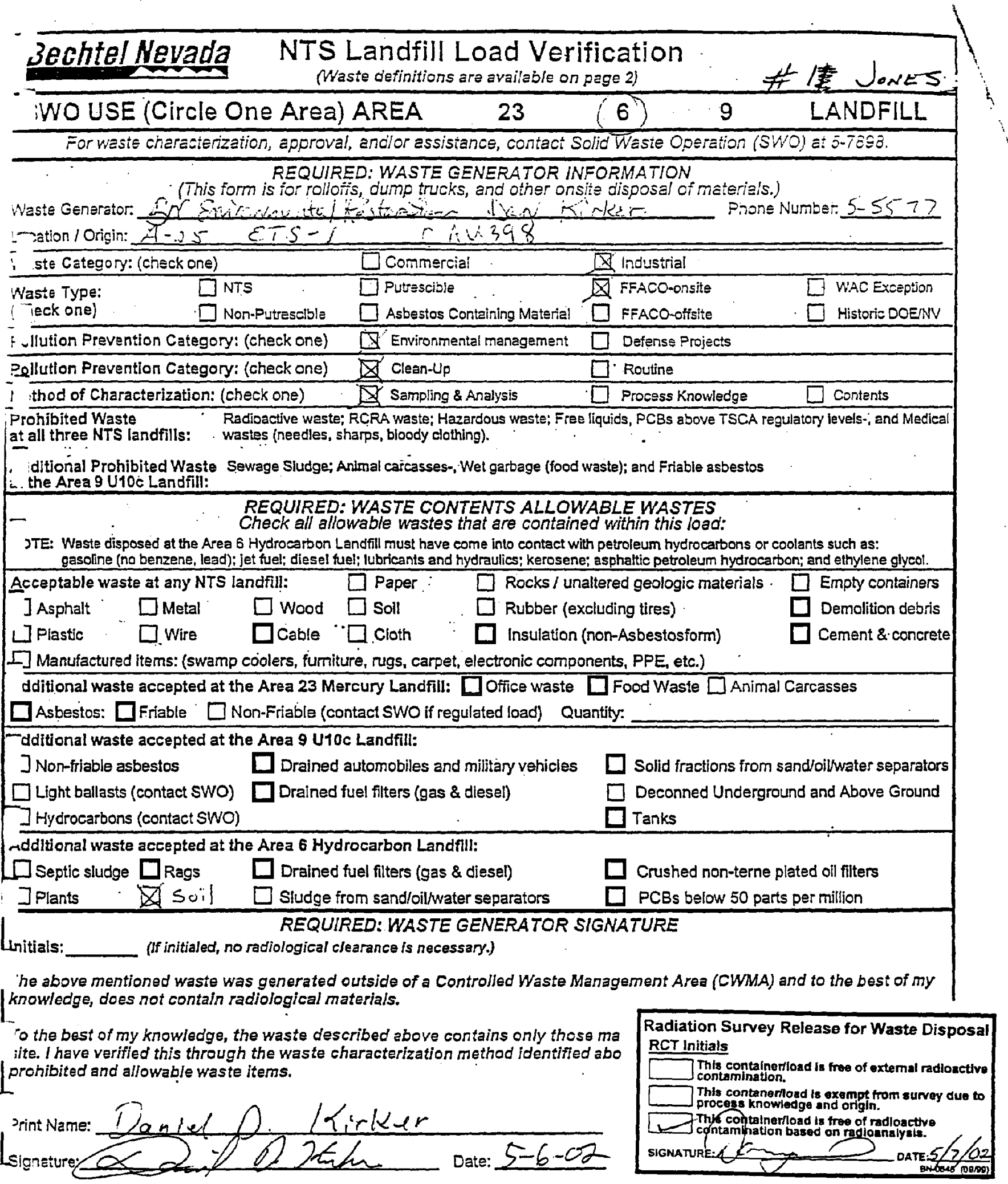

Yote: Food waste, ofijce trash and/or animal carcasses are considered not to contain added radjoactivity, and therefore do not \begin{tabular}{l} 
require a radiological slearanee. \\
\hline
\end{tabular}

SWO USE ONLY

Load Weight (net from scale or Estimate:

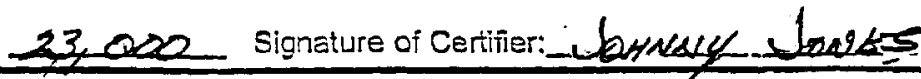




\title{
Bechtel Nevada NTS Landfill Load Verification \\ Waste definitions are available on pagez्र.
}

\begin{tabular}{|c|c|c|c|c|}
\hline SI & 23 & $6 i$ & 9 & LANDFILL \\
\hline
\end{tabular}

REQUIRED: WASTE GENERATOR INFORMATION

Waste Generator:

(This form is for rolloffs, dump trucks, and other onsite disposal of materiais.)

\begin{abstract}
Location / Origin: Are 25 CAS 25-25-02 (TCA) T-5 Ce" "P" (AV 395
Waste Category: (check one)

Pollution Prevention Category: (check one)

Pollution Prevention Category: (check one) \C Clean-Up $\square$ Routine

Method of Characterization: (Check one) at all three NTS landfills: wastes (needles, shaps, bloody clothing).

Additional Prohibited Waste Sewage Sludge; Animal carcasses-, Wet garbage (food waste); and Friable asbestos at the Area 9 U10c Landfill:

FEQUIFED: WASTE CONTENTS ALLOWABLE WASTES

Check all allowable wastes that are contained within this load:
\end{abstract}

Waste Type: $\square$ NTS

(check one) 7 ft $\square$ Non-Putrescible $\square$ Asbestos Containing Material $\square$ FFACO-offsite $\square$ Historic DOENV

Pover

Prohibited Waste

NOTE: Waste disposed at the Area 6 Hydrocarbon Landfill must have come into contact with petroleum hydrocarbons or coolants such as:

gasoline (no benzene, lead); jet fuel; diesel fuel; lubricants and hydrauljes; kerosene; asphaltic petroleum hydrocarbon: and ethylene glycol.

Acceptable waste at any NTS landfill: $\square$ Paper $\square$ Rocks / unaltered geologic materials $\square$ Empty containers

$\square$ Asphalt $\square$ Metal $\square$ Wood $\quad \square$ Soil $\quad \square$ Rubber (excluding tires) $\quad \square$ Demolition debris

$\square$ Plastic $\square$ Wire $\square$ Cable $\square$ Cloth $\quad \square$ insulation (non-Asbestosform) $\square$ Cement \& concrete

$\square$ Manufactured items: (swamp coolers, fumiture, rugs, carpet, electronic components, PPE, etc.)

Additional waste accepted at the Area 23 Mercury Landfill: $\square$ Office waste $\square$ Food Waste $\square$ Animal Carcasses

$\square$ Asbestos: $\square$ Friable $\square$ Non-Friable (contact SWO if regulated load) Quantity:

Additional waste accepted at the Area 9 U10c Landfill:
$\square$ Non-friable asbestos
Drained automobiles and military vehicles
$\square$ Light ballasts (contact SWO)
Drained fuel filters (gas \& diesel)
Deconned Underground and Above Ground
$\square$ Hydrocarbons (contact SWO)
Additional waste accepted at the Area 6 Hydrocarbon Landfill:
$\square$ Septic sludge $\square$ Rags
Plants
Drained fuel filters (gas \& diesel) Tanks
Sludge from sand/oilwwater separators
Crushed non-teme plated oil filters

Solid fractions from sand/oil/water separators

FEQUIRED: WASTE GENERATOR SIGNATURE

Initials: (If initialed, no radiological clearance is necessary.)

The above mentioned waste was generated outside of a Controlled Waste Management Area (CWMA) and to the best of my knowledge, does not contain radiological materials.

To the best of my knowledge, the waste described above contains only those materials that are allowed for disposal at this site. I have verified this through the waste characterization method identified abc prohibited and allowable waste items.

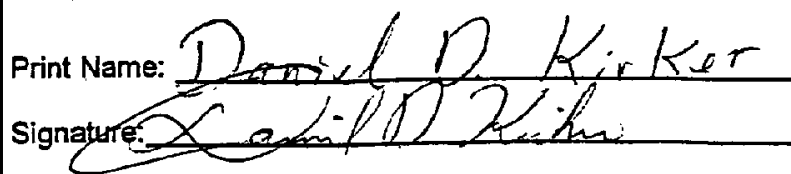

Date: $3-16-02$

Note: Food waste, office trash and/or animal carcasses are considered not to contain : require a radiological clearance.

\section{SWO USE ONLY}

Load Weight (net from scale or éstimate):
1,600

Signature of Certifier.

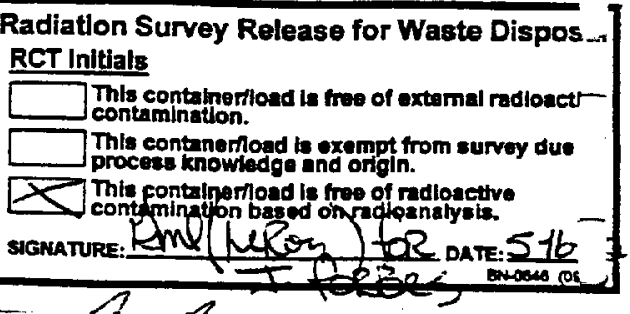

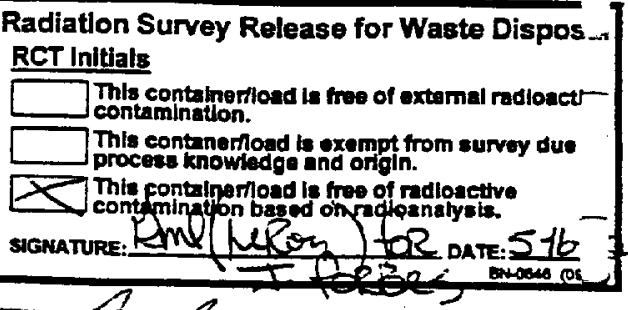

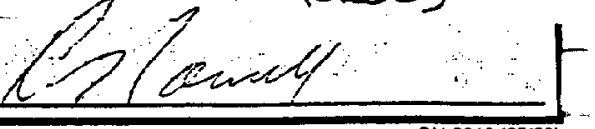




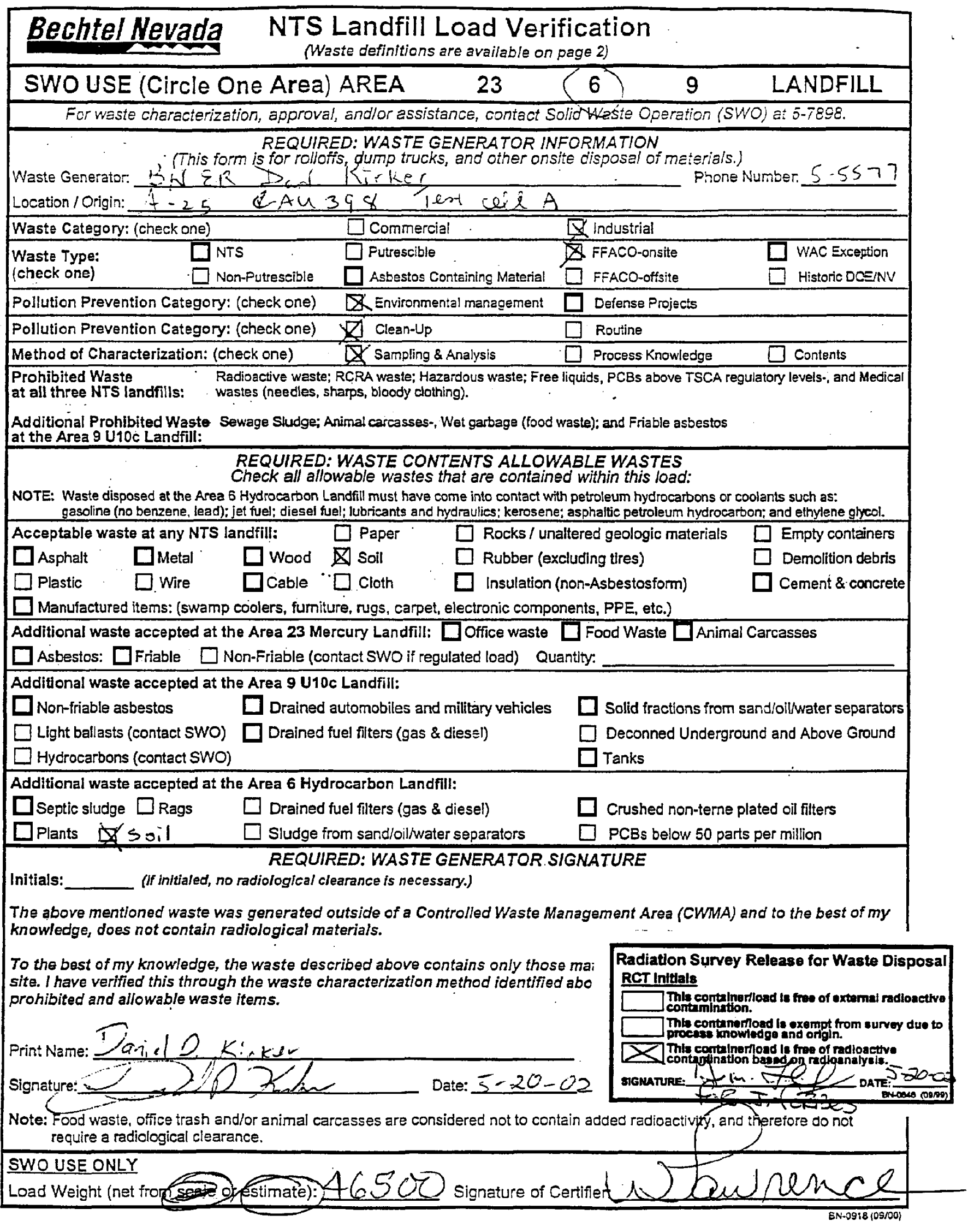




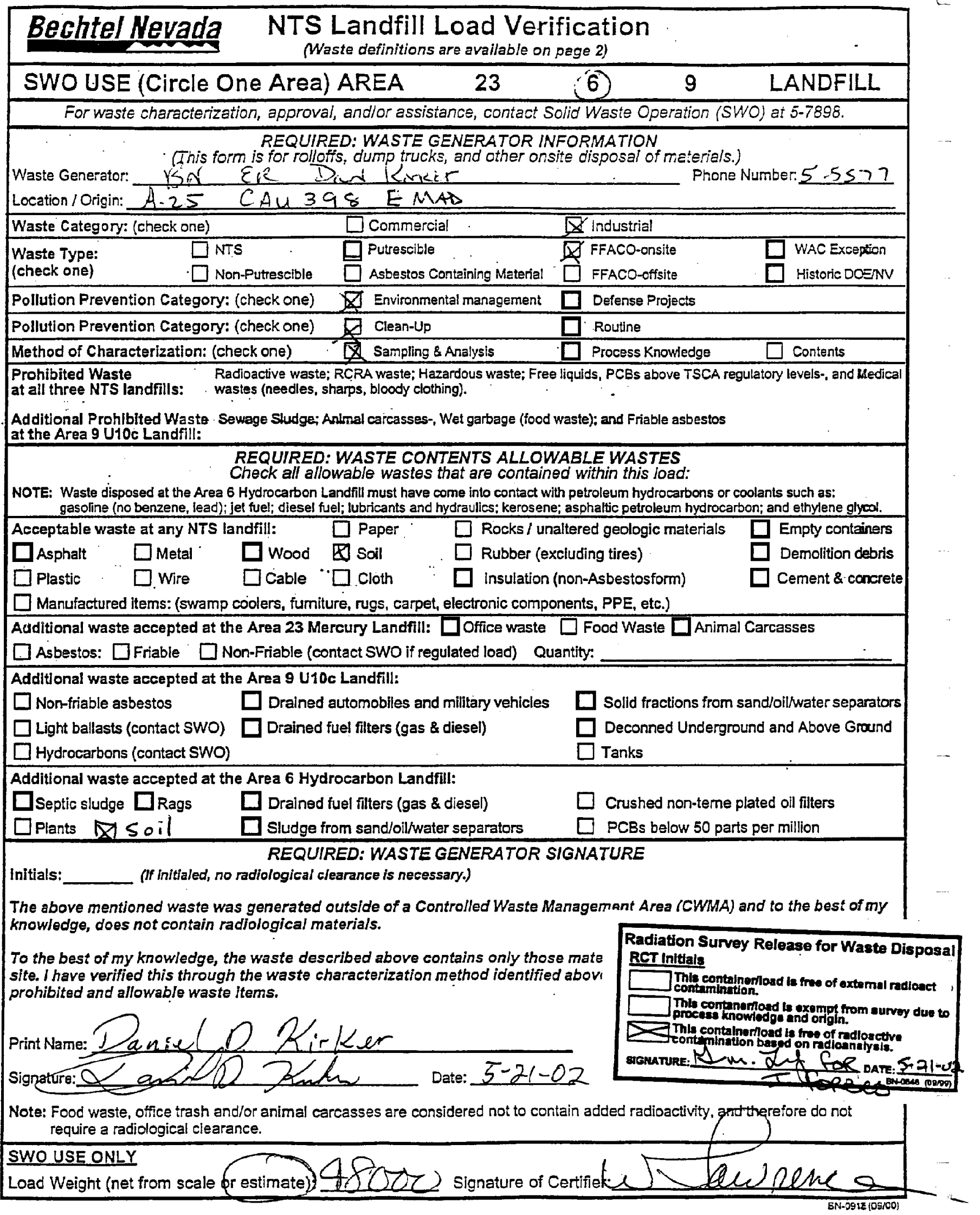




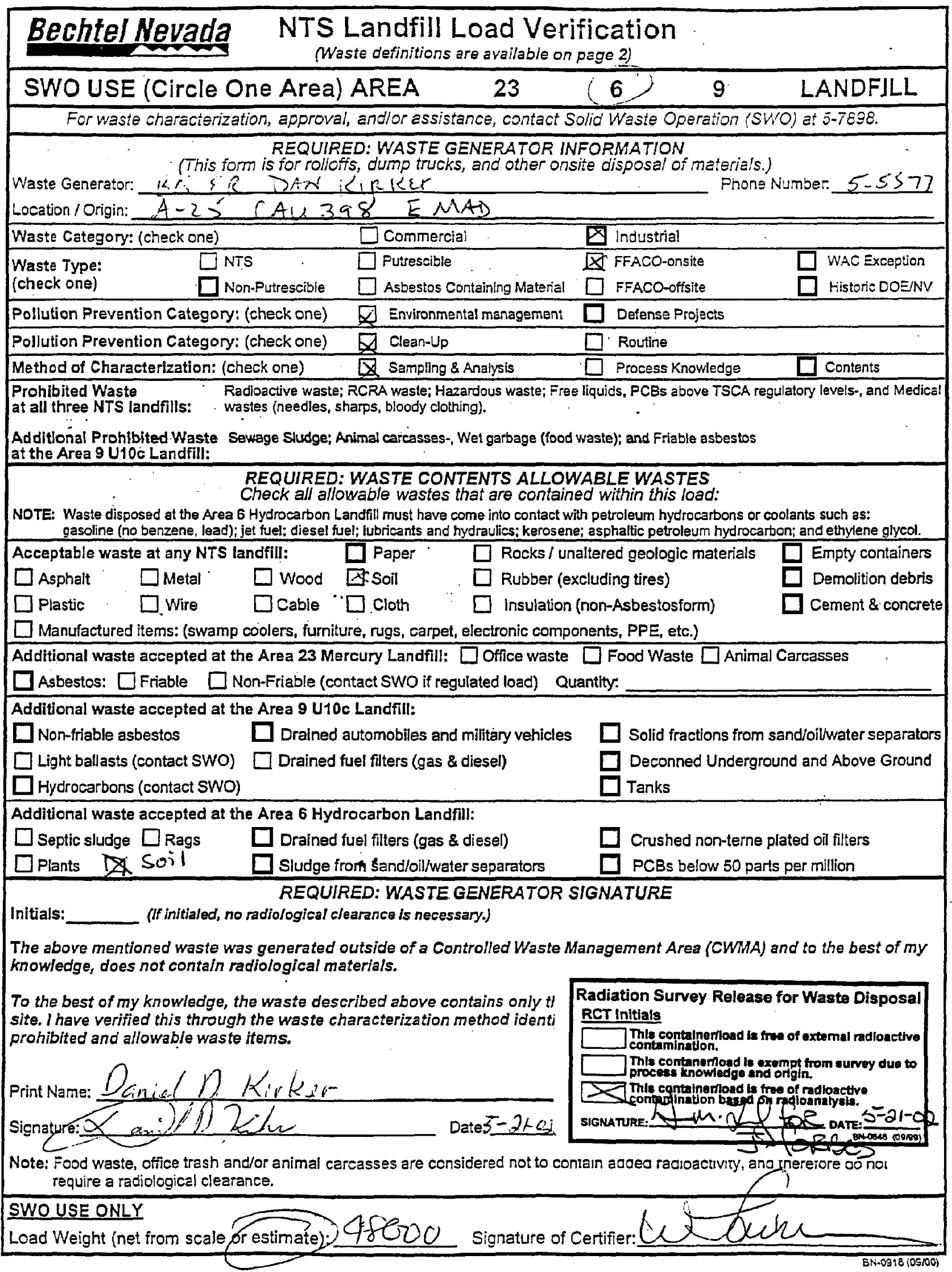




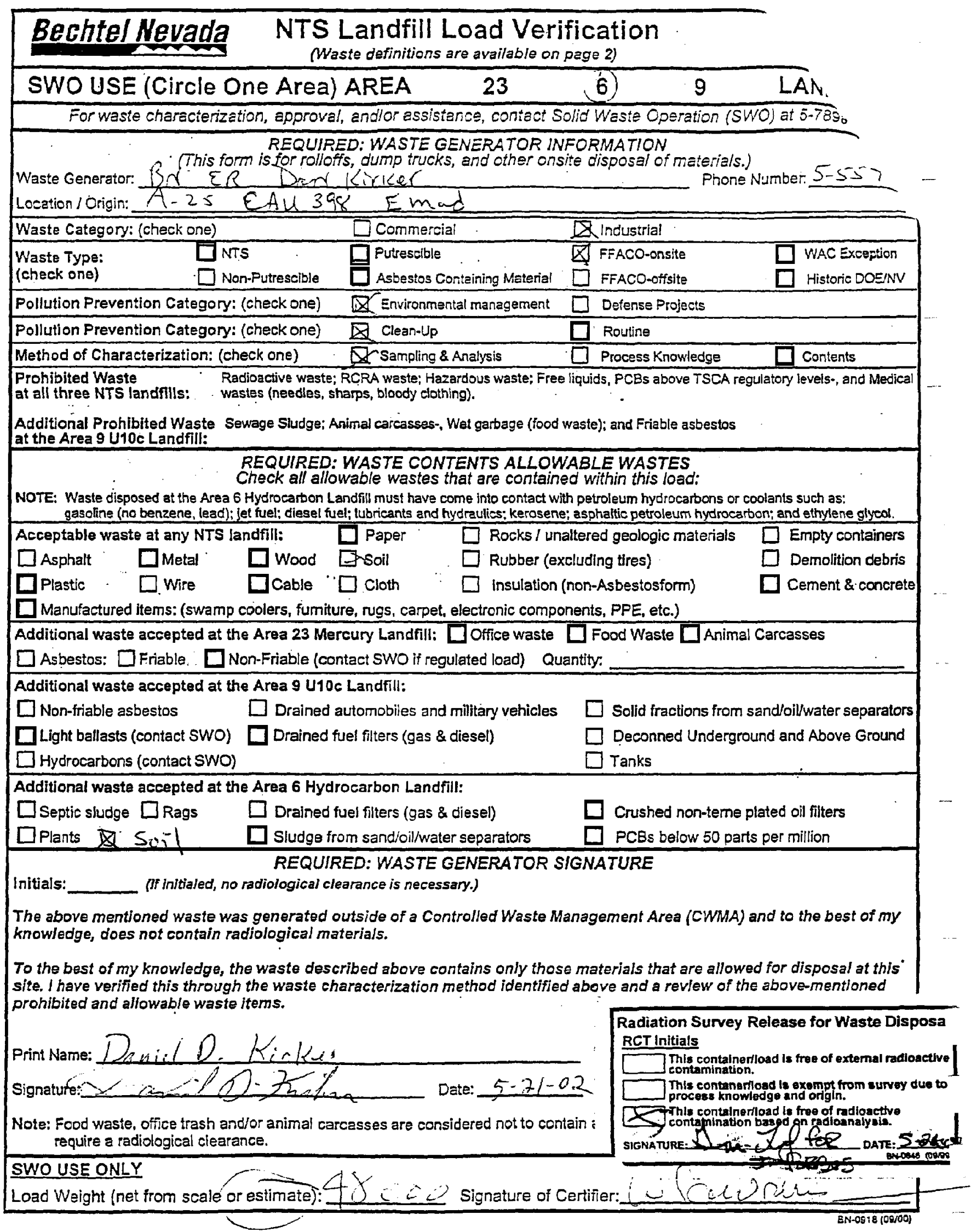




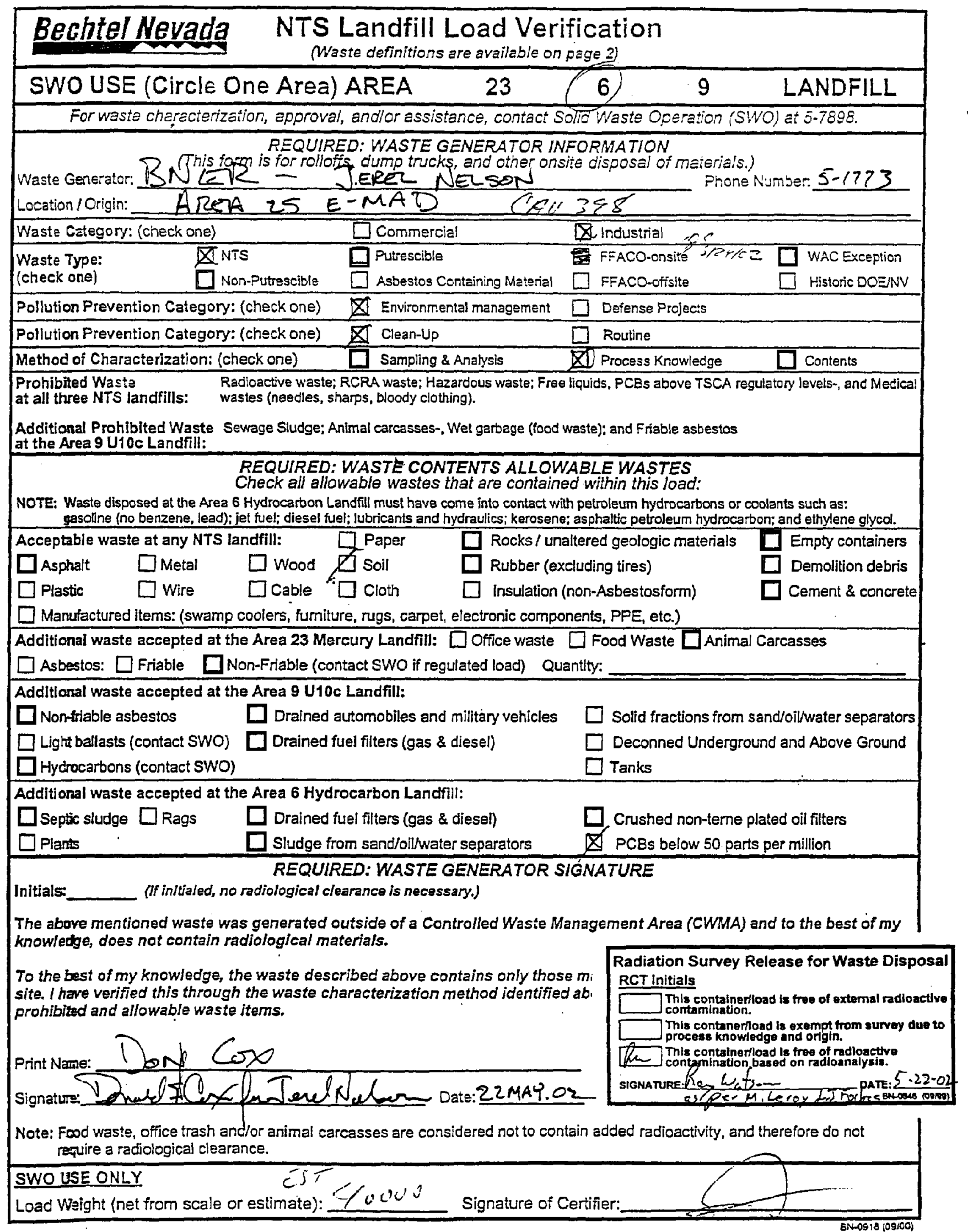




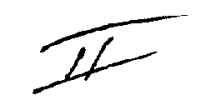

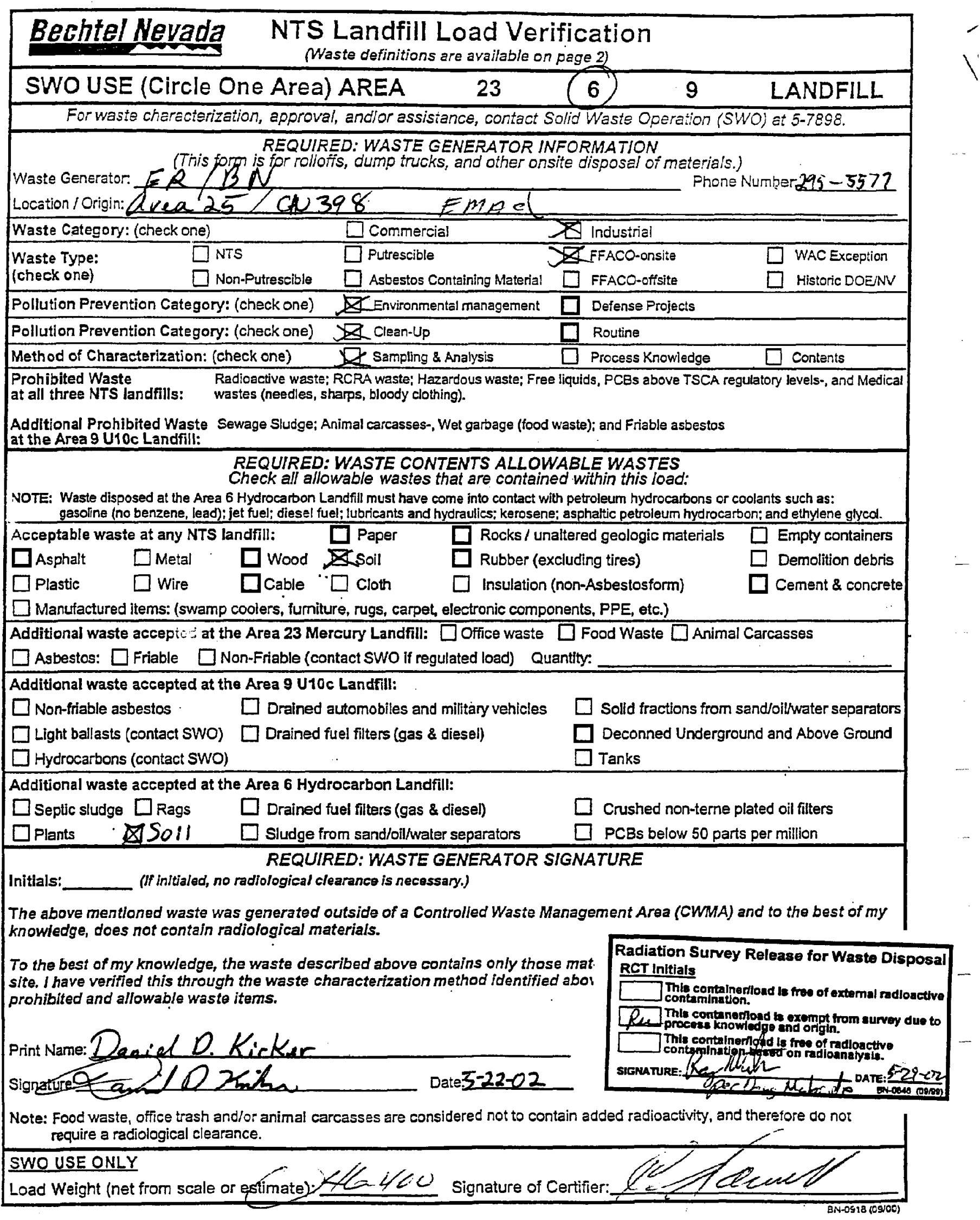




SWO USE (Circle One Area) AREA $\quad 23 \quad$ (6) 9 LANDFILL

For waste characterization, approval, and/or assistance, contact Solid Waste Operation (SWO) at 5-7898. REQUIRED: WASTE GENERATOR INFORMATION

(This form is for rolloffs, dump trucks, and other onsite disposal of materials.) Waste Generator: $B N / E R$ Phone Number: $295-5572$ Location / Origin: E-MAD $C A \cup 398$ Waste Category: (check one) Waste Type: $\square$ NTS (check one) Pollution Preventjon Category: (Check one) Environmental management $\square$ Defense Projects Pollution Preventon Categor Pollution Prevention Category: (check one) Clean-Up Method of Characterization: (check one) Prohibited Waste at all three NTS landfills: wastes (needles, sharps, bloody clothing).

Additional Prohibited Waste Sewage Sludge; Animal carcasses-, Wet garbage (food waste); and Friable asbestos at the Area 9 U10c Landfill:

REQUIRED: WASTE CONTENTS ALLOWABLE WASTES

Check all allowable wastes that are contained within this load:

NOTE: Waste disposed at the Area 6 Hydrocarbon Landfill must have come into contact with petroleum hydrocarbons or coolants sueh as:

gasoline (no benzene, lead); jet fuel; diesel fuel; lubricants and hydraulics; kerosene; asphaltic petroleum hydrocarbon; and ethylene glycol.

Acceptable waste at any NTS landfill: $\square$ Paper $\square$ Rocks / unaltered geologic materials $\square$ Empty containers

$\square$ Asphalt $\square$ Metal $\square$ wood $\quad \square$ Roil $\quad \square$ Rubber (excluding tires)

$\square$ Plastic

$\square$ Wire

$\square$ Cable $\square$ Cloth Insulation (non-Asbestosform)

$\square$ Demolition debris Manufactured items: (swamp coolers, fumiture, rugs, capet, electronic components, PPE, etc.)

Additional waste accepted at the Area 23 Mercury Landfill: $\square$ Office waste $\square$ Food Waste $\square$ Animal Carcasses $\square$ Asbestos: $\square$ Friable $\square$ Non-Friable (contact SWO if regulated load) Quantity: Additional waste accepted at the Area 9 U10c Landfill:

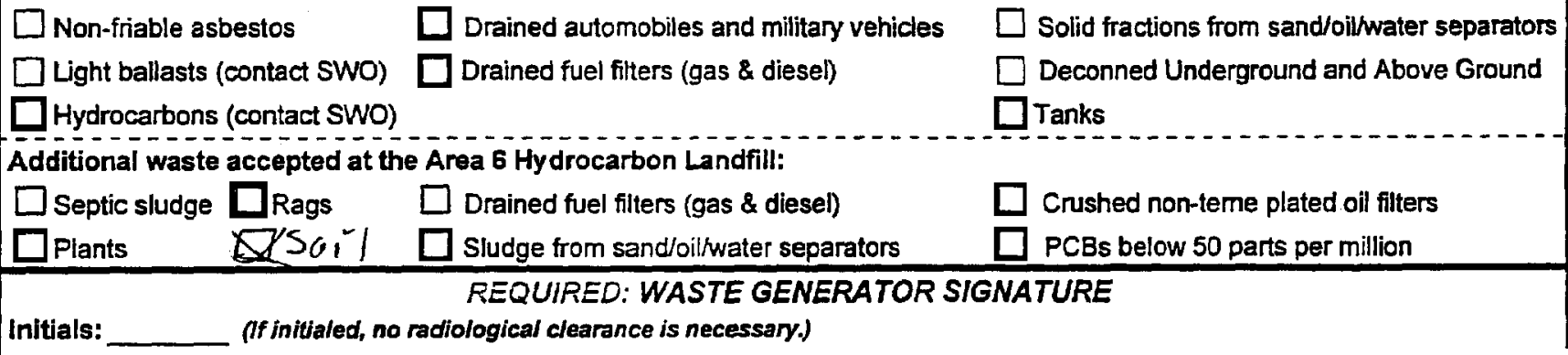

The above mentioned waste was generated outside of a Controlled Waste Mani knowfedge, does not contain radiological materials.

To the best of my knowledge, the waste described above contains only those $n$ site. I have verified this through the waste characterization method identified al prohibited and allowable waste items.

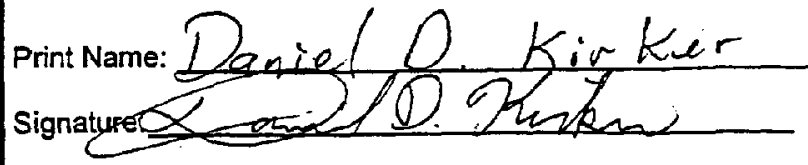
Date: $5-28-02$

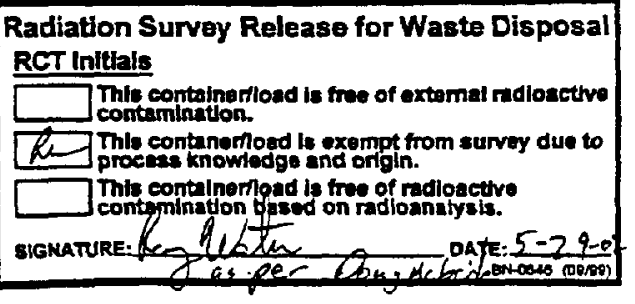

Note: Food waste, office trash and/or animal carcasses are considered not to contain added radioactivity, and therefore do not require a radiological clearance.

SWO USE ONLY
Load Weight (net form scale or éstimate): $\$ 5,0 \cup \mathrm{V}$

Signature of Certifier:

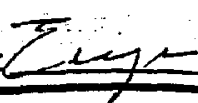

7

? 
te Category: (check one)

te Type:

NTS

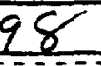

Phone Number: $5-55>2$

*k one)

Non-Putreseible

Commercial

$\square$ Pitrescible

$\square$ Asbestos Containing Material

X'́ndustrial

$\square$ FFACO-Oifite $\square$ Historic DOENV

ition Prevention Category: (check one)

Environmental management

XFACO-onsite

11882

S.

jon Prevention Category: (check one)

od of Characterization: (check one)

\& Clean-Up

$\square$ Deiense Projects

ibited Waste

three NTS landfills: $\quad$ wastes (needles, sharps, bloody dothing).

tional Prohibited Waste Sewage Sludge; Animal carcasses-, Wet garbage (food waste); and Friable asbestos

a Area 9 U10c Landrill:

FEQUIRED: WASTE CONTENTS ALLOWABLE WASTES

Check all allowable wastes that are contained within this load:

:: Waste disposed at the Area 6 Hydrocarbon Landfill must have come into contact with petroleum hydrocarbons or coolants such as:

gasoline (no benzene, lead); jet fuel; diesel fuel; lubricants and hydrautics; kerosene; asphaltic petroleum hydrocabon; and ethylene glycol.

ptable waste at any NTS landfill:

sphalt $\square$ Metal $\square$ wood $\square$ Soil $\square$ Rubber (excluding tires) $\square$ Demolition debris

lastic $\square$ Wire $\square$ Cable $\square$ Cloth $\square$ Insulation (non-Asbestostorm) $\square$ Cement \& concrete

lanufactured items: (swamp coolers, fumiture, ngs, carpet, electronic components, PPE, etc.)

tjonal waste accepted at the Area 23 Mercury Landfill: $\square$ Office waste $\square$ Food Waste $\square$ Animal Carcasses

sbestos: $\square$ Friable $\square$ Non-Friable (contact SWO if reguiated load) Quantity:

tional waste accepted at the Area 9 U10 Landfill:

lon-friable asbestos $\quad \square$ Drained automabiles and military vehicles

ight ballasts (contact SWO) $\square$ Drained fuel filters (gas \& diese)

Solid fractions from sand/oillwater separators

lydrocarbons (contact SWO)

Deconned Underground and Above Ground

tional waste accepted at th

eptic sludge $\square$ Rags $\square$ Drained fuel filters (gas \& diesel)

lants

X) So: 1

$\square$ Sludge from sand/oillwater separators Tanks

.REQUIRED: WASTE GENERATOR SIGNATURE

ls: (If initialed, no radiological clearance is necessary.)

above mentioned waste was generated outside of a Controlled Waste Management Area (CWMA) and to the best of my viedge, does not contain radiological materials.

je best of my knowledge, the waste described above contains only those matorials that are allowed for disoosal at this I have verified this through the waste characterization method identified at

ibited and allowable waste items.

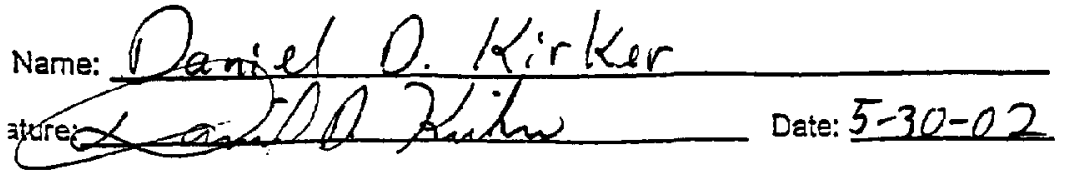

: Food waste, office trash andjor animal carcasses are considered not to contair require a radiological clearance.

Radiation Survey Release for Waste Disposal RCT Initials

$\square$ This containerfload is troe of external radloactlve contumington.

Thls contenemoad is exompt from survey due to process knowidge end origin.

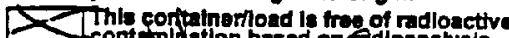

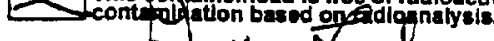
sematura:

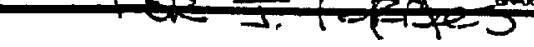

JUE ONLY

I Weicht (net from scale or estimate): $66, \infty \infty 0$ ats

Signatire of Certifier

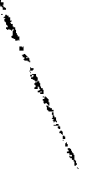

s 
Additional Prohibited Waste Sewage Sludge; Animal carcasses, Wet garbage (food waste); and Friable asbestos at the Area 9 U10c Landfill:

\section{REQUIRED: WASTE CONTENTS ALLOWABLE WASTES}

Check all allowable wastes that are contained within this load:

NOTE: Waste disposed at the Area 6 Hydrocarbon Landfill must have come into contact with petroleum hydrocarbons or coolants such as: gasoline (no benzene, lead); iet fuel; diesel fuel; lubricants and hydraulics; kerosene; asphaltic petroleum hydrocarbon; and ethylene glycol. Acceptable waste at any NTS landfill: $\square$ Paper $\square$ Rocks / unaltered geologic materials $\square$ Empty containers

$\square$ Asphalt $\quad \square$ Metal $\square$ wood $\square$ Soil $\square$ Rubber (excluding tires)

$\square$ Plastic $\square$ Wire $\quad \square$ Cable $\square$ Cloth $\square$ Insulation (non-Asbestosform)

$\square$ Demolition debris $\square$ Cement \& conicrete

$\square$ Manufactured items: (swamp coolers, fumiture, nugs, carpet, electronic components, PPE, etc.)

Additional waste accepted at the Area 23 Mercury Landfill: $\bar{D}$ Office waste $\square$ Food Waste $\square$ Animal Carcasses

$\square$ Asbestos: $\square$ Friable $\square$ Non-Friable (contact SWO if regulated load) Quantity:

Additional waste accepted at the Area 9 Uioc Landfill:

\begin{tabular}{|c|c|c|}
\hline $\begin{array}{l}\square \text { Non-friable asbestos } \\
\square \text { Light ballasts (contact SWO) } \\
\square \text { Hydrocarbons (contact SWO) }\end{array}$ & $\begin{array}{l}\square \text { Drained automobiles and military vehicles } \\
\square \text { Drained fuel filters (gas \& diesel) }\end{array}$ & $\begin{array}{l}\square \text { Solid fractions from sand/oilwater separators } \\
\square \text { Deconned Underground and Above Ground } \\
\square \text { Tanks }\end{array}$ \\
\hline $\begin{array}{l}\text { Additional waste accepted at th } \\
\square \text { Septic sludige } \square \text { Rags } \\
\square \text { Plants }\end{array}$ & $\begin{array}{l}\square \text { Drained fuel filters (gas \& diesel) } \\
\square \text { Sludge from send/oilwwater separators }\end{array}$ & $\begin{array}{l}\square \text { Crushed non-teme plated oil filters } \\
\square \text { PCBs below } 50 \text { parts per million }\end{array}$ \\
\hline
\end{tabular}

The above mentioned waste was generated outside of a Controlled Waste Management Area (CWMA) and to the best of my knowledge, does not contain radiological materials.

To the best of my knowledge, the waste described above contains only those mat site. I have verified this through the waste characterization method identified abor prohibited and allowable waste items.

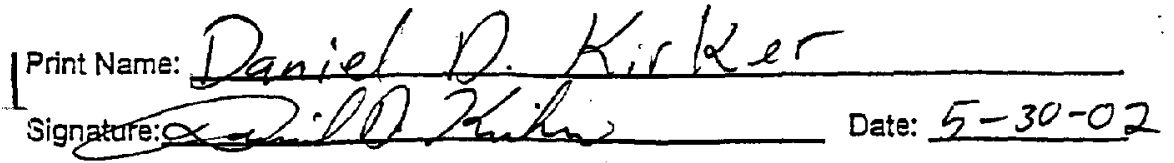

Note: Food waste, ofice trash and/or animal carcasses are considered not to contain a 1 require a radiological clearance.

SWO USE ONLY
Radiation Survey Release for Waste Disposal RCT Initials

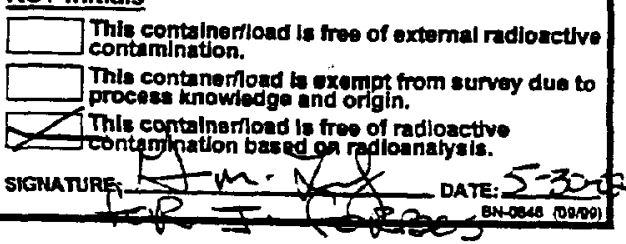

Thls contanerfload bexomp from survey dus to process knowledge and origin.

2 This contalneriond is free of radloact

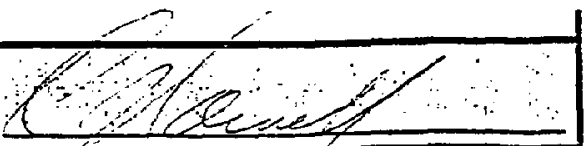




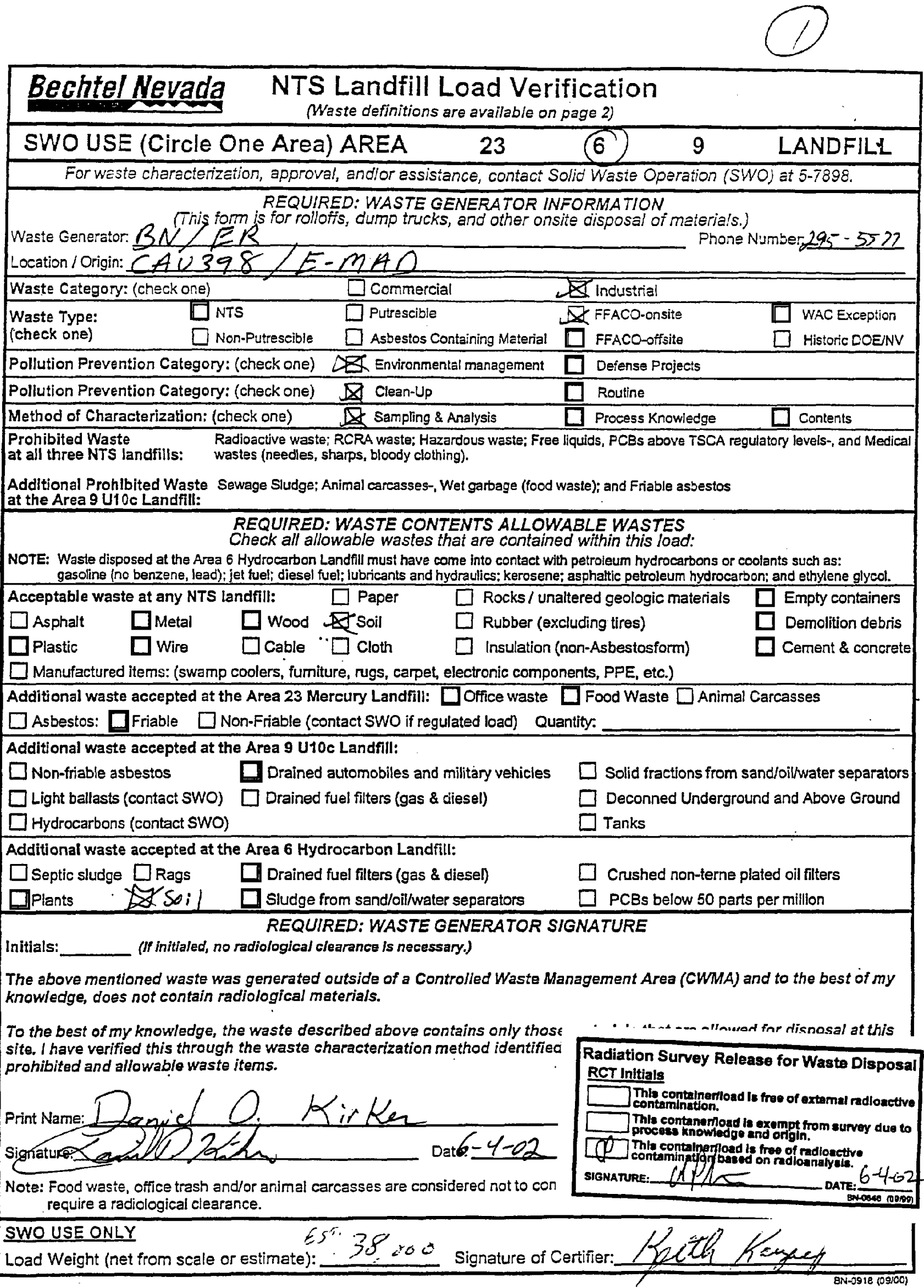




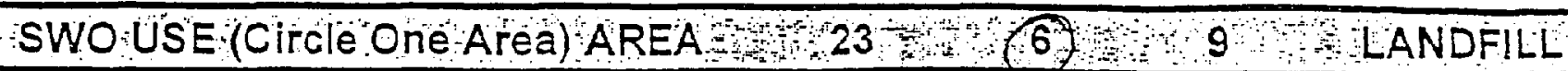
Forwaste characterization, approval, and/or assistance, contact Solid Waste Operation (SWO) at 5-7898.

1 REQUIPED: WASTE GENERATOR INFORMATION

(This iorm is for rollofits, dump trucks, and other onsite disposal of meterials.

Naste Generator: BN/ER

Location / Origin: $C 4 V 398 / E-M A D$ Phone Number: $295-557$ ?

Naste Category: (check one)

Waste Type:

(check one) Commercial

$\square$ Putrescibla

$\square$ Non-Putrescible $\square$ Asbestos Containing Material

'ollution Prevention Category: (check one) Q Environmental management

Pollution Prevention Category: (check one) Clean-Up $\square$ Routine

Let

lethod of Characterization: (check one)

De Sampling \& Analysis

Process Krowlodge

rohibited

lat all three NTS landfills: $\quad$ wastes (needles, sharps, bloody dothing)

dditional Prohibited Waste Sewage Sludge; Animal carcasses-, Wet garbage (food waste); and Friabie asbestos

the Area 9 U10c Landfill:

FEQUIRED: WASTE CONTENTS ALLOWABLE WASTES

OTE: Waste disposed at the Area 6 Hydrocarbon Landfill must have come into contact with petroleum hydrocarbons or coolants such as:

. . . gasoline (no benzene, lead); jet fuel; diesel fuel; lubricants and hydraulics; kerosene; asphaltic petroleum hydrocarbon; and ethylene ghycol.

Acceptable waste at any NTS landfill

$\begin{array}{llllll}i .] \text { Asphalt } & \square \text { Metal } & \square \text { Wood } & \square \text { Soil } & \square \text { Rubber (excluding tires) } & \square \text { Demolition debris } \\ \square \text { Plastic } & \square \text { Wire } & \square \text { Cable } & \square \text { Cloth } & \square \text { Insulation (non-Asbestosform) } & \square \text { Cement \& concrete }\end{array}$

dditional waste accepted at the Area 23 Mercury Landfill: $\square$ Otice waste $\square$ Food Wasie $\square$ Animal Carcasses

$\square$ Asbestos: $\square$ Friable $\square$ Non-Friable (contact SWO if regulated load) Quantity:

dditional waste accepted at the Area 9 U10 Landfill:
$\square$ Non-friable asbestos
$\square$ Drained automobiles and military vehicles
Solid fractions from sand/oilfwater separators
- Light ballasts (contact SWO)
Drained fuel filters (gas \& diesel)
Deconned Underground and Above Ground
J Hydrocarbons (contact SWO)
Tanks
Additional waste accepted at the Area 6 Hydrocarbon Landfill:

$\begin{array}{llll}\begin{array}{l}\text { J septic sludge } \\ \text { J Rags }\end{array} \text { Plants } & \square \text { Drained fuel filters (gas \& diesel) } & \square \text { Crushed non-terne plated.oil nilters } \\ \text { L Soil } & \square \text { sludge from sand/oilwater separators } & \square \text { PCBs below } 50 \text { parts per million }\end{array}$
itials:

FEQUIRED: WASTE GENERATOR SIGNATURE

The above mentioned waste was generated outside of a Controlled Waste Management Area (CWMA) and to the best of my towledge, does not contain radiological materials.

To the best of my knowledge, the waste described above contains only those ma site. I have verified this through the waste characterization method identified abi ohibited and allowable waste items.

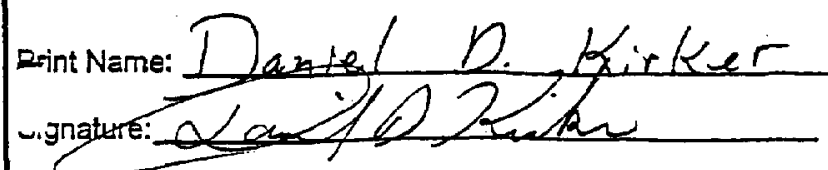

Date: $6-4-02$

Ste: Food waste, office trash and/or animal carcasses are considered not to contain require a radiological clearance.

SWO USE ONLY

jad Weight (net from scale or estimate):

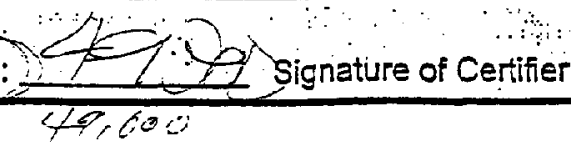

Radiation Survey Release for Waste Disposal RCT Initials

\begin{tabular}{|c|c|}
\hline & fiload la froe of axtemal rat \\
\hline & $\begin{array}{l}\text { Thla contenorloud ls exompt from survoy duo to } \\
\text { process knowiodge end ongin. }\end{array}$ \\
\hline (1) & 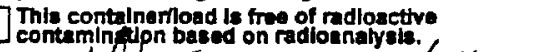 \\
\hline
\end{tabular}

110,600

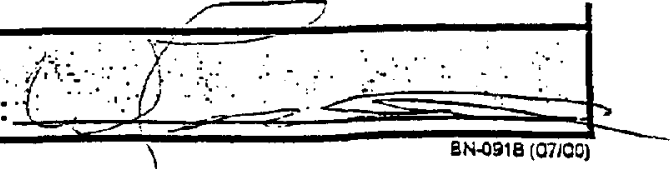




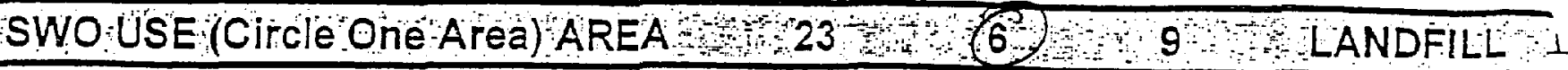

For waste characterization, approval, and/or assistance, contact Solid Waste Operation (SWO) at 5-7898.

\section{REQUIFED: WASTE GENERATOR INFORMATION}

Wastis iorm is for rollotis, dump trucks, and other onsite disposal of materials.)

Location / Origin: E-MAU/CAU398

Waste Category: (check one)

(chechor

XFFACO-Onsile

(check one)

Pollution Prevention Category: (Check one) E Environmental management $\square$ Deiense Projects

Pollution Prevention Category: (check one) $\mathbb{X}$ Clean-Up

Method of Characterization: (check one)

Prohibited Waste

at all three NTS landfills: wastes (needles, sharps, bloody clothing).

Additional Prohibited Waste Sewage Sludge; Animal careasses-, Wet garbage (food waste); and Friable asbestos

at the Area 9 U10c Landfill:

FEQUIRED: WASTE CONTENTS ALLOWABLE WASTES

Check all allowable wastes that are contained within this load:

NOTE: Waste disposed at the Area 6 Hydrocarbon Landill must have come into contad with petroleum hydrocarbons or coolants such as:

NOTE: Waste disposed at the Area 8 Hydrocaroon Landfill must have come into contad with petroleum hydrocarbons or coolants such as: Acceptable waste at any NTS landfill: $\square$ Paper $\square$ Rocks / unaltered geologic materials $\square$ Empty containers
$\square$ Asphalt
$\square$ Metal
$\square$ Wood
Esoil
$\square$ Rubber (excluding tires)
Plastic
Wire
$\square$ Cable $\square$ Cloth
insulation (non-Asbestosform)
$\square$ Demolition debris
$\square$ Cement \& concrete

$\square$ Manufactured items: (swamp coolers, fumiture, nugs, carpet, electronic components, PPE, etc.)

Additional waste accepted at the Area 23 Mercury Landfill: $\square$ Ofice waste $\square$ Food Waste $\square$ Animal Carcasses

Asbestos: $\square$ Friable $\square$ Non-Friable (contact SWO if regulated load) Quantity:

Additional waste accepted at the Area 9 U10c Landfill:
$\square$ Non-friable asbestos
$\square$ Drained automobiles and military vehicles
$\square$ Solid fractions from sand/oilhwater separators
Light ballasts (contact SWO)
Drained fuel filters (gas \& diesel)
Deconned Underground and Above Ground
Hydrocarbons (contact SWO)
Additional waste accepted at the Area 6 Hydrocarbon Landfill:
$\square$ Septic sludge $\square$ Rags $\$ 4$ soil
$\square$ Drained fuel filters (gas \& diesel)
Crushed non-teme plated.oil filters
Dlants
Sludge from sand/oil/water separators
PCBs below 50 parts per million
Initials: REQUIRED: WASTE GENERATOR SIGNATURE

The above mentioned waste was generated outside of a Controlled Waste Management Area (CWMA) and to the best of my knowledge, does not contain radiological materials.

To the best of my knowledge, the waste described above contains only those materials that are allowed for disposal at this site. I have verified this through the waste characterization method identified above and a review of the above-mentioned prohibited and allowable waste items.

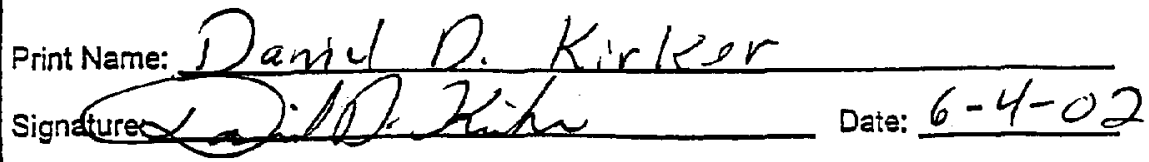

Note: Food waste, office trash andior animal carcasses are considered not to contain ac quire a radiological clearance. 
REQUIFED: WASTE GENERATOR INFORMATION
This iom is for rollo its, dump trucks, and other onsite disposal of materials,

Waste Generator: $B N / E R$

Locstion Origin: $C A U 398 / E-M A D$

Phone Number: $295-55>2$

Waste Category: (check one)

(c)

[ Commercia

Waste Type: $\square$ NTS Industrial

(check one)

Non-Putressible

$\square$ Asbestos Containing Material

Q FFACO-Onsite

WAC Excepticn

Pollution Prevention Category: (check one)

Pollution Prevention Category: (check one)

Method of Characterization: (check one)

Environmental management

$\square$ FFACO-oñite Historie DOENN

lat all three NTS landfills: wastes (needles, sharps, bloody dothing).

Ydditional Prohibited Waste Sewage Sludge; Animai carcasses-, Wet garbage (food waste); and Friable asbestos it the Area 9 U10c Landfill:

FEQUIRED: WASTE CONTENTS ALLOWABLE WASTES
Check all allowable wastes that are contained within this load:

VOTE: Waste disposed at the Area 6 Hydrocarbon Landfill must have come into contact with petroleum hydrocarbons or coolants such as: . - - - gasoline (no benzene, lead); jet fuel; diesel fuel; lubricants and hydrauljes; kerosene; asphaltic petroleum hydrocarbon; and ethylene glycol. Acceptable waste at any NTS landfill:

$\square$ Paper $\square$ Rocks / unaltered geologic materials $\square$ Empty containers

$\square$ Asphalt $\square$ Metal $\square$ wood $\triangle$ soil $\square$ Rubber (excluding tires)

UPlastic $\square$ Wire $\square$ Cable $\square$ Cloth $\square$ insulation (non-Asbestosform)

$\square$ Demolition debris

$\square$ Manufactured items: (swamp coolers, fumiture, ngs, carpet, electronic components, PPE, etc.)

Idditional waste accepted at the Area 23 Mercury Landfill: $\square$ Ofñce waste $\square$ Food Waste $\square$ Animal Carcasses

$\square$ Asbestos: $\square$ Friable $\square$ Non-Friable (contact SwO if regulated load) Quantity:

Idditional waste accepted at the Area 9 U10 Landfill:

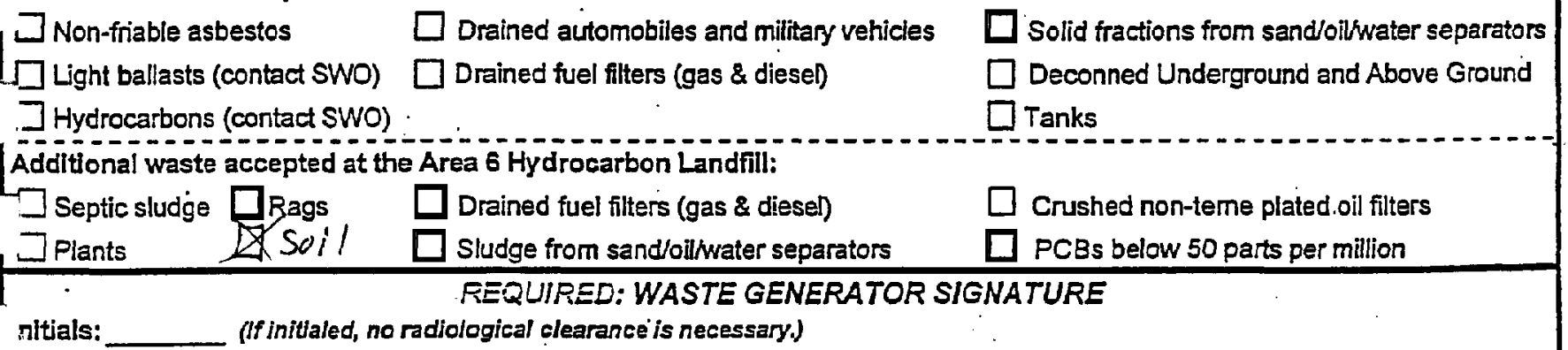

The above mentioned waste was generated outside of a Controlled Waste Management Area (CWMA) and to the best of my

Lnowledge, does not contain radiological materials.

ro the best of $m y$ knowledge, the waste described above contains only those materials that are allowed for disposal at this site. I have verified this through the waste characterization method identified above and a review of the ahnuamentinnar urohibited and allowable waste items.

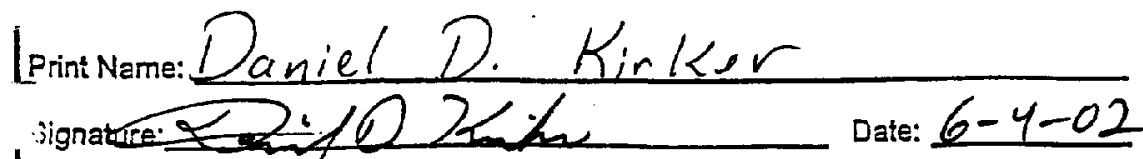

Wote: Food waste, office trash and/or animal carcasses are considered not to contain a require a radiological clearance.

Radiation Survey Release for Waste Disposal RCT Inittals

\begin{tabular}{|c|c|}
\hline & 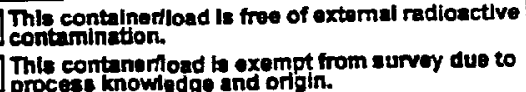 \\
\hline$e^{2}$ & $\begin{array}{l}\text { tainerfload is reo of radioactive } \\
\text { nation based on radioanatyols. }\end{array}$ \\
\hline
\end{tabular}

SWO USE ONLY _oad Weight (net fom scale or estimate) 45 Signature of Cerifier: 
CLOSURE REPORT - CAU 398

Section: Appendix E

Revision: 1

Date: April 2003

\section{APPENDIX E}

\section{FIELD PHOTOGRAPHS}


CLOSURE REPORT - CAU 398 Section: Appendix E

Revision:

Date: April 2003

THIS PAGE INTENTIONALLY LEFT BLANK 


\section{PHOTOGRAPH LOG}

\begin{tabular}{|c|c|c|}
\hline $\begin{array}{c}\text { PHOTO } \\
\text { NUMBER }\end{array}$ & DATE & DESCRIPTION \\
\hline 1 & $05 / 2001$ & CAS 25-44-01 before remediation \\
\hline 2 & $04 / 04 / 2002$ & CAS 25-44-01 after remediation \\
\hline 3 & $05 / 16 / 2002$ & CAS 25-44-02 during remediation \\
\hline 4 & $08 / 21 / 2002$ & CAS 25-44-02 after remediation \\
\hline 5 & $05 / 2001$ & CAS $25-44-03$ before remediation \\
\hline 6 & $08 / 21 / 2002$ & CAS 25-44-03 after remediation \\
\hline 7 & $04 / 29 / 2002$ & CAS 25-25-02 during remediation \\
\hline 8 & $08 / 21 / 2002$ & CAS 25-25-02 after remediation \\
\hline 9 & $05 / 2001$ & CAS $25-25-03$ before remediation \\
\hline 10 & $08 / 21 / 2002$ & CAS 25-25-03 after remediation \\
\hline 11 & $05 / 30 / 2002$ & CAS 25-25-04 during remediation \\
\hline 12 & $08 / 21 / 2002$ & CAS 25-25-04 after remediation \\
\hline 13 & $05 / 2001$ & CAS 25-25-05 before remediation \\
\hline 14 & $04 / 29 / 2002$ & CAS 25-25-05 during remediation \\
\hline 15 & $08 / 21 / 2002$ & CAS 25-25-05 after remediation \\
\hline 16 & $05 / 2001$ & CAS 25-25-16 (from CAS 25-01-02) before remediation \\
\hline 17 & $08 / 21 / 2002$ & CAS 25-25-16 (from CAS 25-01-02) after remediation \\
\hline
\end{tabular}


CLOSURE REPORT - CAU 398

Section: Appendix E

Revision: 1

Date: April 2003

THIS PAGE INTENTIONALLY LEFT BLANK

E-2 


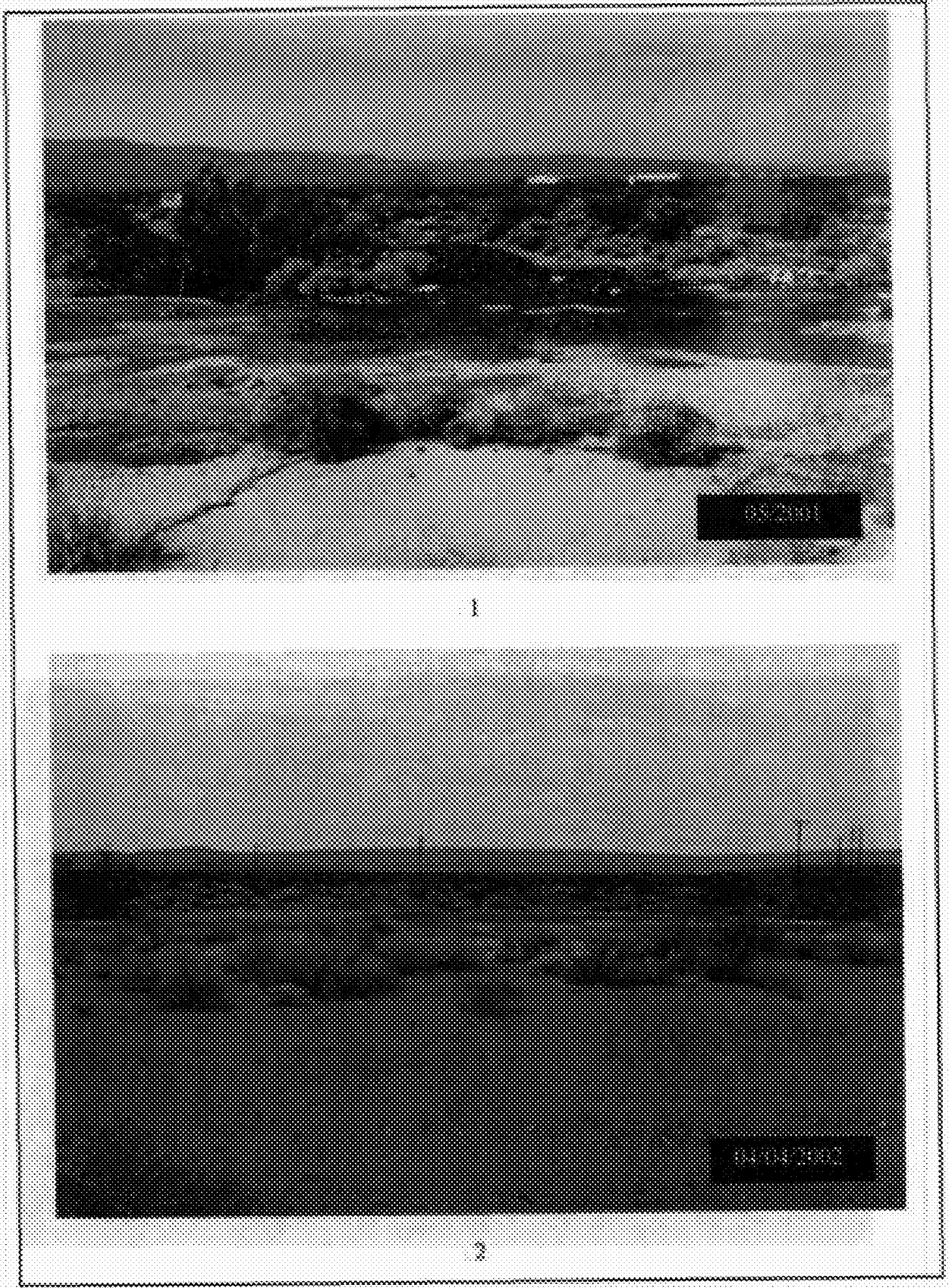

8 


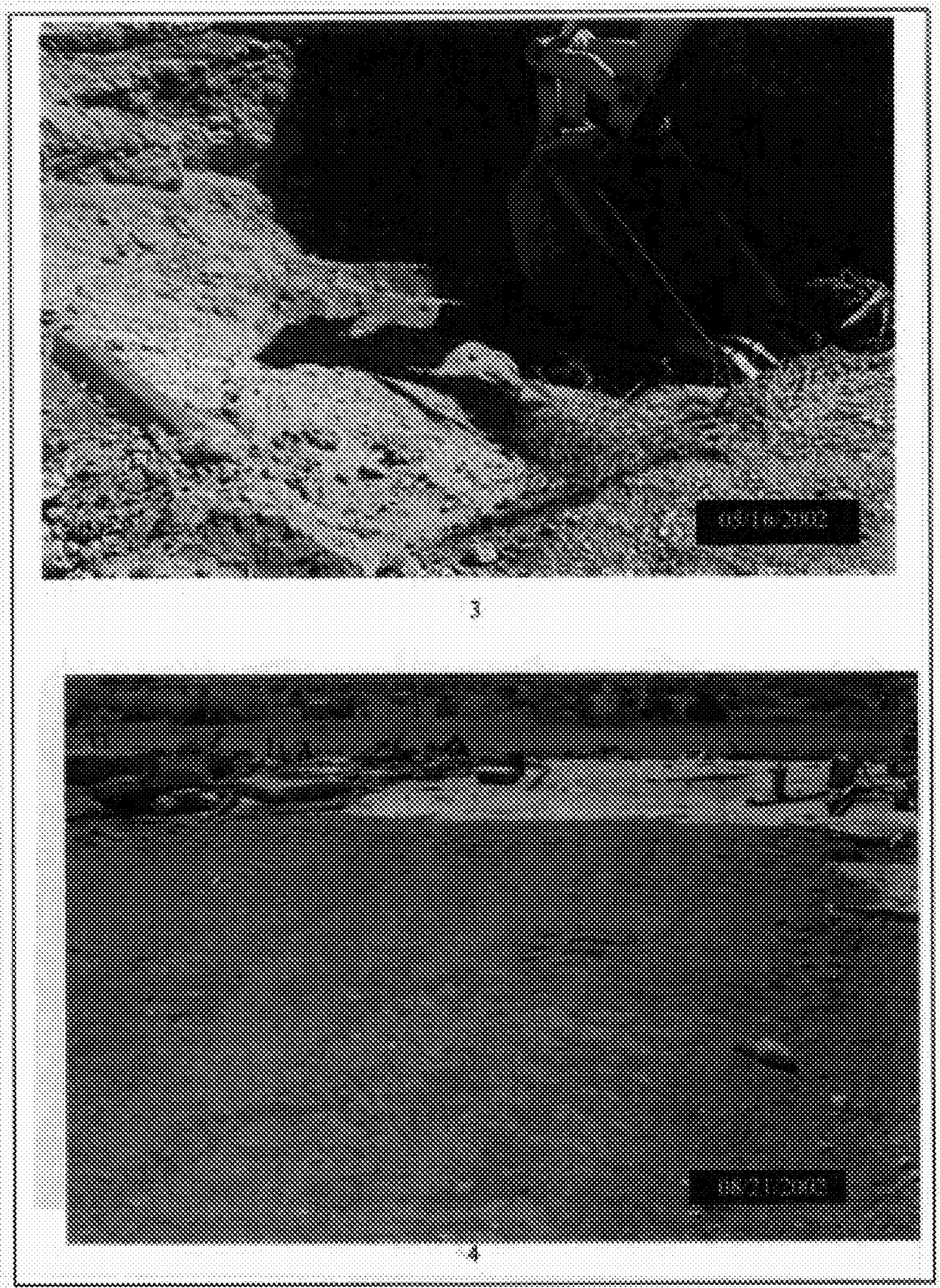

(3) 웅 


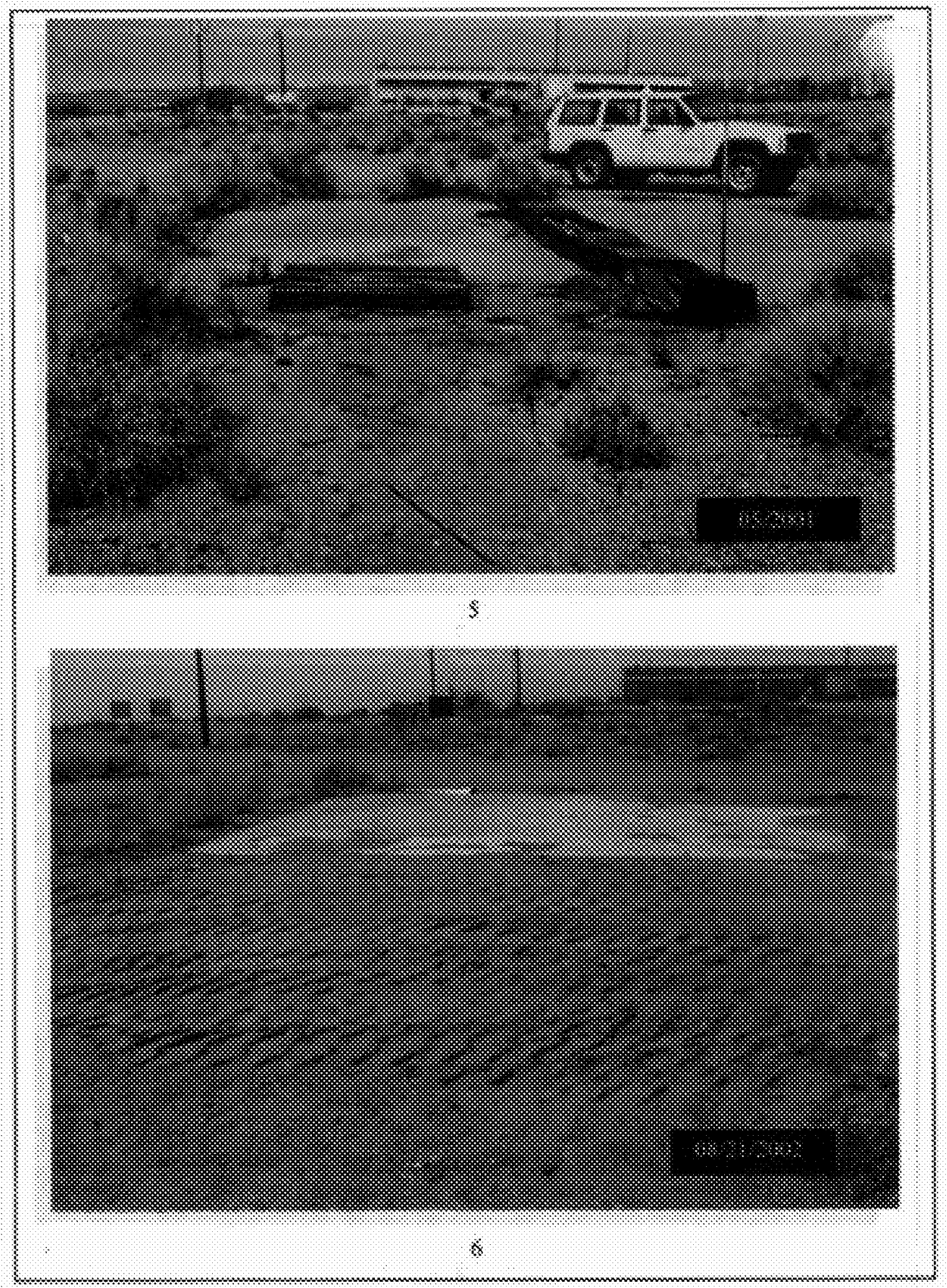




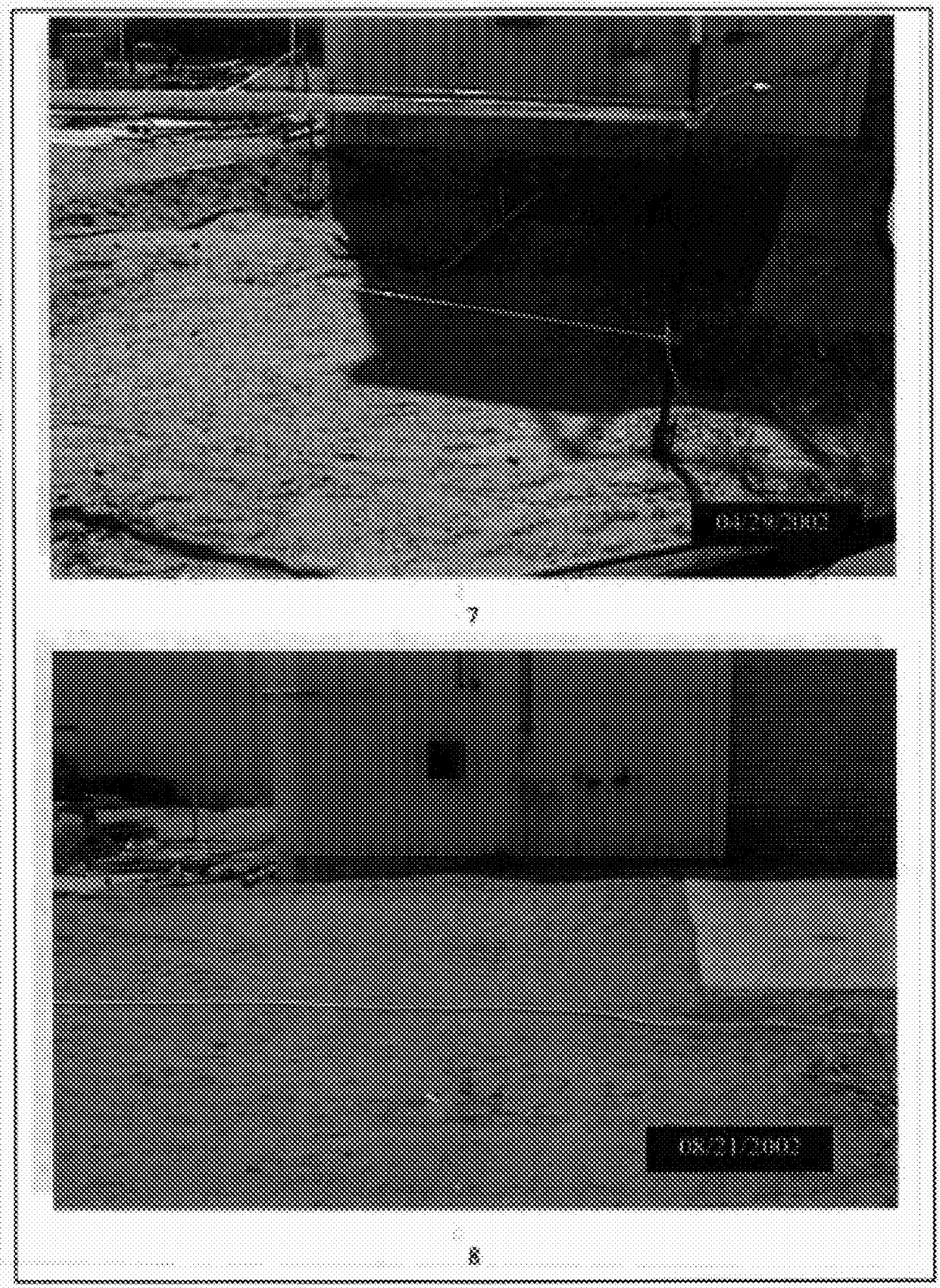

\% 8 


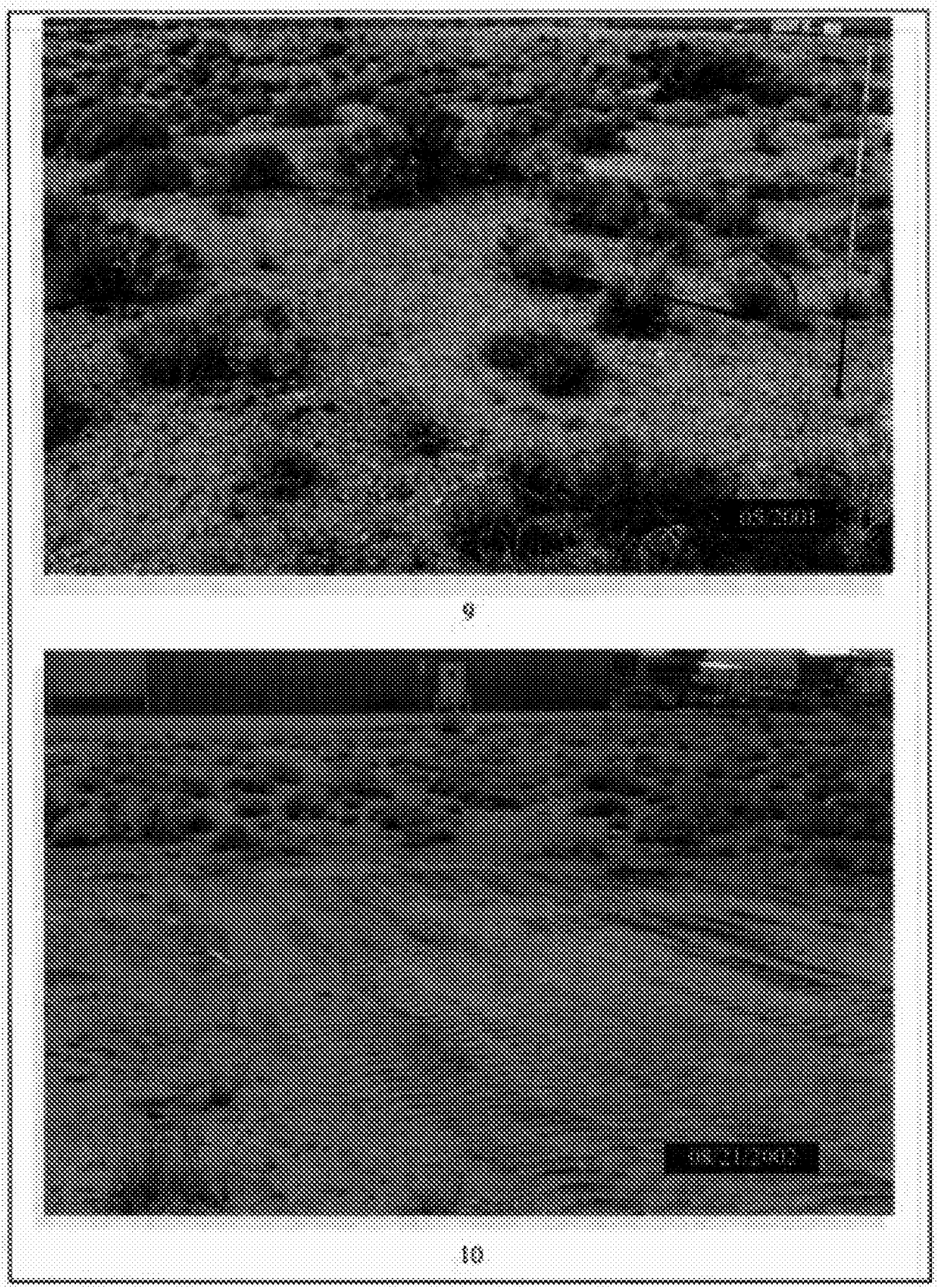

เ 
$3 \%$

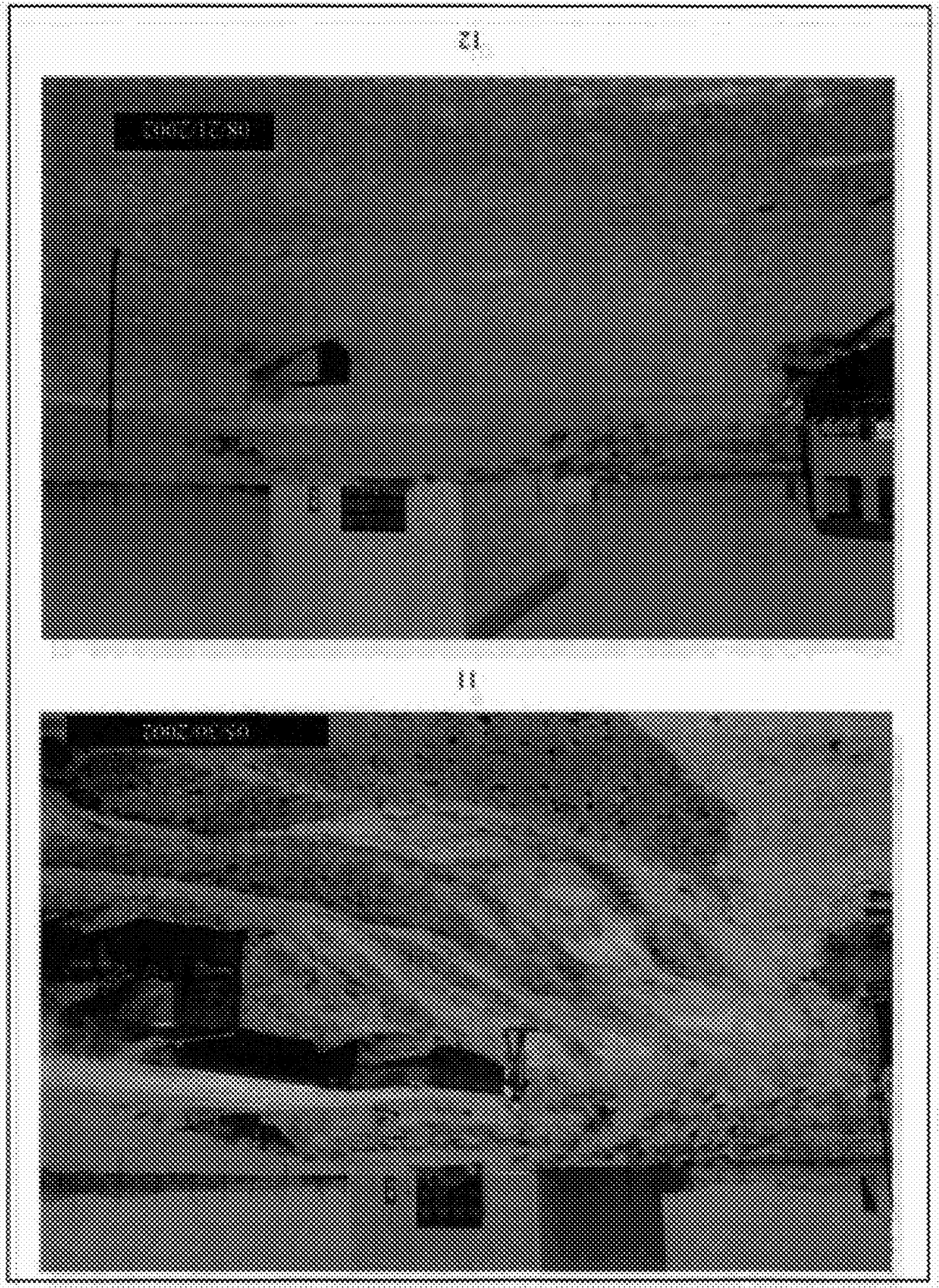




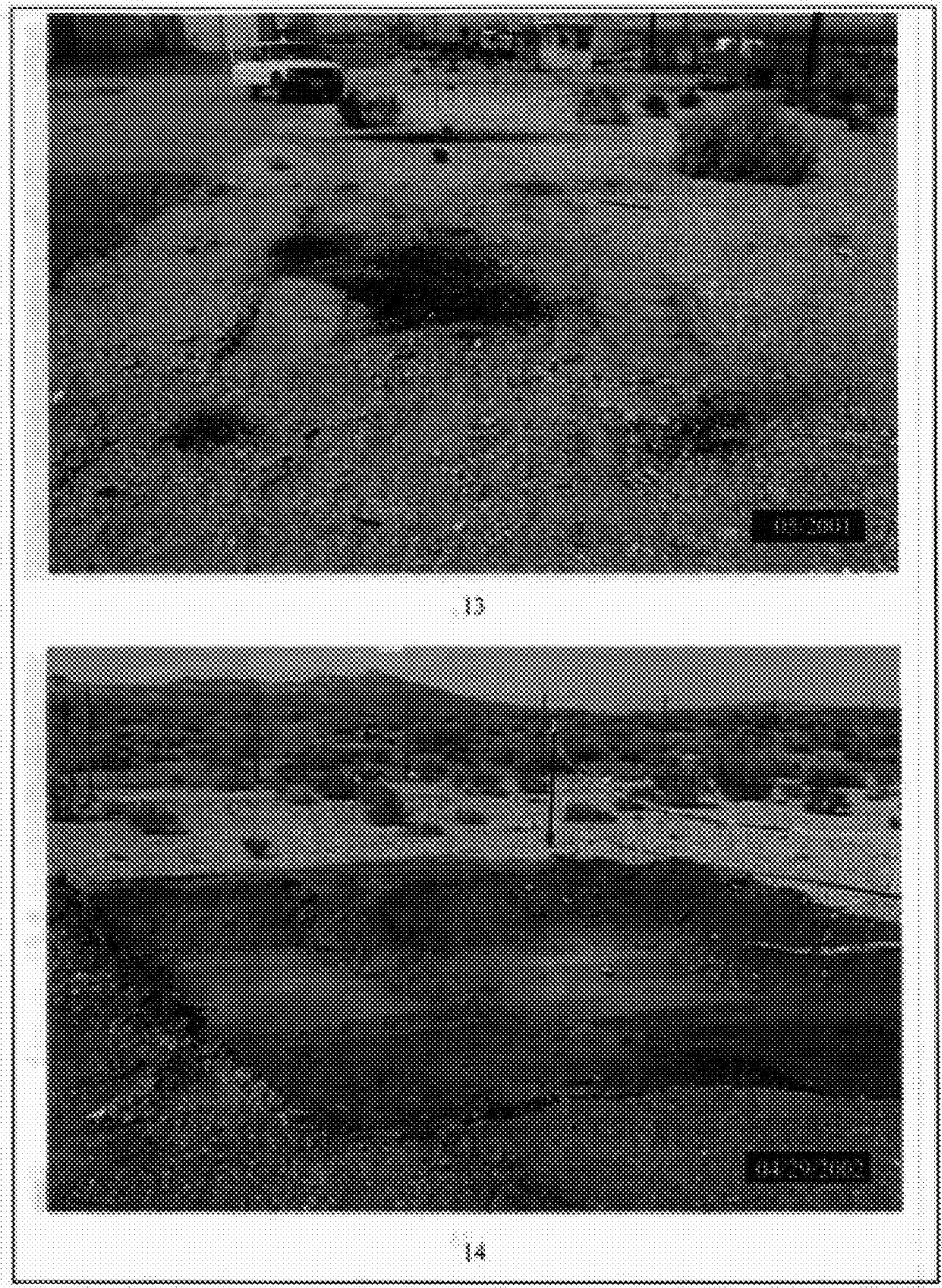

$\$$ 


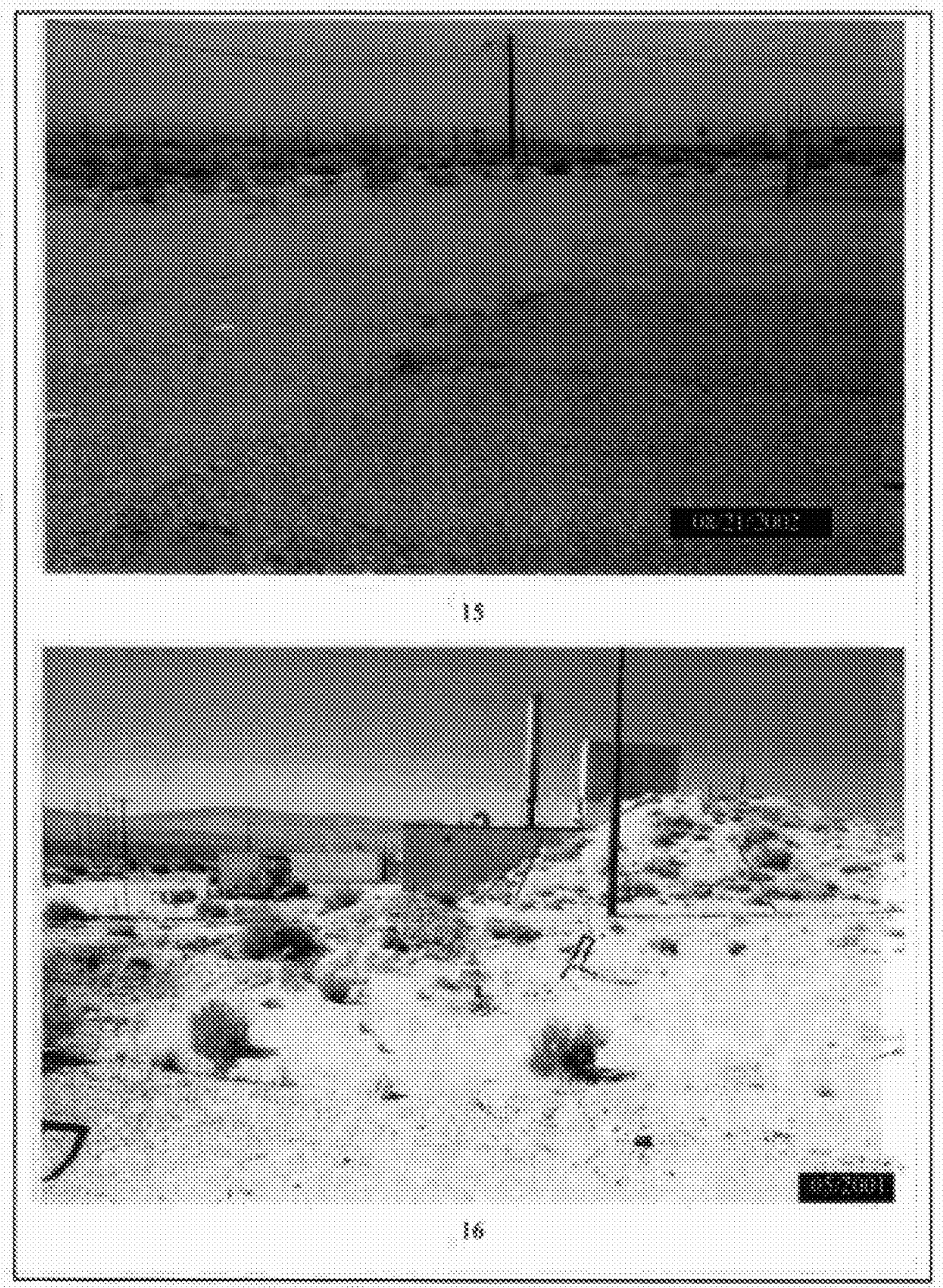

48 


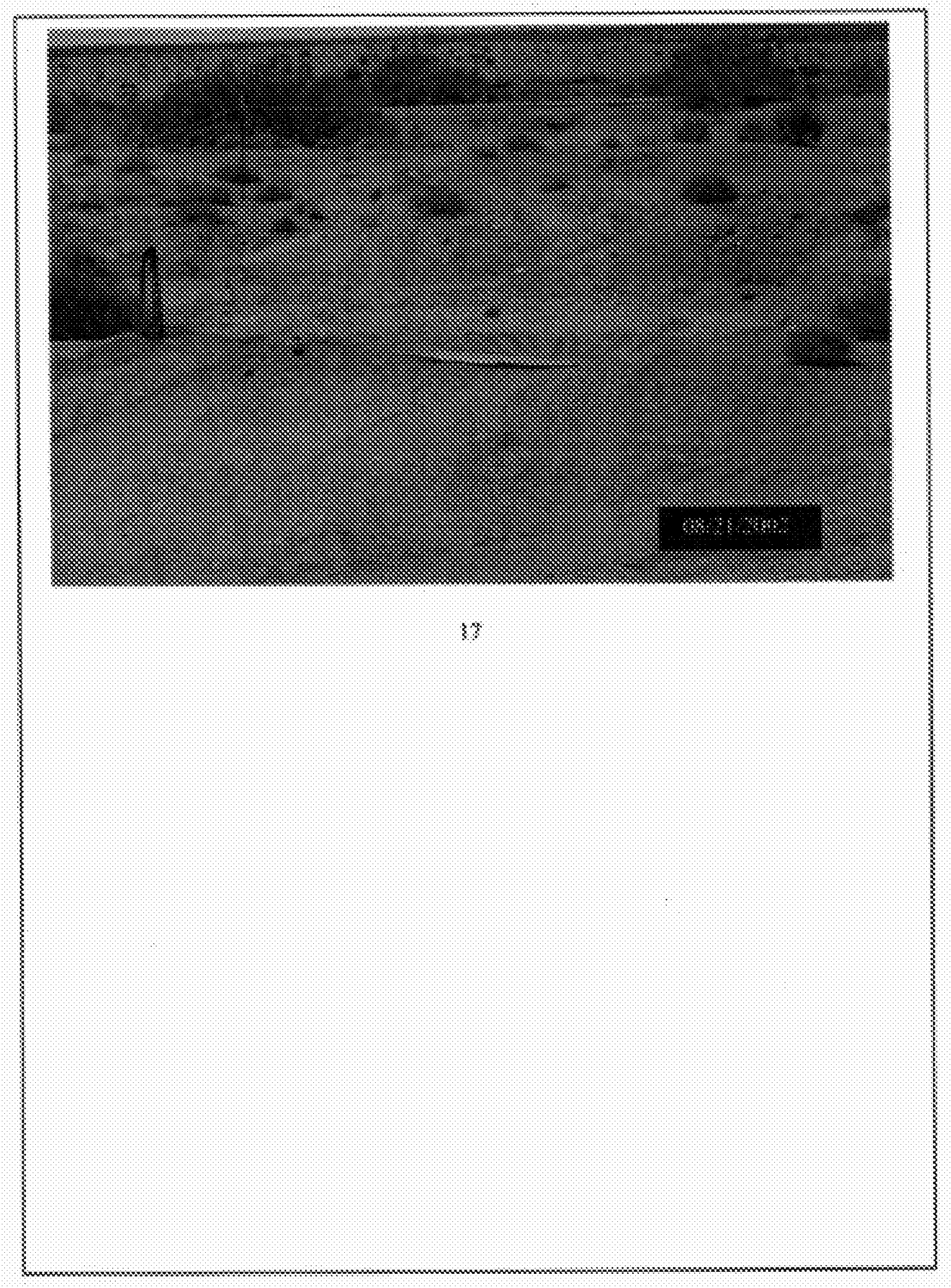

$\{3\}$ 
CLOSURE REPORT - CAU 398

Section: Appendix F

Revision: 1

Date: April 2003

\section{APPENDIX F}

\section{NEVADA ENVIRONMENTAL RESTORATION} PROJECT DOCUMENT REVIEW SHEET 
CLOSURE REPORT - CAU 398 Section: Appendix F

Revision: 1

Date: April 2003

THIS PAGE INTENTIONALLY LEFT BLANK 


\section{NEVADA ENVIRONMENTAL RESTORATION PROJECT \\ DOCUMENT REVIEW SHEET}

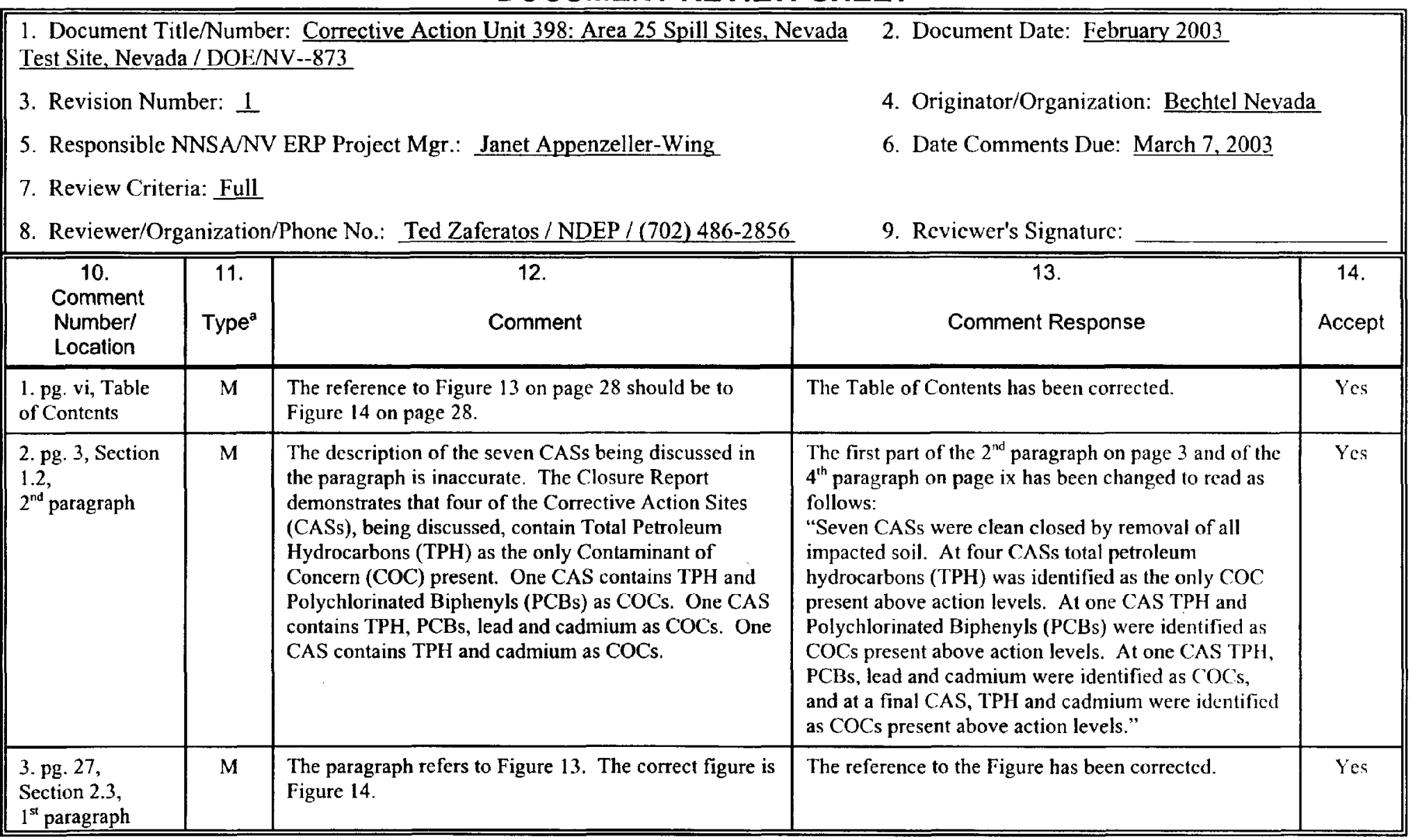


Page 2 of 2

\begin{tabular}{|c|c|c|c|c|}
\hline $\begin{array}{l}10 . \\
\text { Comment } \\
\text { Number/ } \\
\text { Location }\end{array}$ & $\begin{array}{l}11 . \\
\text { Type }^{a}\end{array}$ & $\begin{array}{l}12 . \\
\text { Comment }\end{array}$ & $\begin{array}{c}13 . \\
\text { Comment Response }\end{array}$ & Accept \\
\hline $\begin{array}{l}\text { 4. pg. } 39, \\
\text { Section } 5.1\end{array}$ & $\mathrm{M}$ & $\begin{array}{l}\text { The section describes site closure activities as eight of } \\
\text { the CASs in the CAU, but does not mention or describe } \\
\text { activities at the remaining five CASs in the CAU. }\end{array}$ & $\begin{array}{l}\text { Text describing the closure activities at the five CASs } \\
\text { not previously mentioned has been added to Section } \\
5.0 \text { and the list reordered to list the CASs in numerical } \\
\text { order. The following items have been added to the } \\
\text { text list. } \\
\text { - CAS } 25-25-06 \text {. No COC present, site was } \\
\text { closed by taking no further action. } \\
\text { CAS 25-25-07. TPH was the only COC } \\
\text { present and due to site location, limited } \\
\text { access and safety risks, the site was closed in } \\
\text { place with administrative controls instituted. } \\
\text { CAS 25-25-08. TPH was the only COC } \\
\text { present and due to site location, access and } \\
\text { safety risks, the site was closed in place with } \\
\text { administrative controls instituted. } \\
\text { CAS 25-25-17. TPH was the only COC } \\
\text { present and due to site conditions and limited } \\
\text { access, the site was closed in place with } \\
\text { administrative controls instituted. } \\
\text { CAS } 25-44-04 \text {. No COC present, site was } \\
\text { closed by taking no further action. }\end{array}$ & Yes \\
\hline
\end{tabular}


CLOSURE REPORT - CAU 398

Section: Distribution Lisi

Revision:

Date: April 2003

\section{DISTRIBUTION LIST}


CLOSURE REPORT - CAL 398

Section: Distribution List

Revision: 1

Date: April 2003

THIS PAGE INTENTIONALLY LEFT BLANK 


\section{DISTRIBUTION LIST}

*Provide copy of initial distribution of all revisions; others receive NDEP-approved revision only.

\section{Nevada Division of Environmental Protection}

Paul Liebendorfer

1 (Controlled)*

Bureau of Federal Facilities

Division of Environmental Protection

333 W. Nye Lane, Room 138

Carson City, NV 89706-0866

Donald Elle

1 (Controlled)*

Bureau of Federal Facilities

Division of Environmental Protection

1771 E. Flamingo Rd., Suite 121-A

Las Vegas, NV 89193-0837

\section{U.S. Department of Energy}

Janet Appenzeller-Wing

1 (Uncontrolled)*

Environmental Restoration Division

U.S. Department of Energy

National Nuclear Security Administration

Nevada Site Office

P.O. Box 98518 , M/S 505

Las Vegas, NV 89193-8518

Sabine Curtis

1 (Uncontrolled)*

Environmental Restoration Division

U.S. Department of Energy

National Nuclear Security Administration

Nevada Site Office

P.O. Box 98518 , M/S 505

Las Vegas, NV 89193-8518

Sabrina Lawrence

Environmental Restoration Division

U.S. Department of Energy

National Nuclear Security Administration

Nevada Site Office

P.O. Box 98518 , M/S 505

Las Vegas, NV 89193-8518 


\section{DISTRIBUTION LIST (continued)}

\section{U.S. Department of Energy (continued)}

U.S. Department of Energy

National Nuclear Security Administration

Nevada Site Office

Public Reading Facility

P.O. Box 98521 , M/S NLV040

Las Vegas, NV 89193-8521

U.S. Department of Energy

National Nuclear Security Administration

Nevada Site Office

Technical Library

P.O. Box 98518 , M/S 505

Las Vegas, NV 89193-8518

U.S. Department of Energy

Office of Scientific and Technical Information

P.O. Box 62

Oak Ridge, TN 37831-0062

\section{Bechtel Nevada}

Correspondence Control

Bechtel Nevada

P.O. Box 98521, M/S NLV008

Las Vegas, NV 89193-8521

Environmental Management Library

Bechtel Nevada

P.O. Box 98521, M/S NLV080

Las Vegas, NV 89193-8521

Kevin Campbell

Bechtel Nevada

P.O. Box $98521, \mathrm{M} / \mathrm{S}$ NTS306

Las Vegas, NV 89193-8521

Thomas Fitzmaurice

Bechtel Nevada

P.O. Box 98521 , M/S NTS306

Las Vegas, NV 89193-8521
1 (Controlled) \&

1 (Uncontrolled)

1 (Uncontrolled)

1 (Electronic)

1 (Uncontrolled)*

1 (Uncontrolled)*

1 (Uncontrolled)*

1 (Uncontrolled)* 


\section{DISTRIBUTION LIST (continued)}

\section{Bechtel Nevada (continued)}

Brad Jackson

1 (Uncontrolled)*

Bechtel Nevada

P.O. Box 98521 , M/S NTS306

Las Vegas, NV 89193-8521

Wayne Johnson

1 (Uncontrolled)

Bechtel Nevada

P.O. Box 98521, M/S NLV080

Las Vegas, NV 89193-8521

Steve Nacht

1 (Uncontrolled)*

Bechtel Nevada

P.O. Box $98521, \mathrm{M} / \mathrm{S}$ NTS306

Las Vegas, NV 89193-8521

\section{Shaw Environmental Incorporated}

FFACO Public Reading Room Coordinator

1 (Controlled)

Shaw Environmental Inc.

P.O. Box 93838 , M/S 439

Las Vegas, NV 89193-8521

John Stokowski

1 (Uncontrolled)*

Shaw Environmental Inc.

P.O. Box 93838 , M/S 439

Las Vegas, NV 89193-8521

\section{State of Nevada}

Manager, Northern Nevada

1 (Controlled)

FFACO Public Reading Facility

Nevada State Library and Archives Federal Publications

100 North Stewart Street

Carson City, NV 89701-4285 
CLOSURE REPORT - CAU 398

Section: Distribution List

Revision: 1

Date: April 2003

THIS PAGE INTENTIONALLY LEFT BLANK 